
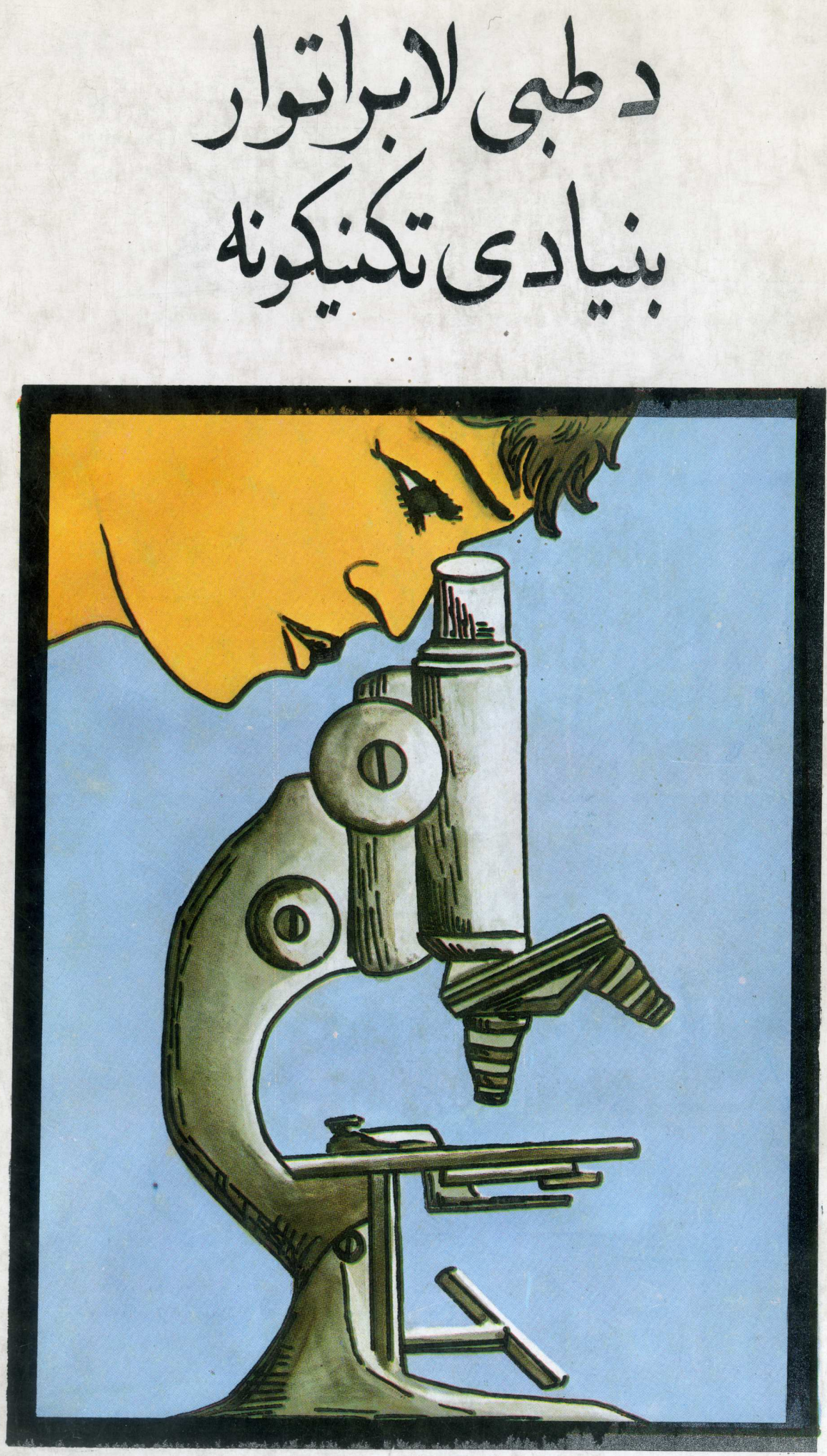


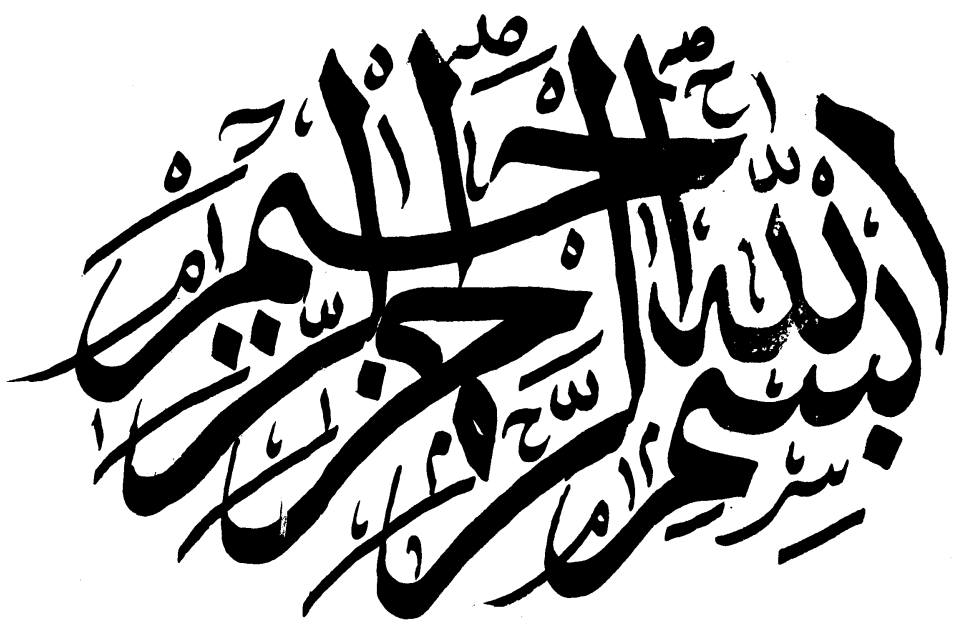




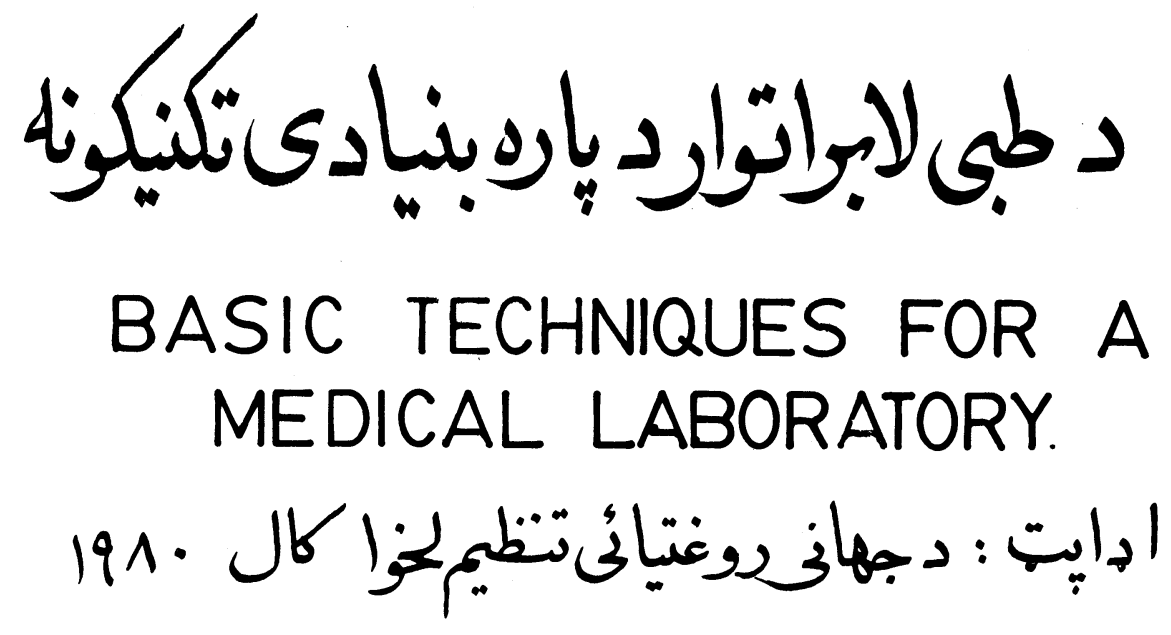

Adapted from: World Health Organization 1980 Edition

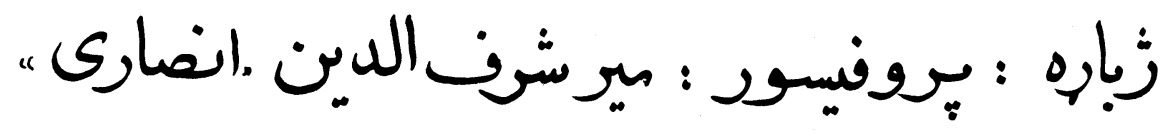

Translated by: Prof. Mir Sharaffuddin Ansari

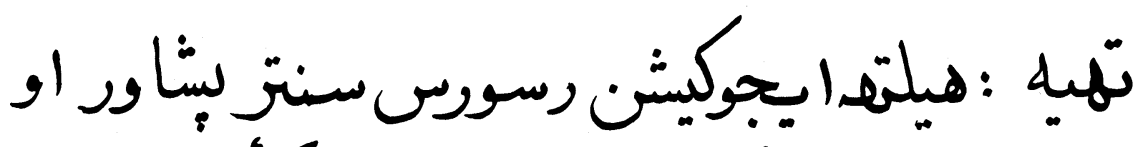

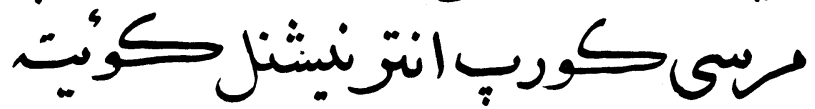

Produced by: HEALTH EDUCATION RESOURCE CENTER \& MERCY CORPS, INTERNATIONAL, QUETTA

Edition: 150 Copies Year: 1987

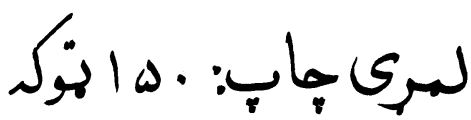

$$
\begin{aligned}
& \text { كال: }
\end{aligned}
$$




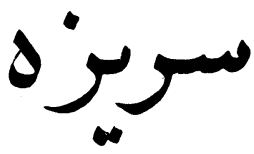

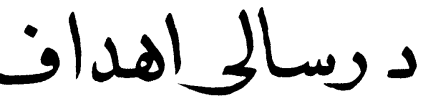

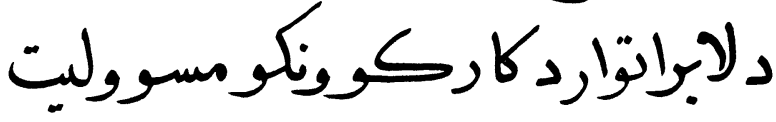

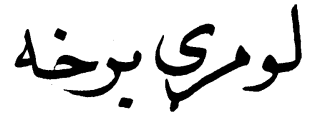

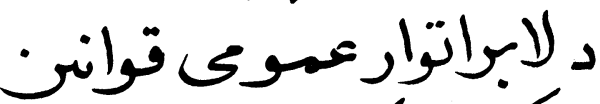

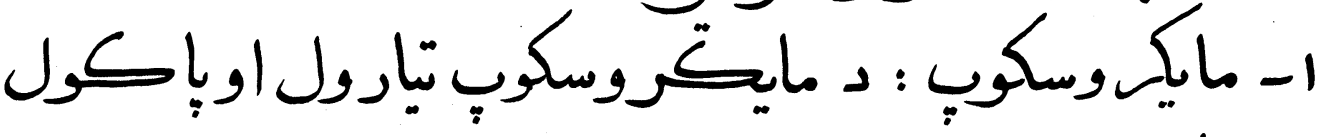

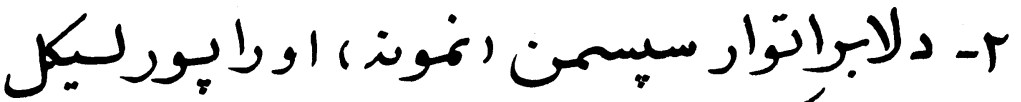

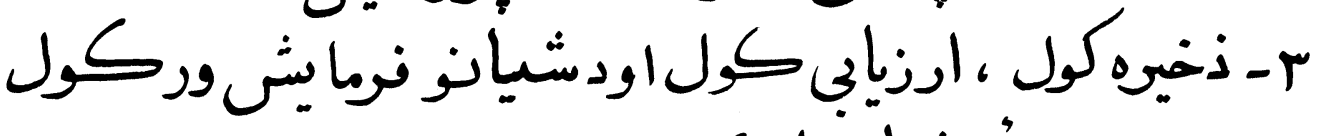

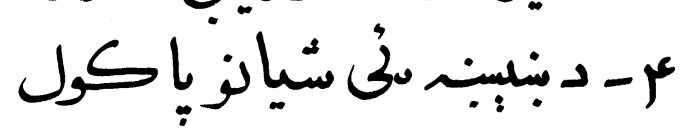

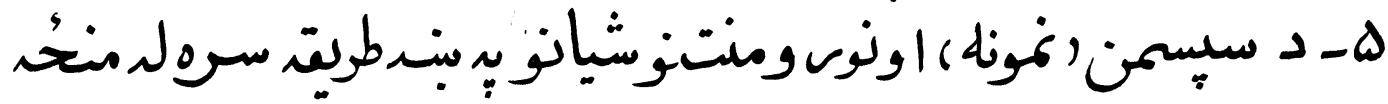
ورل ( وروستها داستعال ن)

$$
\begin{aligned}
& \text { دويمه برخذ }
\end{aligned}
$$

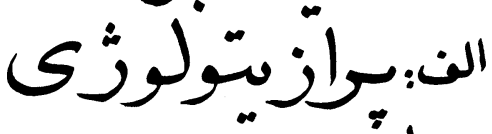

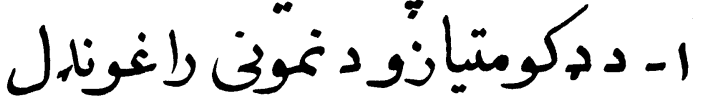

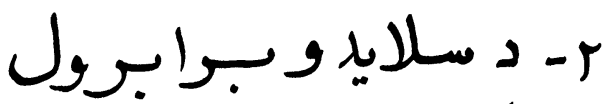

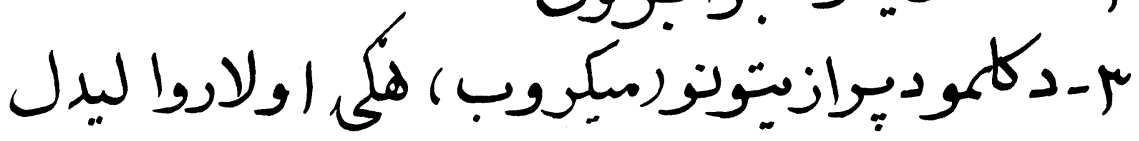




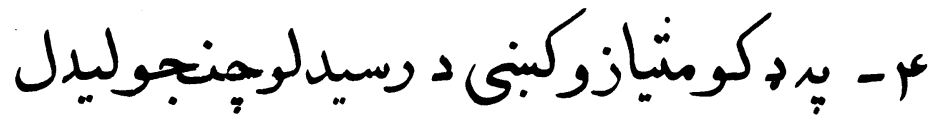

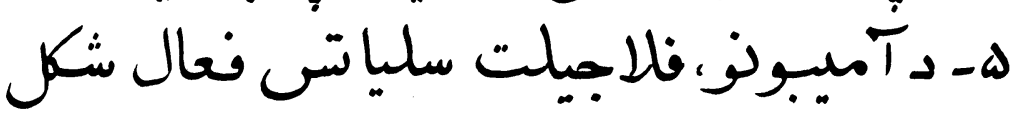

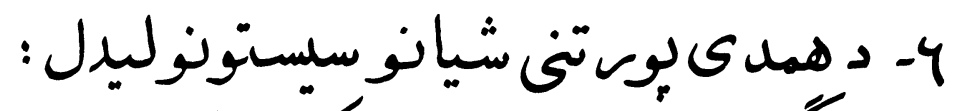

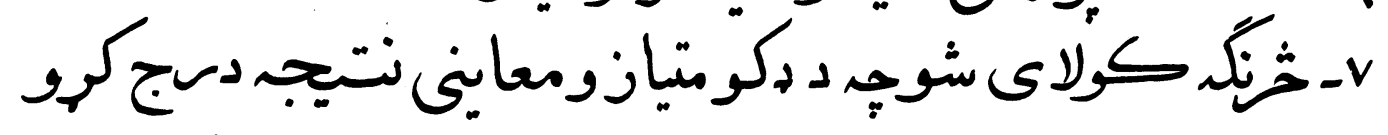

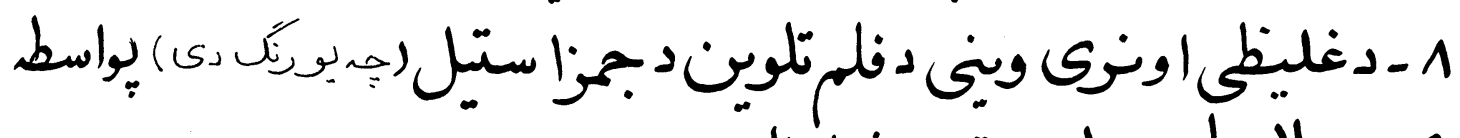

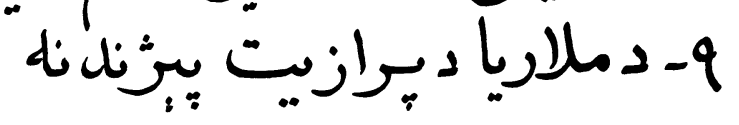

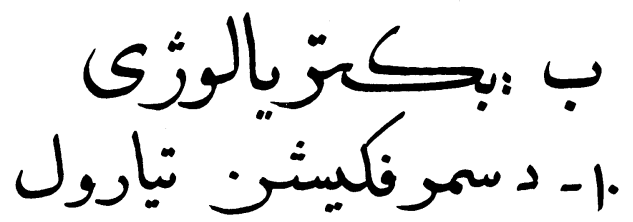

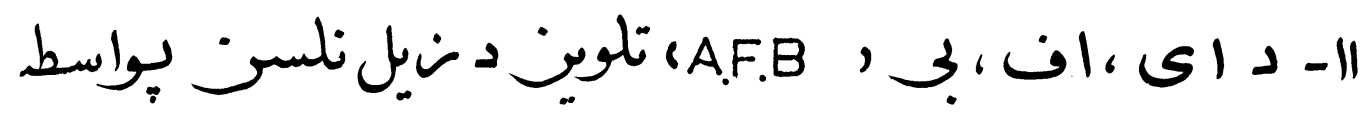

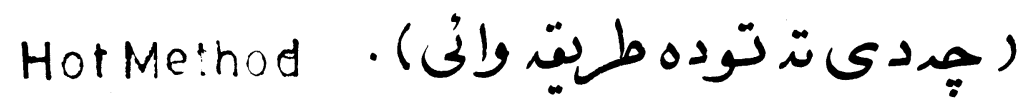

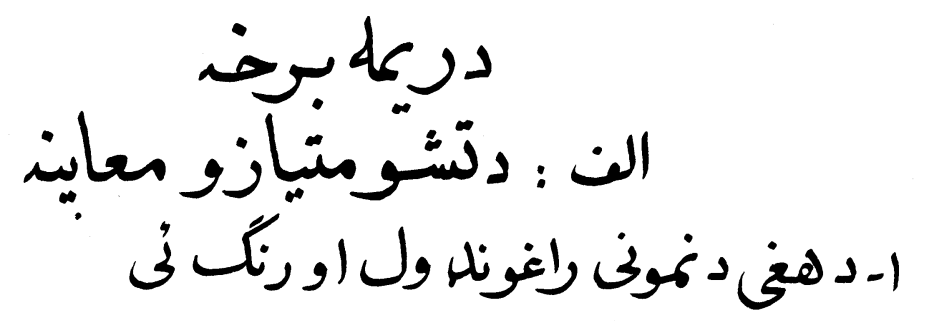

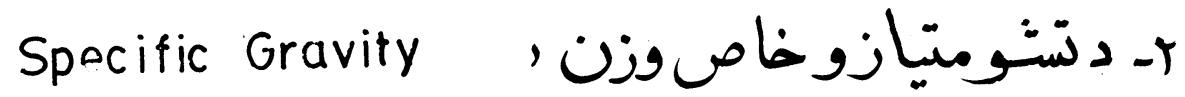

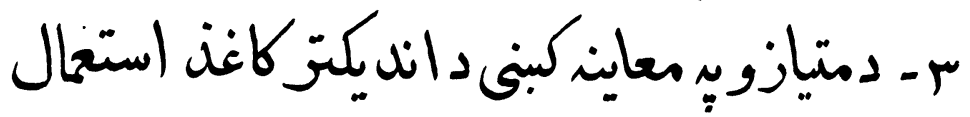

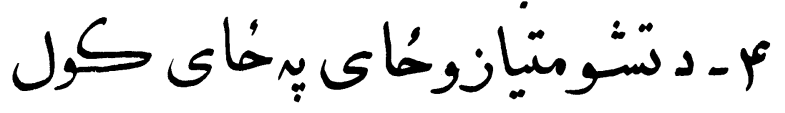




$$
\begin{aligned}
& \text { هـ داوميند و معاين (حاملكى) } \\
& \text { بـ : هيماتولوزى ( د وينى معاين) } \\
& \text { ا ـ دونيى كرويات }
\end{aligned}
$$

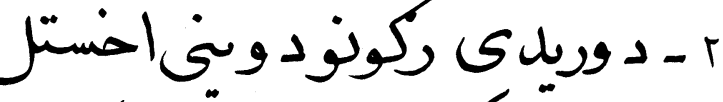

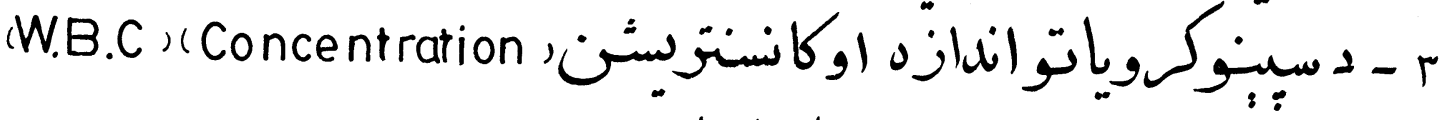

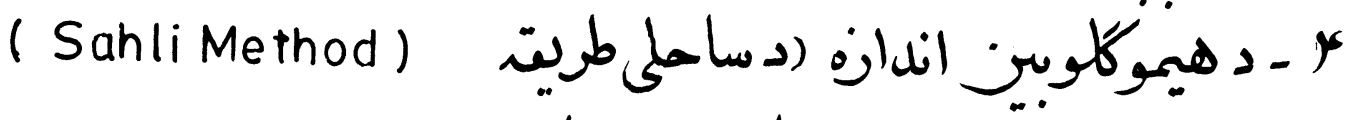

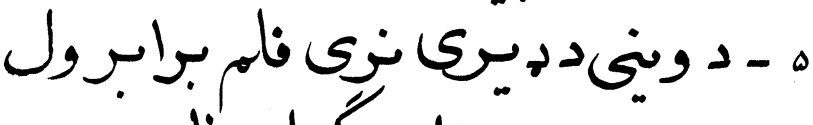

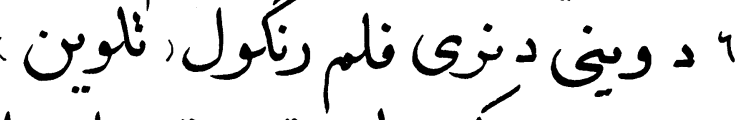

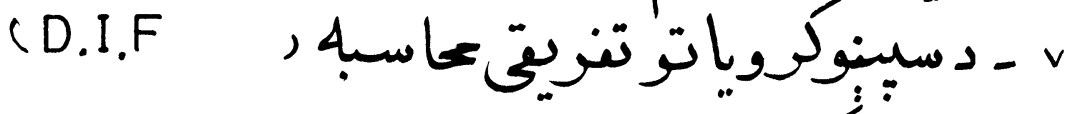

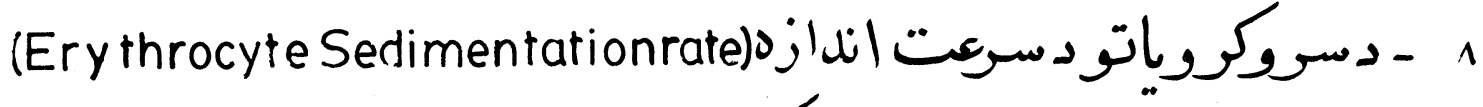

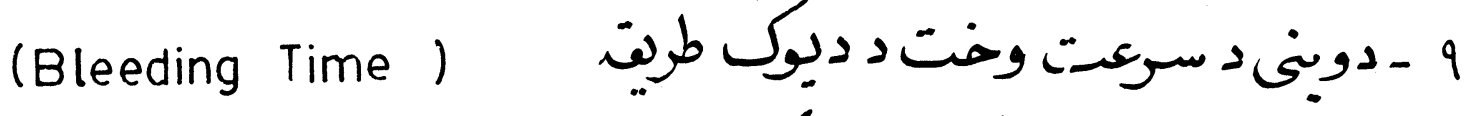

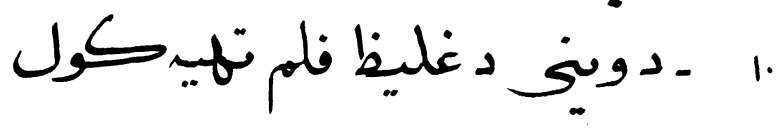

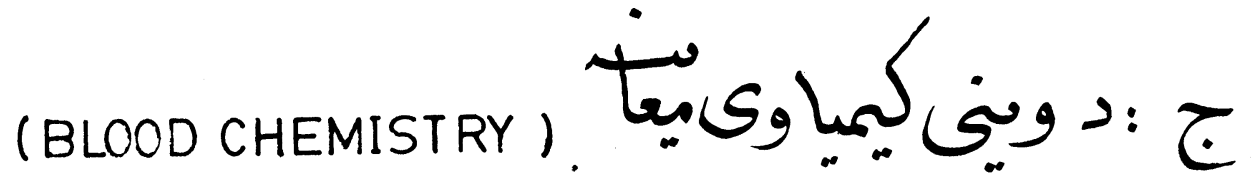
دوينى د شكل اندازه د باره د دكستوزسنك استحال 


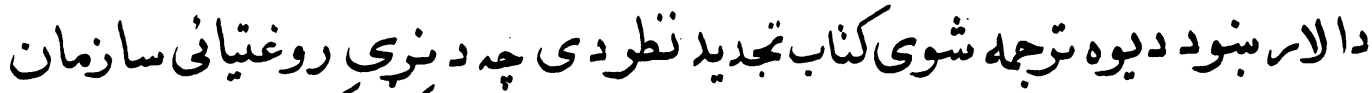

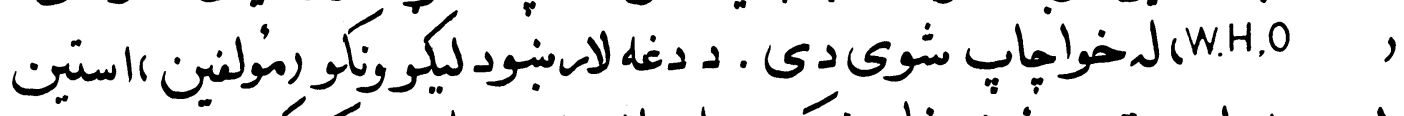

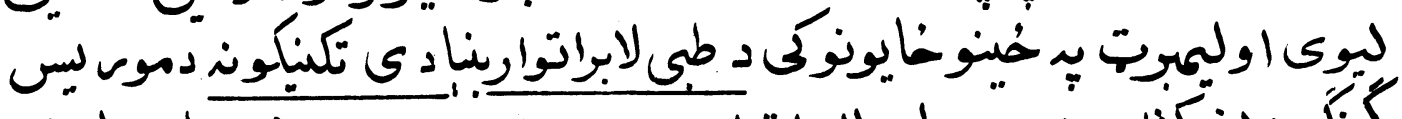

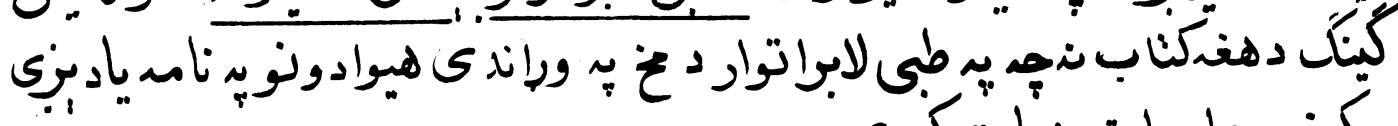

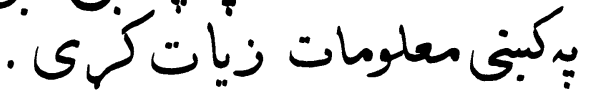

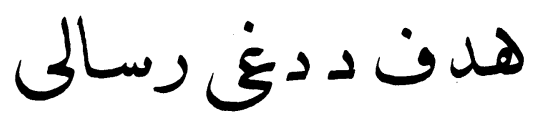

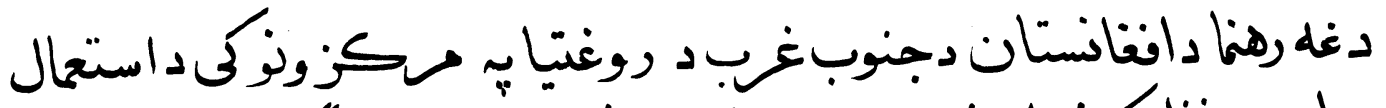

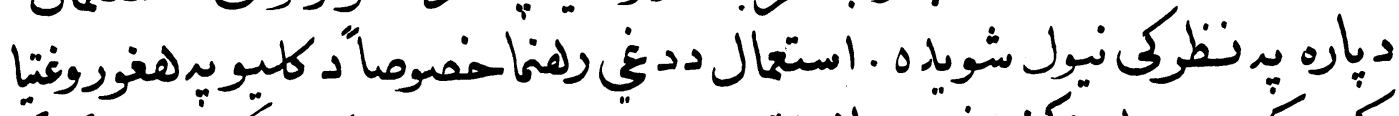

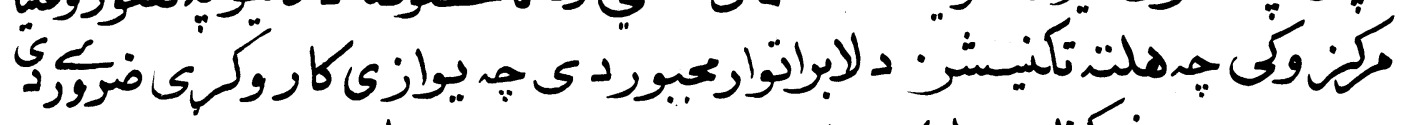

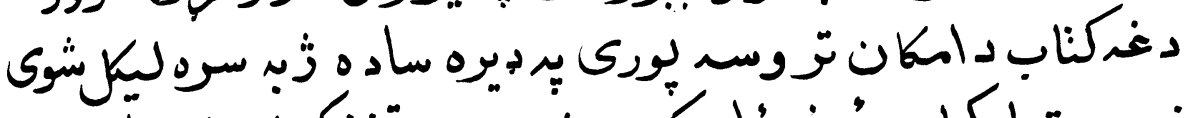

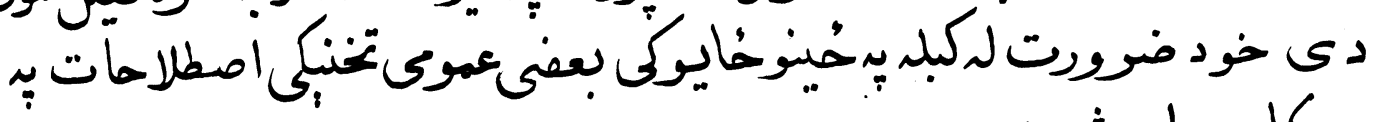

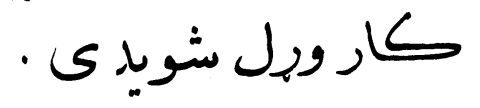

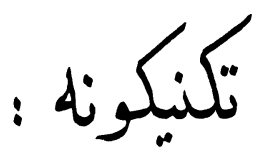

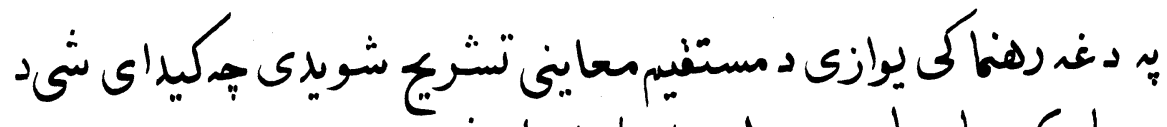

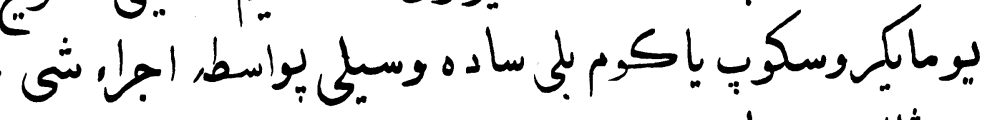

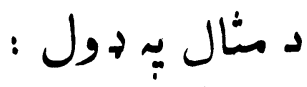

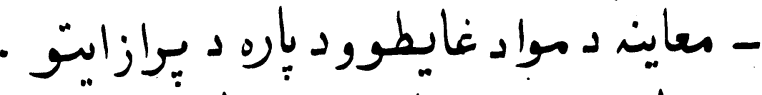

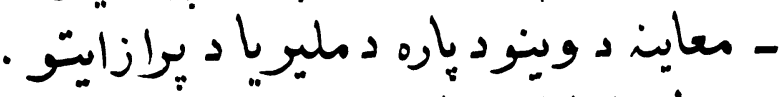

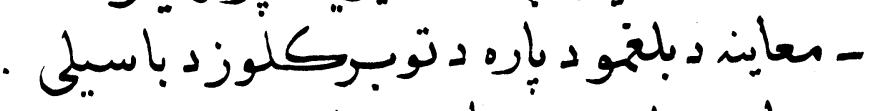

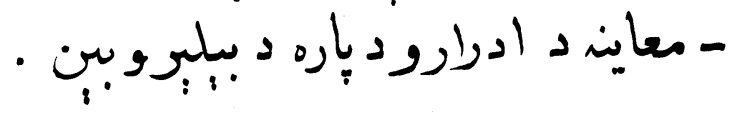




\section{ديودلابراتوارى كاركونكيمسؤليت}

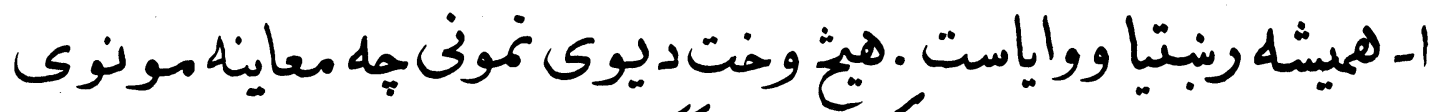

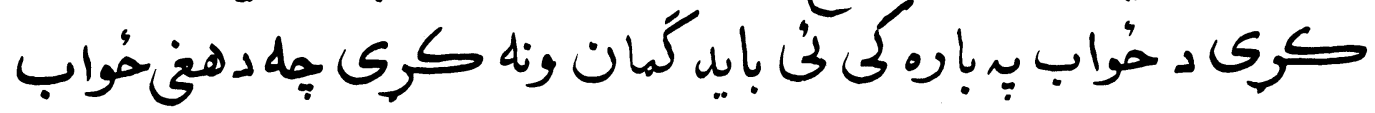

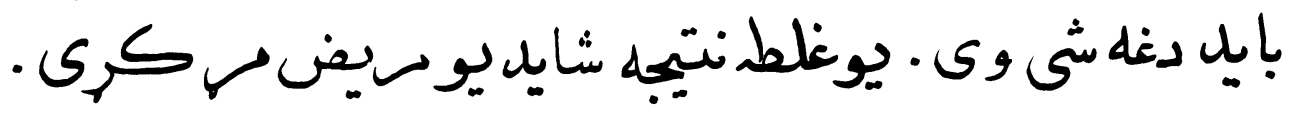

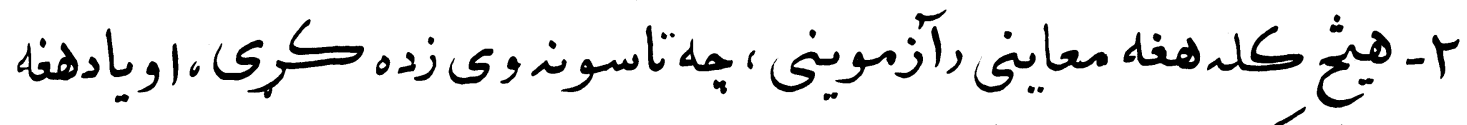

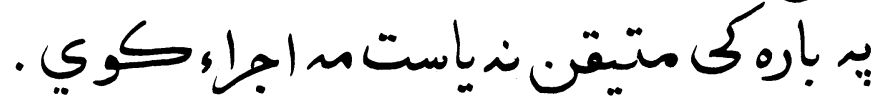

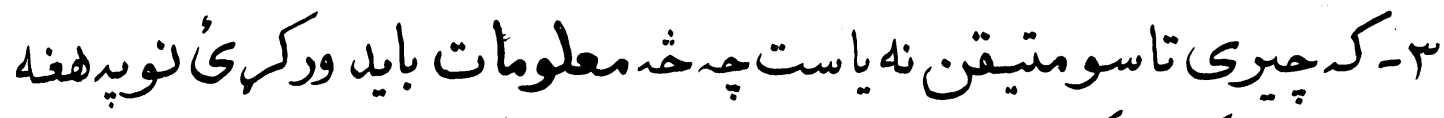

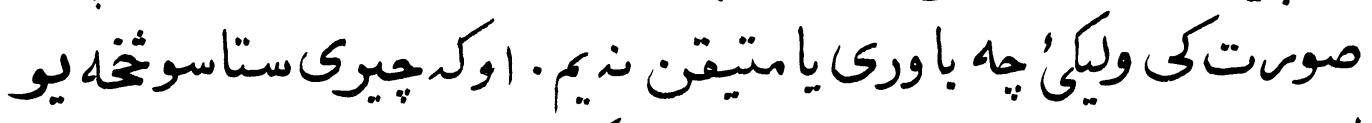

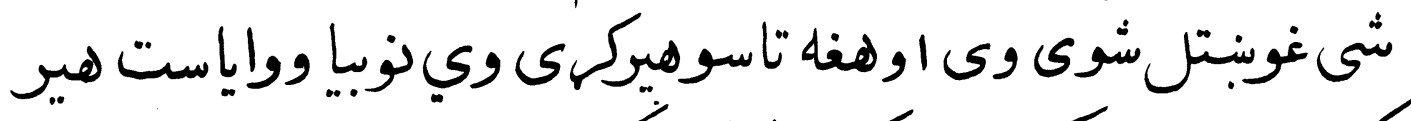

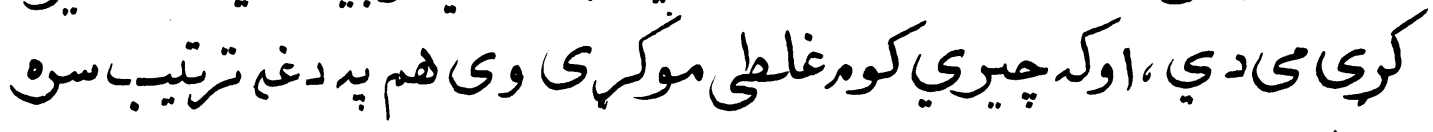
ووإست . ترياست

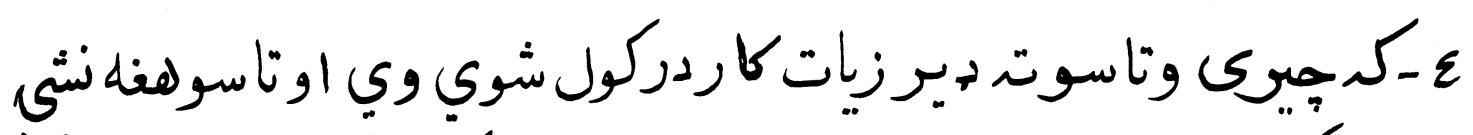

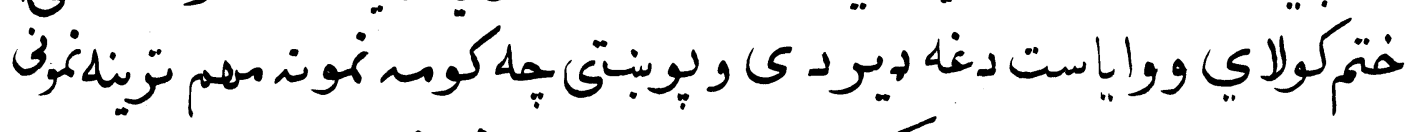

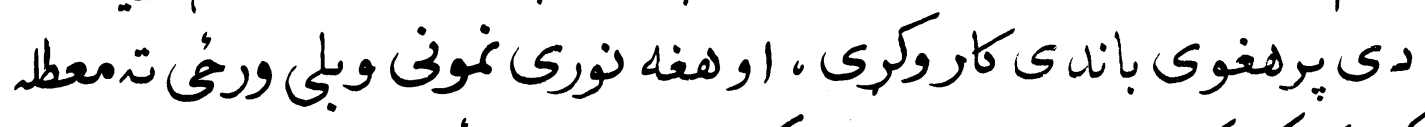

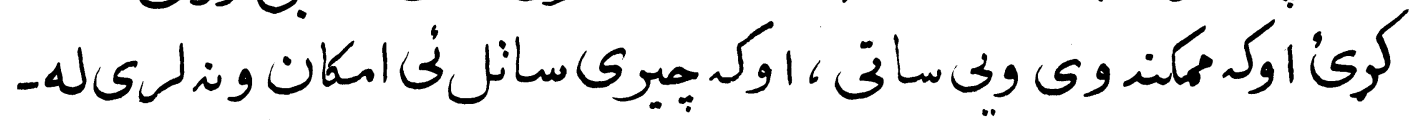




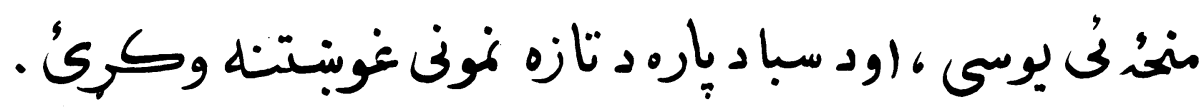

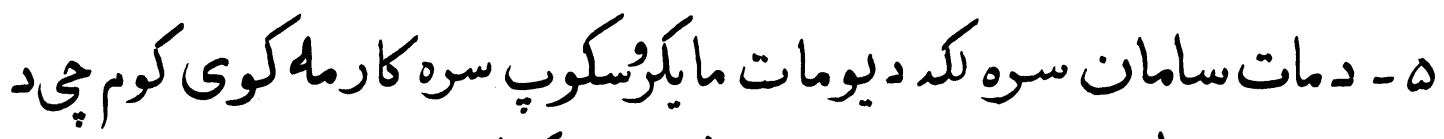

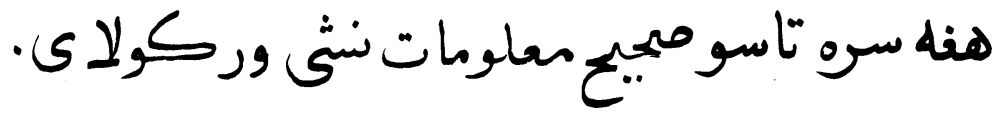

4- سامان اومعيارات ، ريجنتونه، توله تيمتى دي ، نوتوله تجهمبات

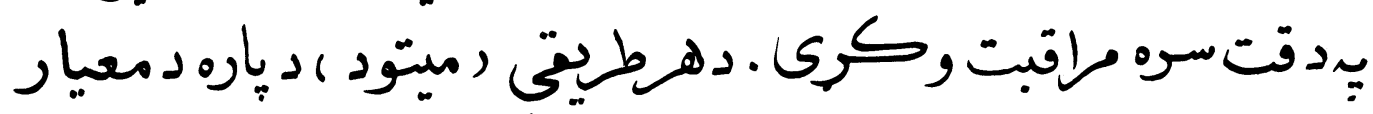

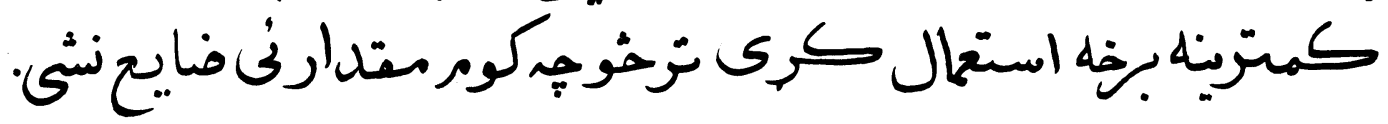

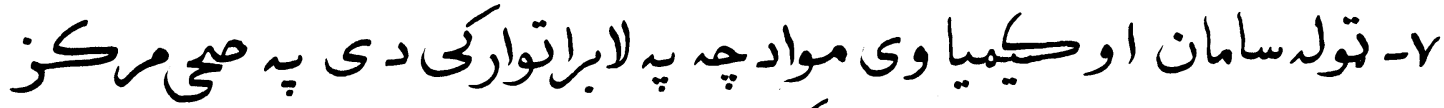

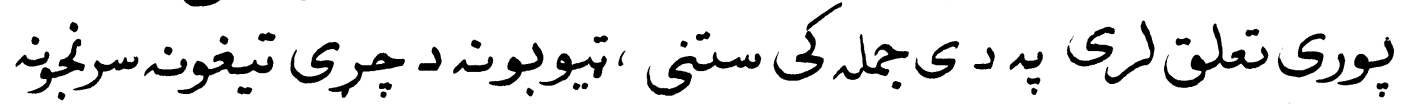

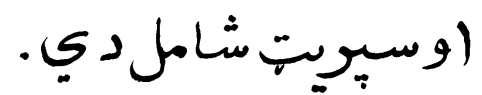

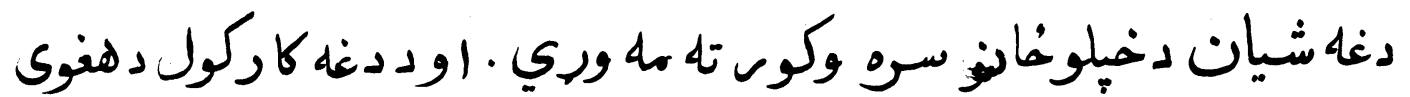

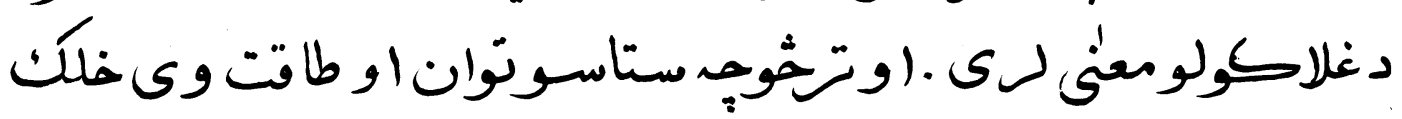

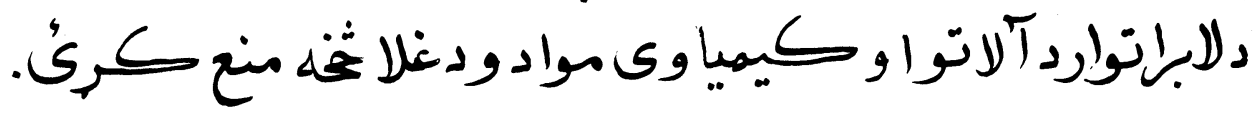

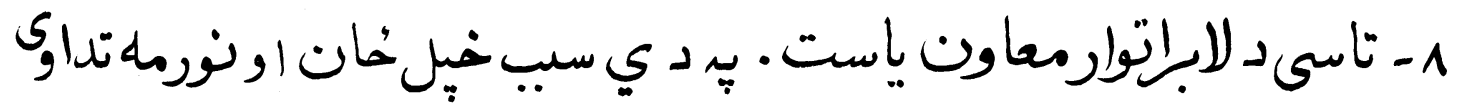

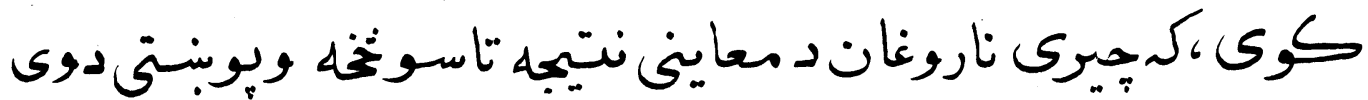

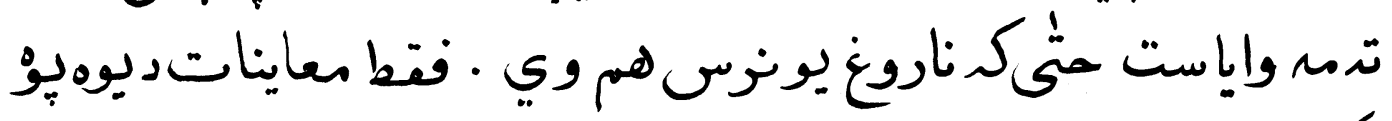

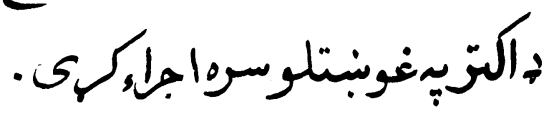




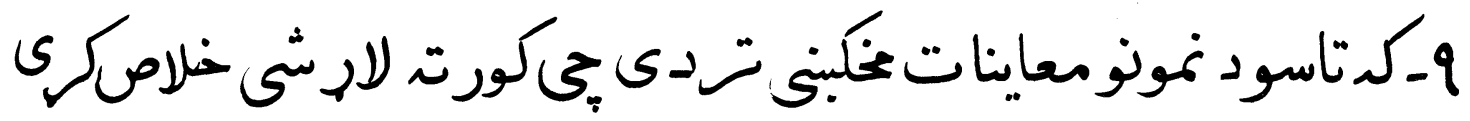

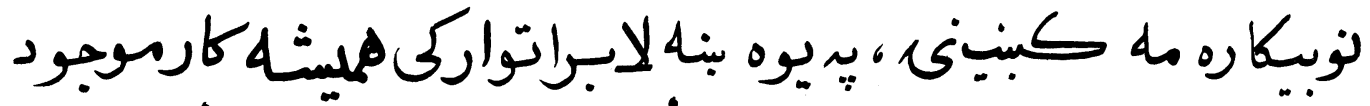

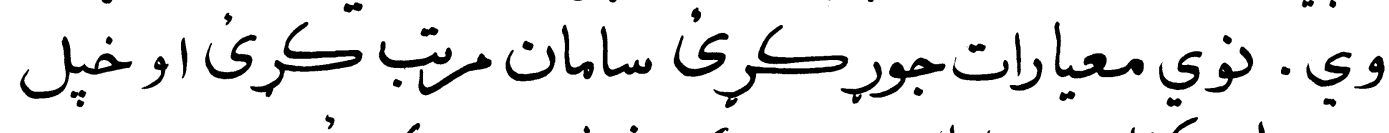

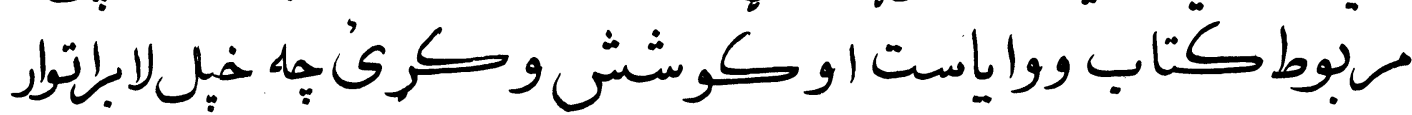

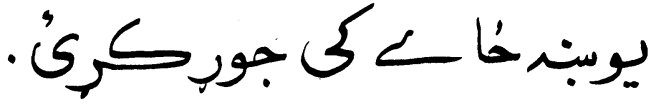




$$
\begin{aligned}
& \text { اولد .ـرخها } \\
& \text { دلابراتواريموكىطزالحلونه }
\end{aligned}
$$

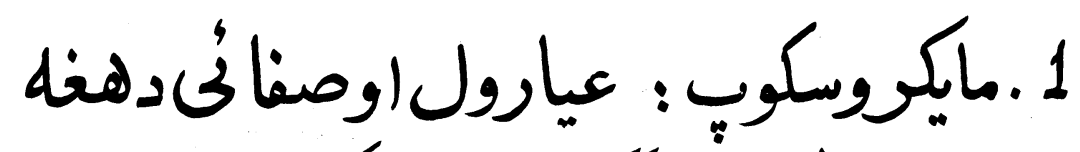

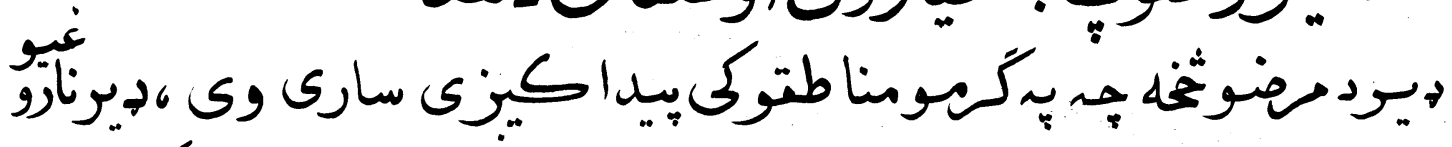

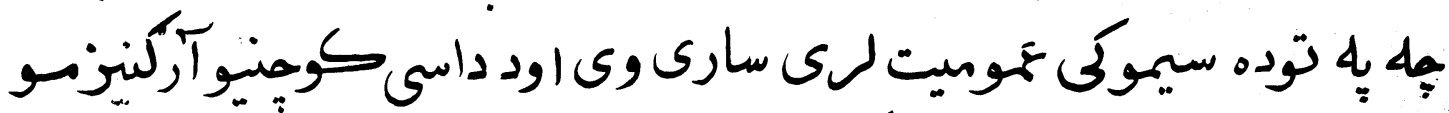

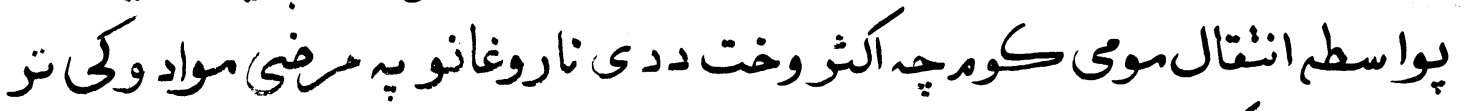

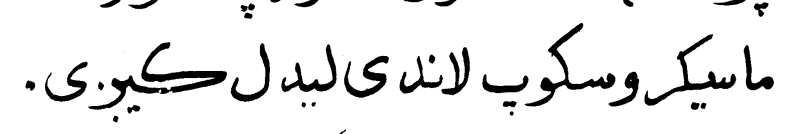

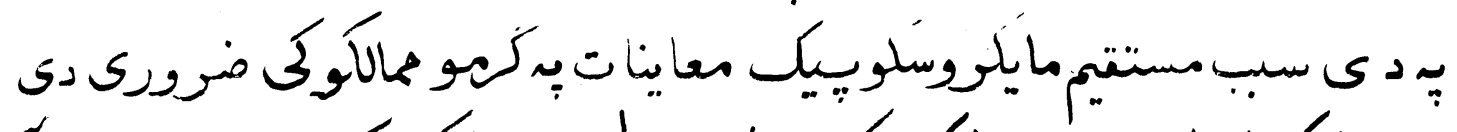

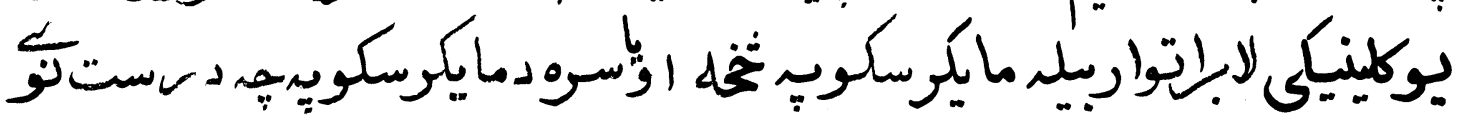

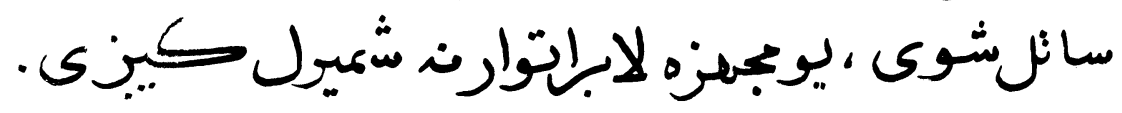

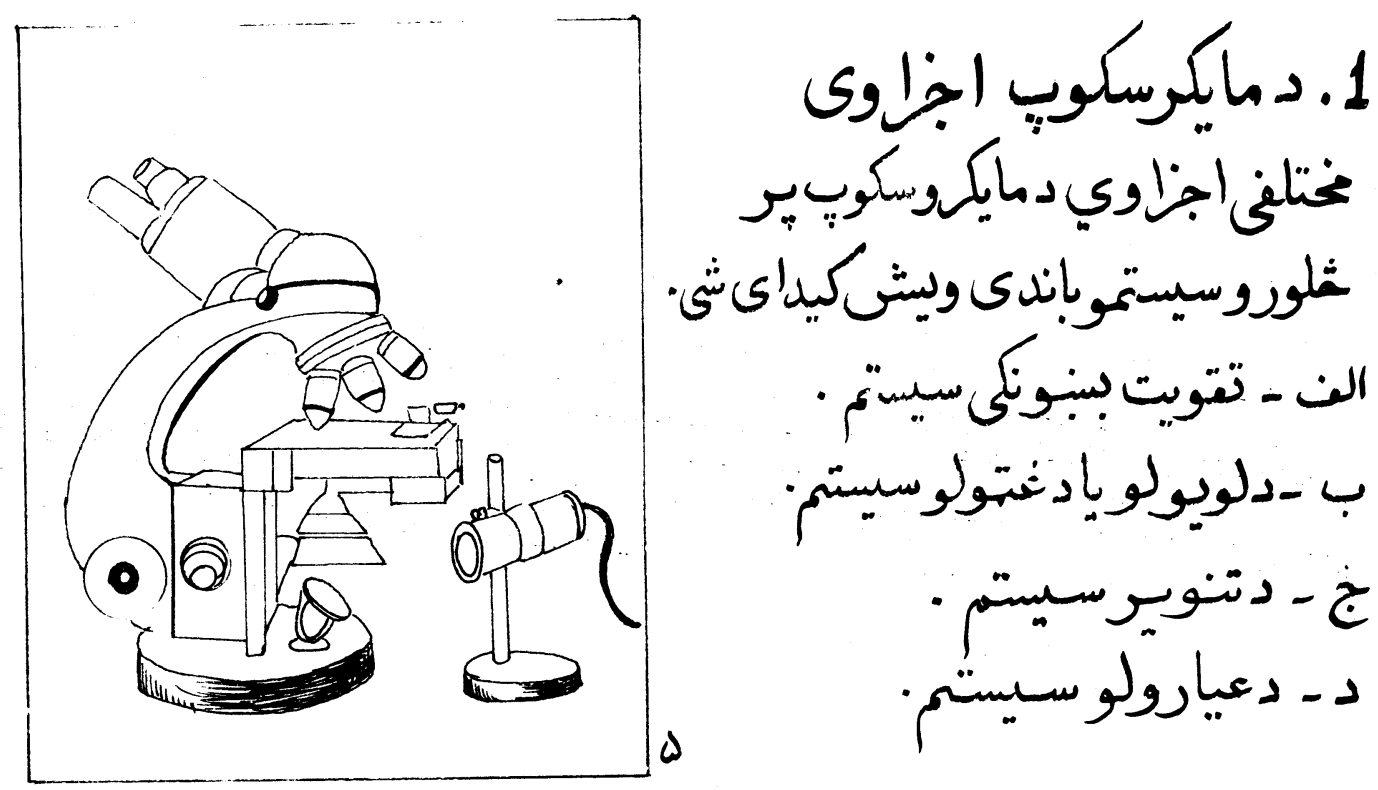




$$
\begin{aligned}
& \text { الن ـ دتقويت يا استحكام سلستم }
\end{aligned}
$$

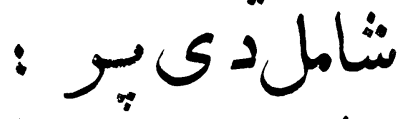

$$
\begin{aligned}
& \text { 1- باي- } \\
& \text { ب- بازي }
\end{aligned}
$$

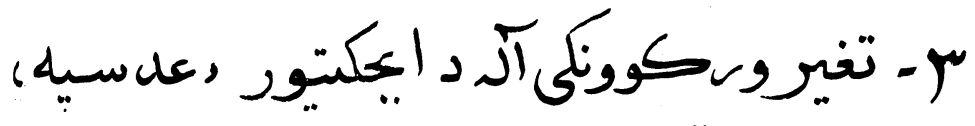

$$
\text { ع - ستيجيج تخت }
$$

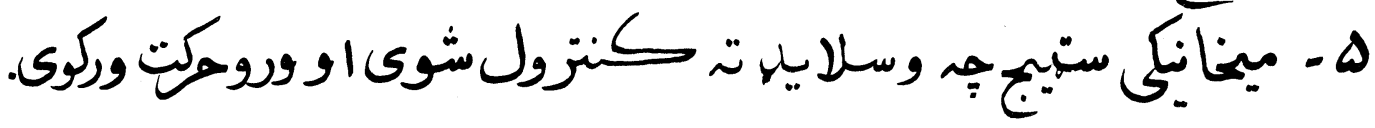

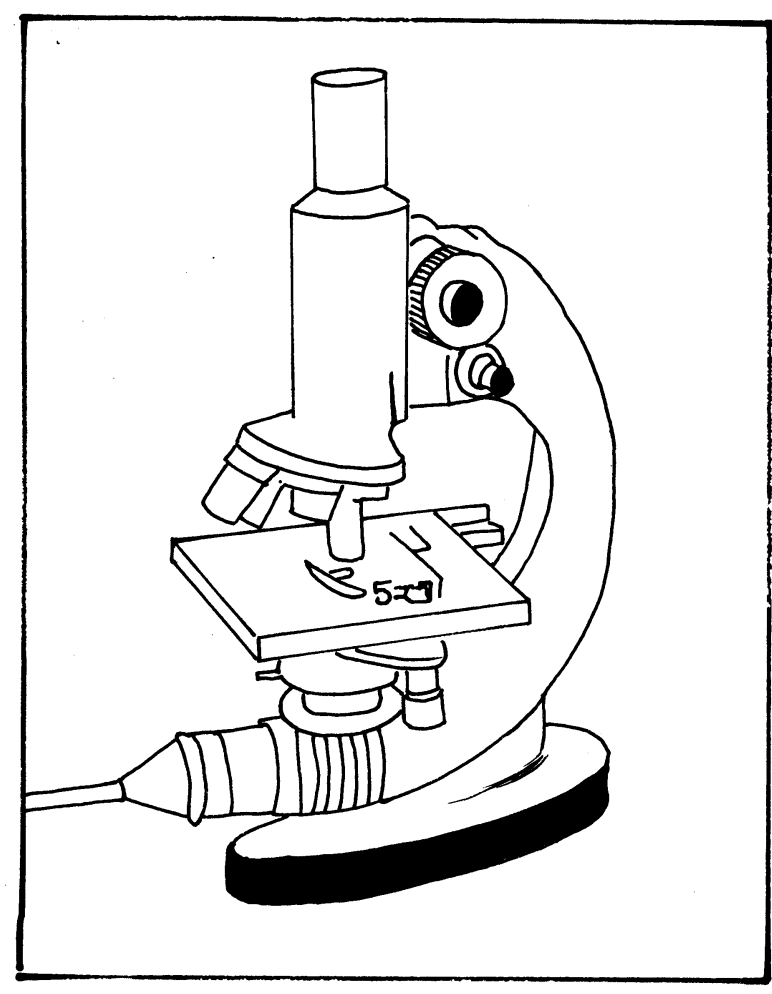




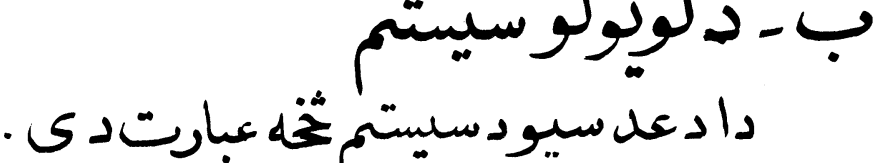

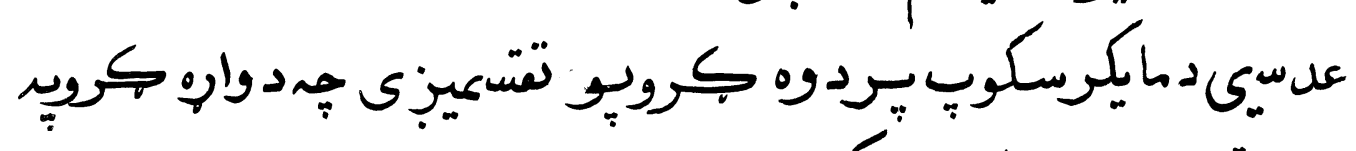

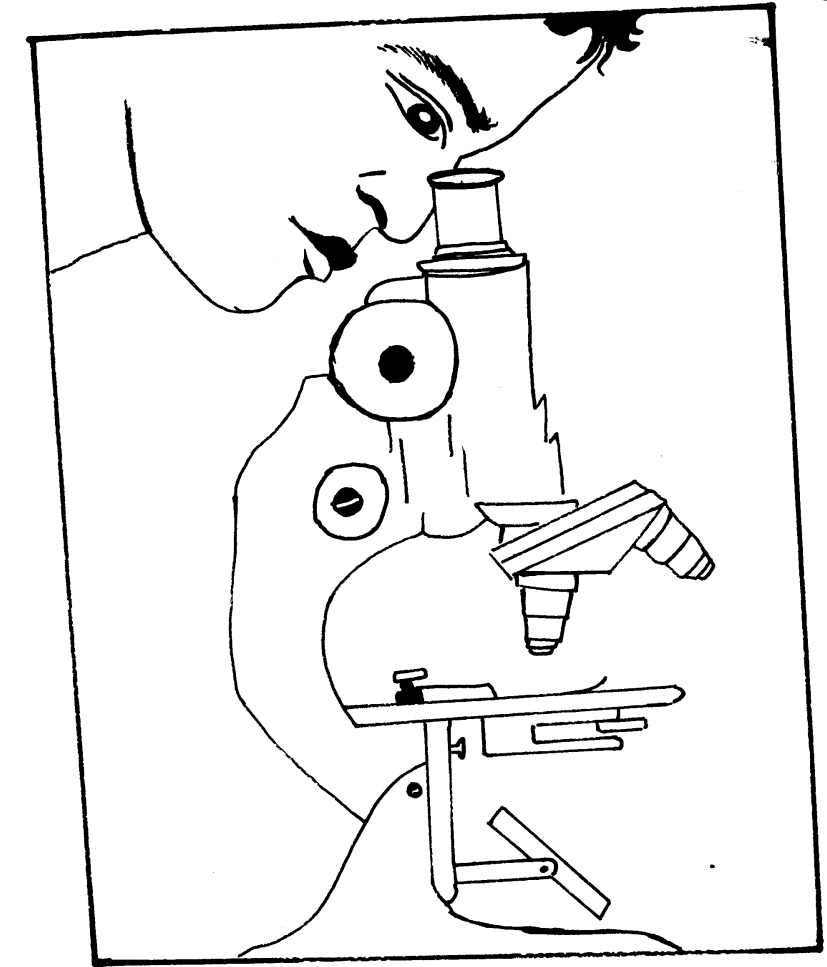

يوه اوزده نتوبـ ي دوارومسك

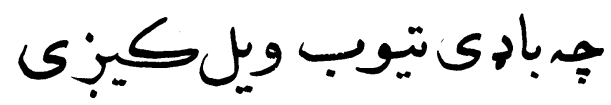

$$
\text { . } v \text { J }
$$

اولَّل يد تاعلهم واتحد ى لعنى نتط برهنو موادو بانلى ده بـدم

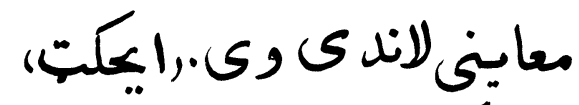

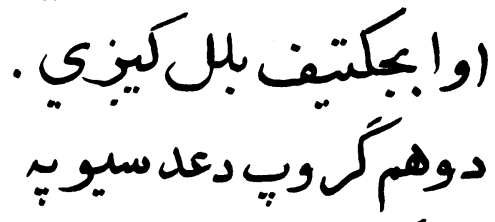

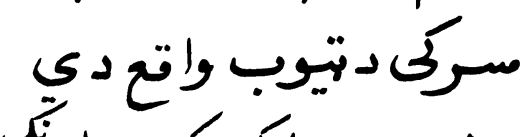

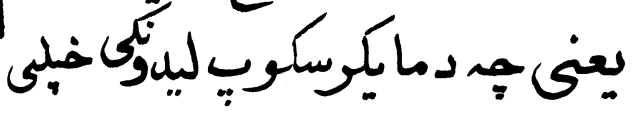

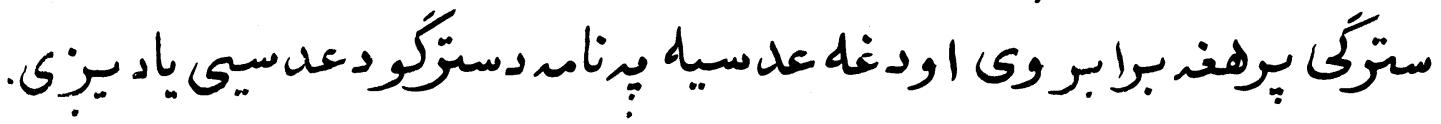



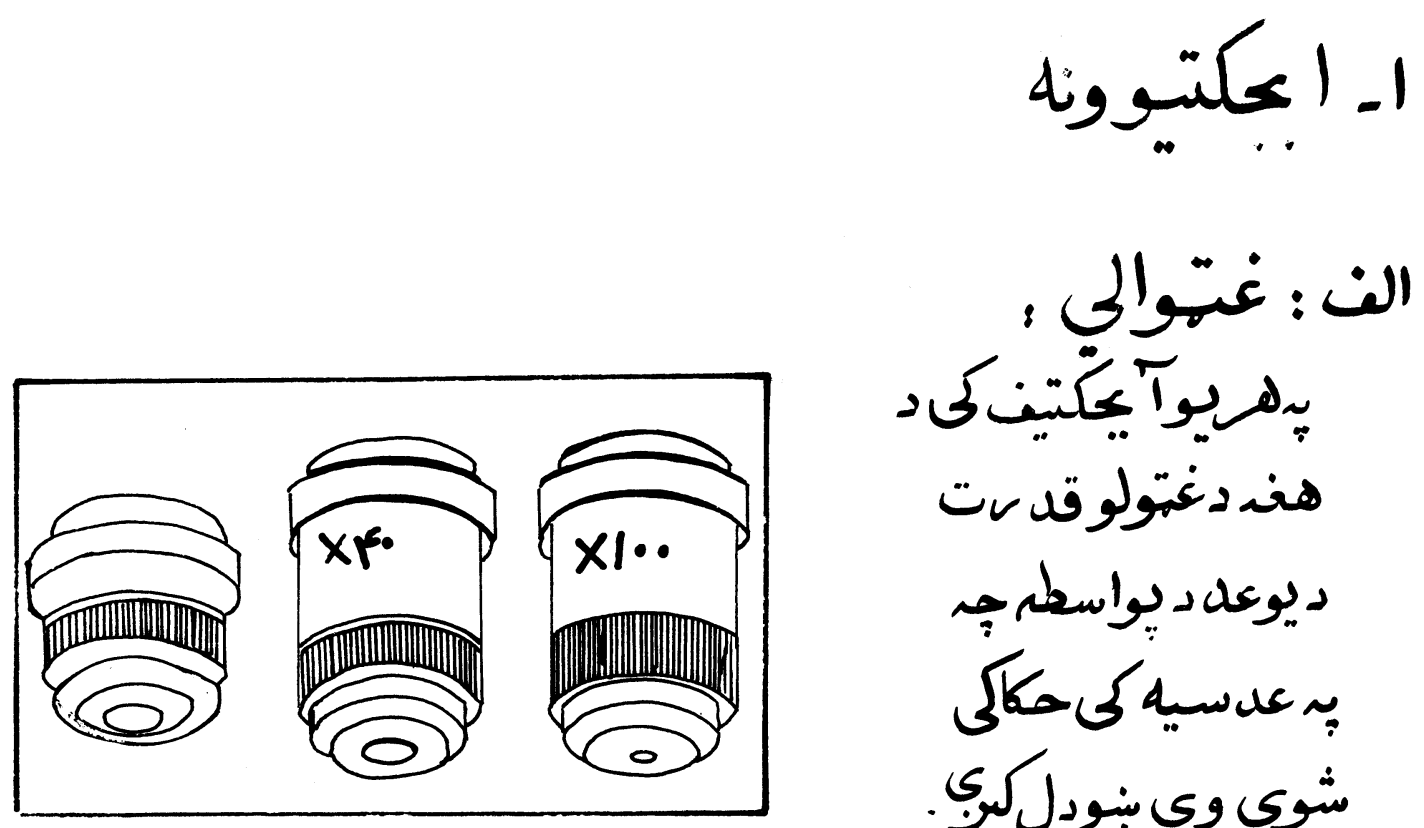

هند دنهّولوقه

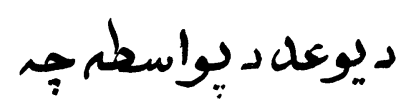

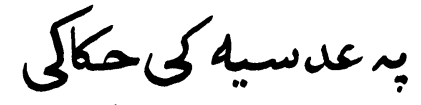
شوى وى بنودليِيج.

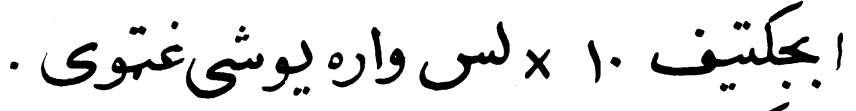

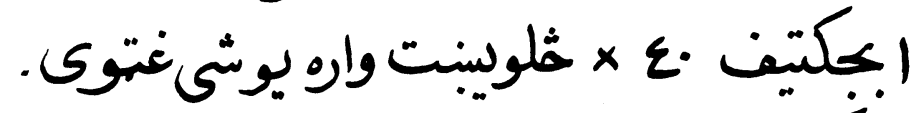

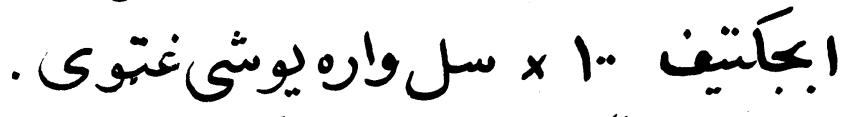

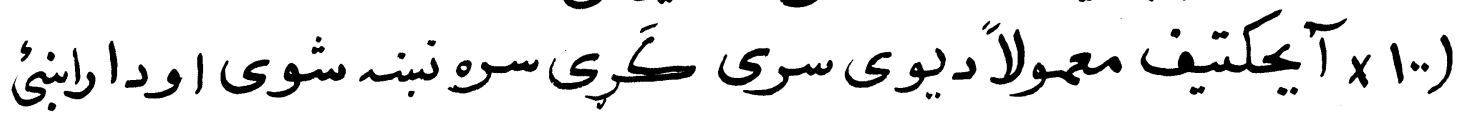

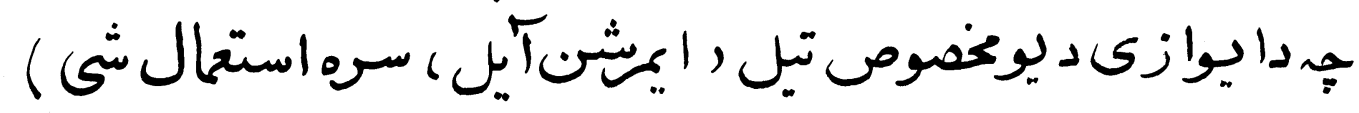
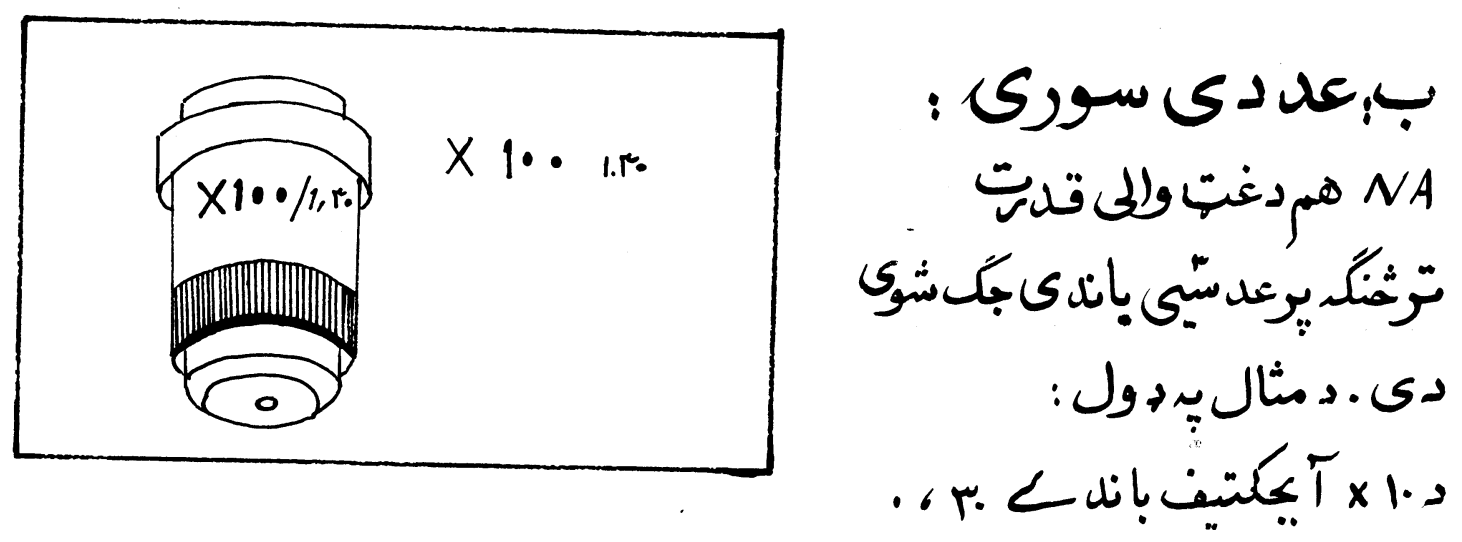


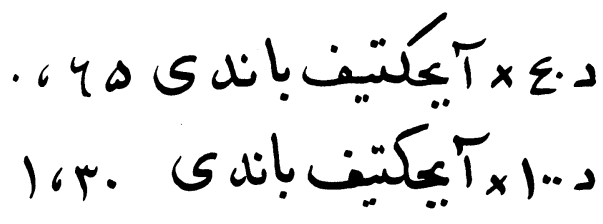

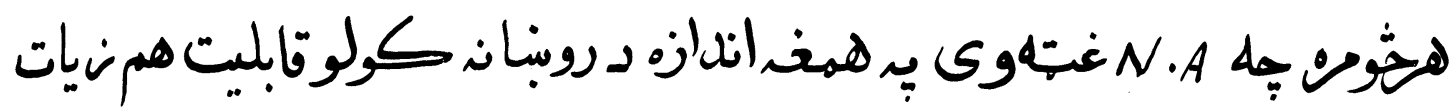
و .

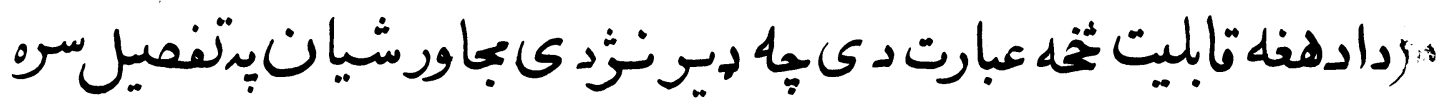

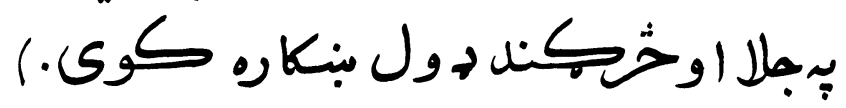

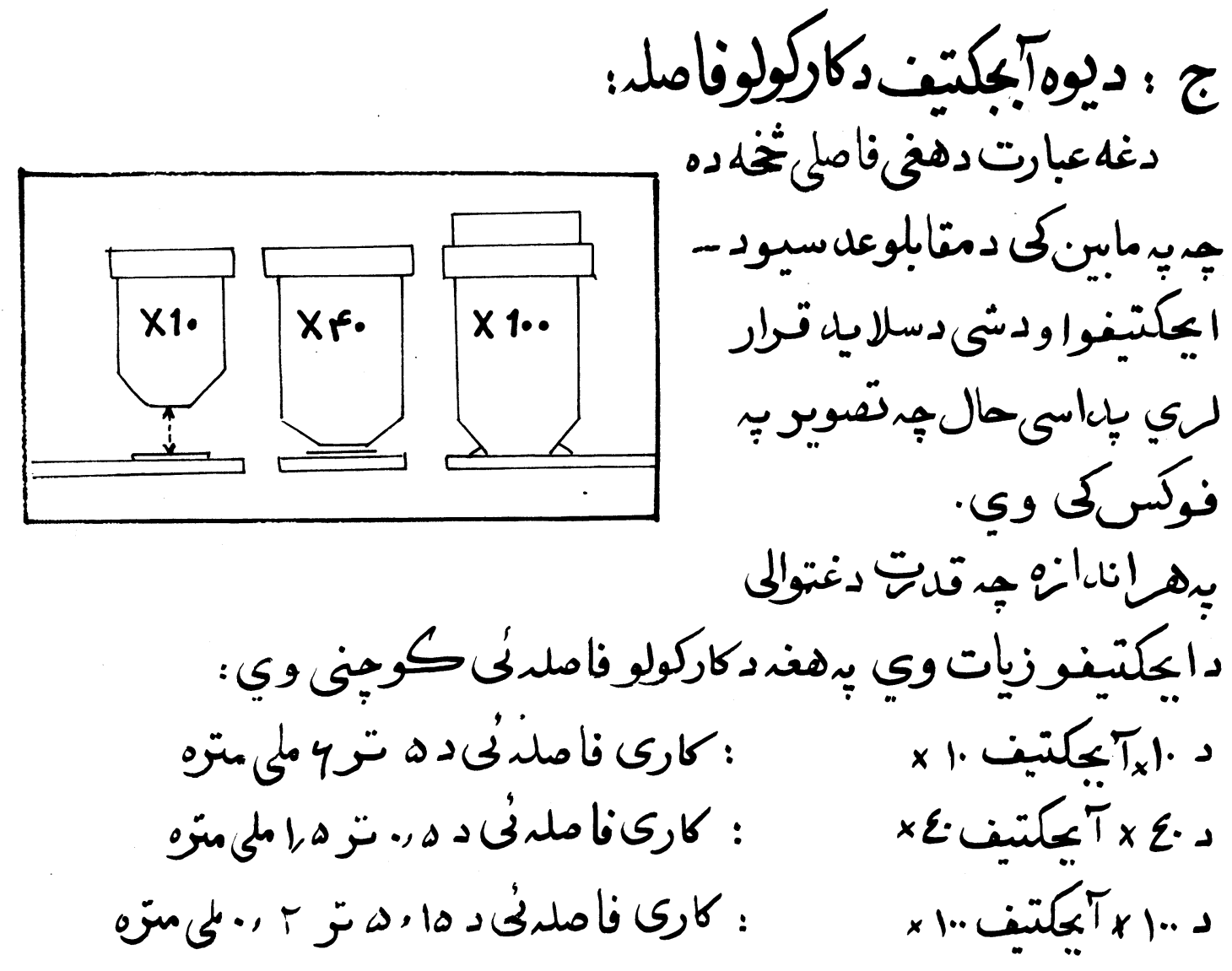




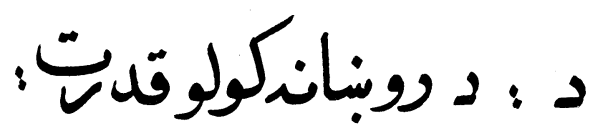

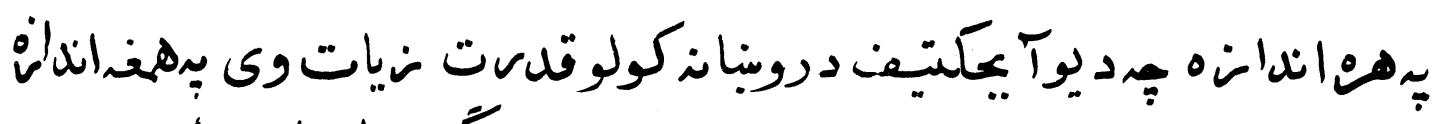

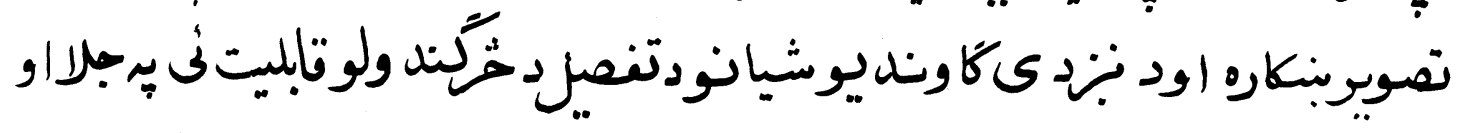

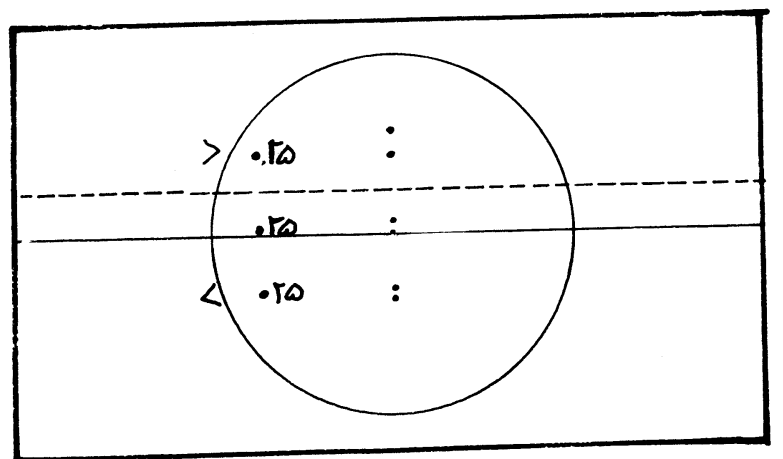

$$
\begin{aligned}
& \text { واضخ دولمبمزيات وى. } \\
& \text { ديوبندبى لابانواردمايكرسكويت }
\end{aligned}
$$

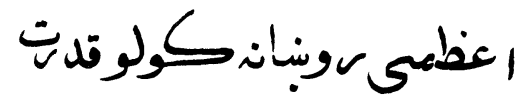

$$
\begin{aligned}
& \text { يحمدود دهز"، مايكوومتز }
\end{aligned}
$$

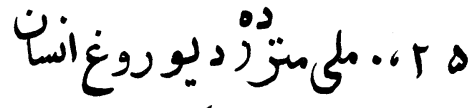

$$
\begin{aligned}
& \text { دستوكىدروبنانكولوتديتي }
\end{aligned}
$$

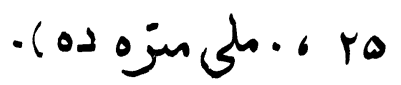

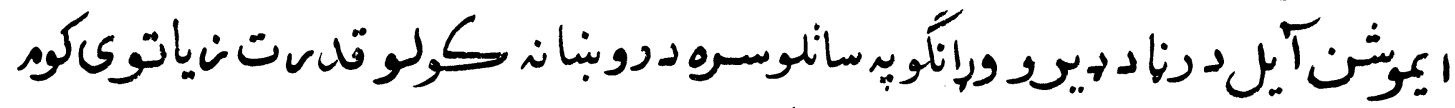

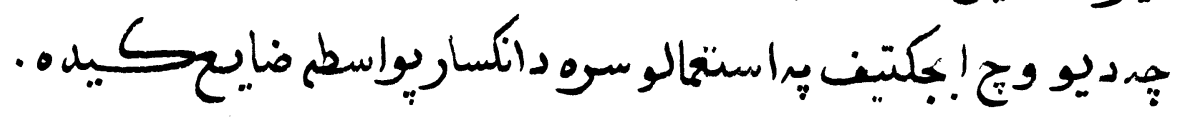
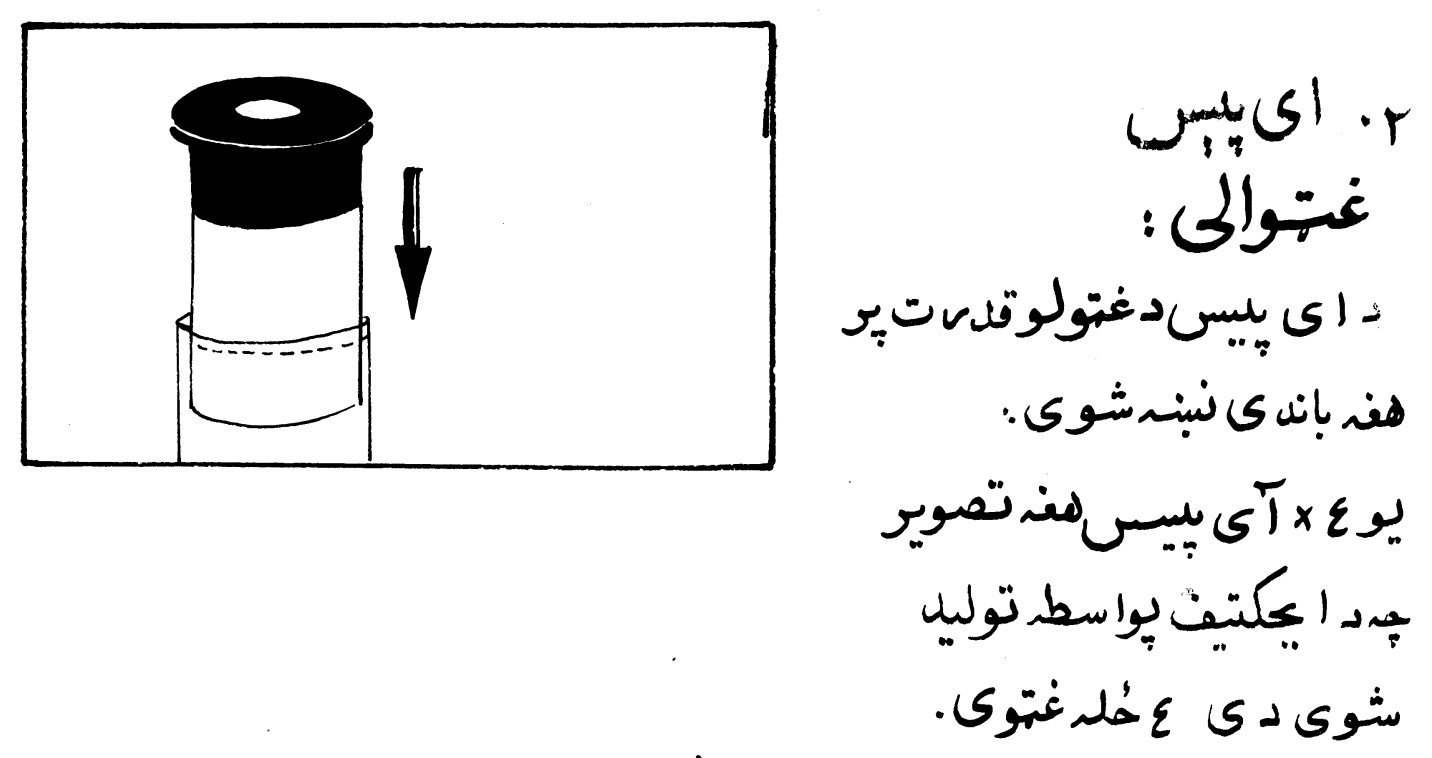


$$
\begin{aligned}
& \text { يو } 4 \text { × آى بنس تصوير } 7 \text { حُله غنتوى. }
\end{aligned}
$$

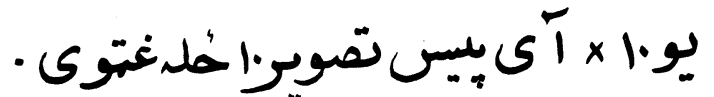

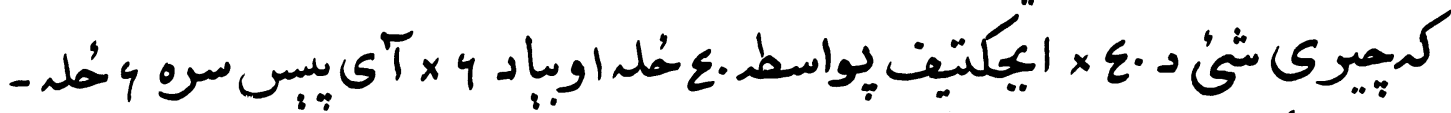

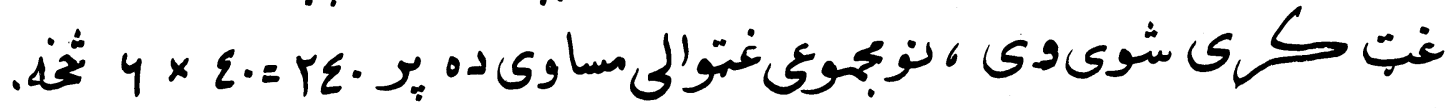

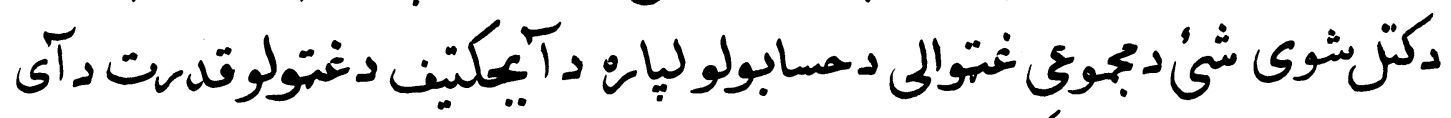

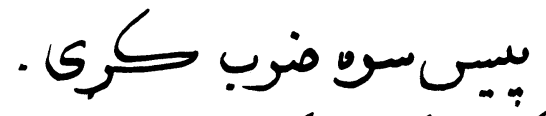

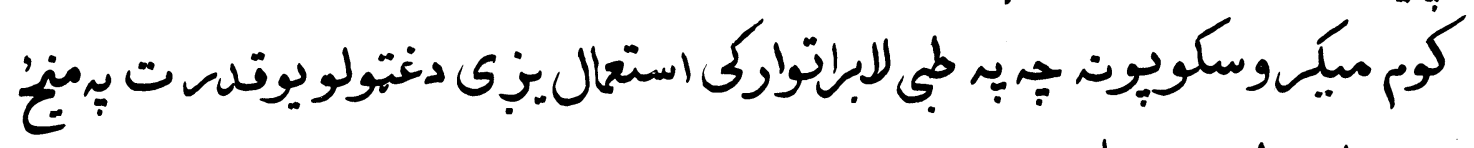

د.

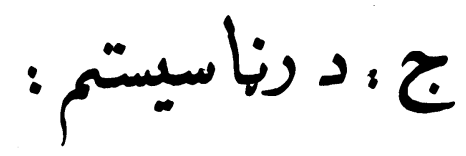

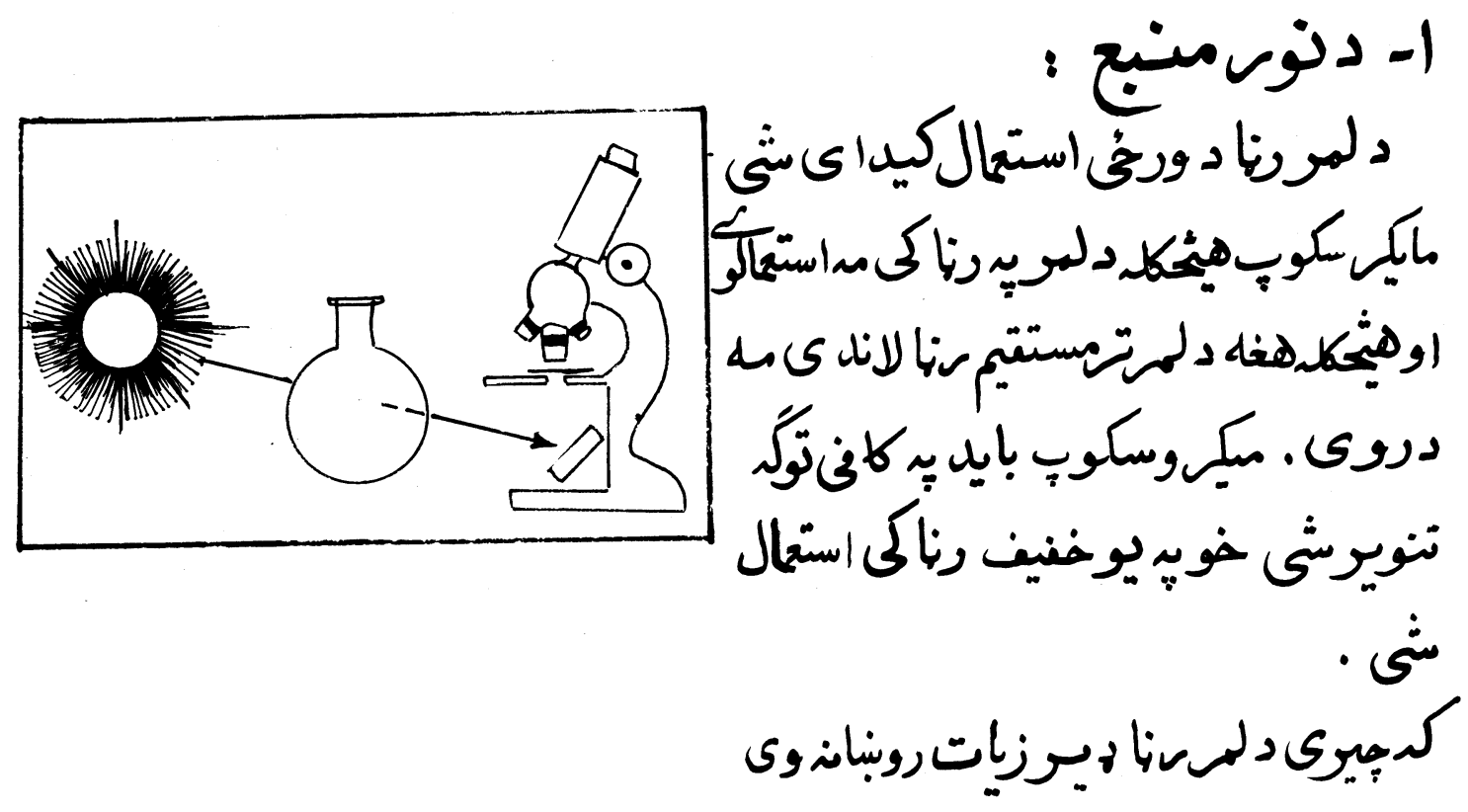




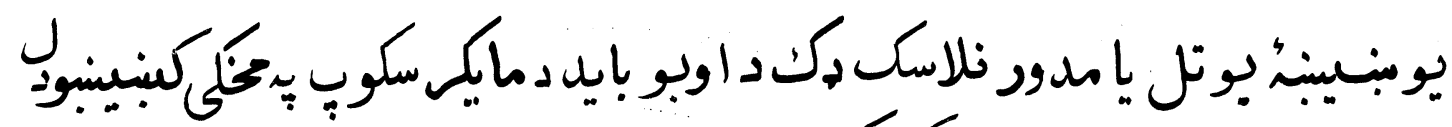

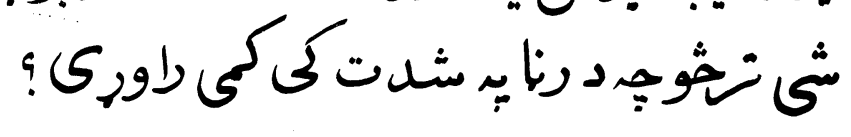
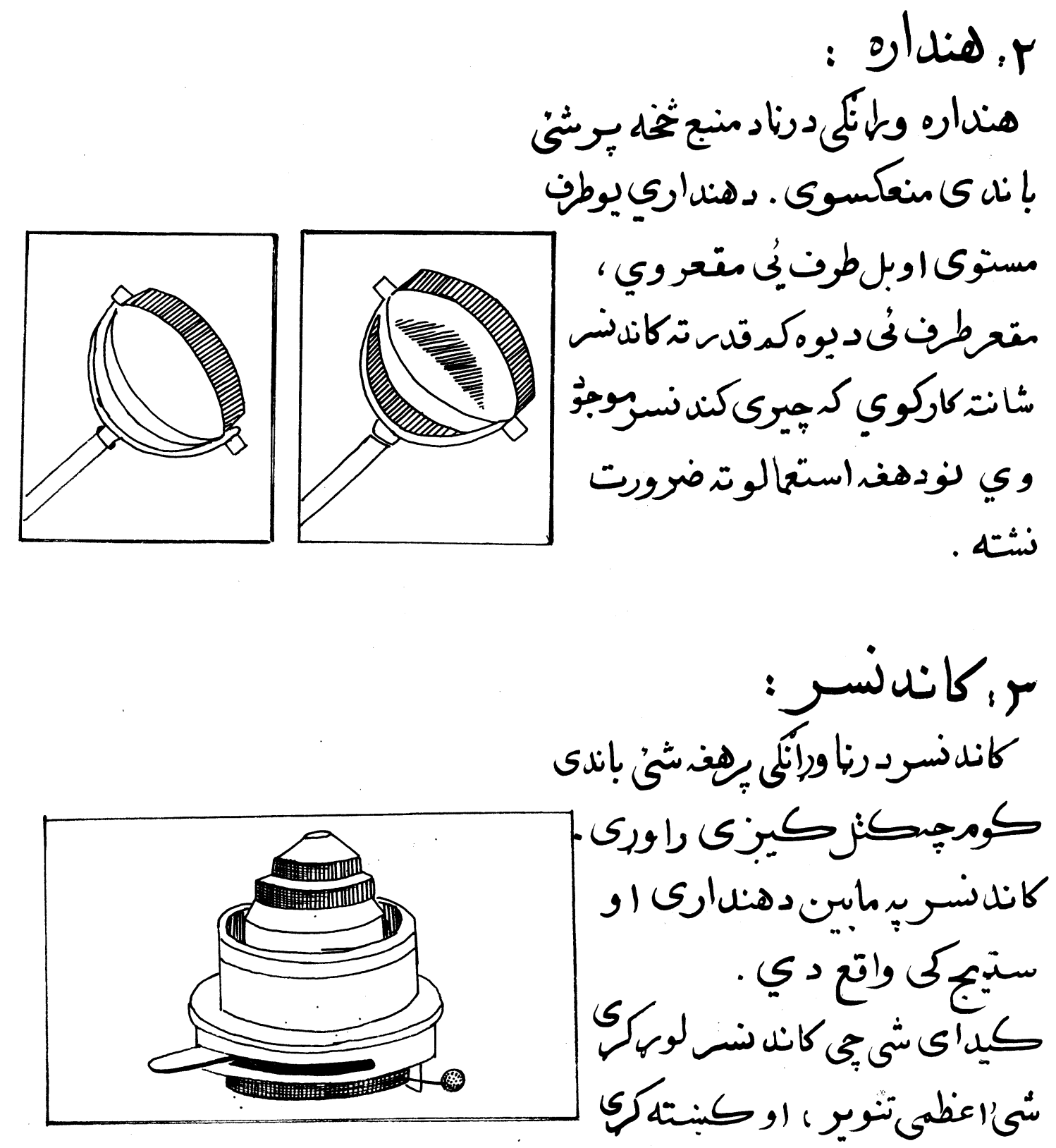

$\pi$ 


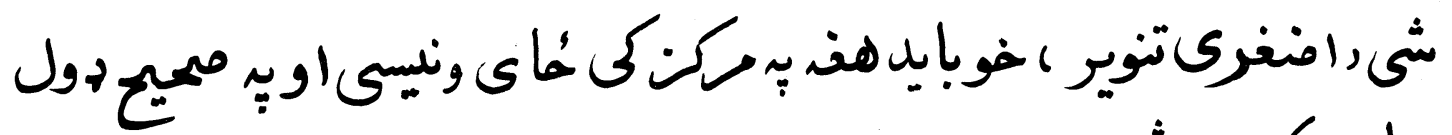

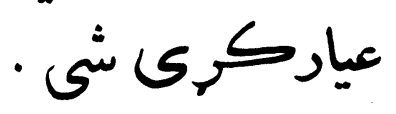

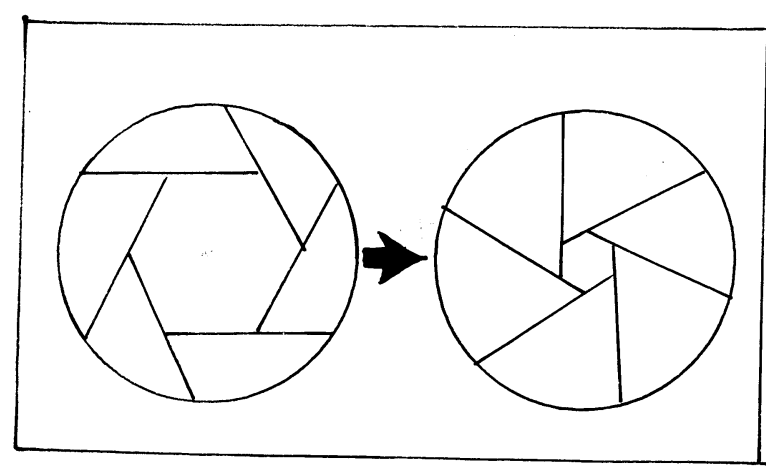

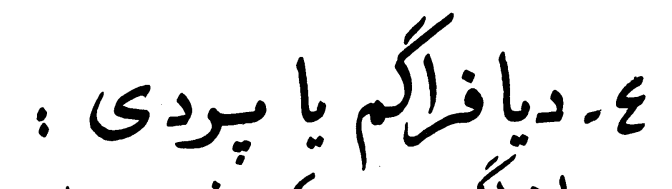

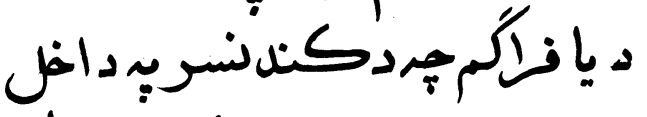

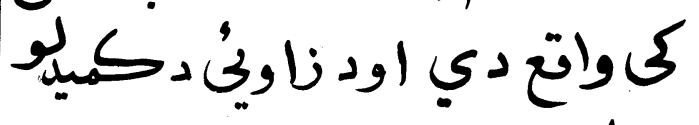

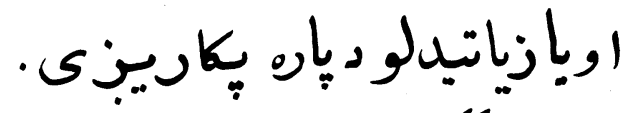

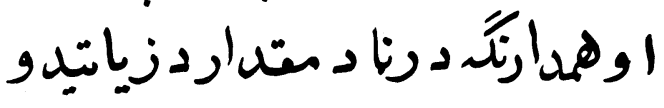
إكميدودياره بم وكاندنسرت

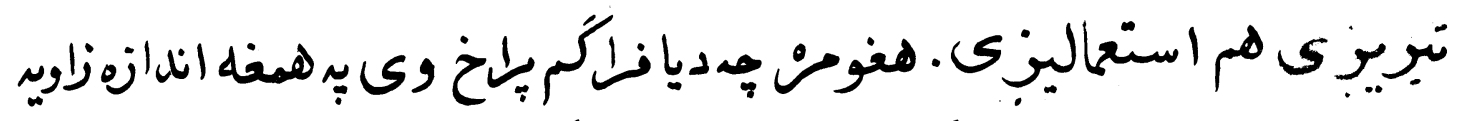

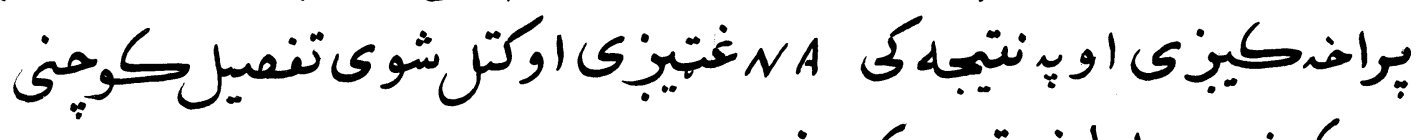

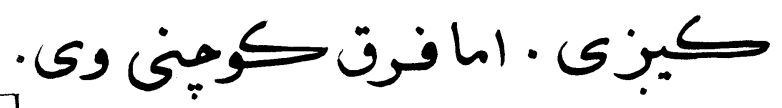
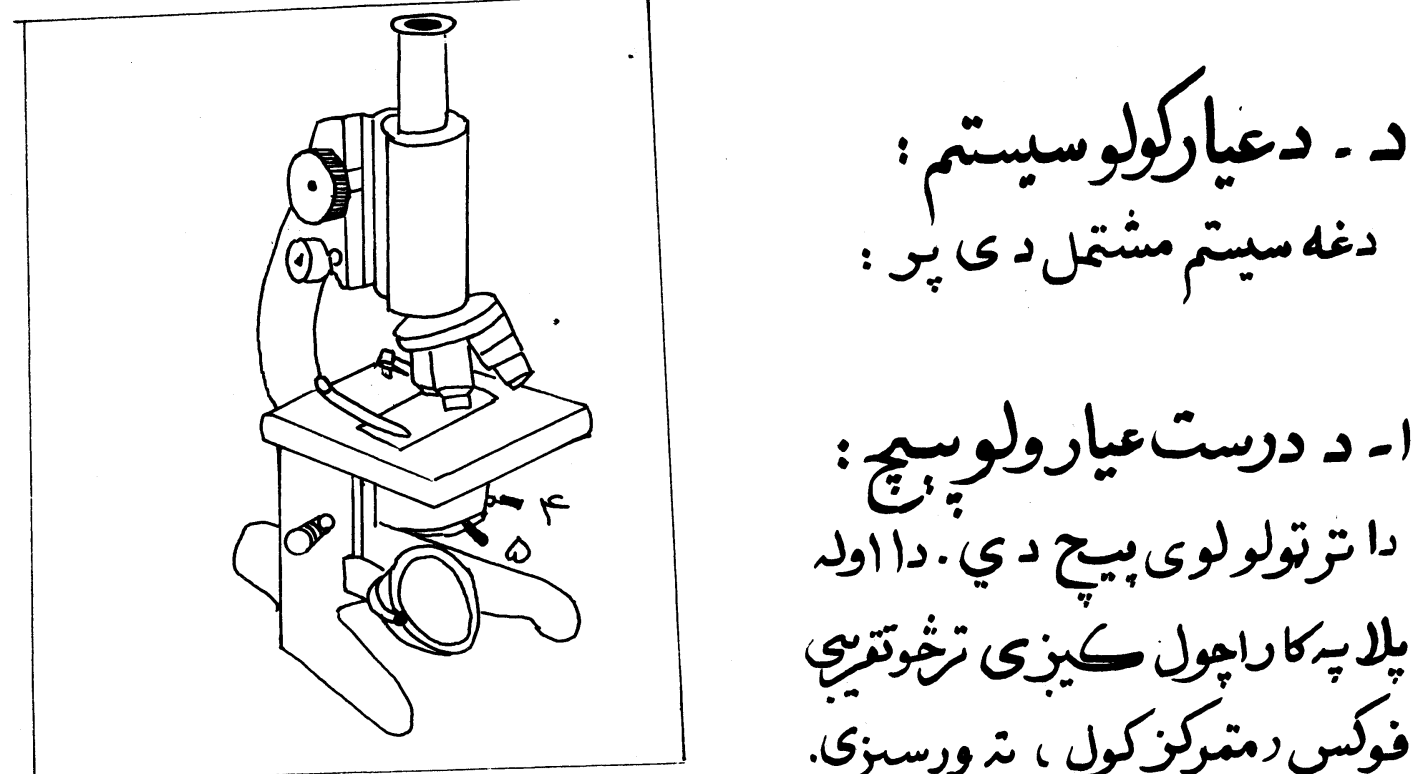

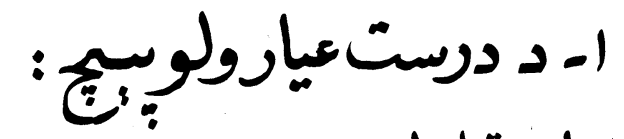

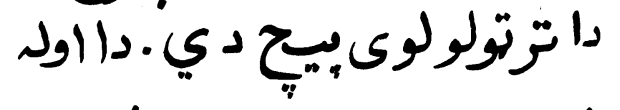

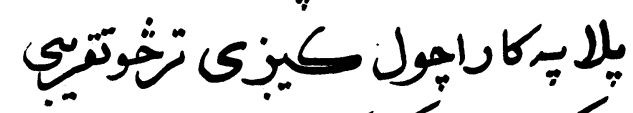

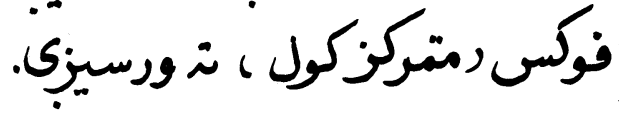




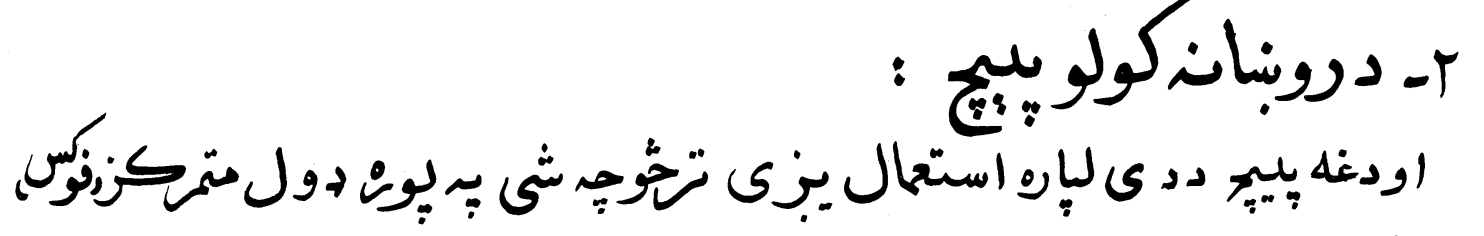

.

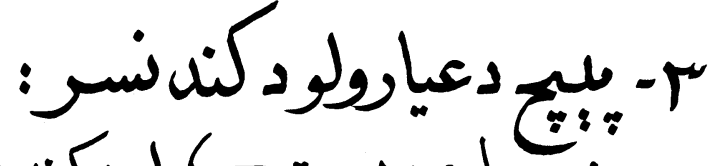

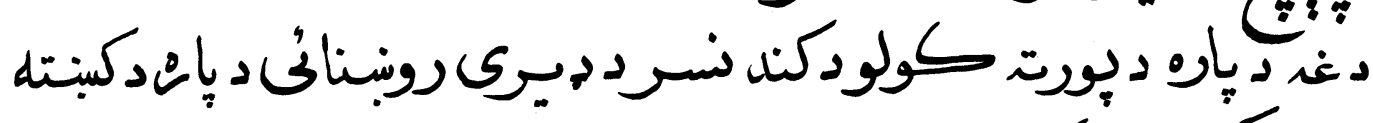

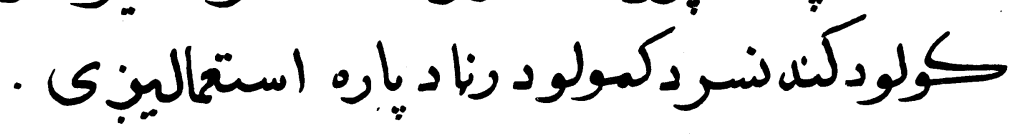

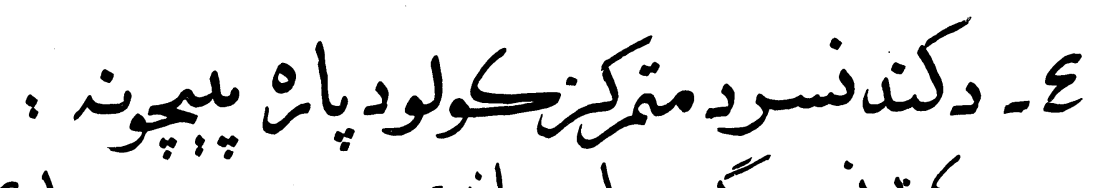

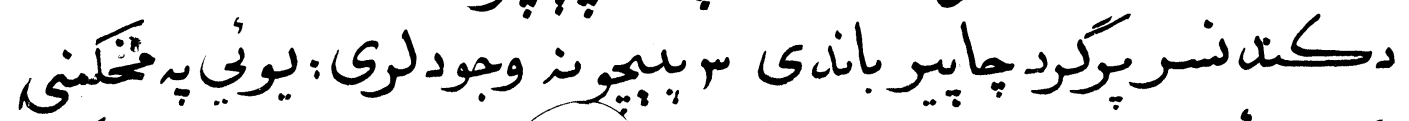

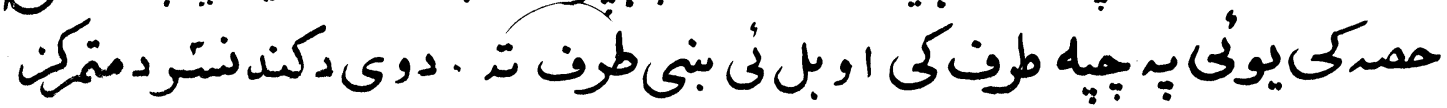

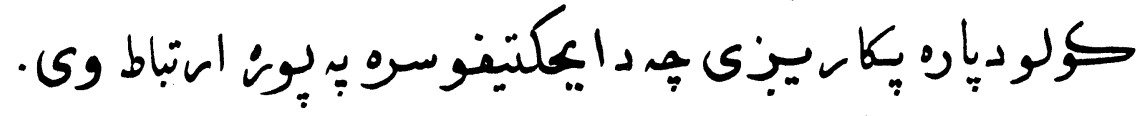

هـد ديا فــأكم دمحورحل :

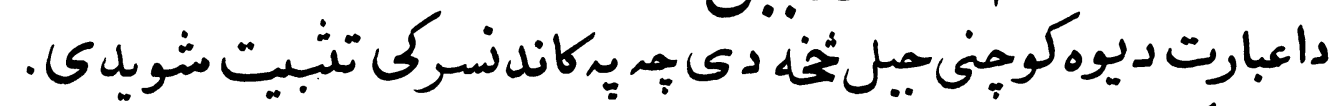

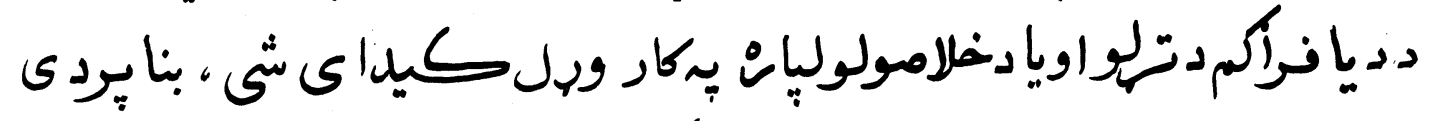

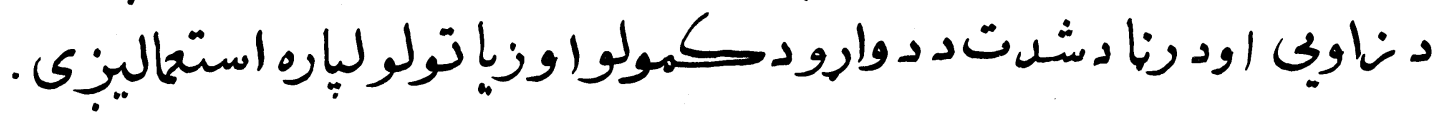




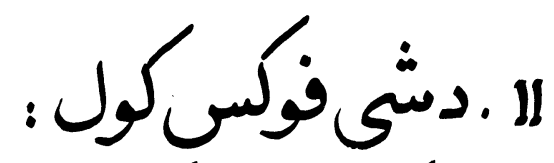

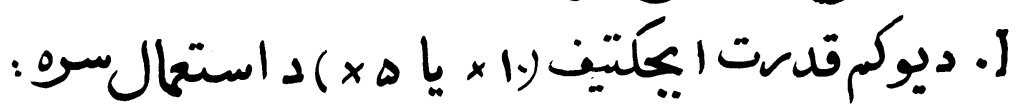

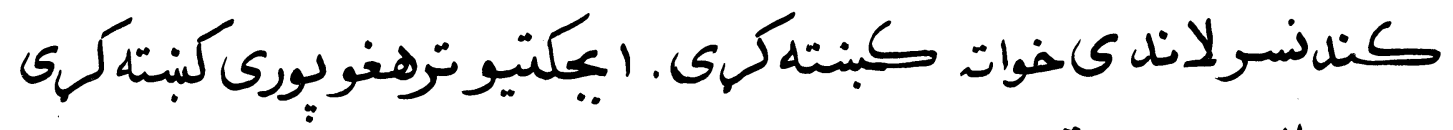

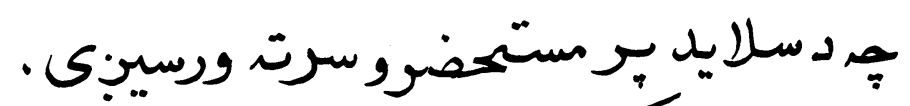

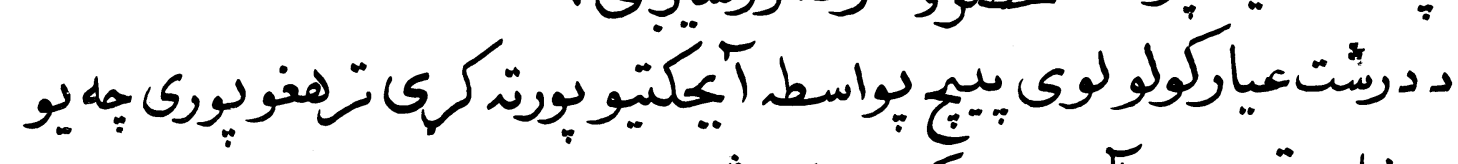

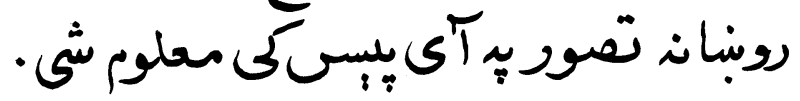

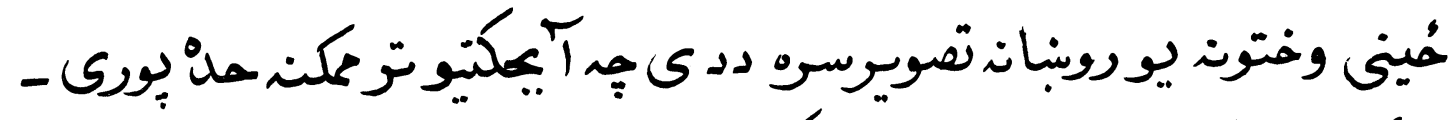

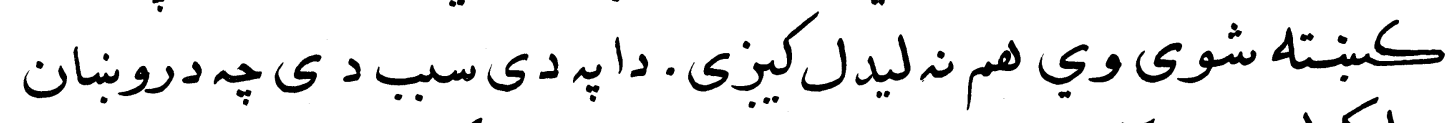

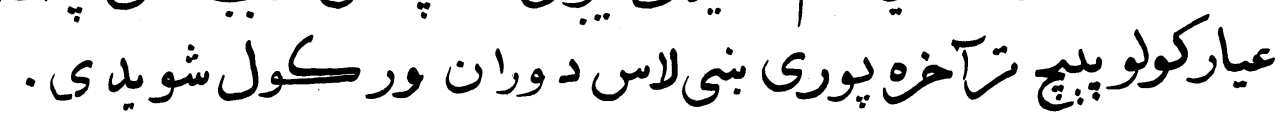

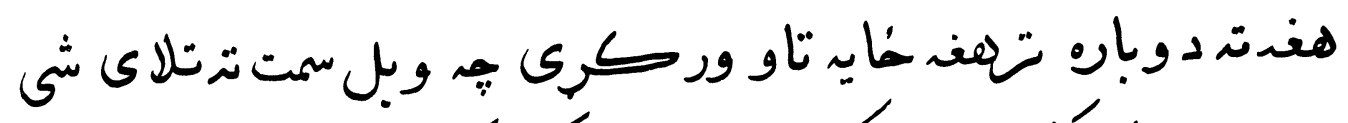

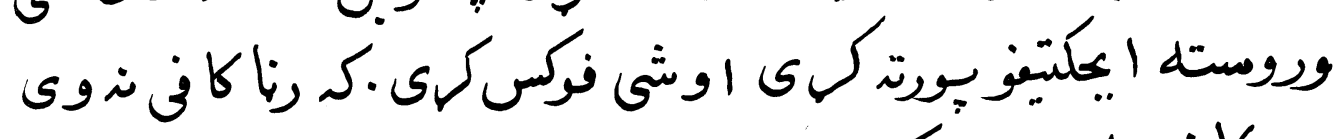

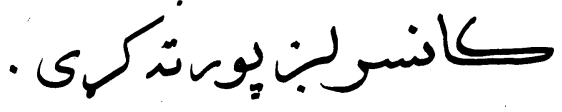

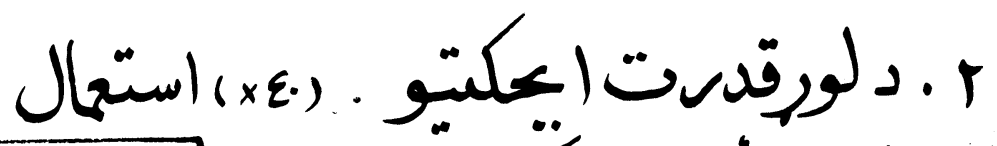

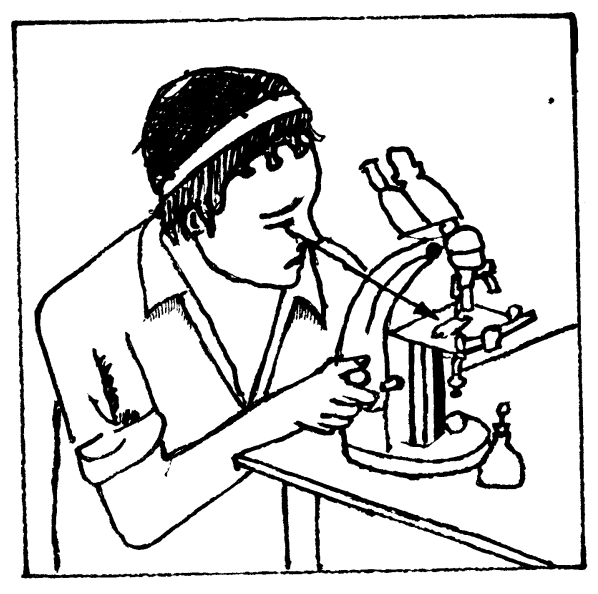

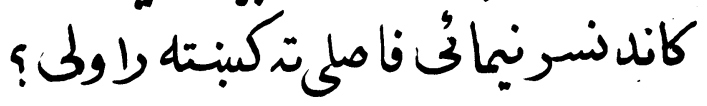

ايجكتيوترهنويورىكبنته راولي

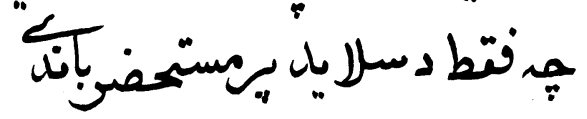

قاروراي.

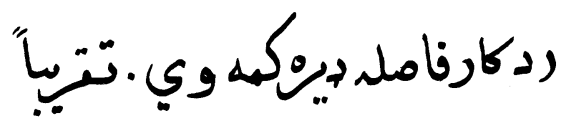

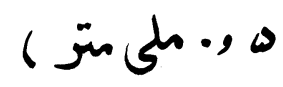

is 


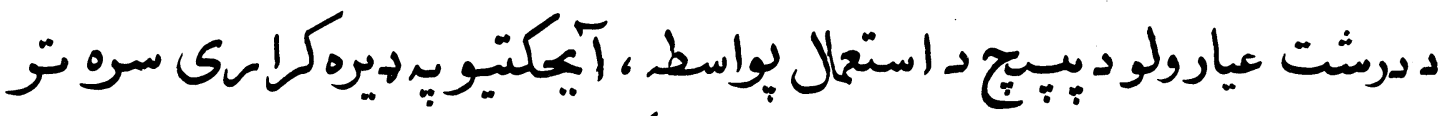

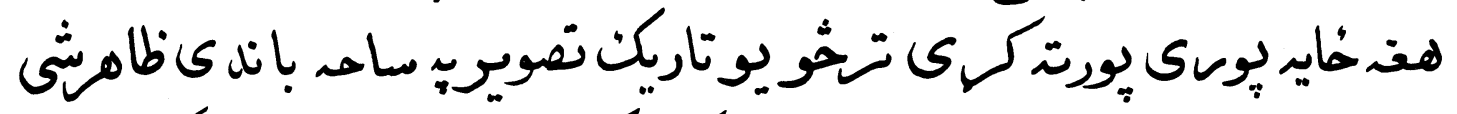

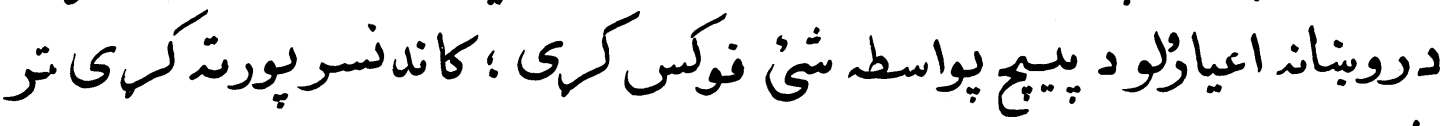

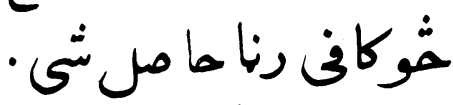

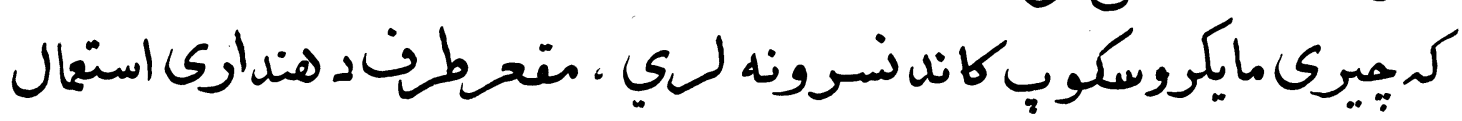
كرئ.

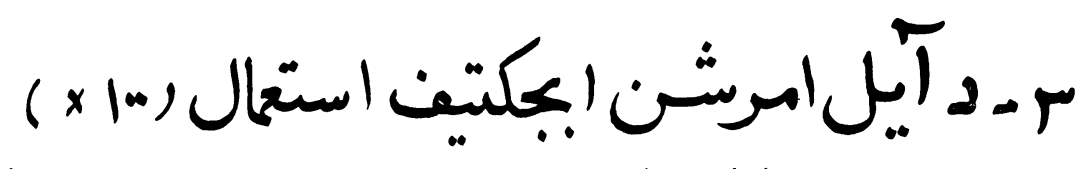

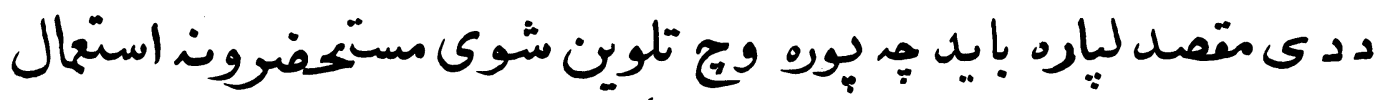

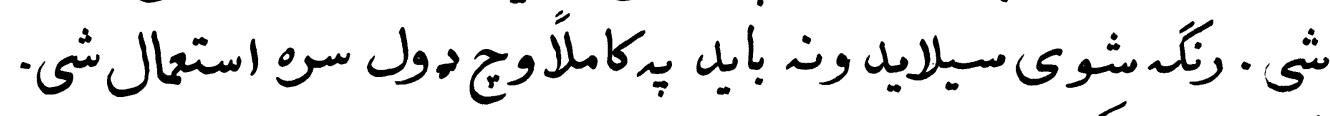

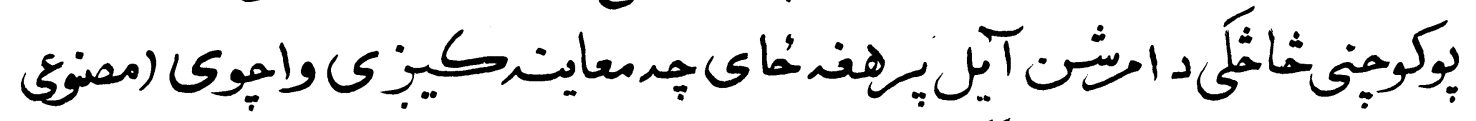

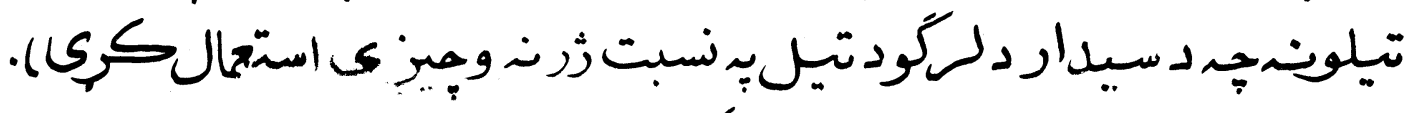




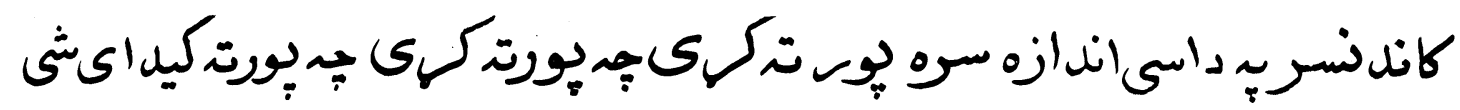

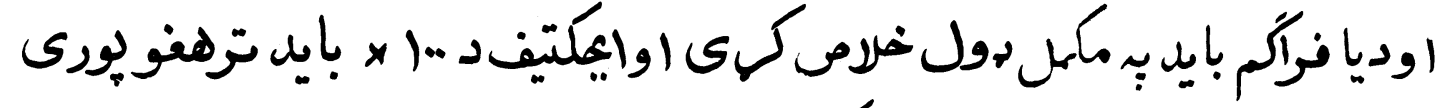

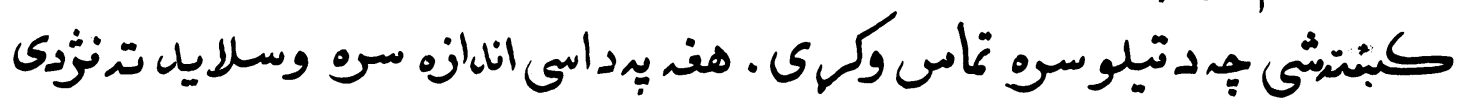

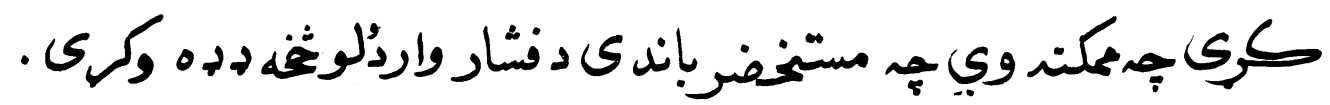

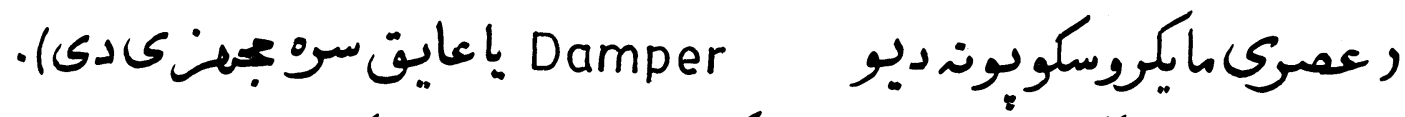

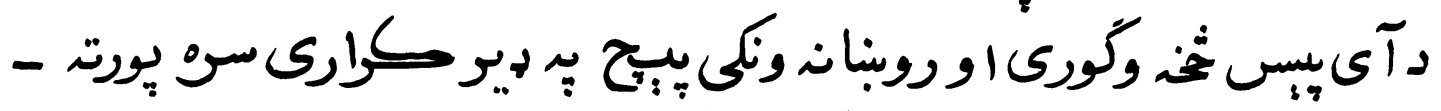

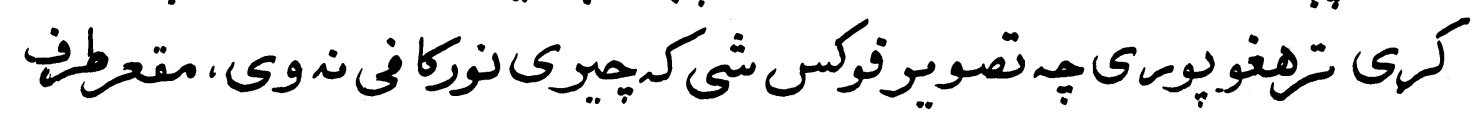

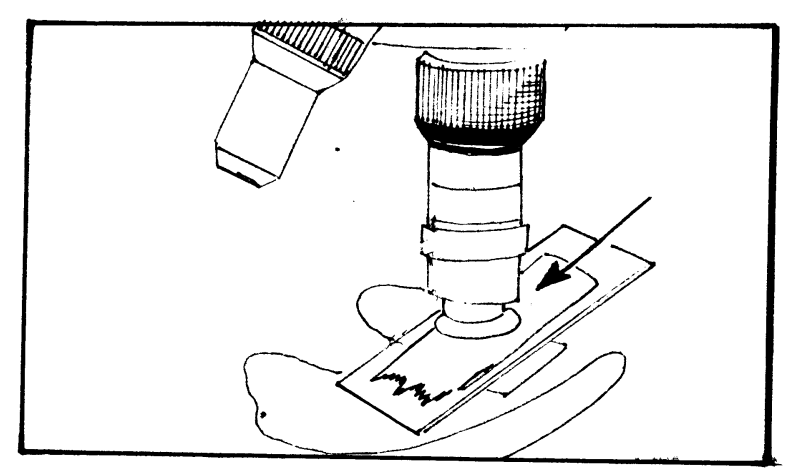




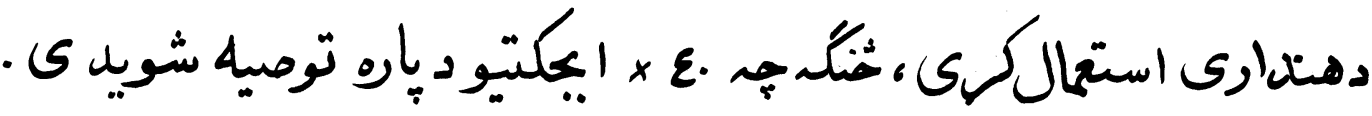

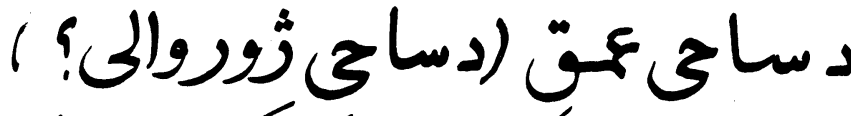

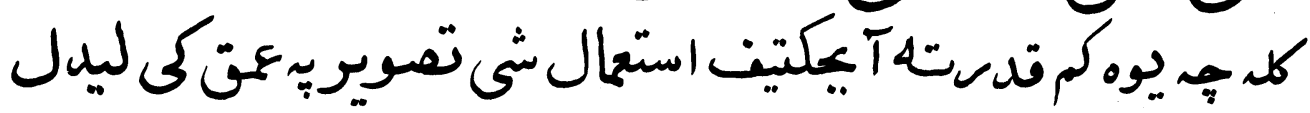

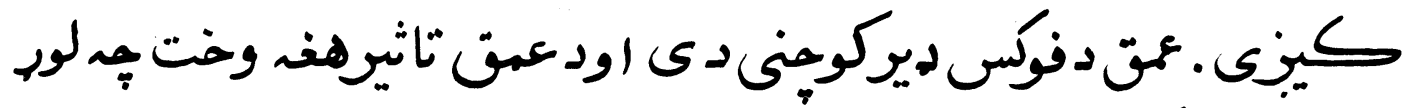

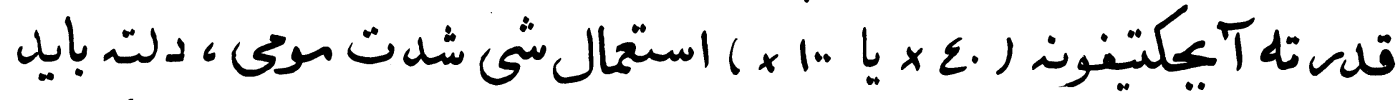

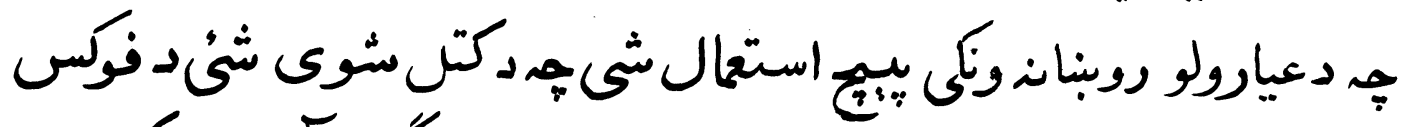

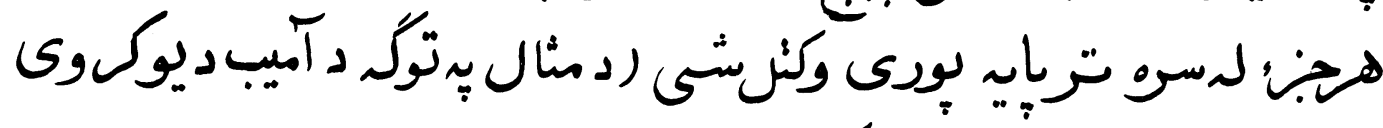

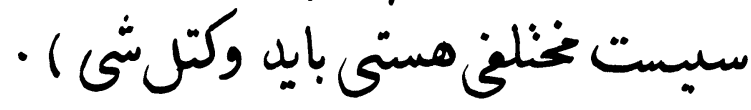

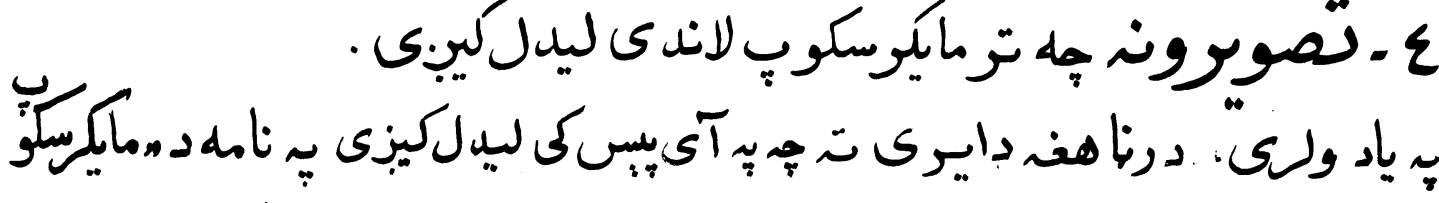

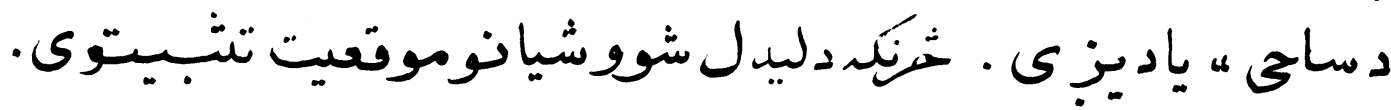

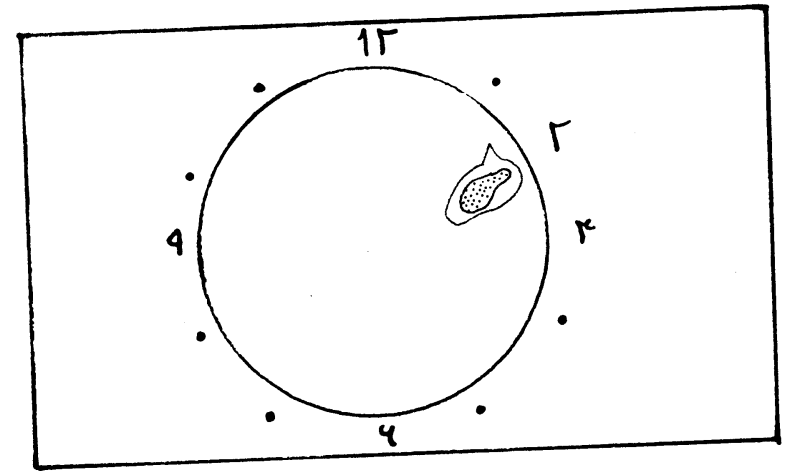

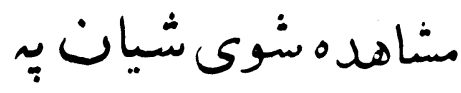

$$
\begin{aligned}
& \text { ماهه كى كبداى شنى } \\
& \text { مَ ارنباط د عتربود } \\
& \text { ساعت وضع شتى . } \\
& \text { دمشال بِد ول : }
\end{aligned}
$$

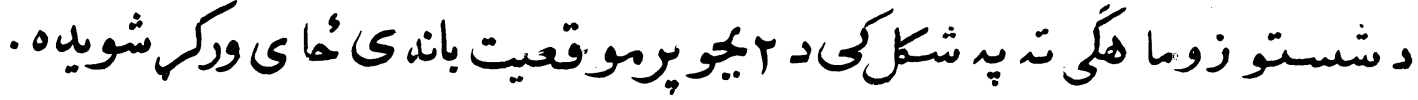




\section{دتصويرو معكوسيدل :}

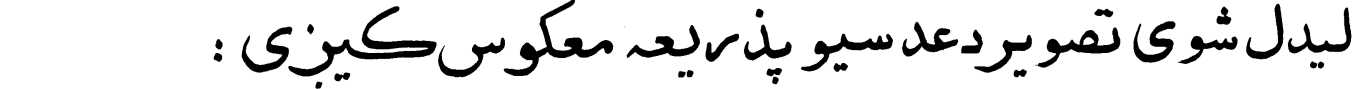

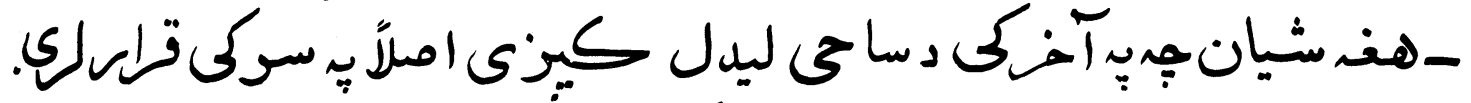

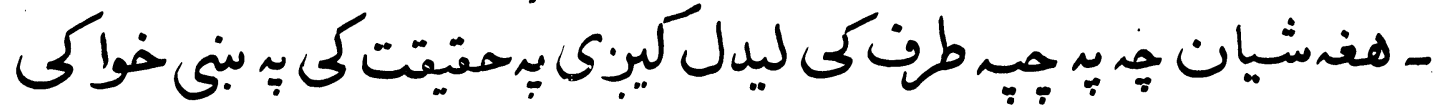

$$
\text { قسراردي. }
$$

$$
\text { حكت وركولوشى تَ : }
$$

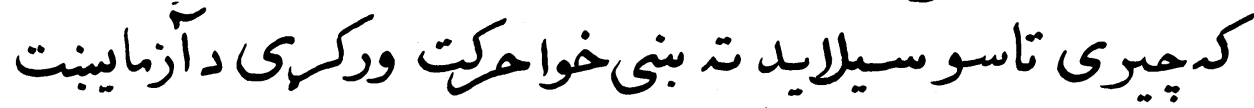

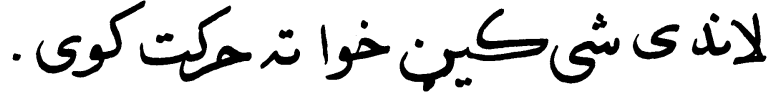

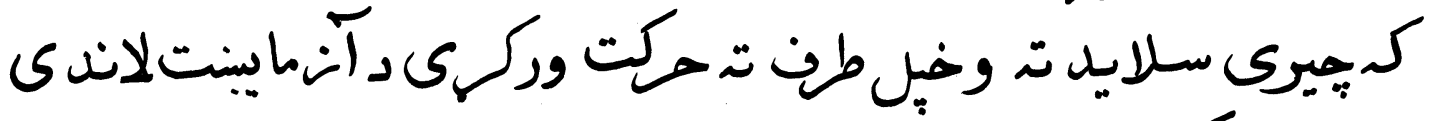

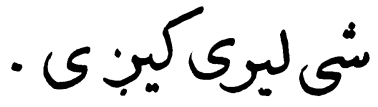
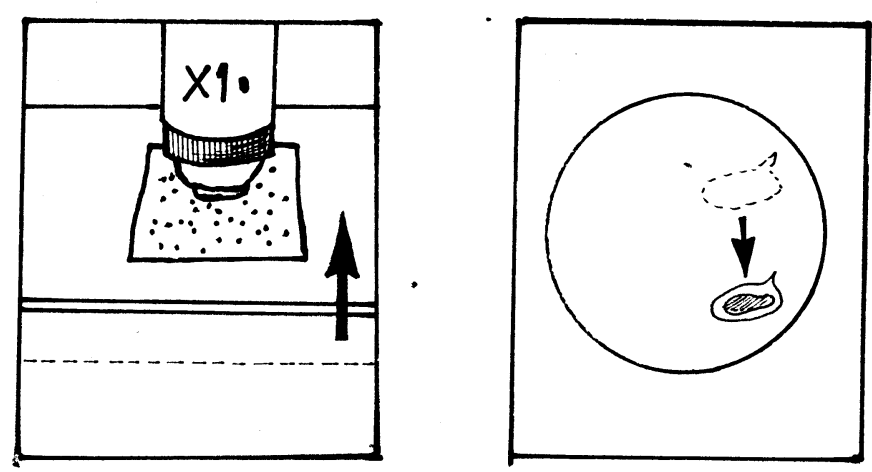


\section{دابكتّتفتغير :}

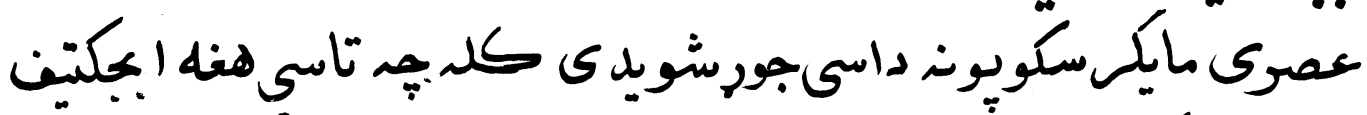

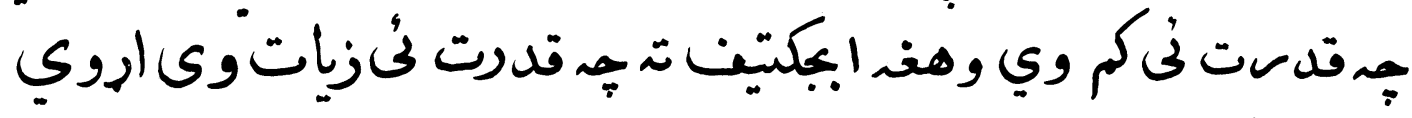

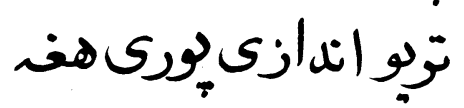
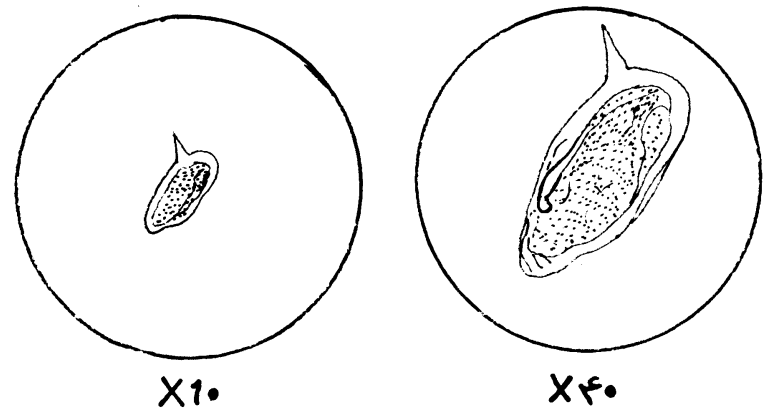

شى تورك داسى ن وى نور

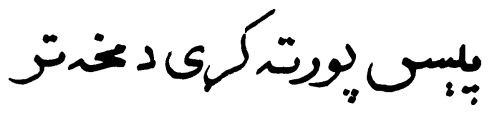

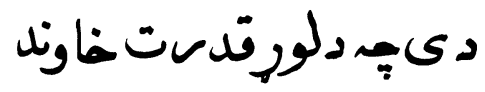
ايكتين وت تغبروركي

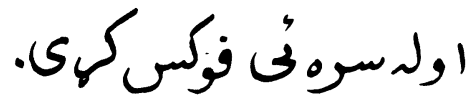

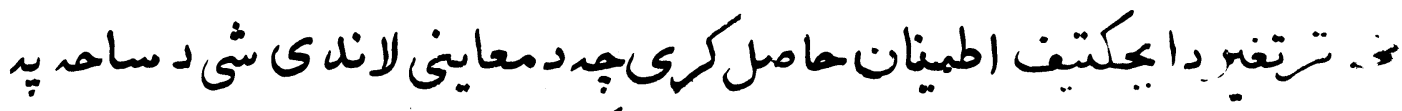

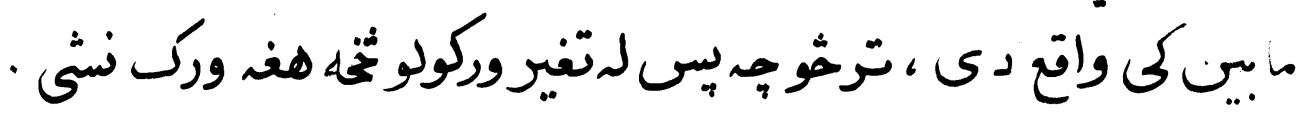

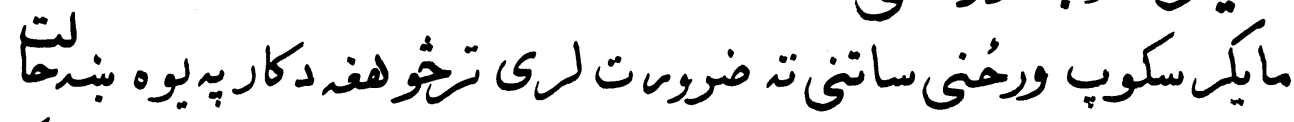

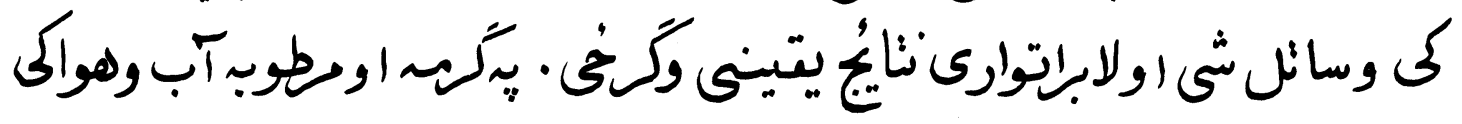

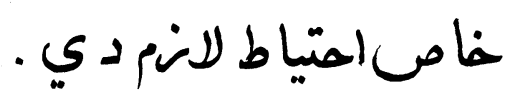

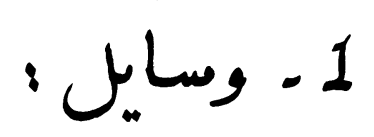

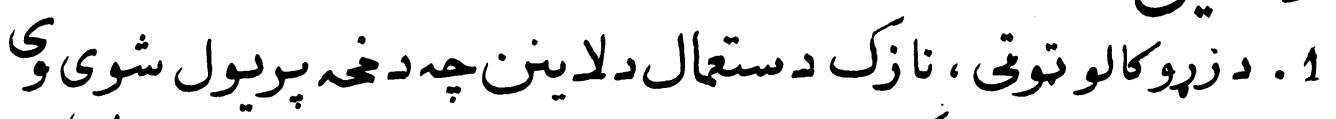

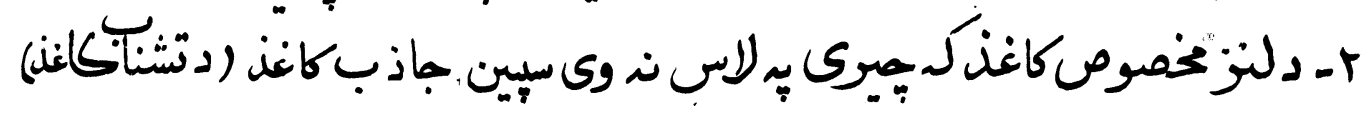




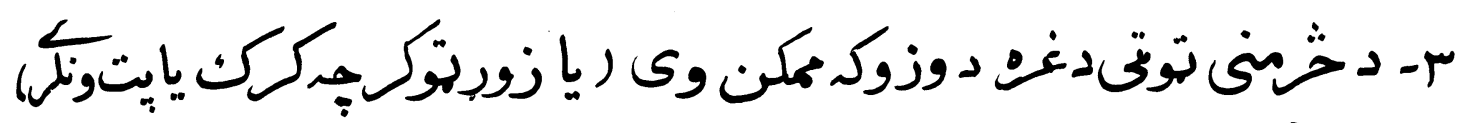

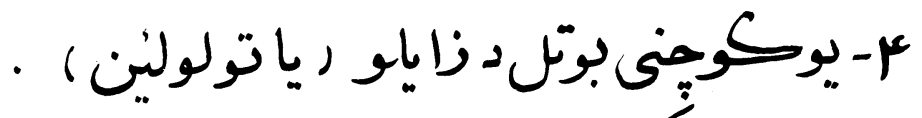

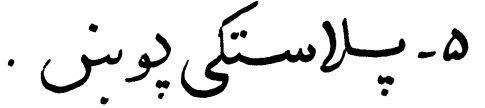

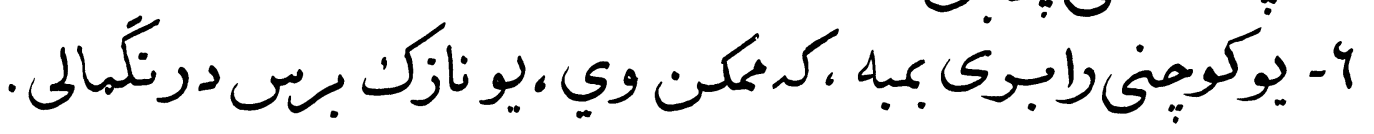

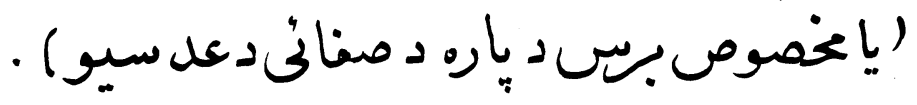

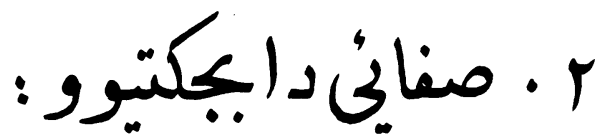

وج (يككتيوتئه :

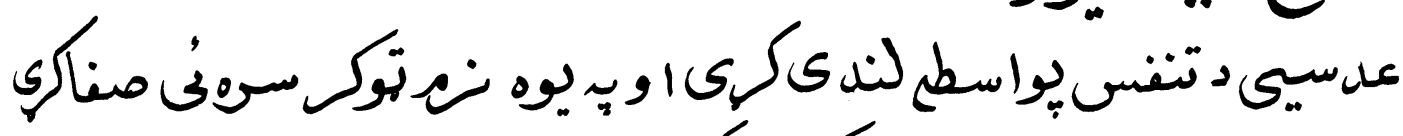

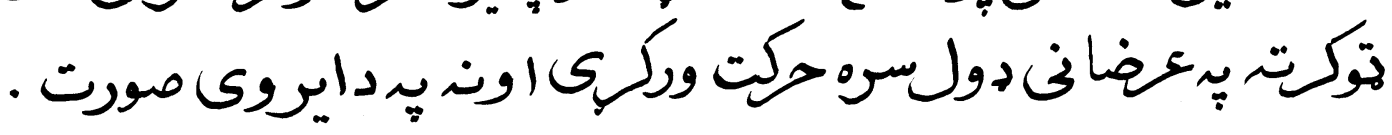

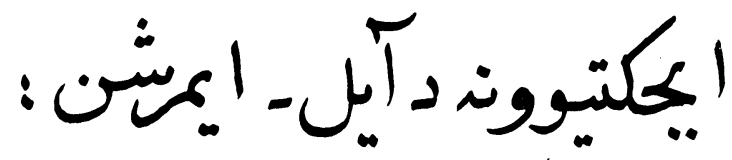

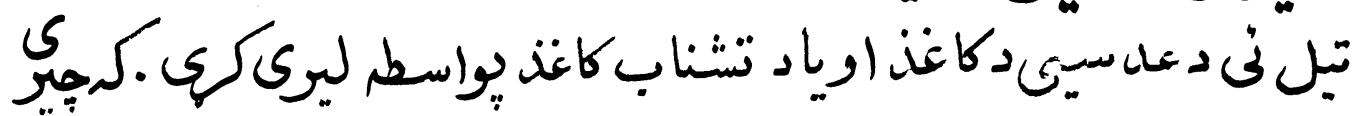

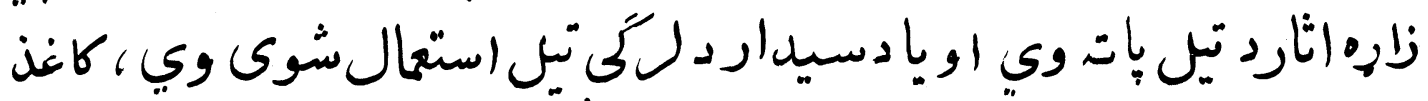

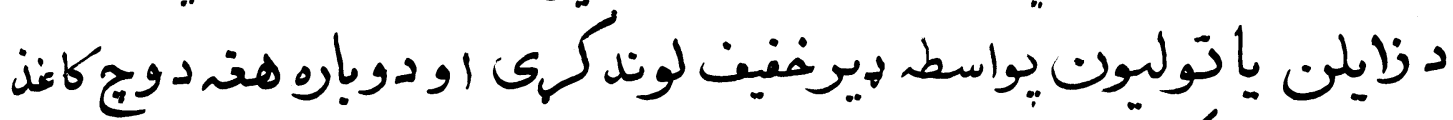

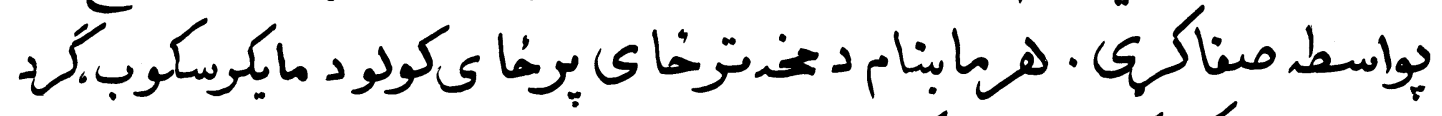

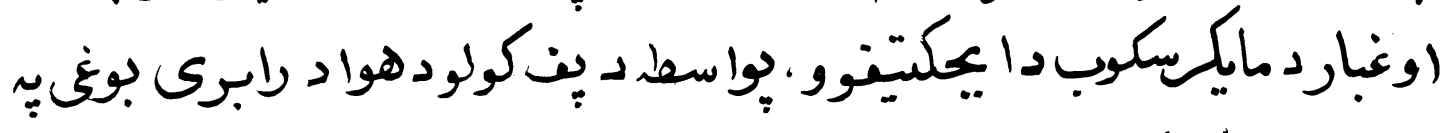

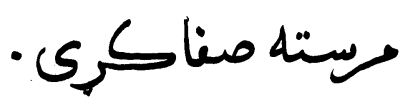

r) 


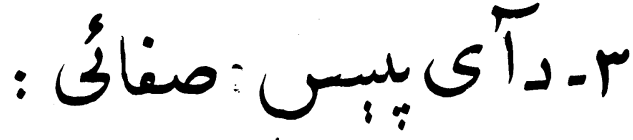

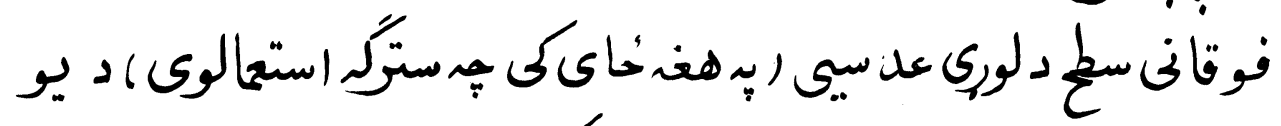

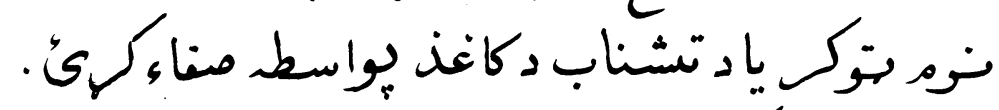

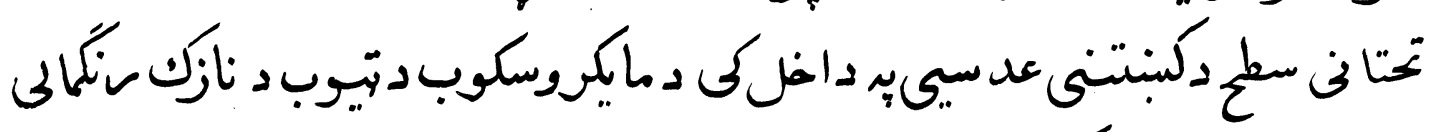

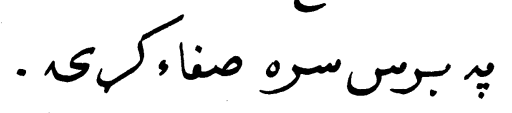

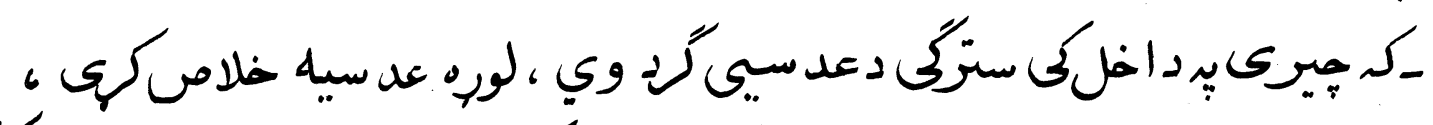

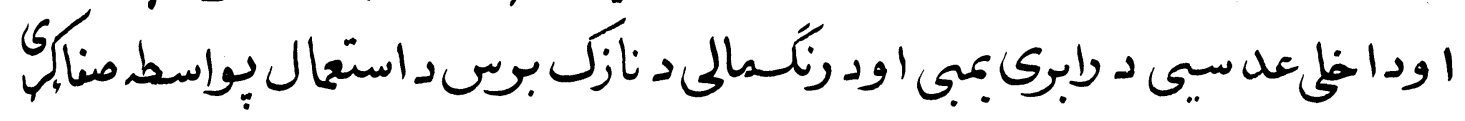

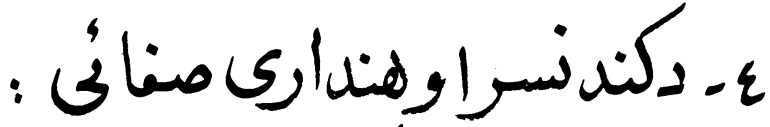

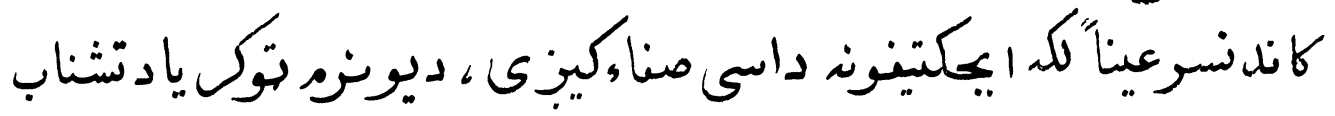

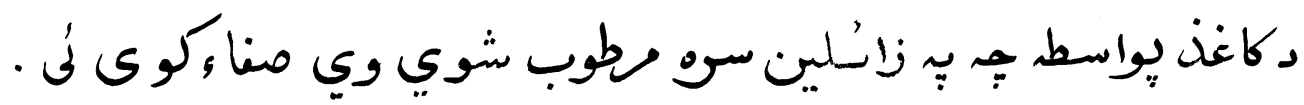

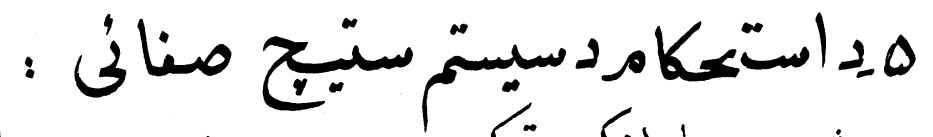

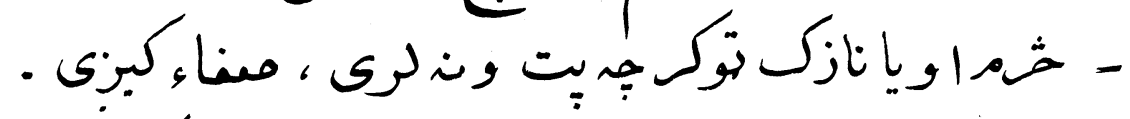

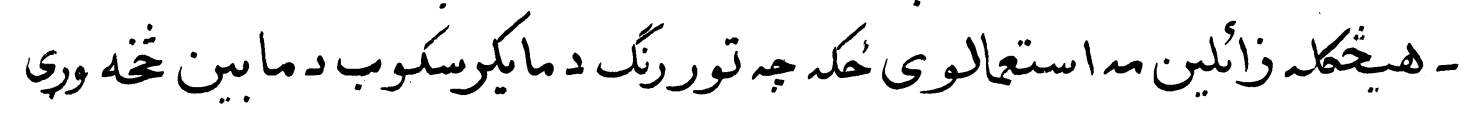

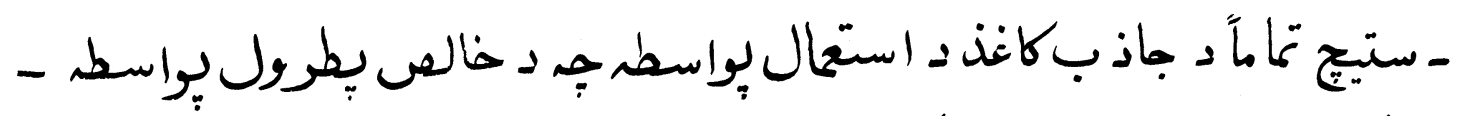

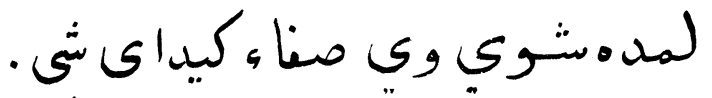

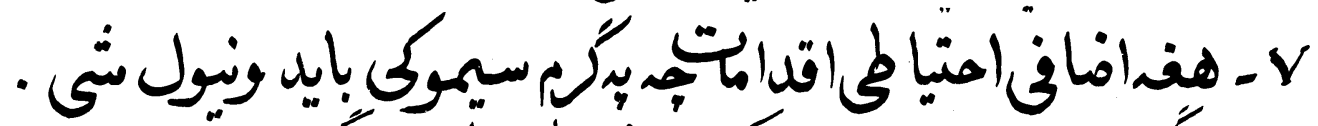

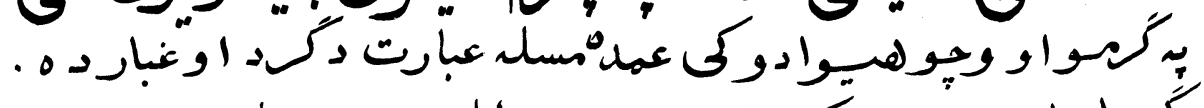

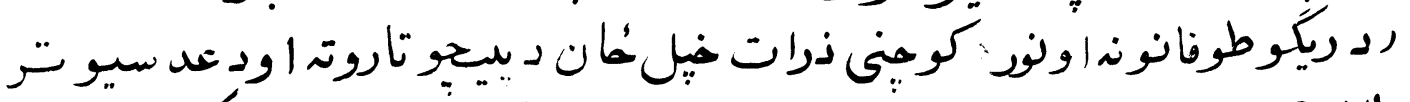

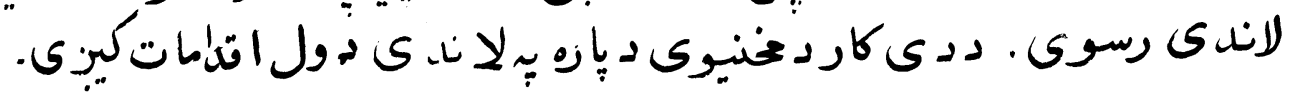




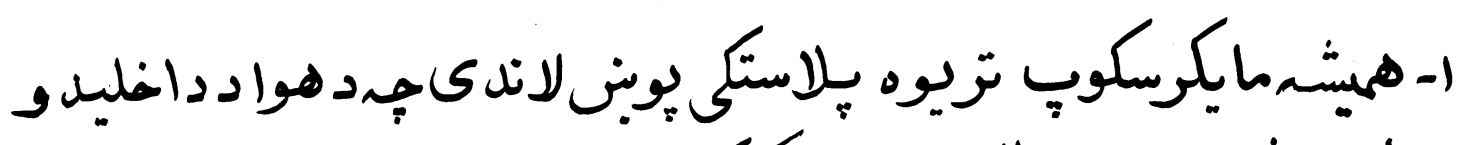

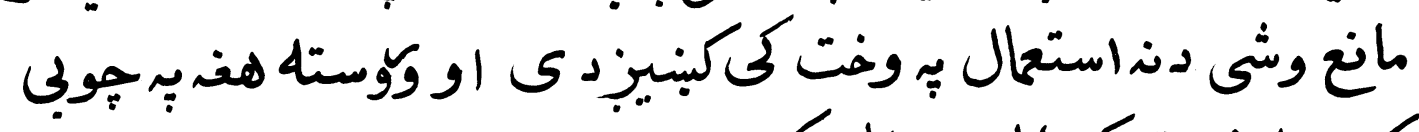

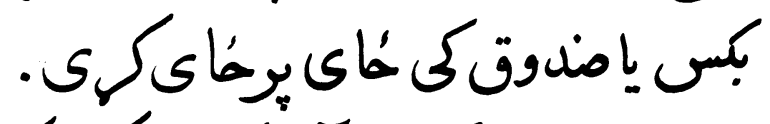

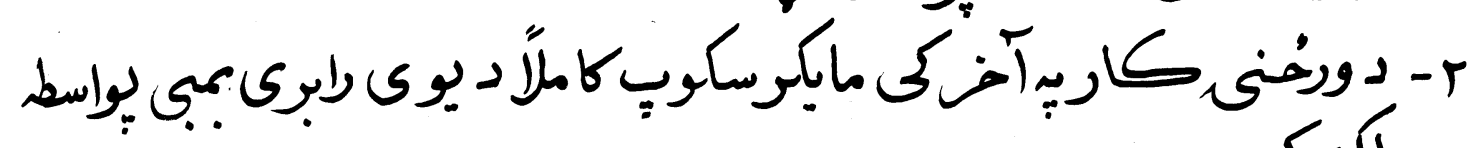

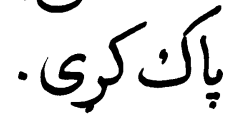

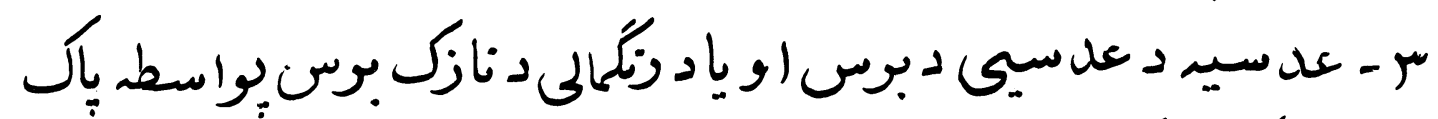

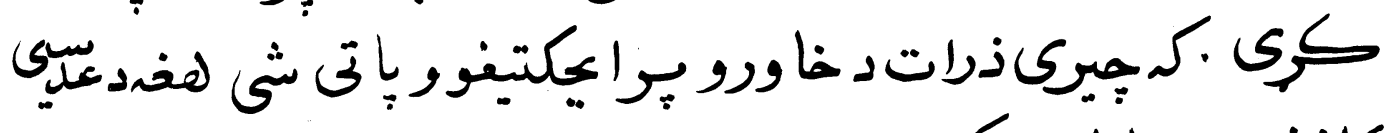

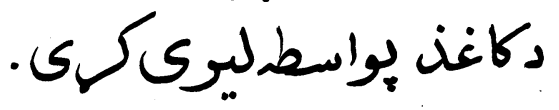

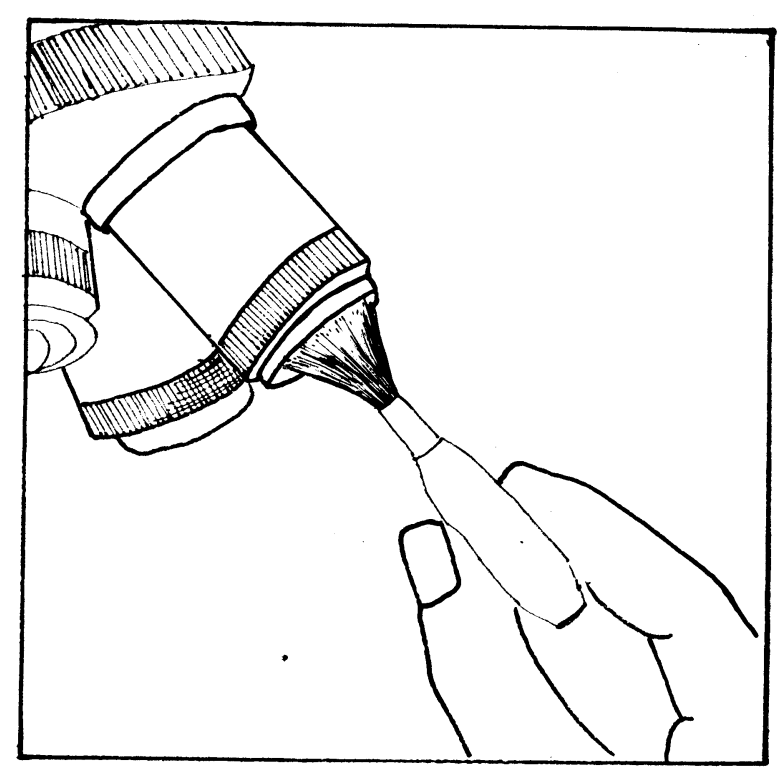

re 


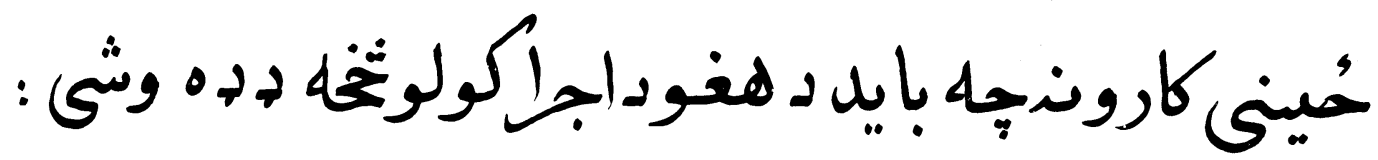

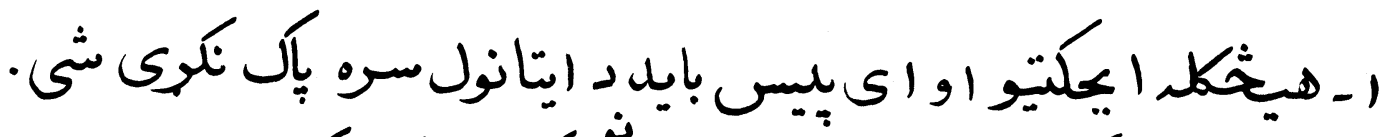

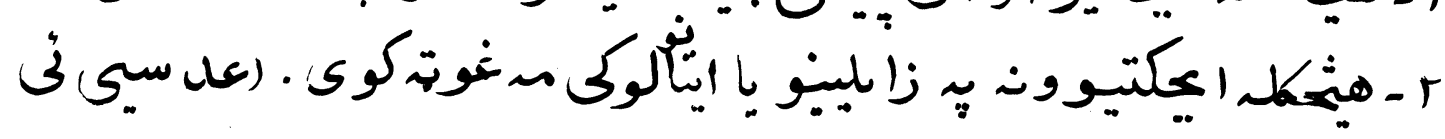

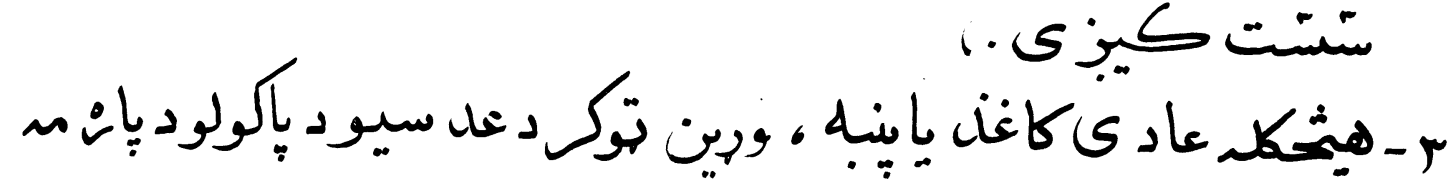
(ستخحالوى .

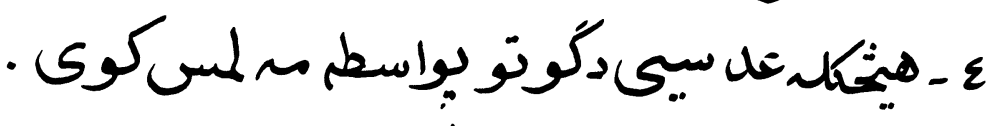

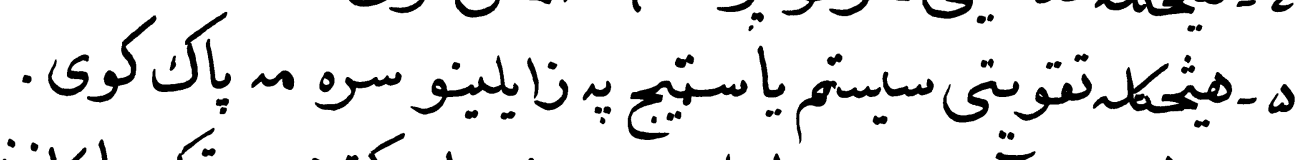

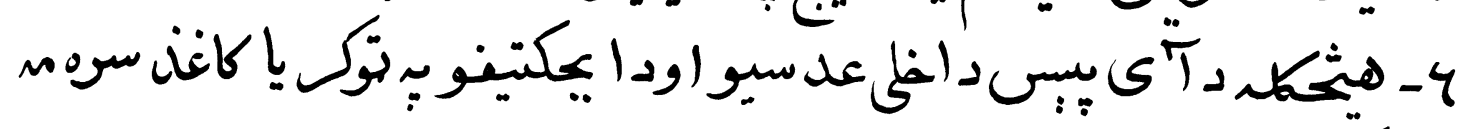

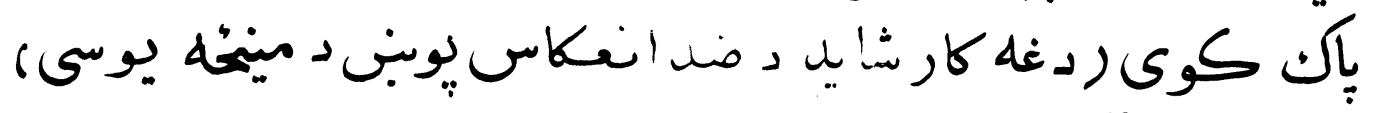

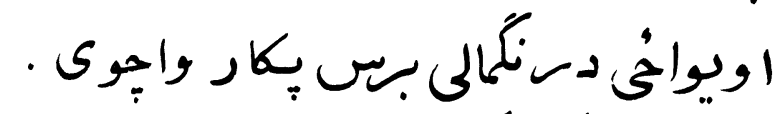

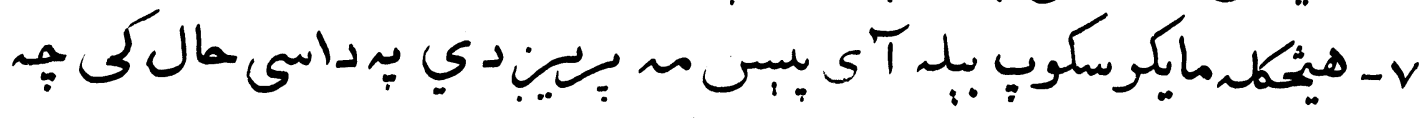

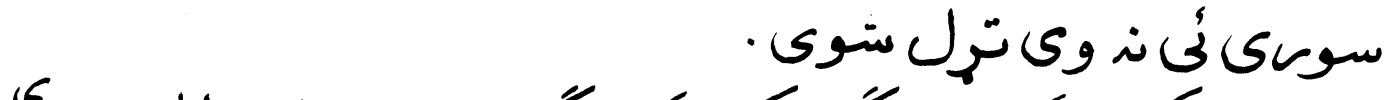

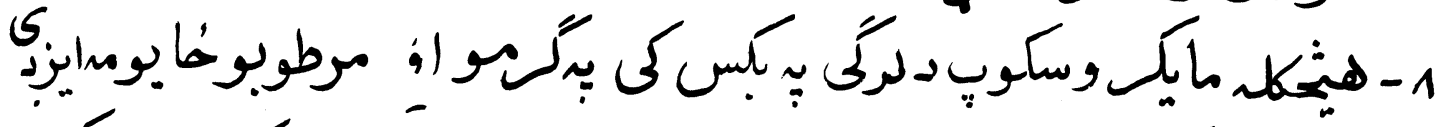

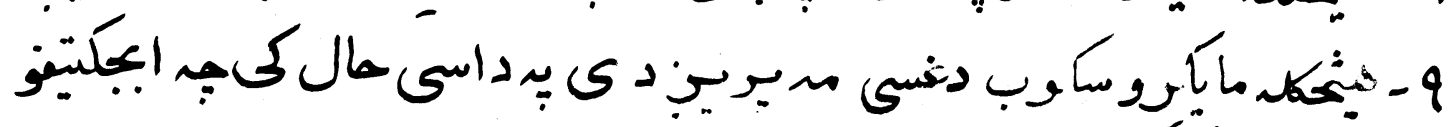

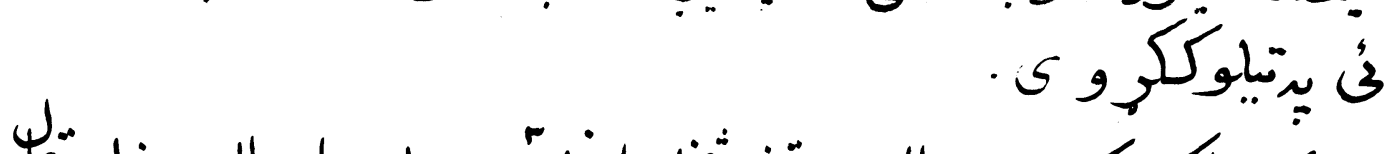

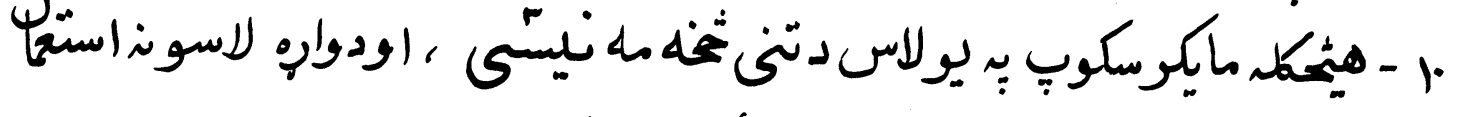

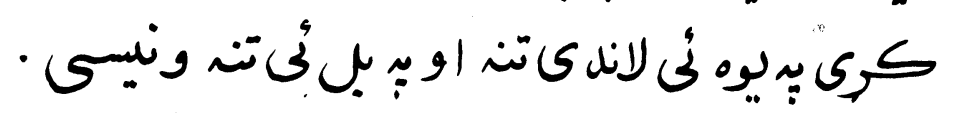




\section{دنمونوثنبتول}

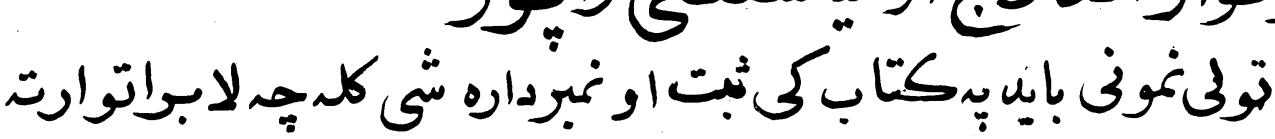

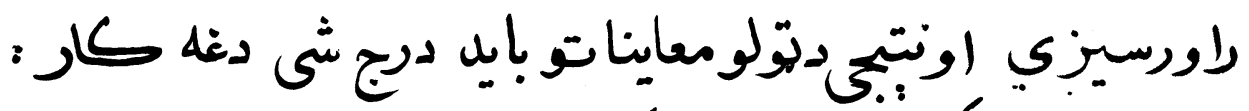

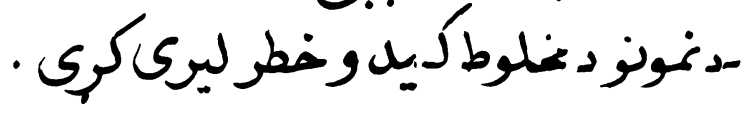

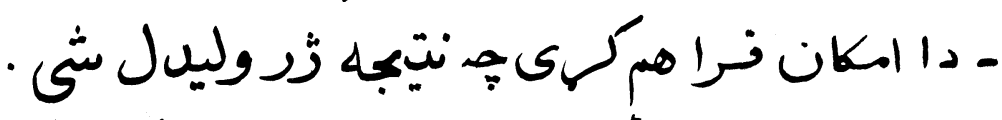

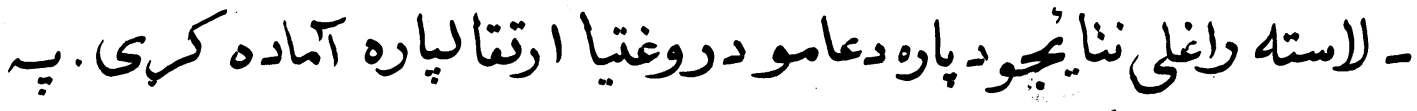

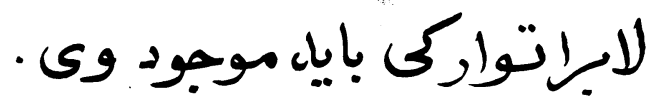

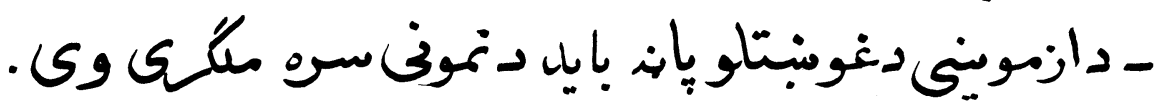

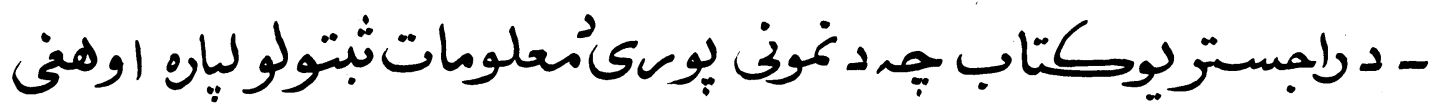

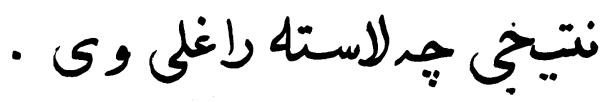

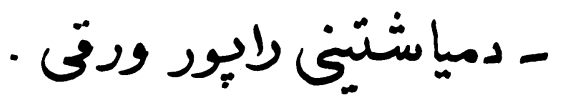

\section{الف : د نهونو نمه دارهوكول :}

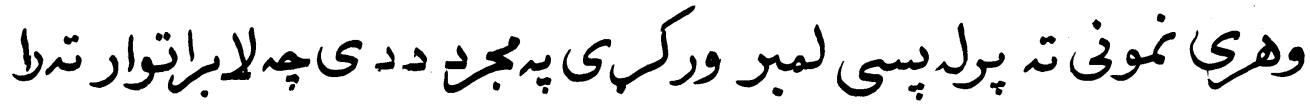

$$
\begin{aligned}
& \text { رسيزي . رئ. } \\
& \text { دغه نبرفسوراً ولكئُ. }
\end{aligned}
$$

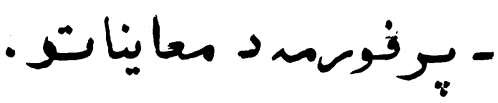



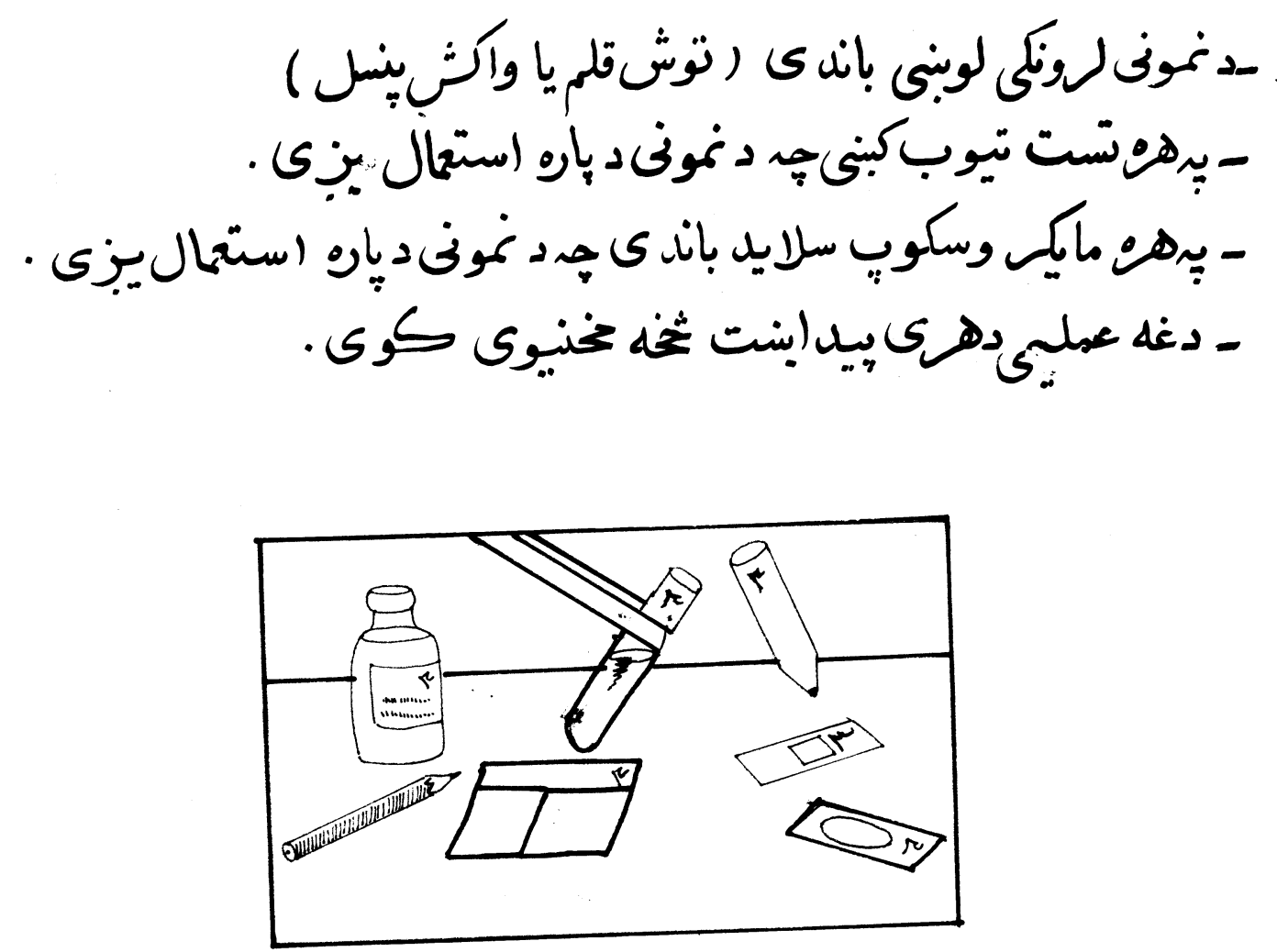

ب ، دلابلاتواردنبت كتابون ( رجستر )

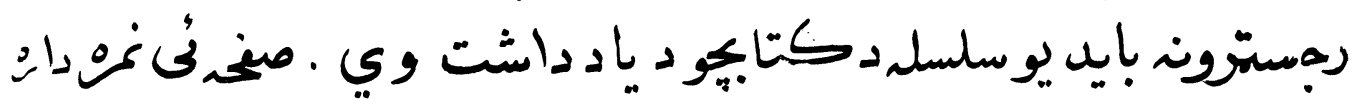

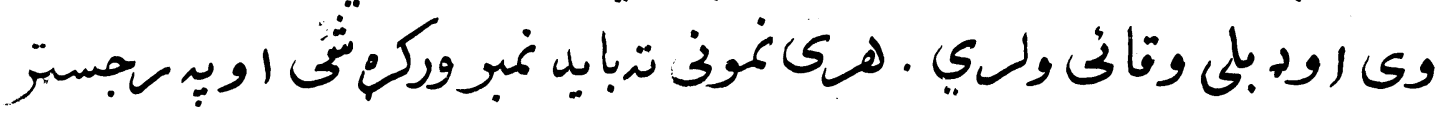

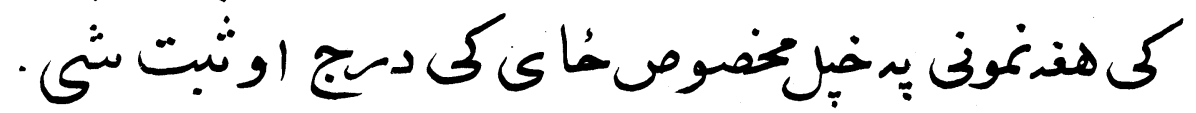

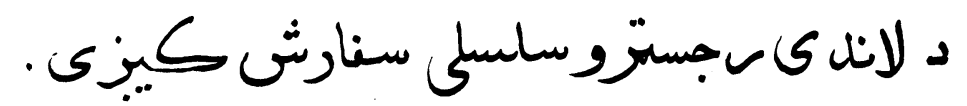

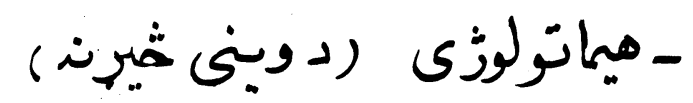

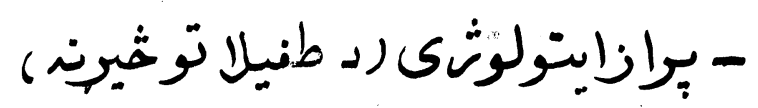




$$
\begin{aligned}
& \text { ـ ـخليددادرارو اود هاملكلي آنموين }
\end{aligned}
$$

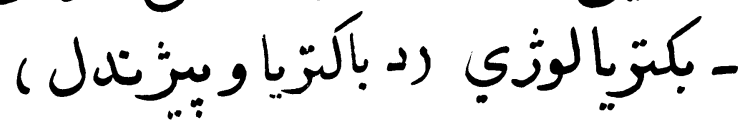

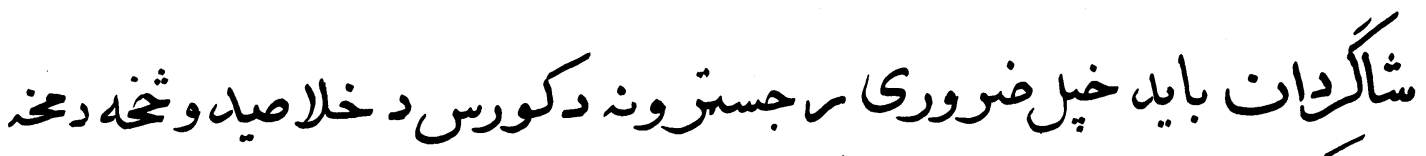

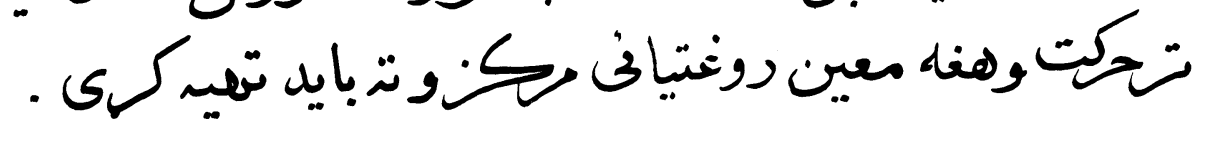

$$
\text { ج : مياشتنتى لِوبور: }
$$

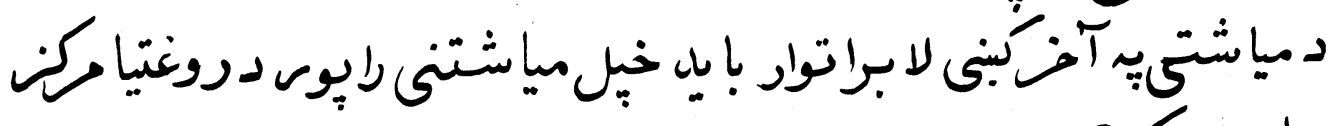

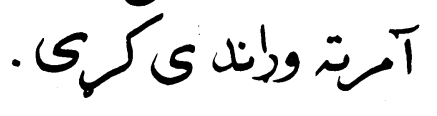

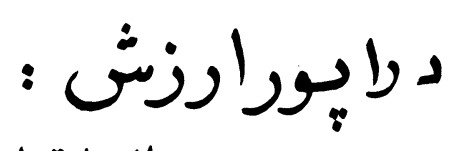

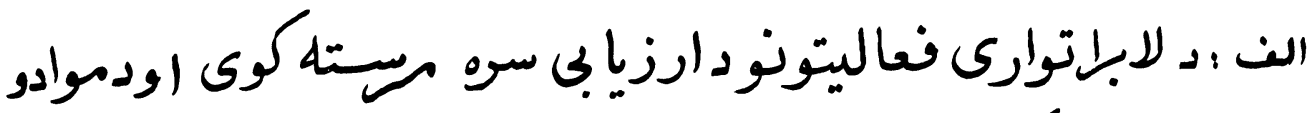

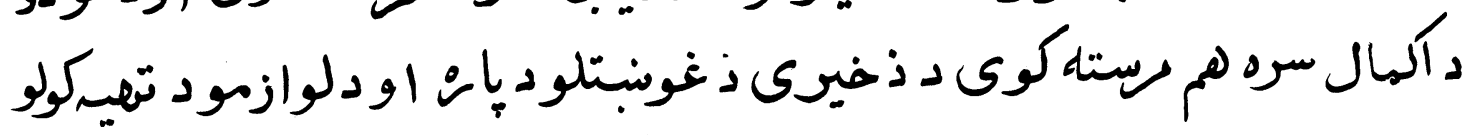

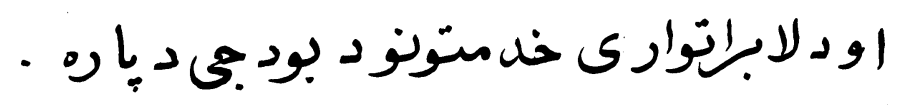

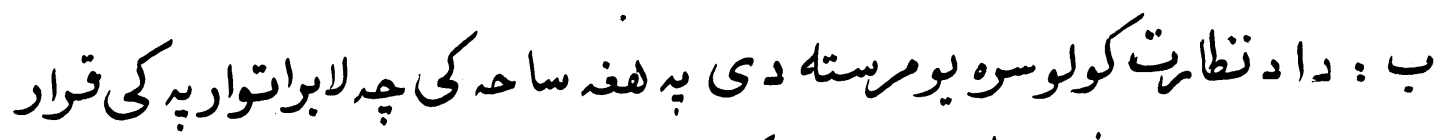

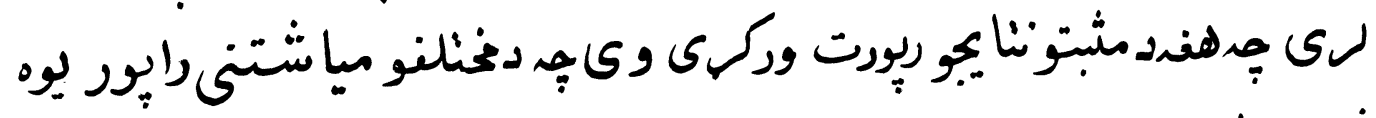

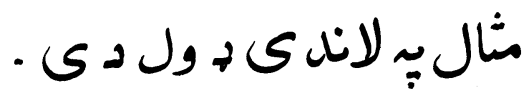




$$
\begin{aligned}
& \text { دلابراتوارنوم: }
\end{aligned}
$$

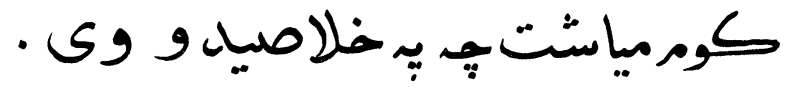

$$
\begin{aligned}
& \text { اـ ــ ايجار ششوو معايناتوتحداد } \\
& \text { هيموكلوبين } \\
& \text { دوينى دسبينوكروياتو تعداد }
\end{aligned}
$$

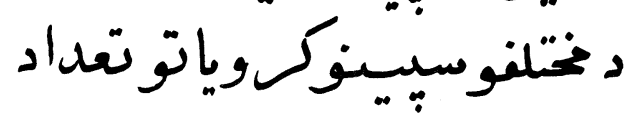

$$
\begin{aligned}
& \text { د دينى د وسوب اندازي } \\
& \text { داداراروتحلبل ويجنج } \\
& \text { حاملكى } \\
& \text { مواد غايطم } \\
& \text { بلث }
\end{aligned}
$$

r،ديتوجنوتعداد جمليلال شويلى :

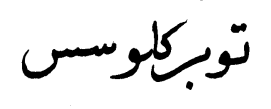$$
\text { اميا سلس }
$$$$
\text { اسكارياسس }
$$$$
\text { جاردياسس }
$$$$
\text { تينياسس }
$$$$
\text { ملر }
$$ 
r، كدام، مورت سوجودي ، ششيانوغونتت

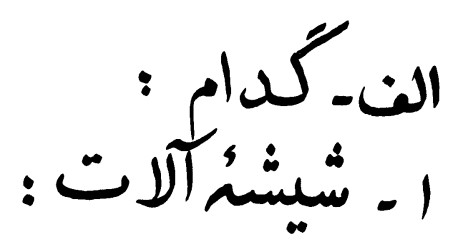

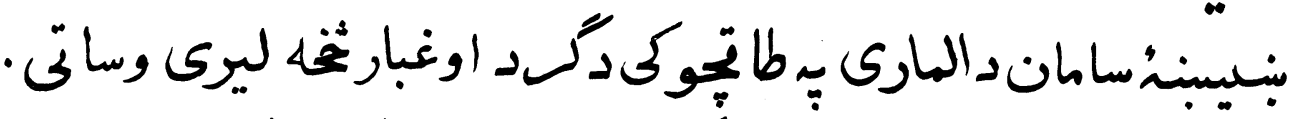

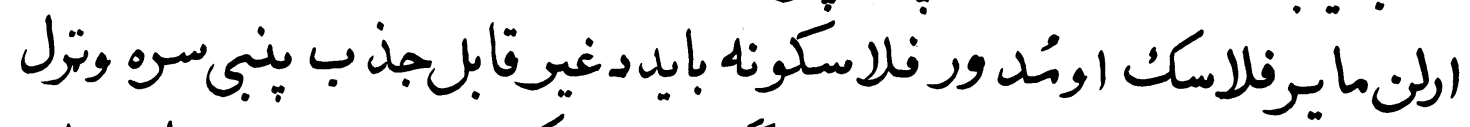

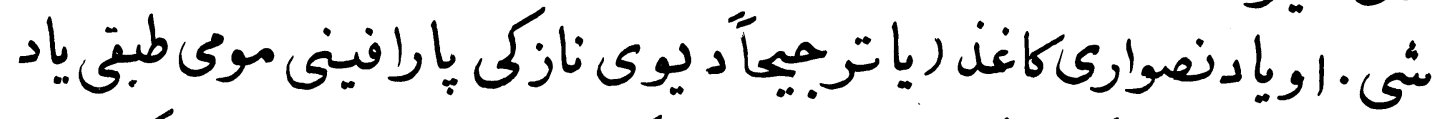

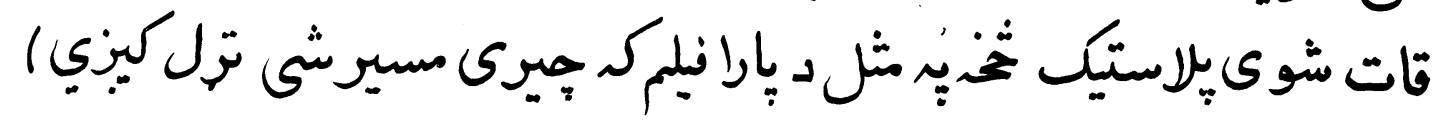

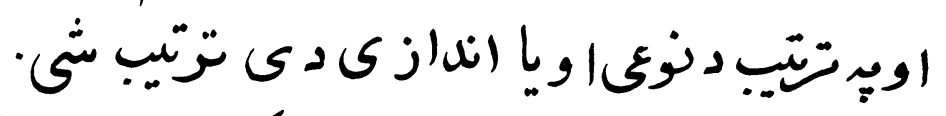

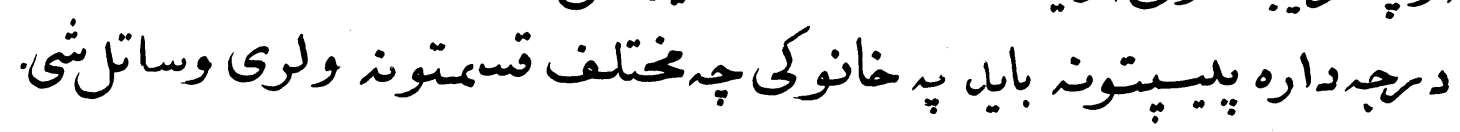

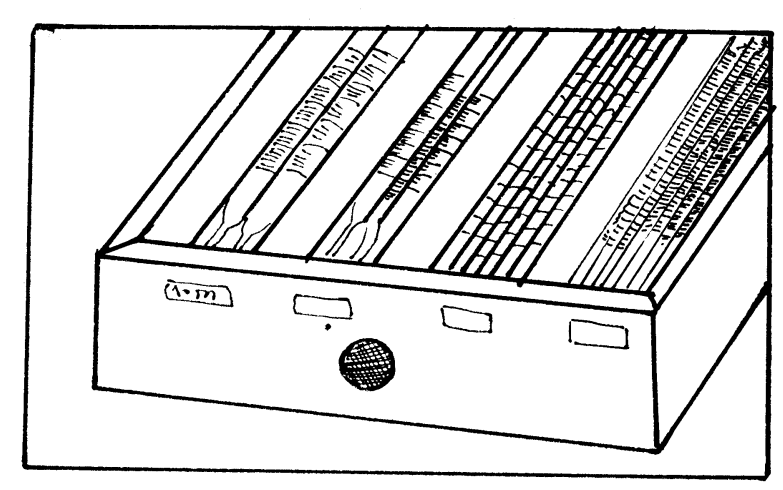




\section{r. كبميا وى مواد او ريجيتون :}

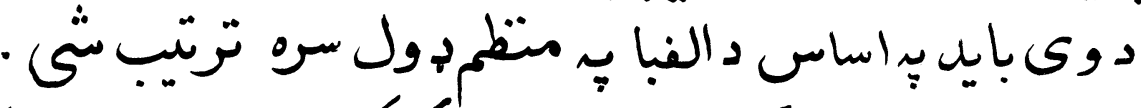

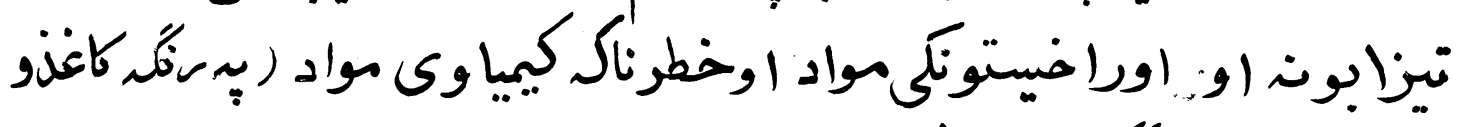

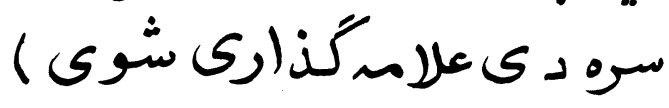

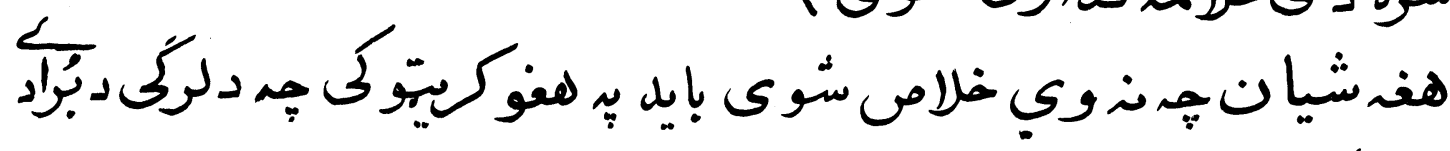

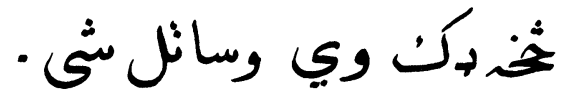

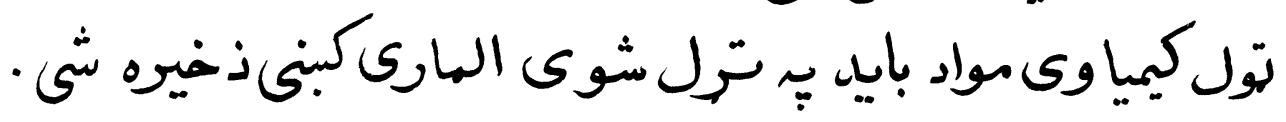

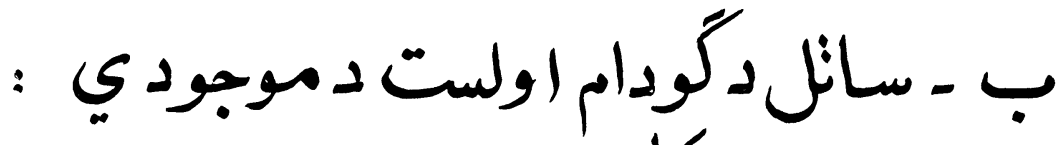

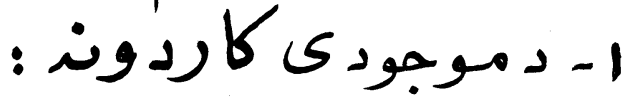

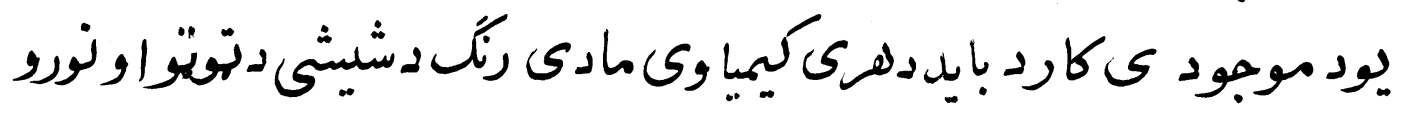

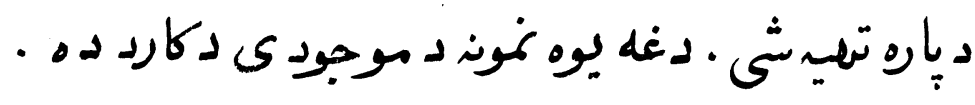

دستاكك كارت ركاردٌ،

\begin{tabular}{|c|c|c|c|c|}
\hline عץ لهبوشى & \multicolumn{4}{|c|}{ اشيا : دكيمناتلويت } \\
\hline \multirow{2}{*}{ פַטיוא كט } & \multicolumn{2}{|c|}{ 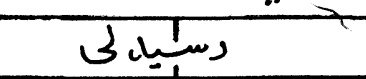 } & \multicolumn{2}{|c|}{ 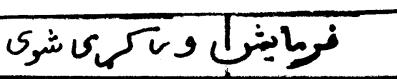 } \\
\hline & مسن ار & نِيَّتر & متشرار & نيِت \\
\hline كبوتل & & 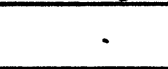 & ${ }^{\circ}$ & $\cdot$ \\
\hline 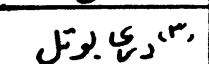 & 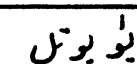 & $6+4$ & r rبوتل & اولددى \\
\hline ك بوت5 & . & . & & . \\
\hline ا بوتك & & & & \\
\hline r بوت" & بكبوتل & دسيتمر .1. & r بوت5 & 10 \\
\hline
\end{tabular}

$r$ 


\section{r- بوجودى كول :}

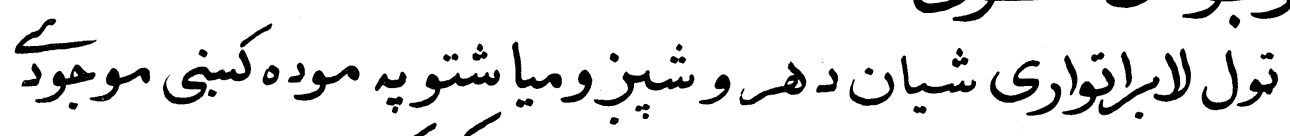

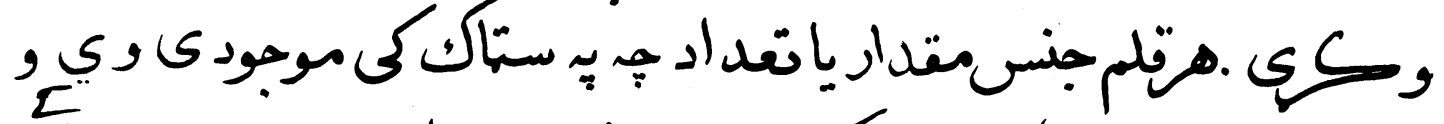

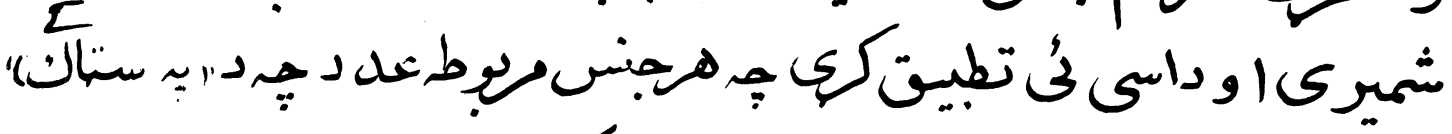

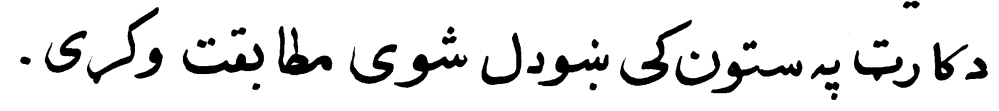

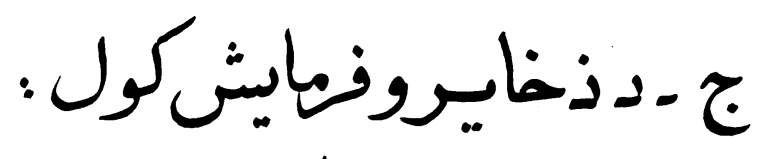

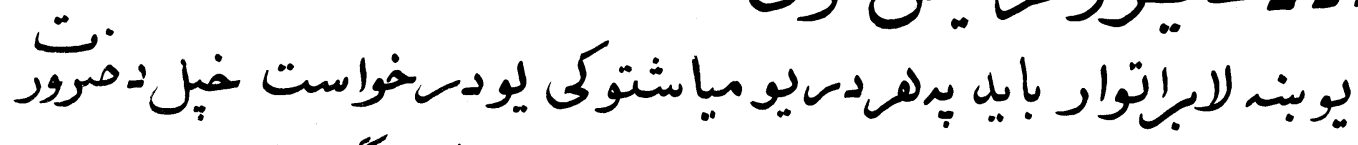

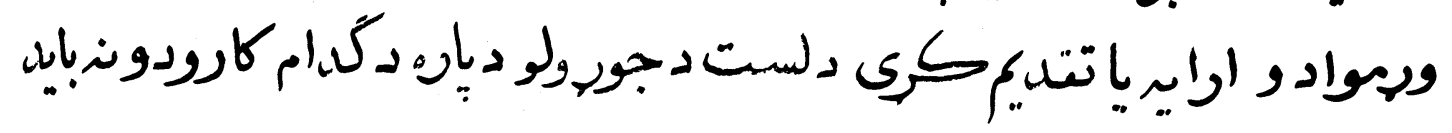

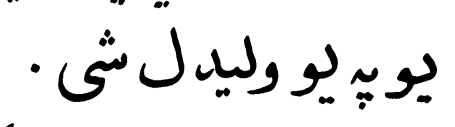

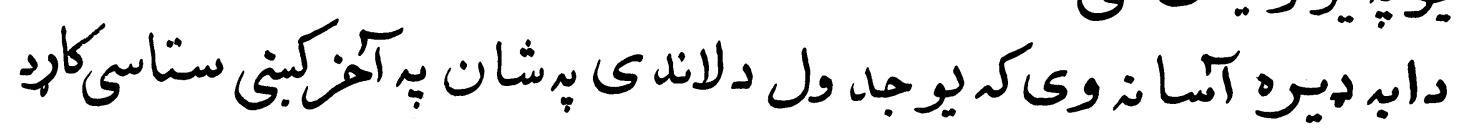

\begin{tabular}{|c|c|c|c|c|c|c|c|c|c|c|c|c|}
\hline دكبر & لزبر & اكتوبر & سبتمبر & اكست & جولاكا & جون & $\mathbf{G}$ & $U^{\prime}$ & طاج & 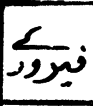 & حبورىا & 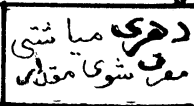 \\
\hline & & & & & & & & & & & & 19 \\
\hline & & & & & & . & & & & & & 19 \\
\hline & & & & & & & & & & & & 19 \\
\hline
\end{tabular}

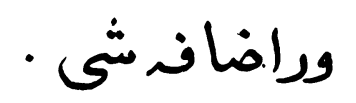




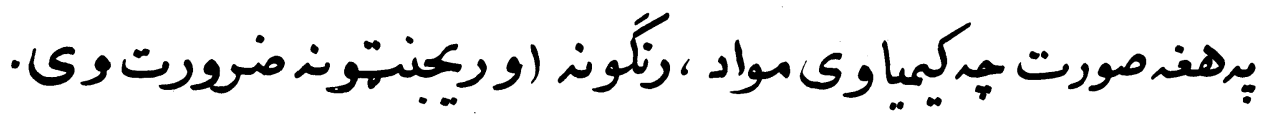

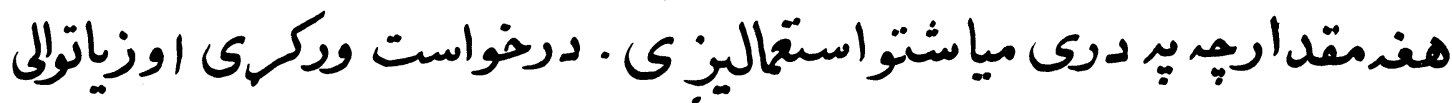

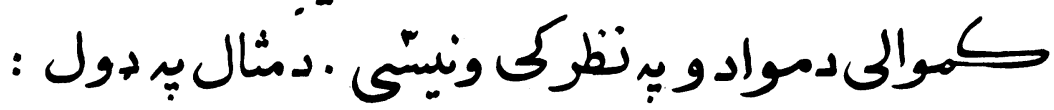

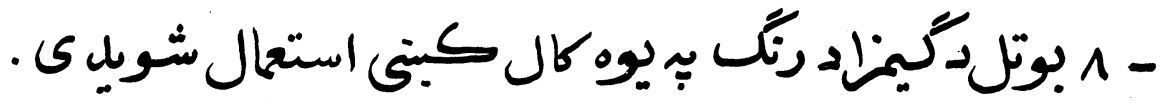

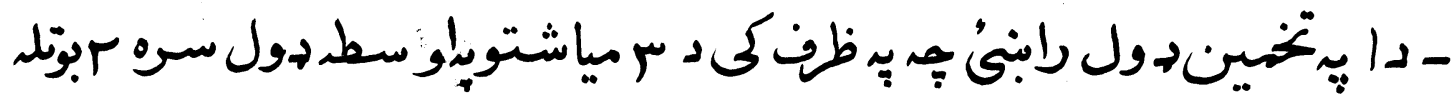

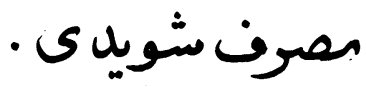

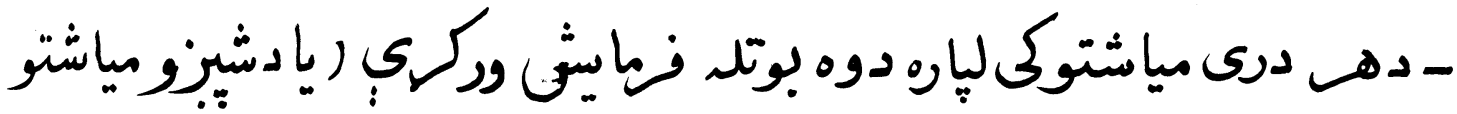

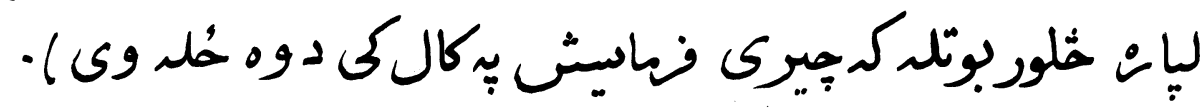

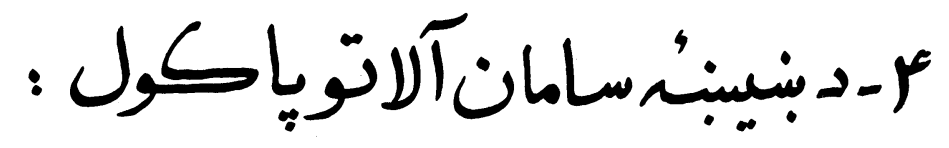

$$
\begin{aligned}
& \text { د بآكوالى طريقت : }
\end{aligned}
$$

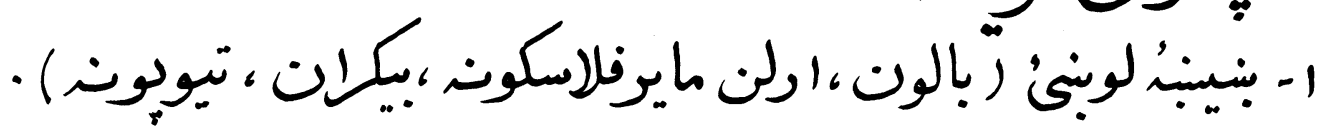

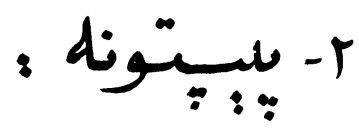

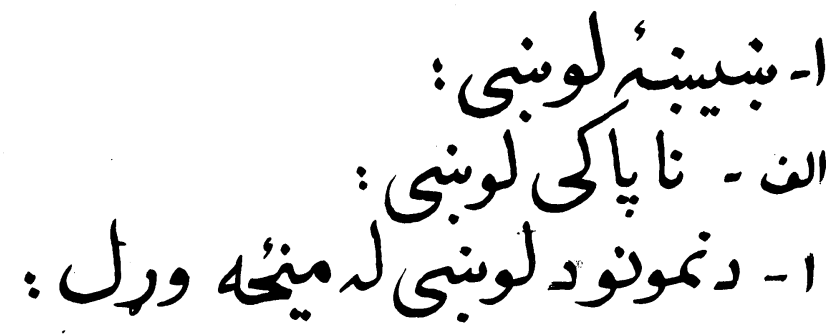

$\pi$ 


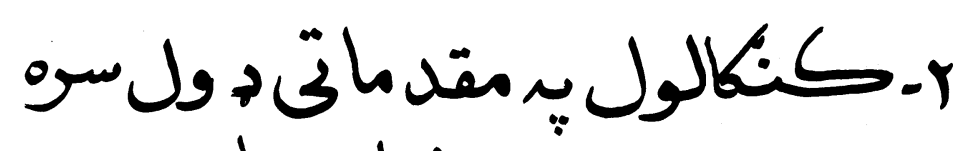

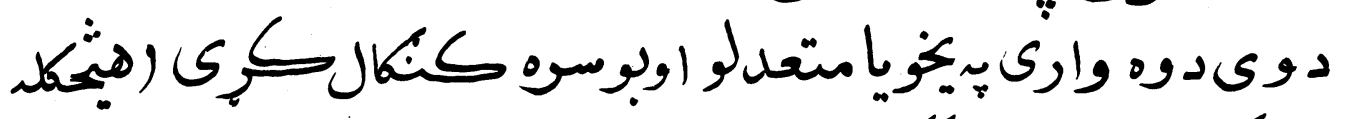

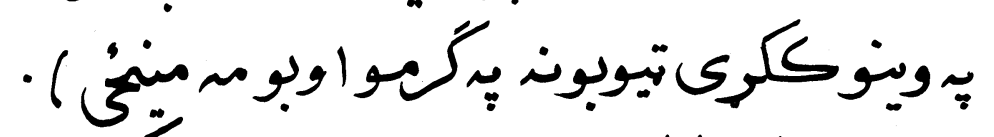

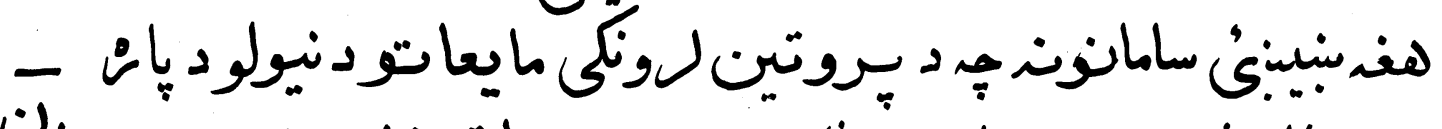

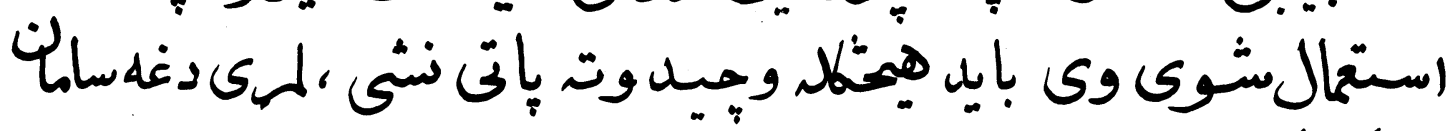

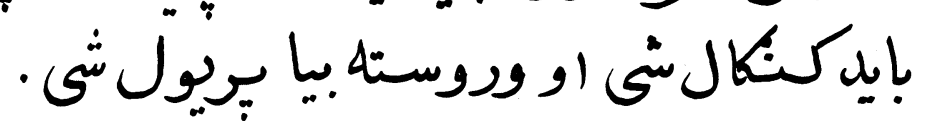

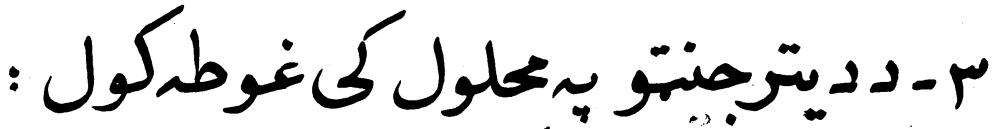

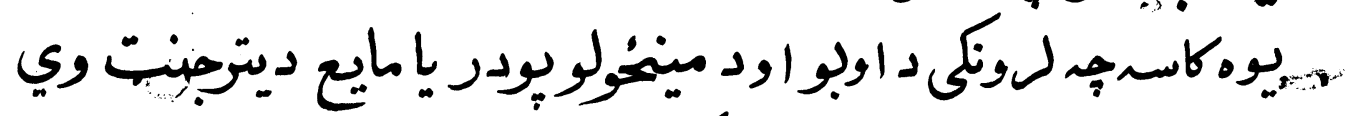

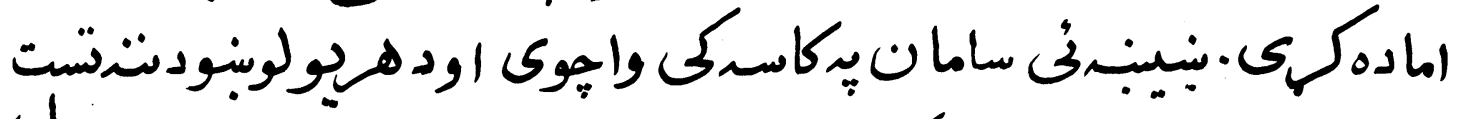

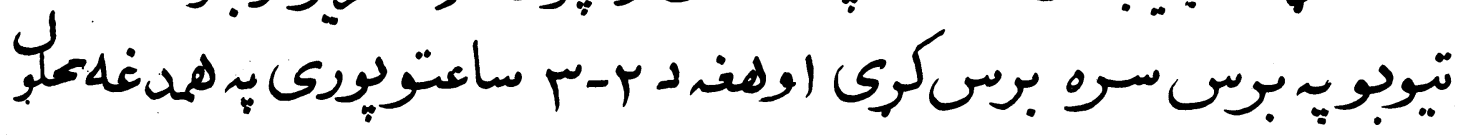

بوينزبدي.

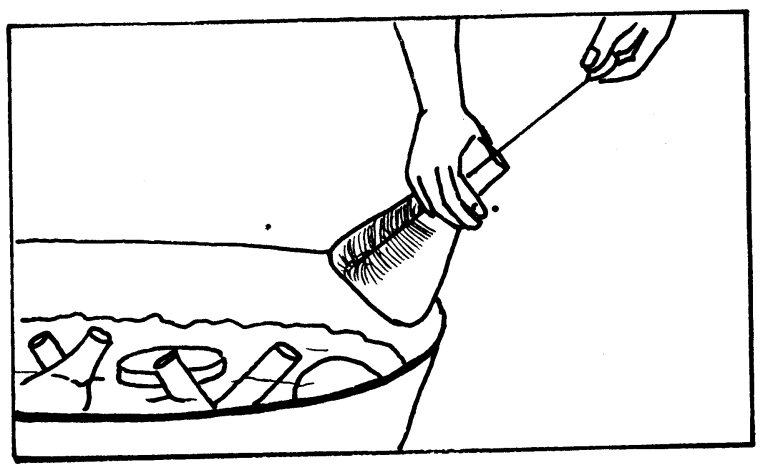




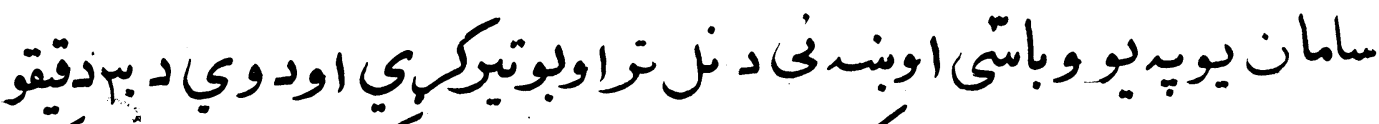

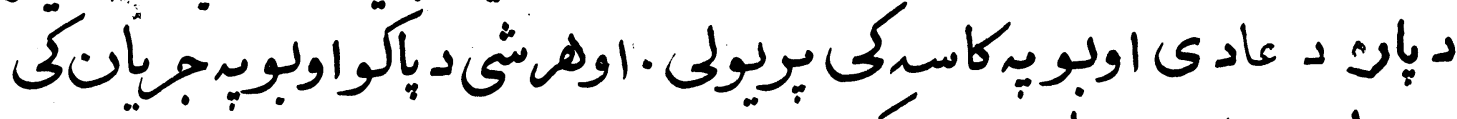

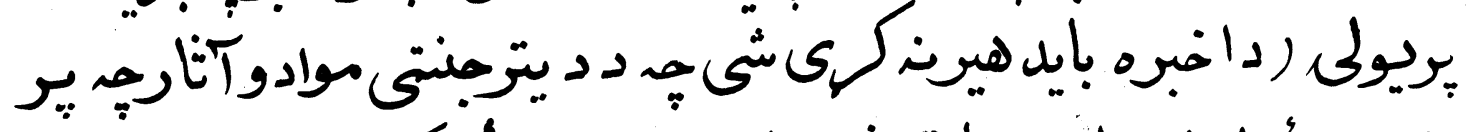

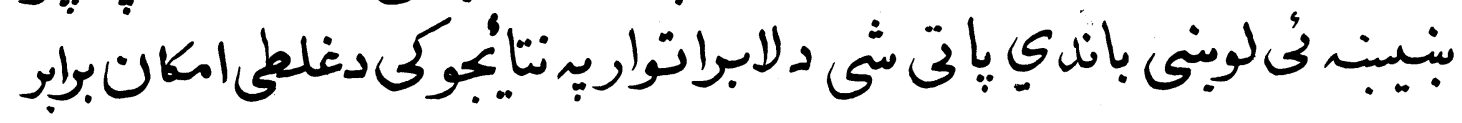

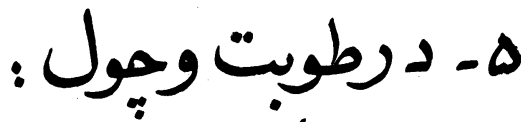

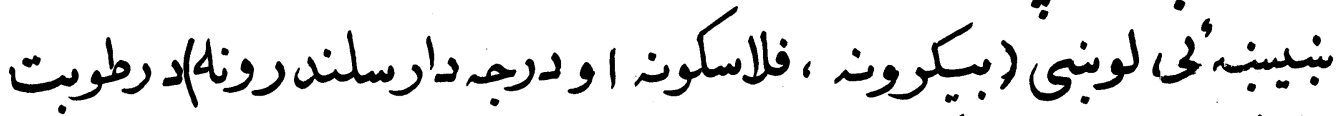

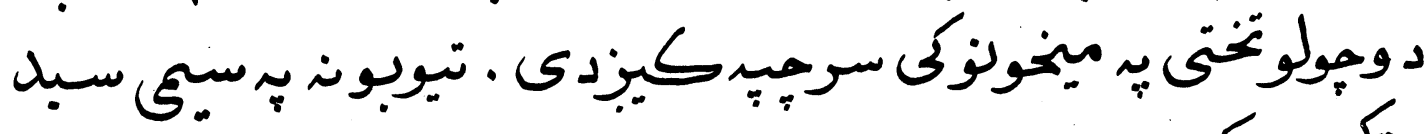

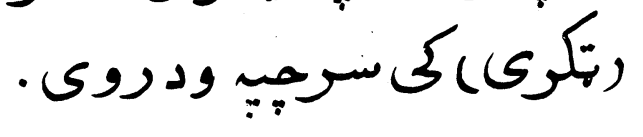

$$
\text { 4- وجول : }
$$

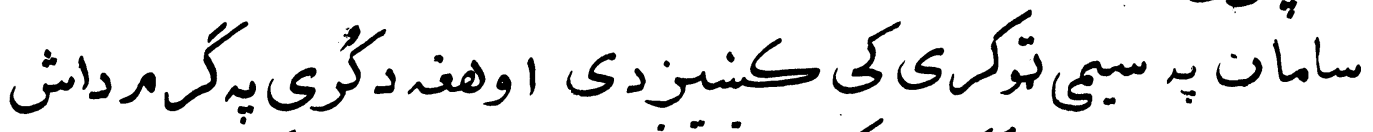

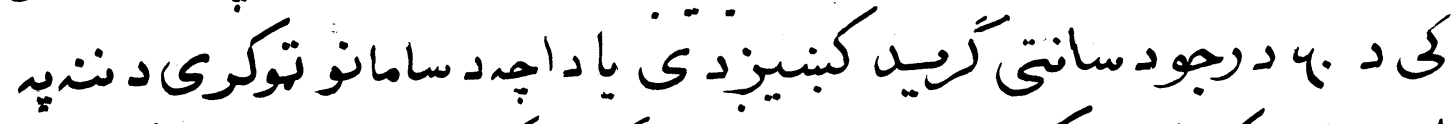

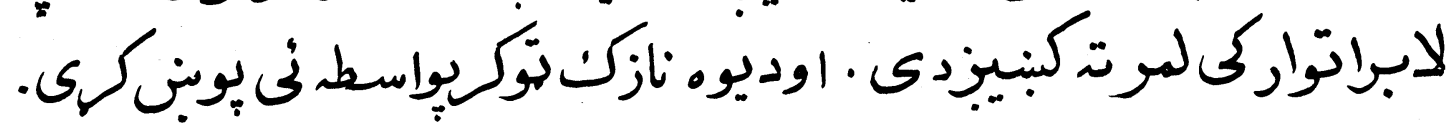

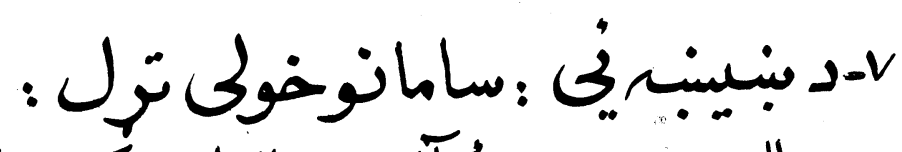

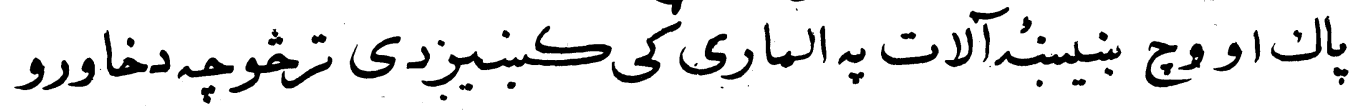




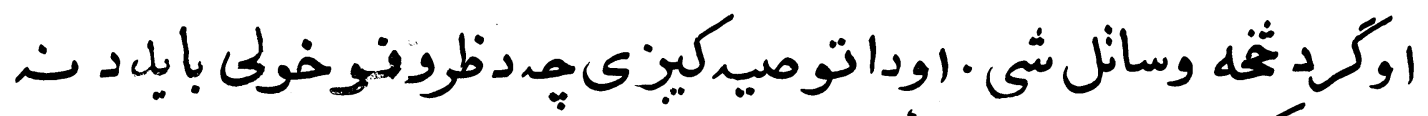

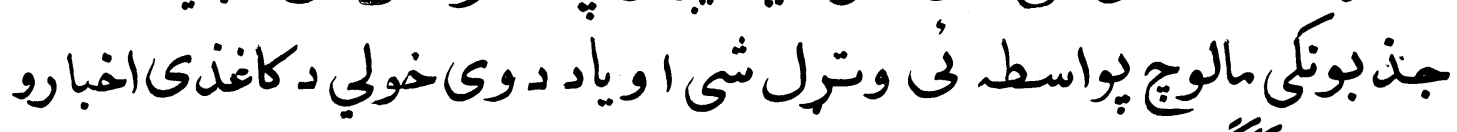

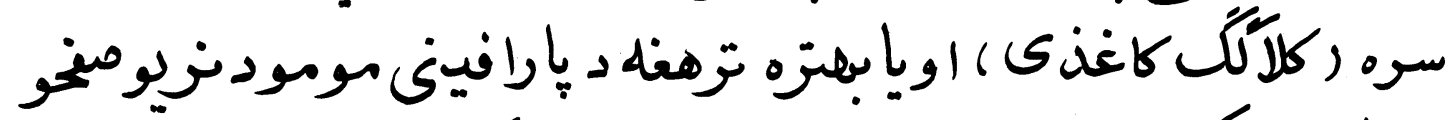

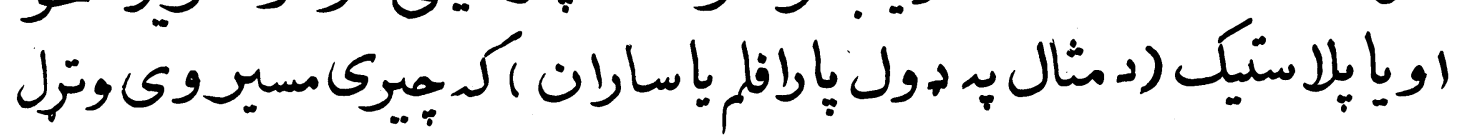

•

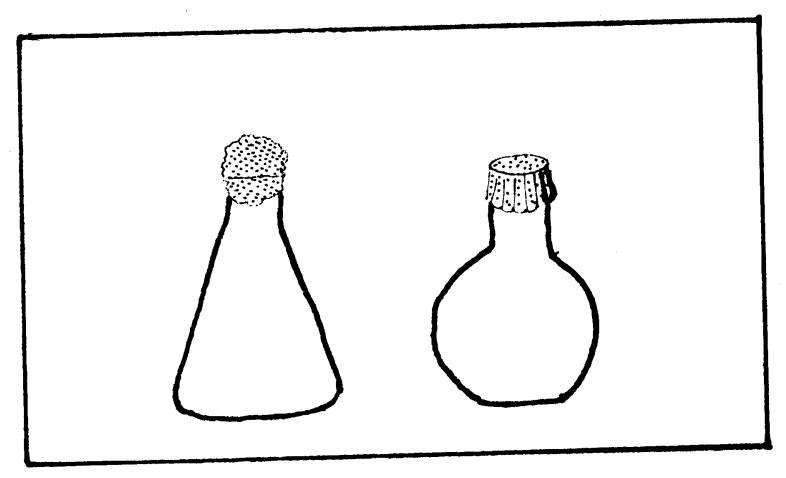

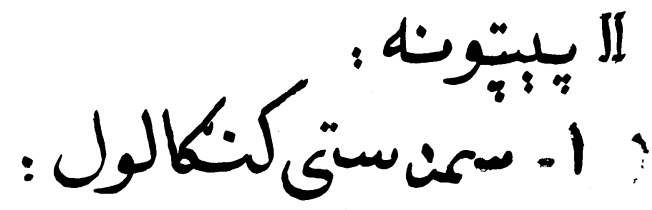

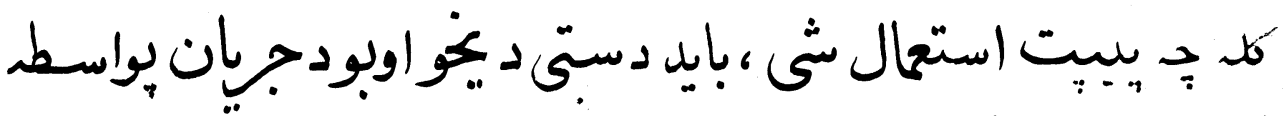

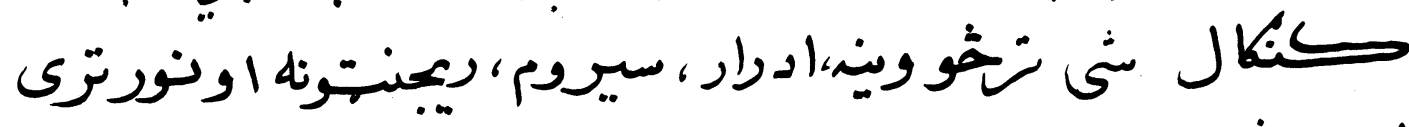
ليوى شنى.

ro 


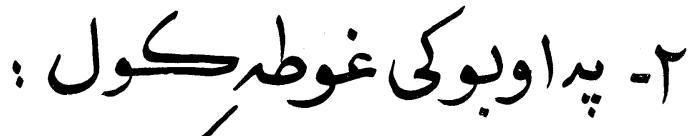

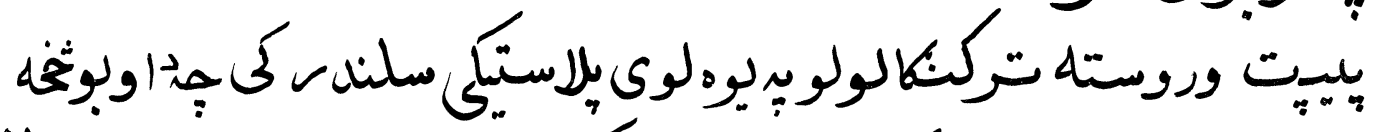

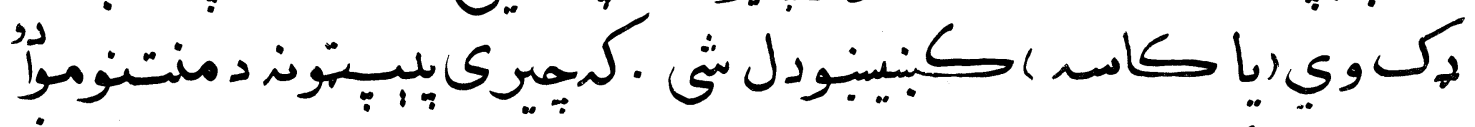

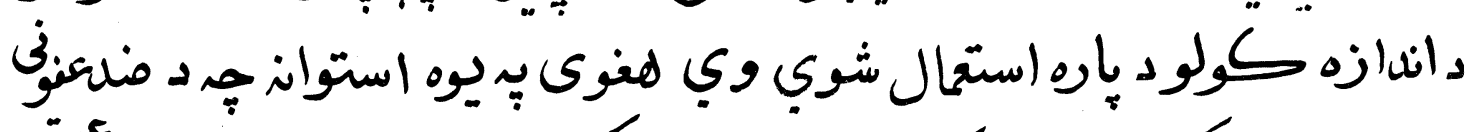

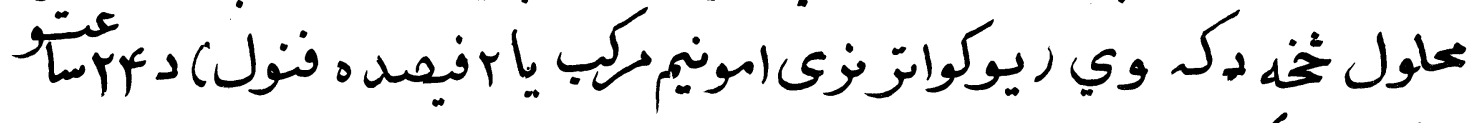

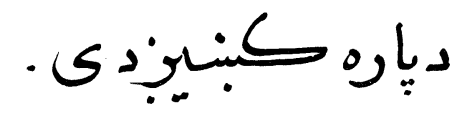

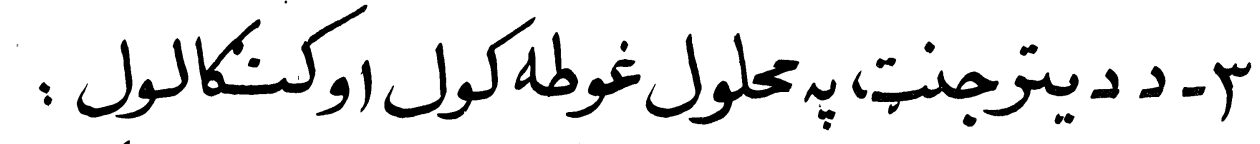

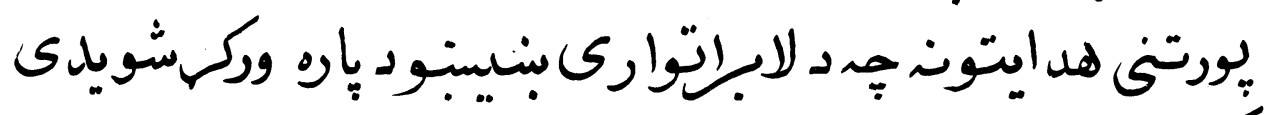

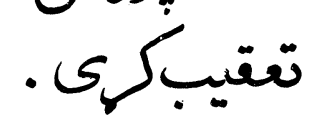

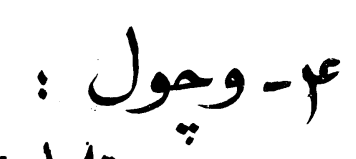

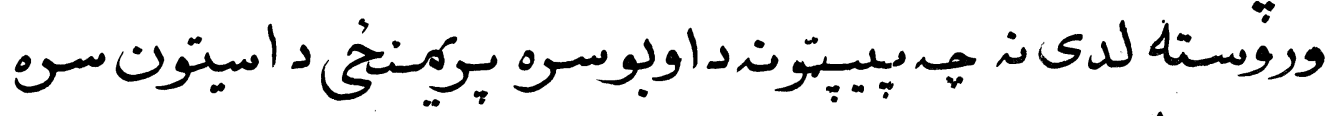

•

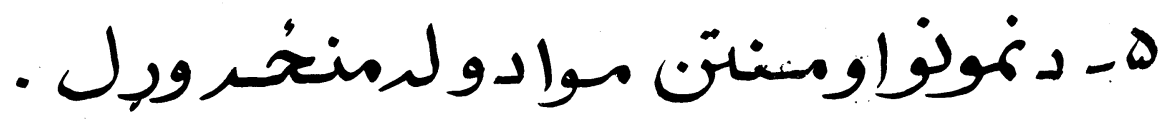

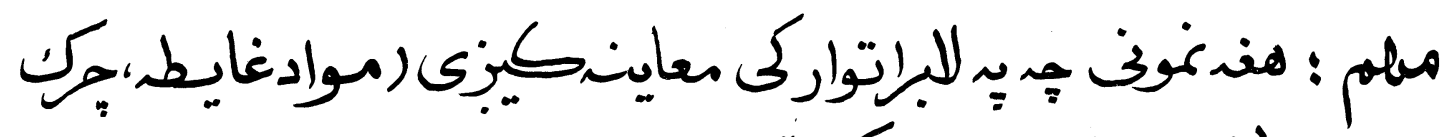

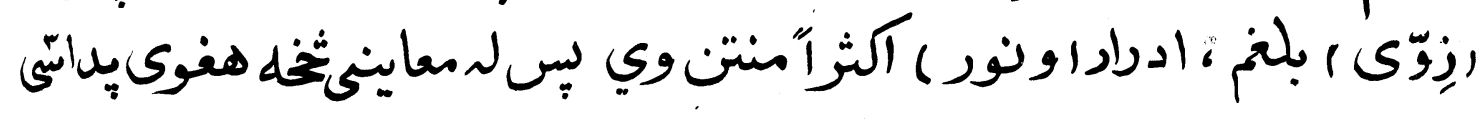




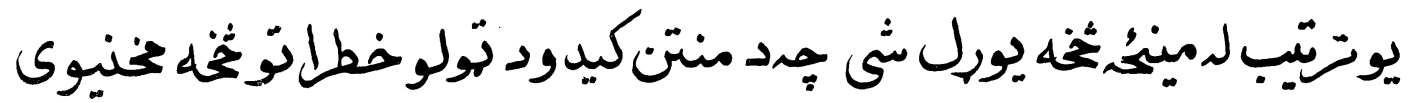
وشى

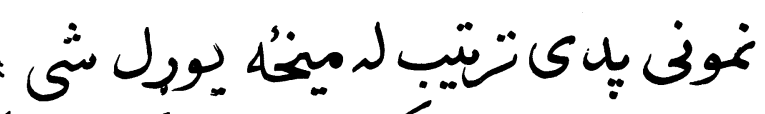

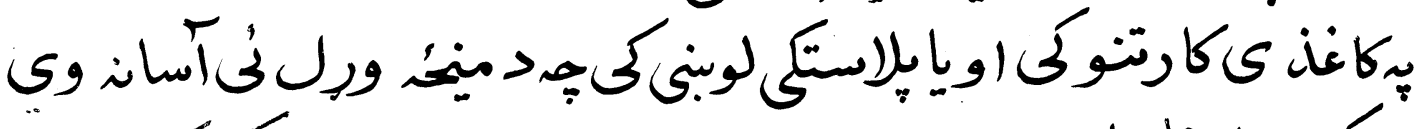

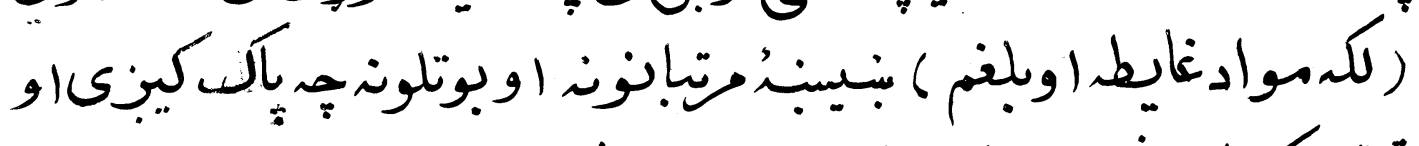

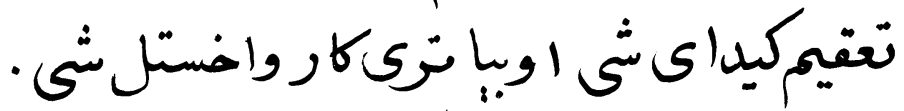

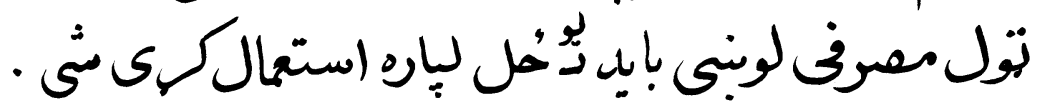

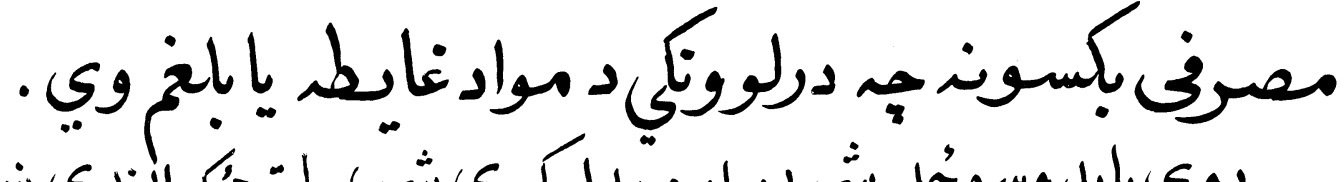

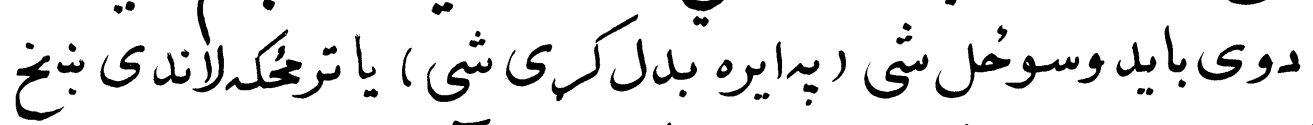

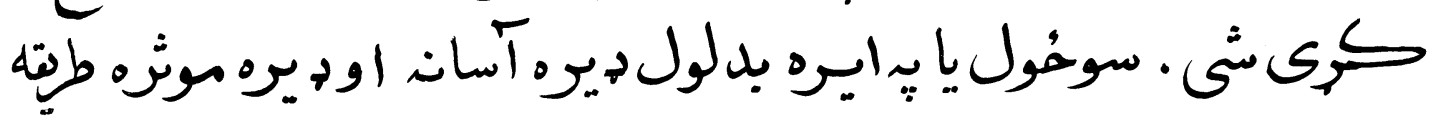
الن : سوحُول ياخاكستركول ( يـود

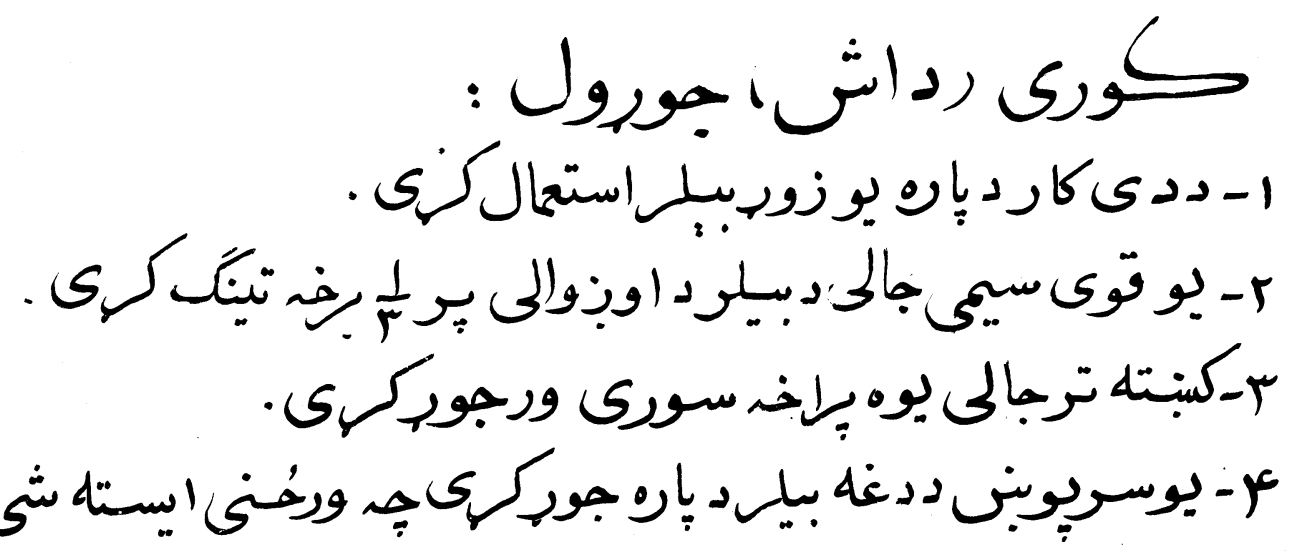




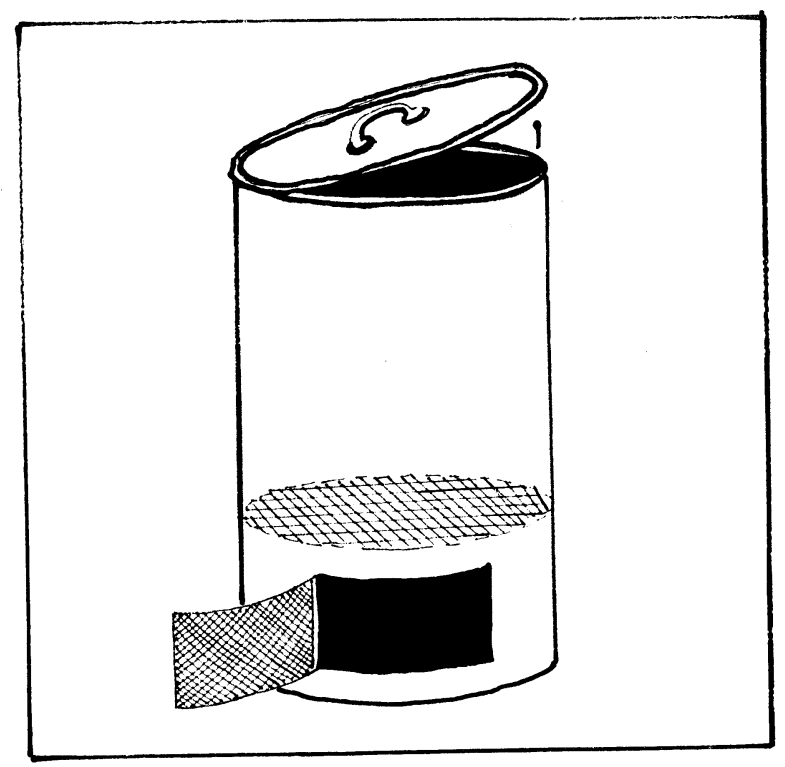

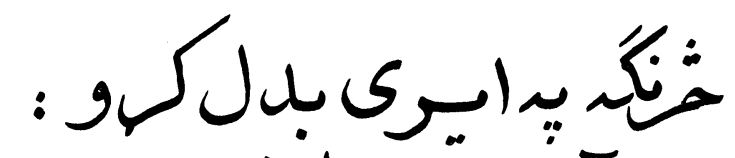

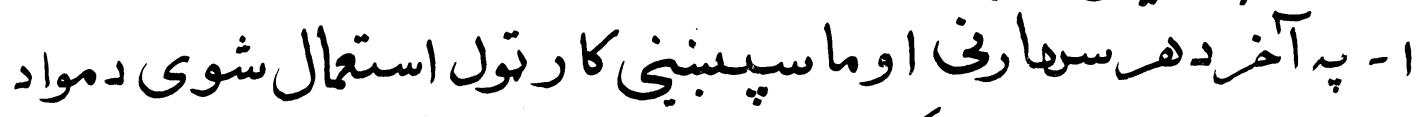

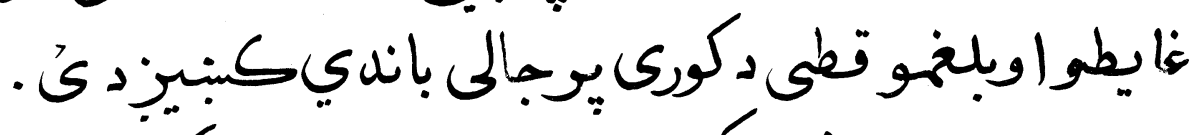

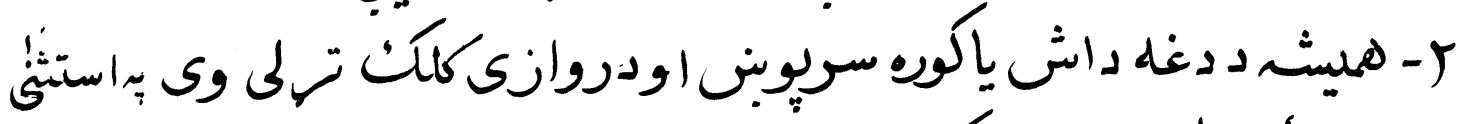

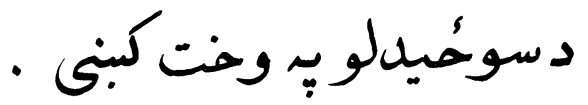

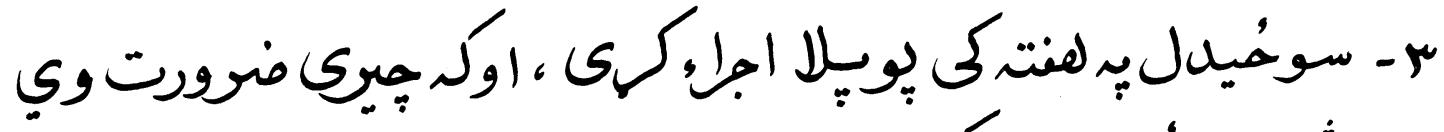

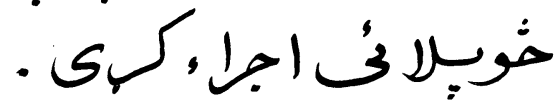

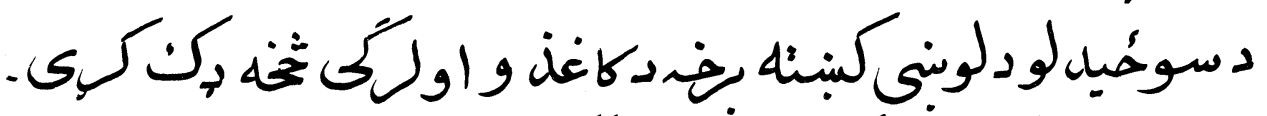

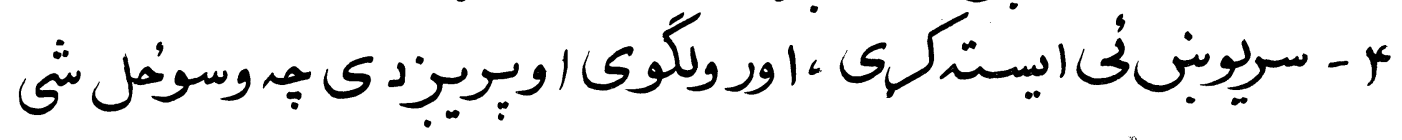




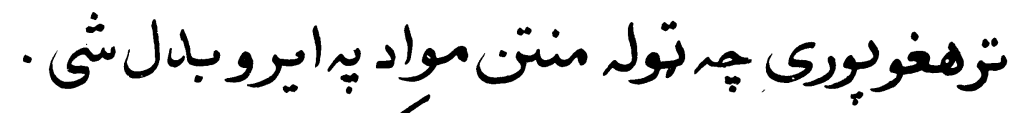

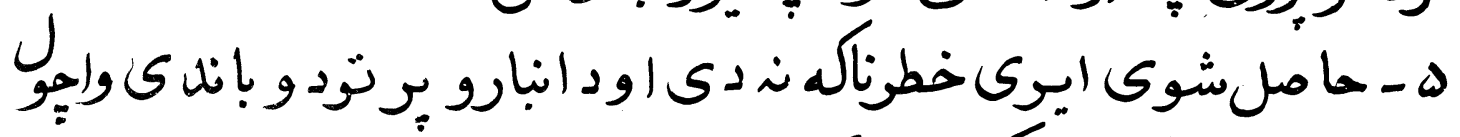

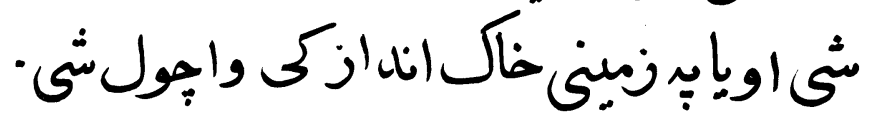

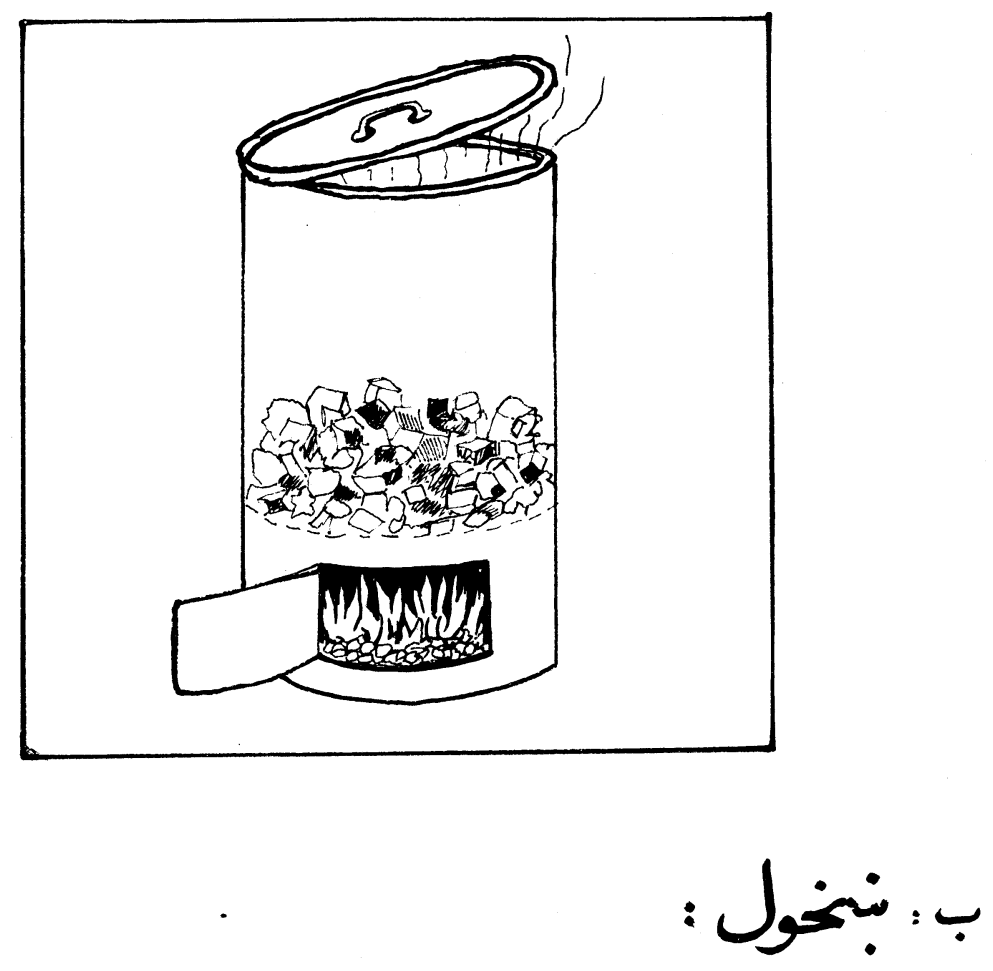

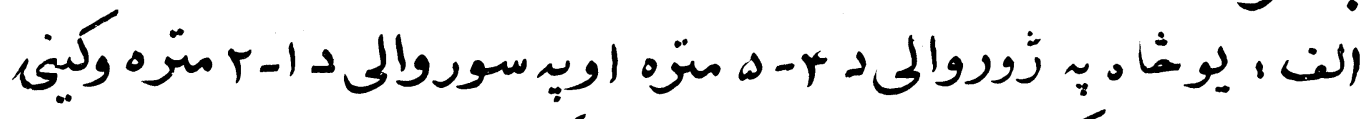

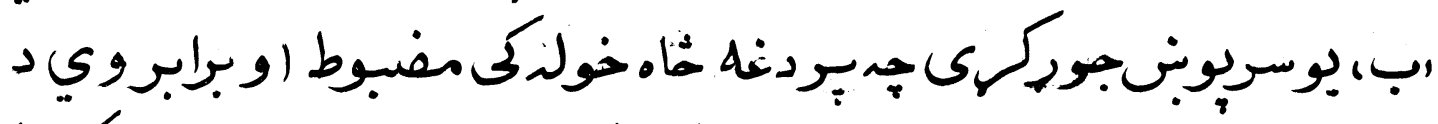

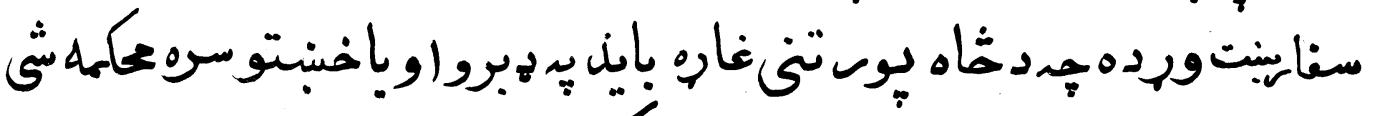

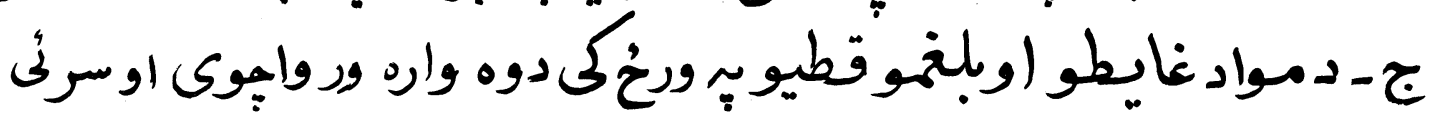

د مستى وترئ .

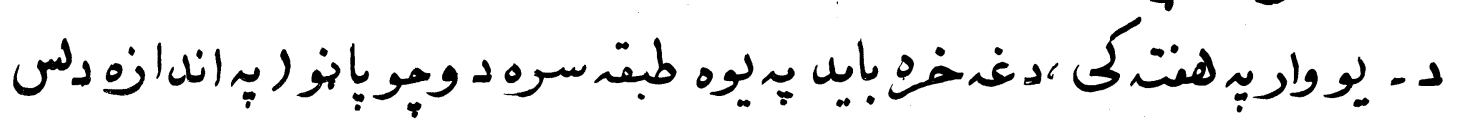

rq

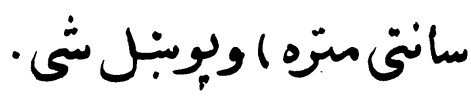




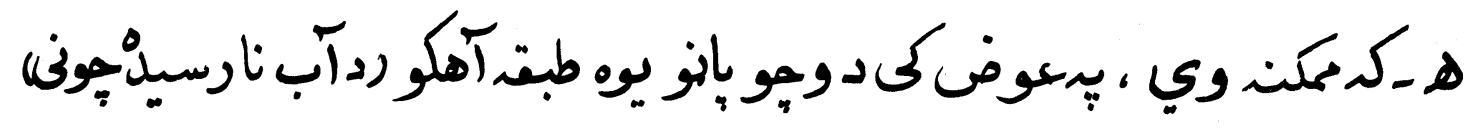

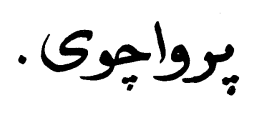

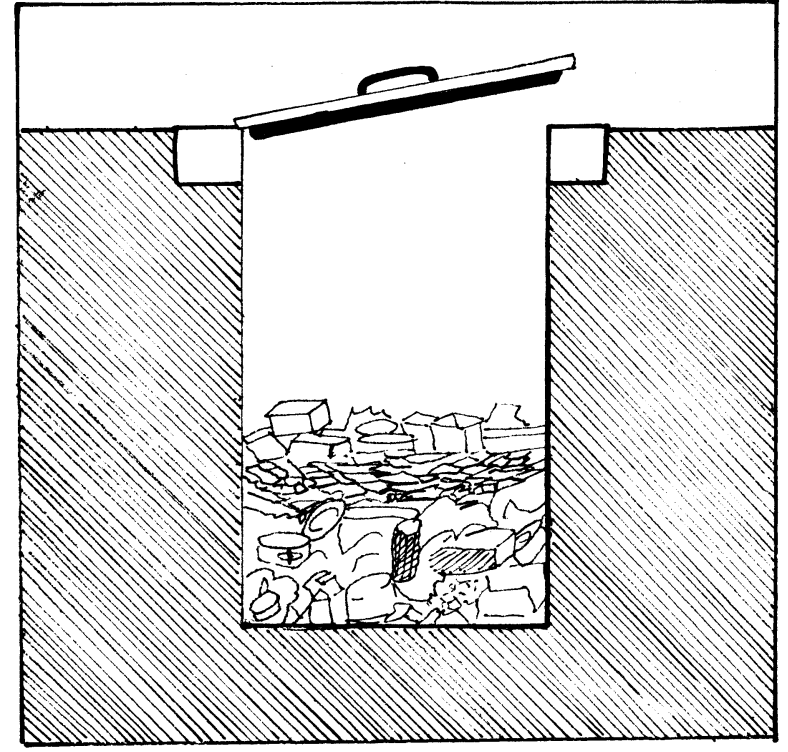

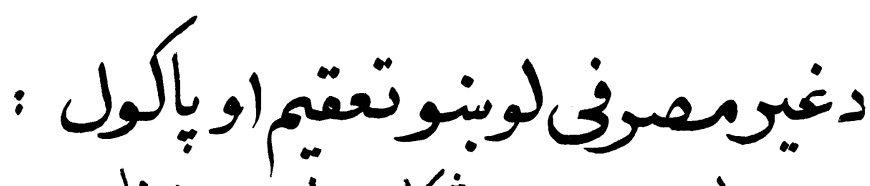

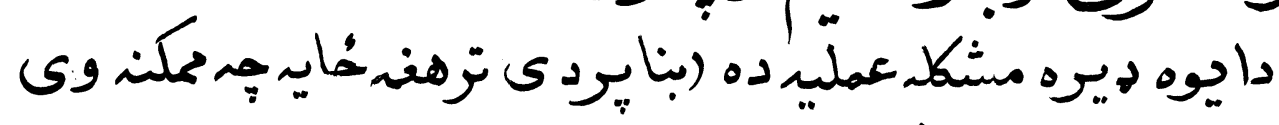
مصنفى لوبنى استخمالثي)

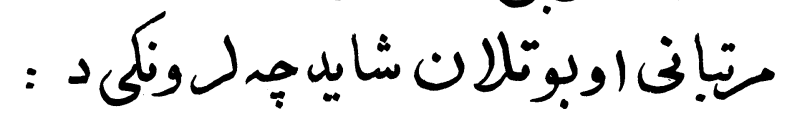

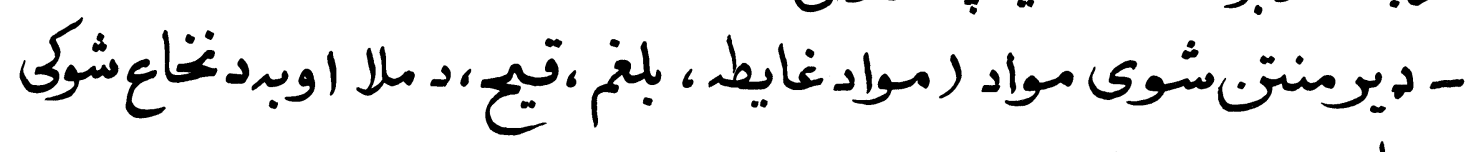

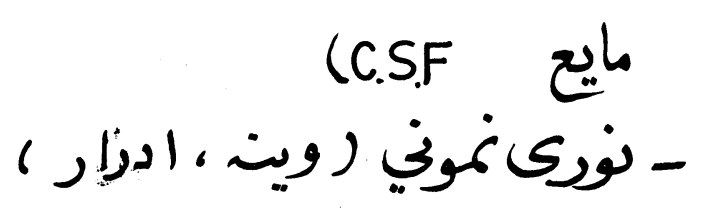




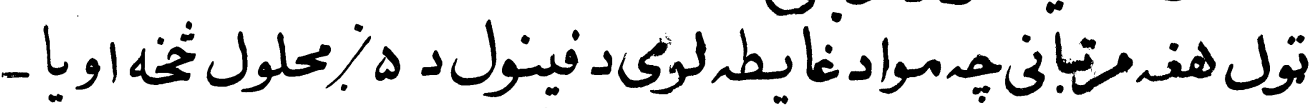

$$
\text { الن ـ د ميواد غاسطورولونى : }
$$

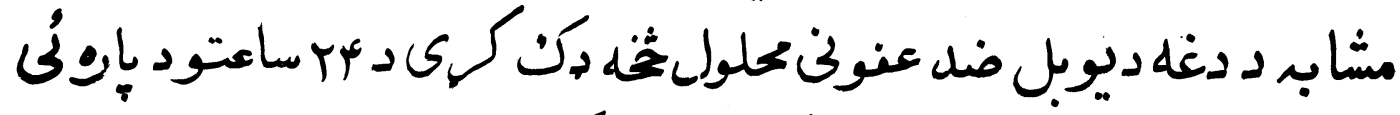

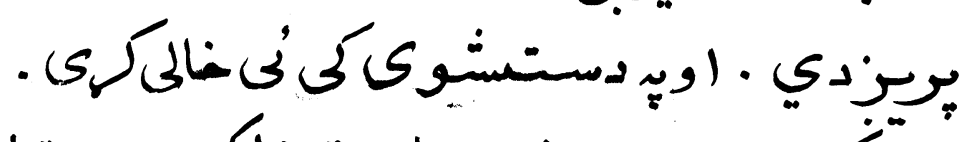

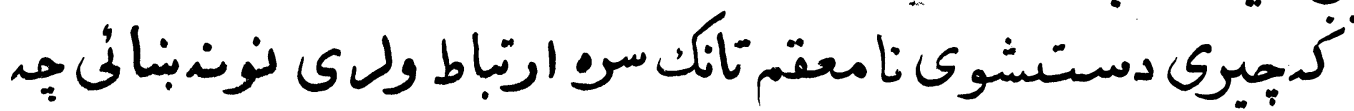

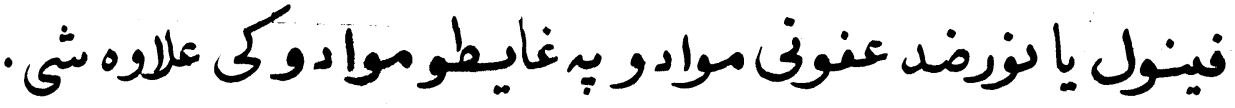

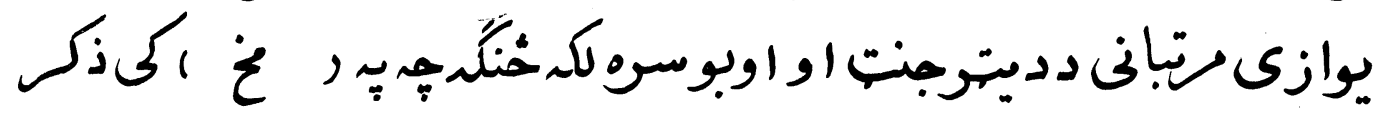

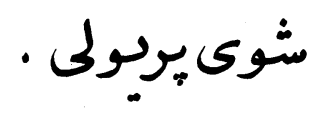

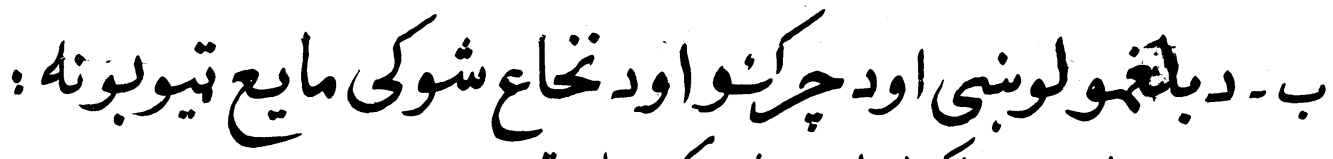

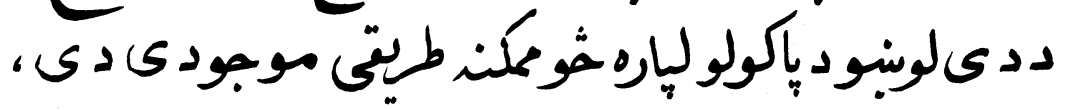

$$
\begin{aligned}
& \text { د فارمالديقايد دمحلول يا فينول داستحال بواسطي } \\
& \text { وله لبتهولوبنى ت وروإِوى . }
\end{aligned}
$$

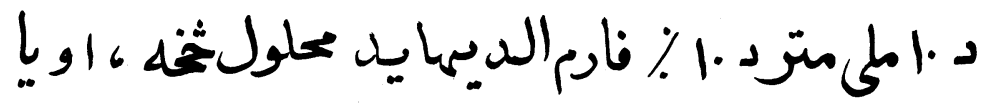

$$
\begin{aligned}
& \text { هـ ملى ليتزد. هـ فينول ثخده. }
\end{aligned}
$$

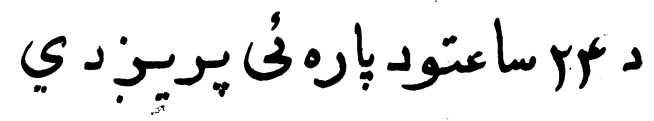




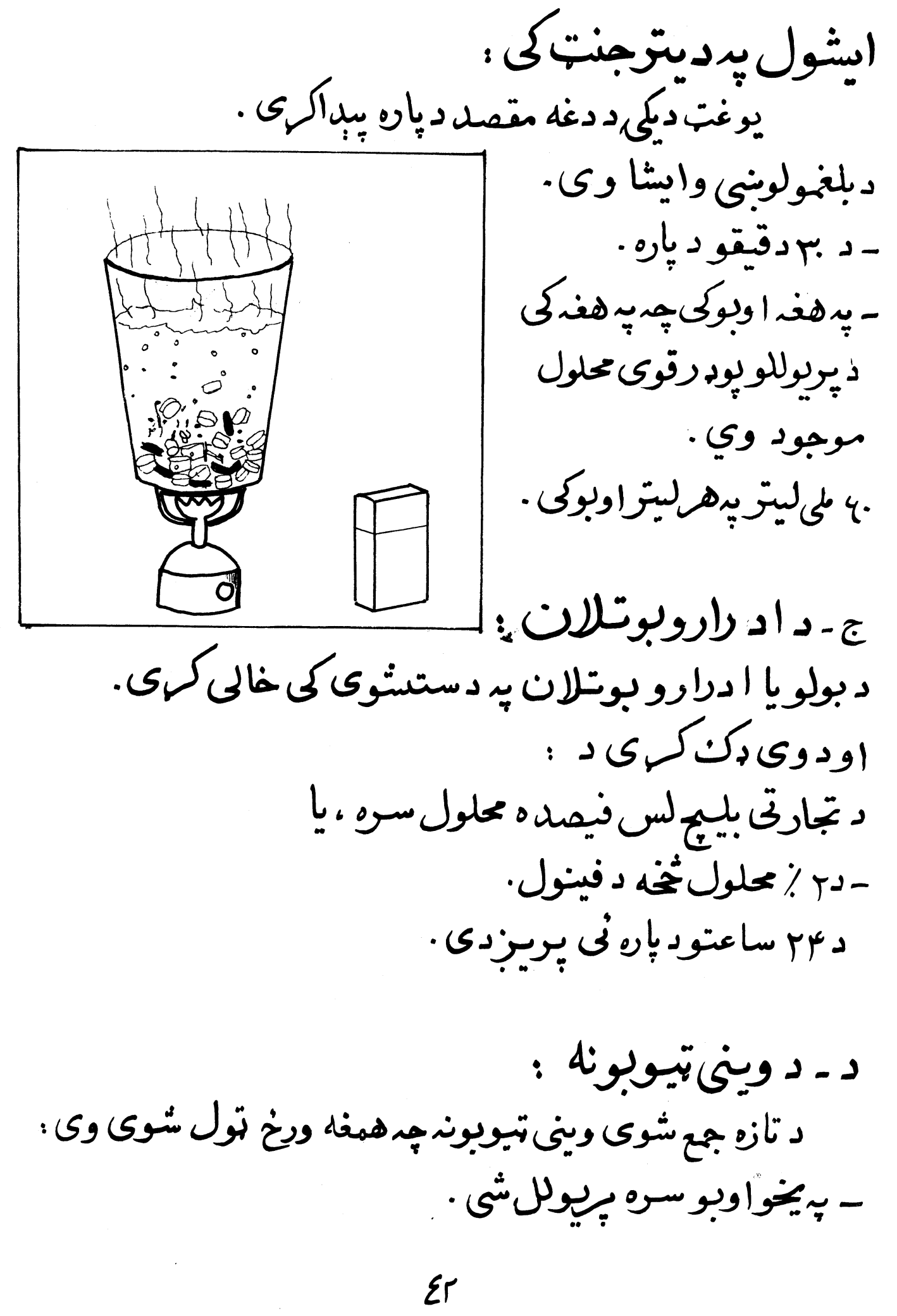




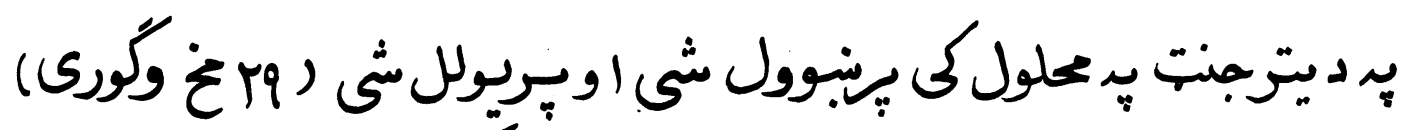

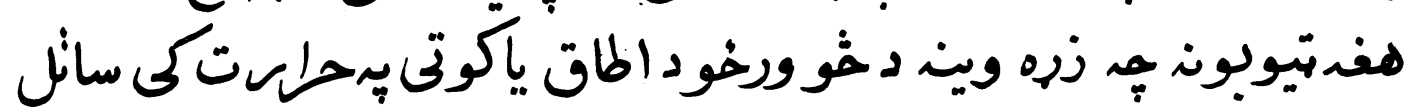

شوى وىى . هقيون

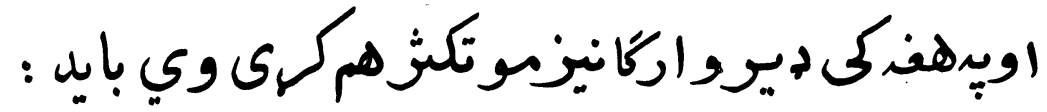

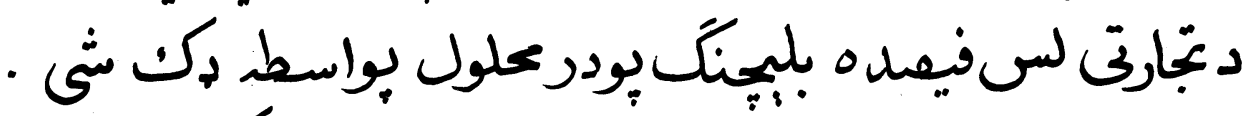

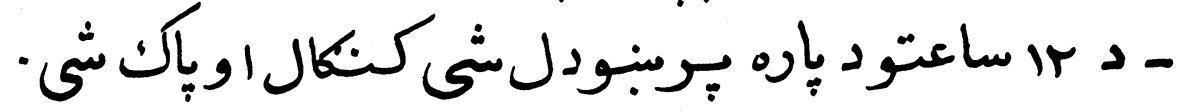

$\varepsilon r$ 


$$
\begin{aligned}
& \text { دوهمه برخت } \\
& \text { بِيراسايتولوبى ( يابرازيتولوثى)، }
\end{aligned}
$$

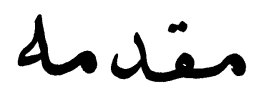

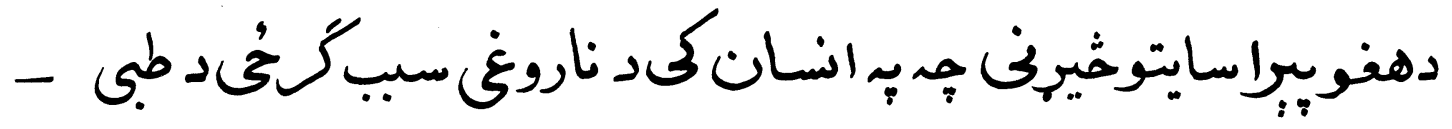

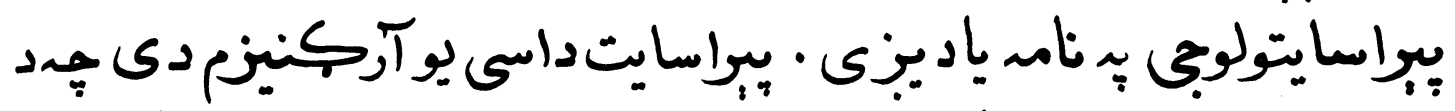

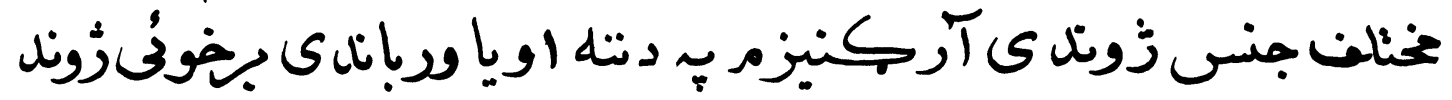

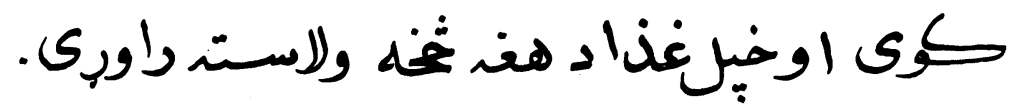

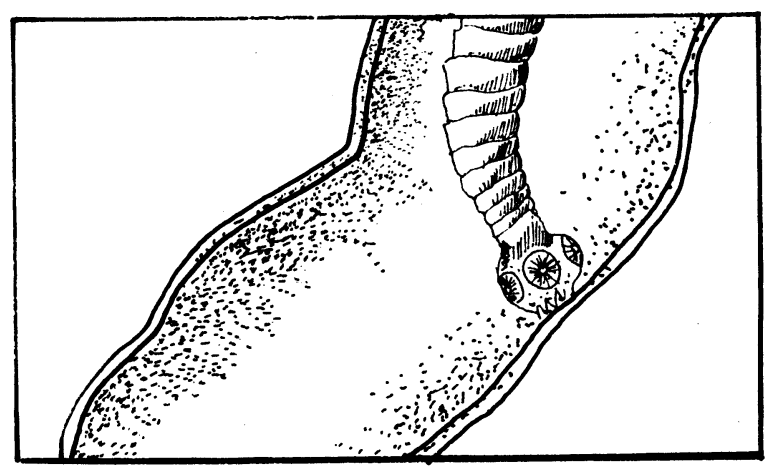




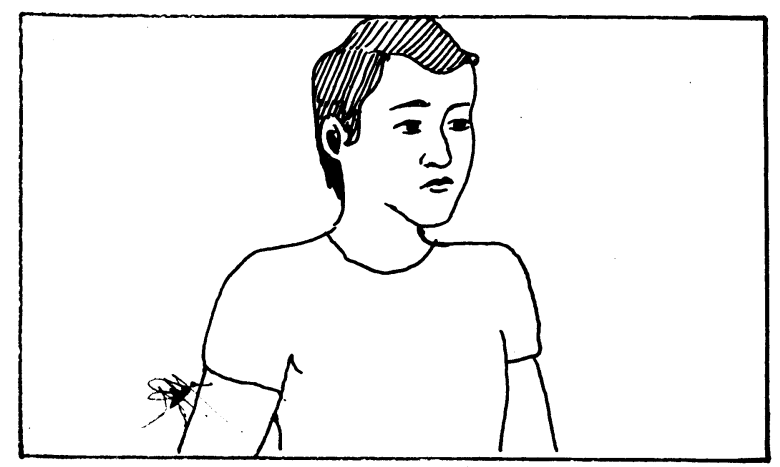

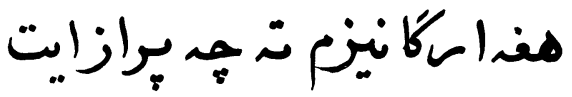

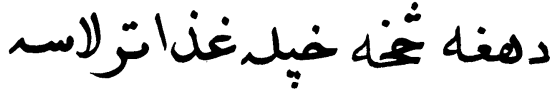

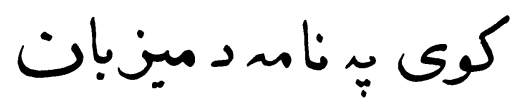

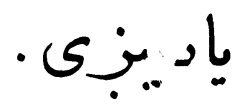

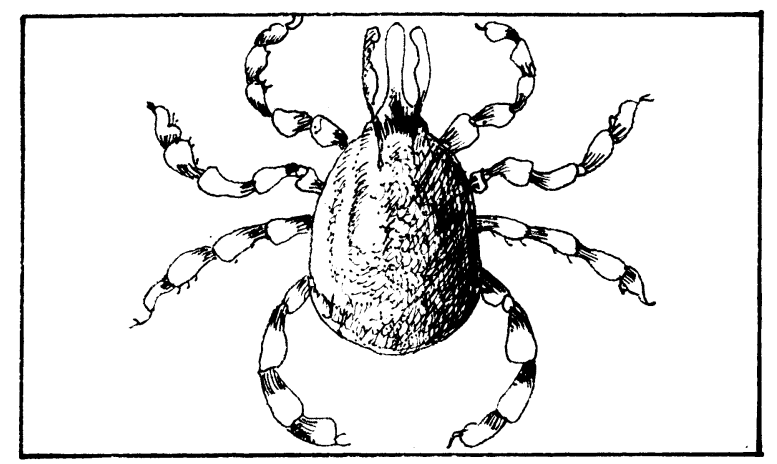

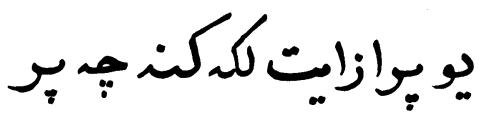

خارجى شيمت د ميزبان

زَوندكوى بنامه داكتوبرازيت

رخارجى بِازيت ،ياديزيى.

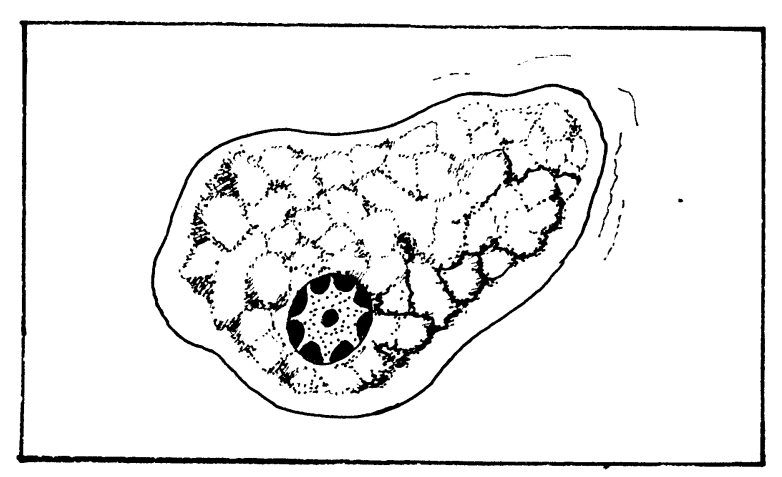

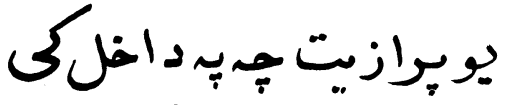

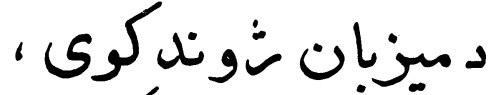

$$
\begin{aligned}
& \text { لكذهوك وارم (Tَثلموستوما ) }
\end{aligned}
$$

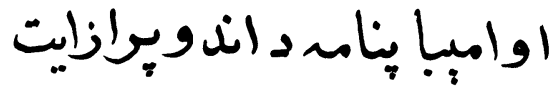

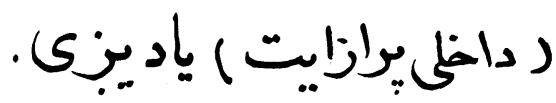




\section{دكومشيى ولتوو · تولول د دوادغايطو :}

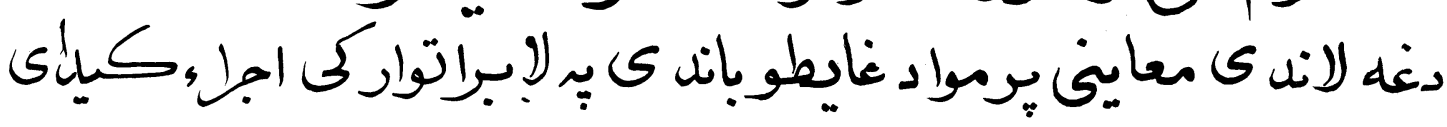
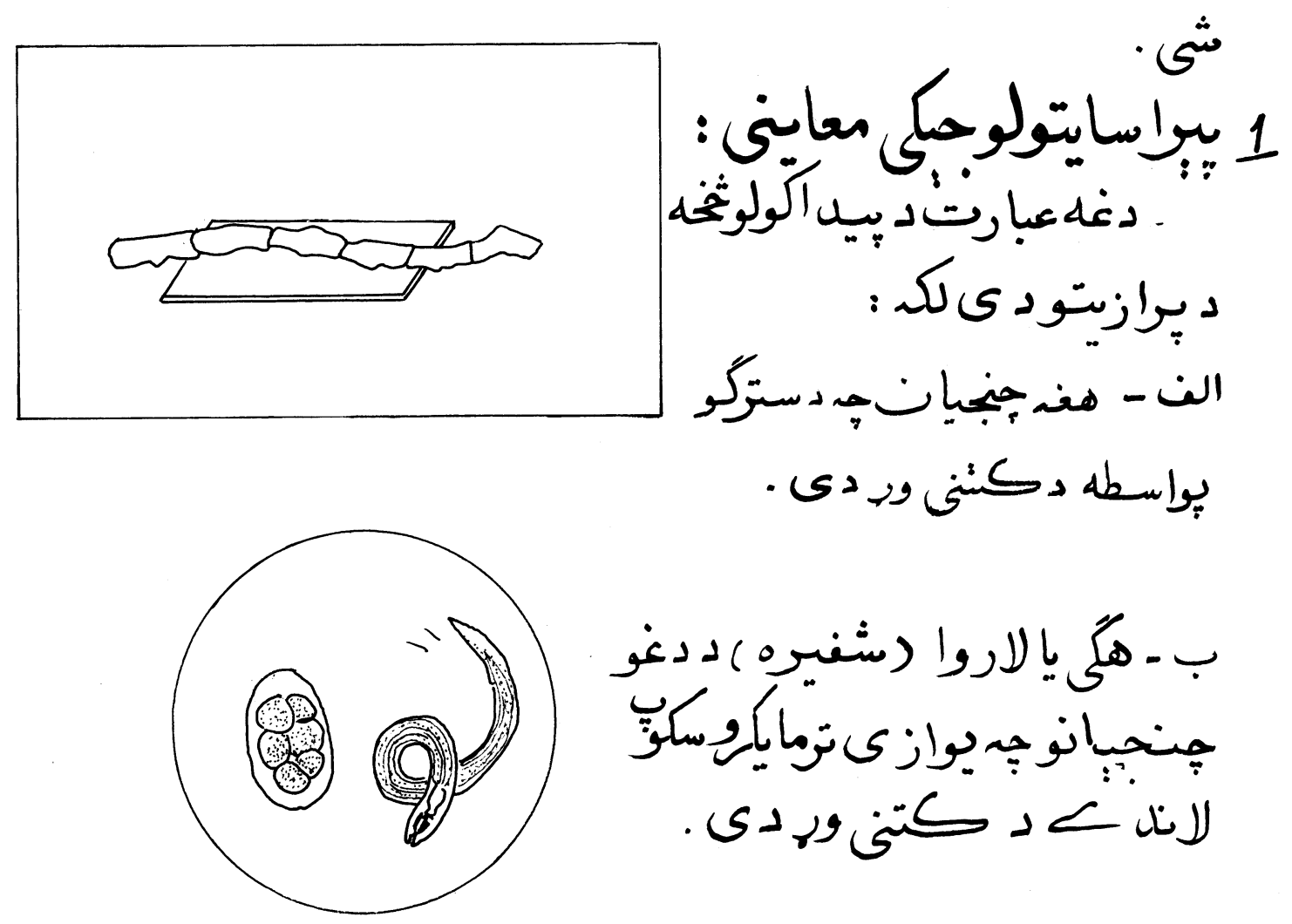

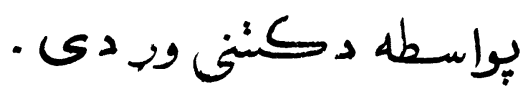
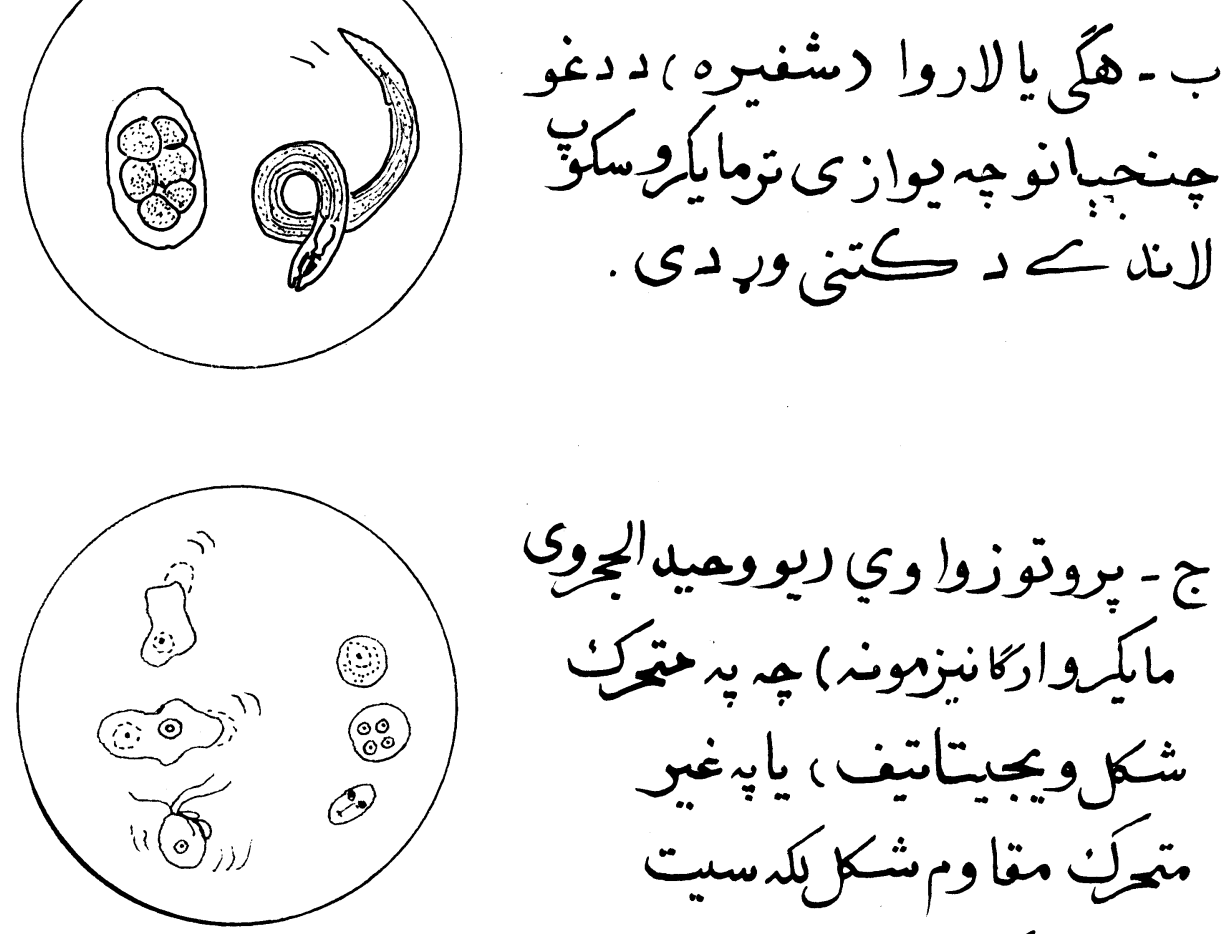

ج - يووتوزوا وي ريووميل الميحىى

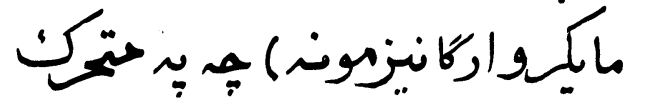

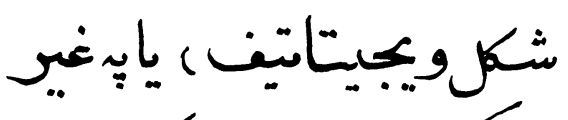

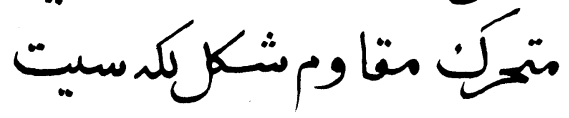

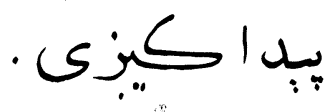




\section{تولول دغايطمروادو :}

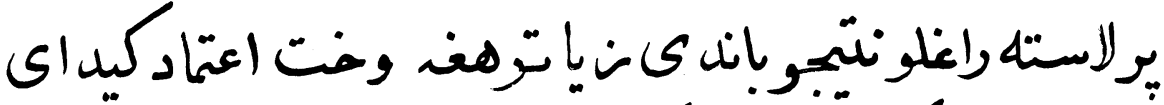

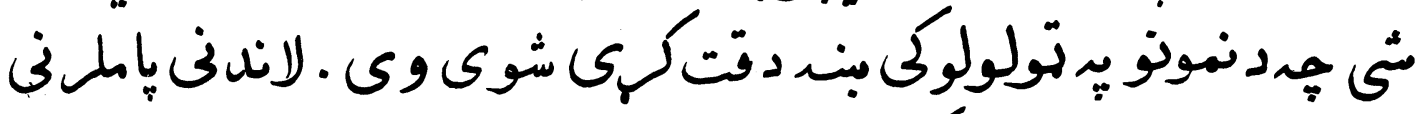

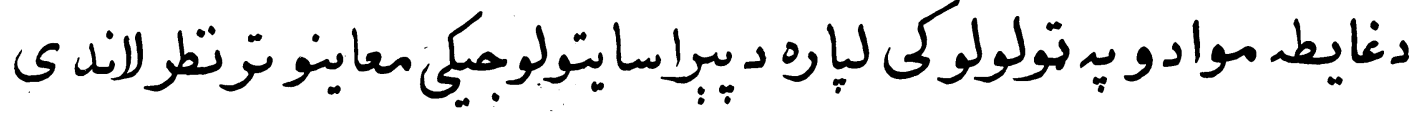
ونيول سى.

$$
\begin{aligned}
& \text { 1- تولولدكافىاندازه ممونى : }
\end{aligned}
$$

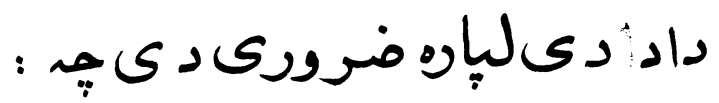

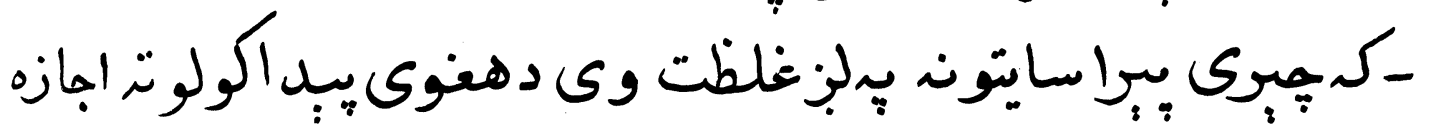

$$
\text { وركيك. }
$$

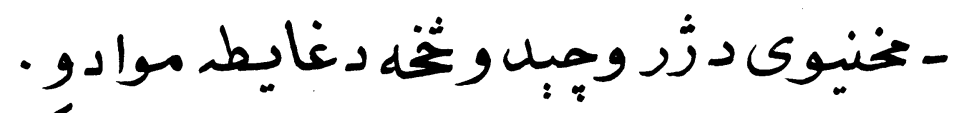

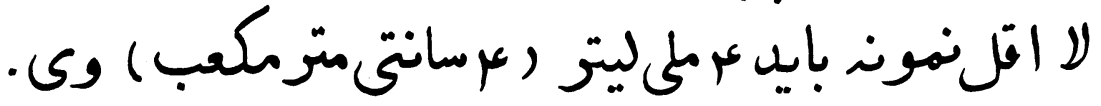

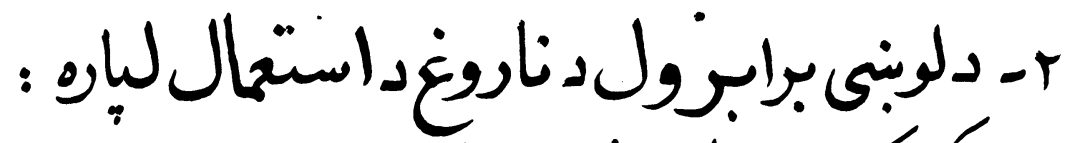

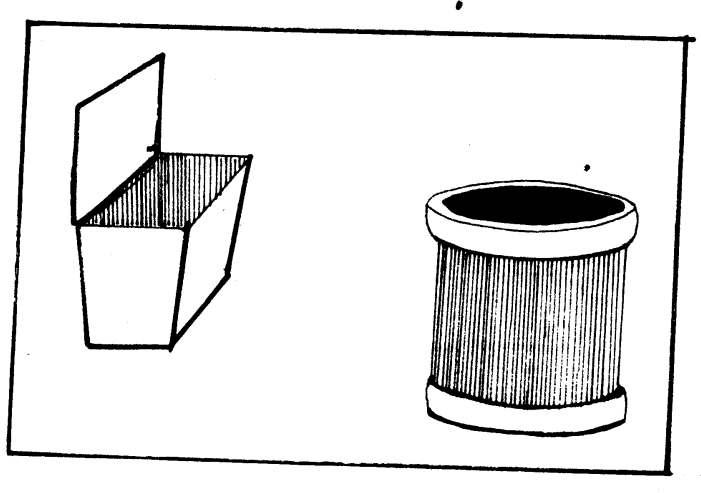

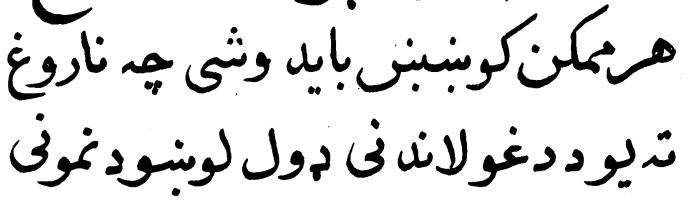

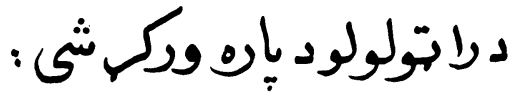

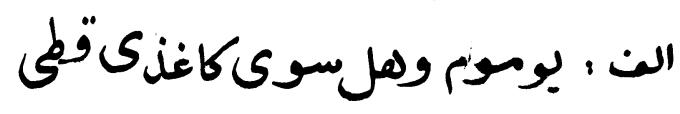

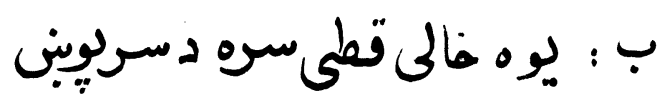




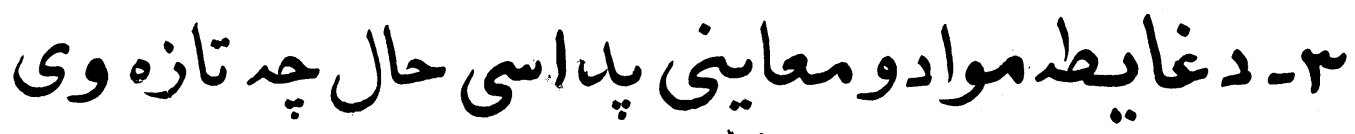

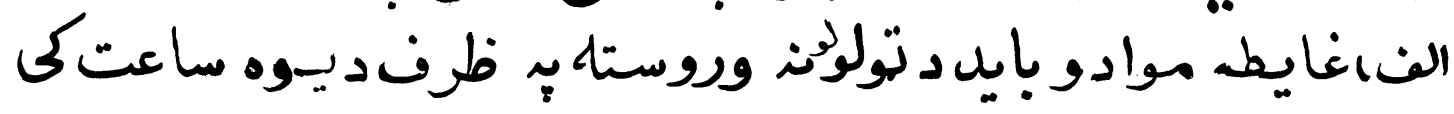

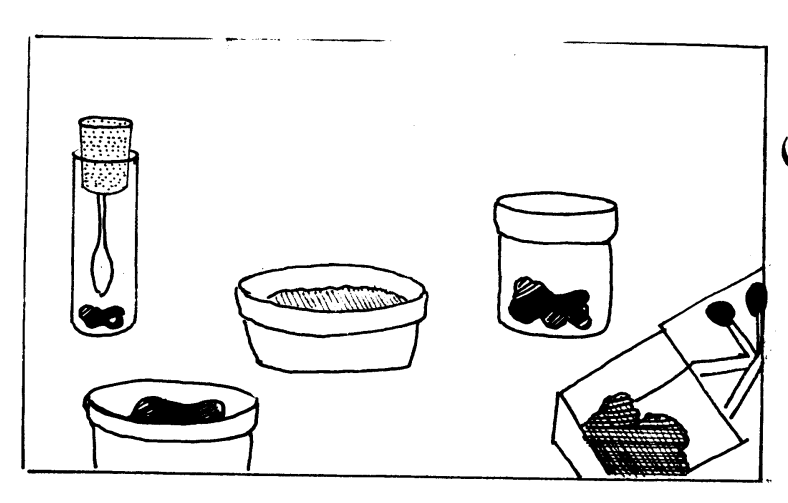

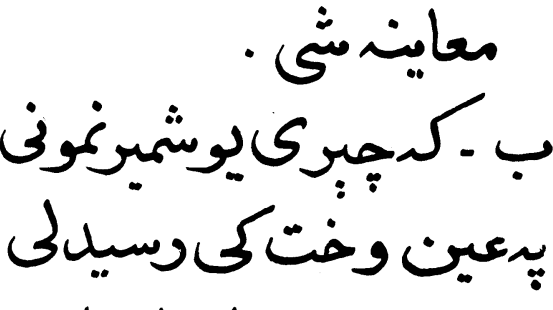

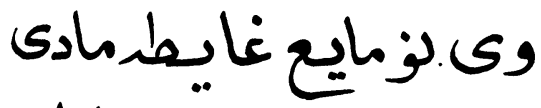

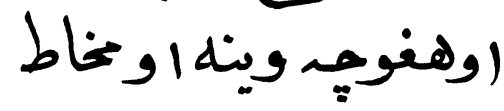

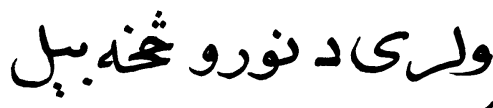

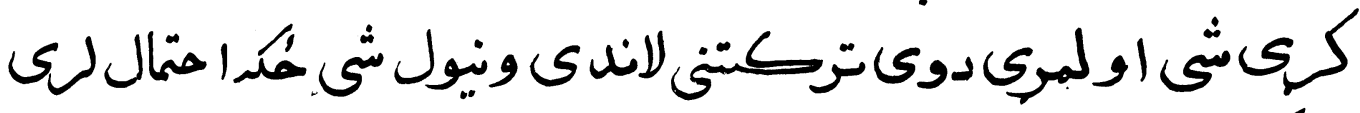

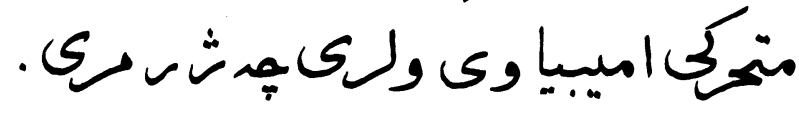

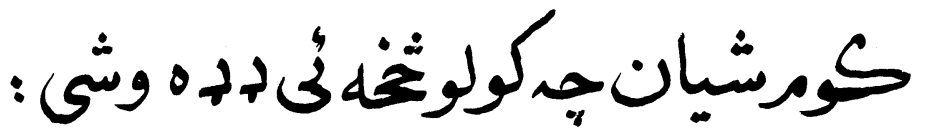

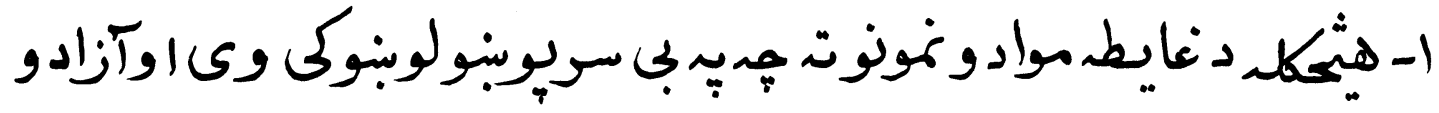

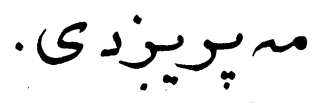

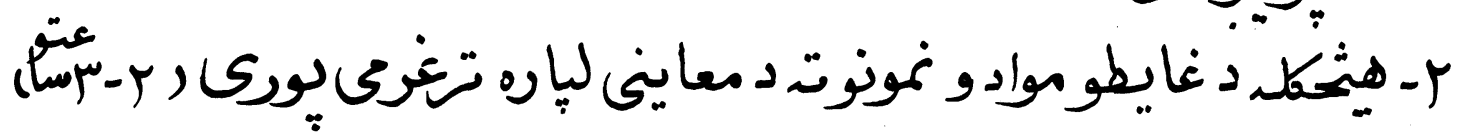

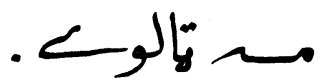

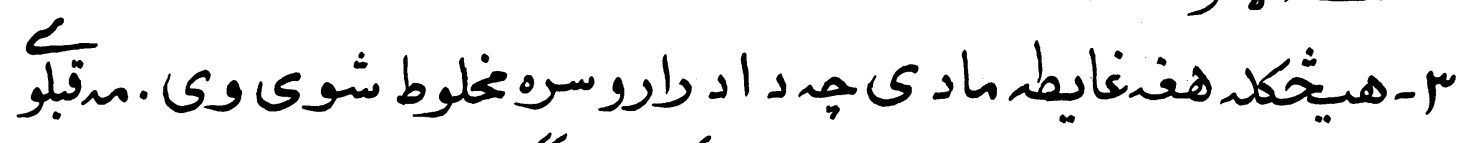

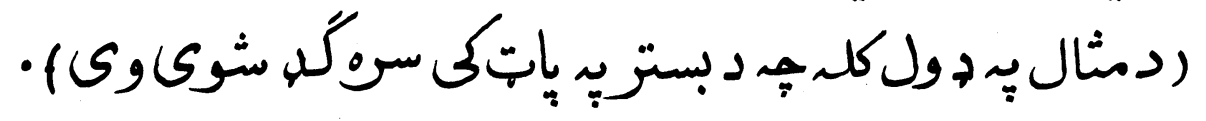

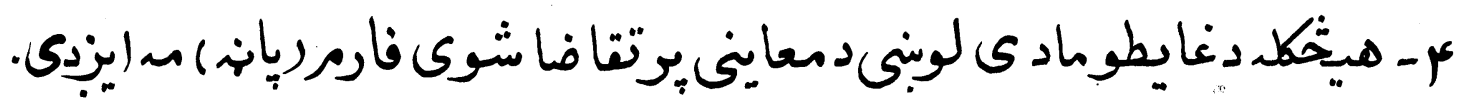




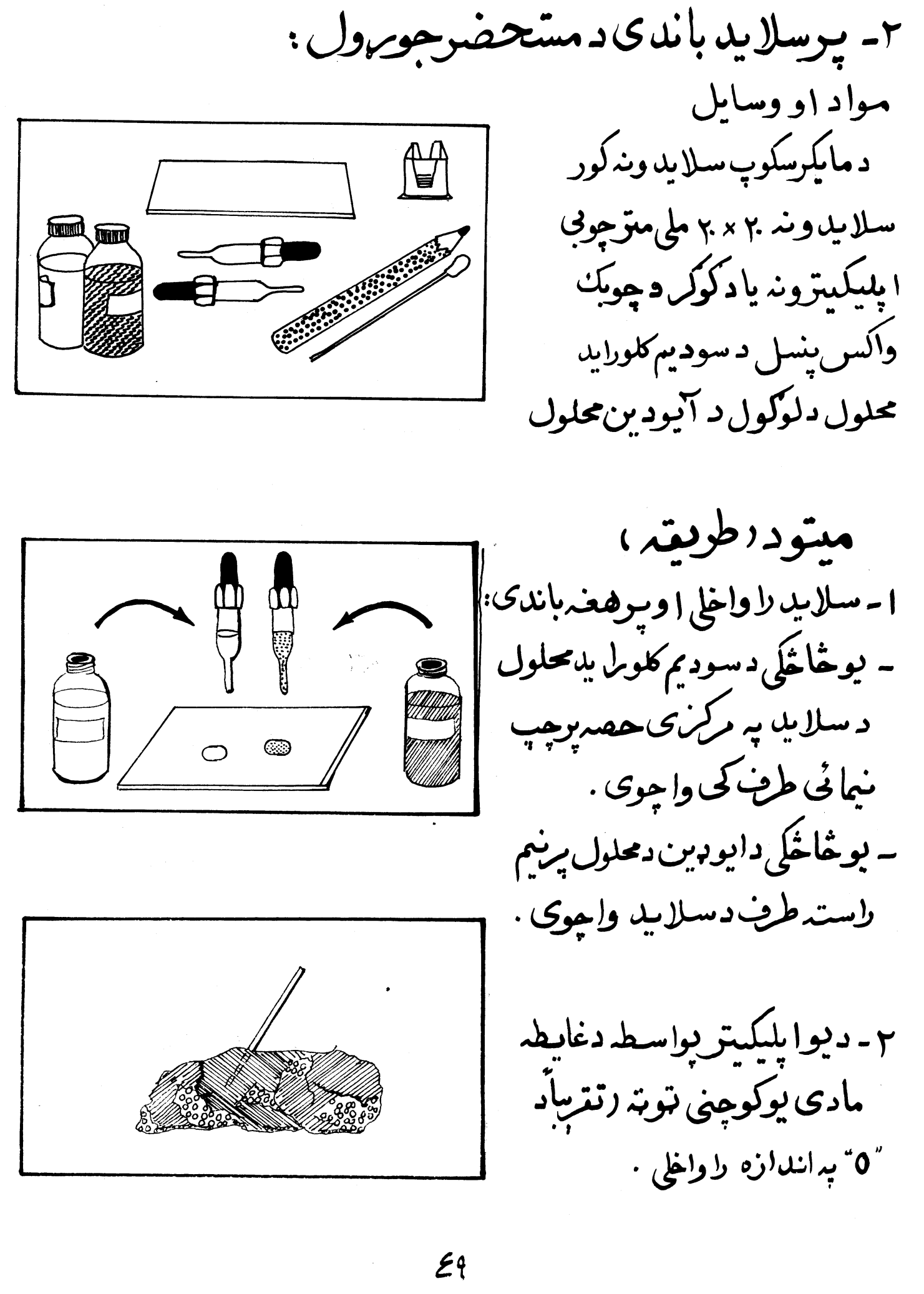




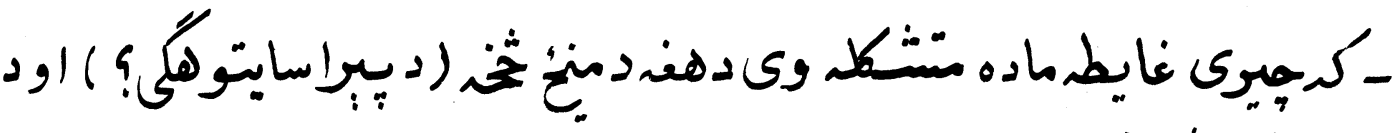
سطحها ثخت نمونى واخلى .

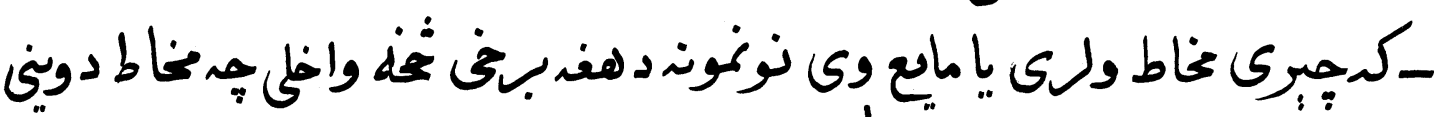

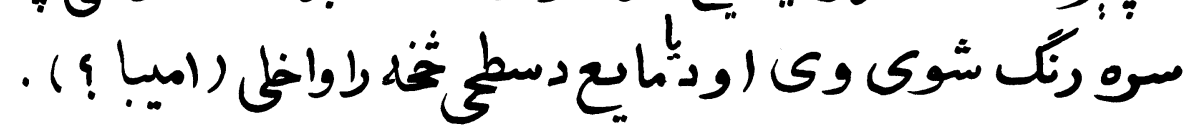
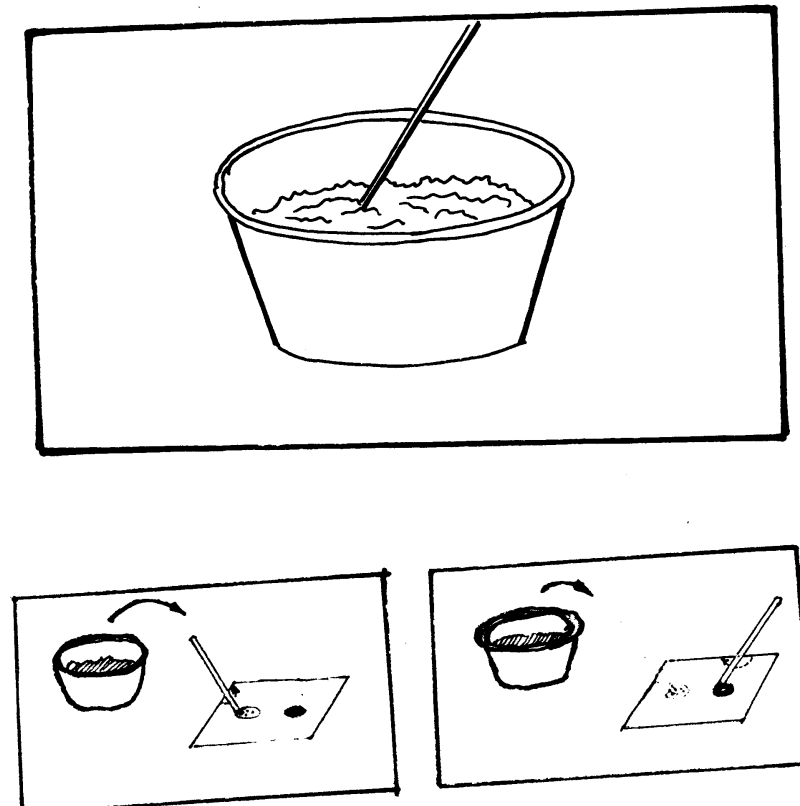

תبوط سنمارن , r)

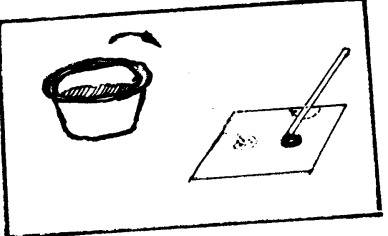

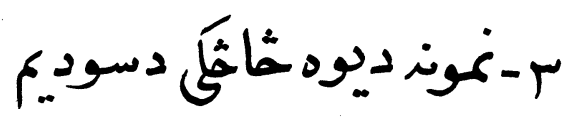

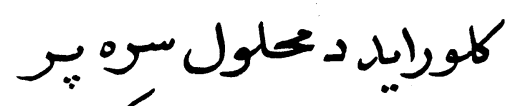

مسلايل باندى عنلوطكى

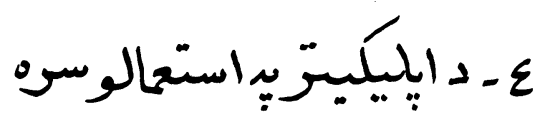

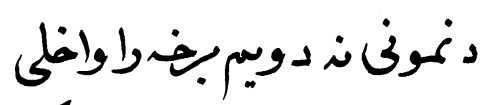

اودايوديت محلول دخاخً]

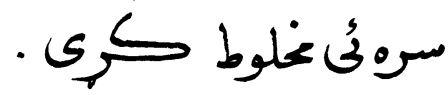

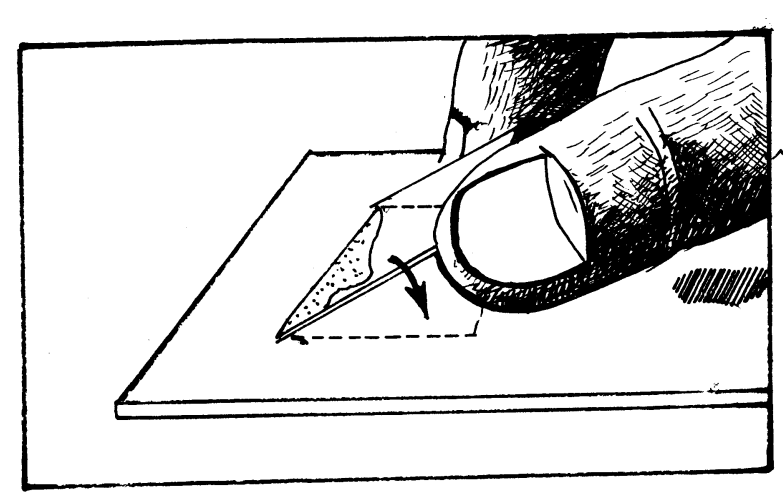

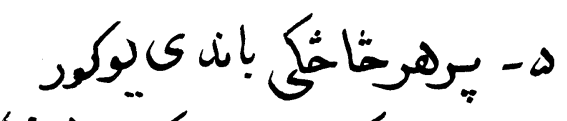

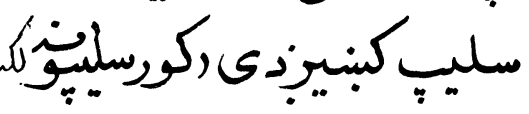

خنكا جمرنود لشوى كنبينبدى

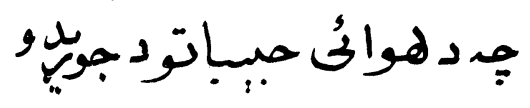

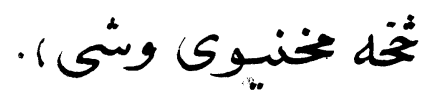

$\Delta$. 


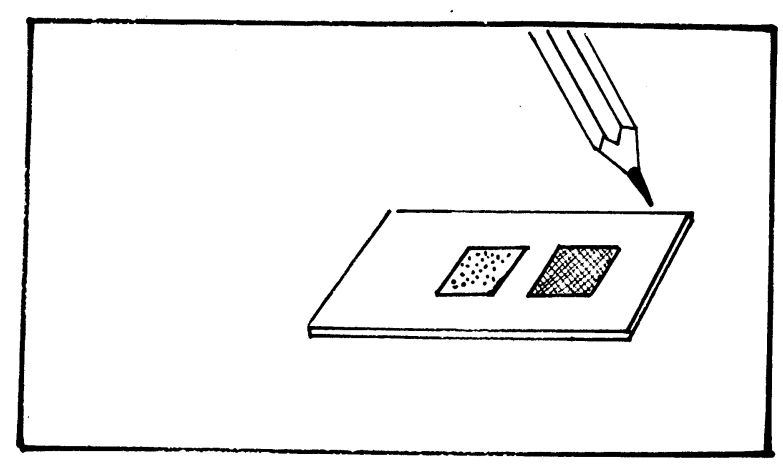

4 - د نموفى لمبربوسيلاياه باندى

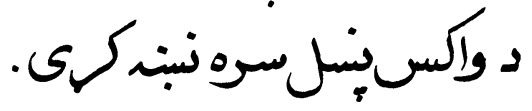

V- آماده ششوى مسلا يدترمسكومكويج

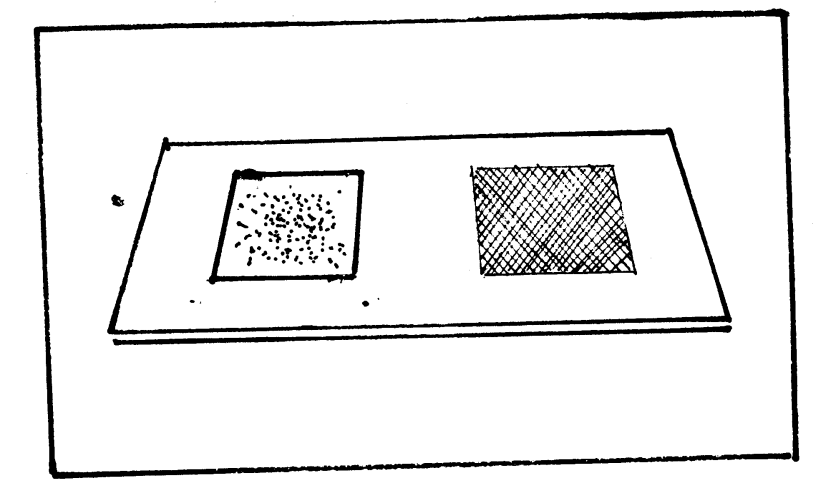

لاندى وكورى .دسوديمكلورايد

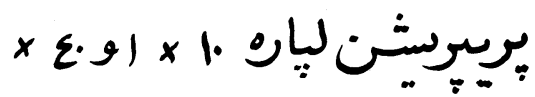

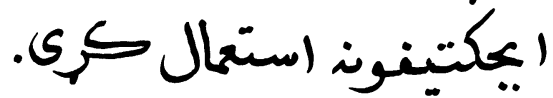

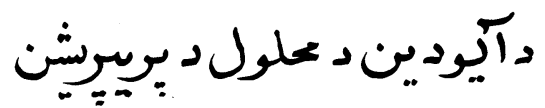

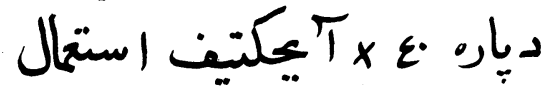

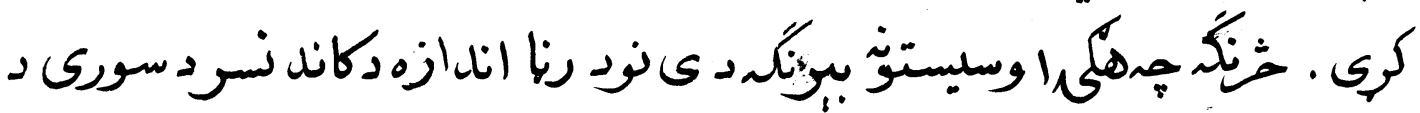

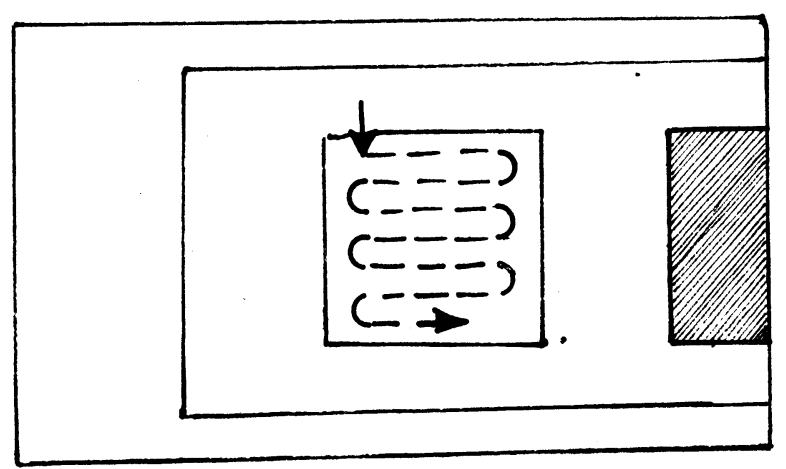

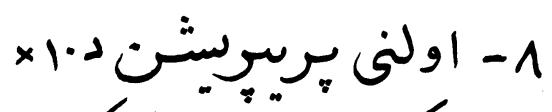

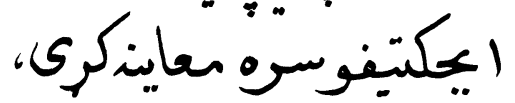

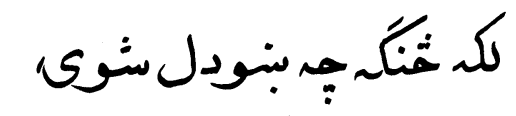

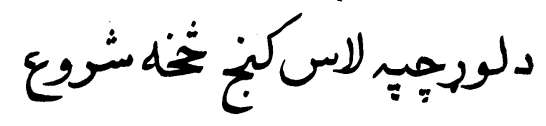
. د د 


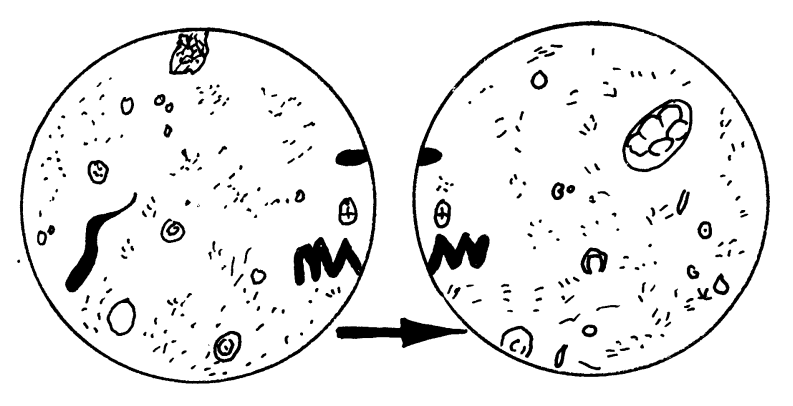

$$
\begin{aligned}
& \text { دبإِ ددى يجيتين هاملثى }
\end{aligned}
$$

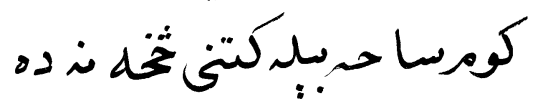

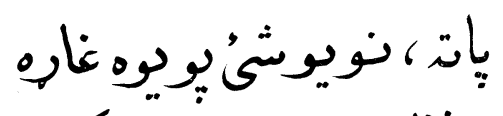

$$
\begin{aligned}
& \text { دنظردساح انتخابكي } \\
& \text { اوهكت وركيى سلابدوت }
\end{aligned}
$$

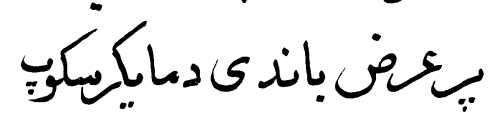

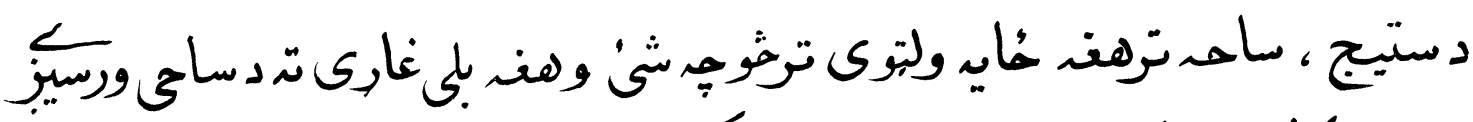

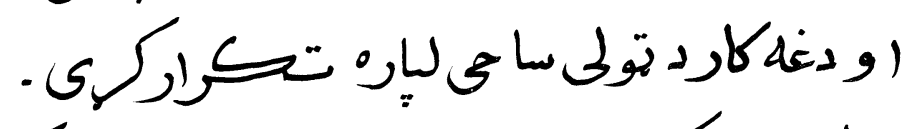

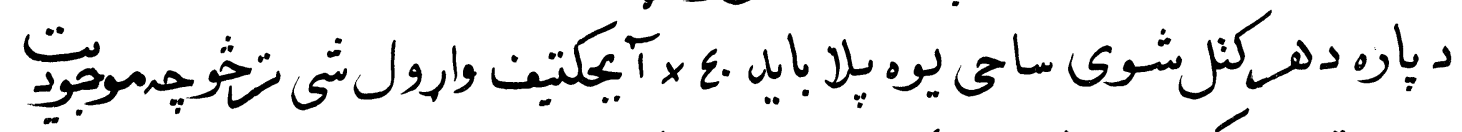

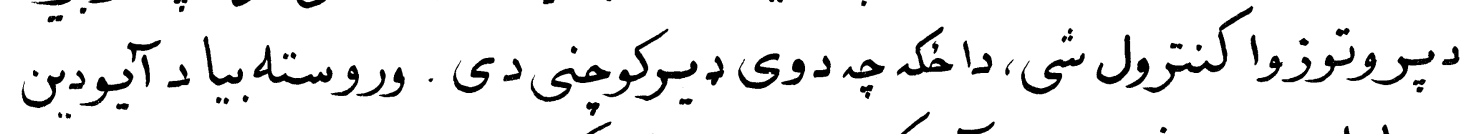

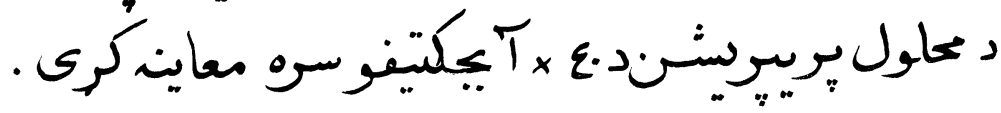

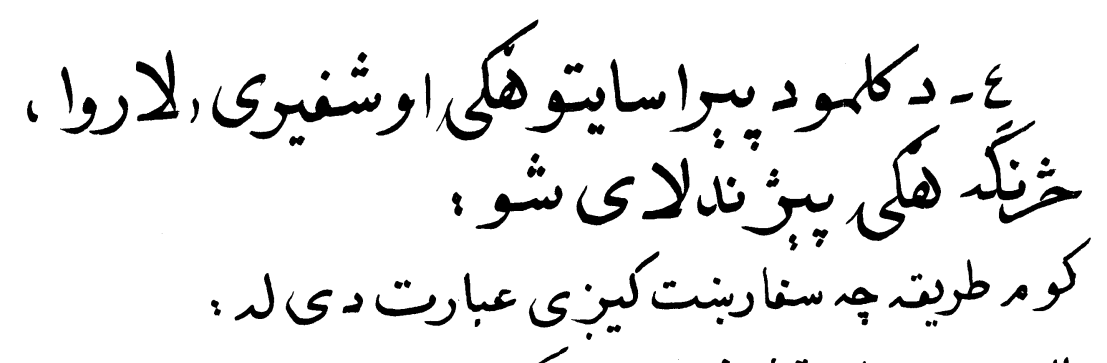

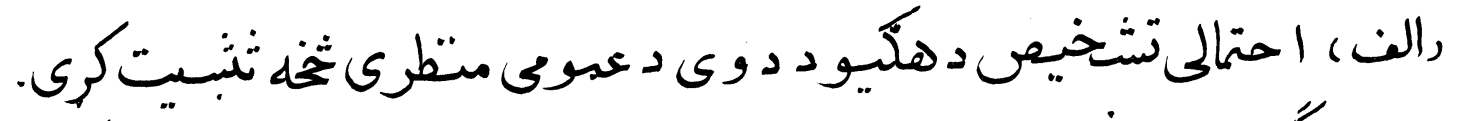

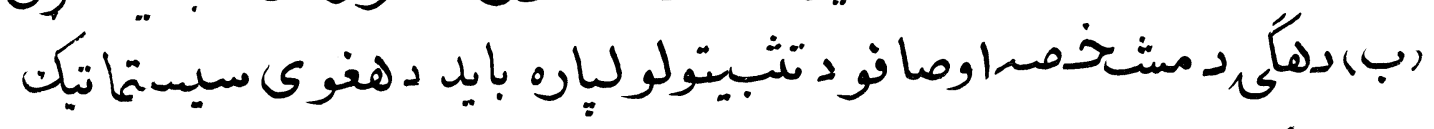

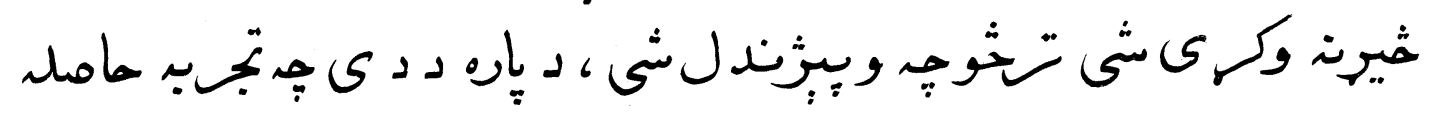

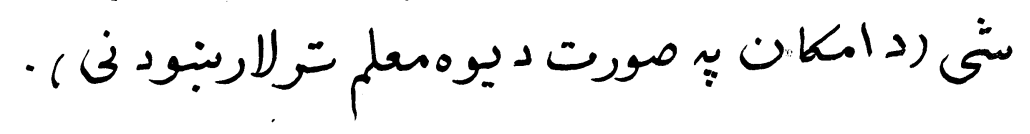




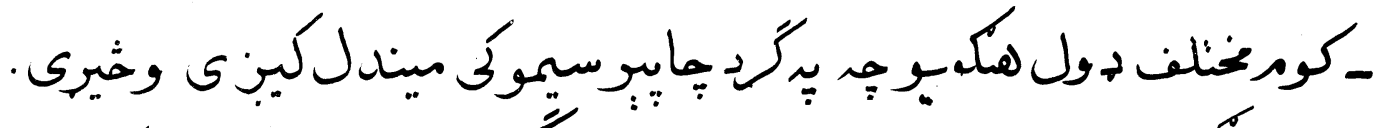

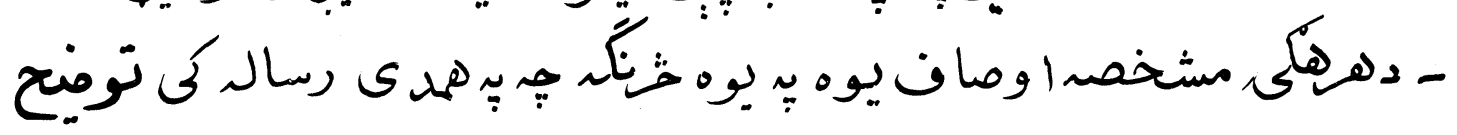

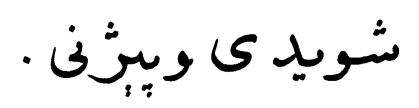

\section{الن ـ مشخصات دهلكي}

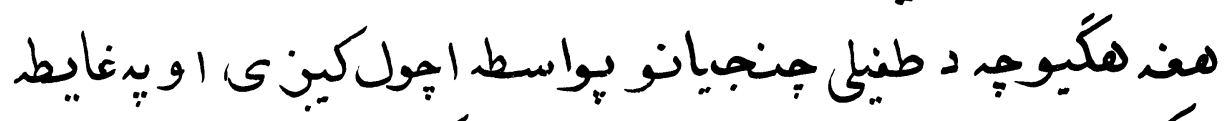

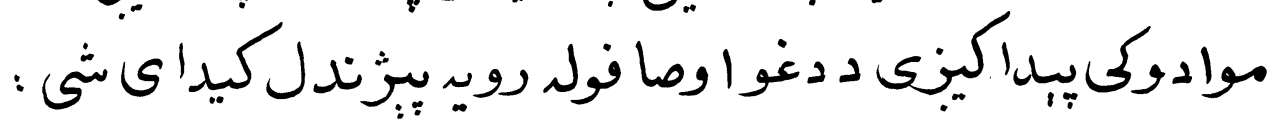

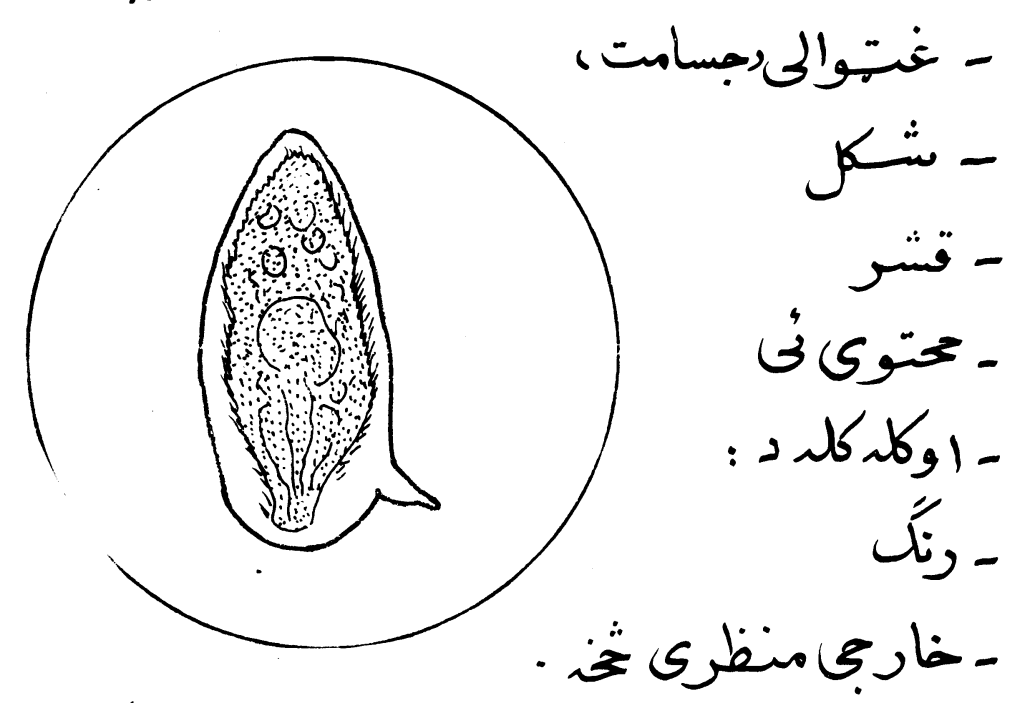

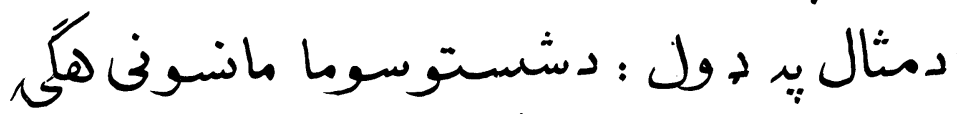

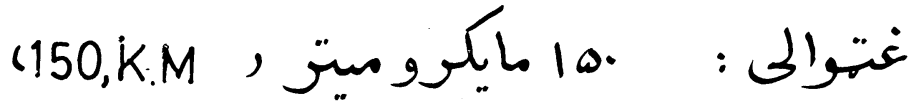

$$
\begin{aligned}
& \text { شيكل : بيفوى : بهري }
\end{aligned}
$$

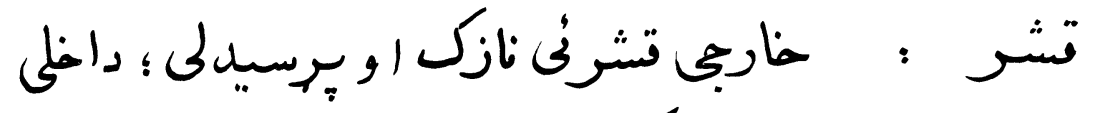

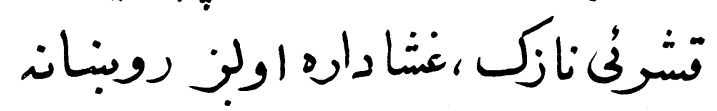



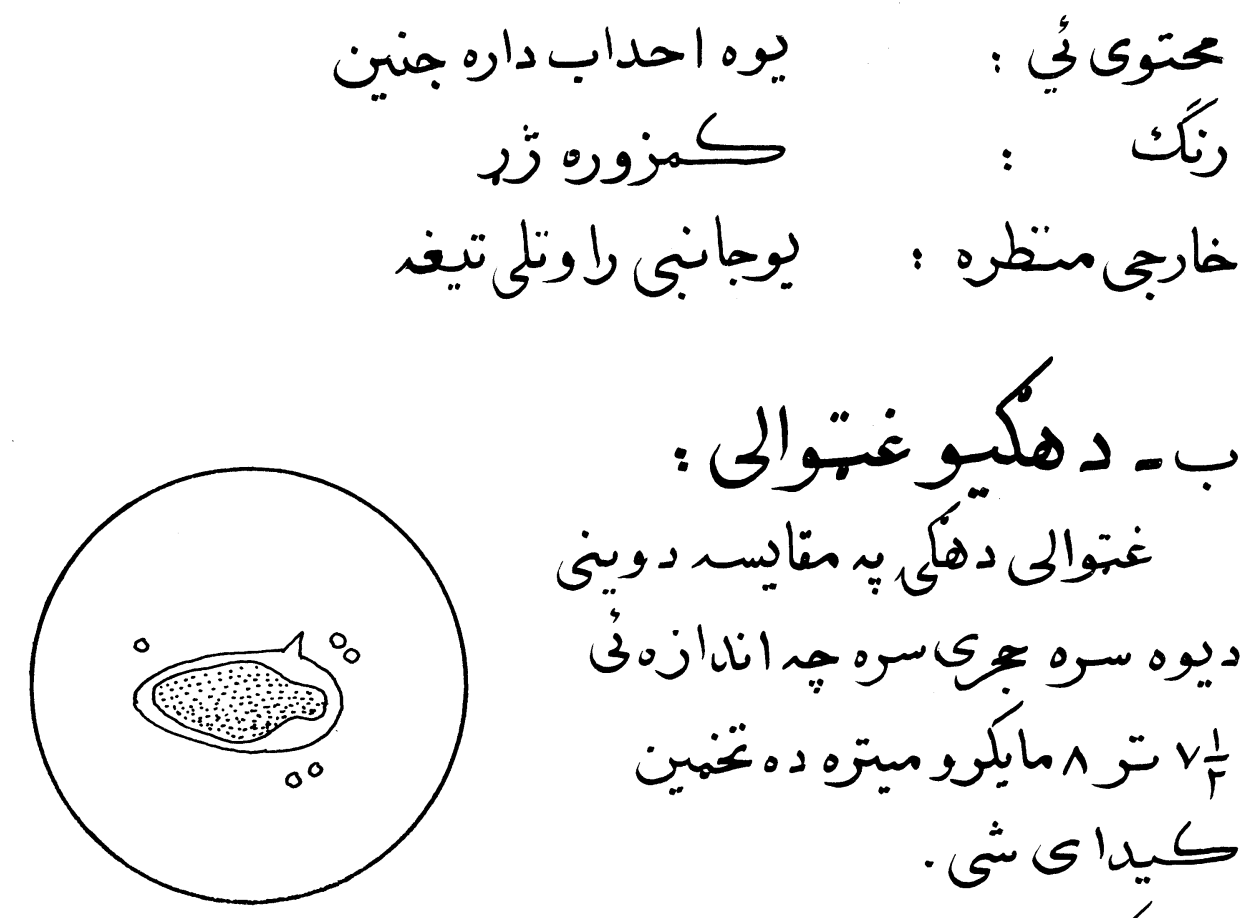

$$
\text { يومايكوميتر ) }
$$

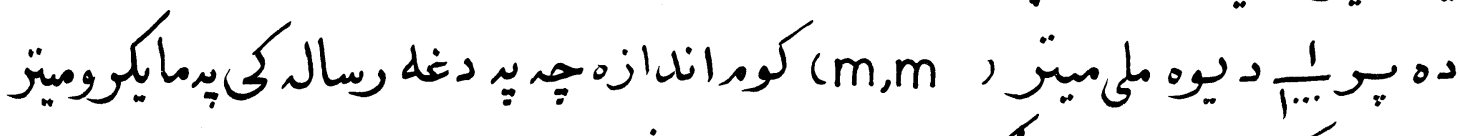

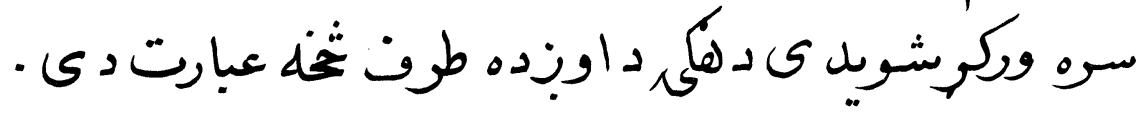

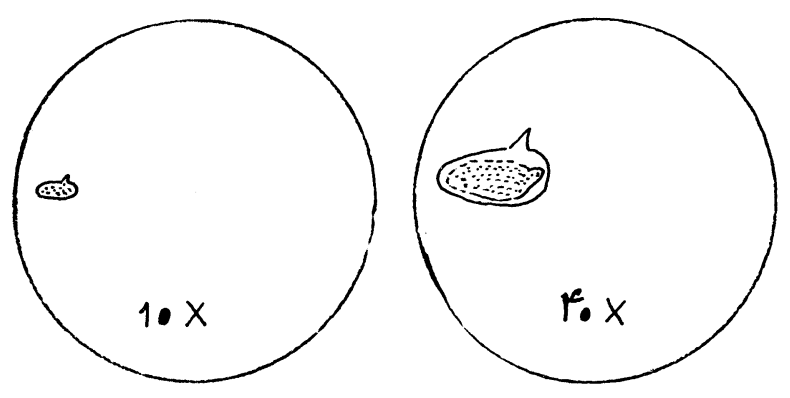

$$
\begin{aligned}
& \text { غنتوالى دهكيكيد إى نتى }
\end{aligned}
$$

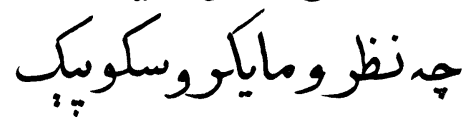

$$
\begin{aligned}
& \text { ساحى ته ارزيابي شى: }
\end{aligned}
$$

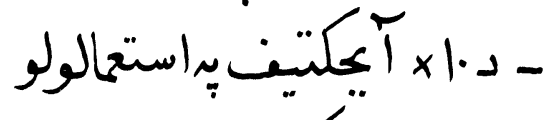

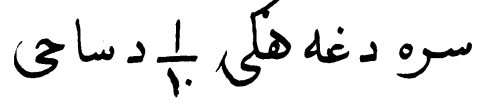

$$
\begin{aligned}
& \text { • ستَّى }
\end{aligned}
$$




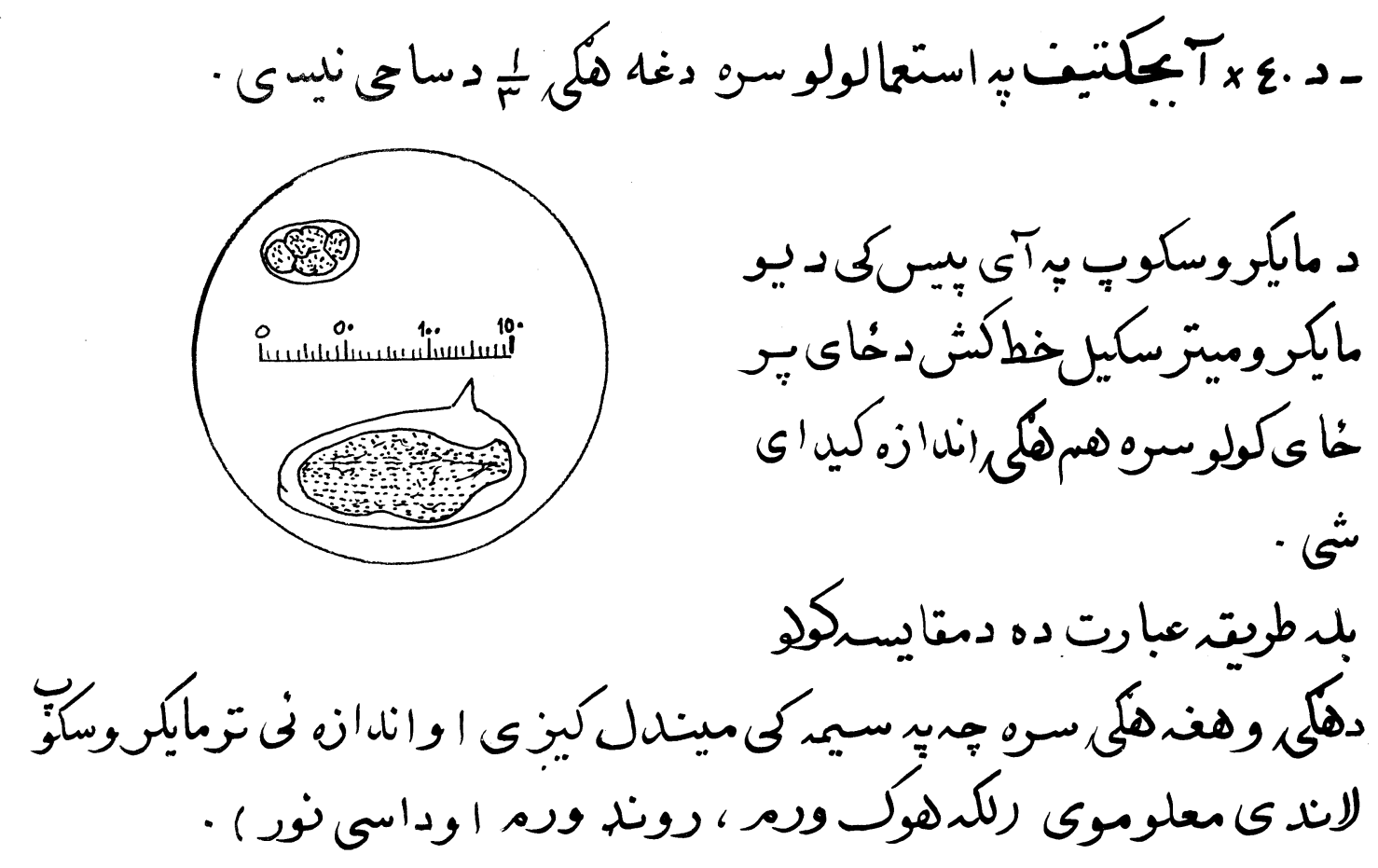


كوماصطلاهاتيى دهكيودتشخيصد بارها استحاليزي.
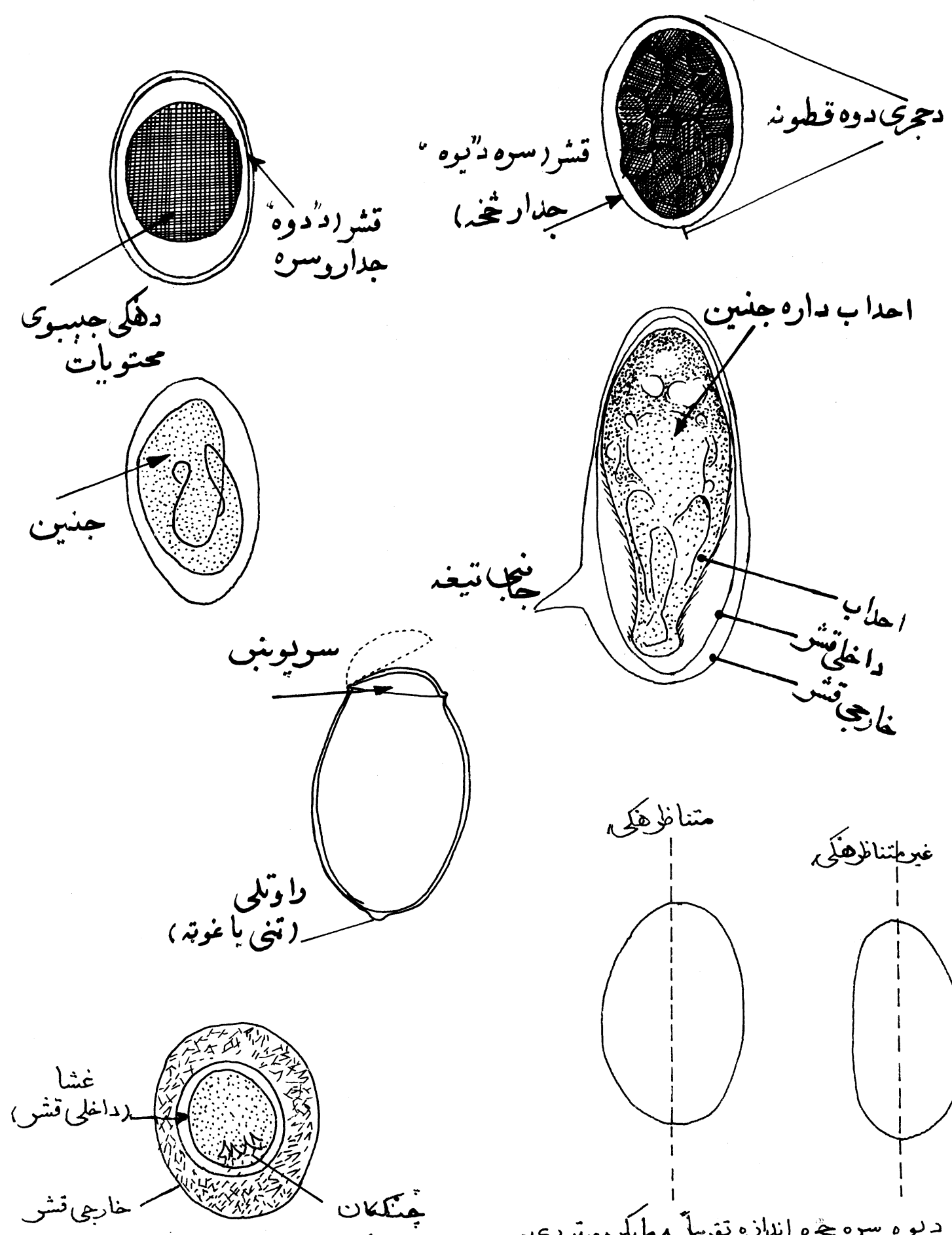

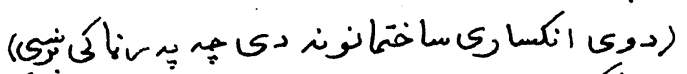

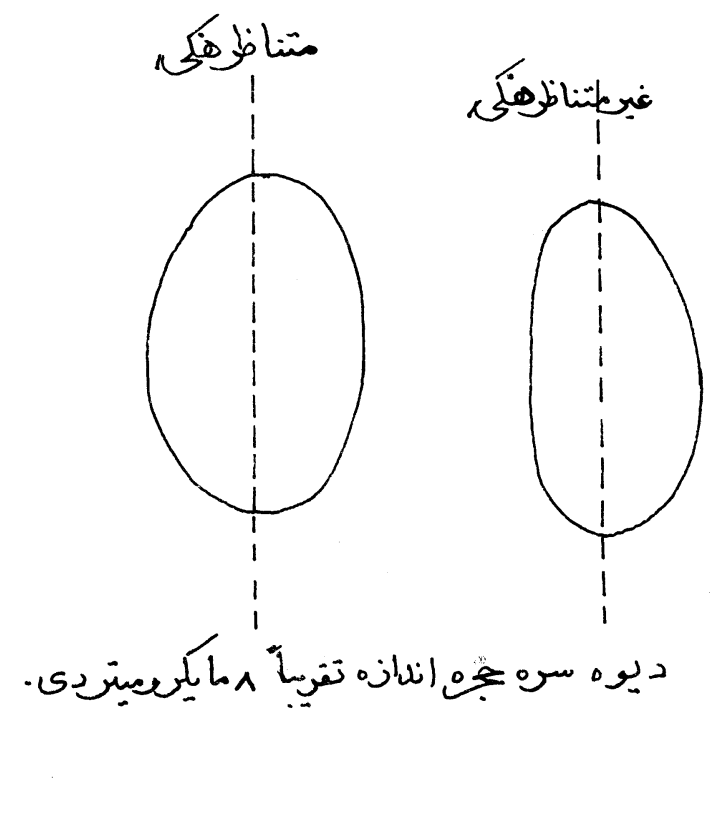

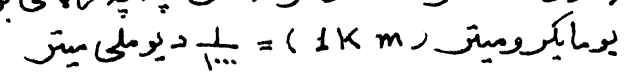




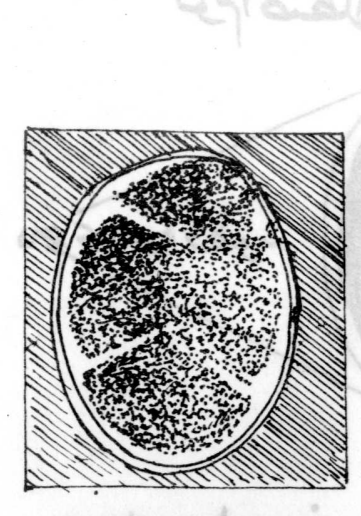

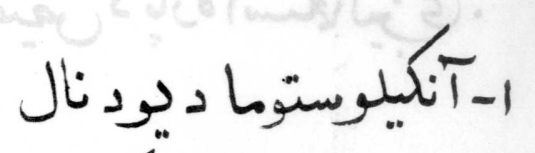

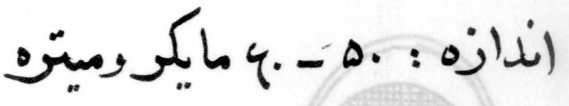

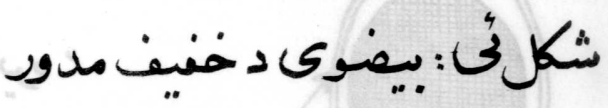

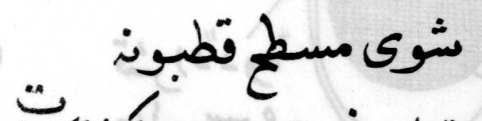

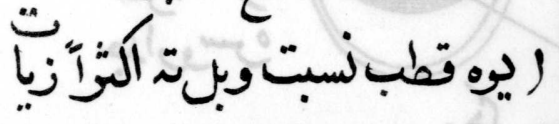

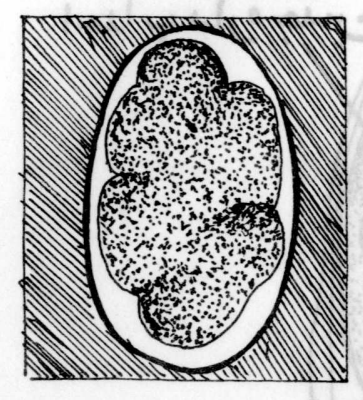

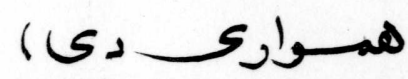

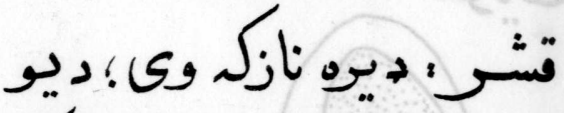

توركسنى شانن ليدليبي.

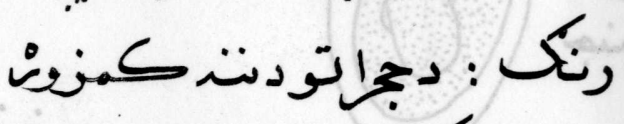

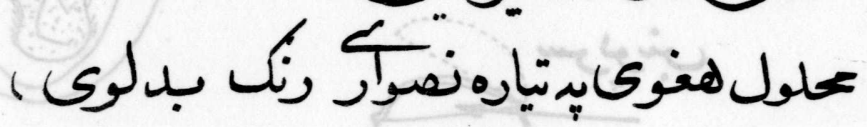

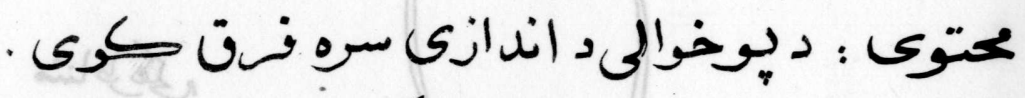

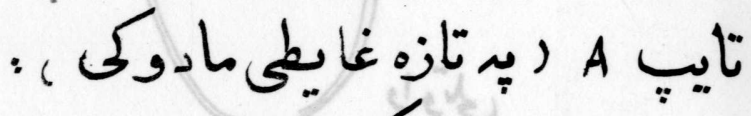

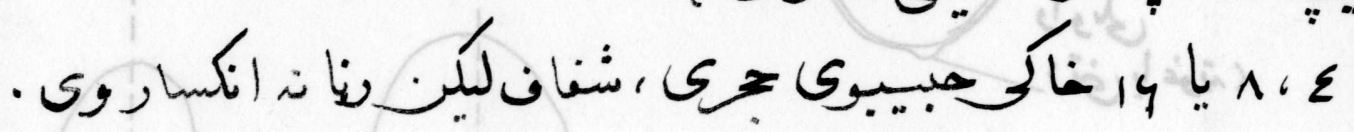



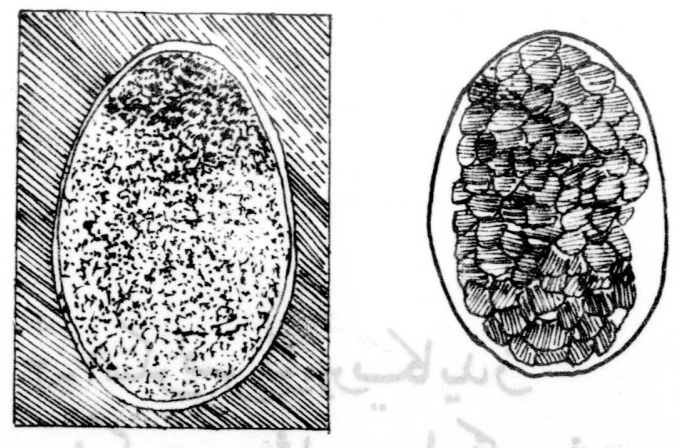

تايب B دكوت غايط مادى

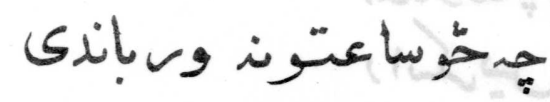

تيوشوى وى :

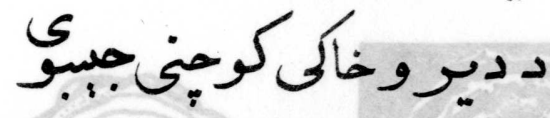

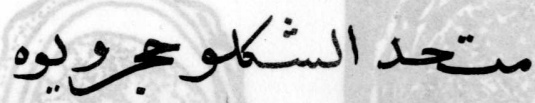

.
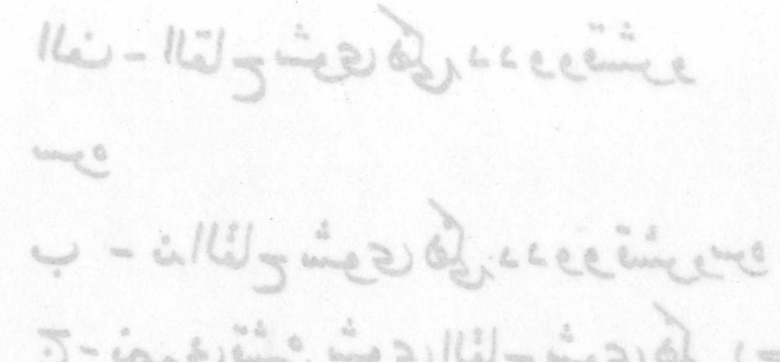

تايس C ركوم غايطمادى

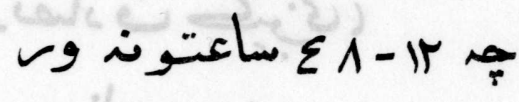
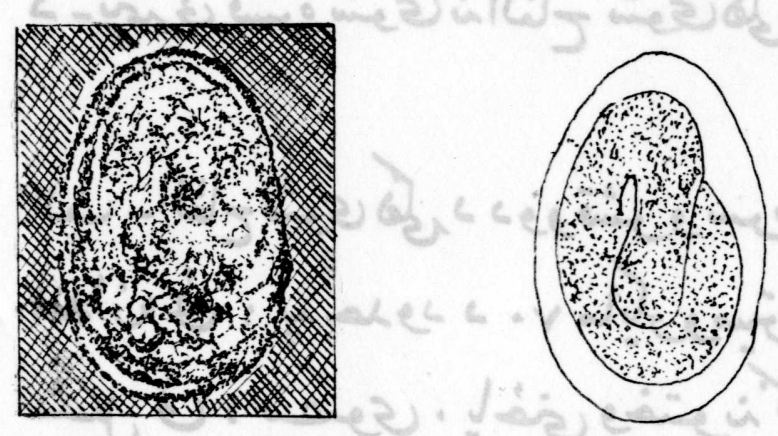
باندى نئيشوي وينا د هكم تونى بحنى دكوحنى

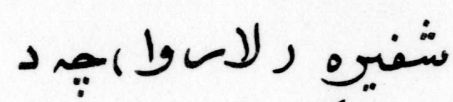

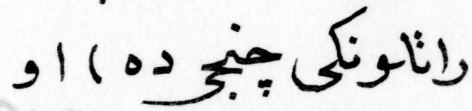

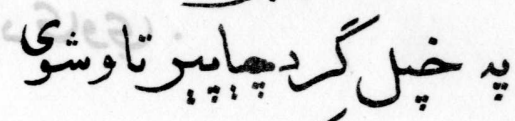
دى اودك شوى دهن.

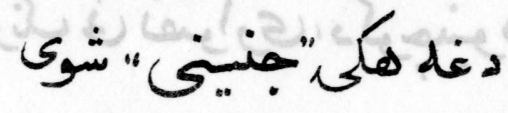
1. 


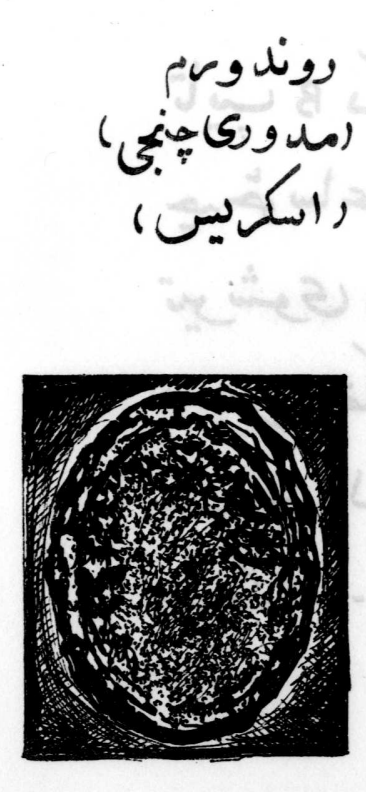

متصلدنىكى

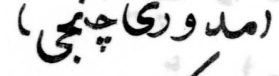

(اسلس )

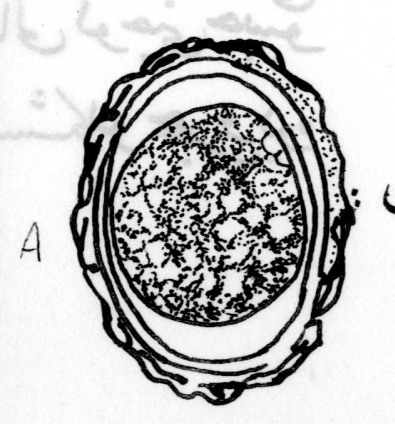

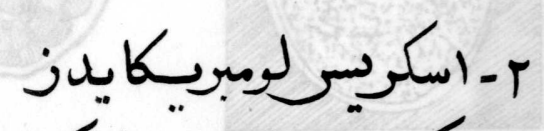

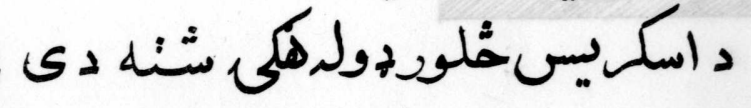

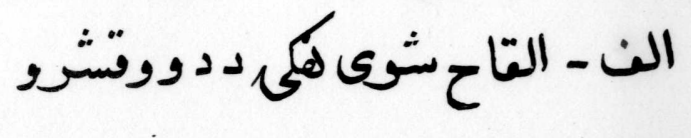

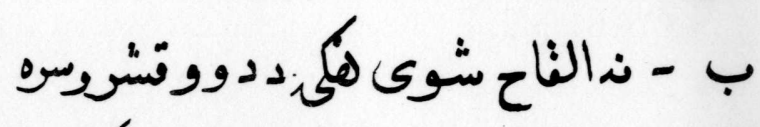

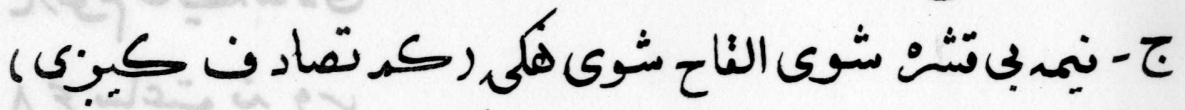

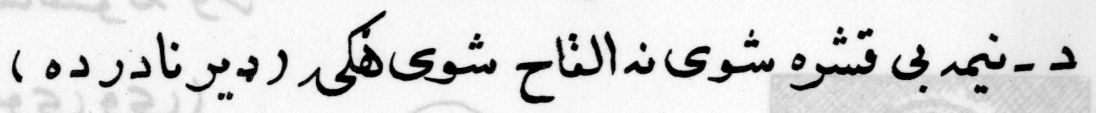

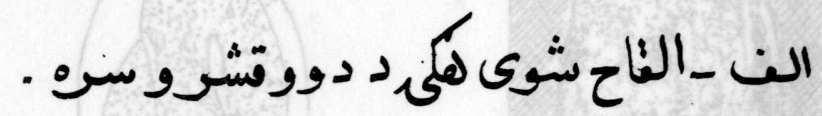

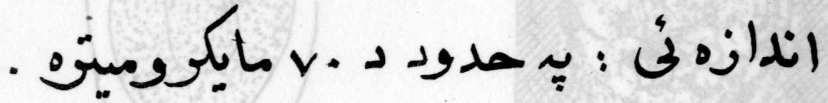

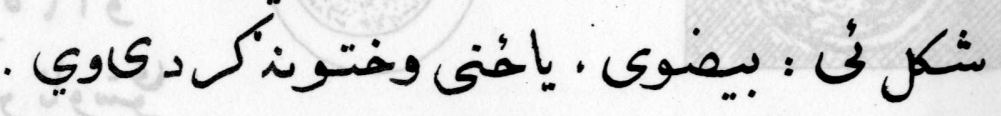

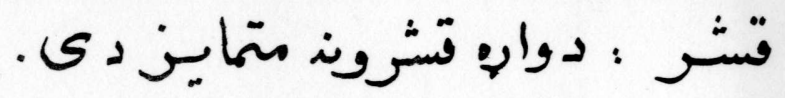

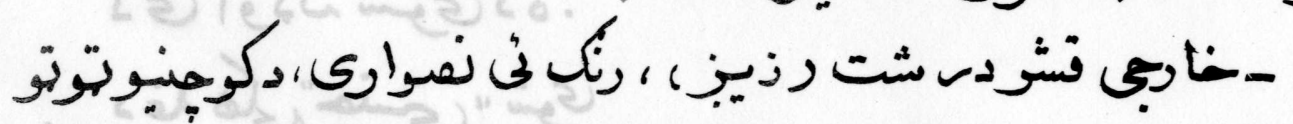

سوه ريت وى (دنتى وسرشانت )

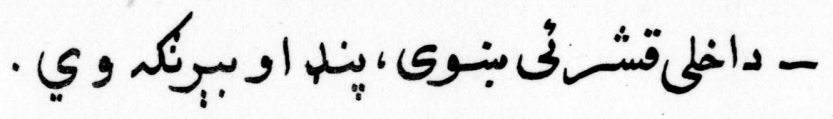




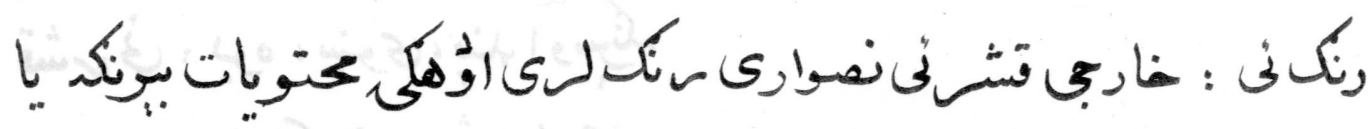
كمزوره شنه وى .

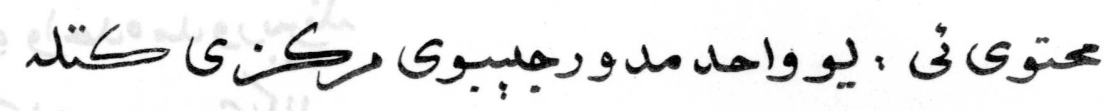

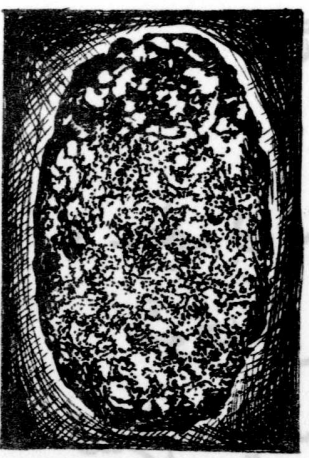

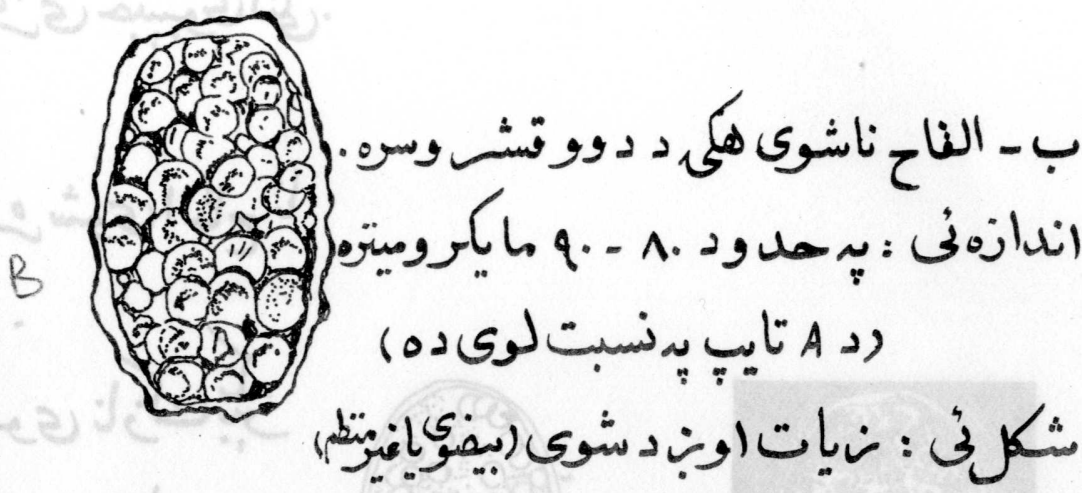

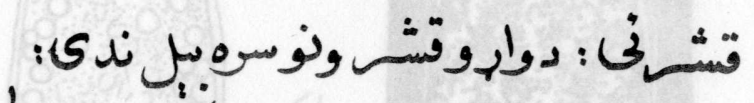

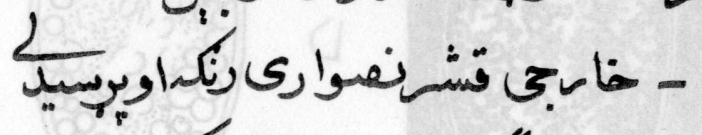

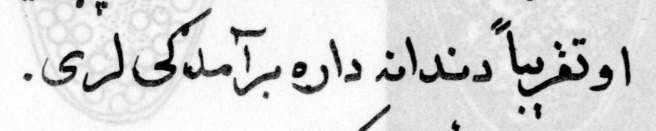

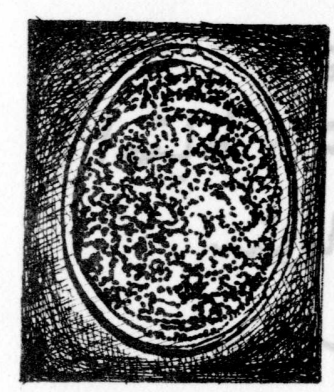

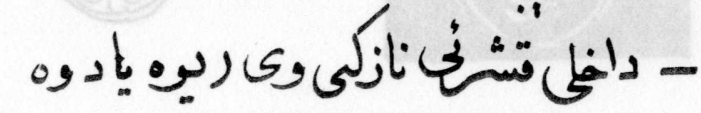

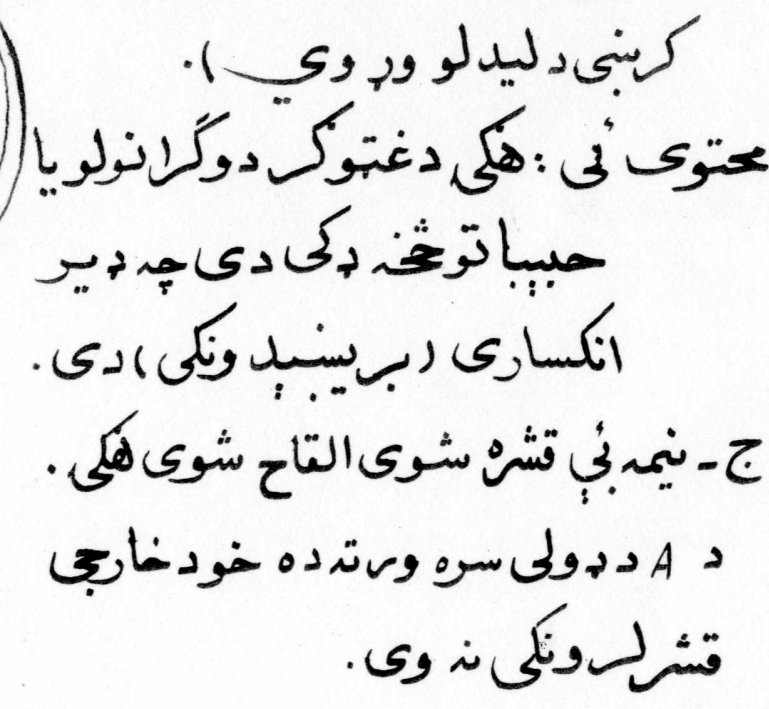



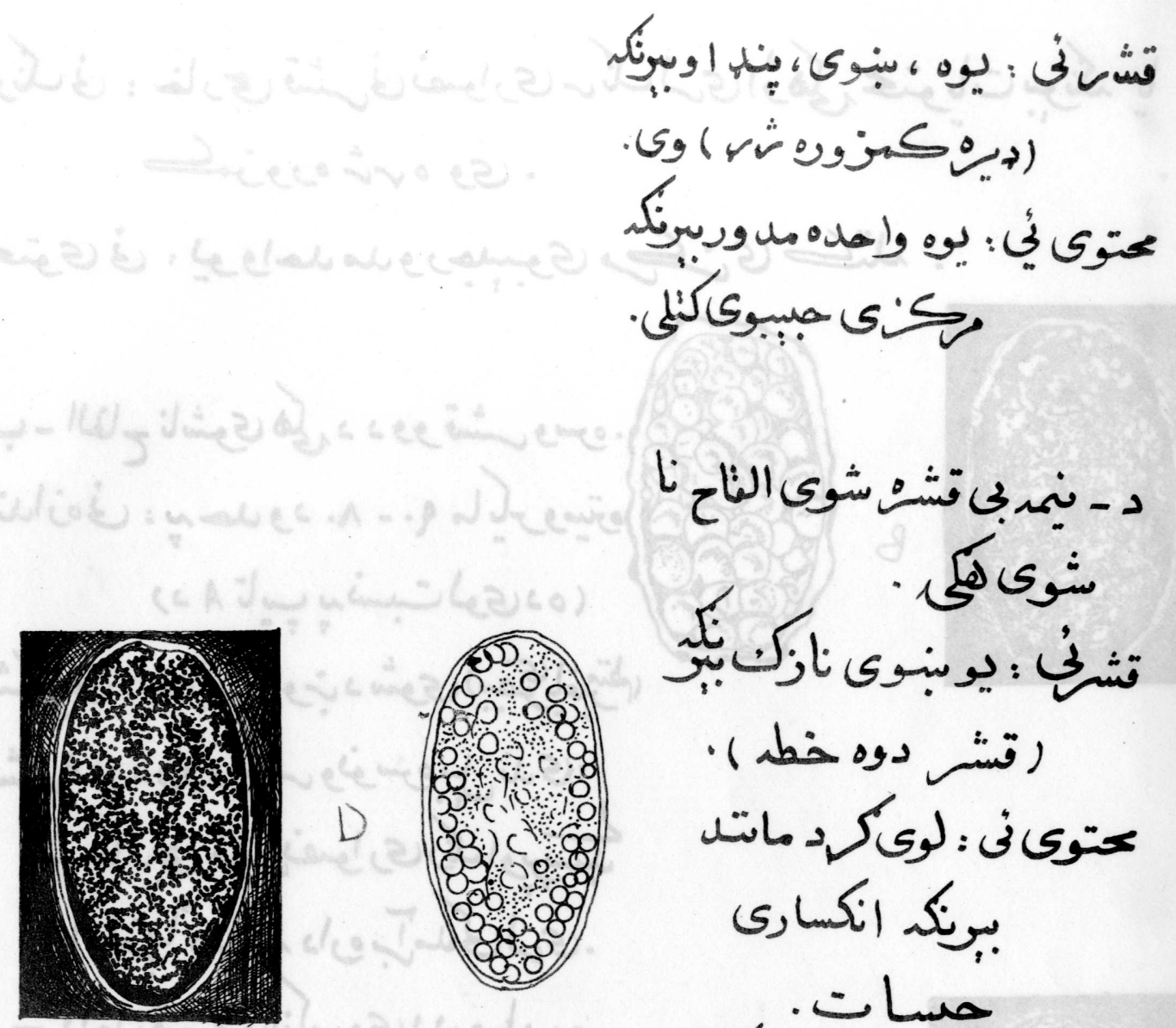

تشخن : يوبنوى نازك بئب

( his ogs :

Hit. S(59): 3450 (5) ئك

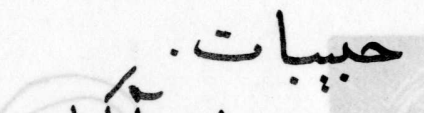

اهتياط : ه هول دآنميلو

ستومايا ديوآسافلوك

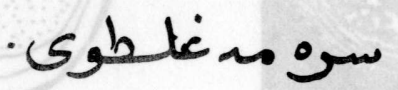

(د يوآسا = ديومانتاه ) 


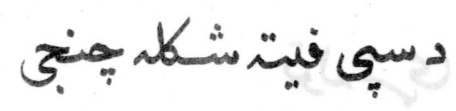
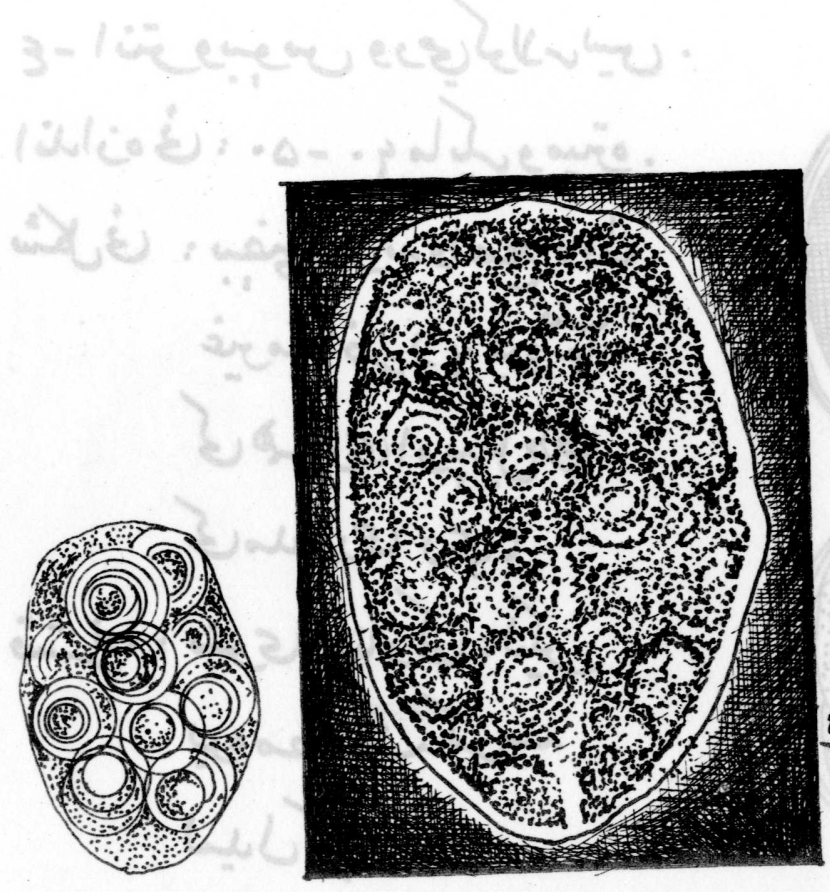

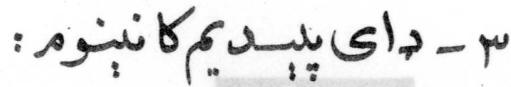

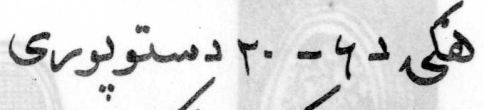

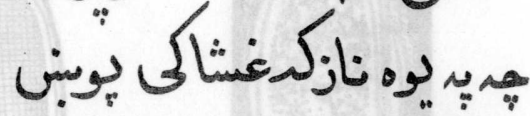

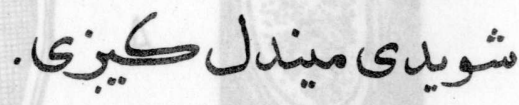

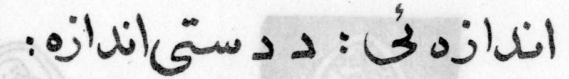

$$
\begin{aligned}
& \text { 吾 }
\end{aligned}
$$

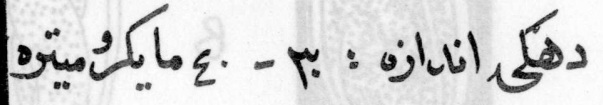

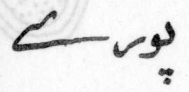

$$
\text { شكرفى : كاكردى. }
$$

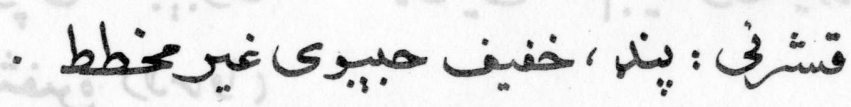

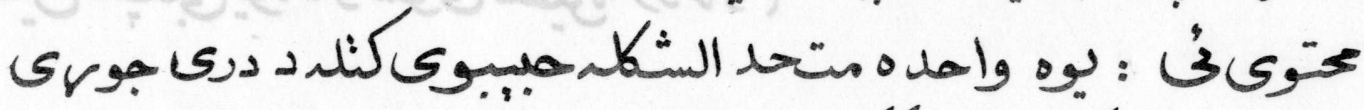

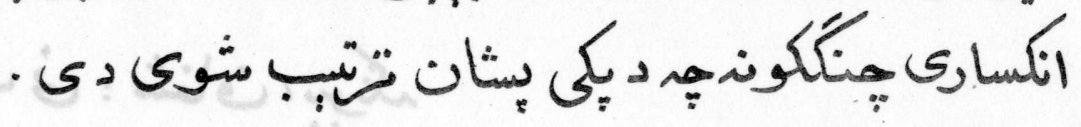

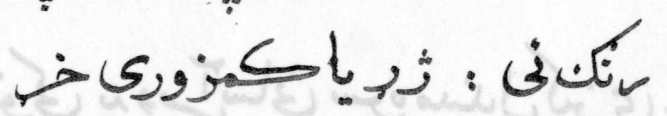




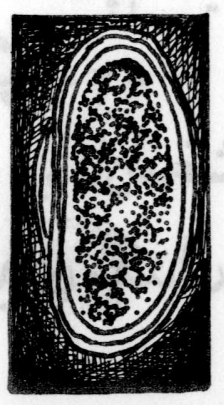

ع- انتوبيوس ورميكولاسيس .

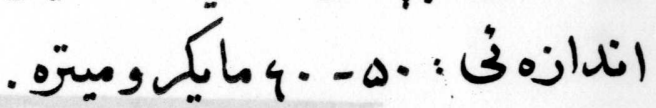

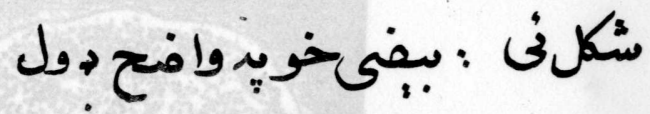
غيمتناظل ديميونجا.

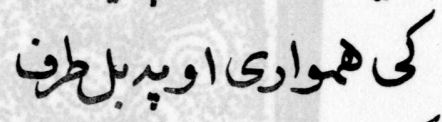

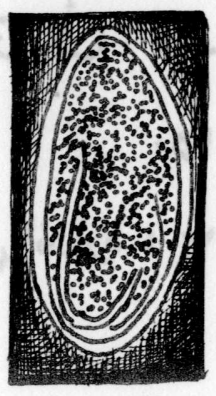

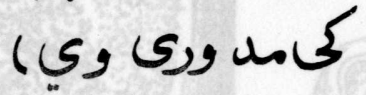
تشثني : بنوى اونازكى ،لئن. يوه مضاعندركنين ليدل كينى . يون.

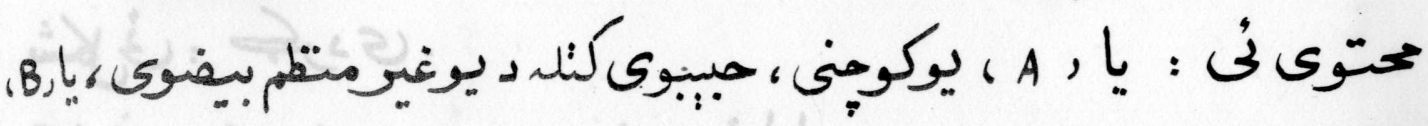

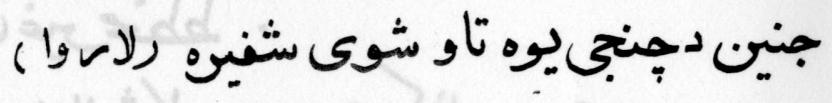

$$
\text { رنكث نى : شناف ،برجنك }
$$

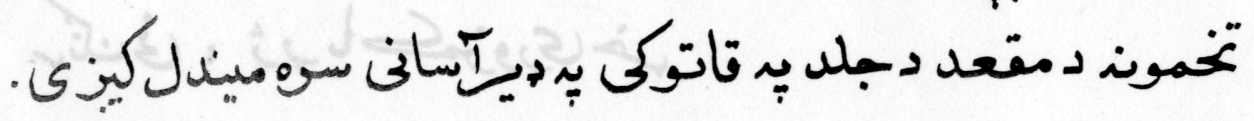


دمزوتيّ: ورم

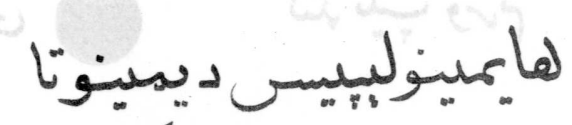

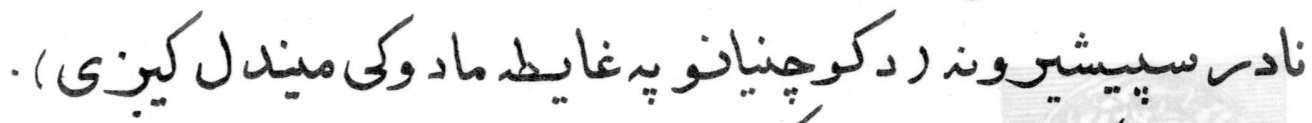

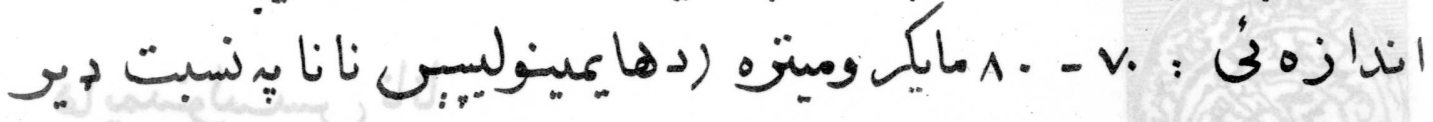

$$
\begin{aligned}
& \text { لوى دي ان مان }
\end{aligned}
$$

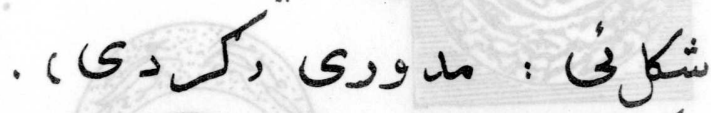

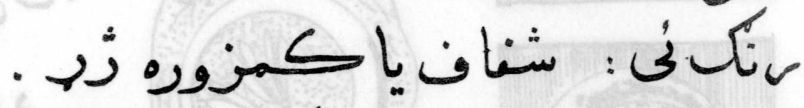

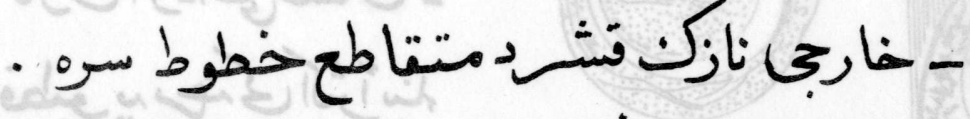

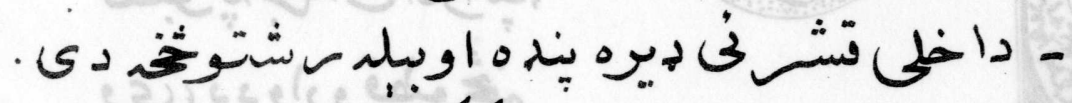

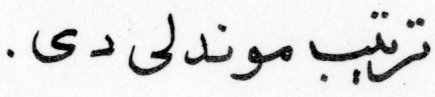

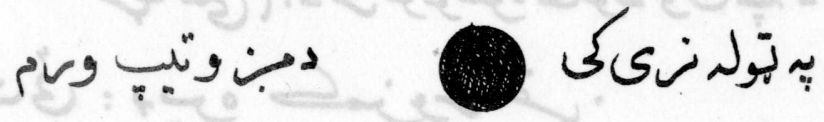
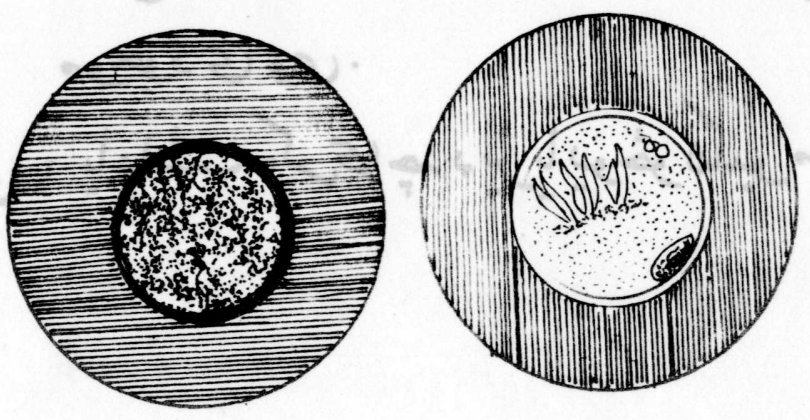


$$
\text { لنه تيبت ومبم }
$$

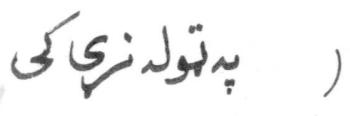
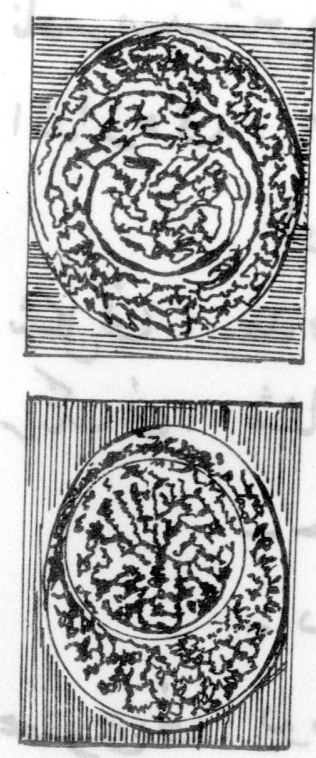

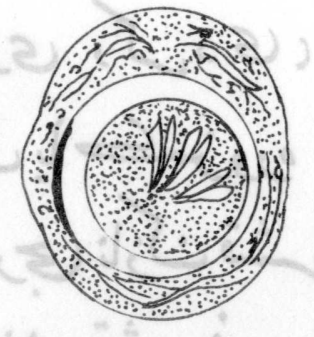
اندانفنى : هـ - . همايكروميتهن.

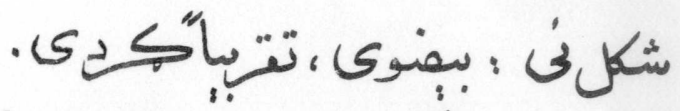

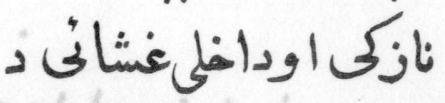

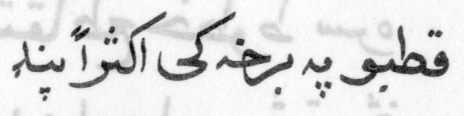
وي ديدواروقطبوثن رئى سانت تاروني راوتلى

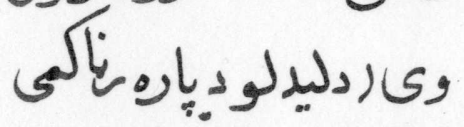

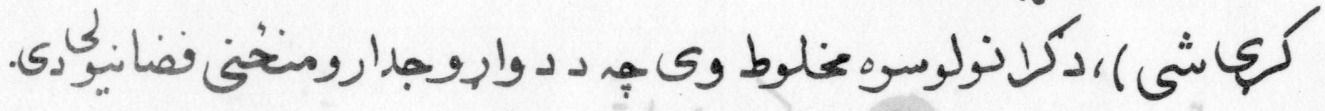

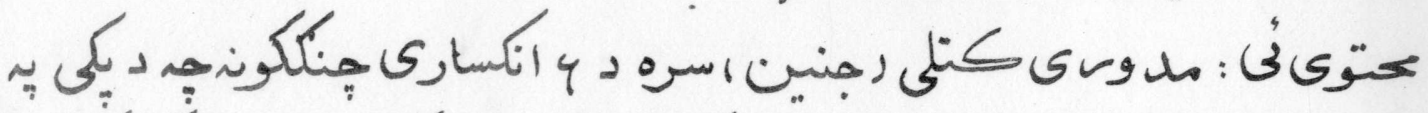

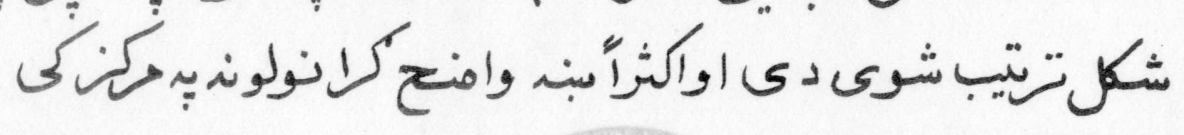
موجودى وى.

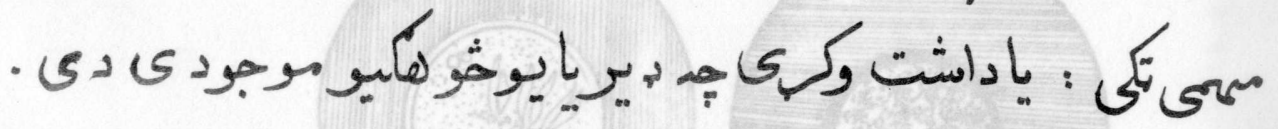




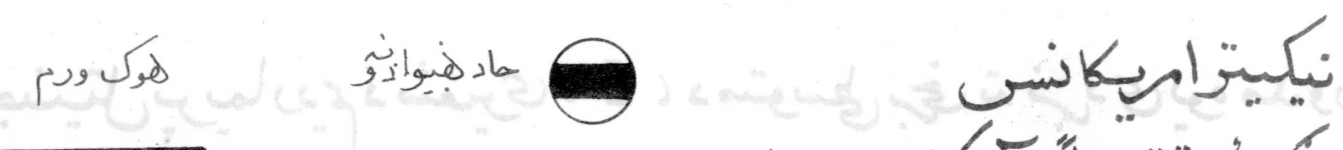
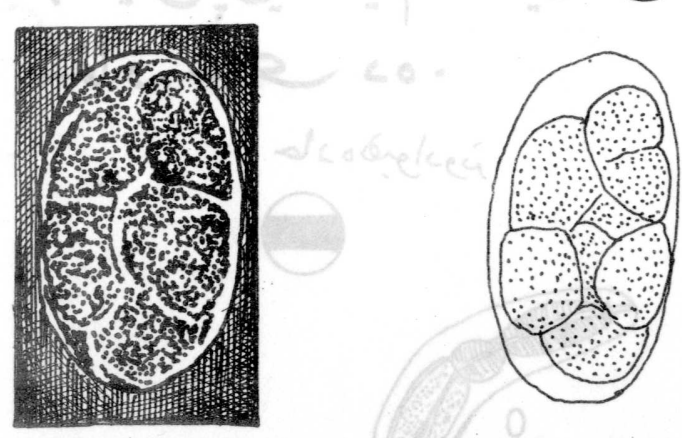

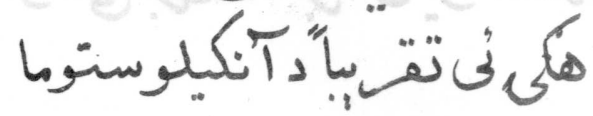

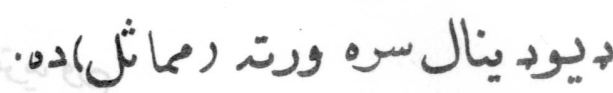

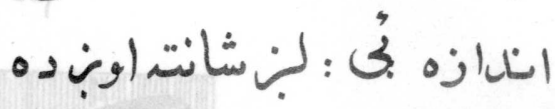

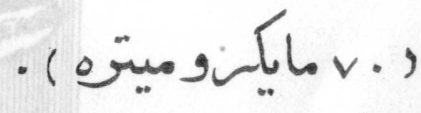

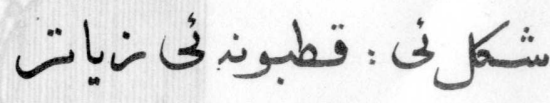

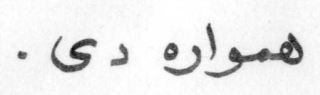

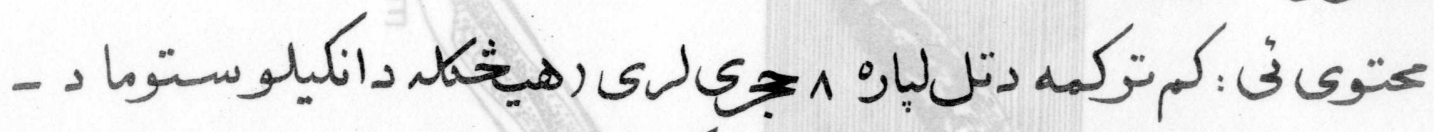

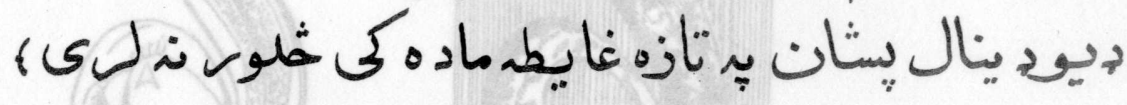

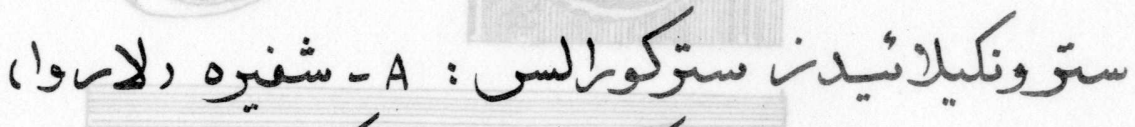

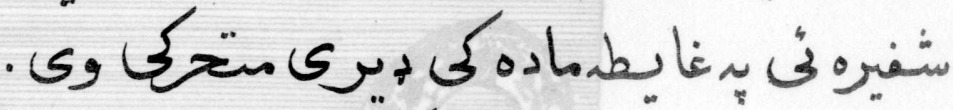

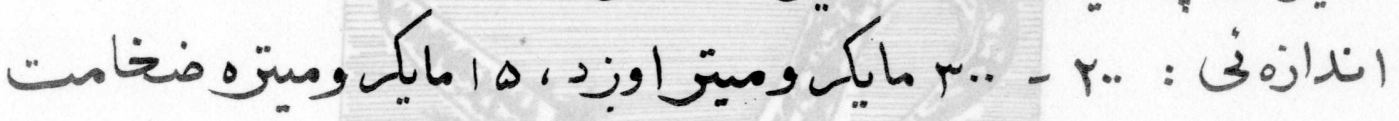

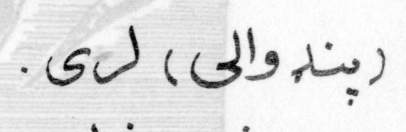

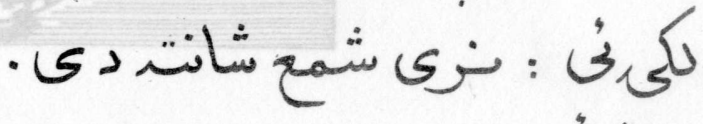

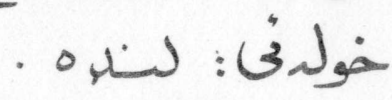

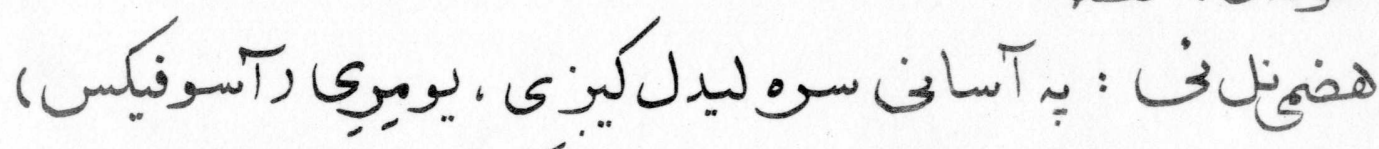

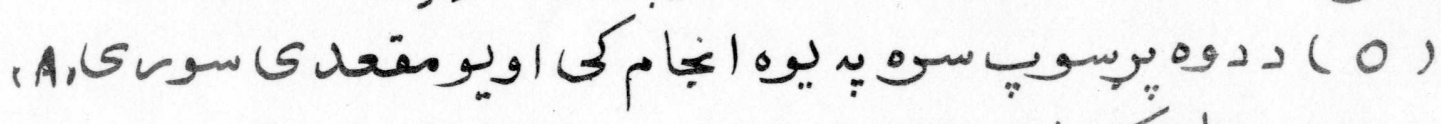

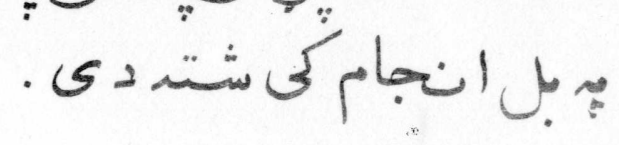



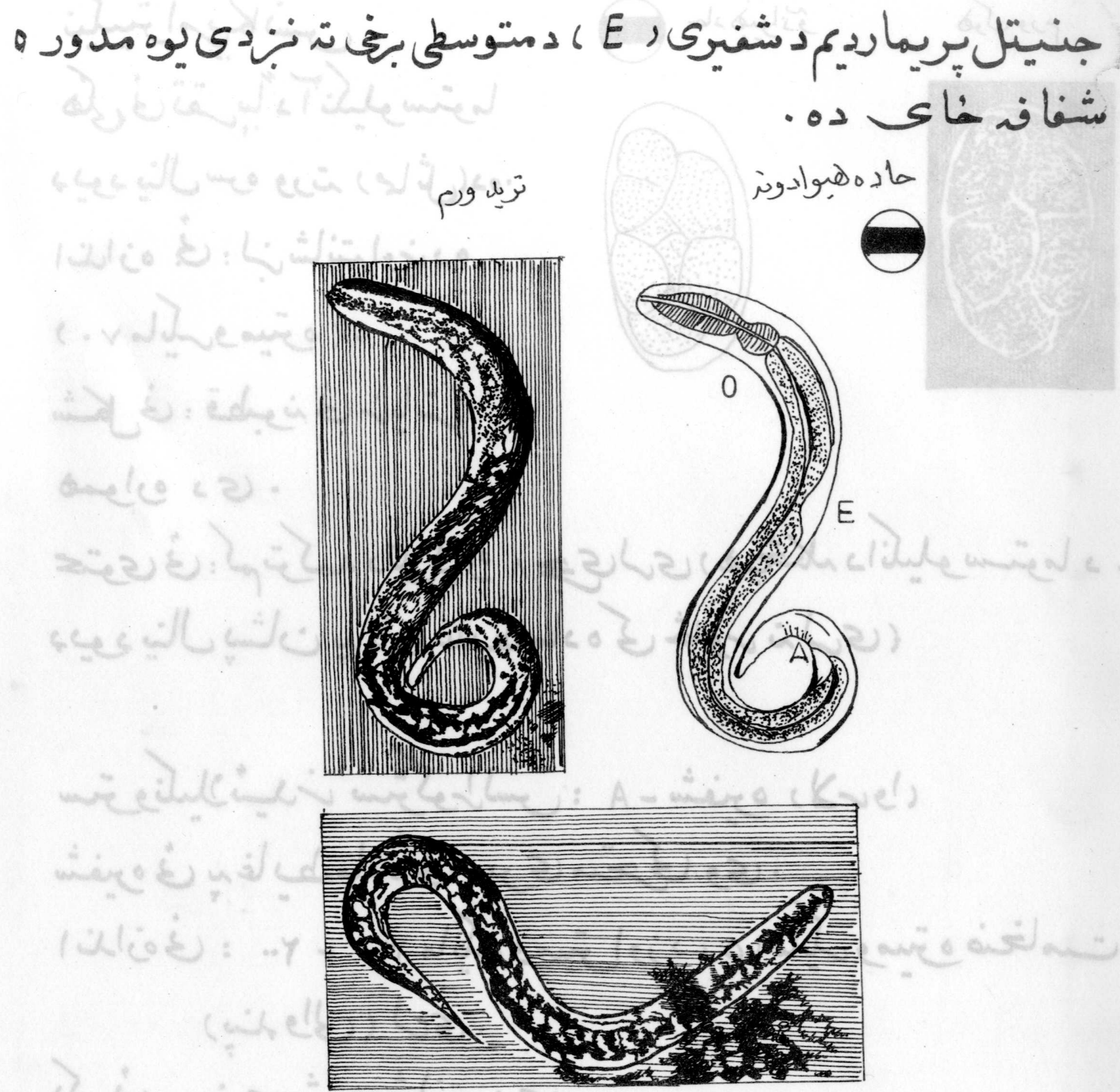


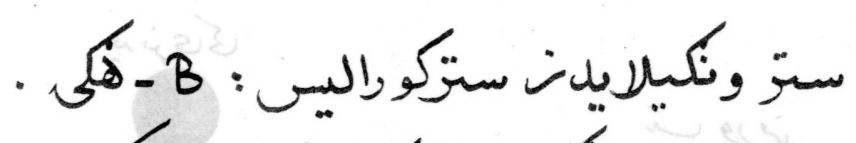

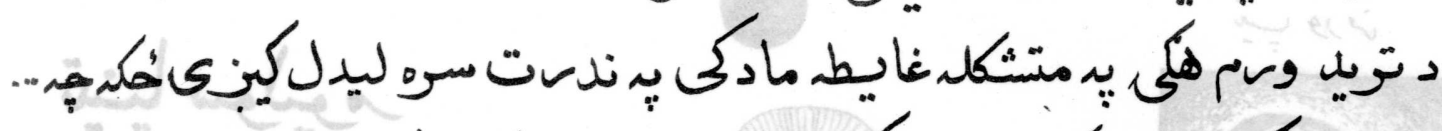

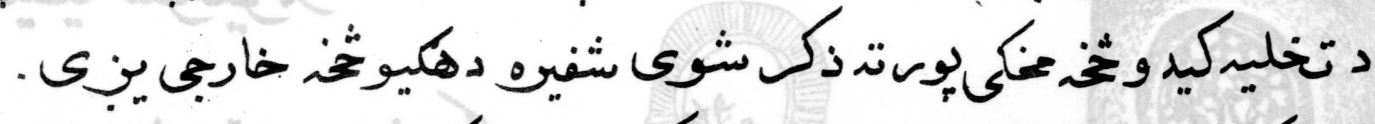

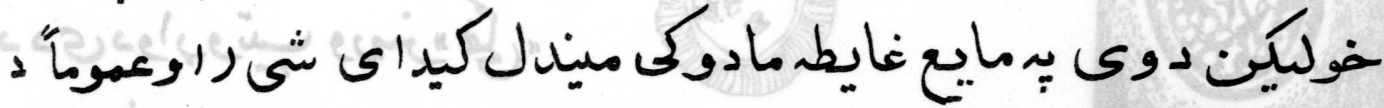

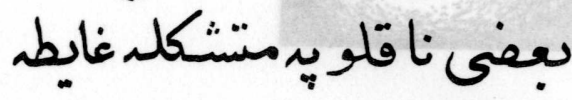

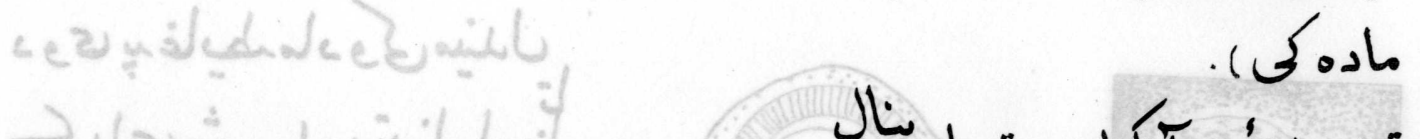

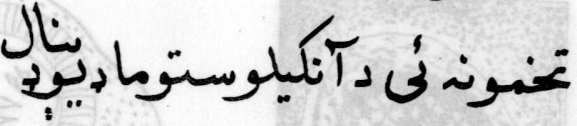

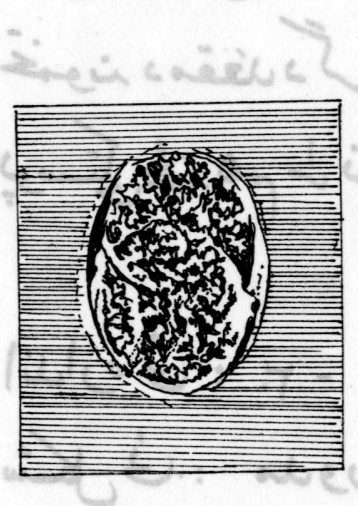
- 0د

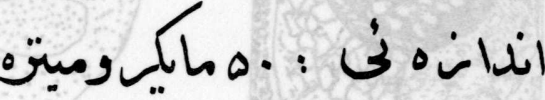
(ك) شغكا . $02 \ddot{2}$ تص: $.0 \pm \tilde{u}$ رنكنه: دانكيلوستصماسو

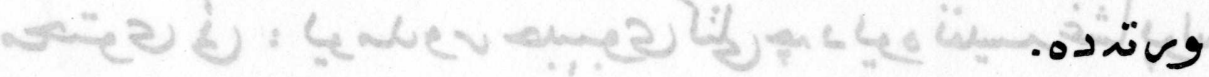

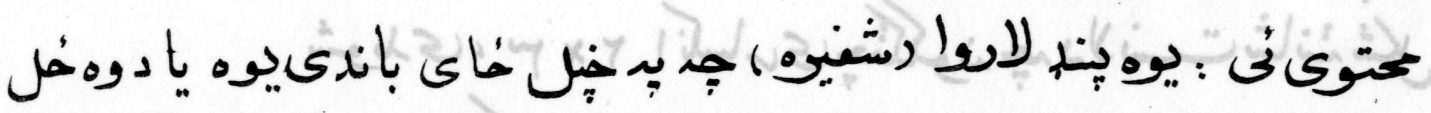

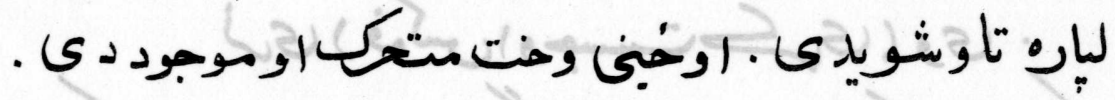




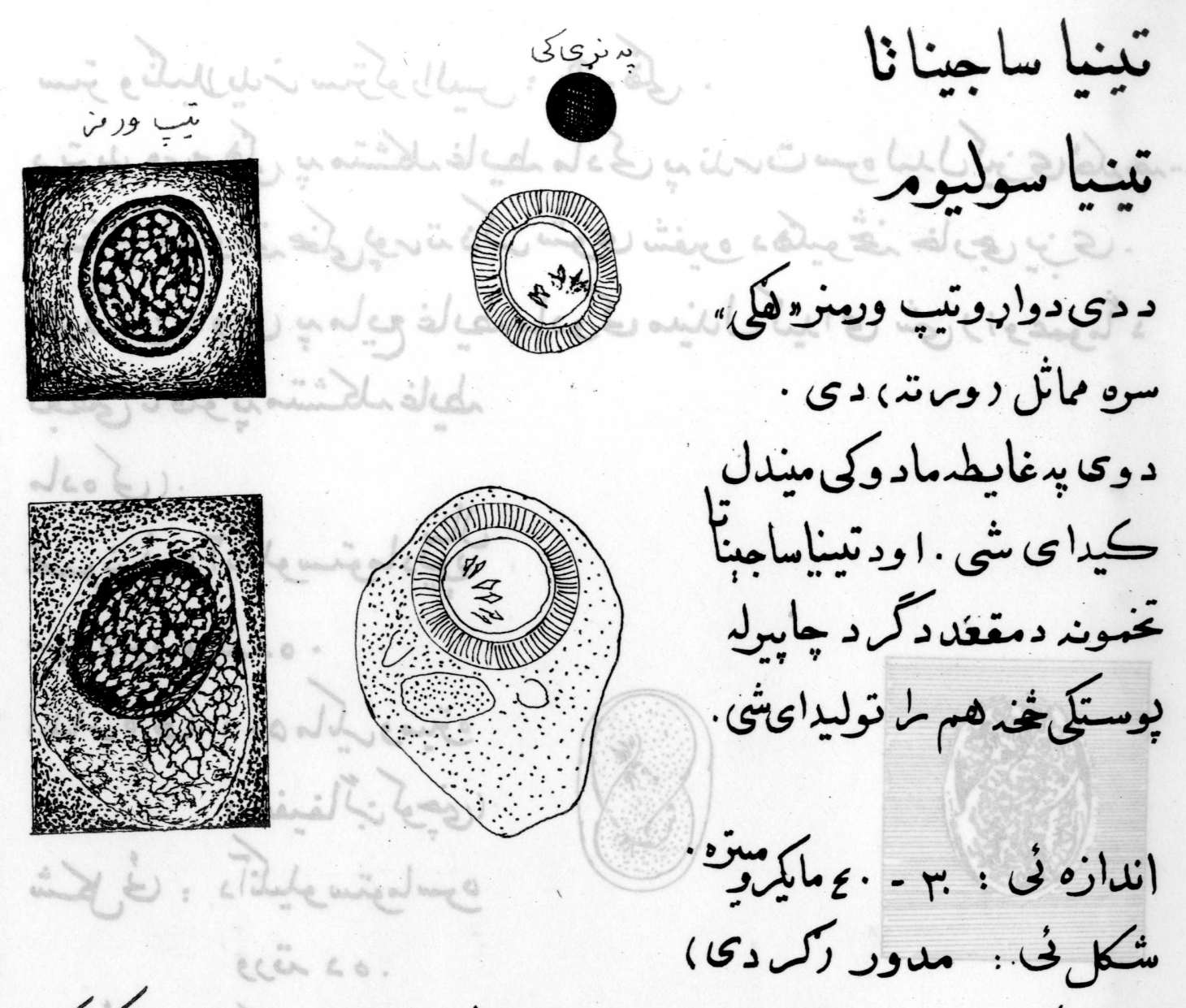

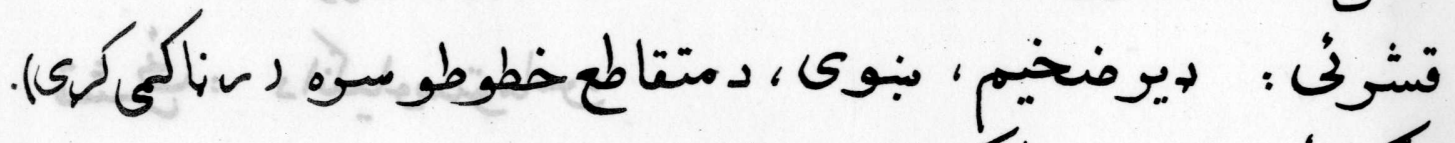

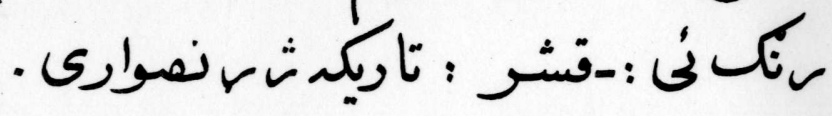

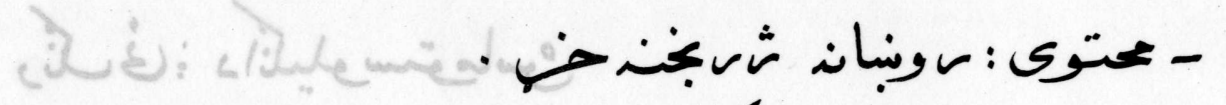

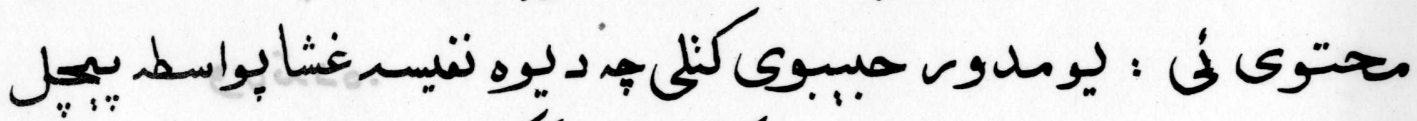

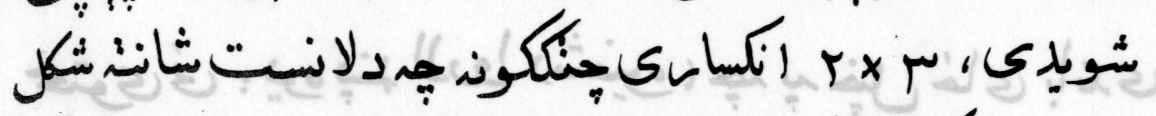

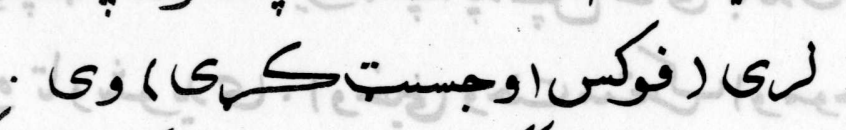

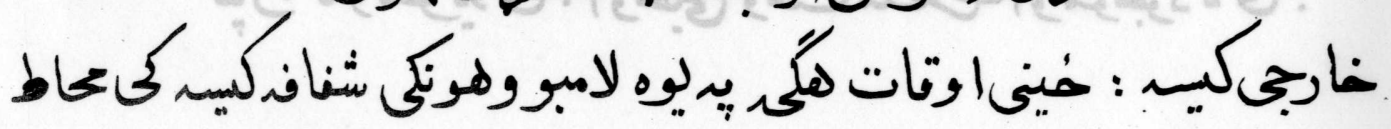

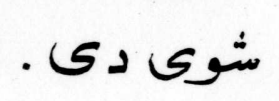




\section{s. $15 \%$}

و פِ ورן
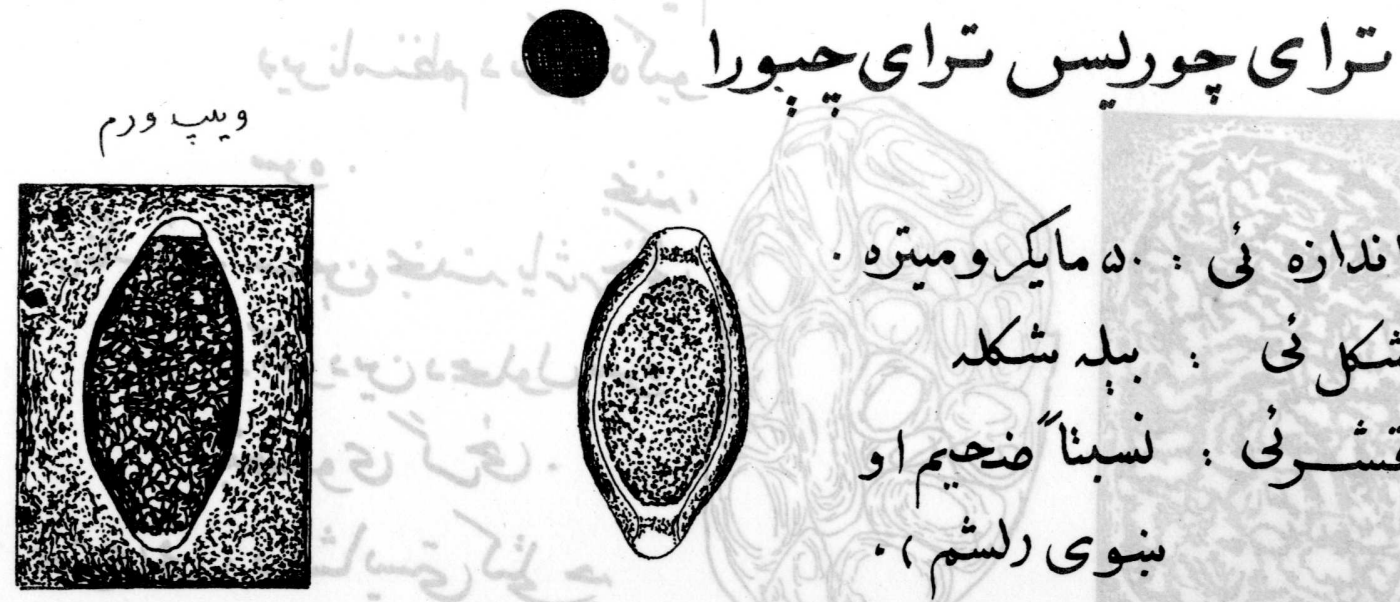

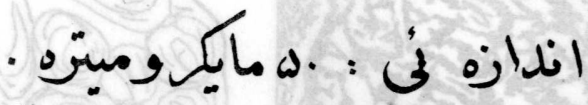

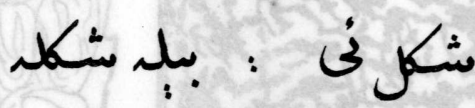

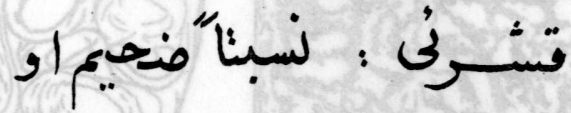

نبوى رلسثم)

دوروطبقوبه.

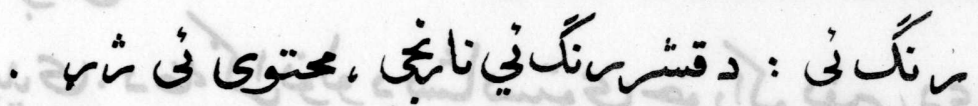

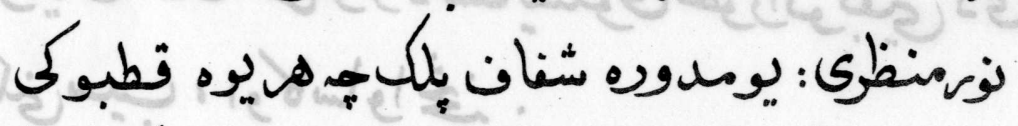

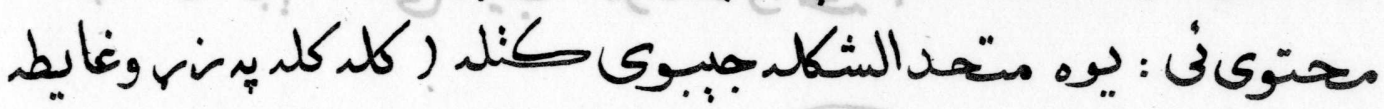

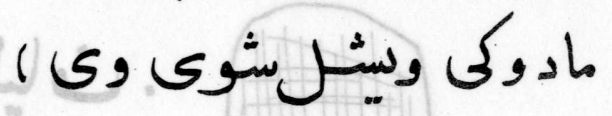

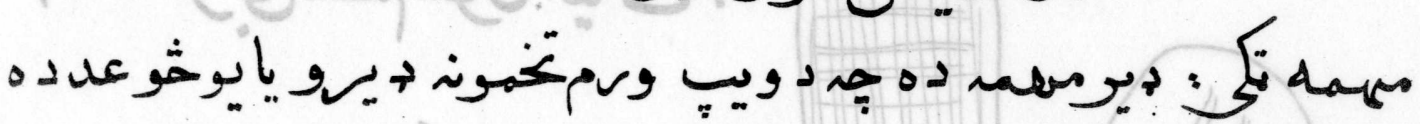

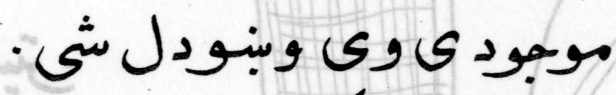

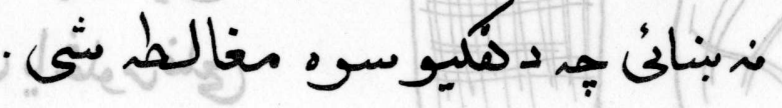

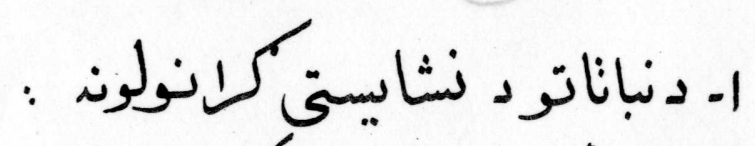

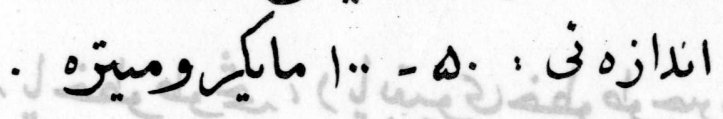

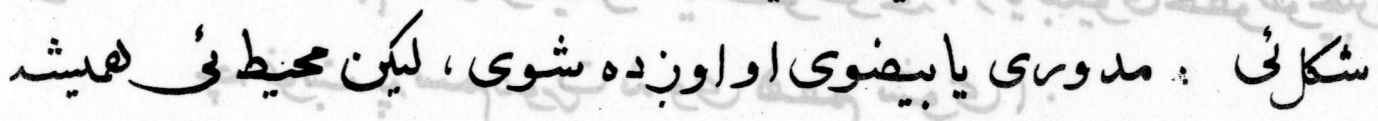

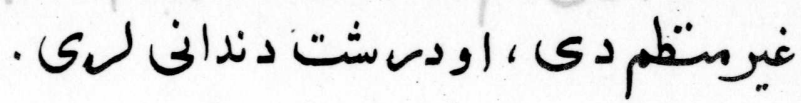



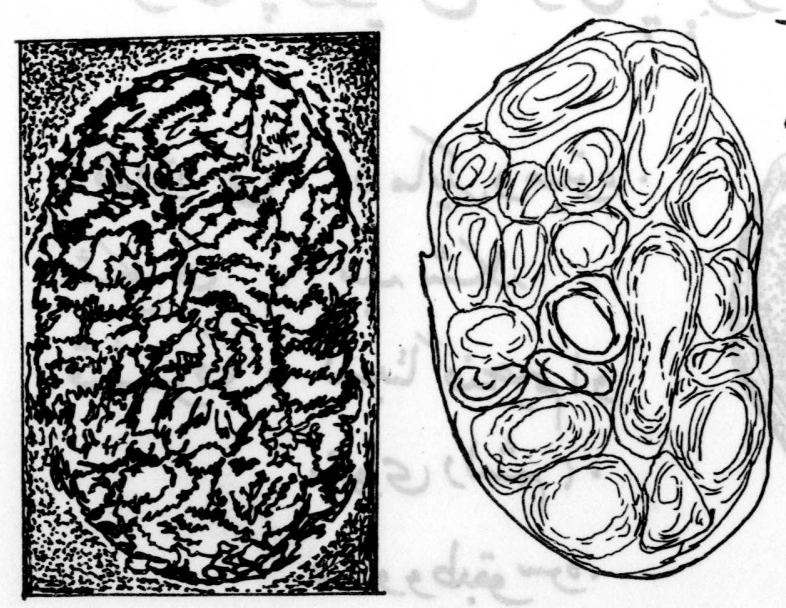

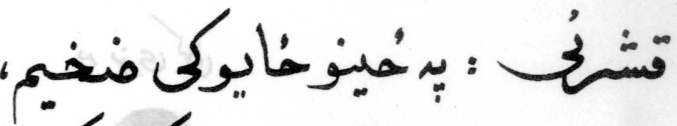

$$
\begin{aligned}
& \text { "يوناستظم دتركيد كيوي" }
\end{aligned}
$$

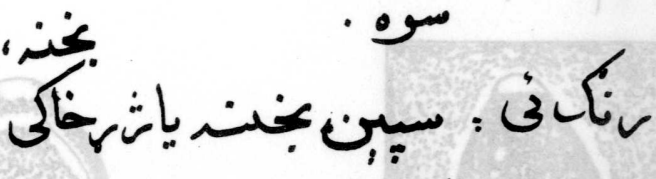
دآيودين دعلولست

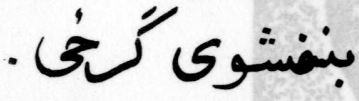

$$
\text { ح }
$$

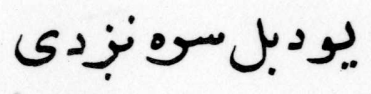

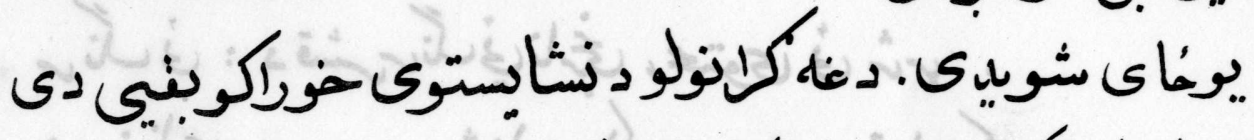

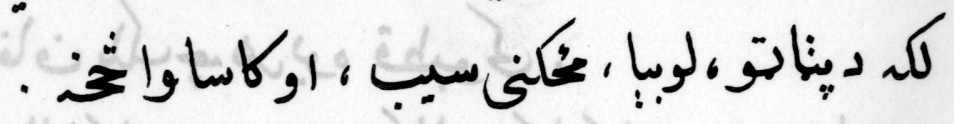
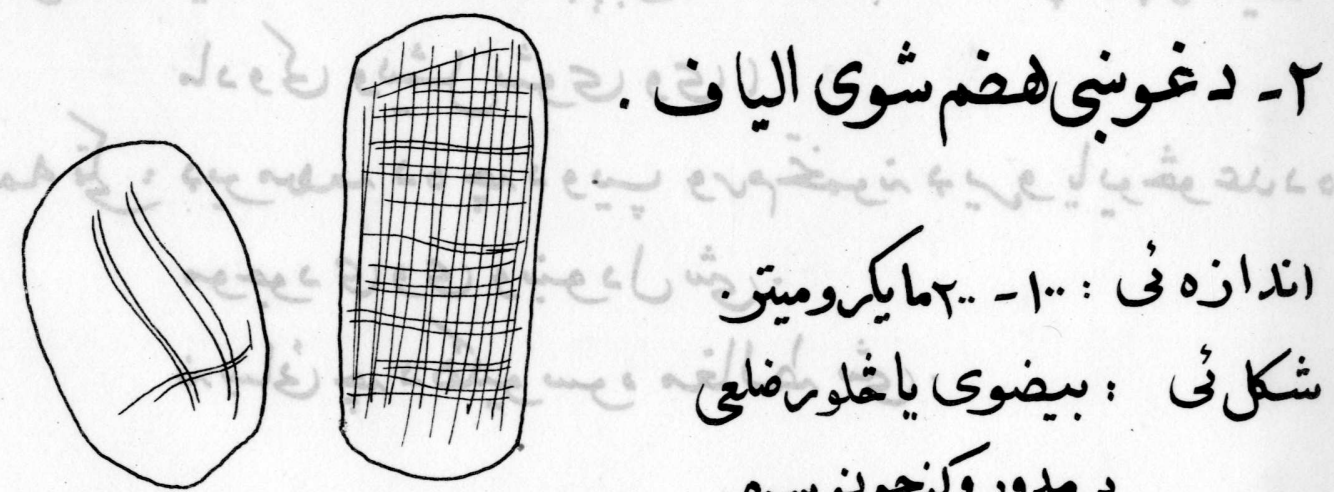

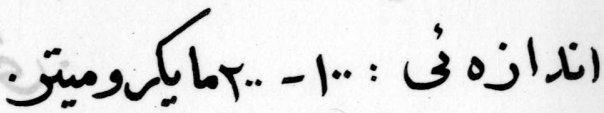

شنك د مدوروكنجونوميوه.

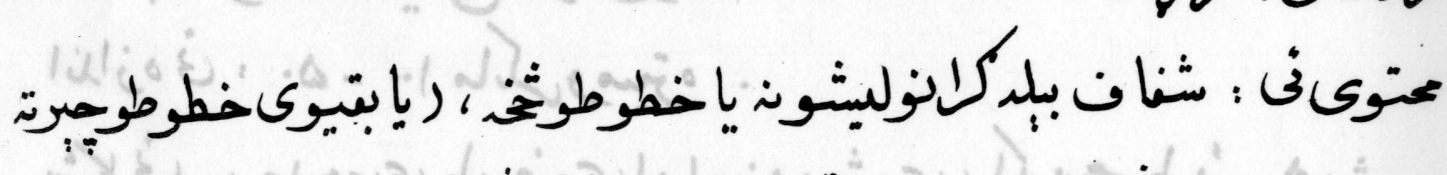

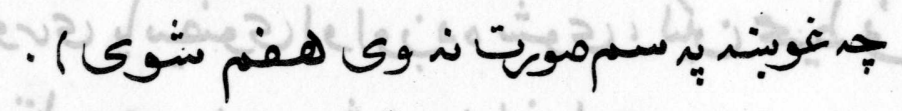



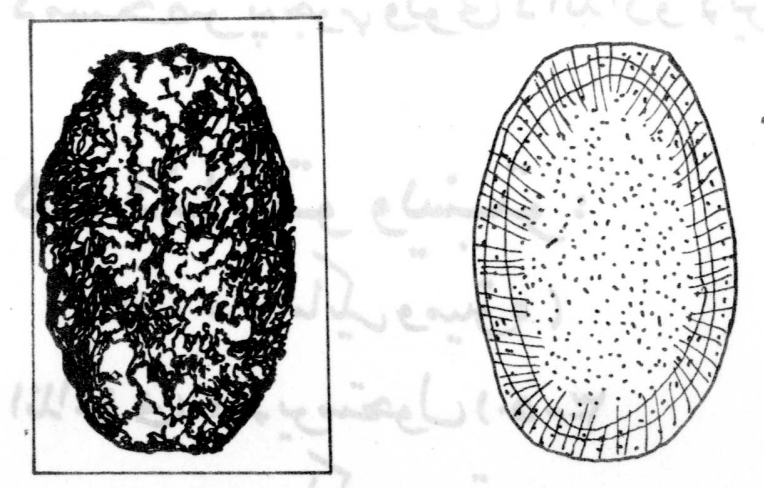

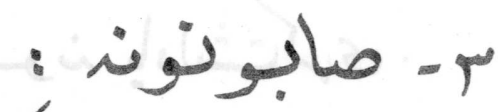

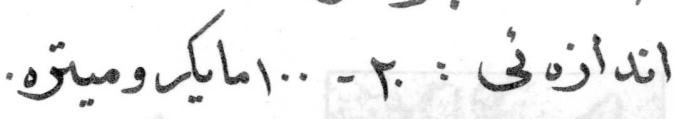

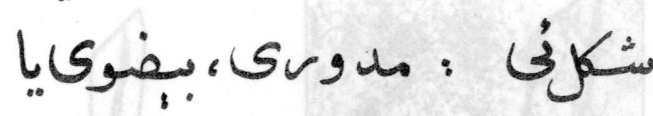

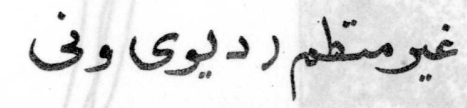
دتنى دمتطع بِ شان)

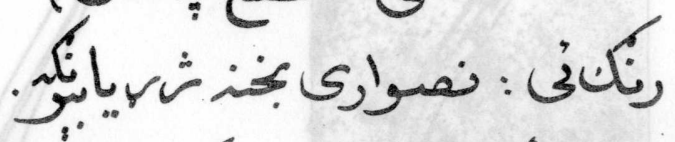

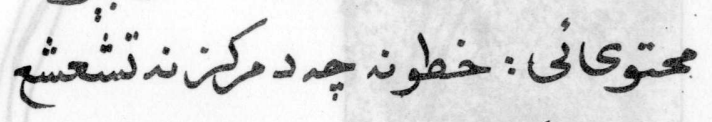

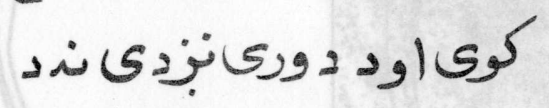

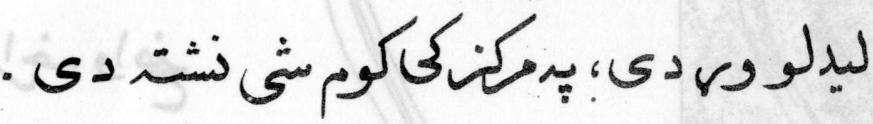

ع - هوأُوحُى - ذَّيلوقطنرى.

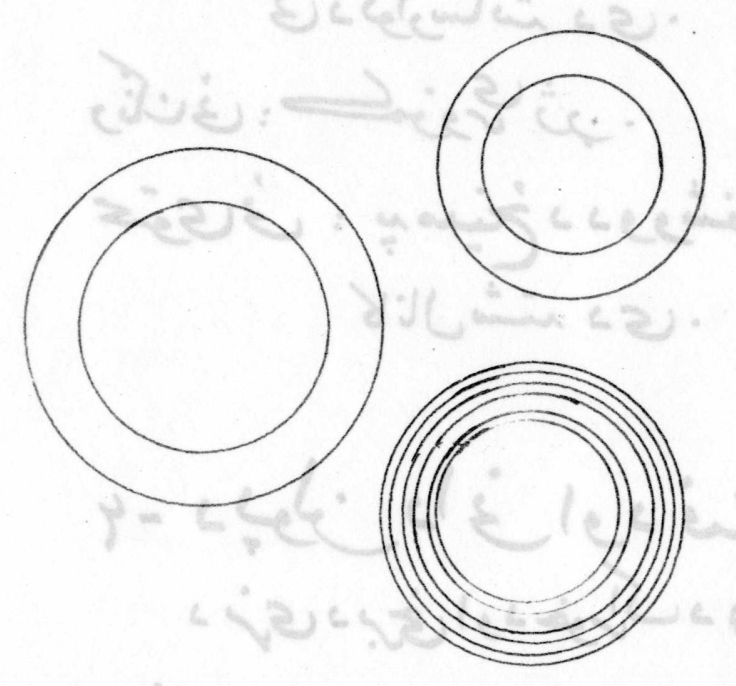

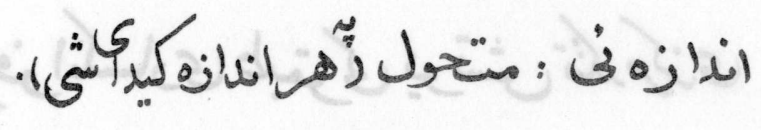

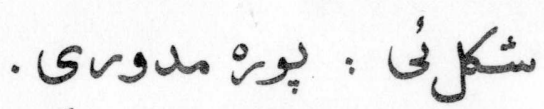

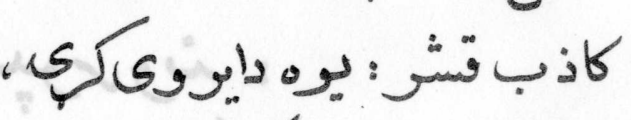
.

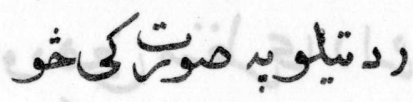

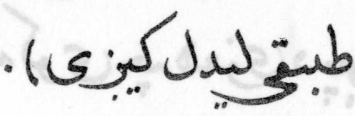

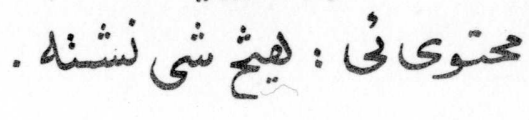




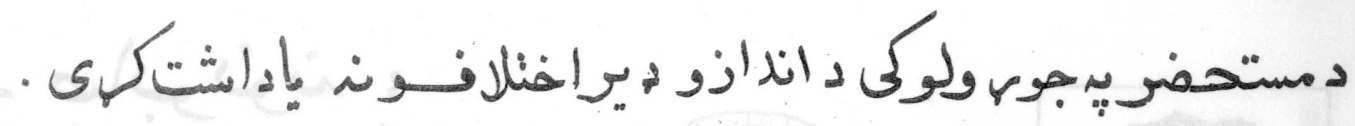
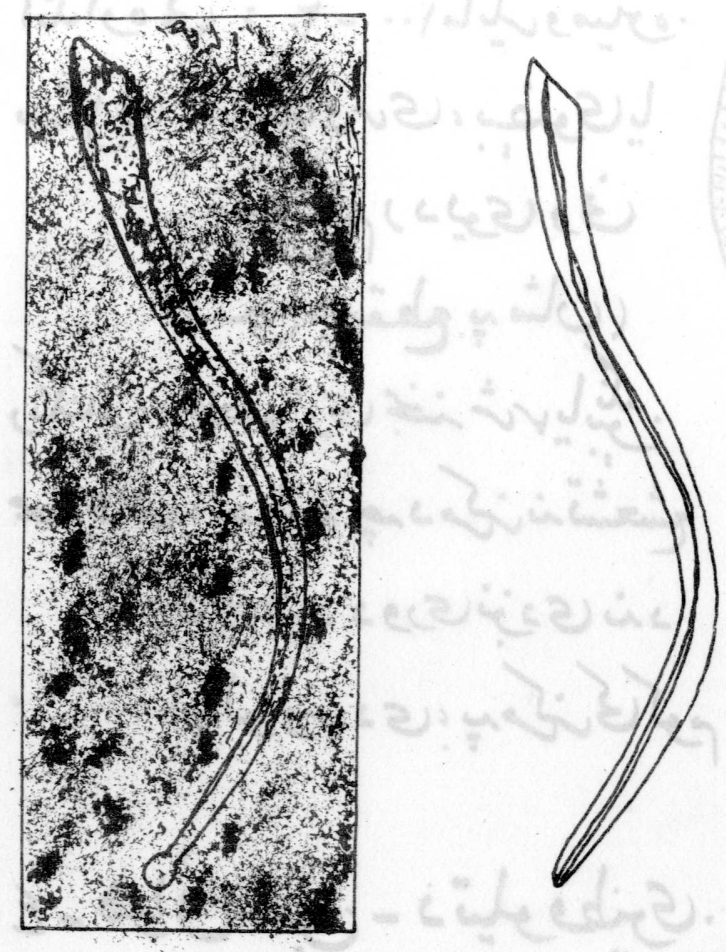

$$
\begin{aligned}
& \text { هـ د دباتاتو وينــتو : }
\end{aligned}
$$

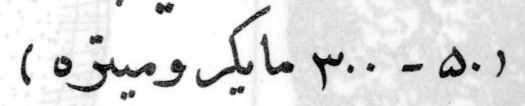

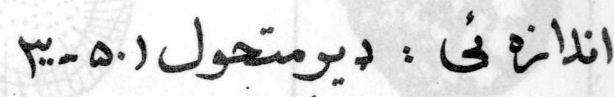

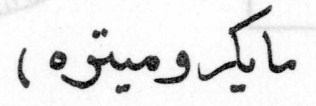

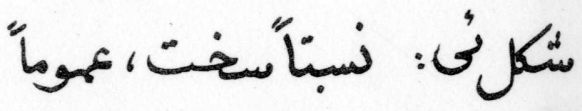

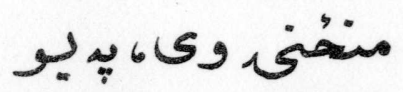

$$
\begin{aligned}
& \text { ابنامكى يراضه وافيخ }
\end{aligned}
$$

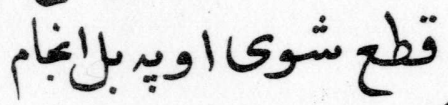

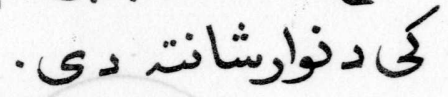

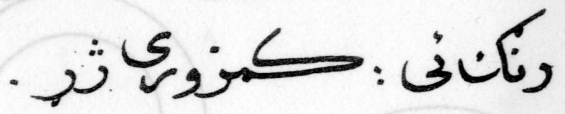

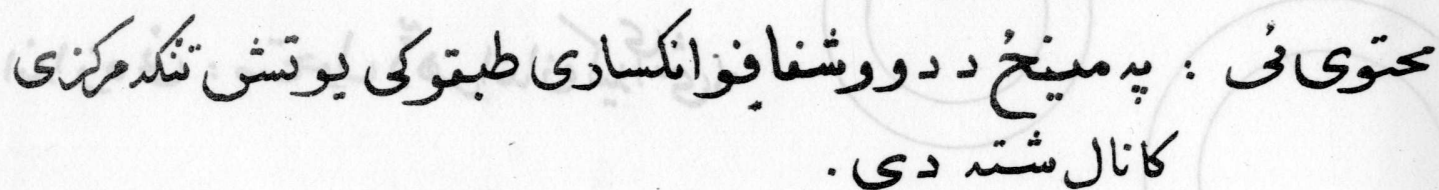

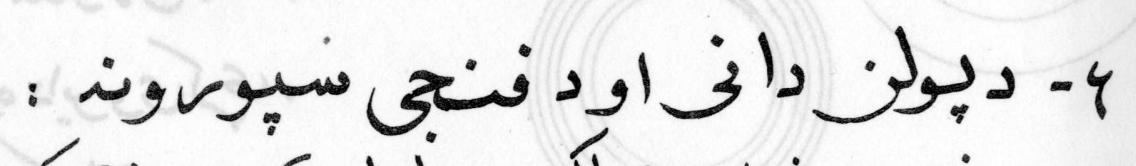

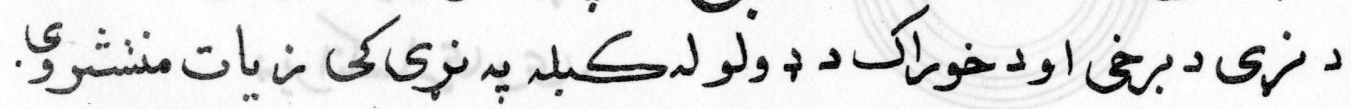

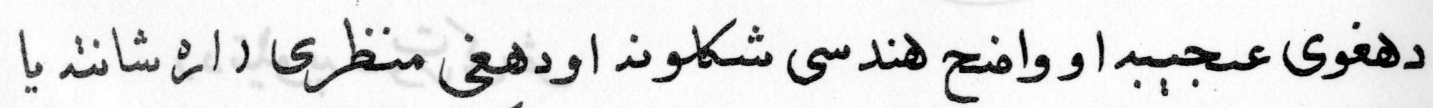

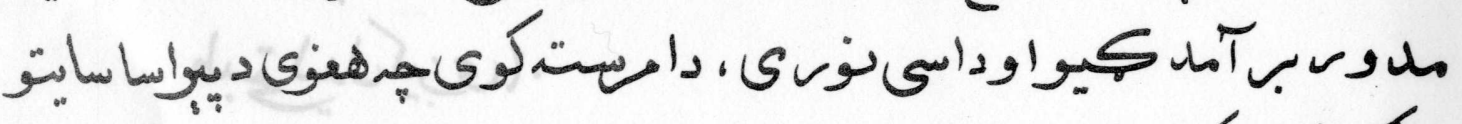



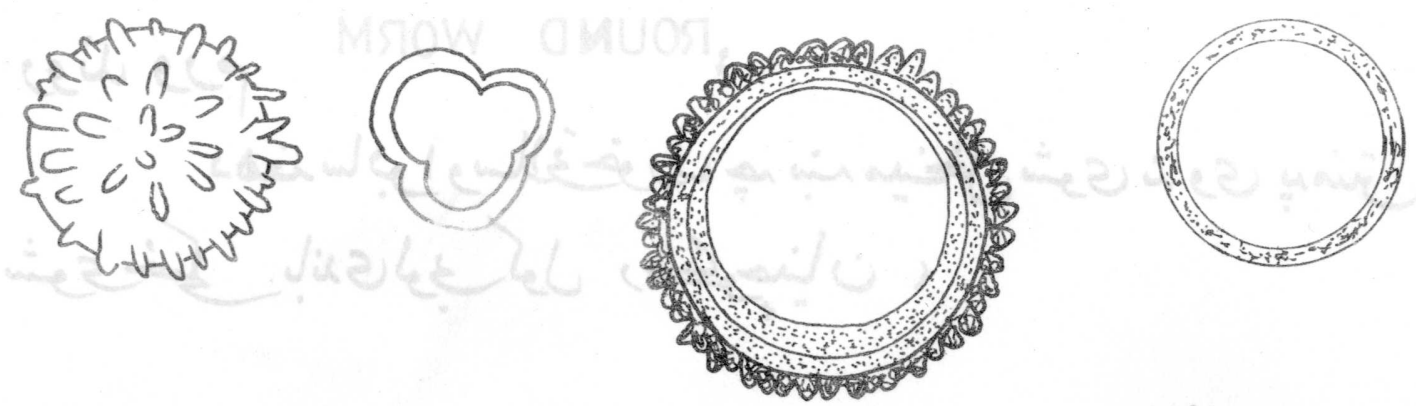

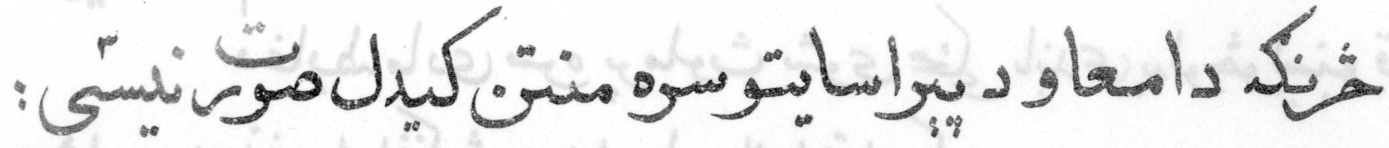

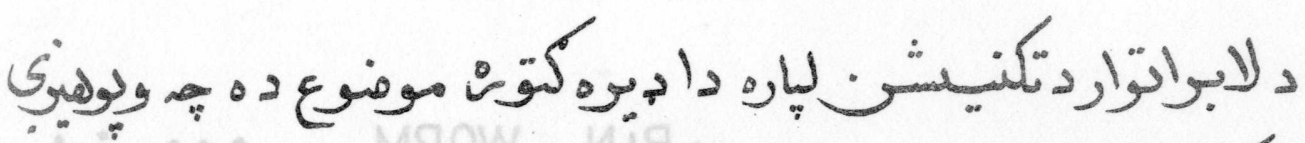

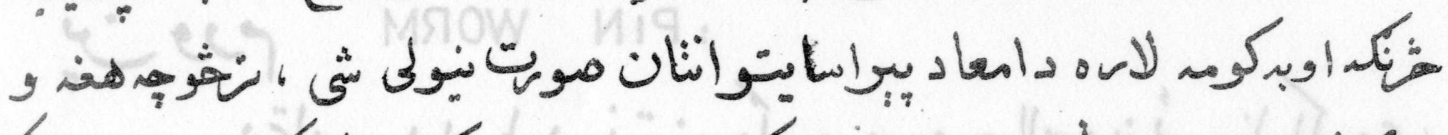

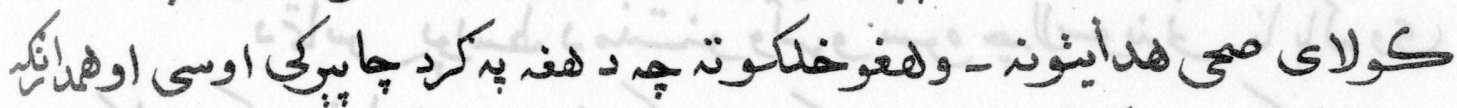

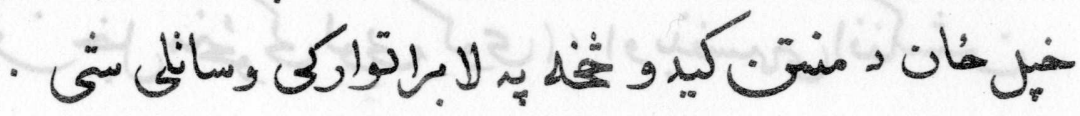

HOOK WORM :

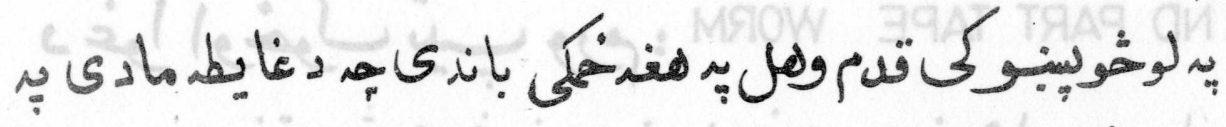

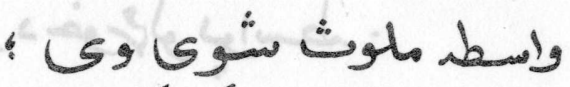

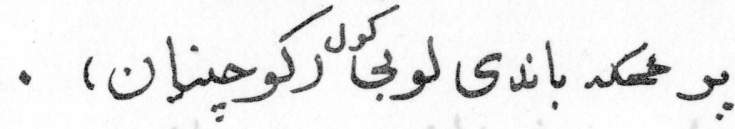




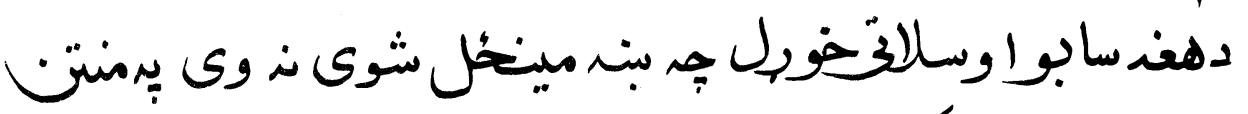

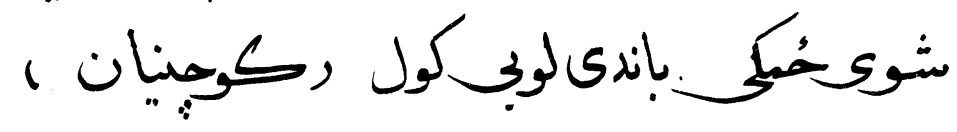

: THREAD WORM

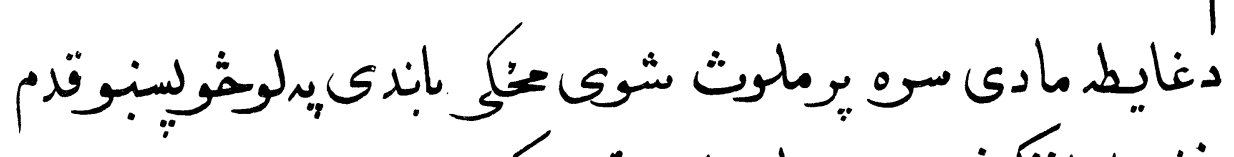

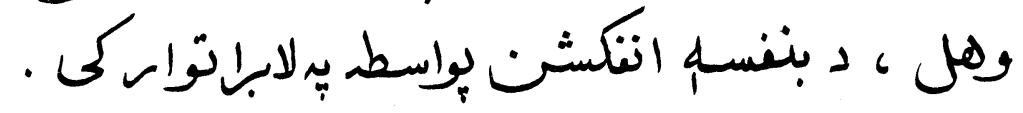

: : PIN WORM :

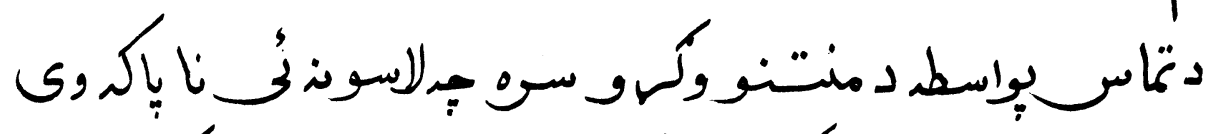

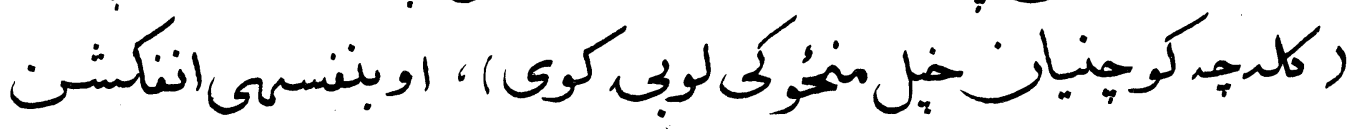

$$
\text { "بواسط. }
$$

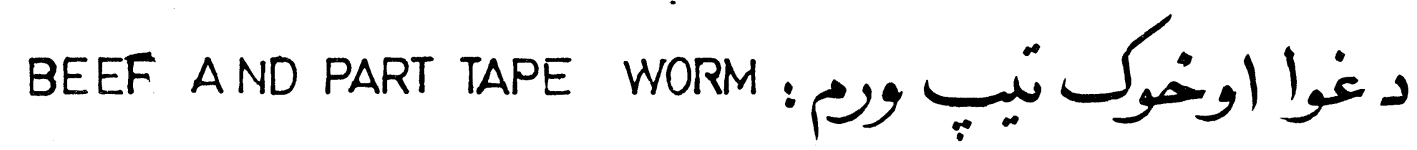

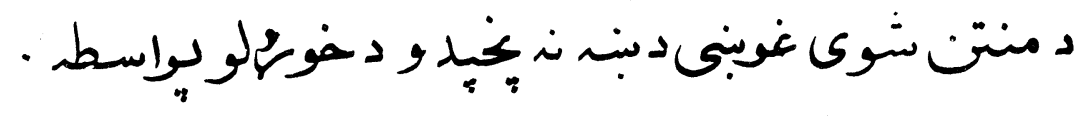

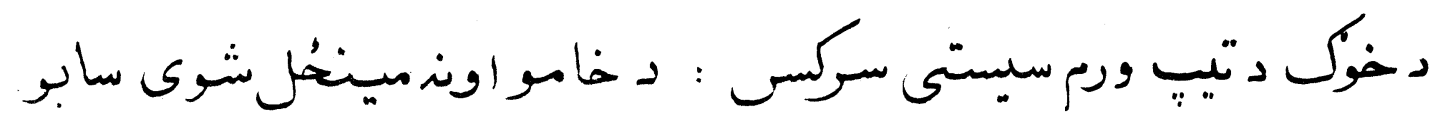

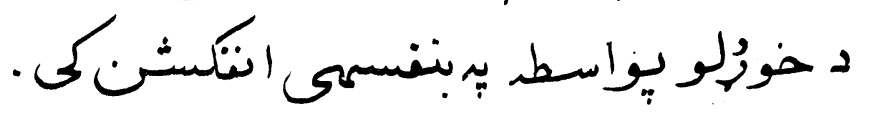




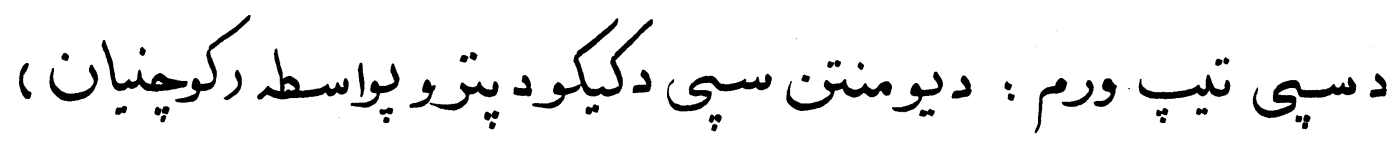

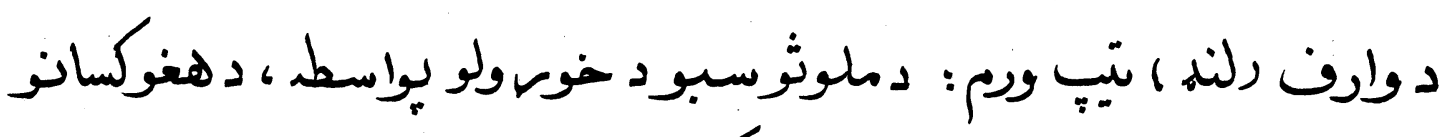

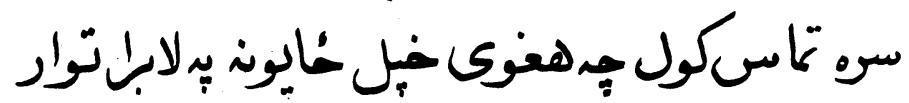

$$
\text { كى منتن كهى وصى . }
$$

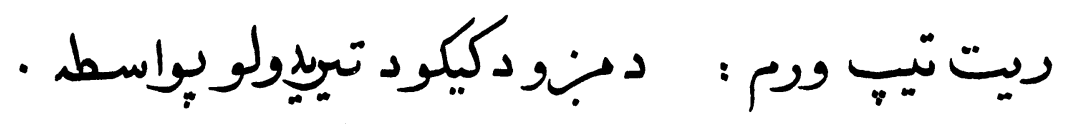

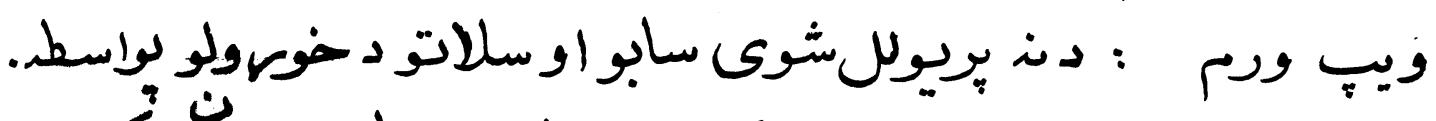

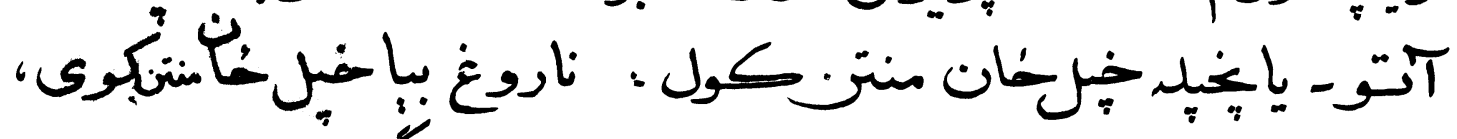

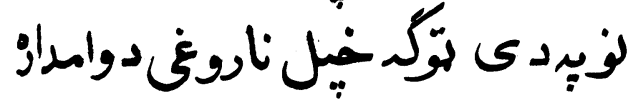

\section{بورتوزوا}

(نتاميبا هيتاليتيكا (وجارجيا ديالمبليا :

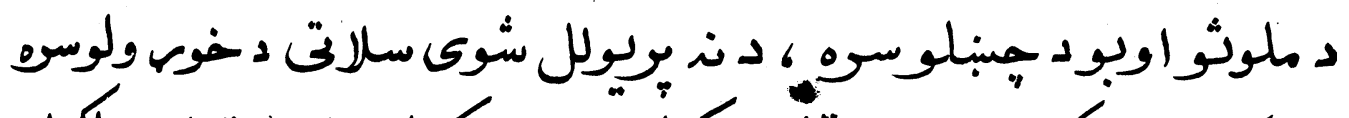

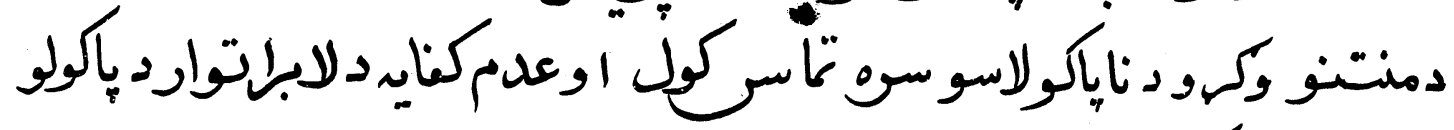

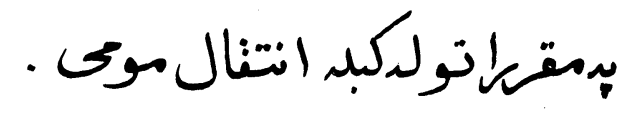




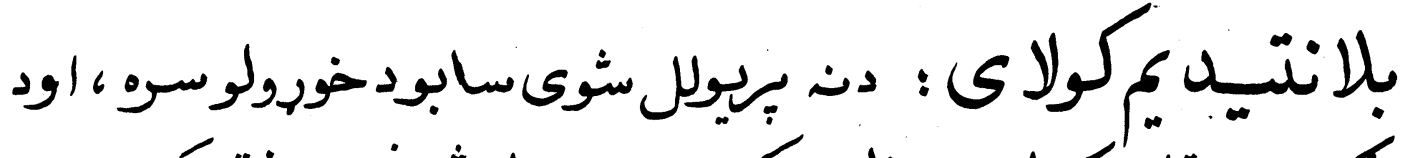

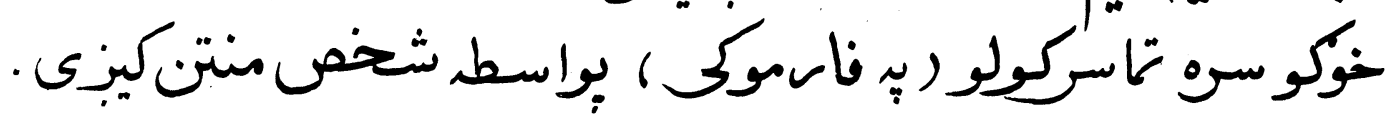

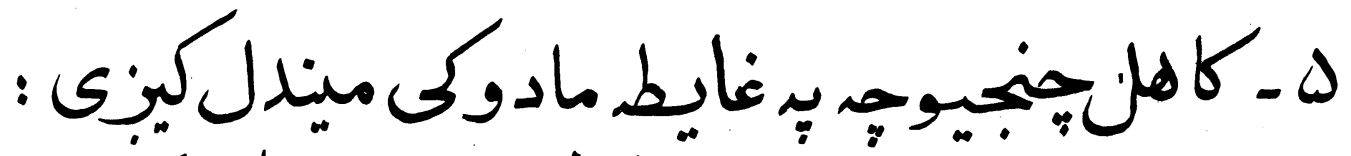

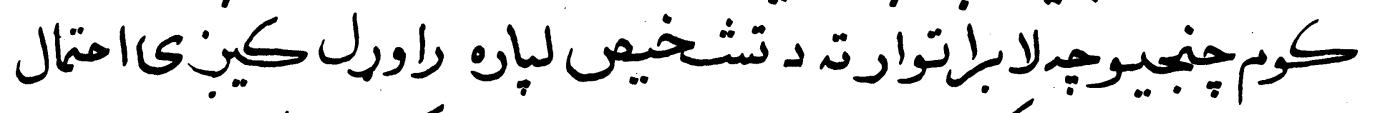

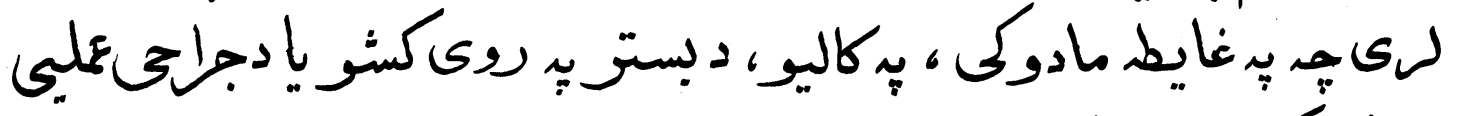

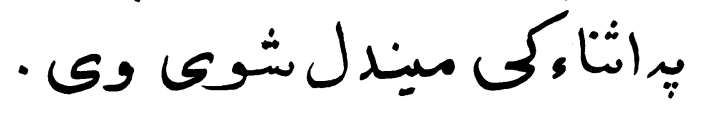

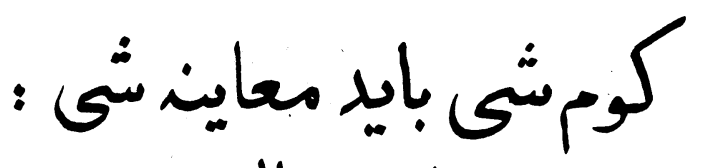

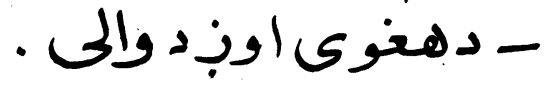

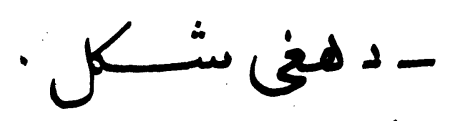

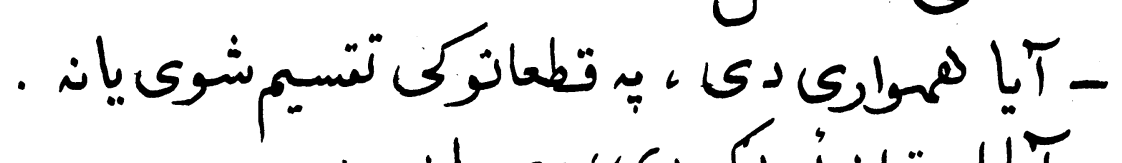

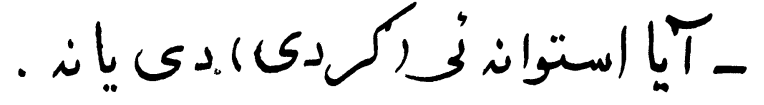

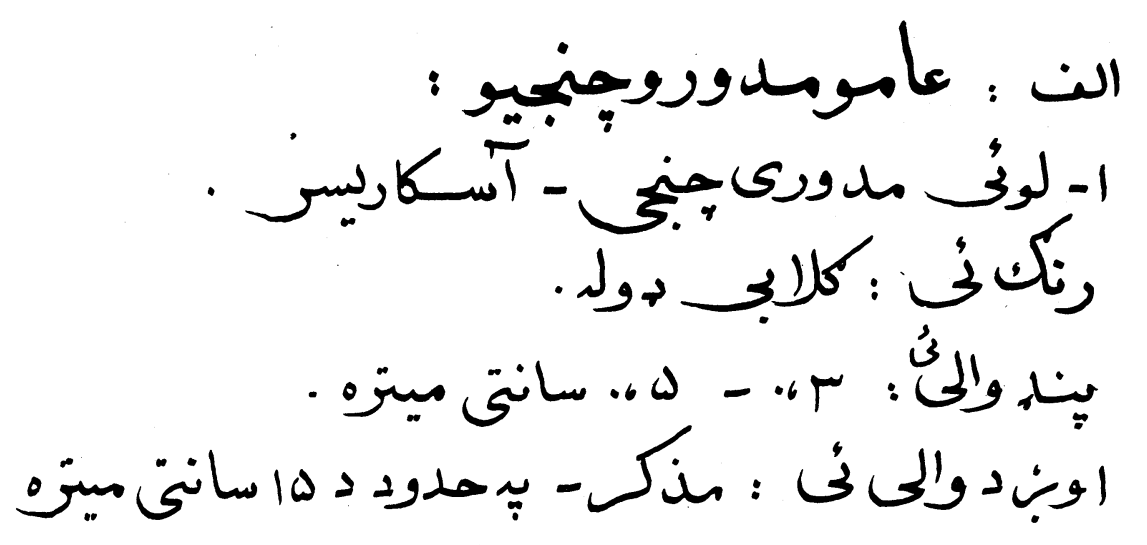




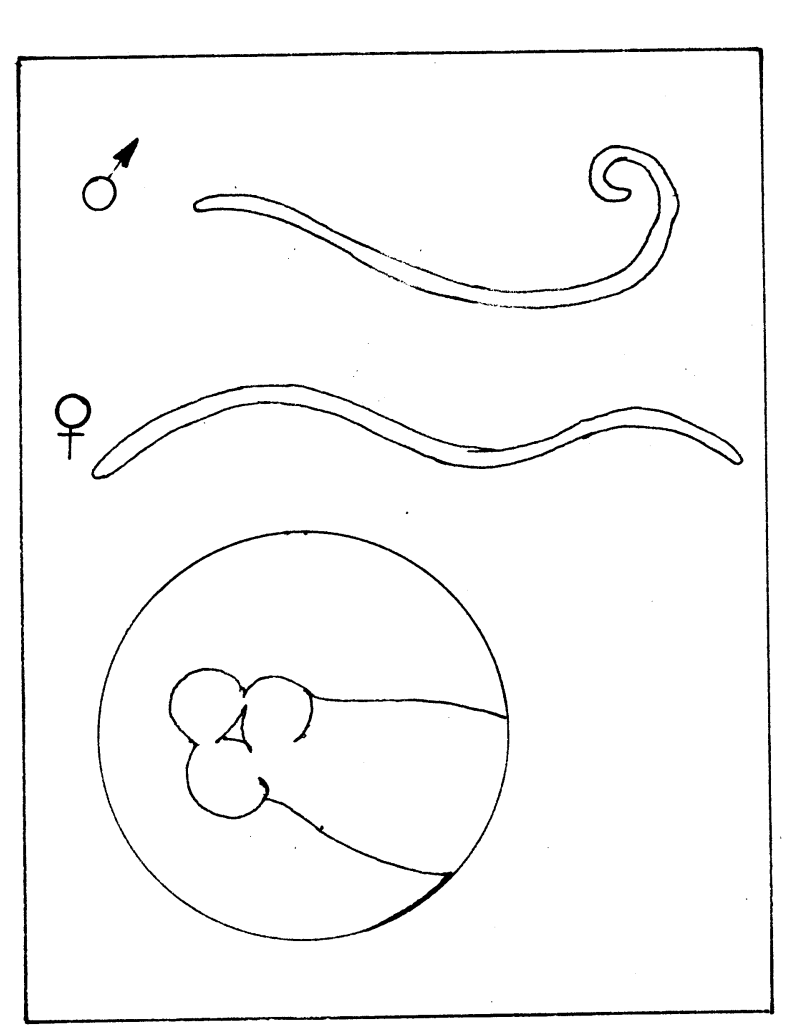

ديوتاوشوى لكىى سره .

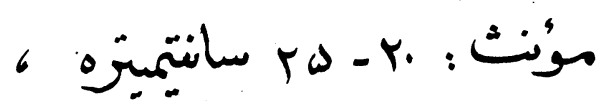

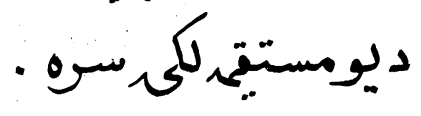

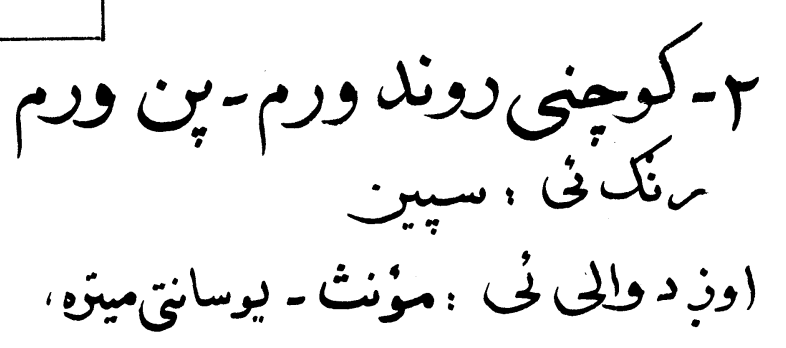

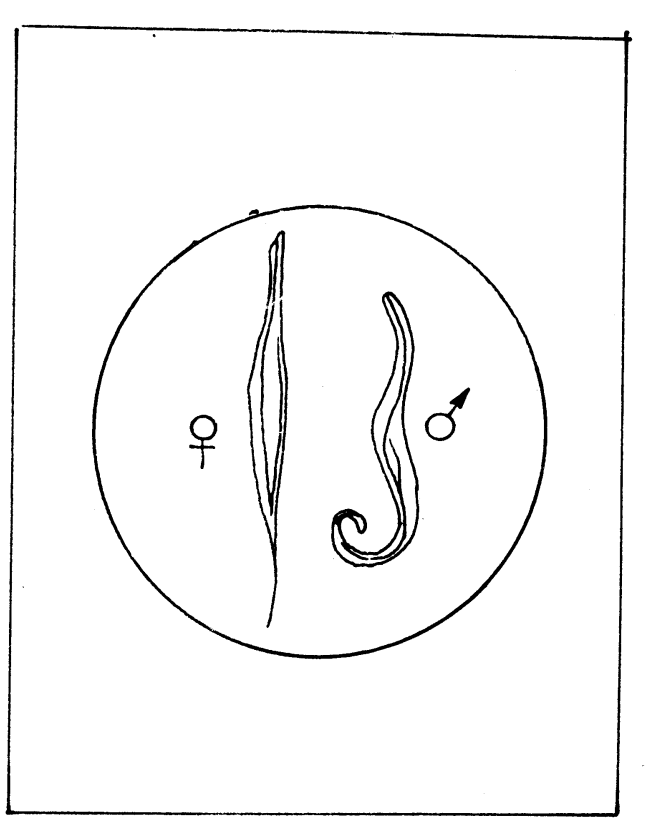

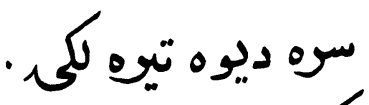

مذك - نيم سانتمينز،

رنك انىكمزيموميت

( ज)

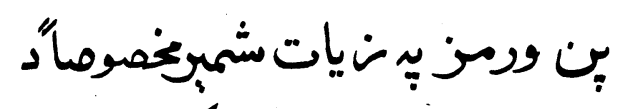

كوجنيانوبِيانيط ماد وكى ميندل

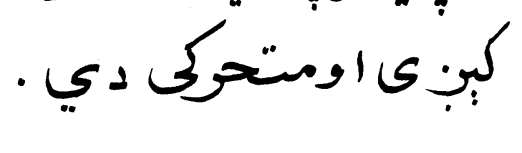

va 


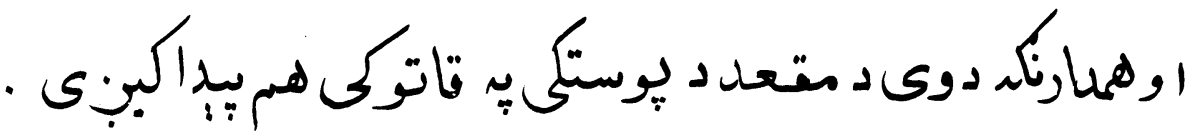

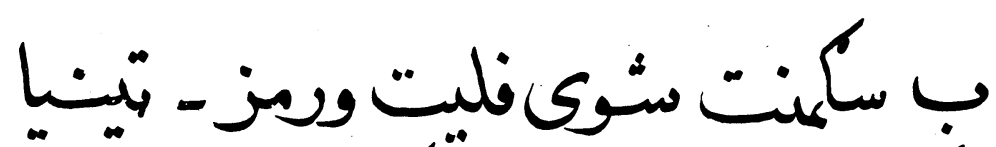

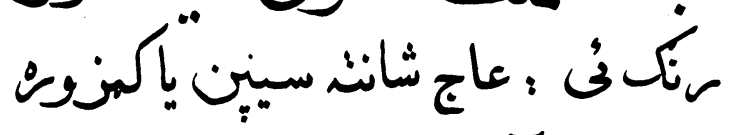

$$
\begin{aligned}
& \text { آبى وى. }
\end{aligned}
$$

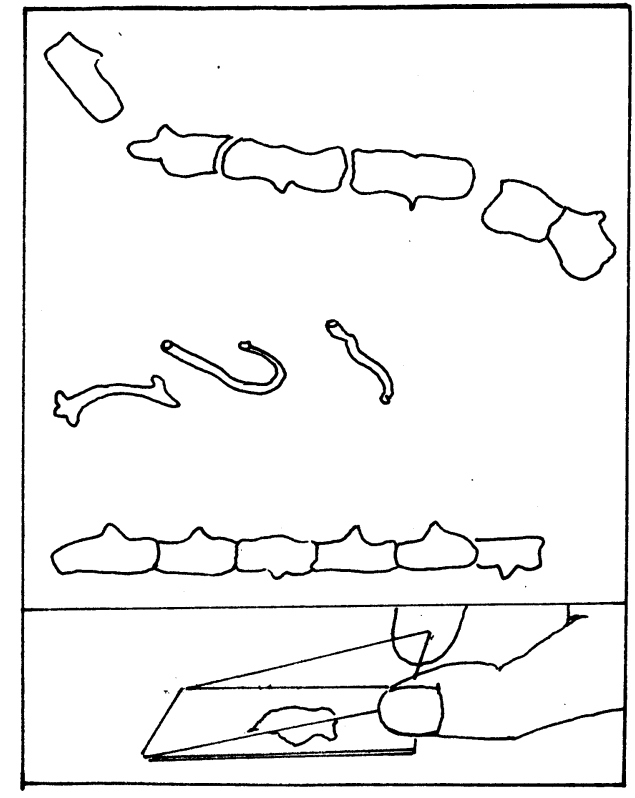

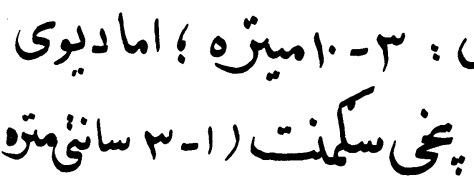

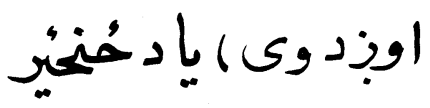

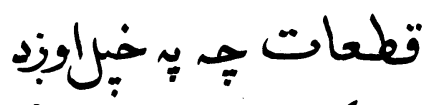

$$
\begin{aligned}
& \text { والىكى ديومتناوك } \\
& \text { دمعاينى لبان ورإنى } \\
& \text { كيبى . دمعاين }
\end{aligned}
$$

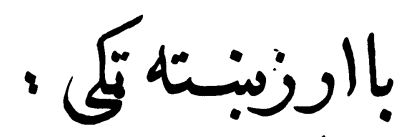

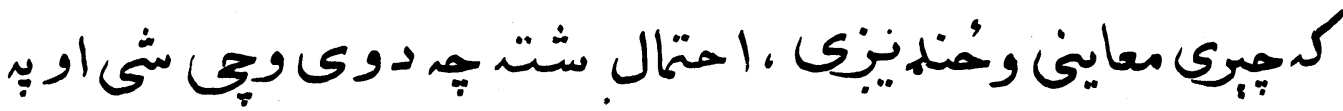

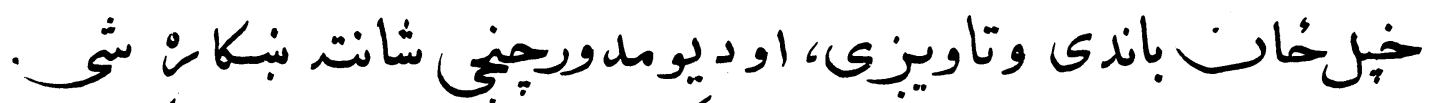

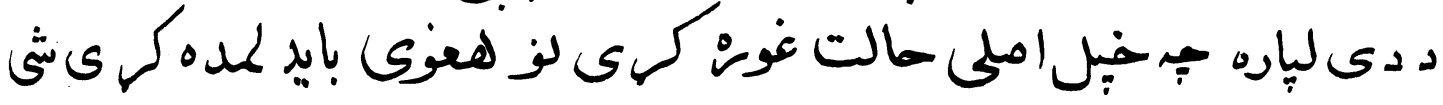




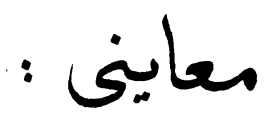

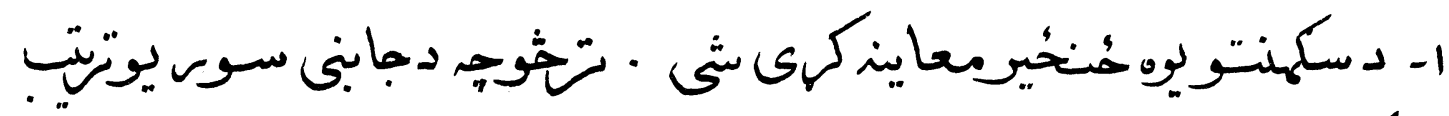

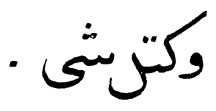

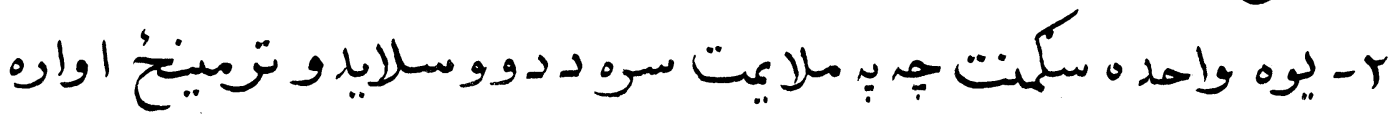

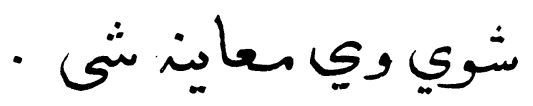
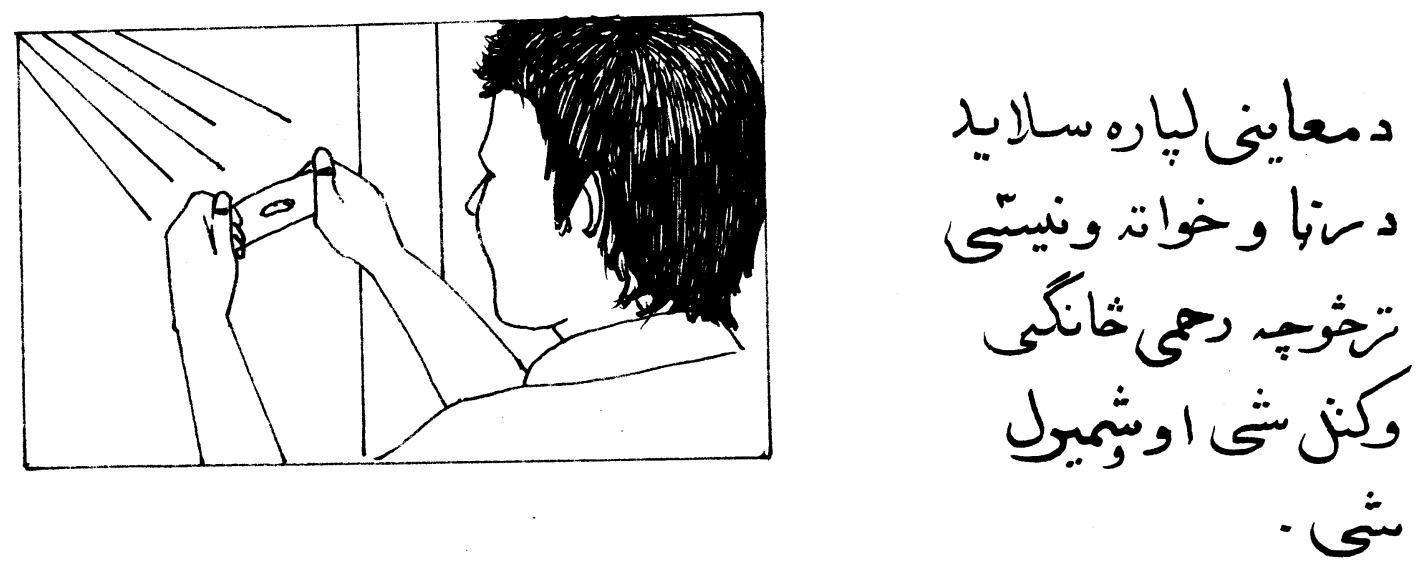


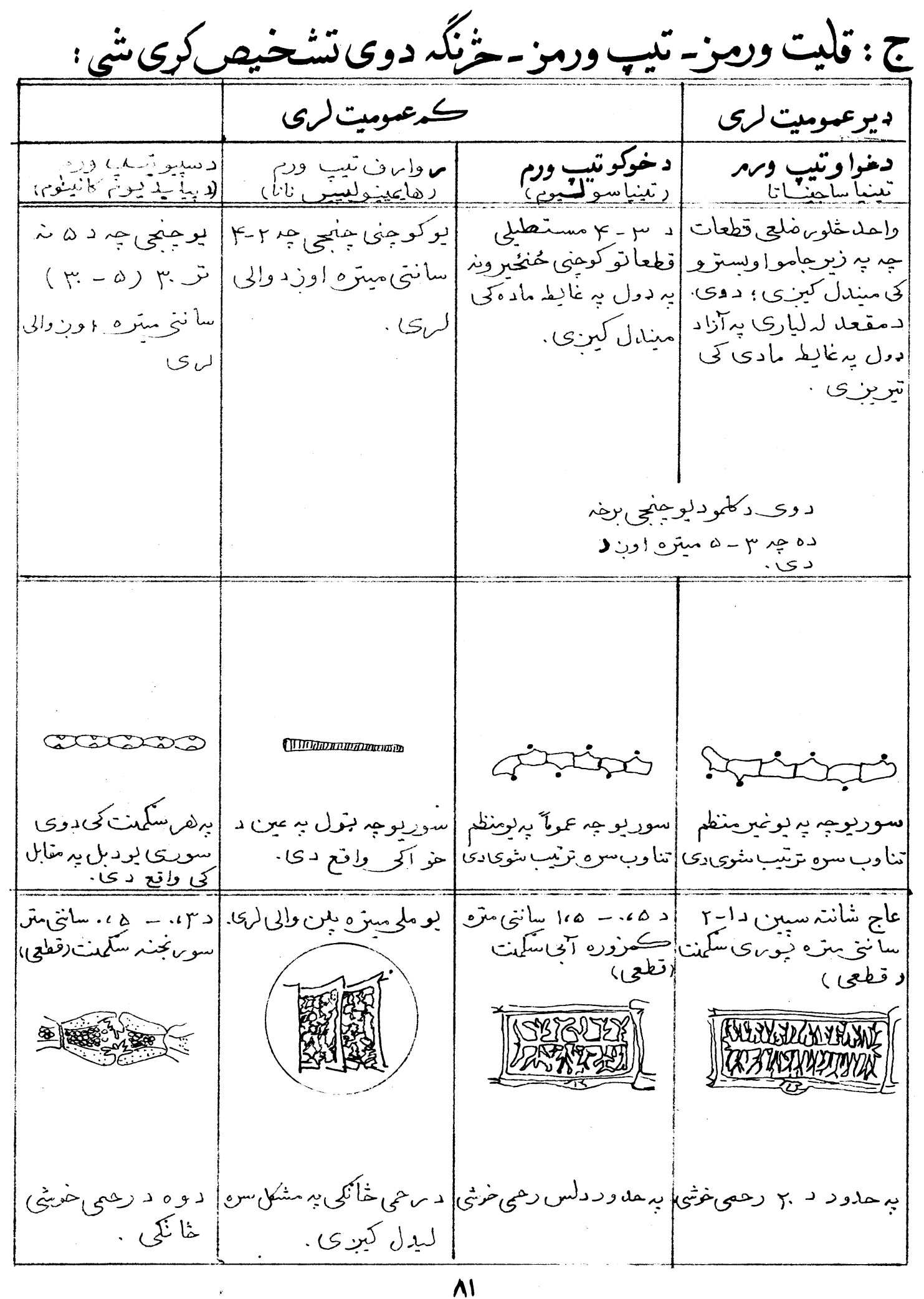


4 - آميبا ، فلاجبلمتون اوسيليتونه : متحك ششكلنه

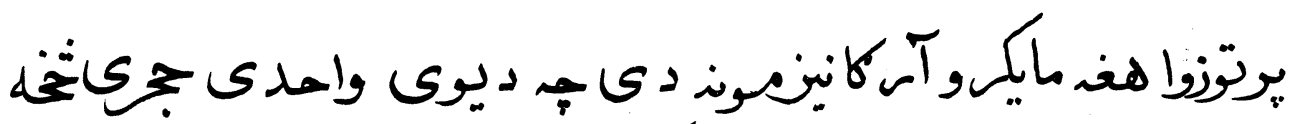

$$
\text { تحبفات : }
$$

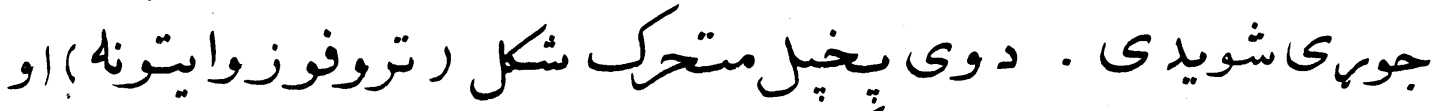

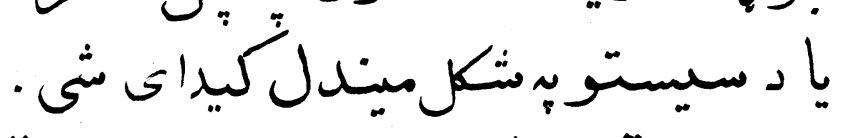

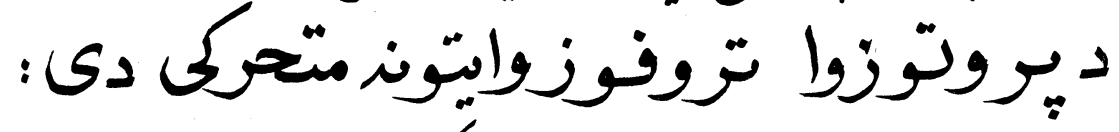

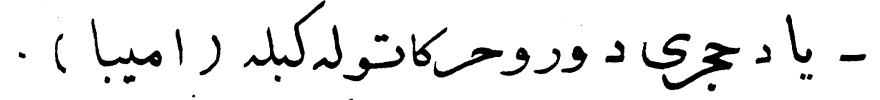

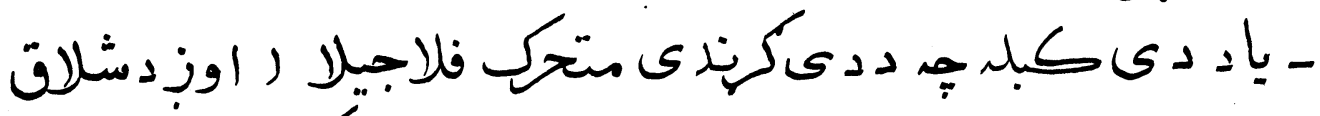

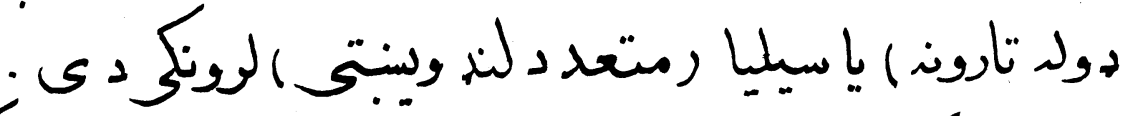

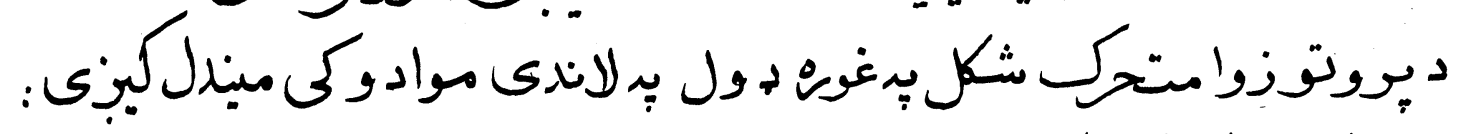
- مايع غايط: مادى ك.

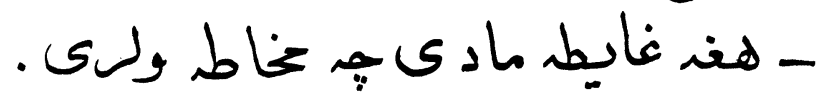

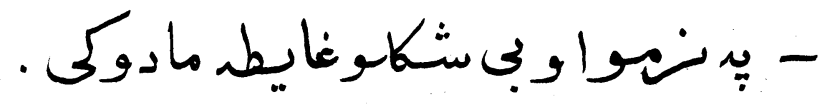




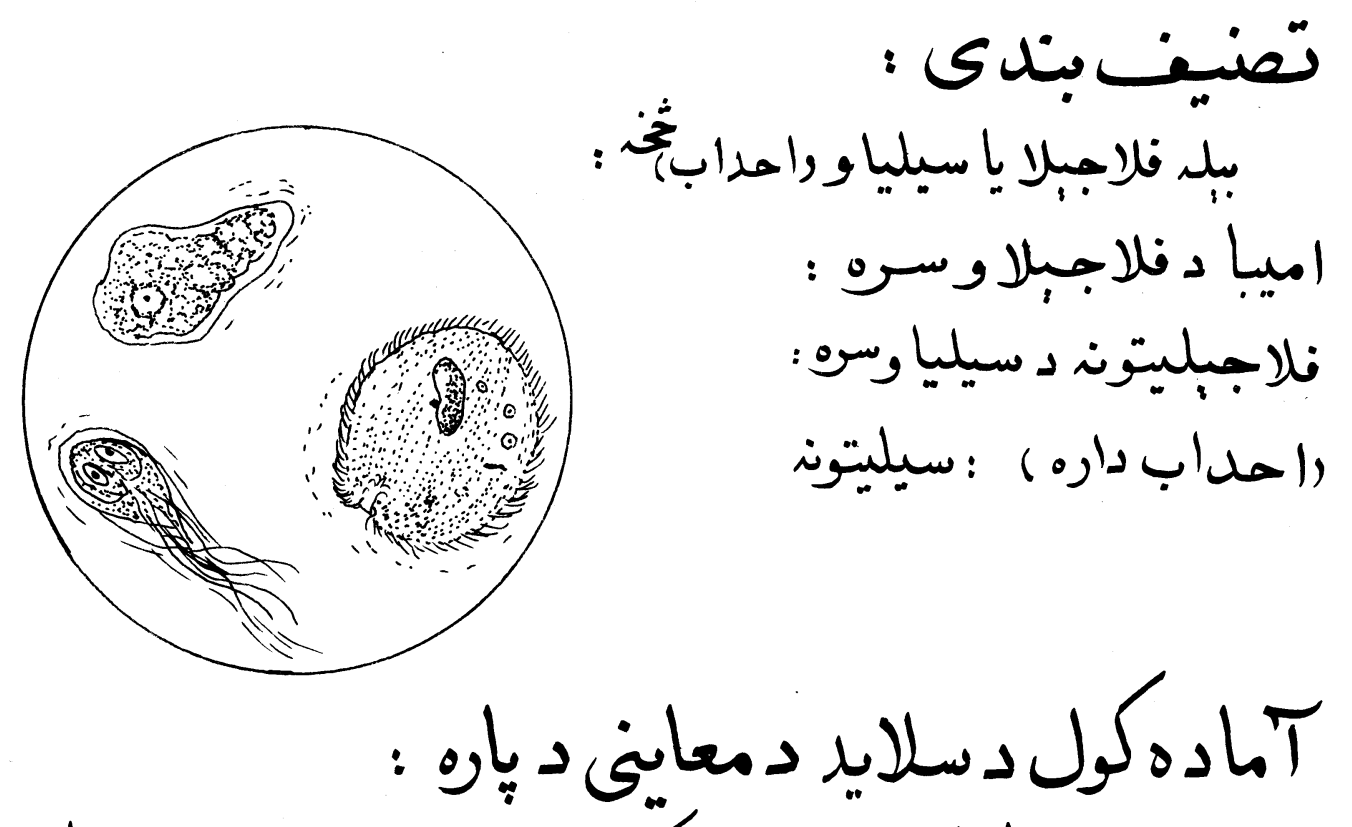

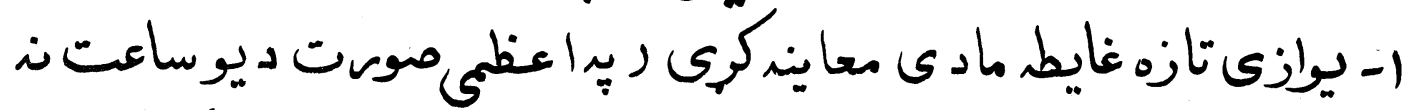

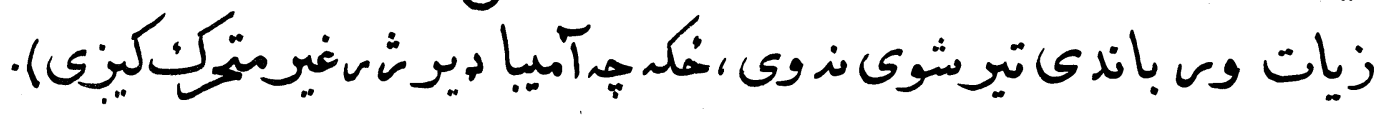

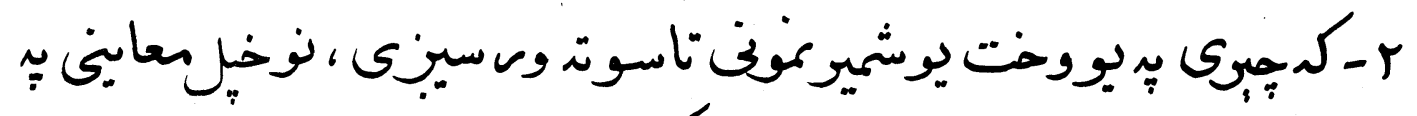

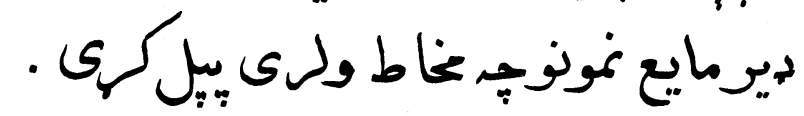

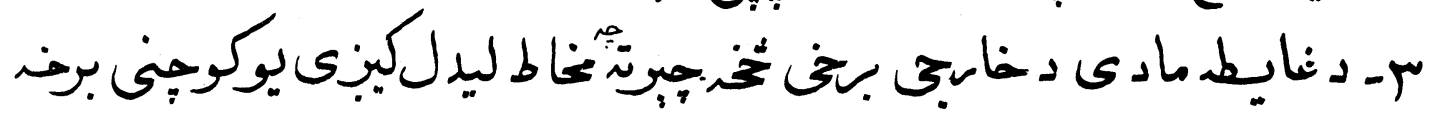
واخلى

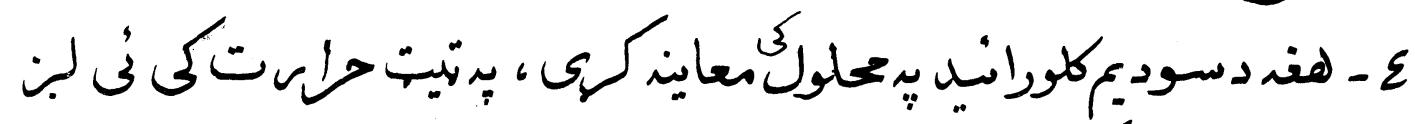

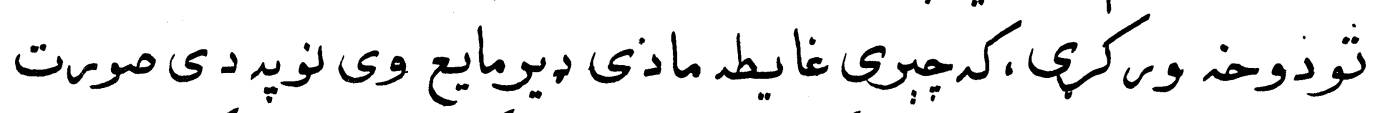

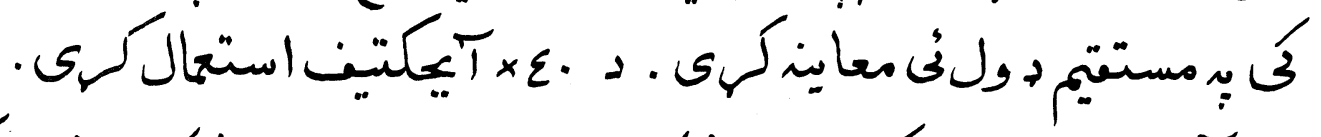

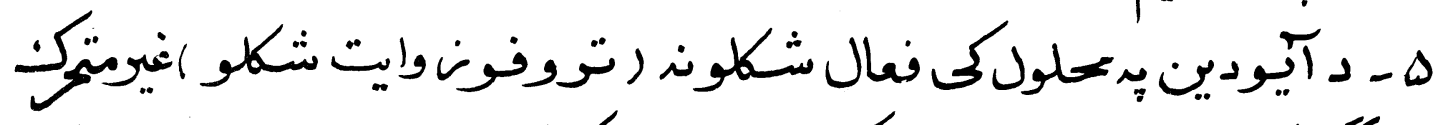

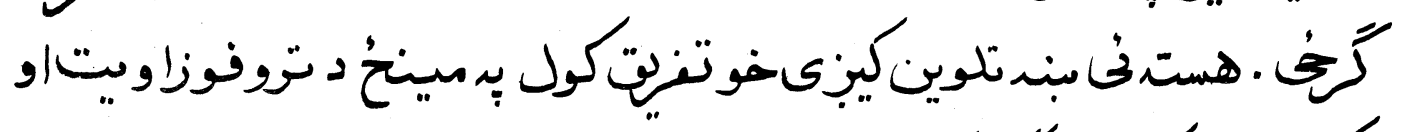

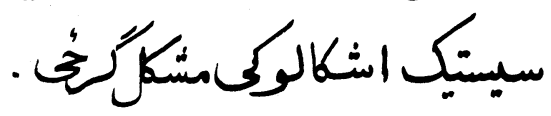




\section{دكمود يووتوزواولست :}

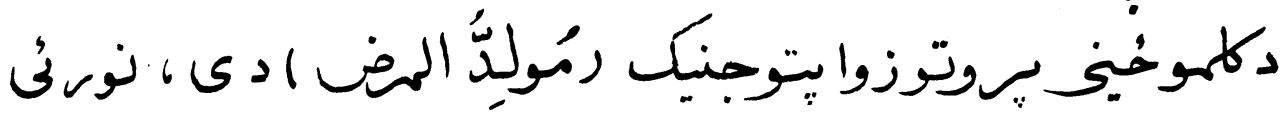

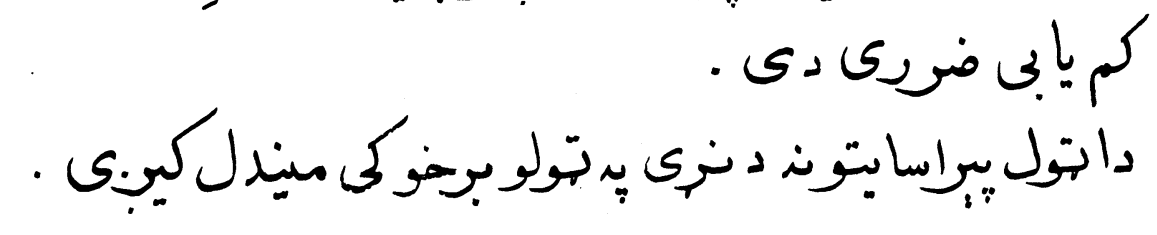

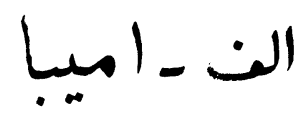

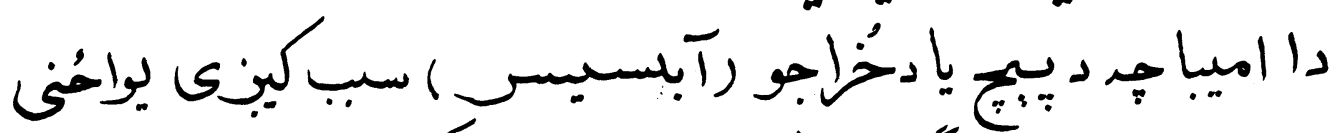

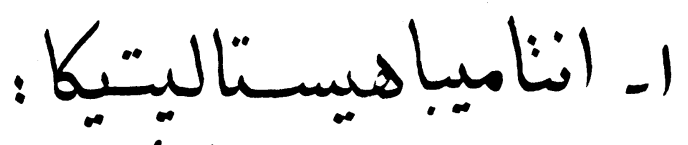

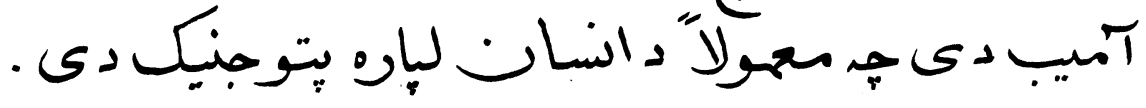

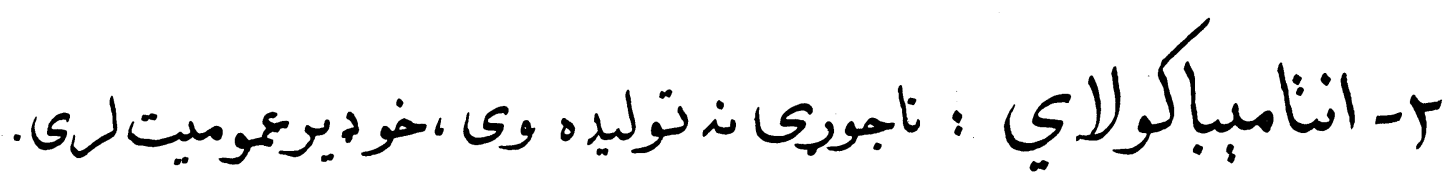

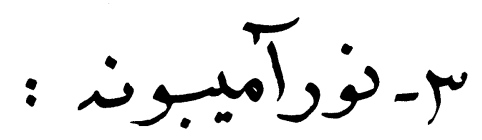

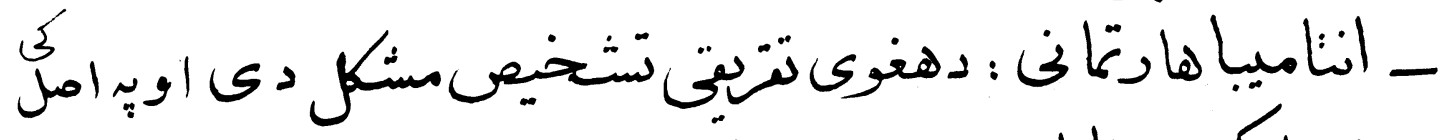

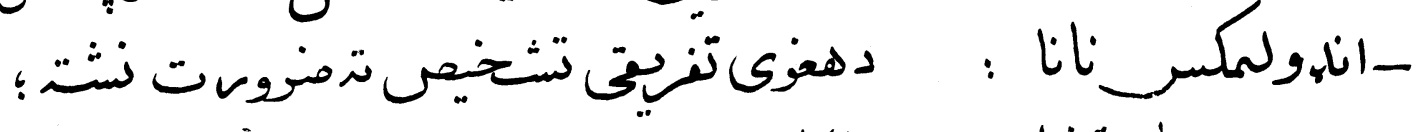

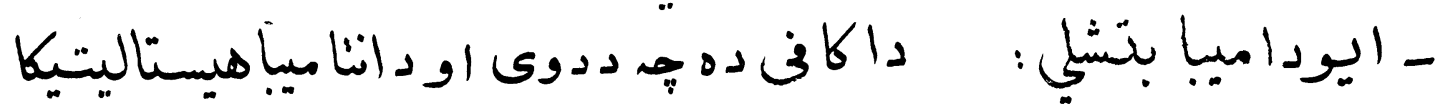

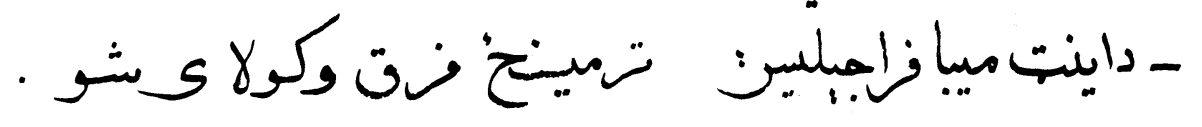




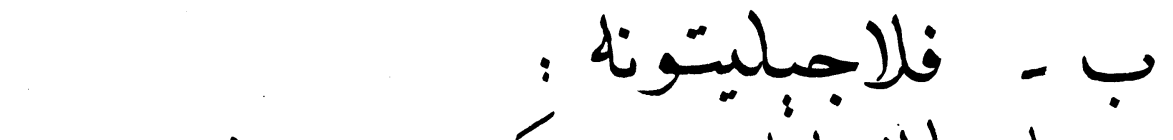

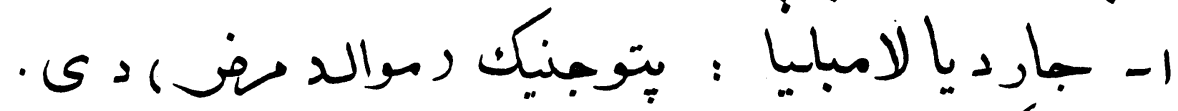

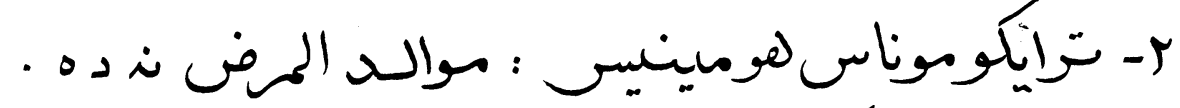

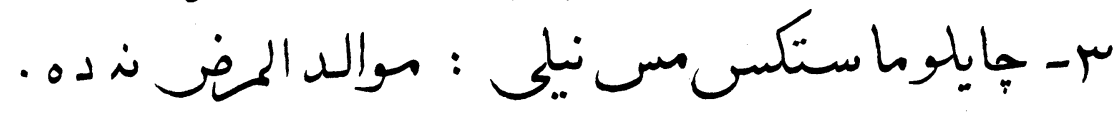

$$
\text { ج - سيليتون احداب دارى ) }
$$

ا- بلانتيد يومكولاى BALAN TIDIYM

$$
\text { COLI }
$$

$$
\begin{aligned}
& \text { د لابِلاتوار لِاره جيوه غوره برابلمعبارت دى ده : }
\end{aligned}
$$

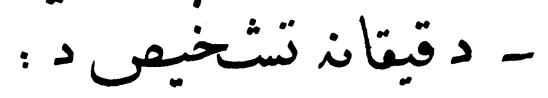

E.histolytica قانتاميبا هيستاليتيكا

G. la mblia

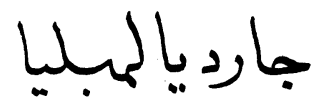

B. coli

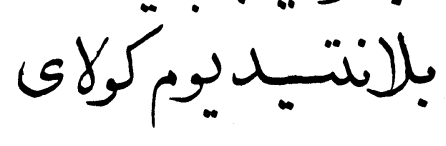

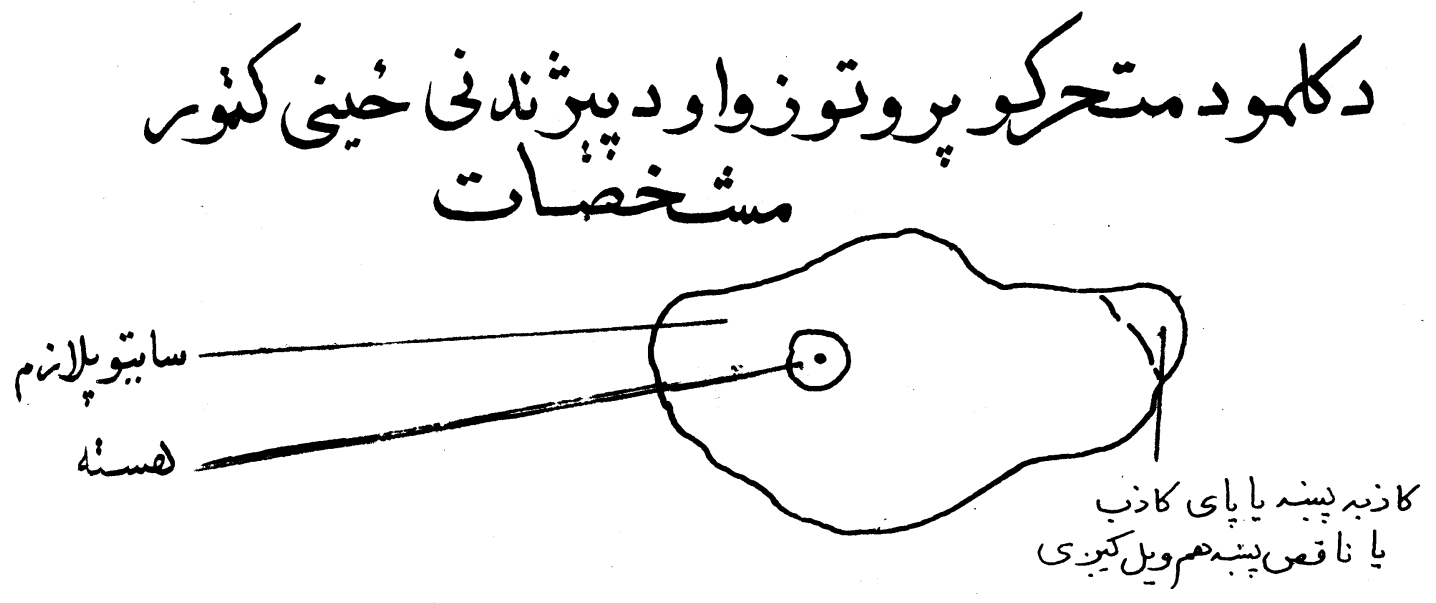




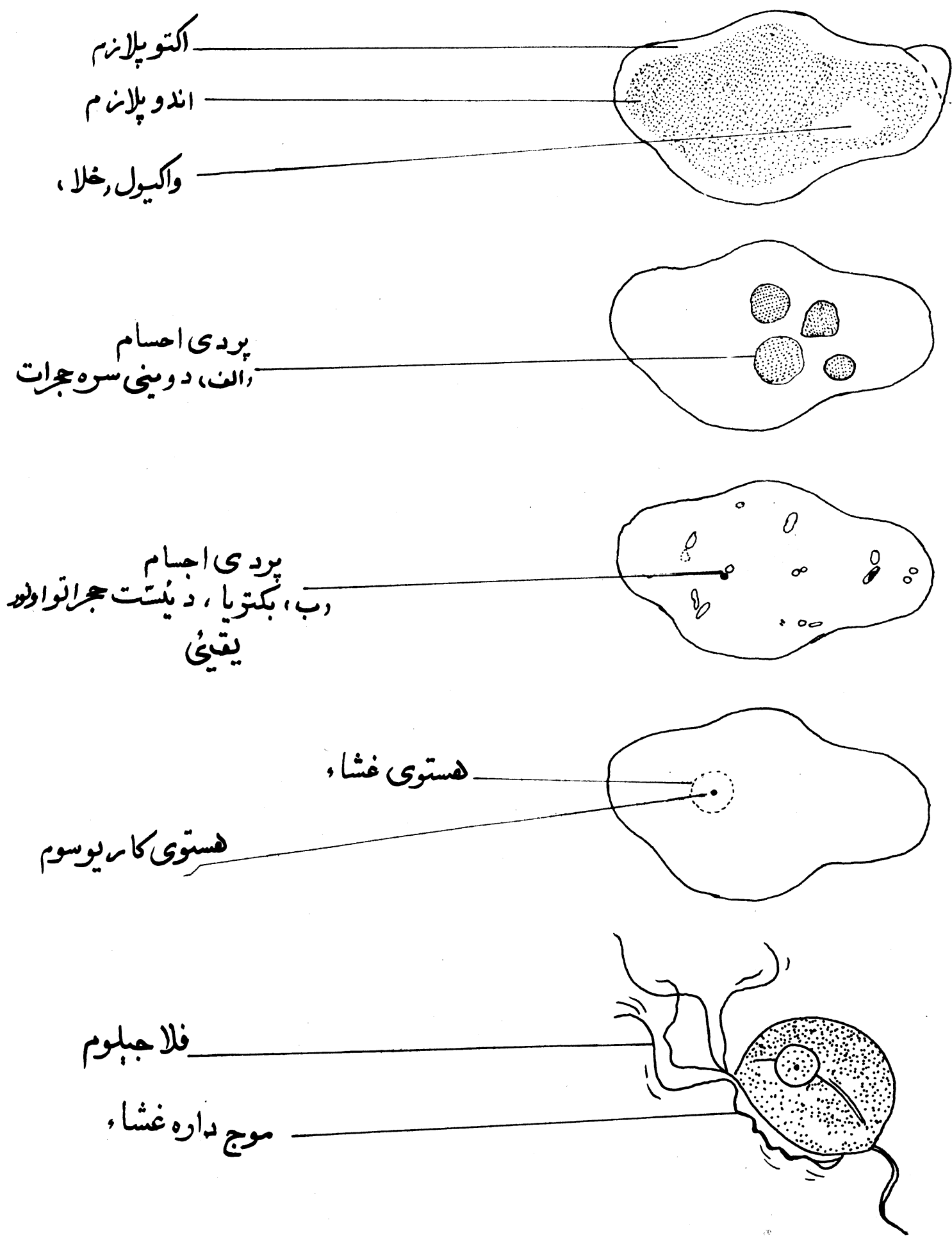

14 


$$
\begin{aligned}
& \text { الن_ آميــ } \\
& \text { اـ (نناميباهيستاليتبكا (ديجِ|ميب) }
\end{aligned}
$$

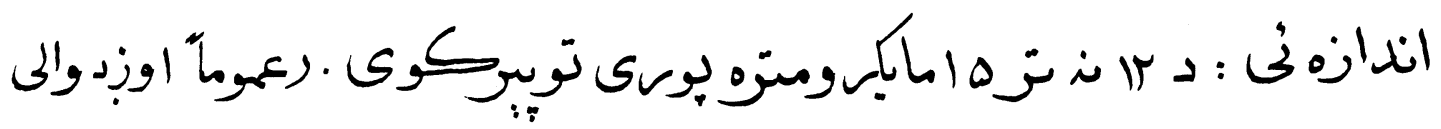

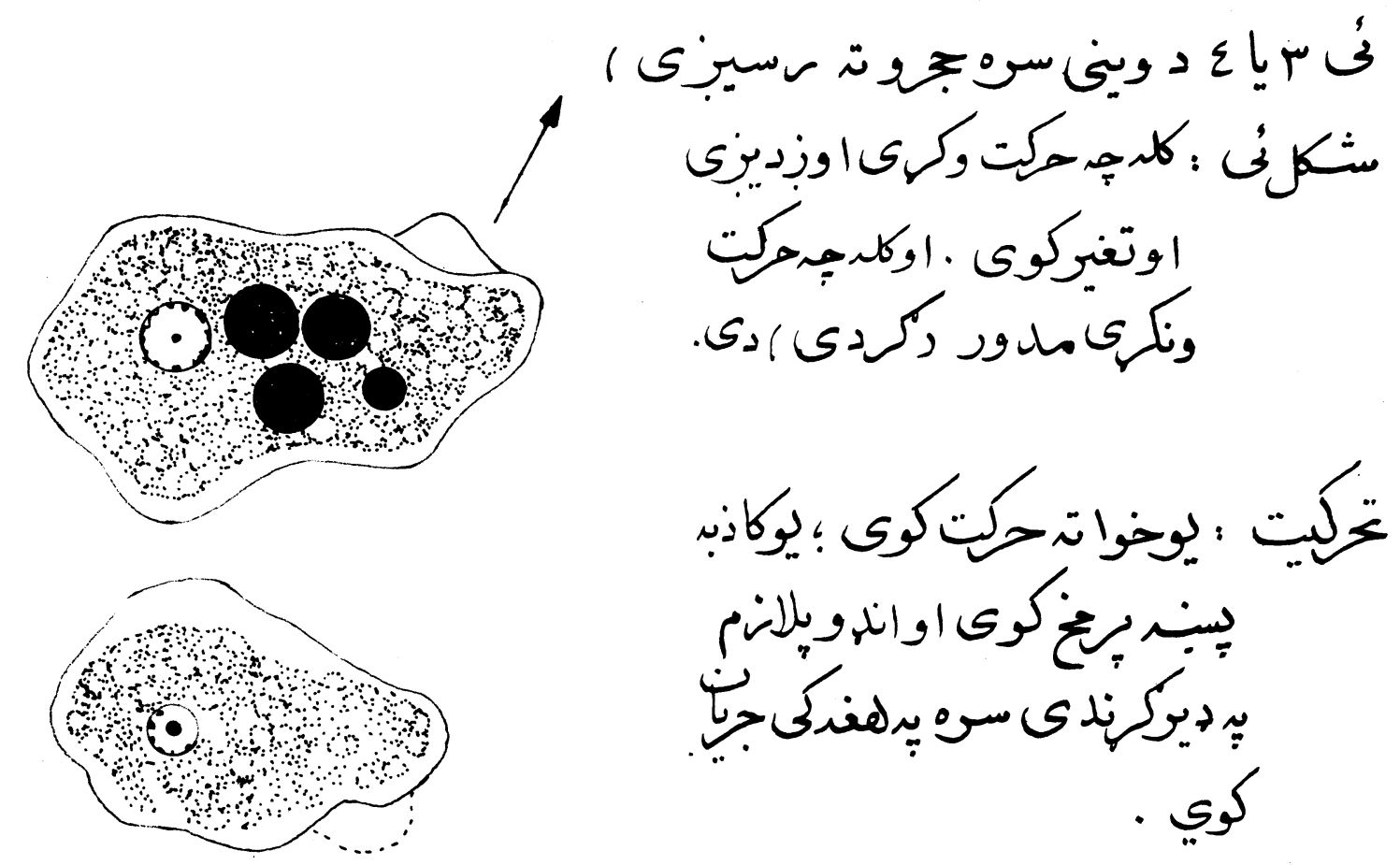

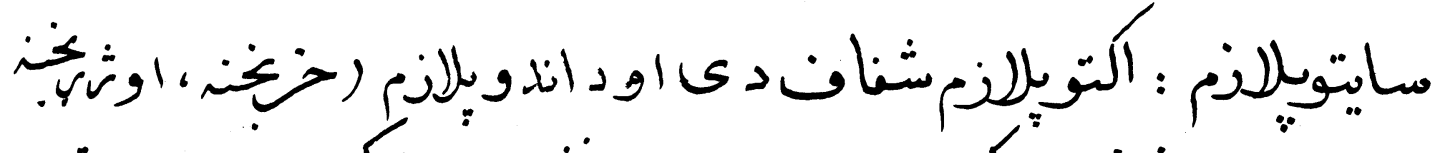

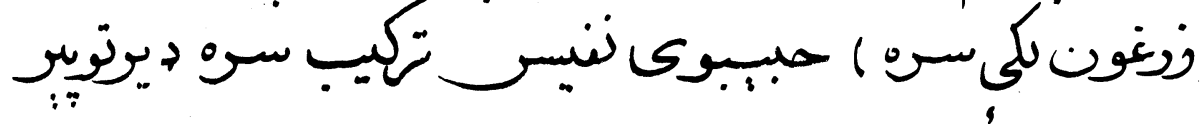

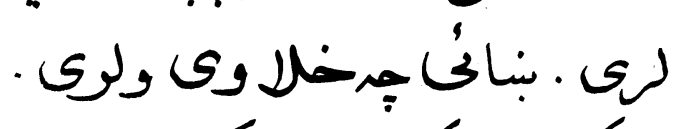

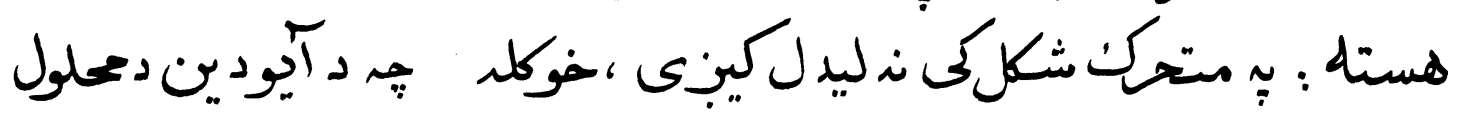




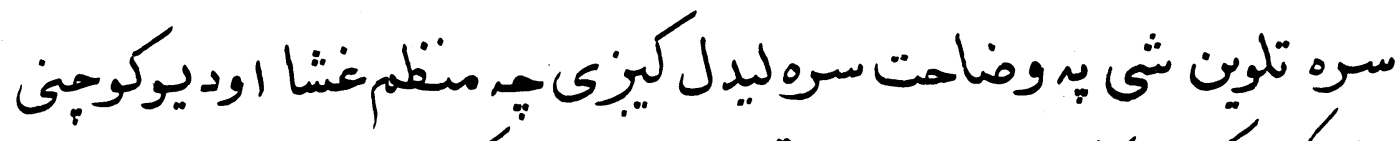

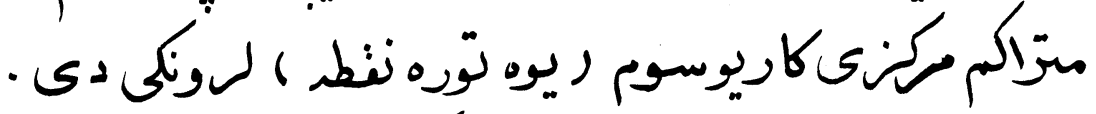

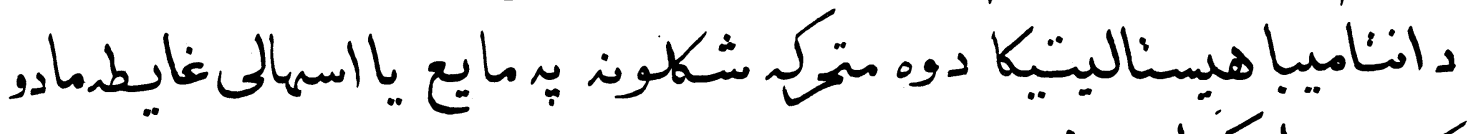
كى ميندل دكيداى شنى :

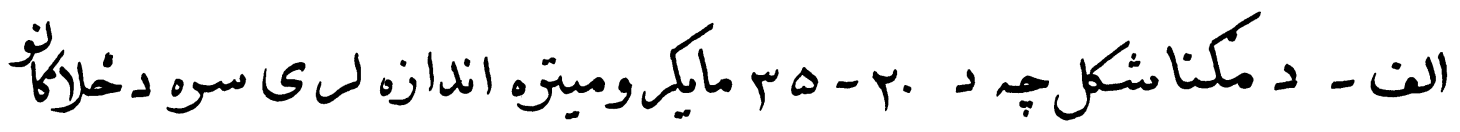

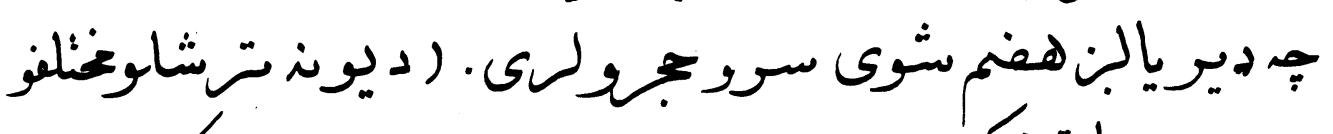

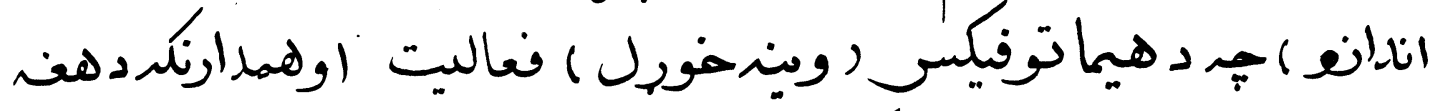

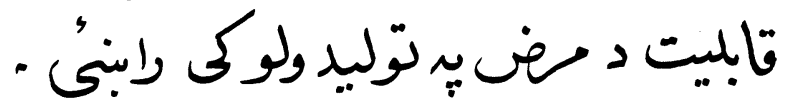

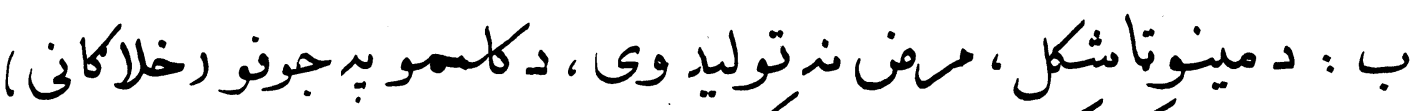

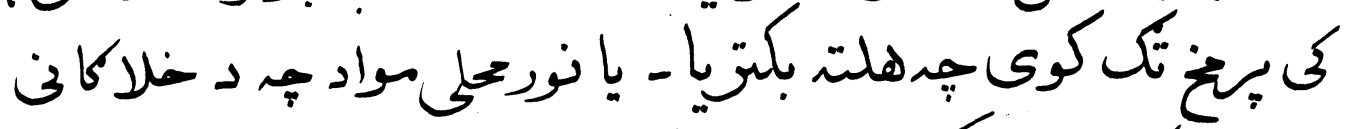

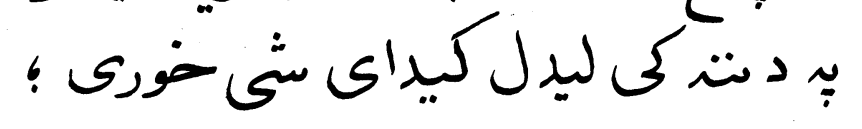

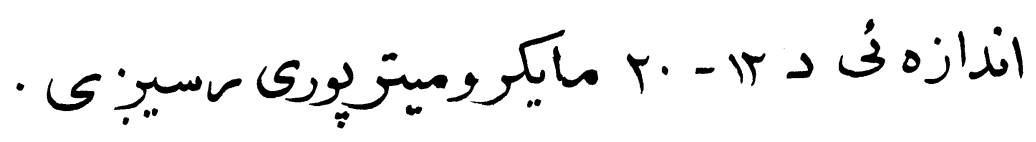




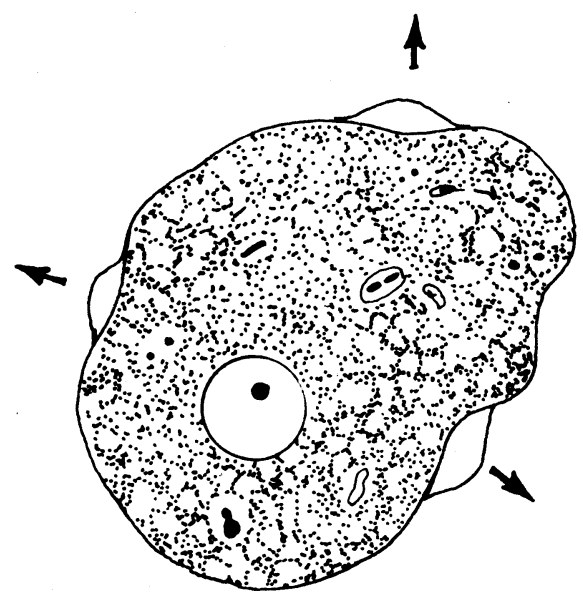

$$
\begin{aligned}
& \text { انتاميباكولاى : زماك }
\end{aligned}
$$

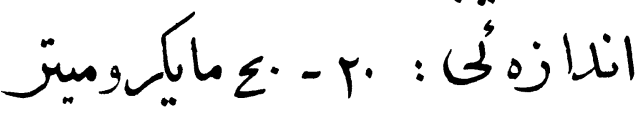

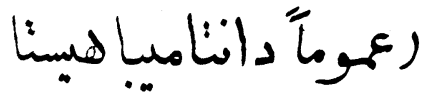

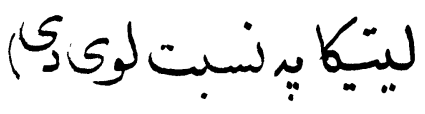

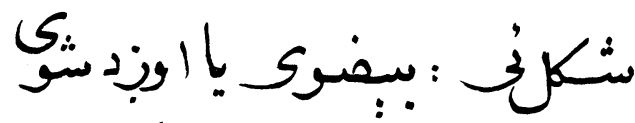

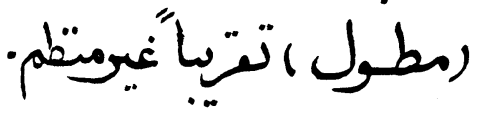

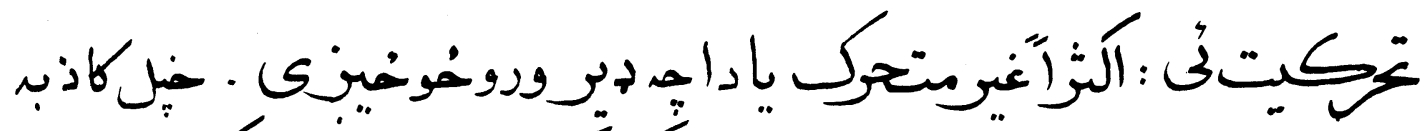

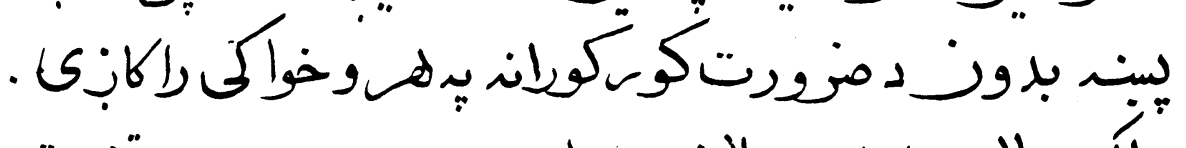

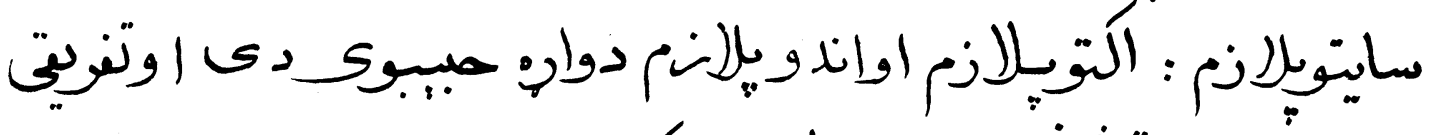

$$
\text { تشخيق ددواروسئل دى . }
$$

اجنبى اجسام : متعدداومنحول بكنيا ، دئيست جات، دئوليو

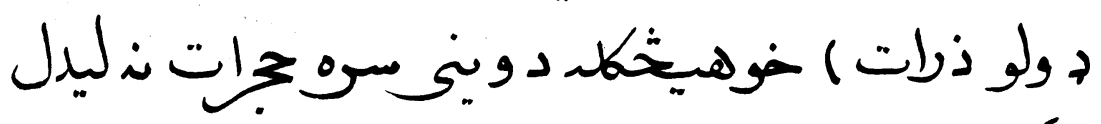

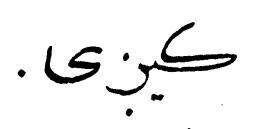

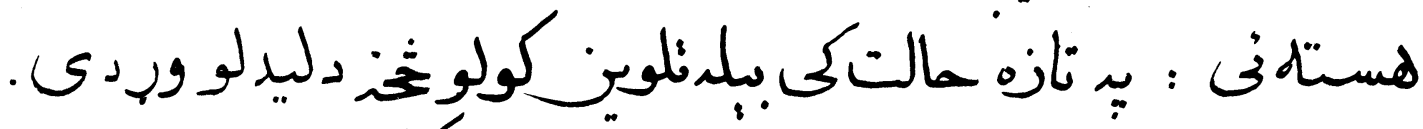

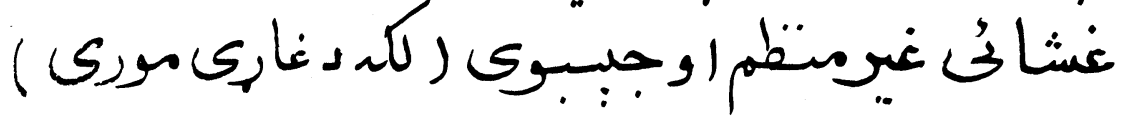


كاسيوسومخنت اوديزن بهد ى .

\begin{tabular}{|c|c|c|}
\hline 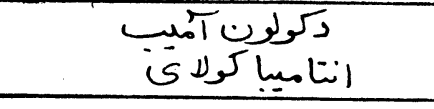 & 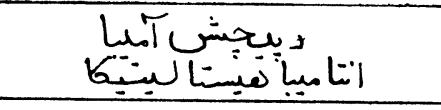 & \\
\hline "' & 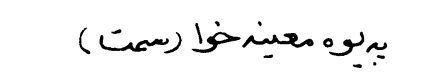 & \\
\hline & . & $-5 x$ \\
\hline 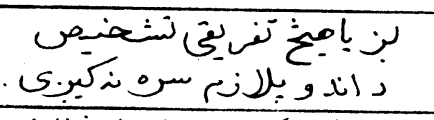 & 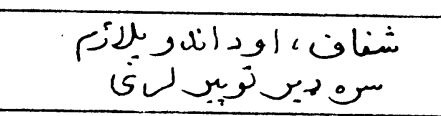 & אים \\
\hline 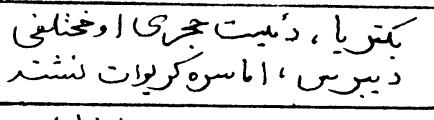 & 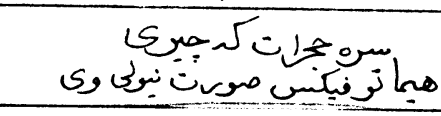 & 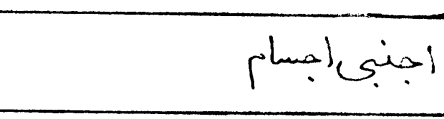 \\
\hline 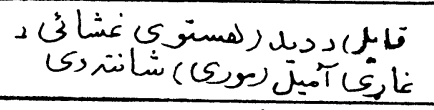 & نمي تابل دي & (ت) \\
\hline 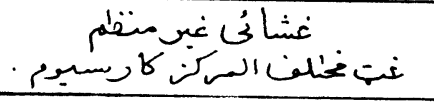 & 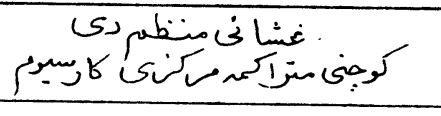 & 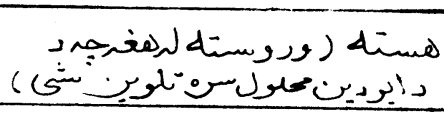 \\
\hline
\end{tabular}
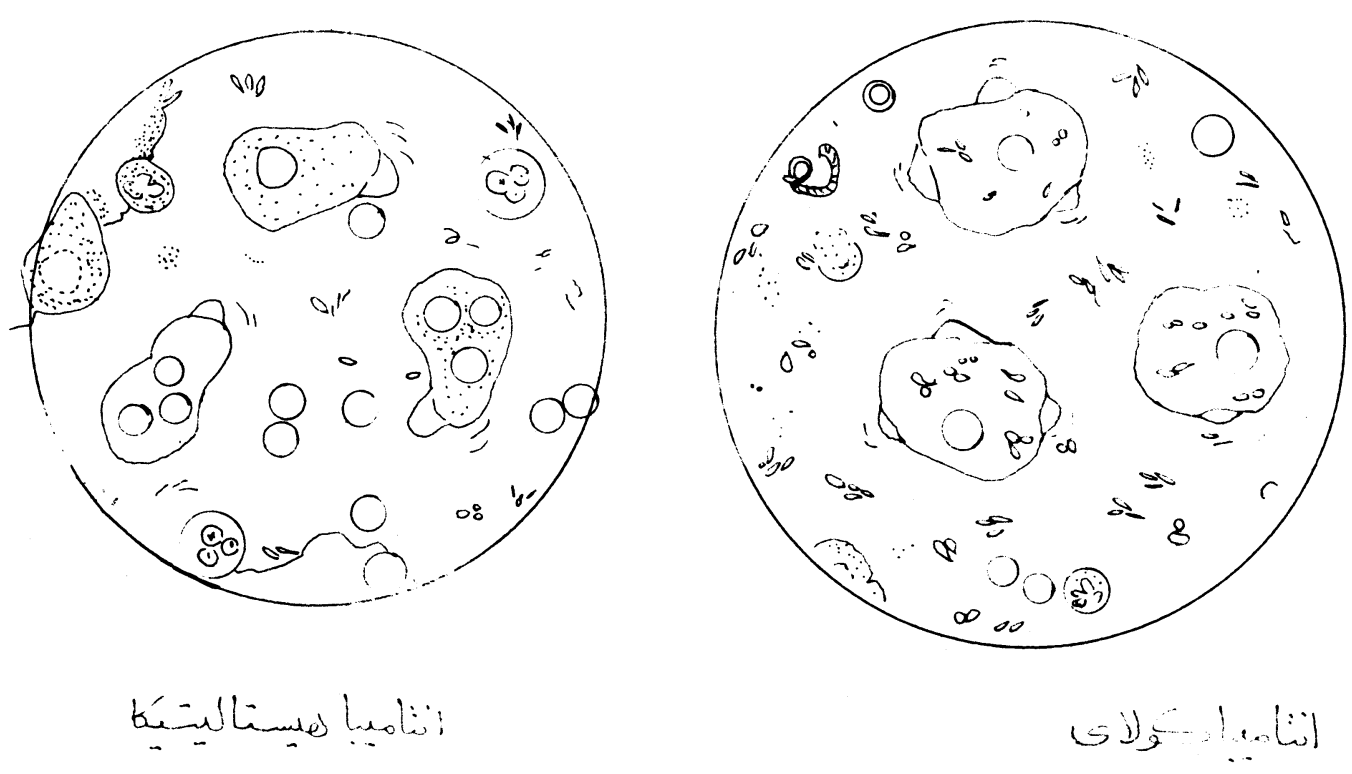


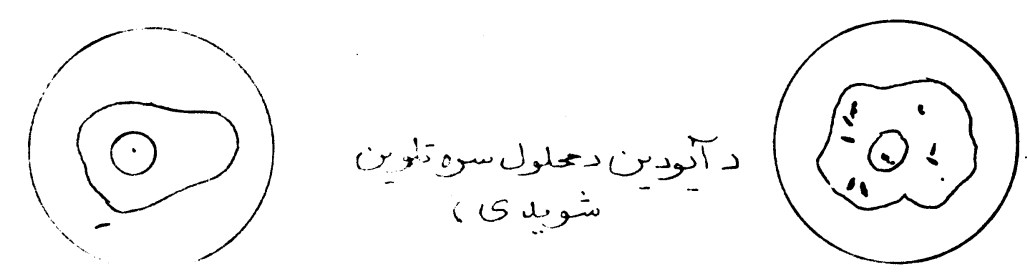

$$
\text { r- نورآميبونه : }
$$

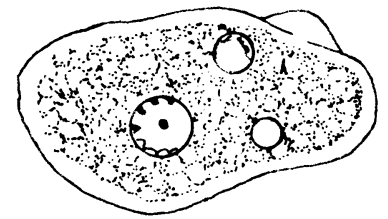

$$
\text { : : }
$$

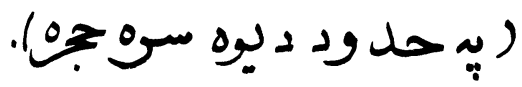

زتر اوصانت

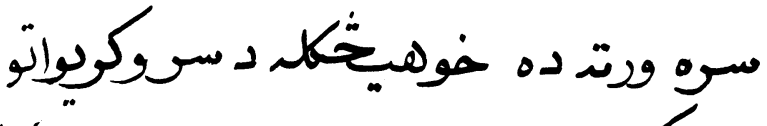

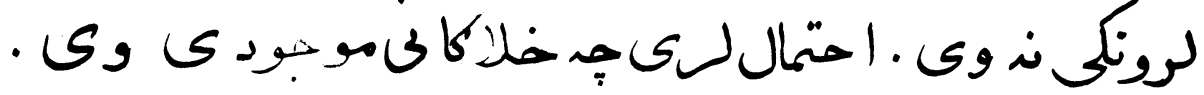
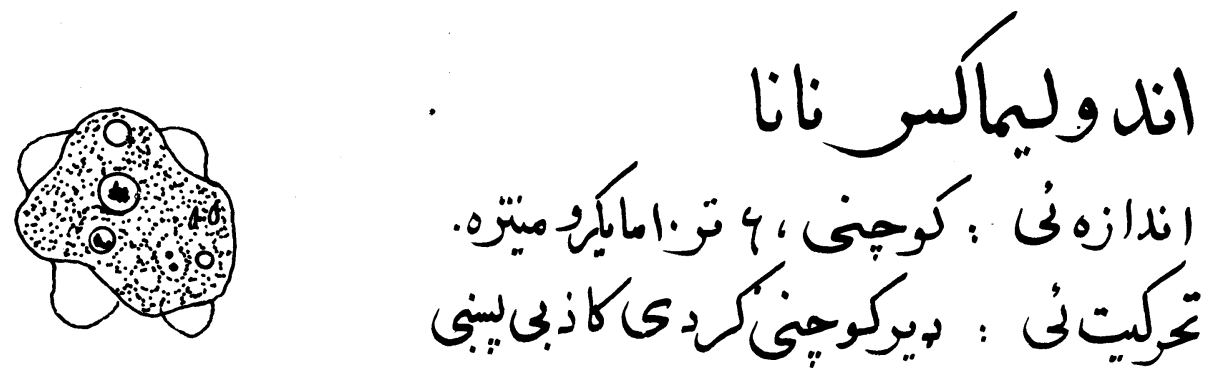


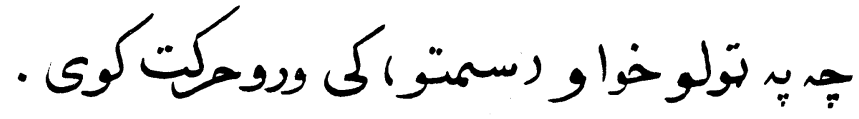

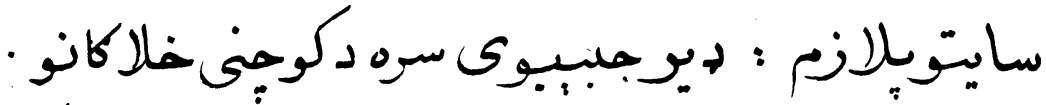

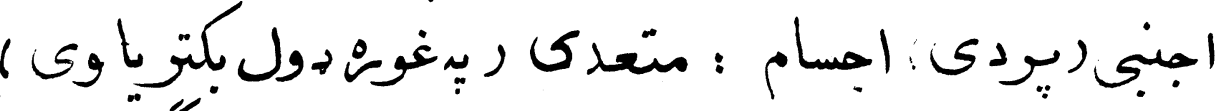

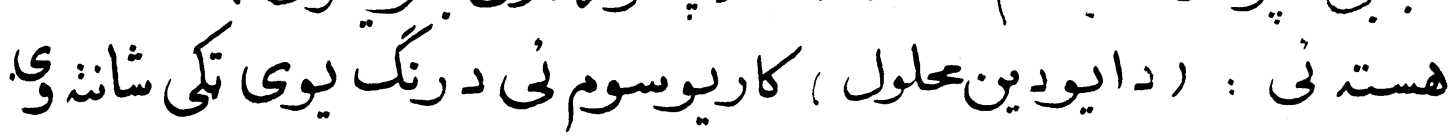

$$
\text { هاى انتاميبا فراحليسّــ : }
$$

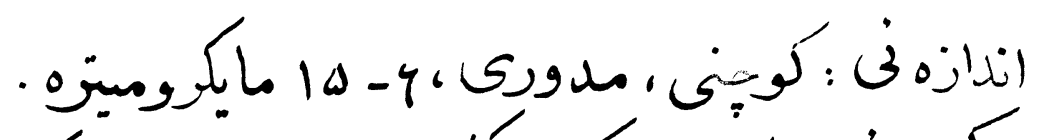

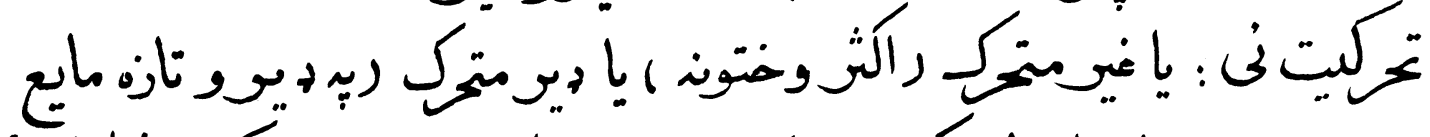

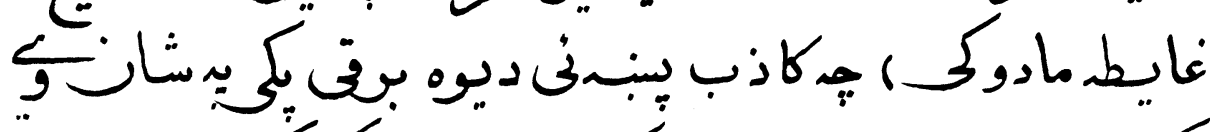

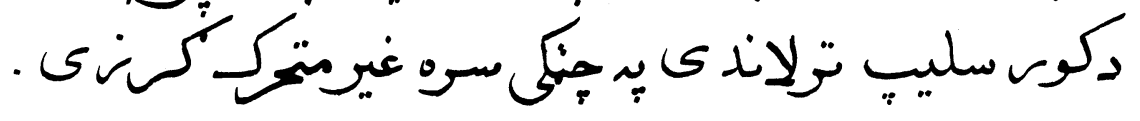

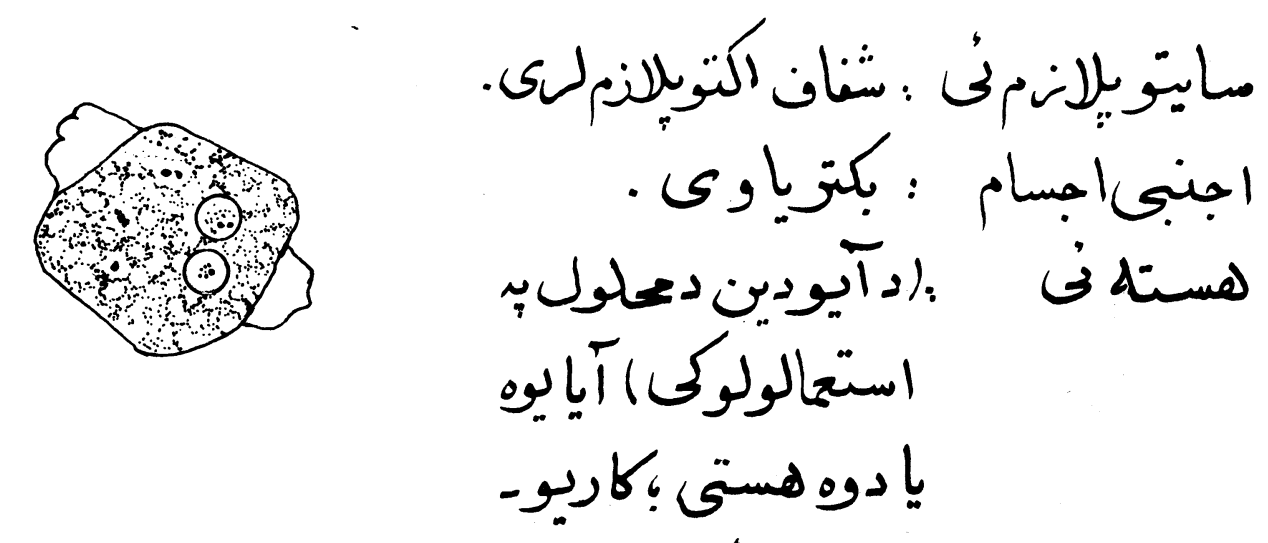

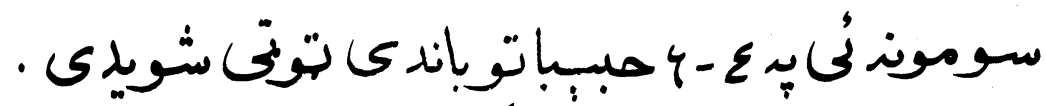

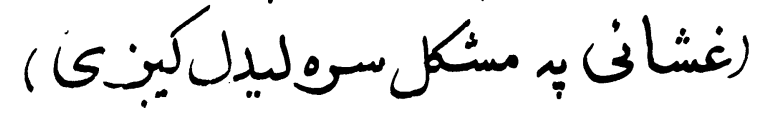




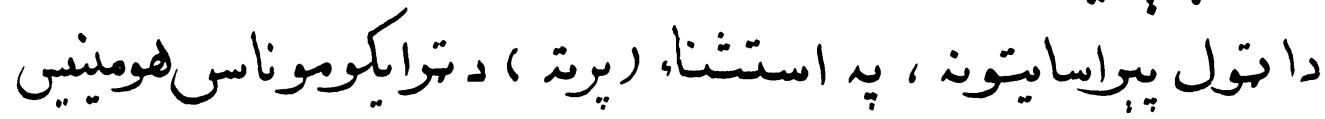

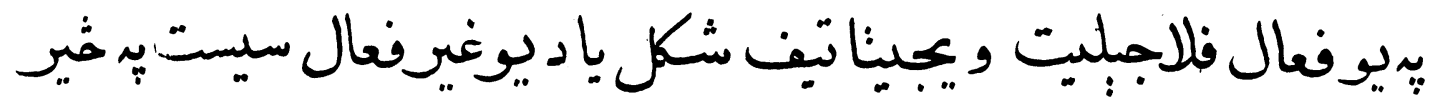

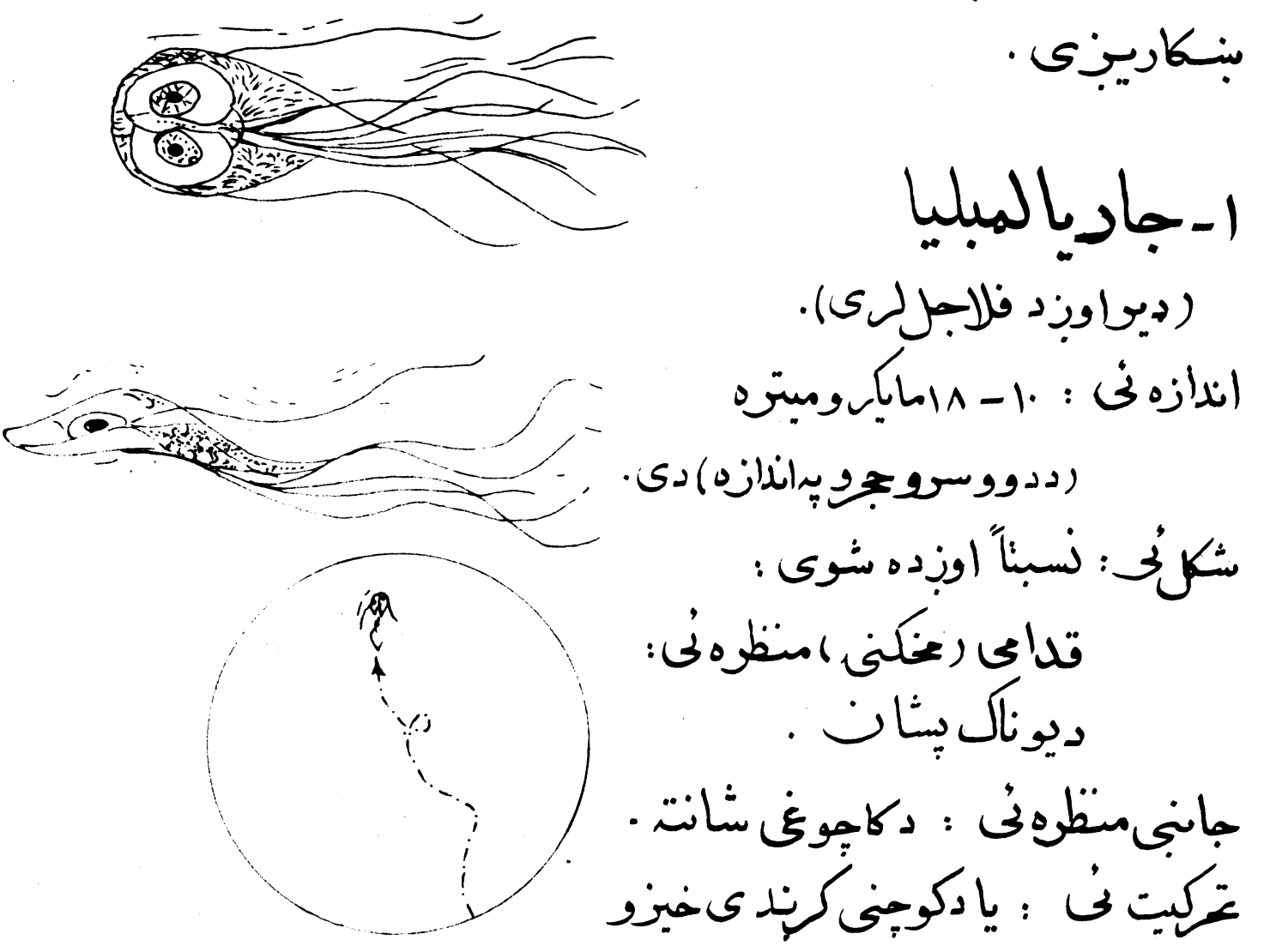

$$
\text { ب ـ فلاجبليتون : }
$$

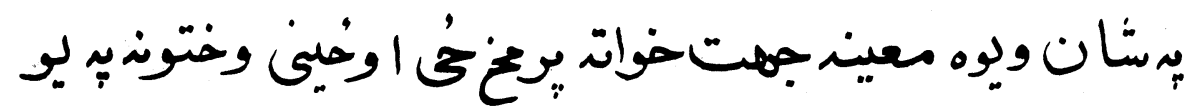

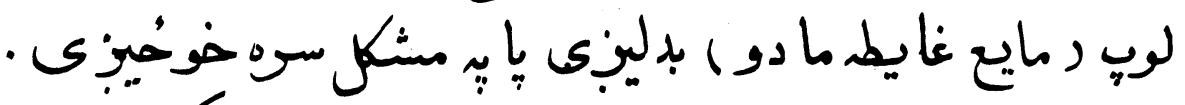

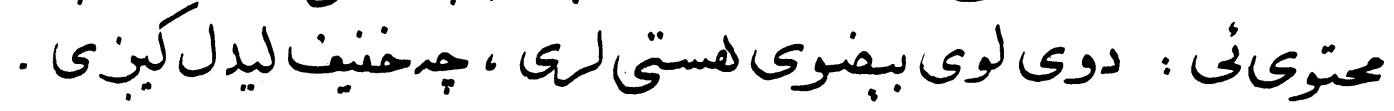




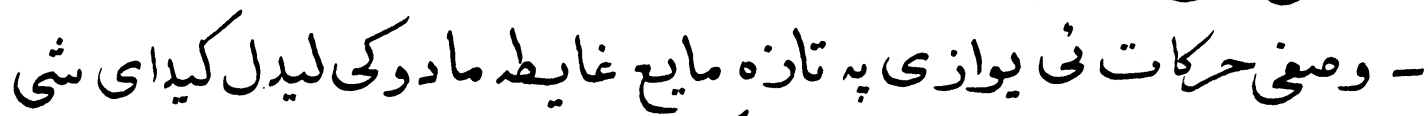

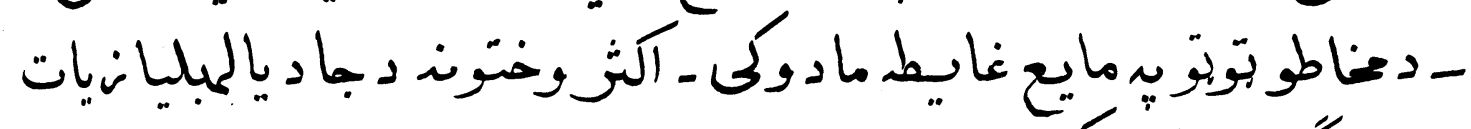

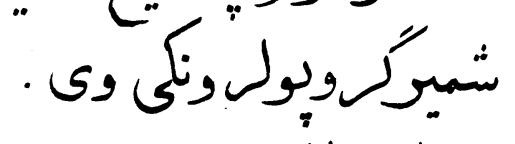

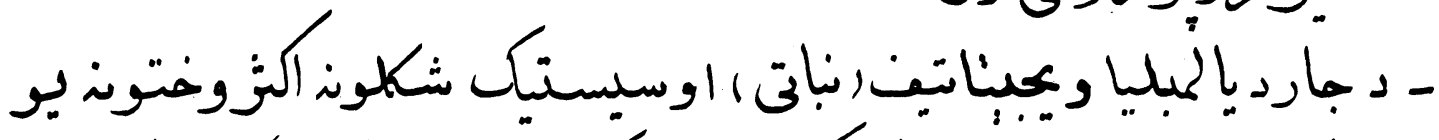
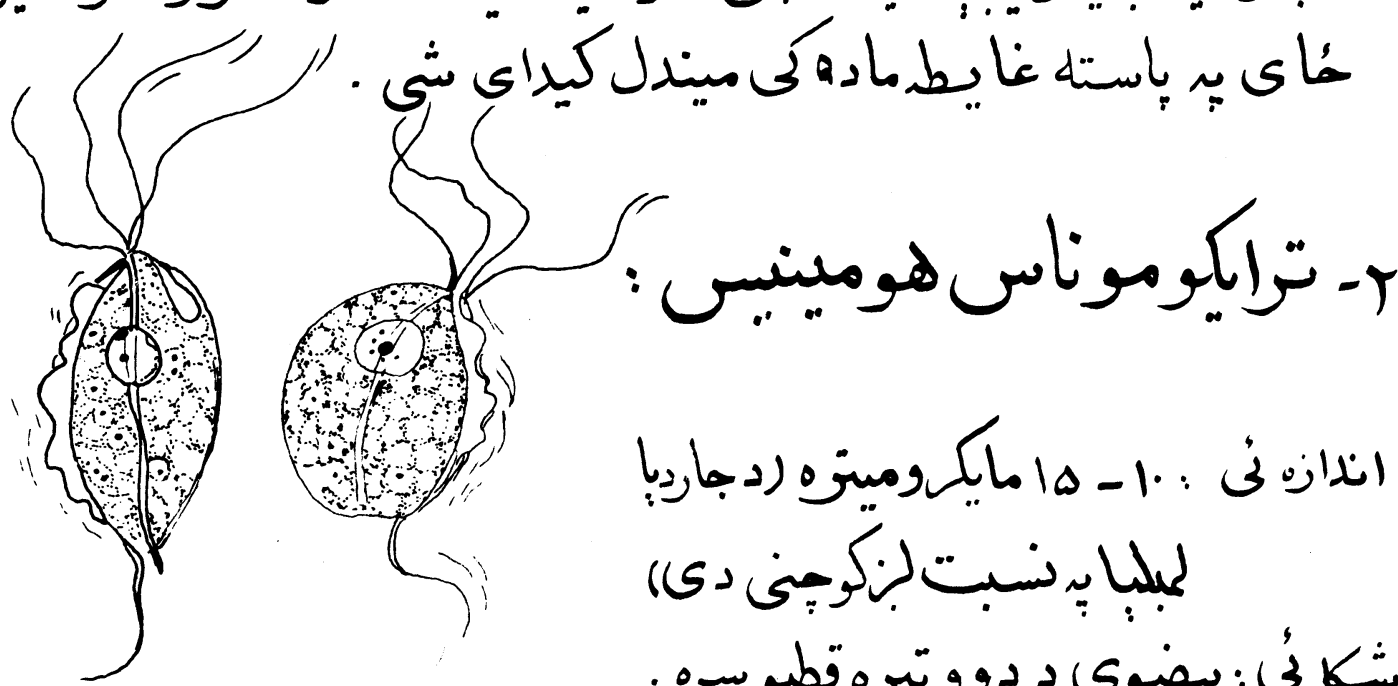

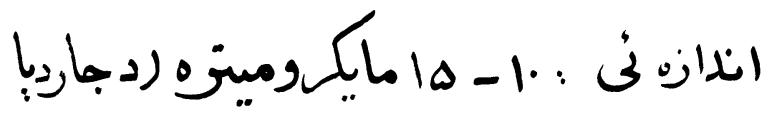

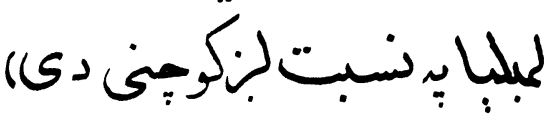

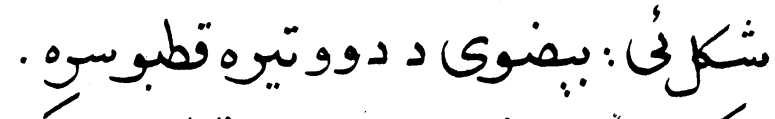

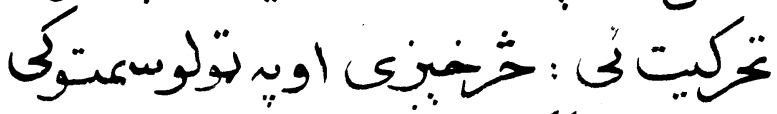

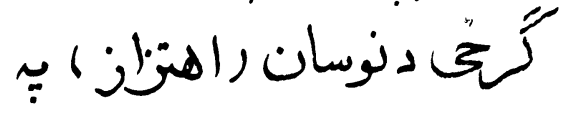

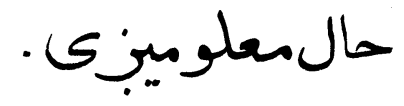

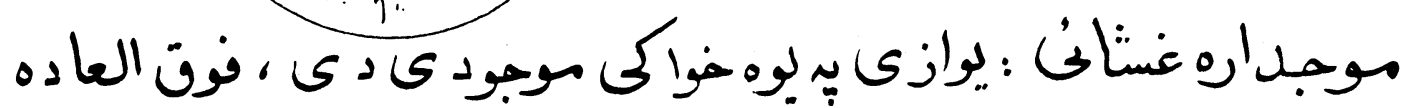

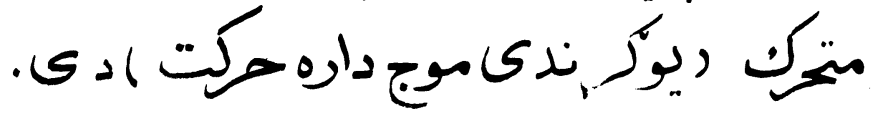

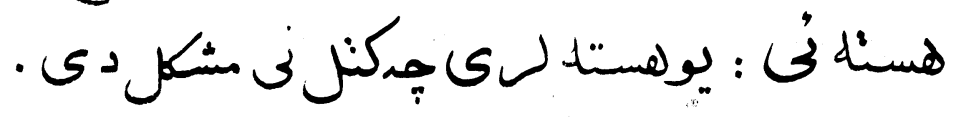




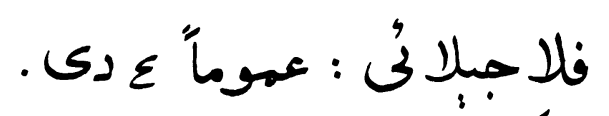

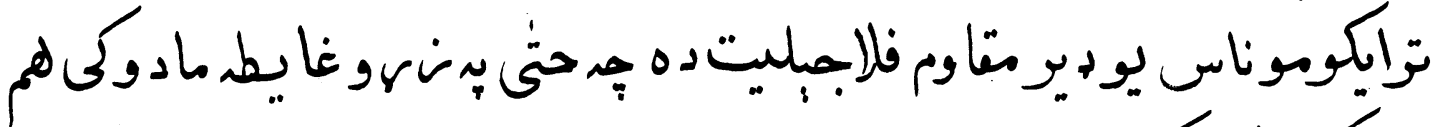

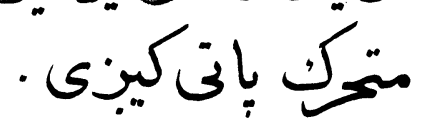

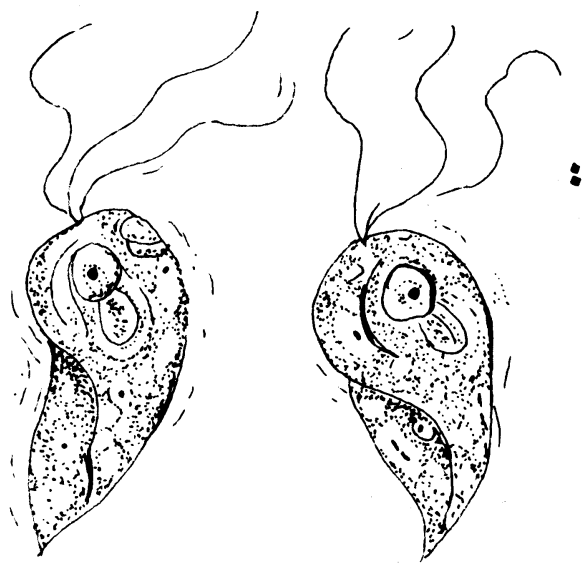

$1 S_{\infty}^{\infty} \int_{\cdots}^{\infty}$

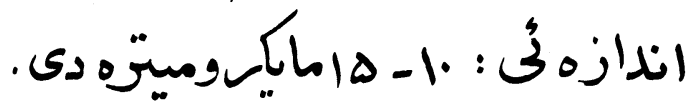

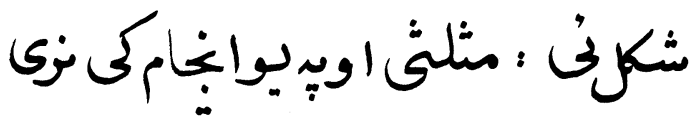
شوى دى اوتئشئي

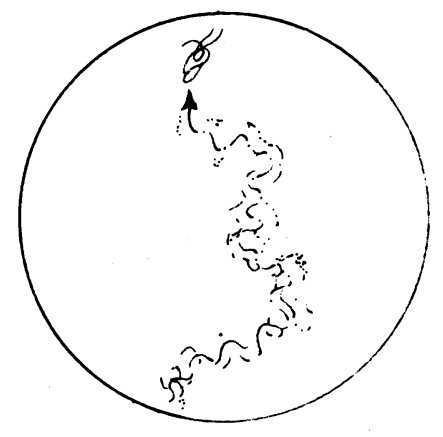

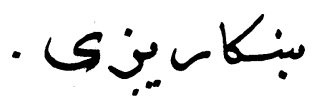

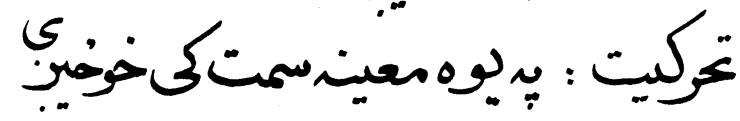

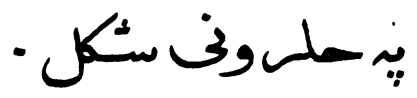

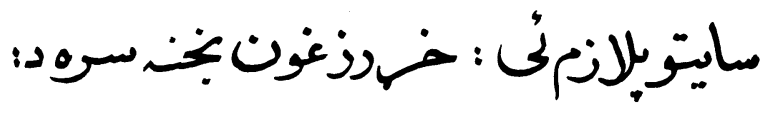

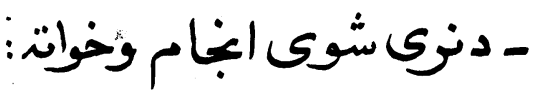

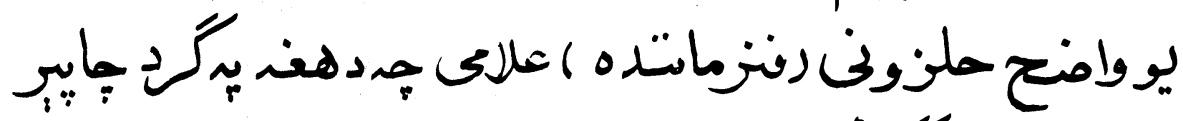

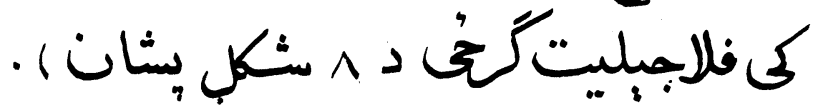

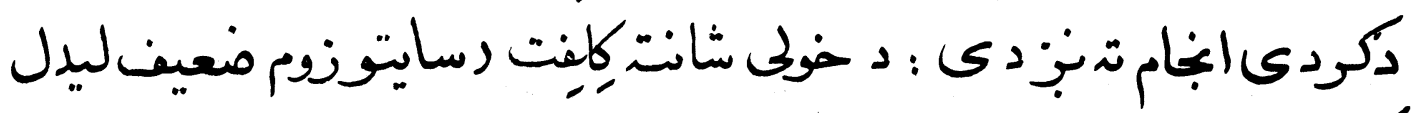

$$
\text { كيْي ك. }
$$

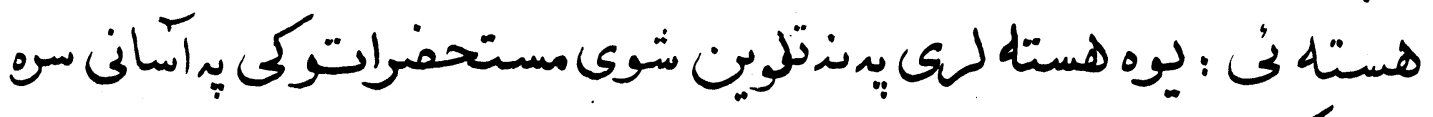




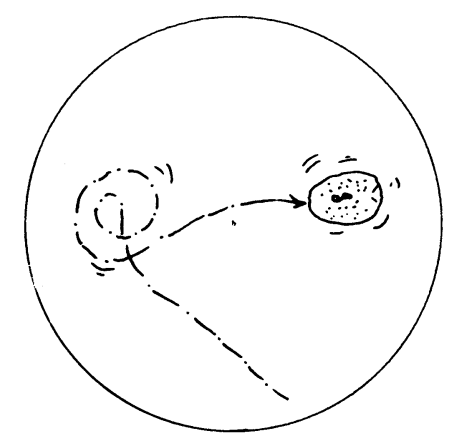

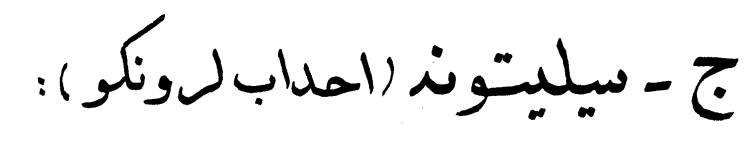

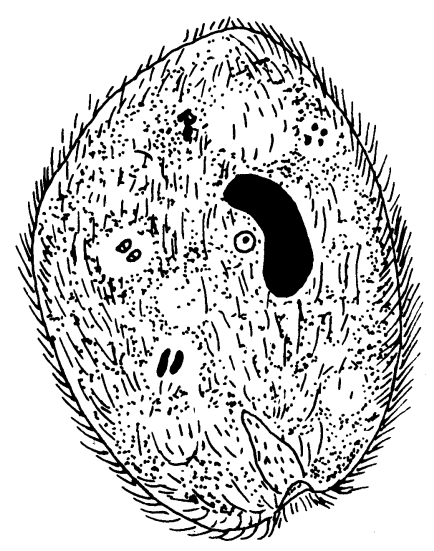

|- بلانتيـديومكولاى (نادي)

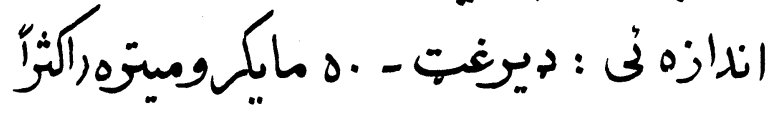

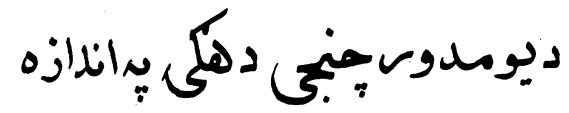
غنَّ وى)،

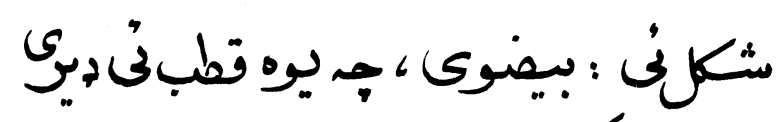

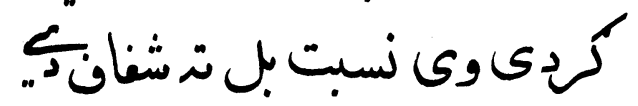

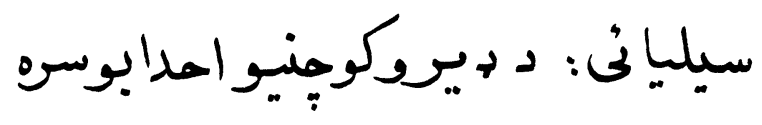

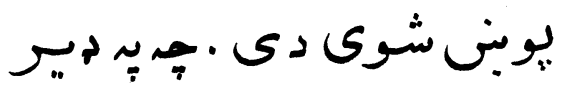

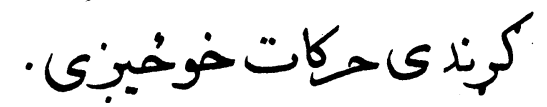

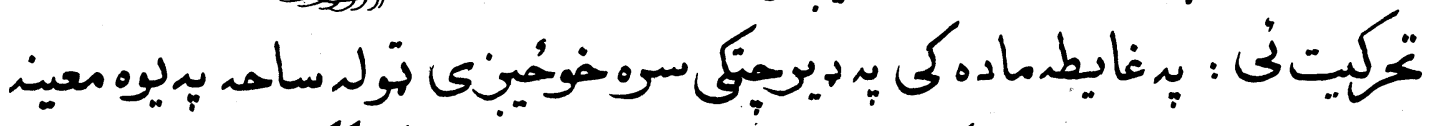

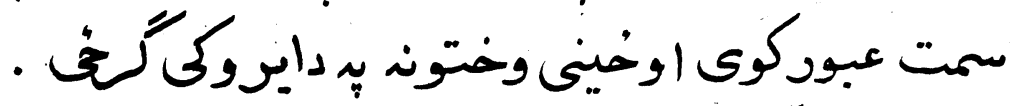

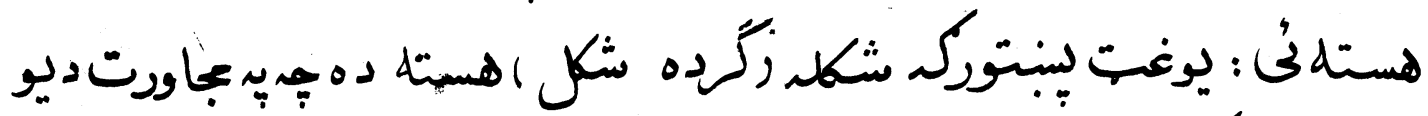

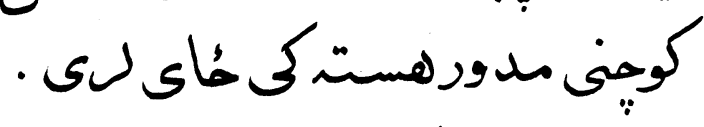

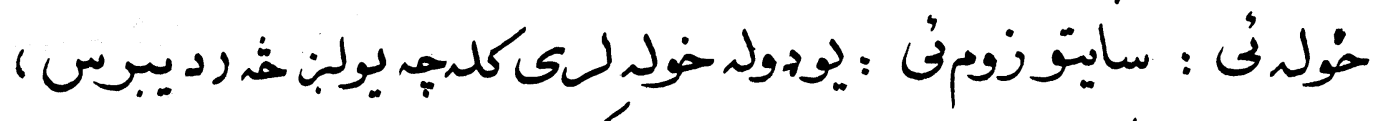

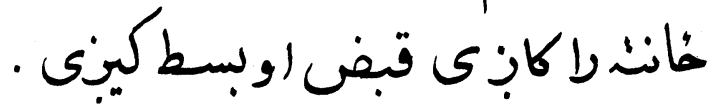

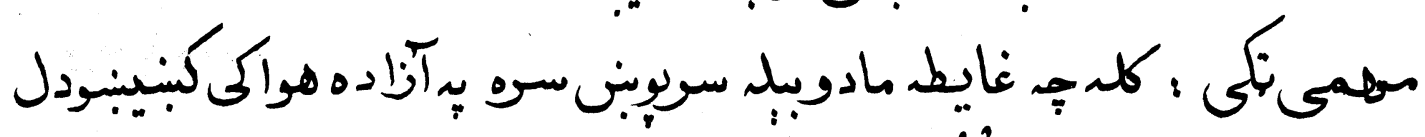

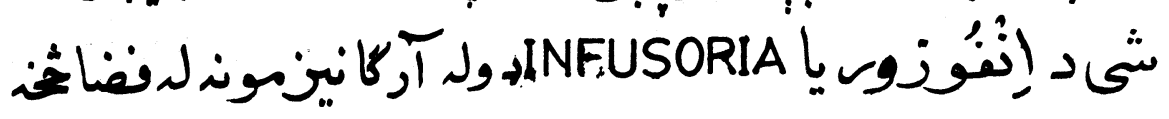




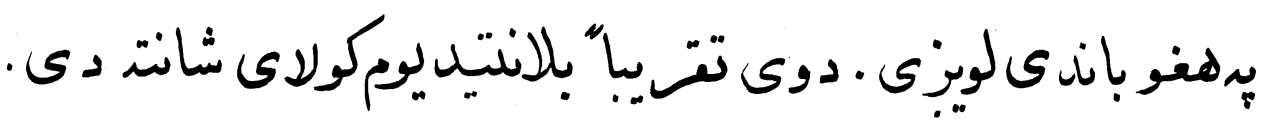

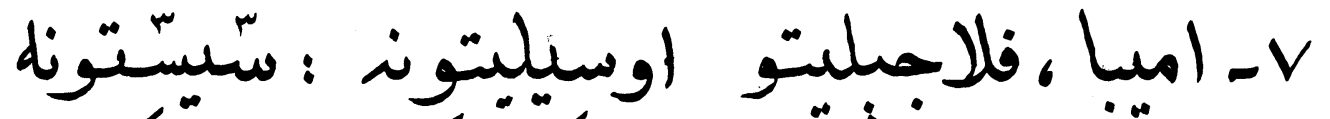

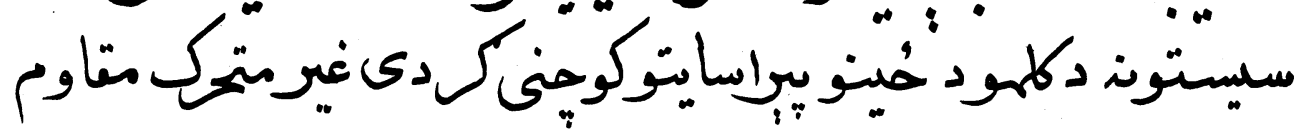

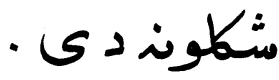

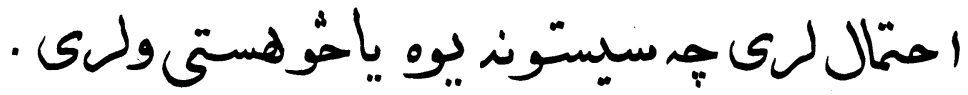

دسيستوالهميت :

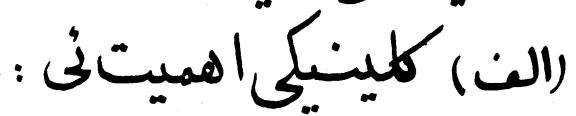

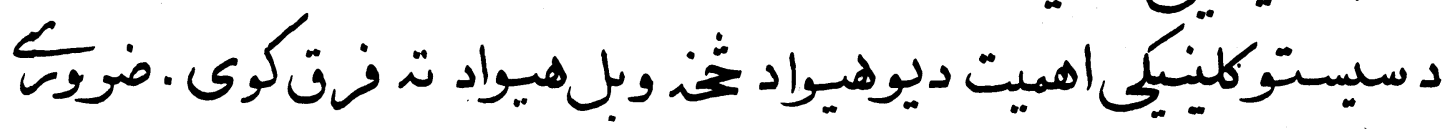

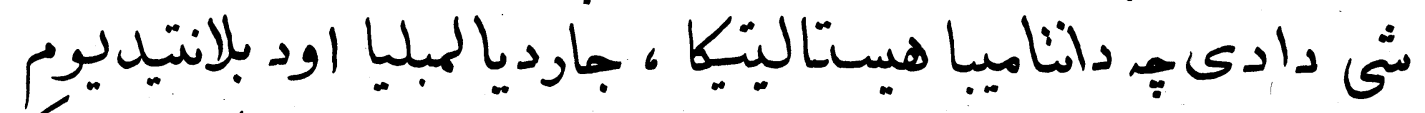

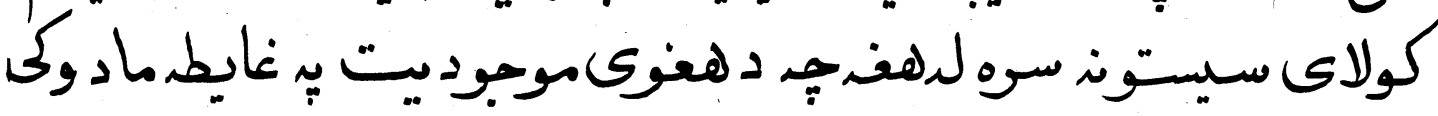

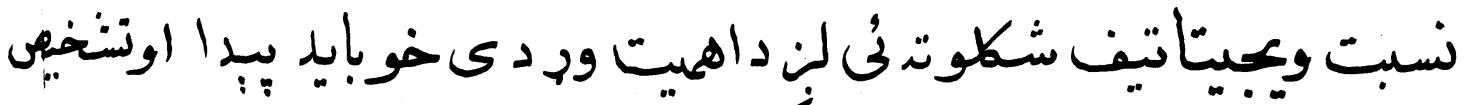

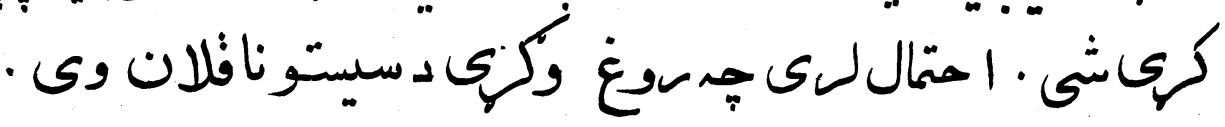

بـ ــ دعاى روغتتيا المميت :

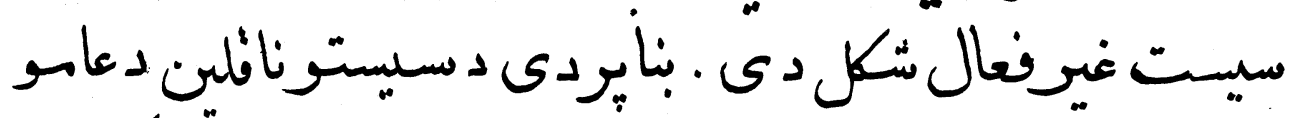

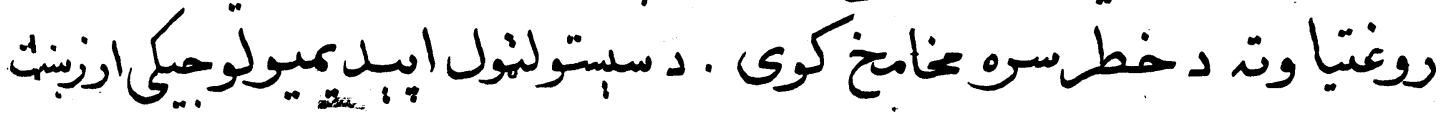

همبرى

$q v$ 


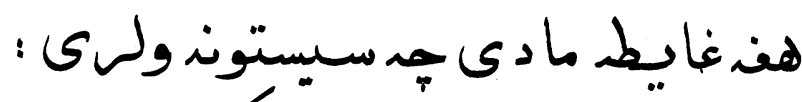

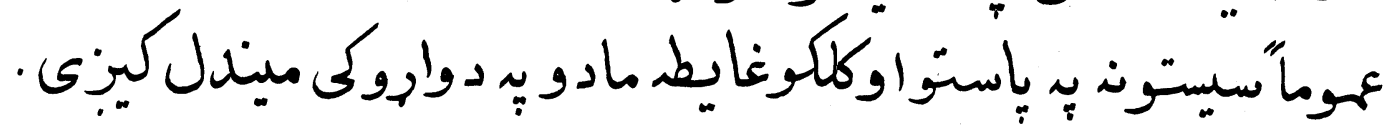

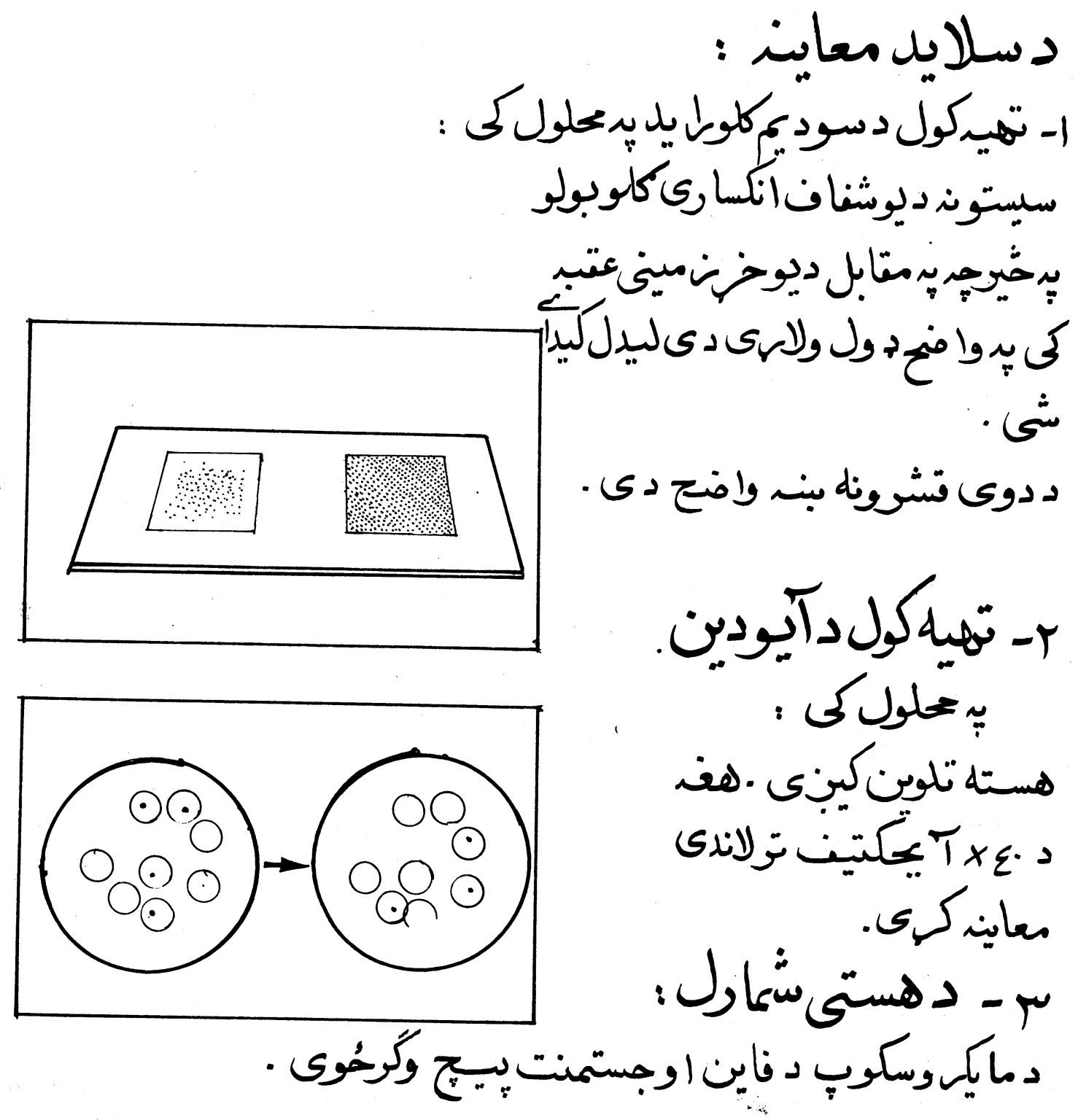




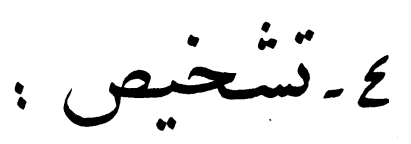

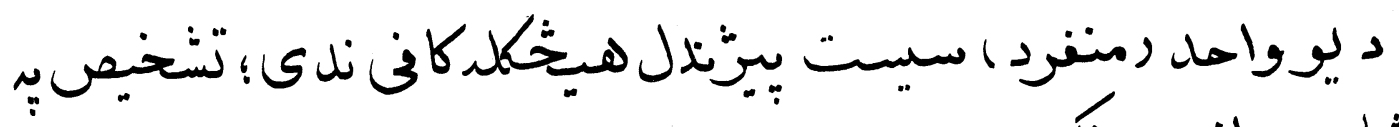

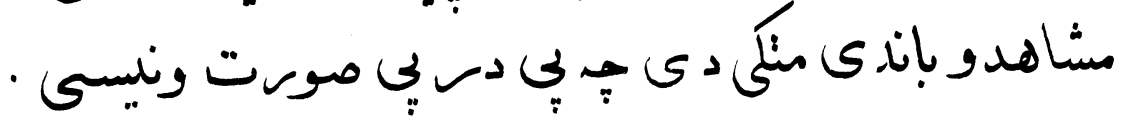

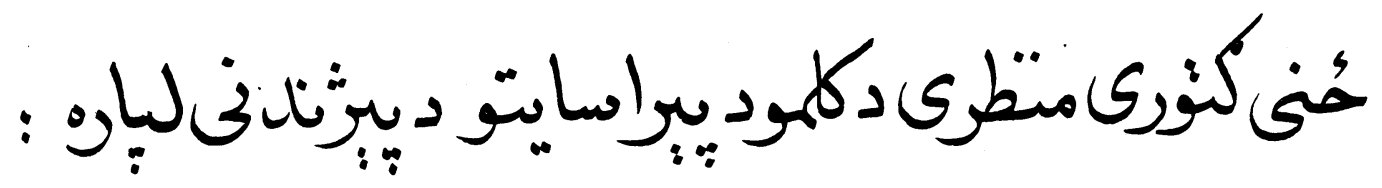
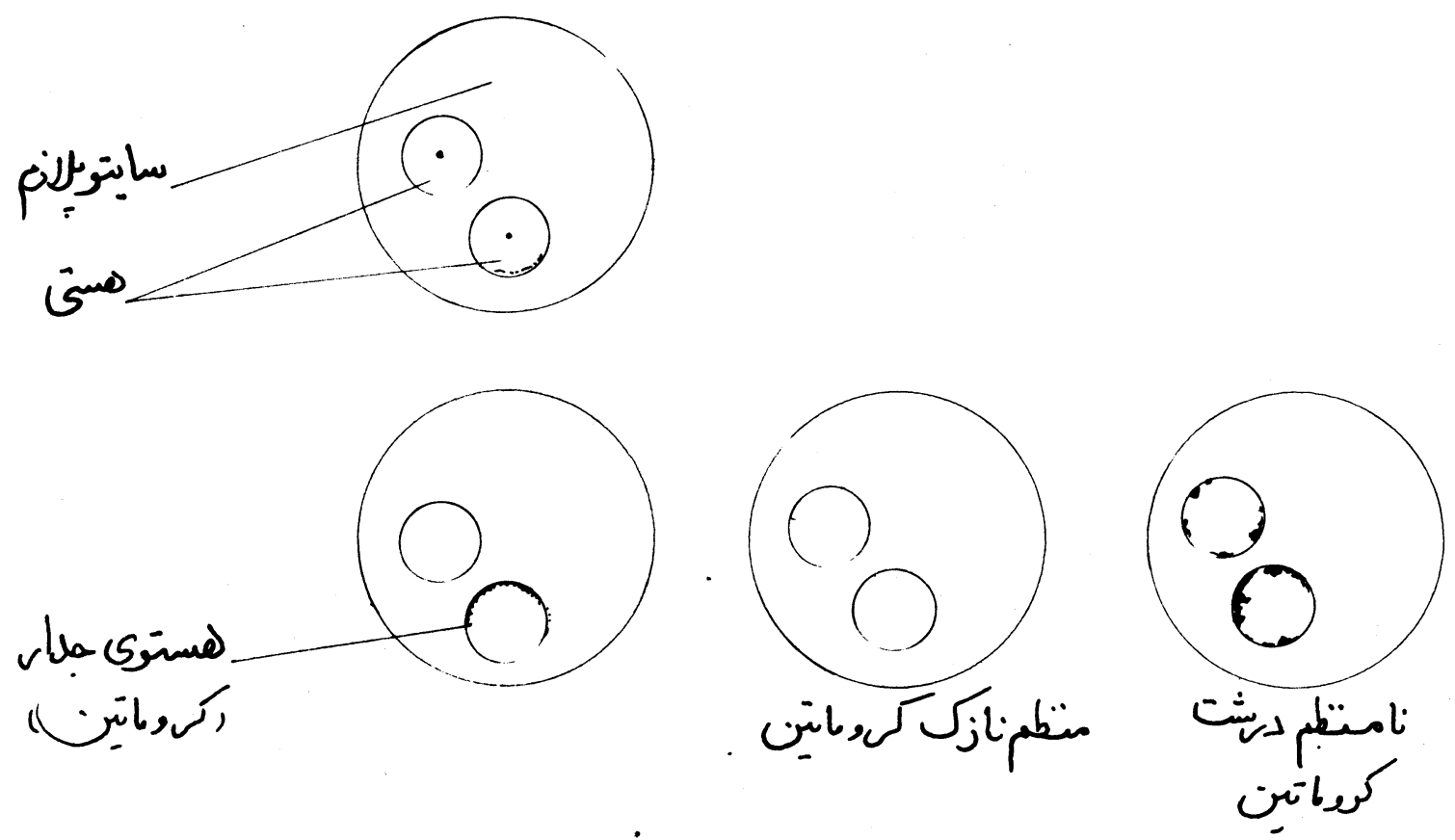

14 

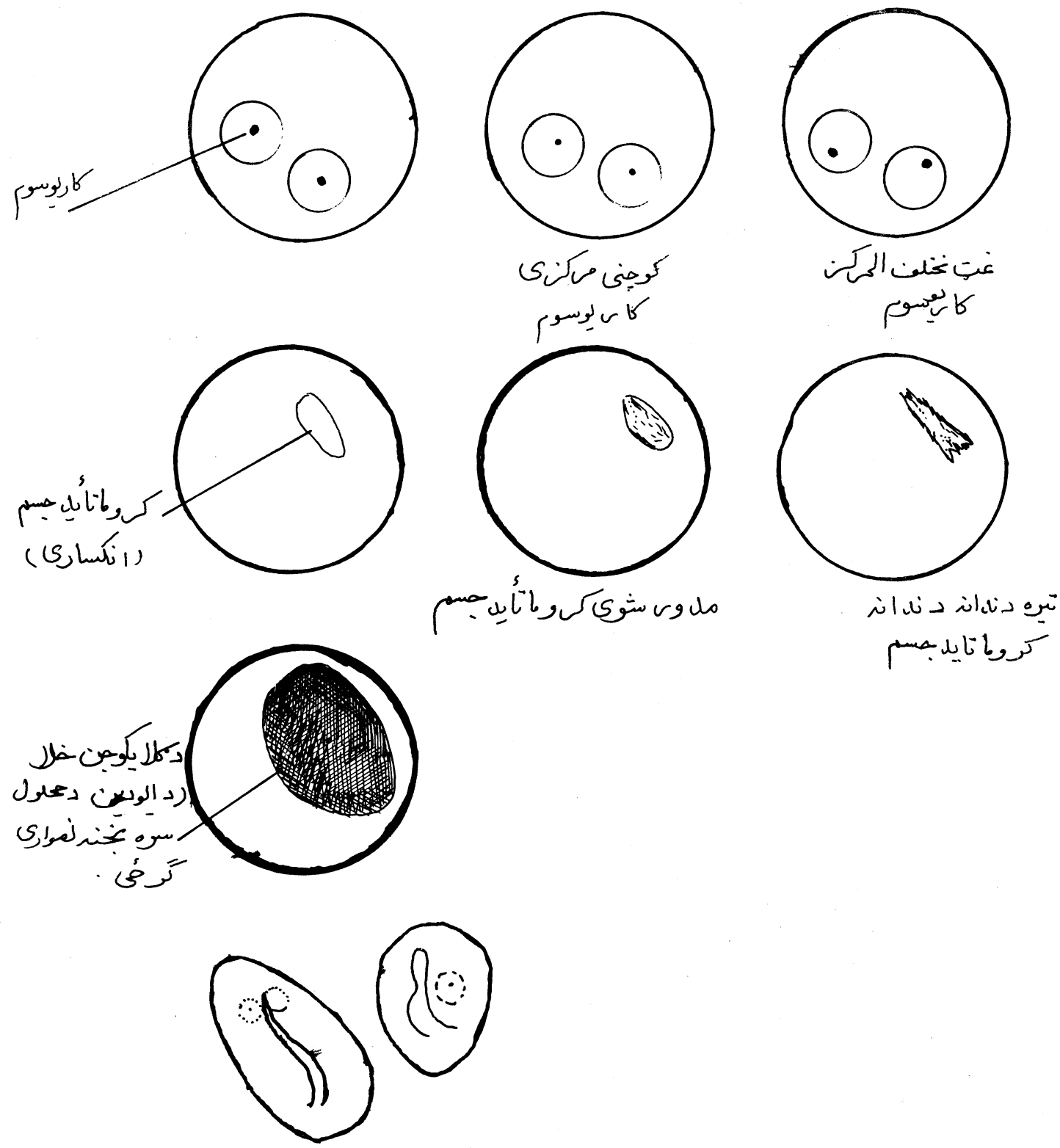

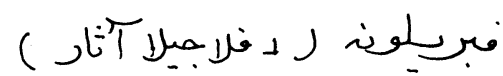



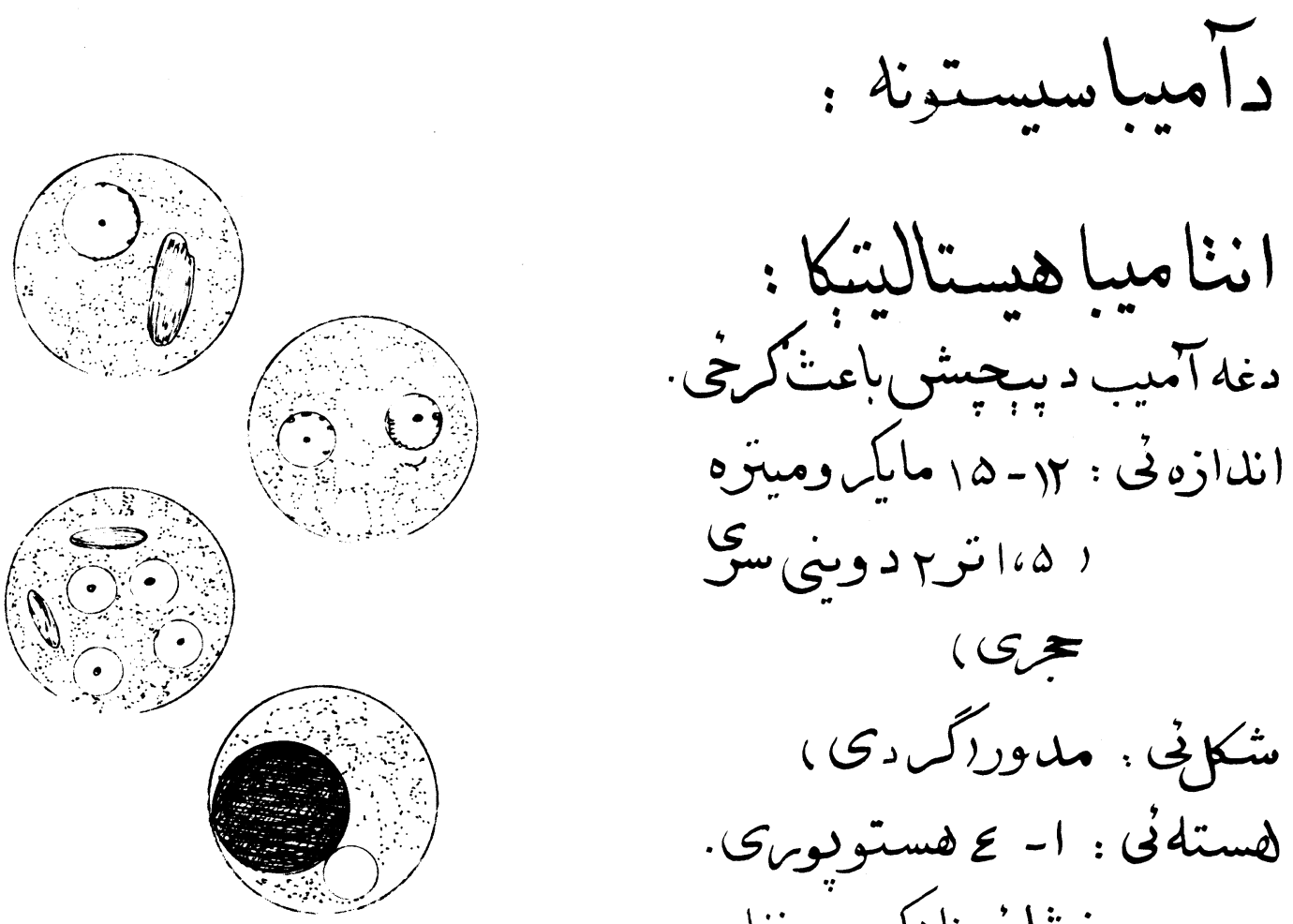

\section{( $)$}

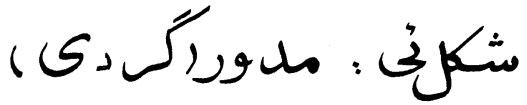

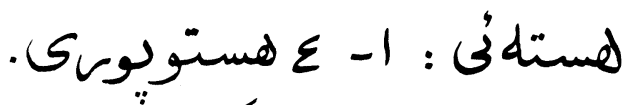

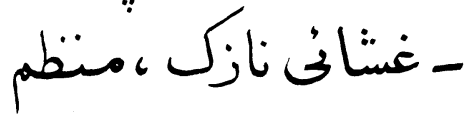

$$
\text { دامو وى . }
$$

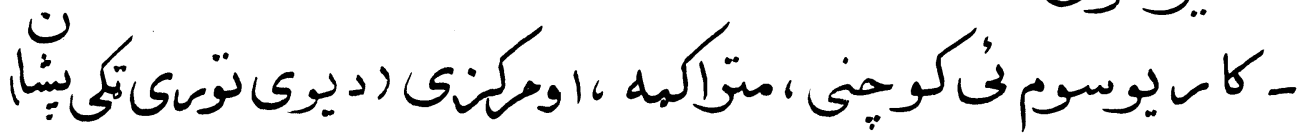

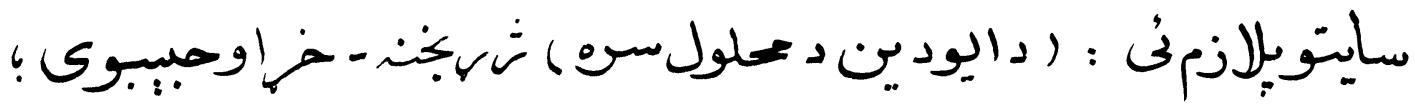

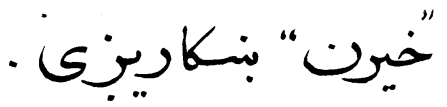

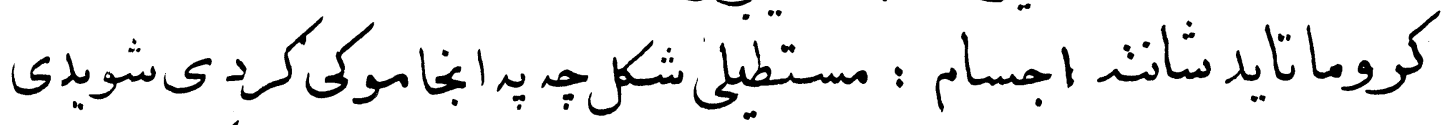

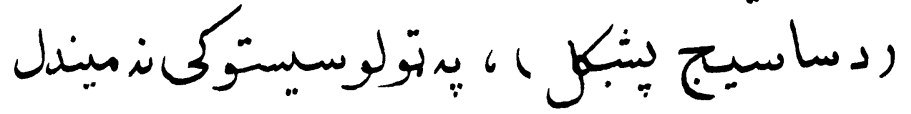

$$
\text { - }
$$

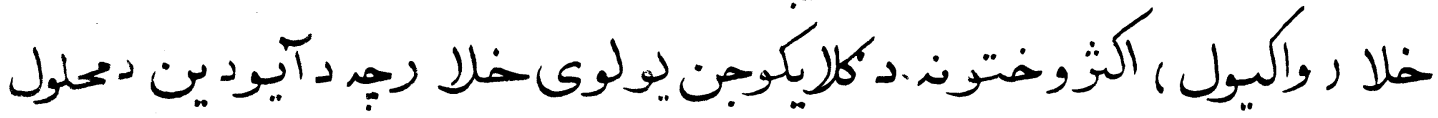

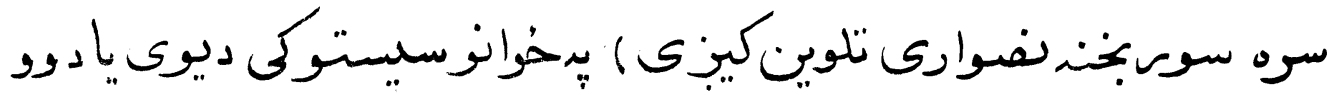




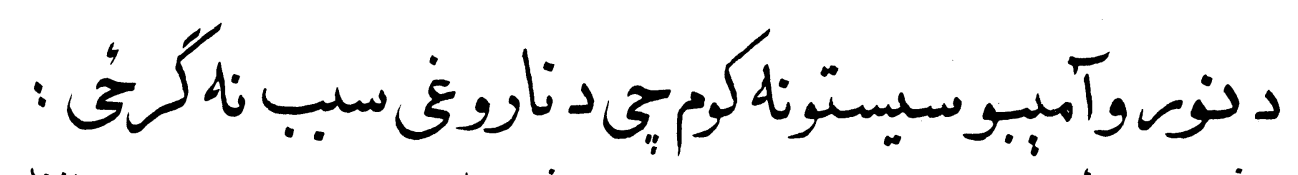

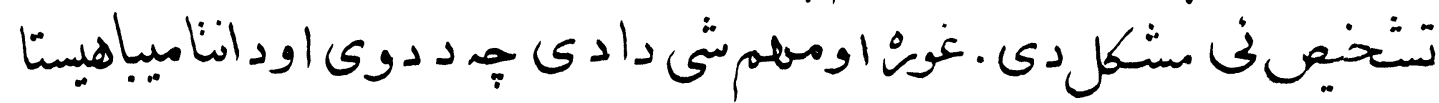

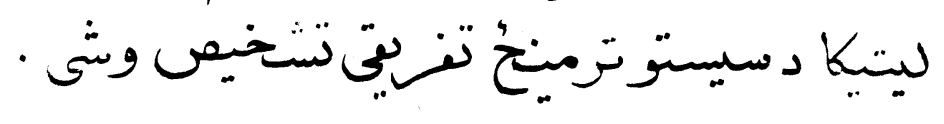

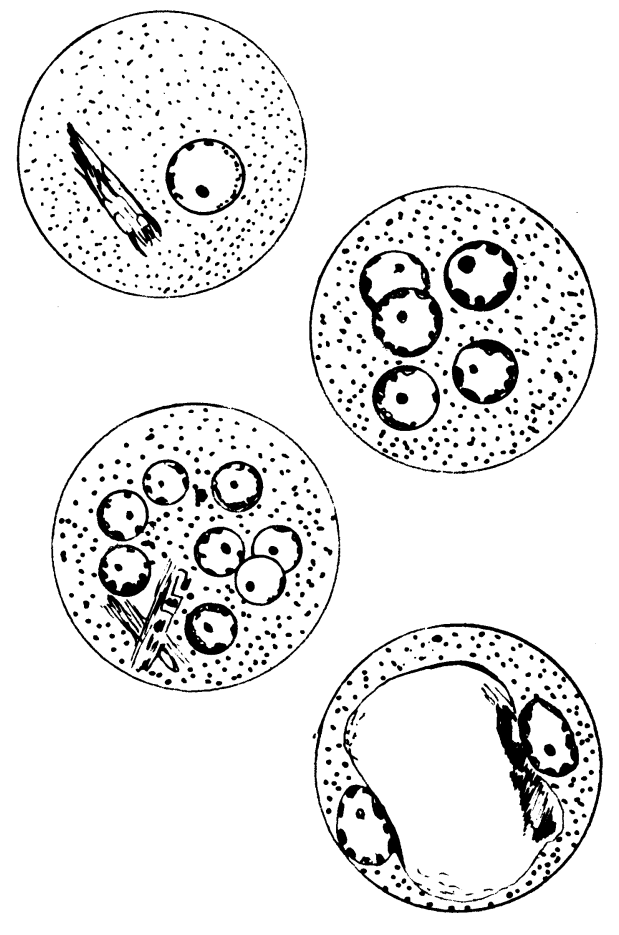

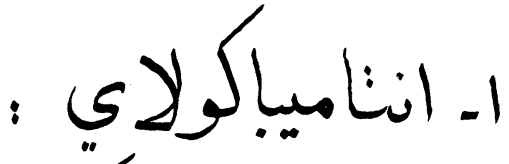

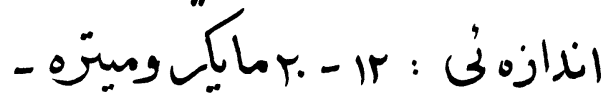

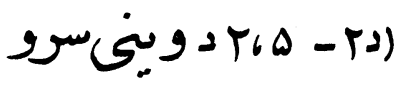

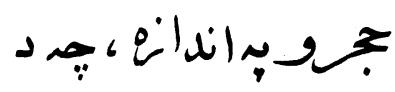

$$
\begin{aligned}
& \text { اناميبا هبيتاليتيكاد }
\end{aligned}
$$

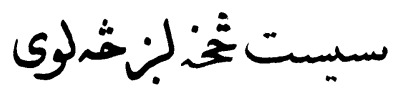

$$
\begin{aligned}
& \text { ( ) (s) }
\end{aligned}
$$

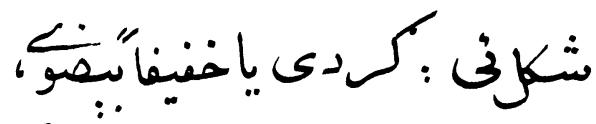

$$
\begin{aligned}
& \text { خينى وختونغيتيمنيمي. }
\end{aligned}
$$

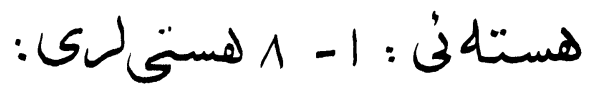

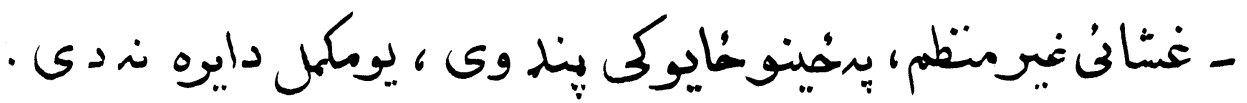

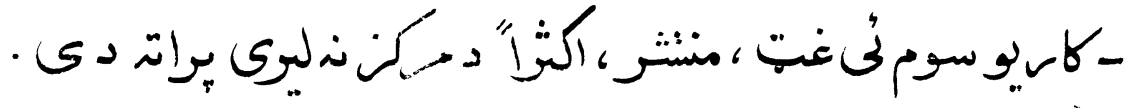

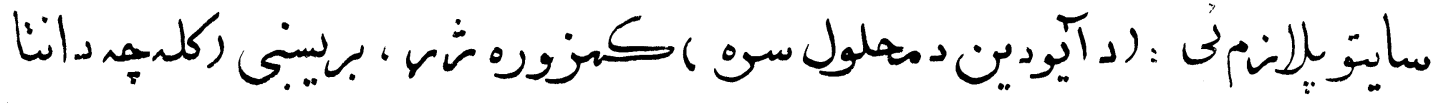

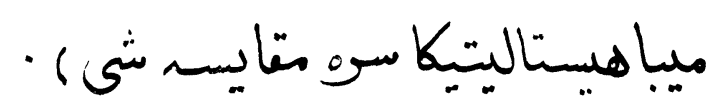

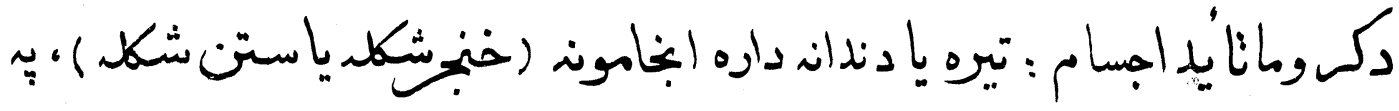




\section{تولوسبتوكى بיداكيّى .}

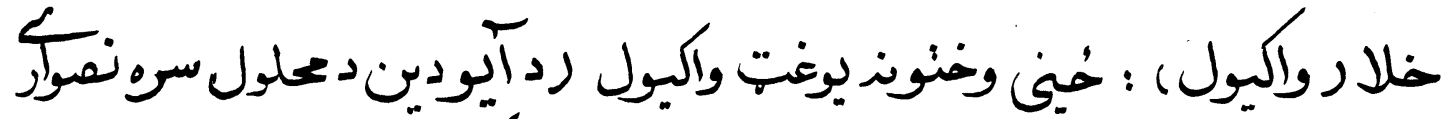

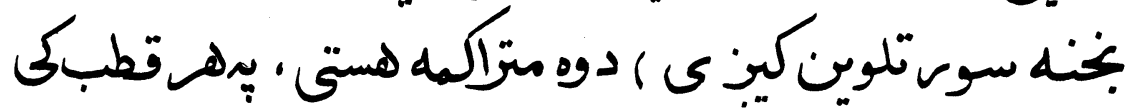

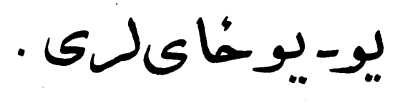

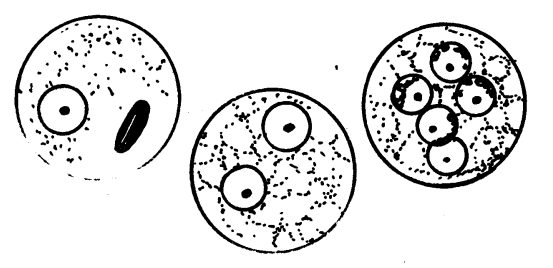

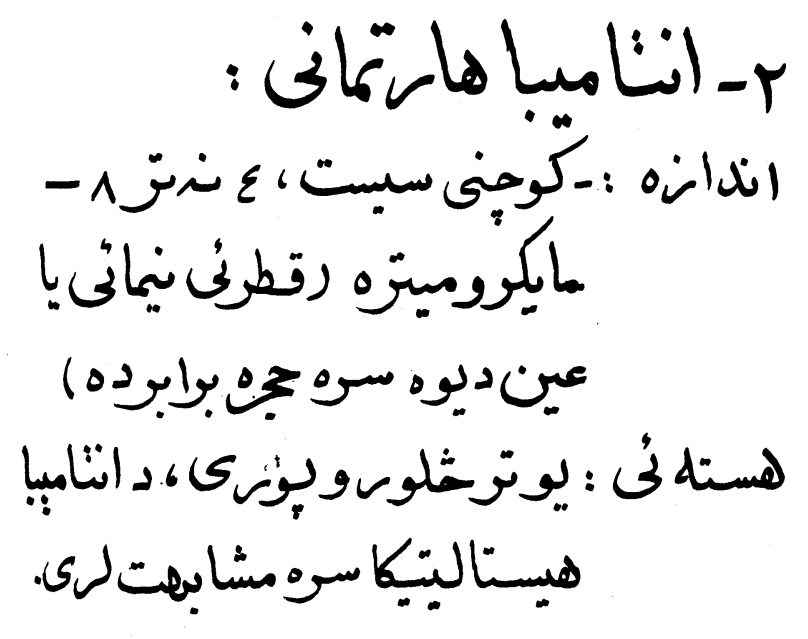

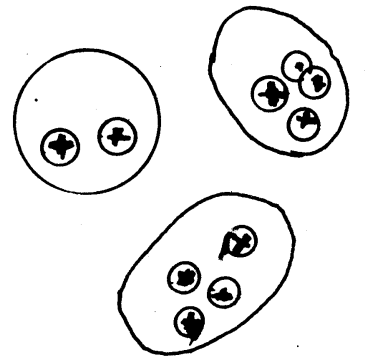

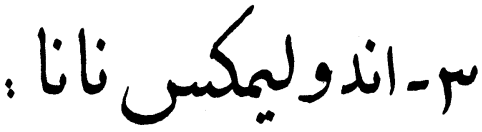

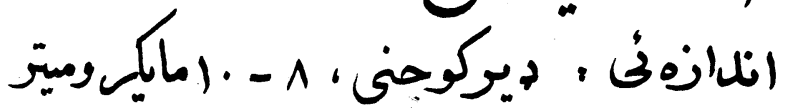

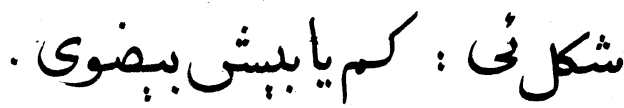

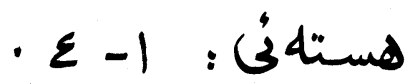

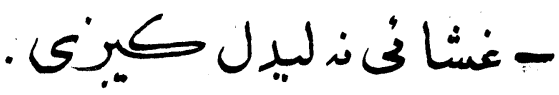

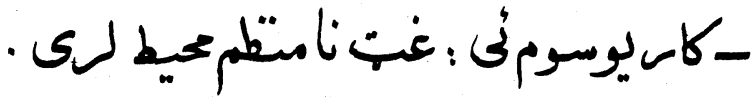




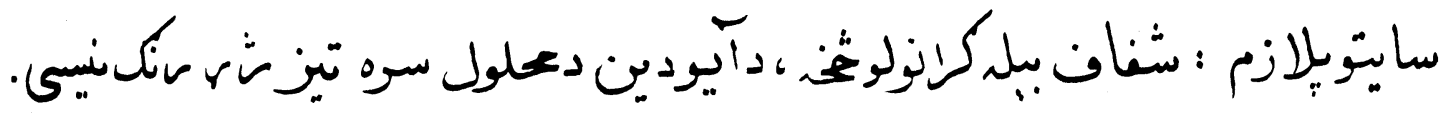

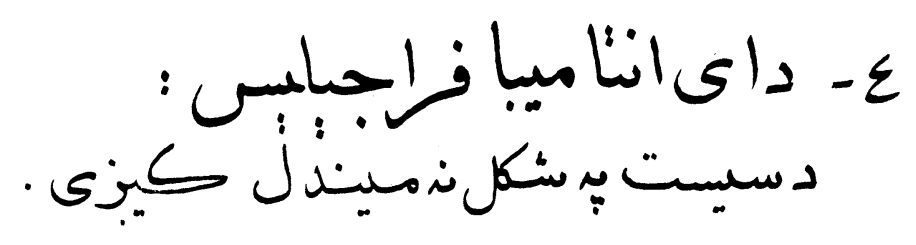
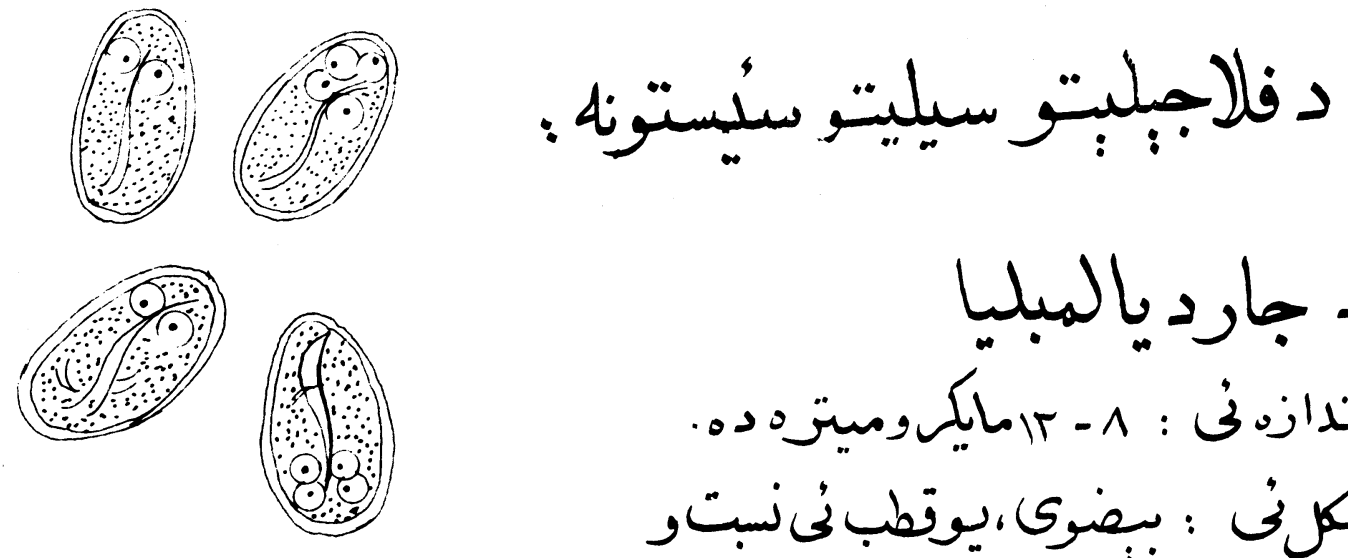

$$
\begin{aligned}
& \text { ا- جارديالهبليا }
\end{aligned}
$$

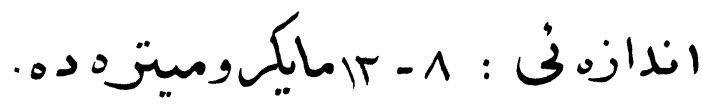

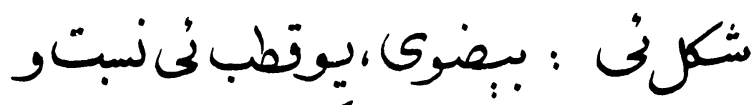

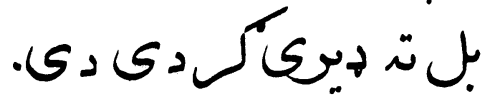

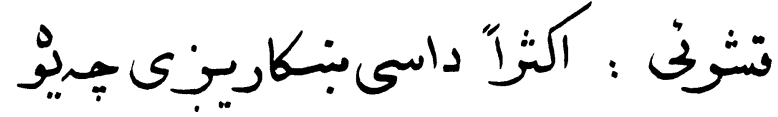

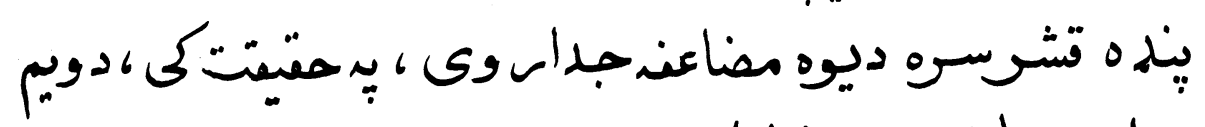

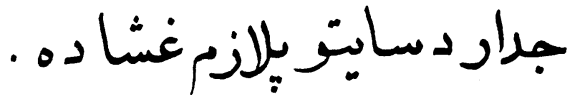

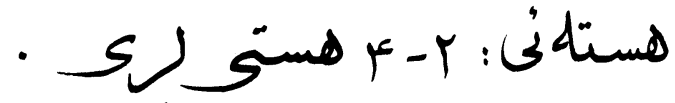

- غنّا: جيرى نازكى دي .

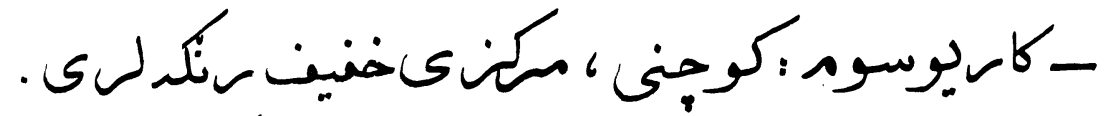

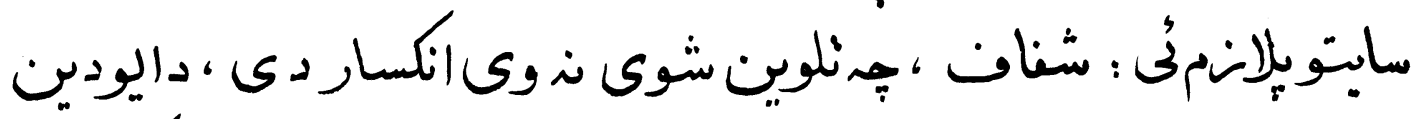

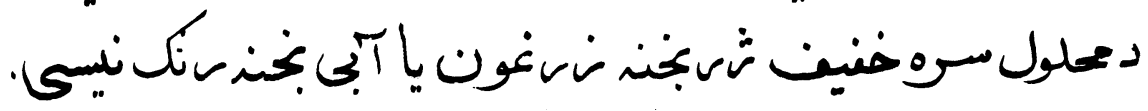




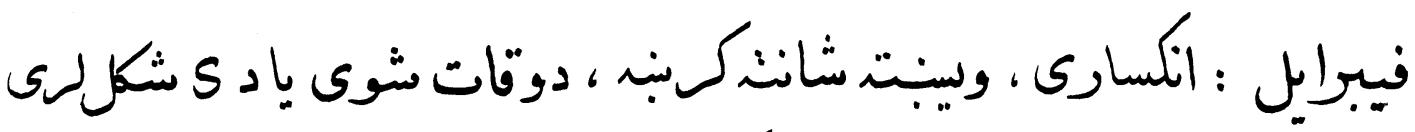

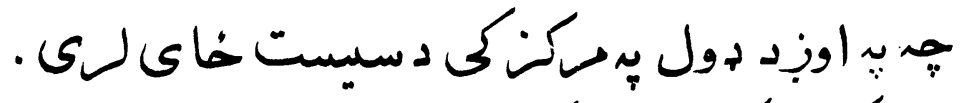

$$
\text { (مايكو وسكوب عيا ركهى). }
$$

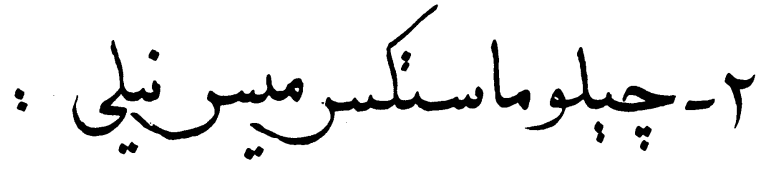

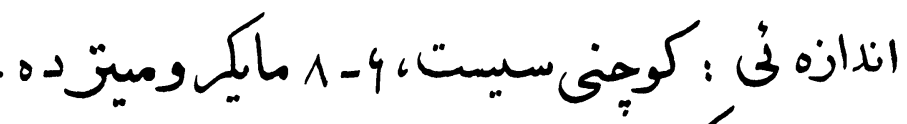

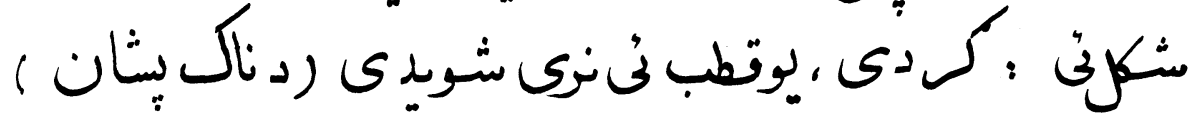

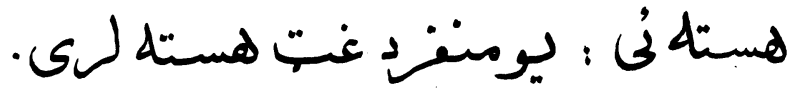

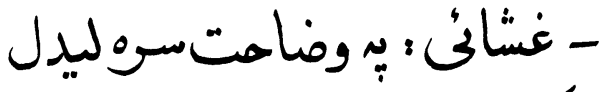
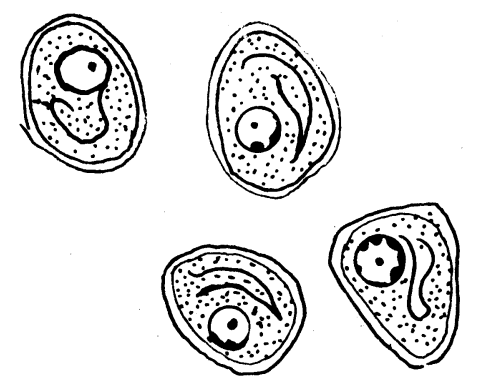

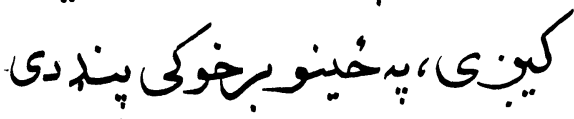

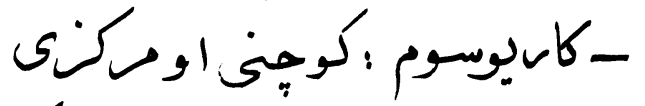

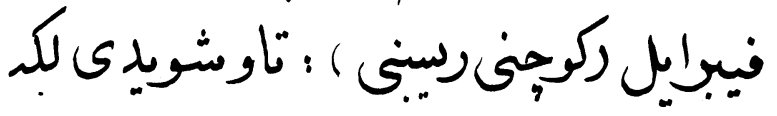

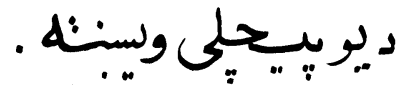

$$
\begin{aligned}
& \text { (ياديوتاوشوى وينينش). }
\end{aligned}
$$




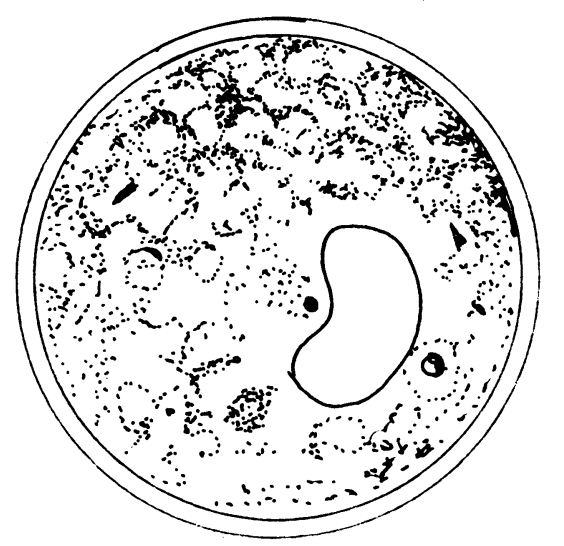

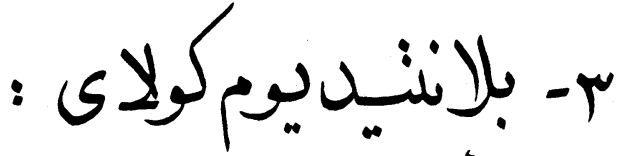

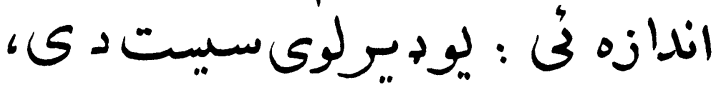

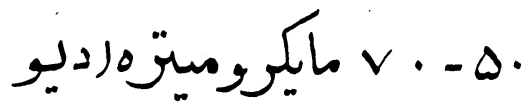

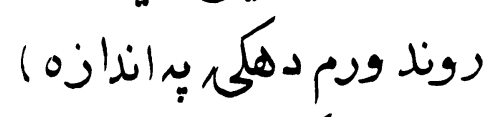

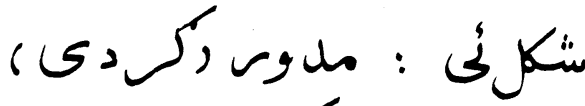

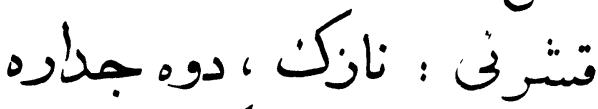

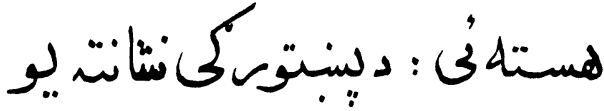

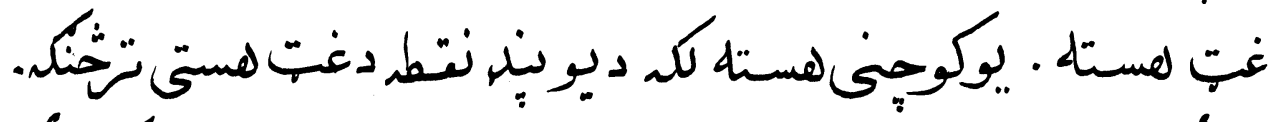

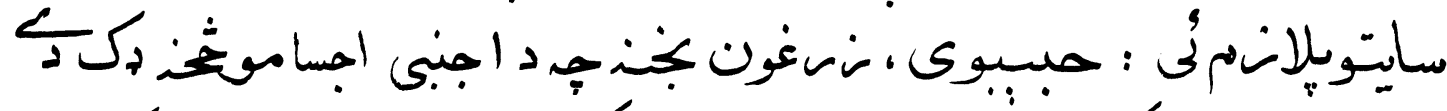

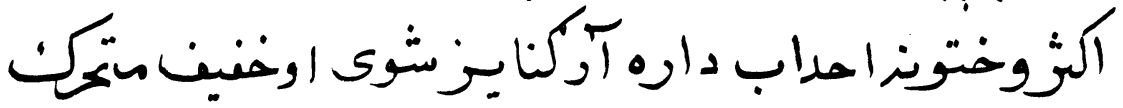

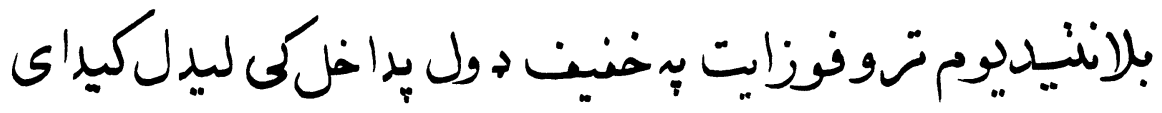

• من

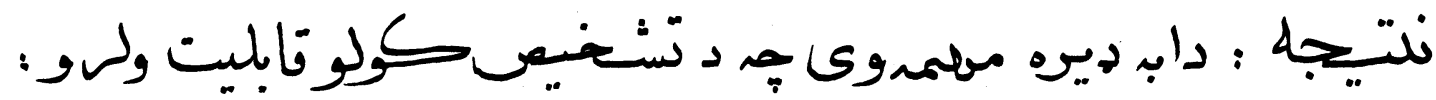

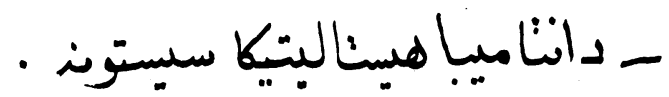

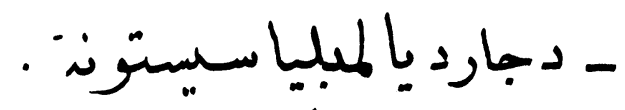

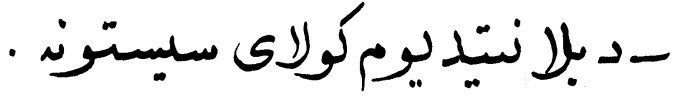




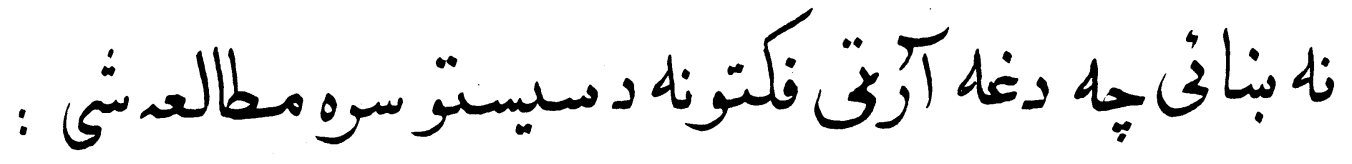
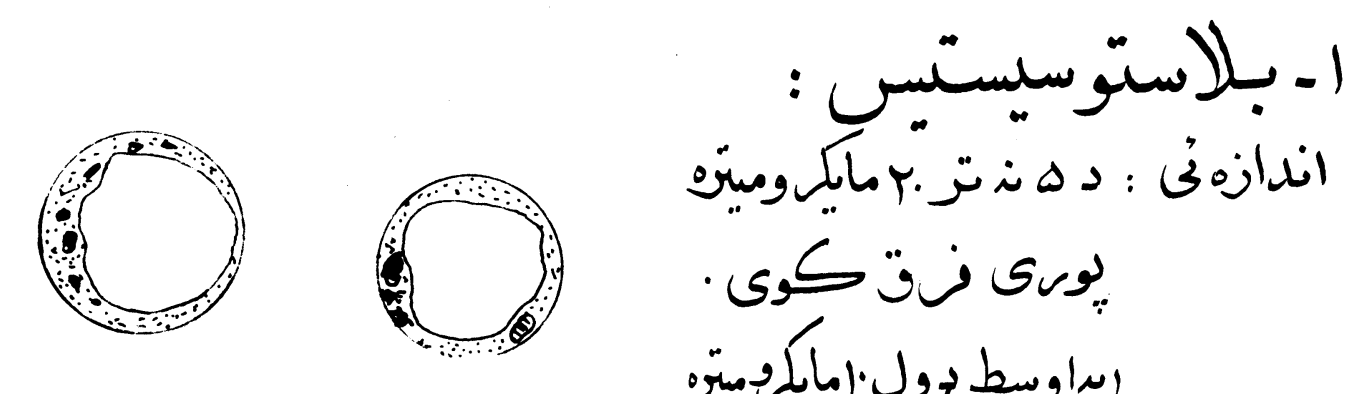

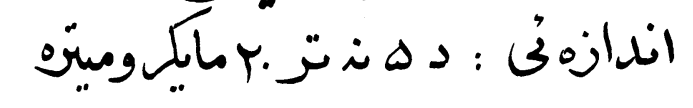

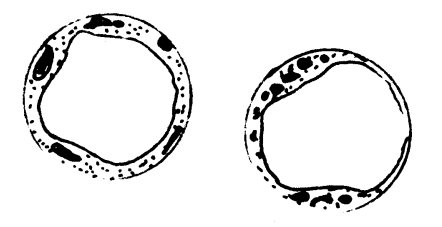

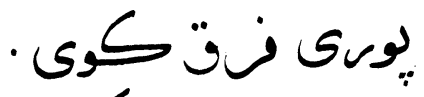

$$
\begin{aligned}
& \text { (يماوسط جهول }
\end{aligned}
$$

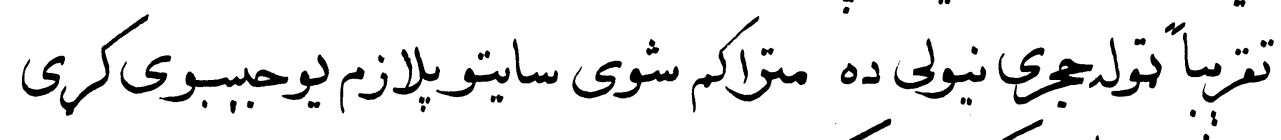

$$
\begin{aligned}
& \text { شّك } \\
& \text { وحتونه بون ويد ونى }
\end{aligned}
$$

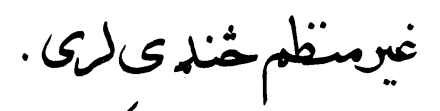

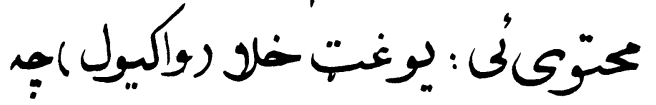

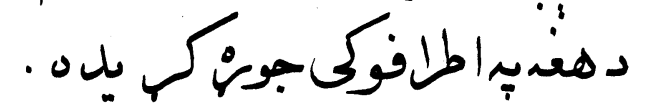

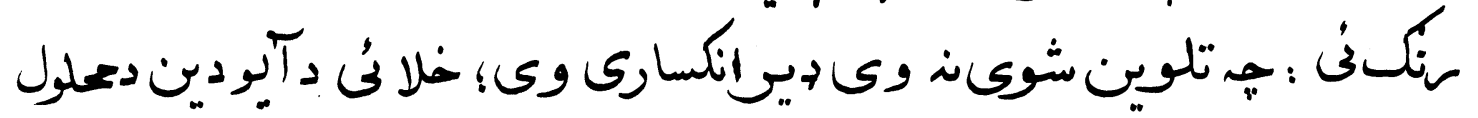

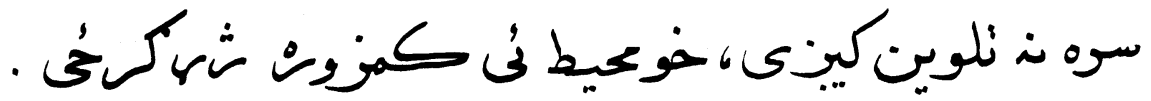

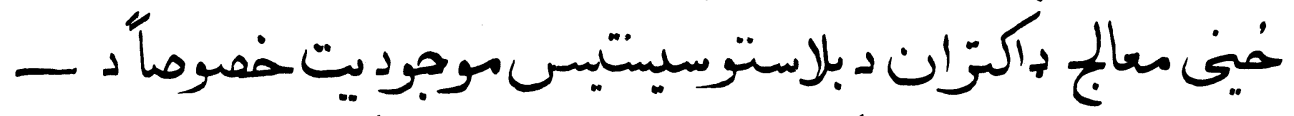

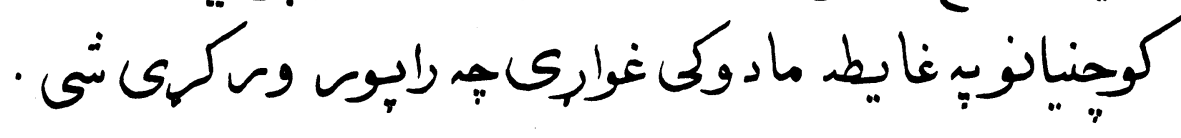




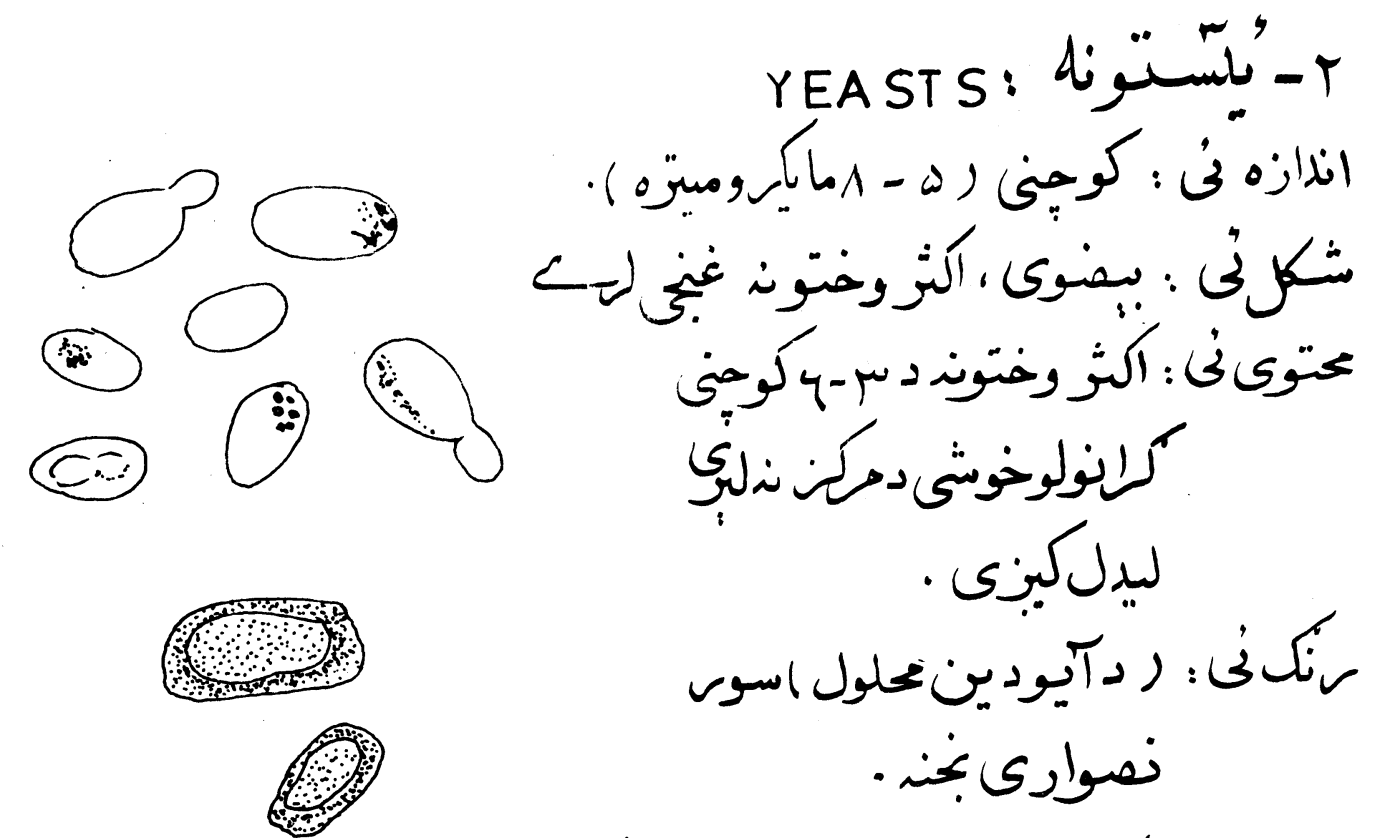

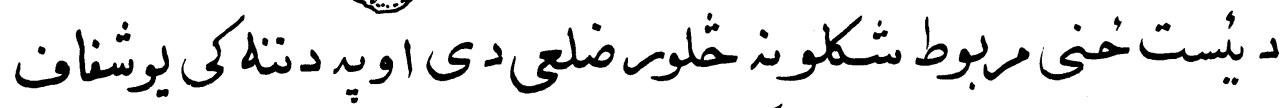

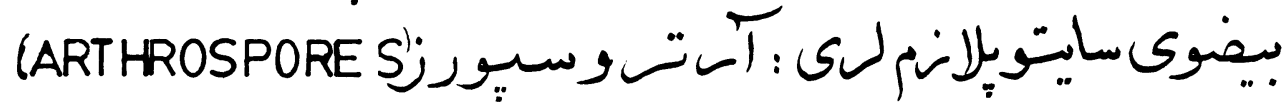

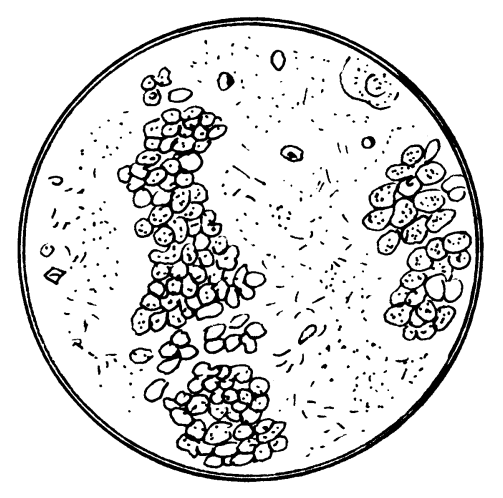

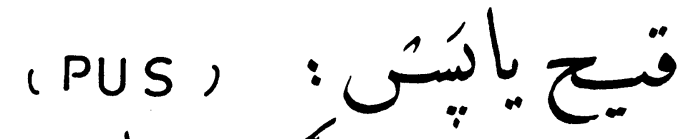

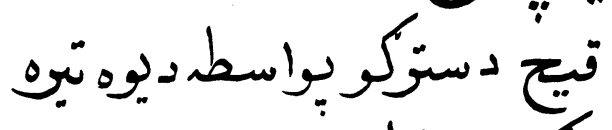

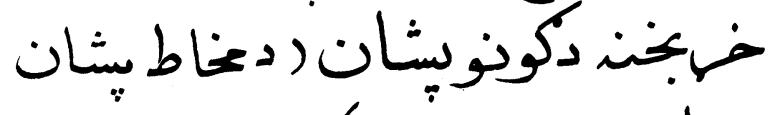

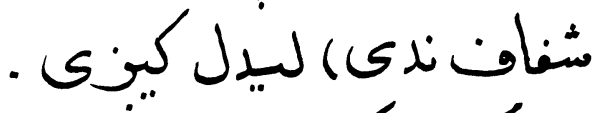

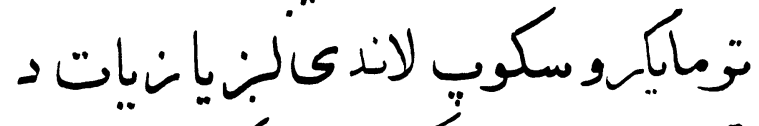

$$
\begin{aligned}
& \text { تخيب شوى لوكيو سايتودكنلى بشنان }
\end{aligned}
$$

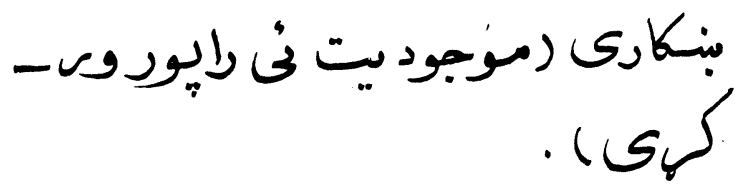




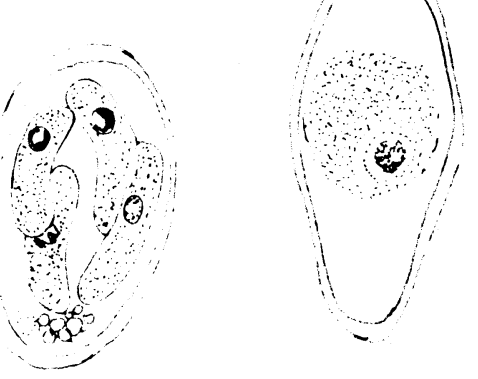

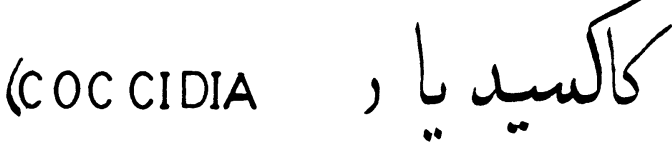

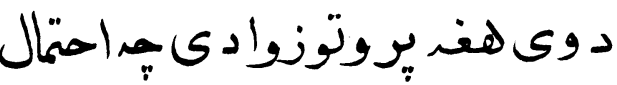

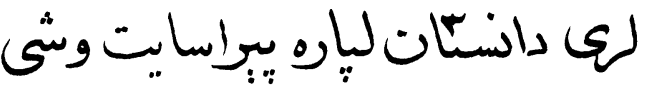

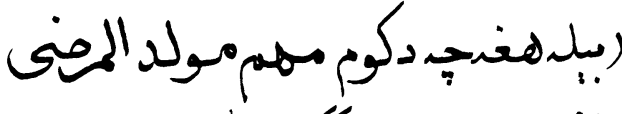

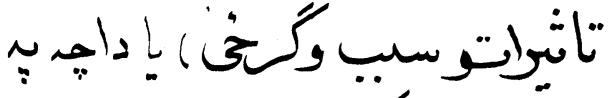

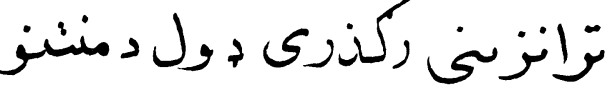

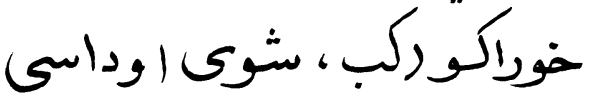

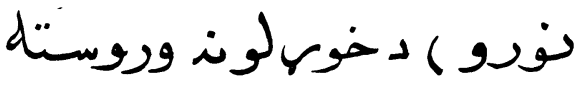

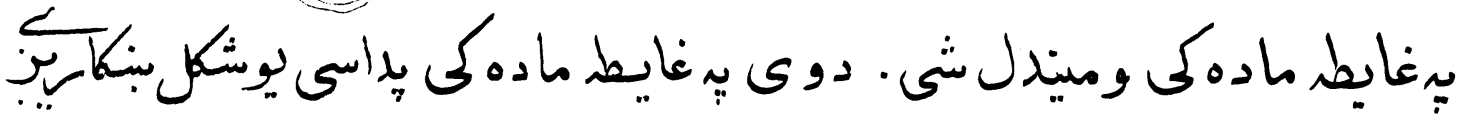

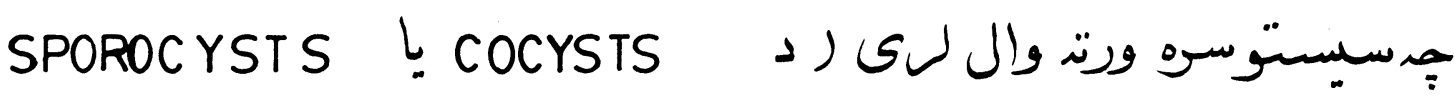

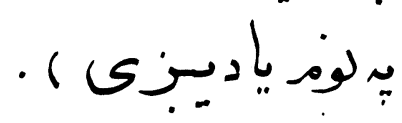

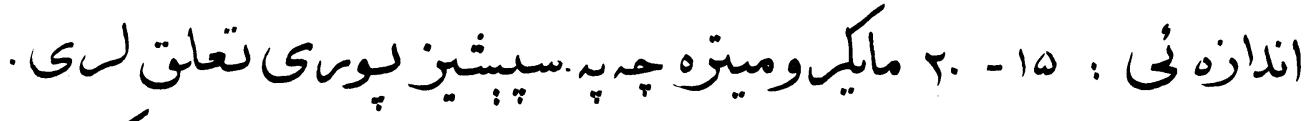

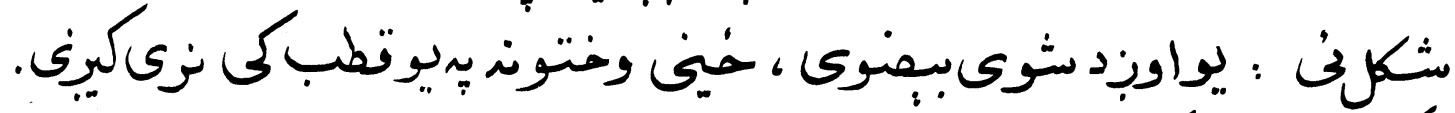

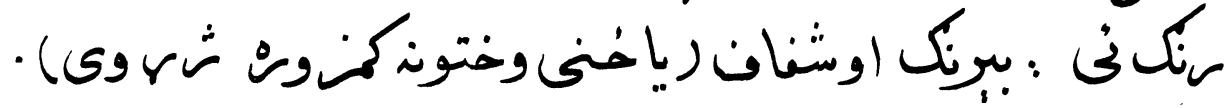

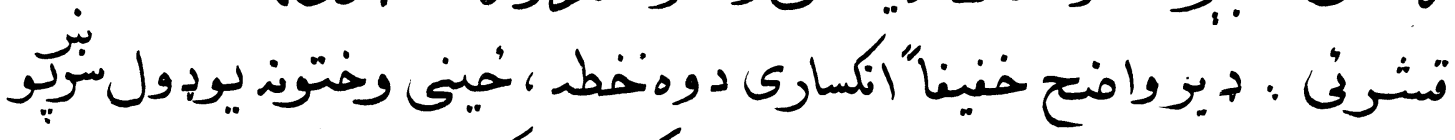
(OPERCULU.M )

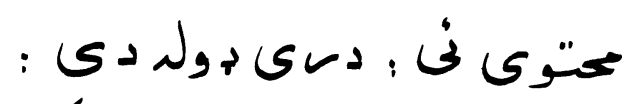

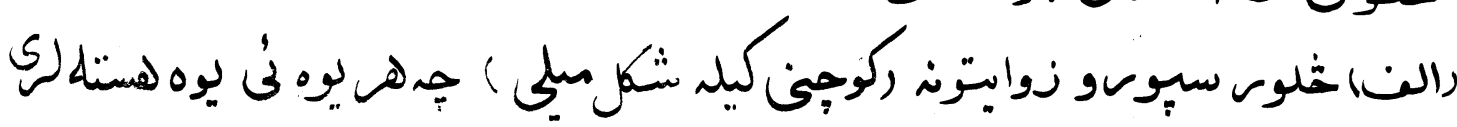




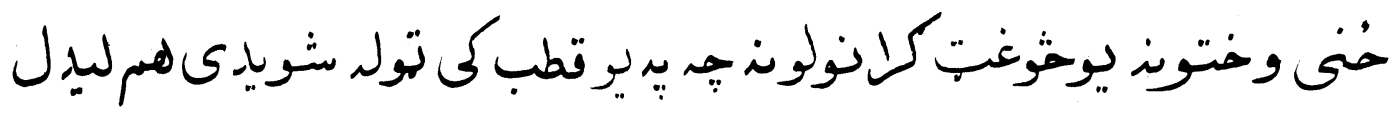

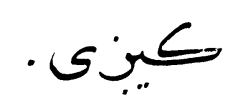

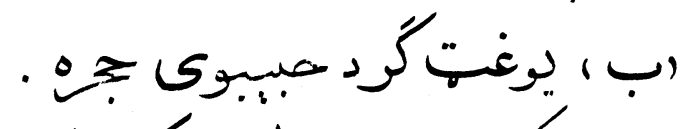

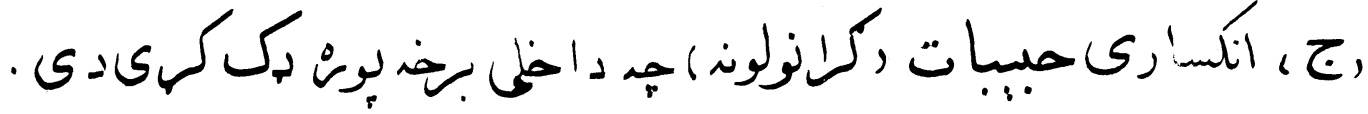

$$
\text { نيست كيوات رلوكوسايتون) : }
$$

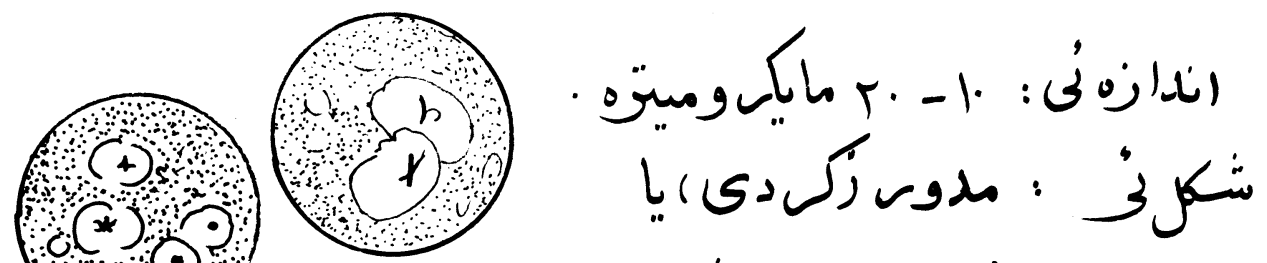

خنيف اونده دُشوى

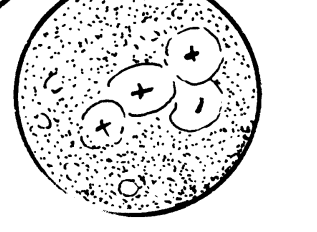

ديوغيومتظم محيط سهو.

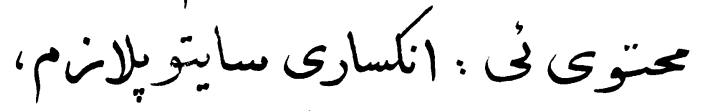

شنان أوكرانولوشانت

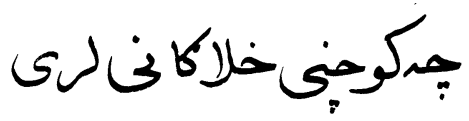

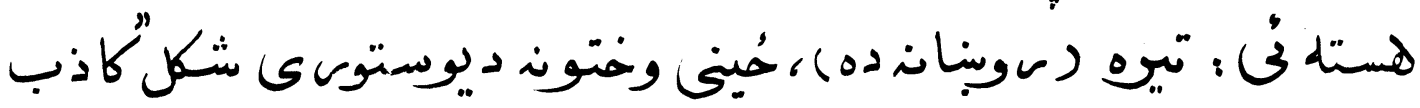

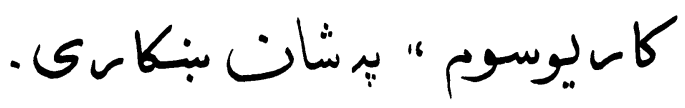


ديند اونازك فلمونوتلوينكول دكيمنادتلوينسوه :

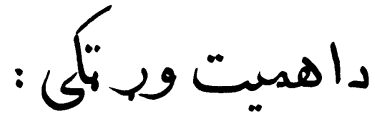

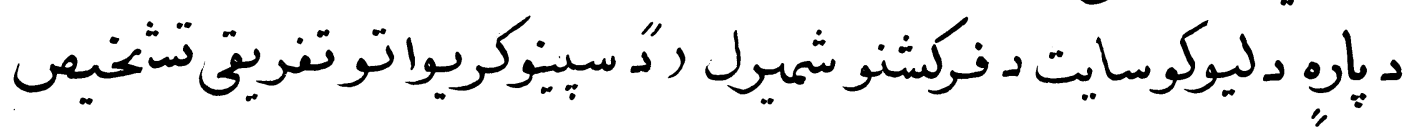

$$
\begin{aligned}
& \text { شمار }
\end{aligned}
$$

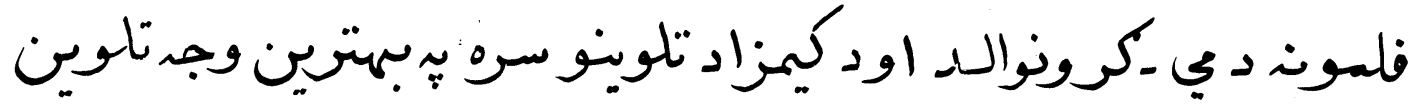

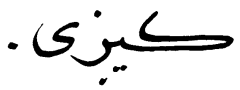

$$
\begin{aligned}
& \text { ودسايل : }
\end{aligned}
$$

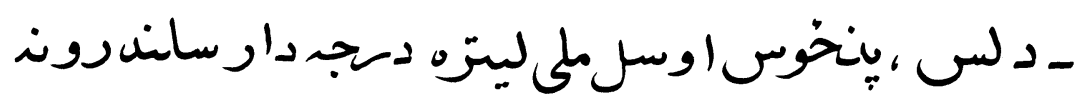

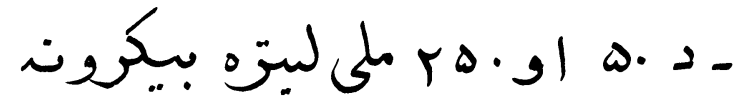

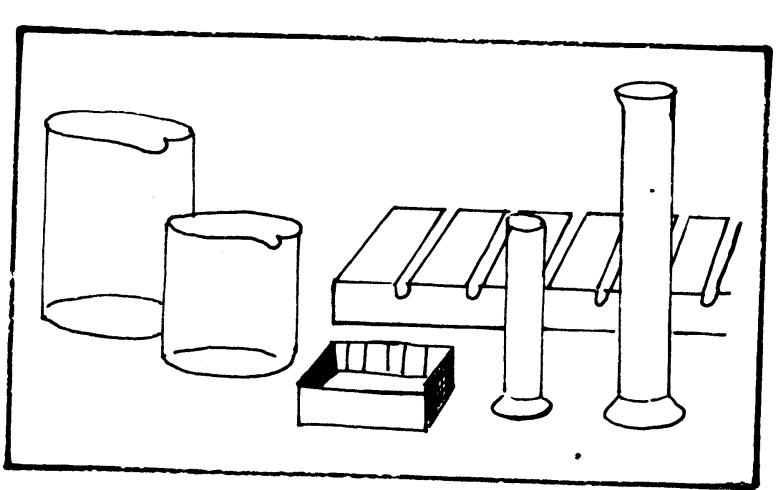

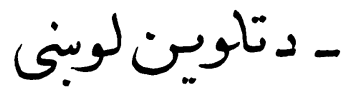

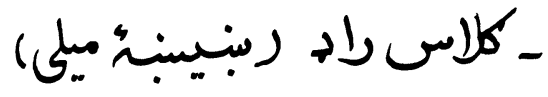

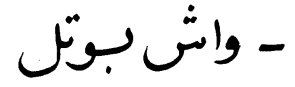

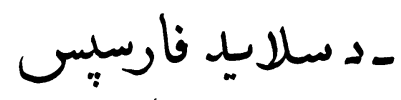

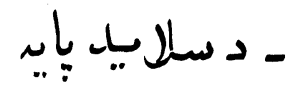

$$
\begin{aligned}
& \text { ـ تايمى } \\
& \text { - دكيمزائوبين }
\end{aligned}
$$

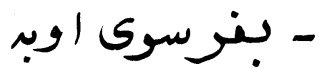




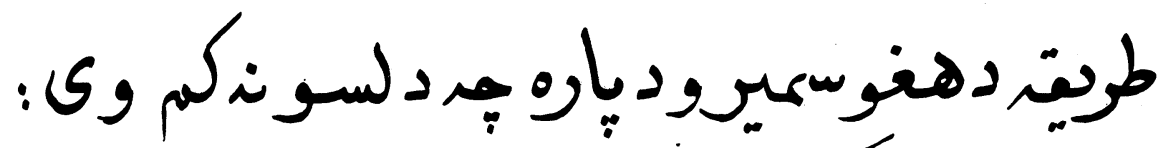
داهميت وريتكي :

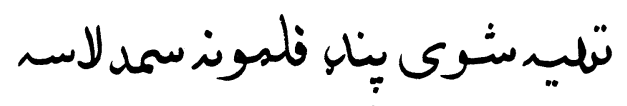
درتين شوىكيمزا سو تلوين
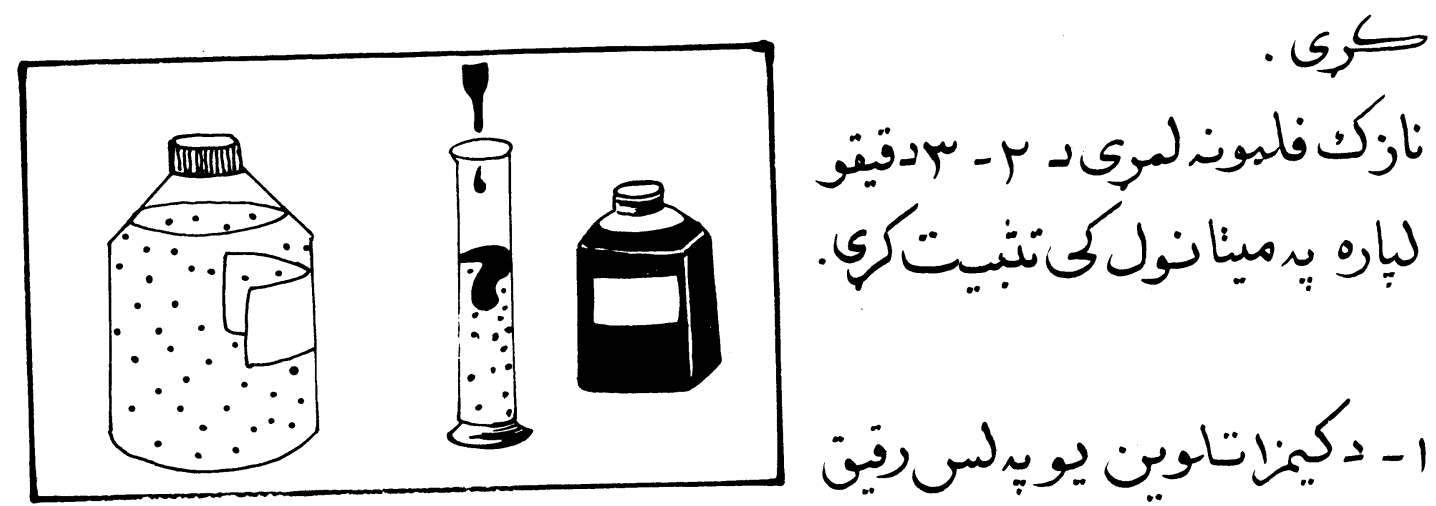

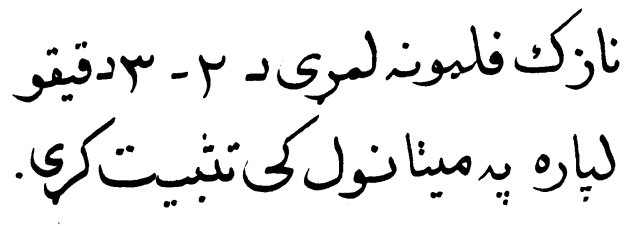

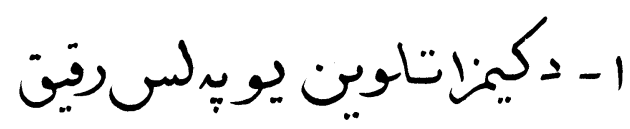

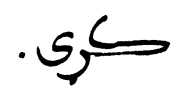

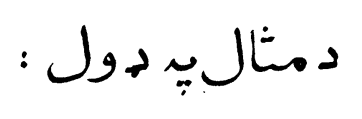

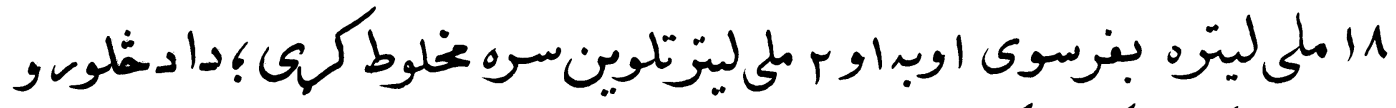

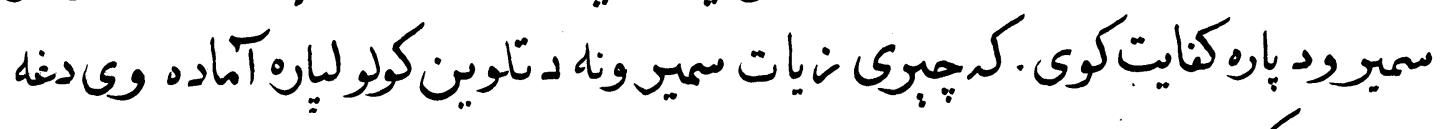

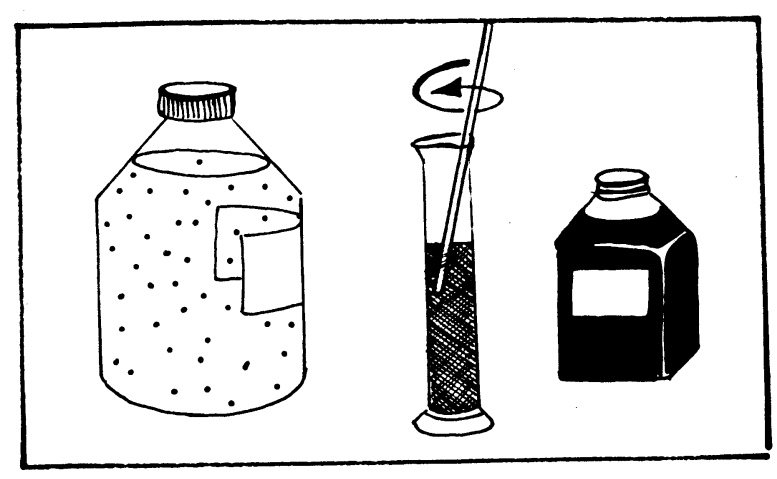

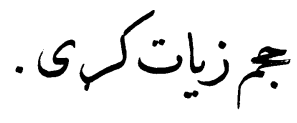

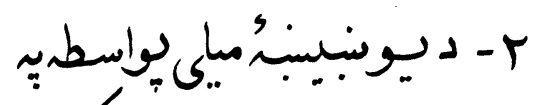

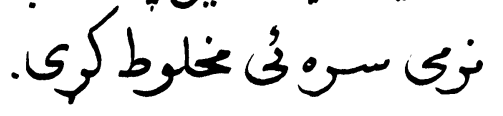




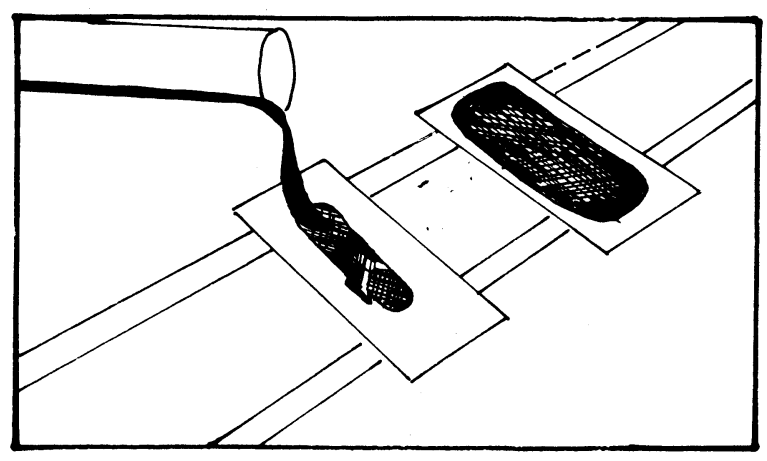

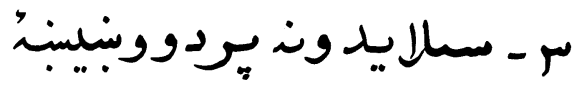

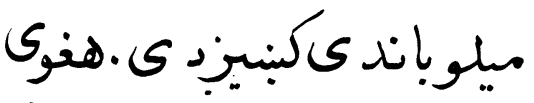

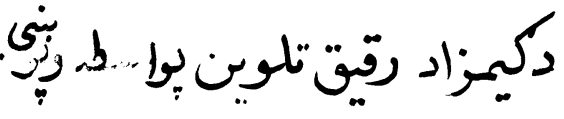

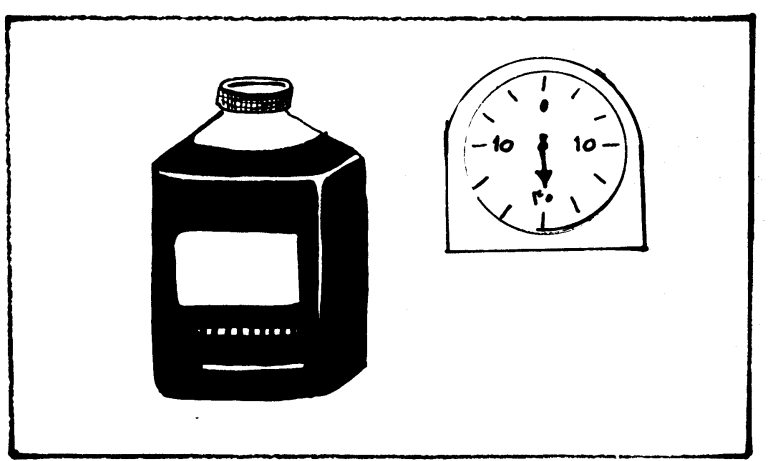

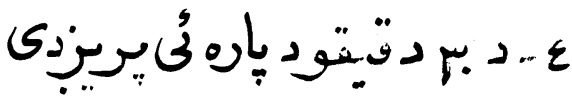
د تاوينكولووخت دجويرونئى

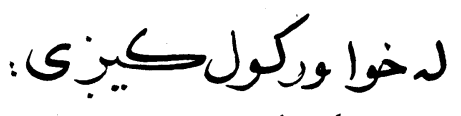

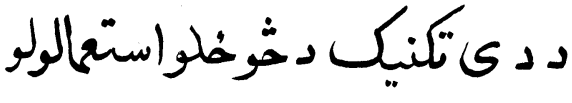

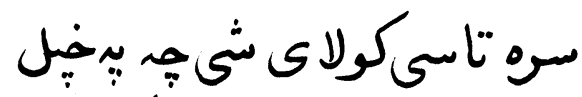

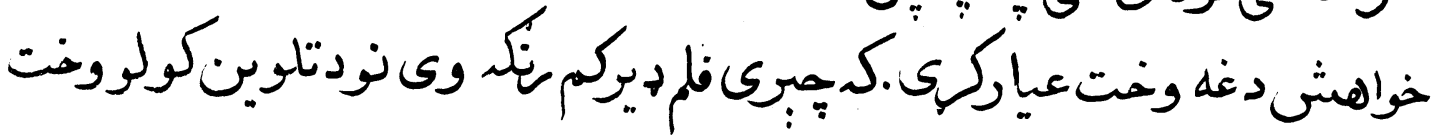

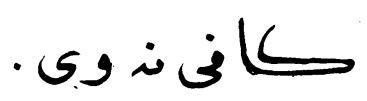

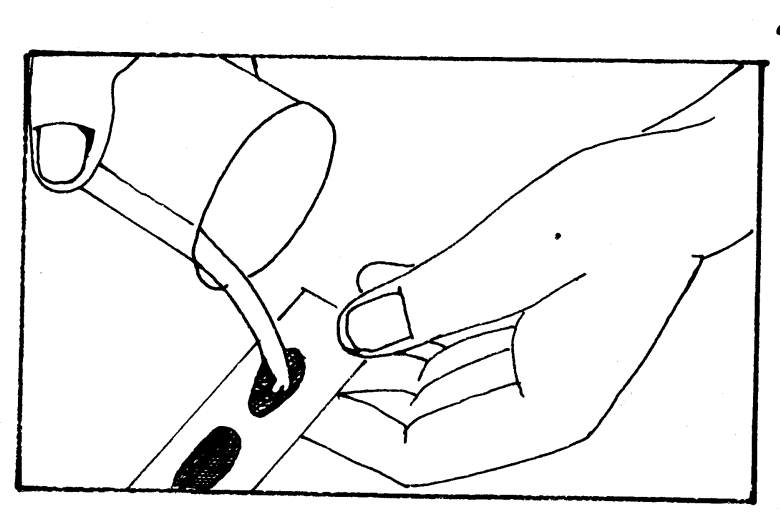

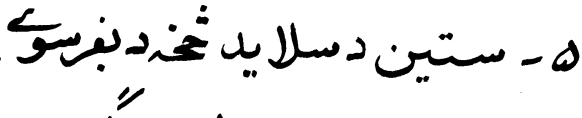

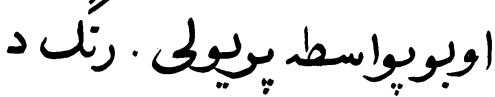

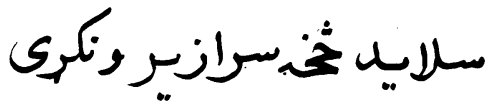

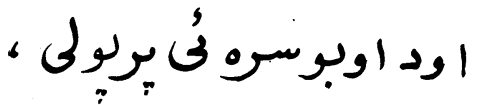

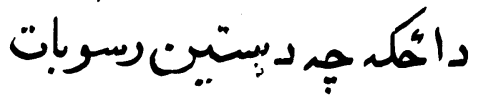

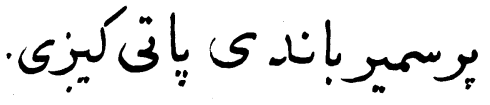




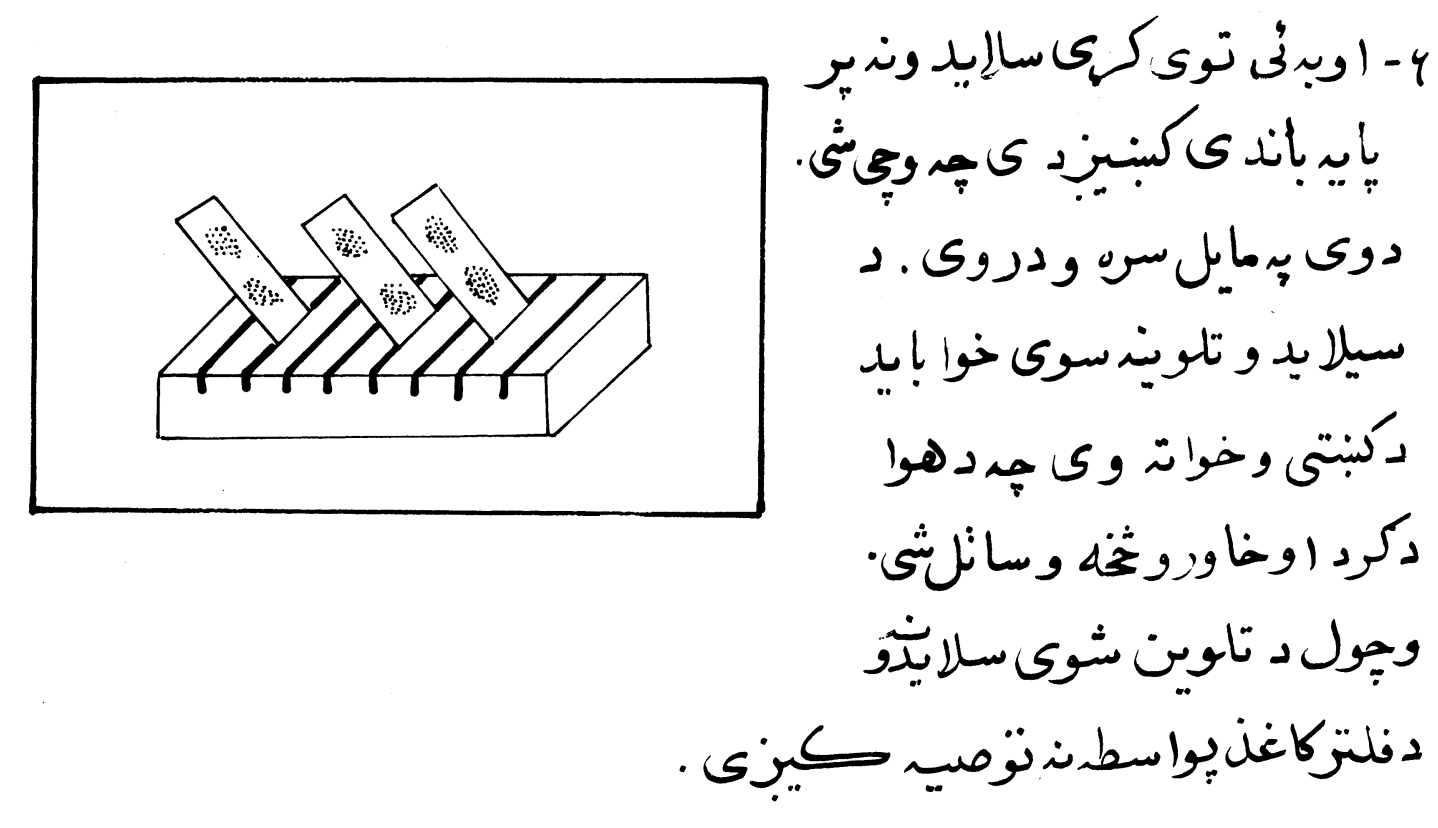




\section{يَّندل د ملاريا بيراسايتون}

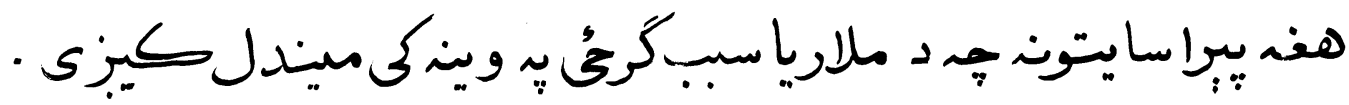

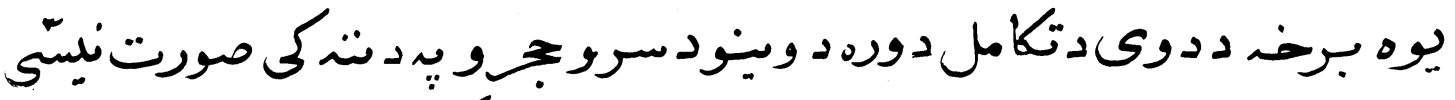

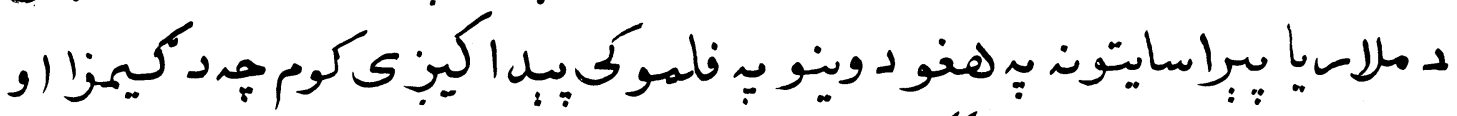

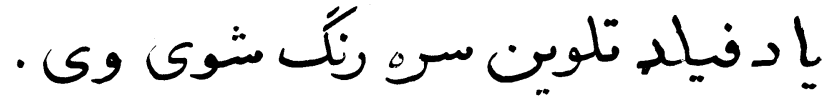

\section{دوينوفاهونوتهيكول

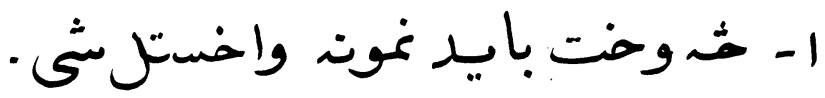

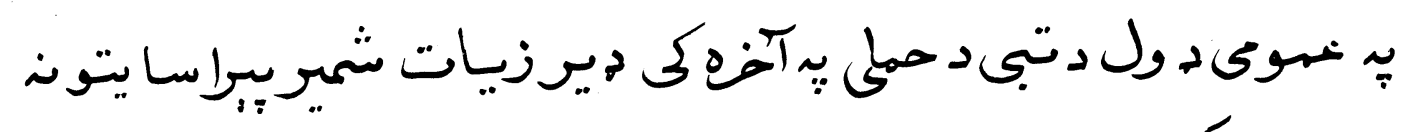

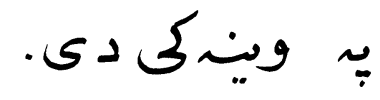
همايشخ وين دملاريا دضد درمل وركولونغنكى واخلى.

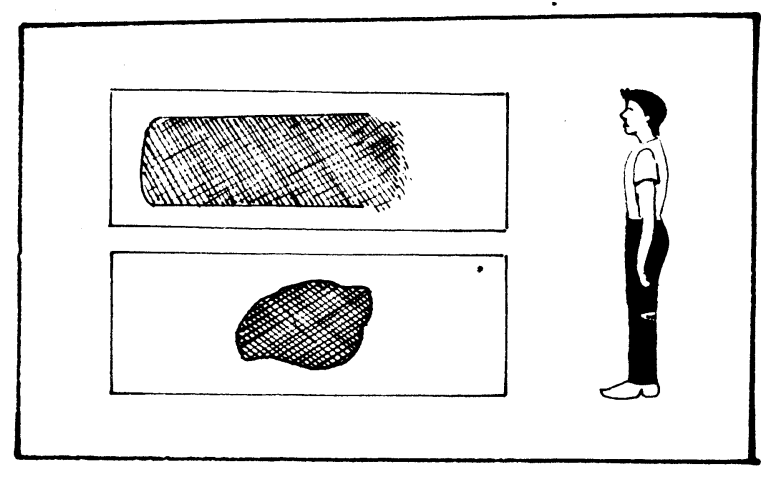

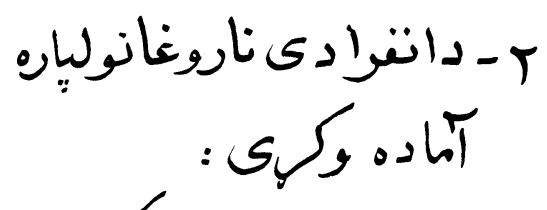

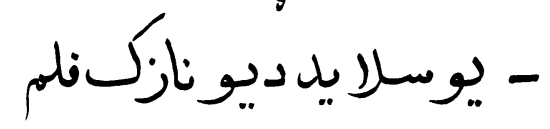

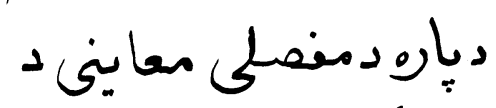

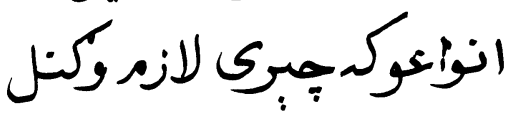


- يوسرو يد ديندنلم د بيراسايتو دلتولولِاهن .

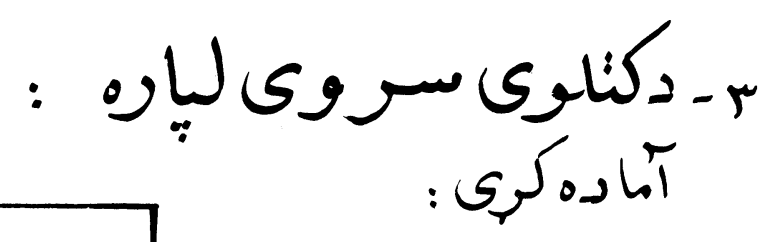

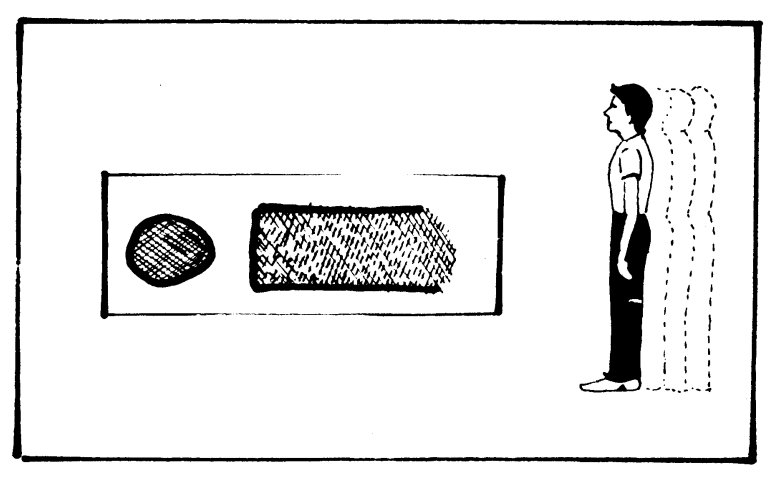

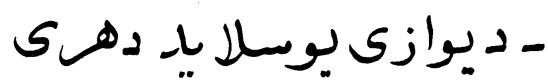

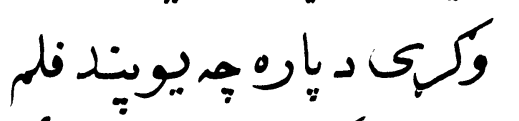

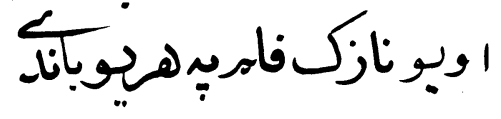

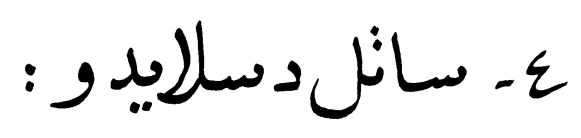

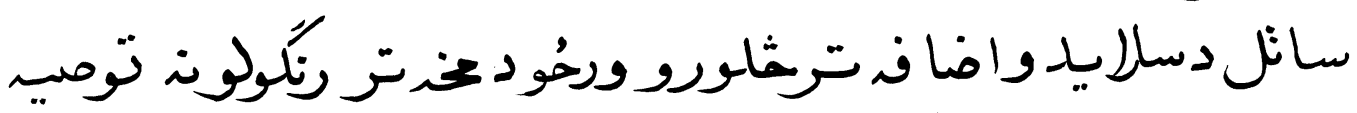

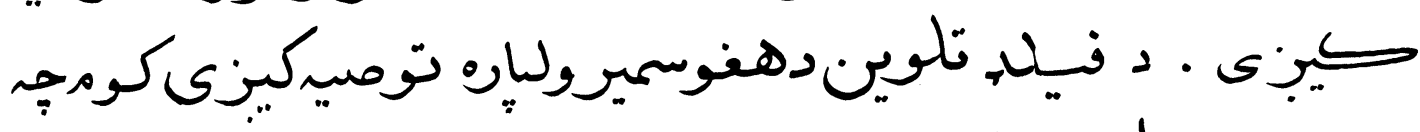

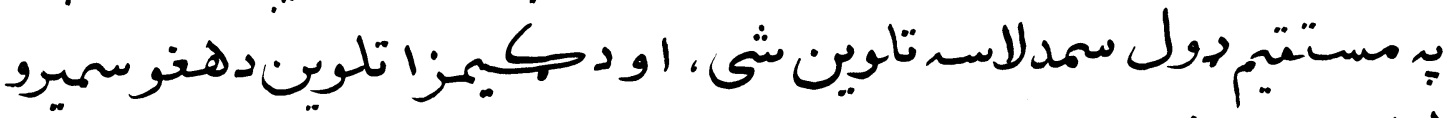

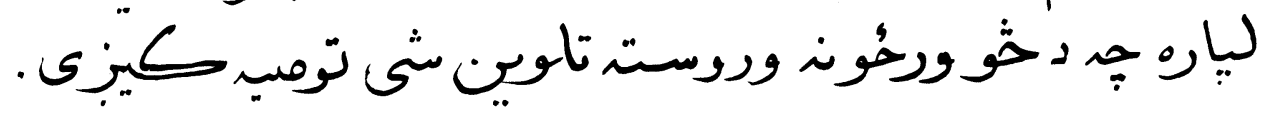

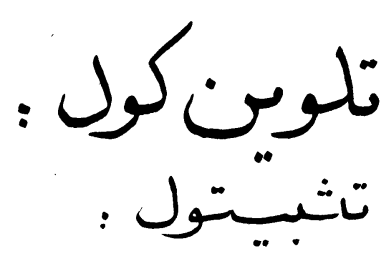

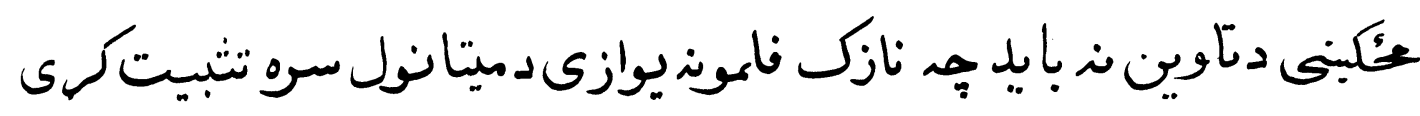
شى . 


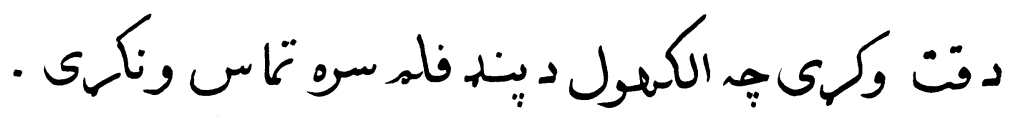

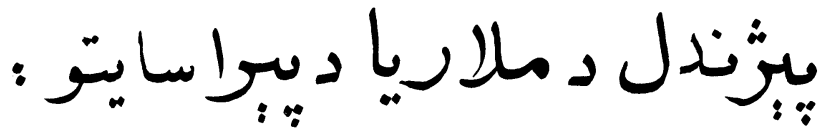

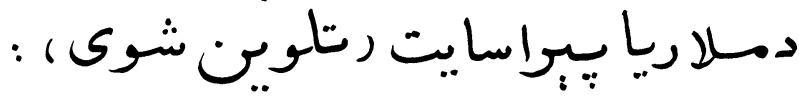

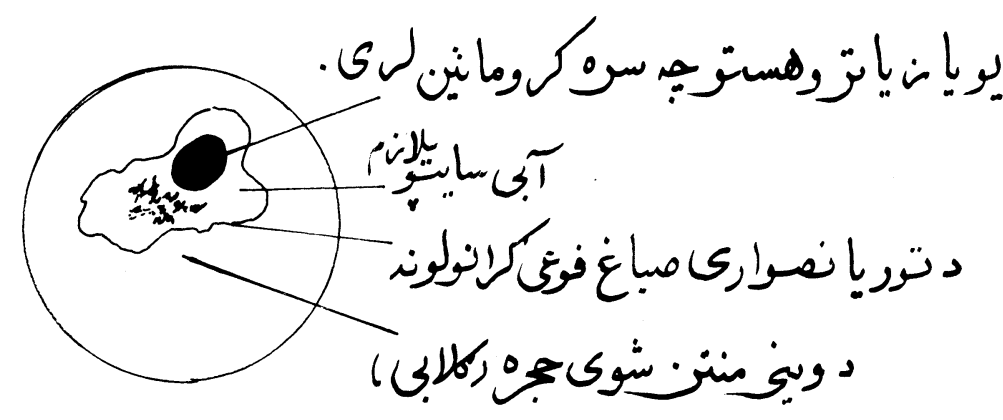

دتكاملمهلى

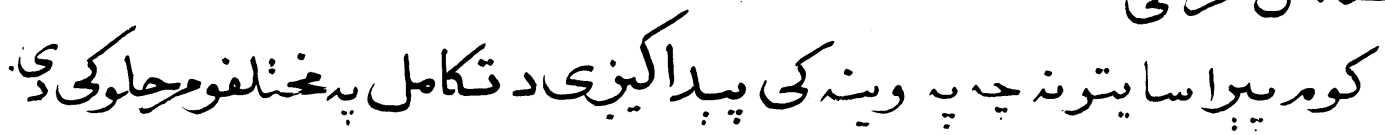

ترونونوايت

حُوان شَل

التحاقُ ترينمي

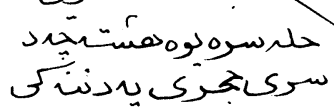

"

jor
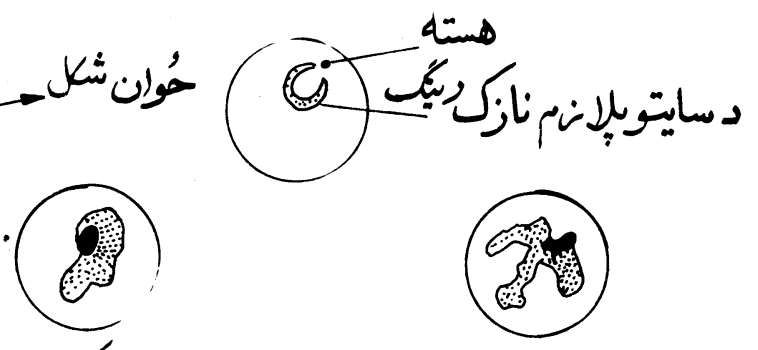

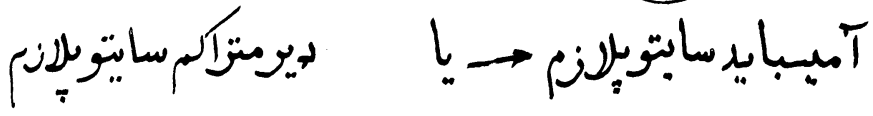

IIV 
بالغ تَوفونايزونت

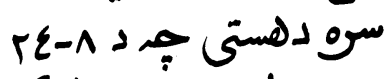
هستوباندى نتسيمشوئي.

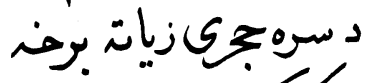

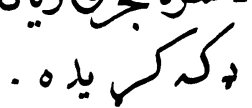

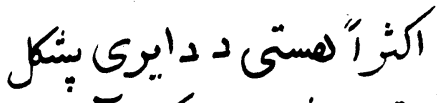
تونيب ستوىاوديكل آميل

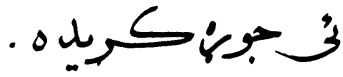

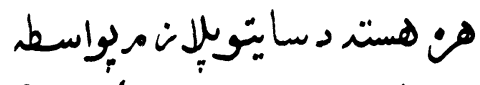

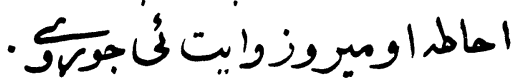

جنسيكل سوند

يوغتت متراكم او ب-كاموسايت
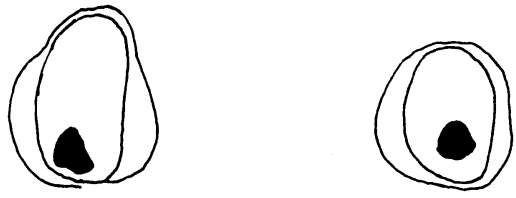

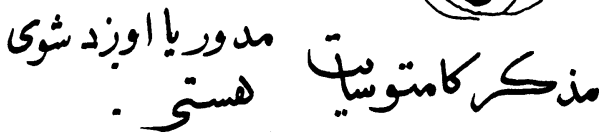

مونثكامتوسايت

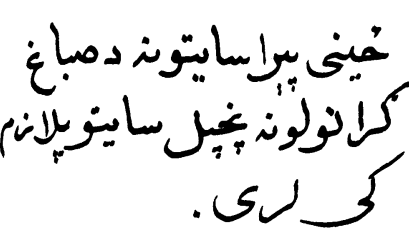

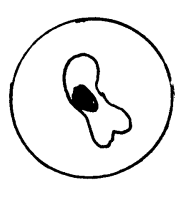

(8)

بلد مباغه تخخ: دبلغوسو

III 


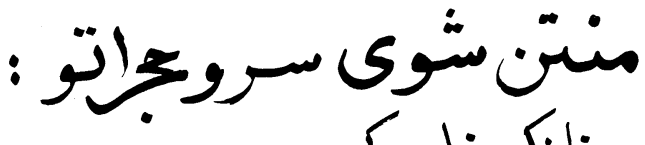

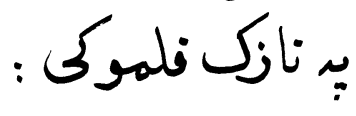

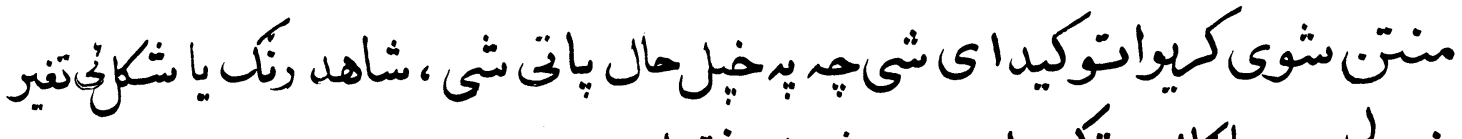

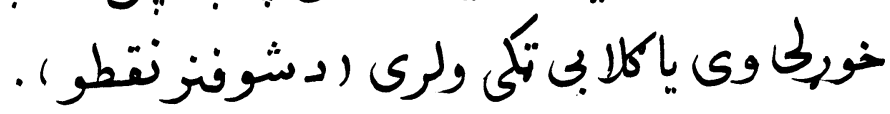

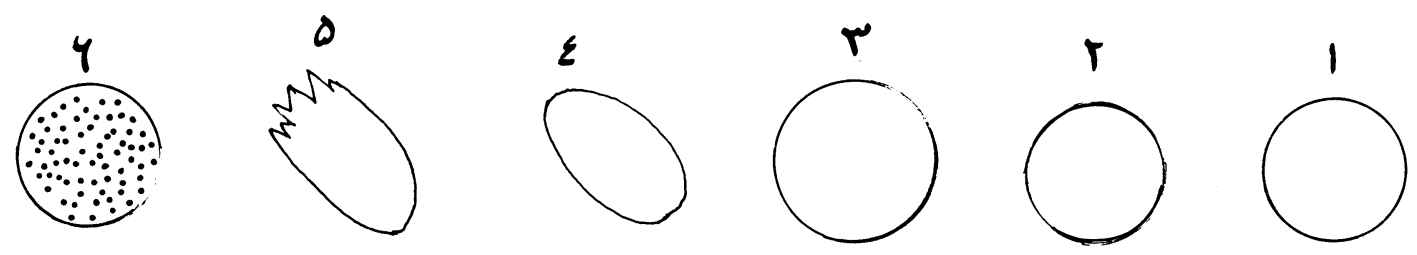

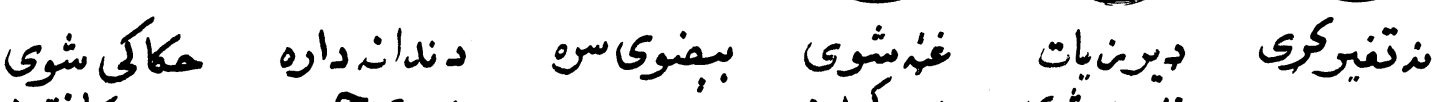

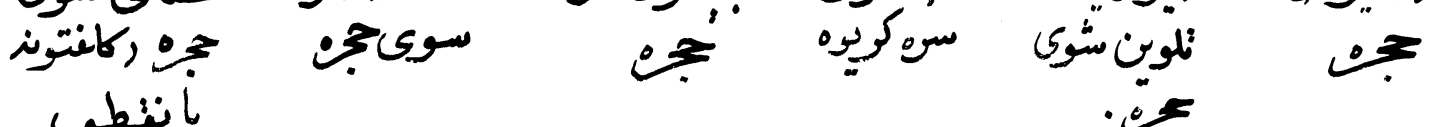
ينتطو،

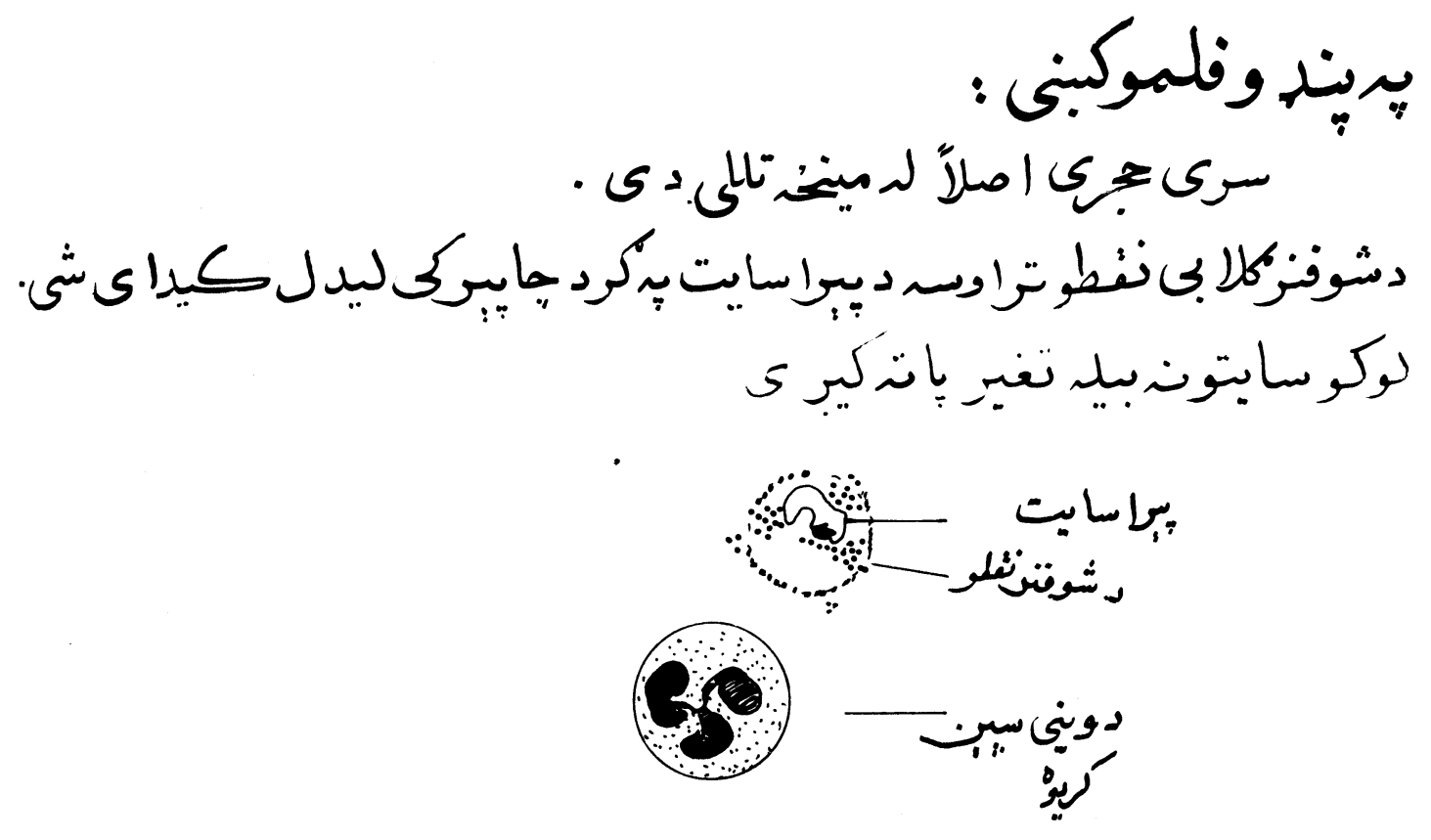

119 


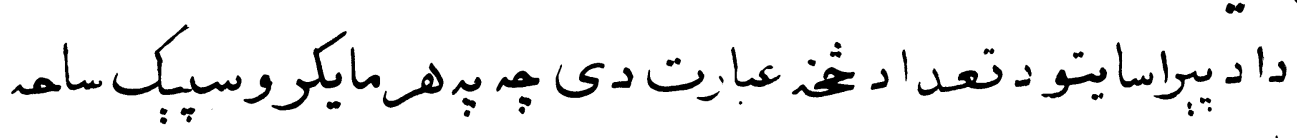

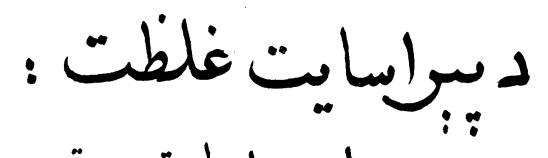

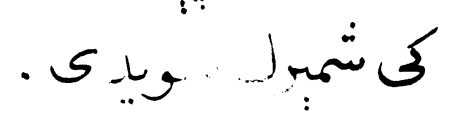

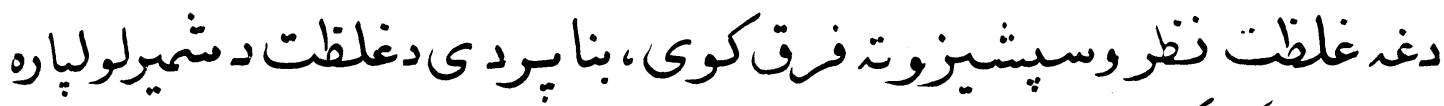

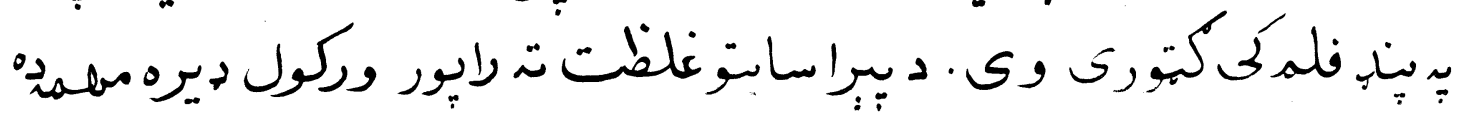
متوسطرغ

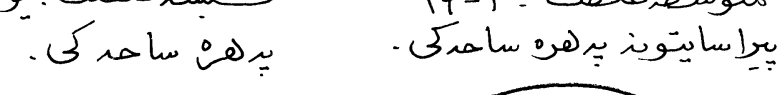
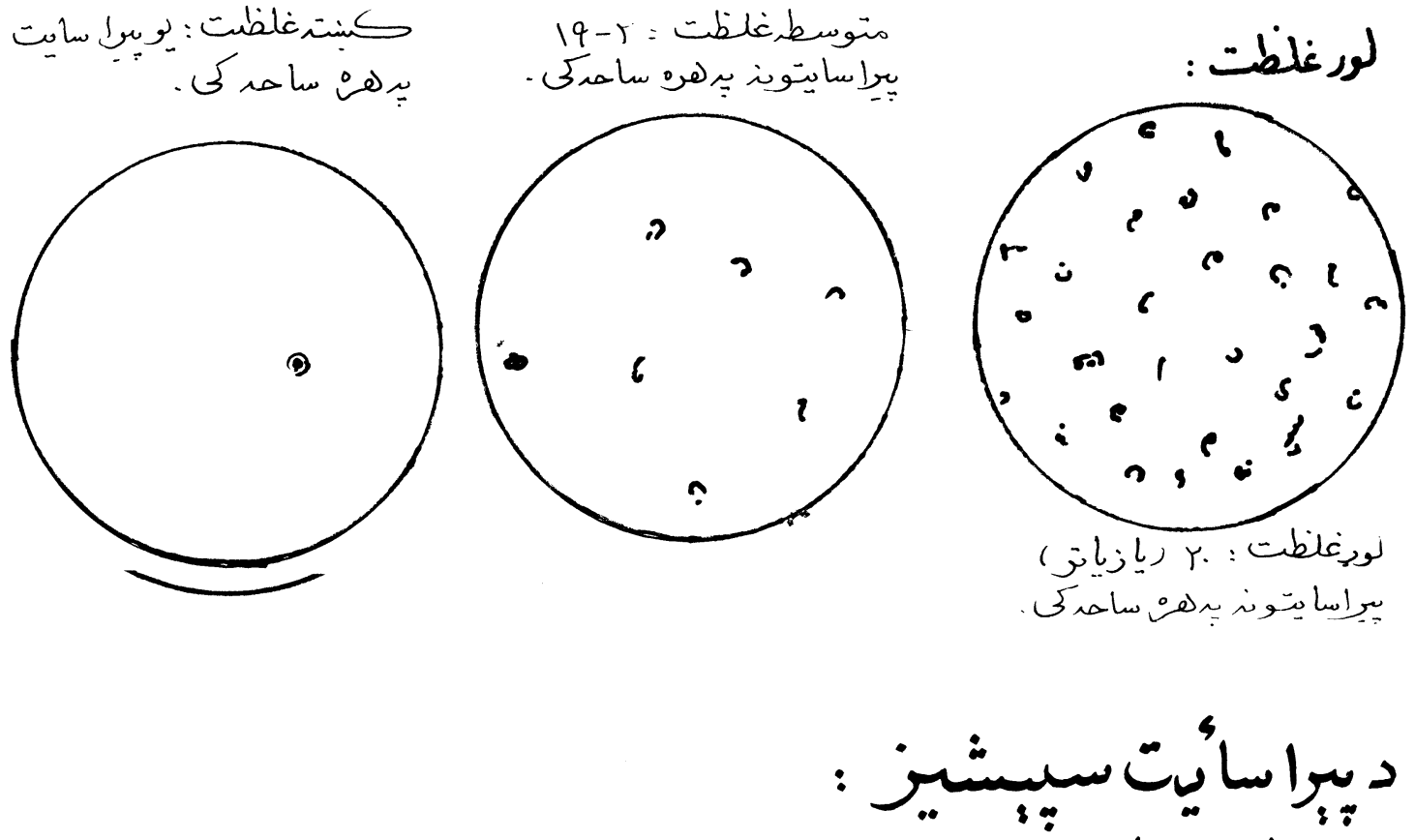

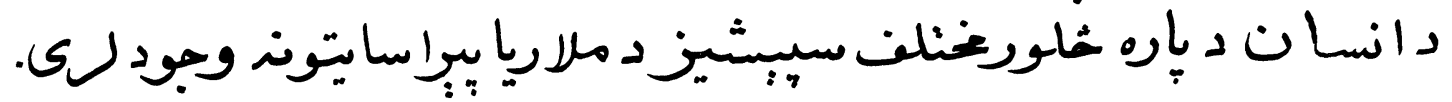

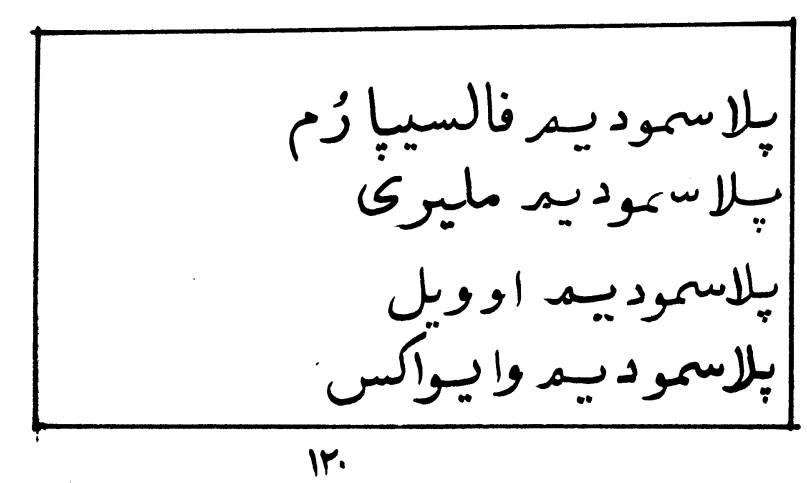




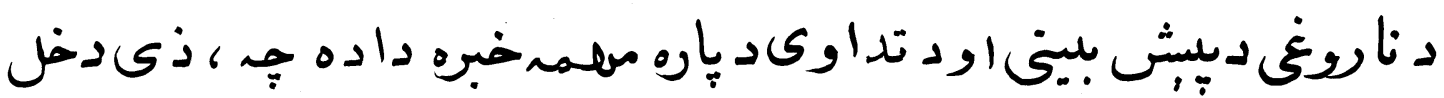

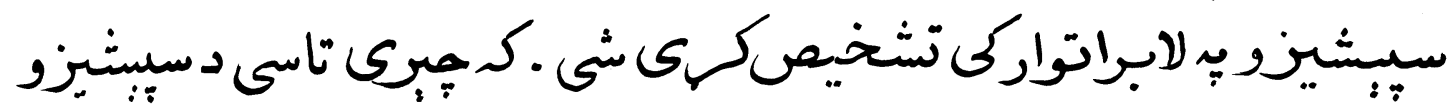

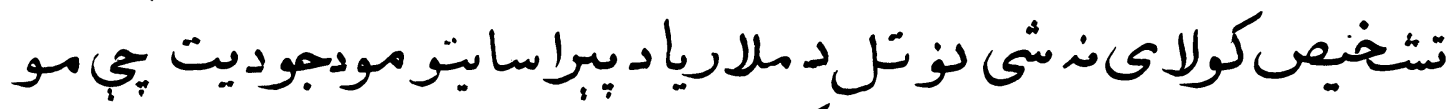

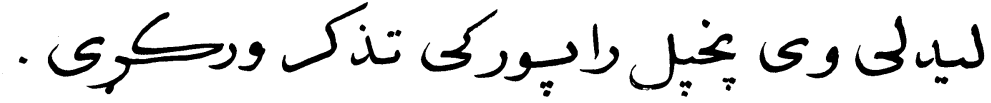

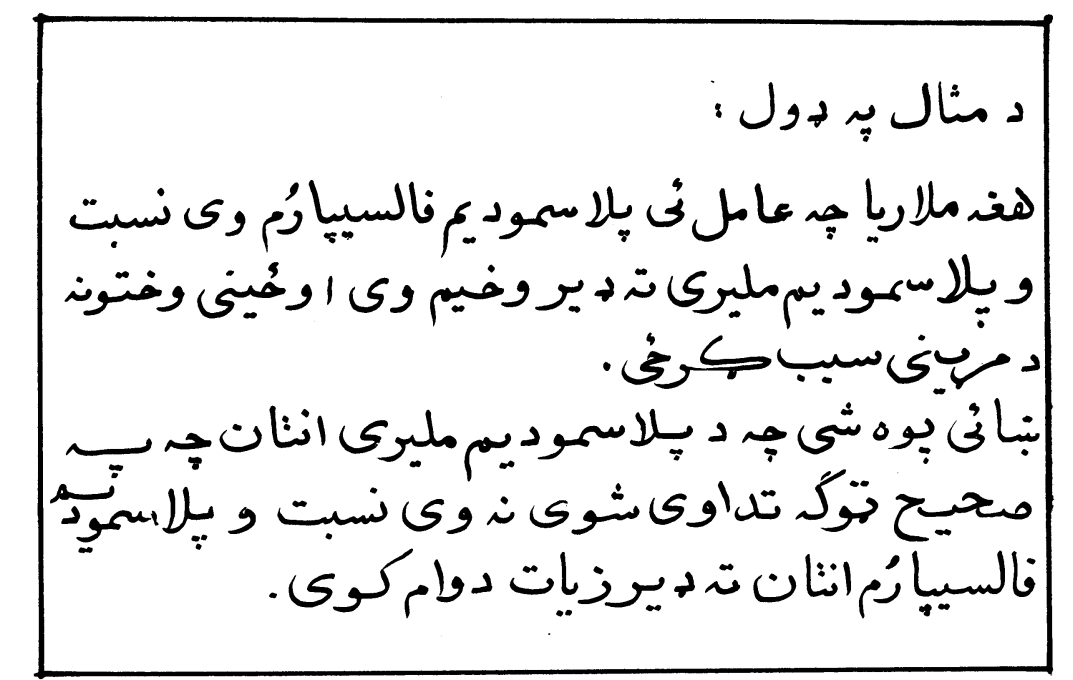

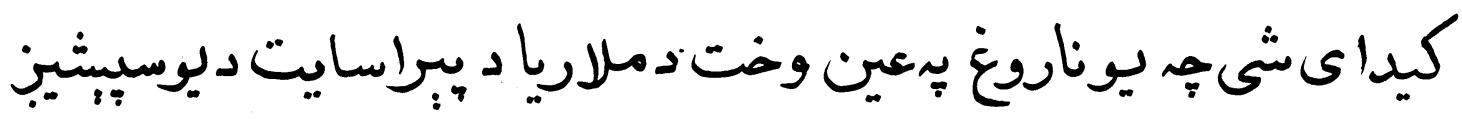

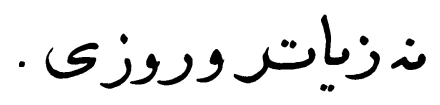

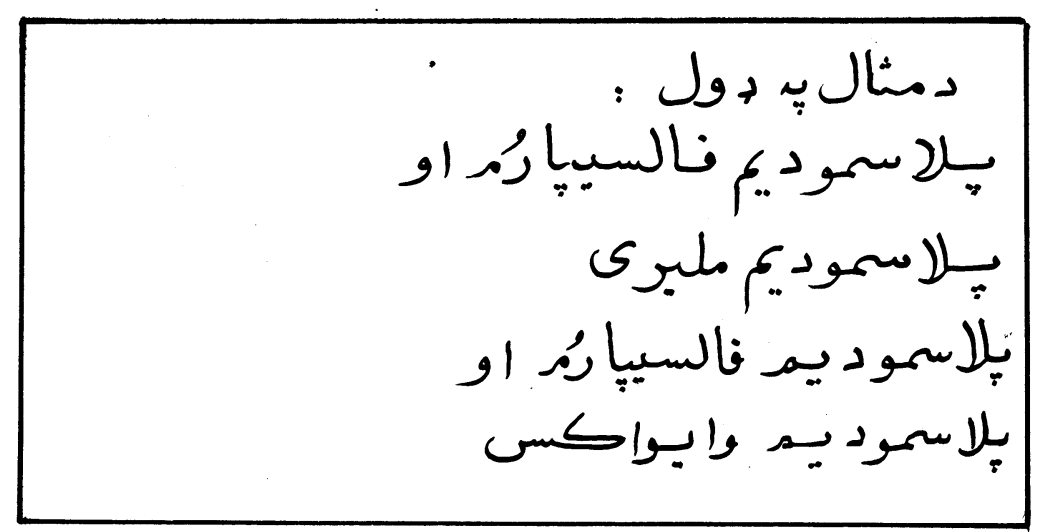

$|r|$ 
جغرافياقُ تتسيمات :

\begin{tabular}{|c|c|c|c|c|}
\hline بلإسموديه وائير & 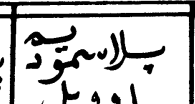 & |تلاسموديم مليرى & بلاسموديم نالسيباء & \\
\hline نــــاوان & ב & يموميت لري & عموميت لري & شالهى اتريقا \\
\hline |ديسنادر & عوميتّك & كموميت نلري & نــاوات & غزي افيقيا \\
\hline |ديونادر & نادر & تهوميت للي & نـراوان & كبكزئيا \\
\hline نادر & نادر & عموميت لري & نــران & ختيز انسيتا \\
\hline |عموميتنلرى & نادر & عموميت لكي & فراوان & مدغاسكى،جهند \\
\hline Fتوميت لعي & - & نادر & تهوميت للي & 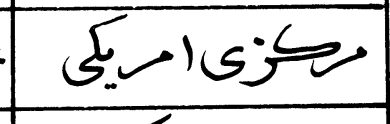 \\
\hline نراوان & $\cdot$ & نادر & عموميت لري & جنوبقاهيكي \\
\hline نراوان & . & عموميت نلرى & عموميت للي & جنوب غربكآسيا \\
\hline | كموميت رك | & - & تموميت نلرى & نراوان & 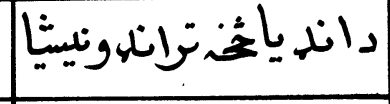 \\
\hline | عوتيت لرى & نادر & عوميت ناسى & نــارات & انـدونيشيا \\
\hline (5) عموميت & نادر & عموميت ناسى & عموميت لهى & جزايرِياِينك \\
\hline & & & & \\
\hline
\end{tabular}




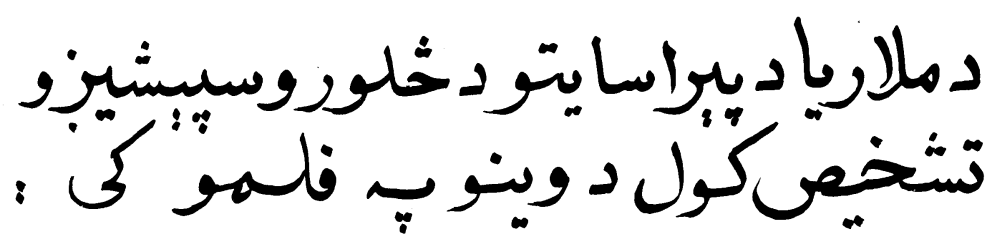

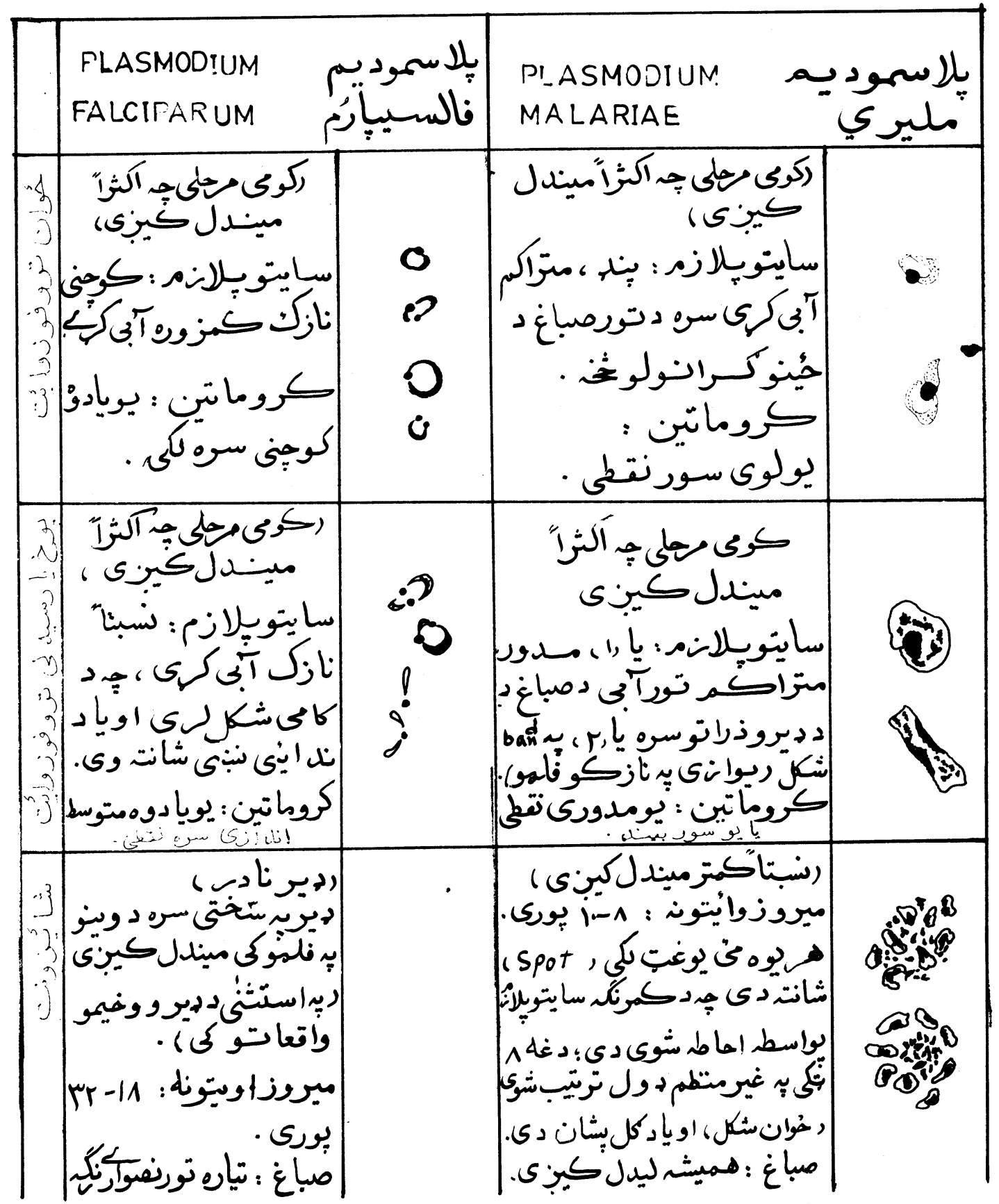




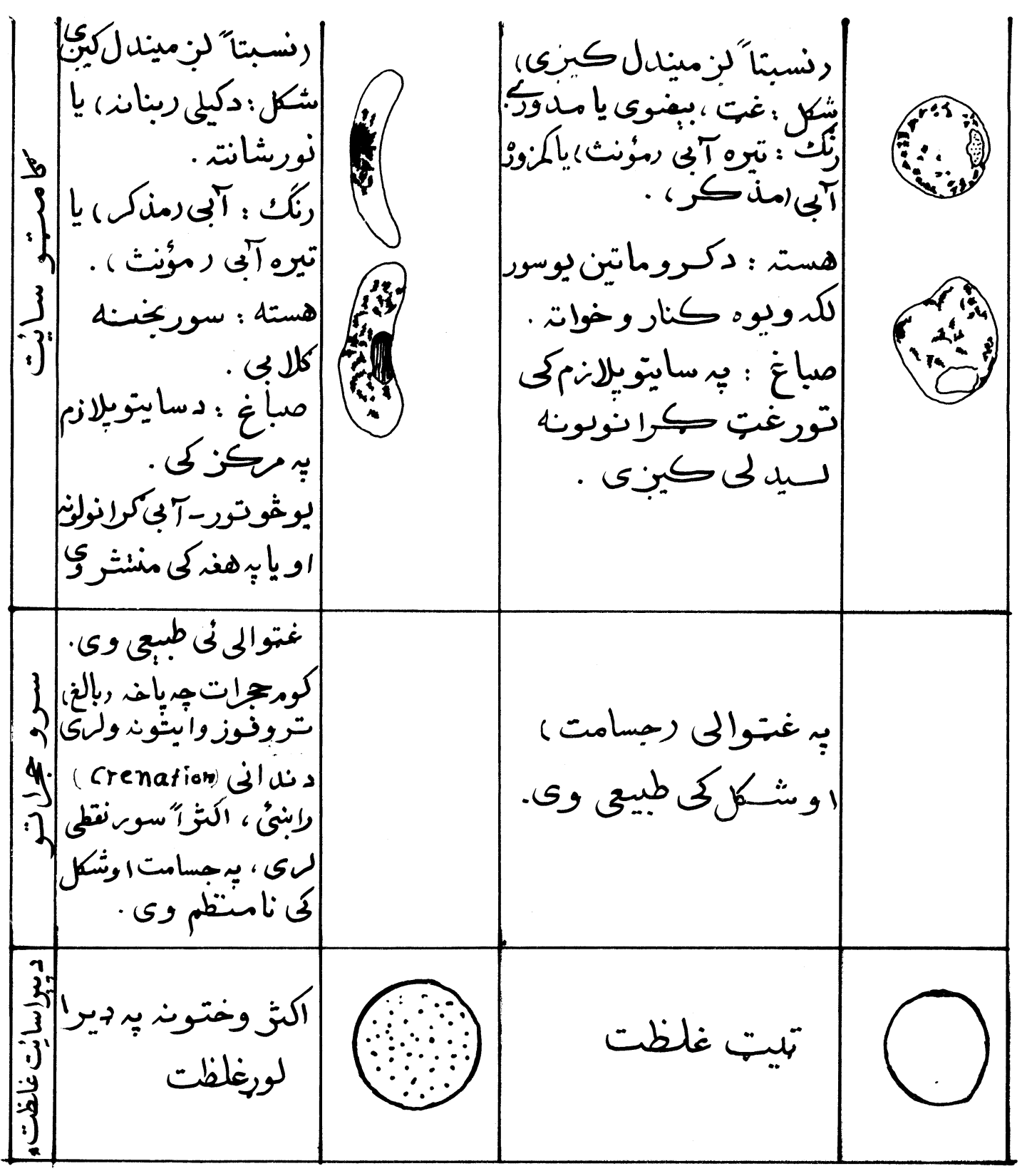

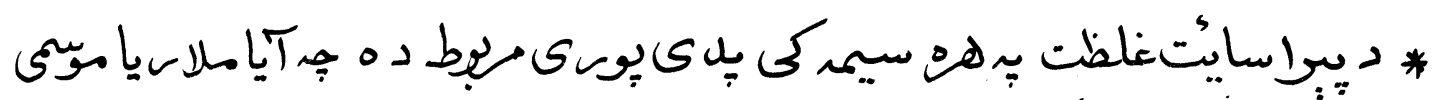

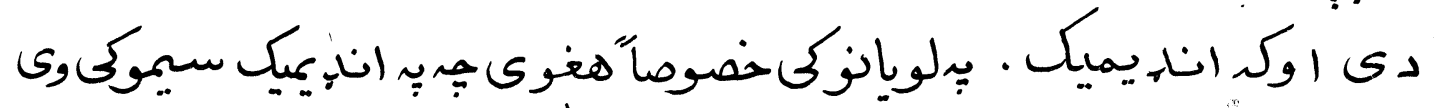

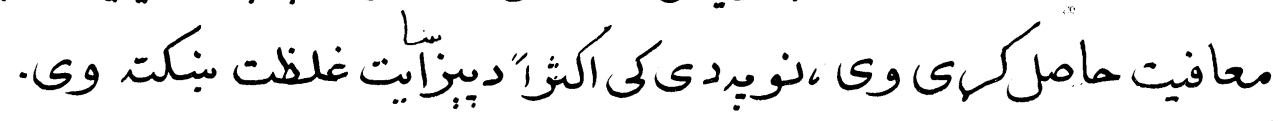




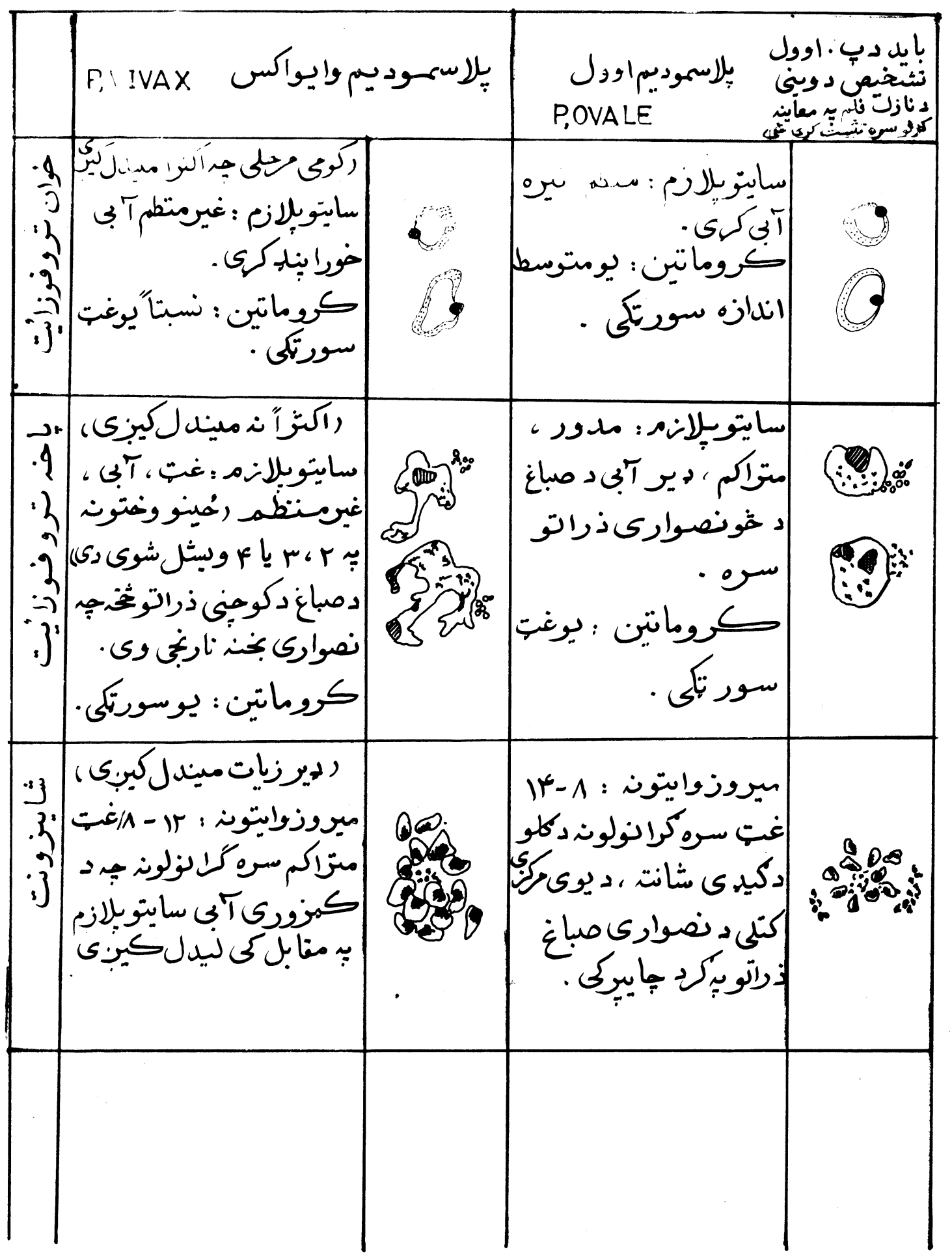




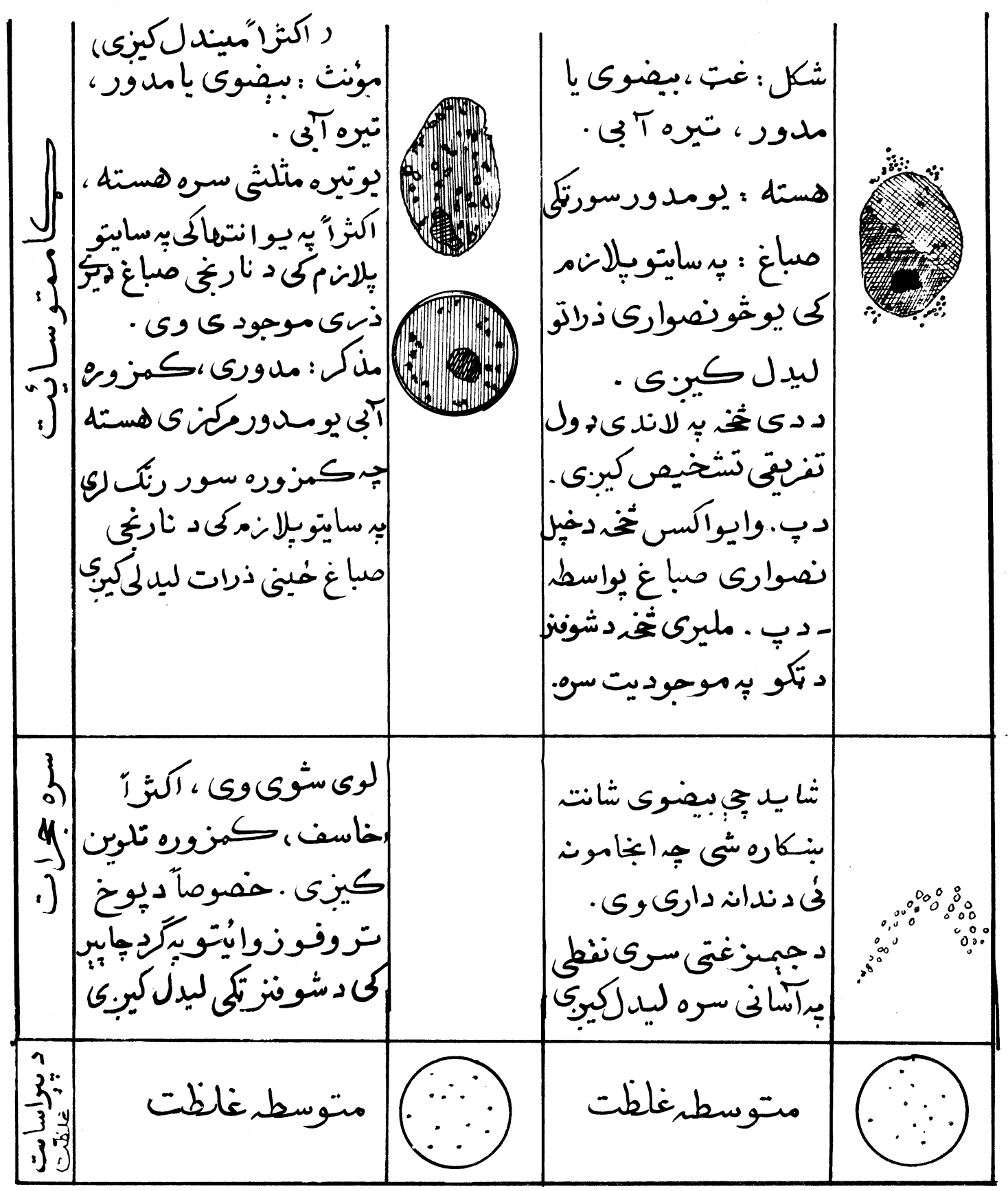


مقايسه كِول دمنتن شوى حجروبه نازكَ فلمكى :

\begin{tabular}{|c|c|c|c|c|}
\hline 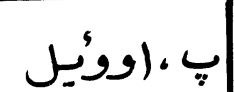 & بِ ، وايواكس & إب مليرى & بِ، فالسيِيِ رُه & \\
\hline & & & & 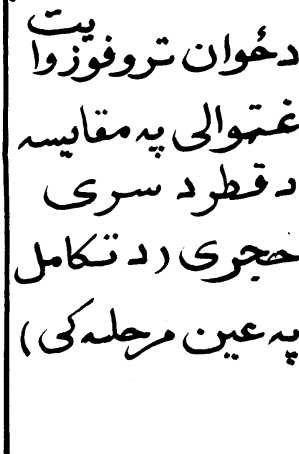 \\
\hline & & & & 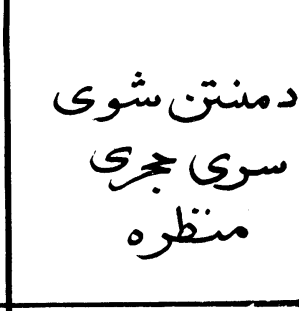 \\
\hline & 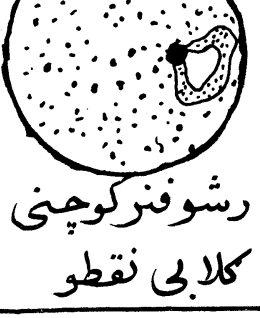 & & اكثرا & 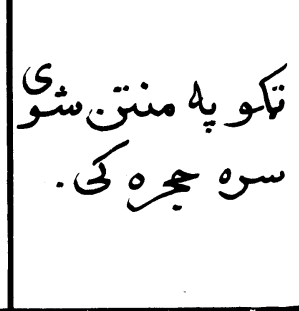 \\
\hline 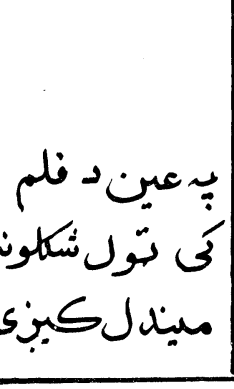 & 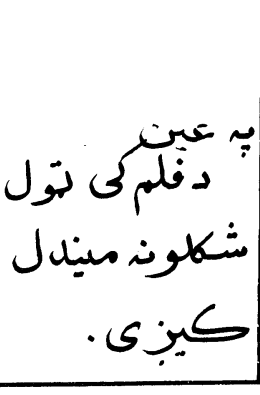 & 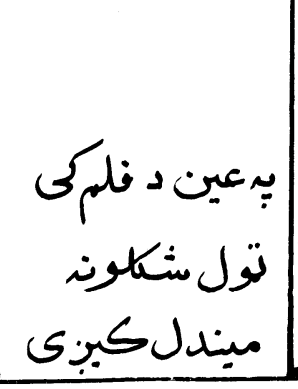 & 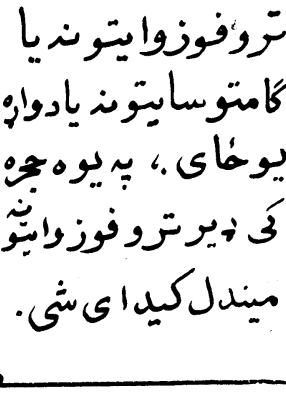 & مبند لكئى \\
\hline
\end{tabular}


دمانوسايتومتطرى (د ماللاريا يُطوبل المدتو واتحاتوكى ) .

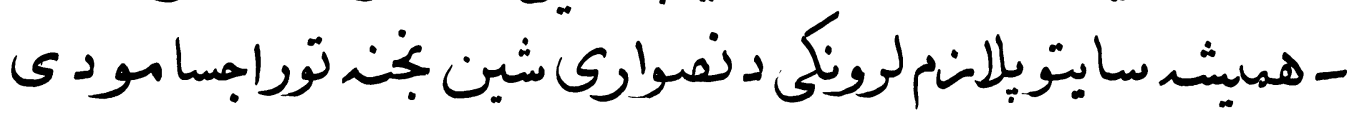

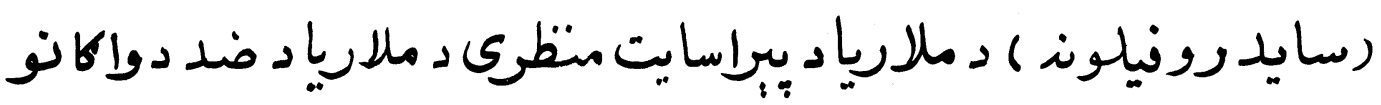

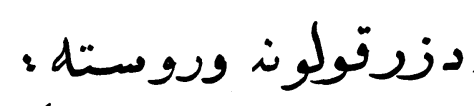

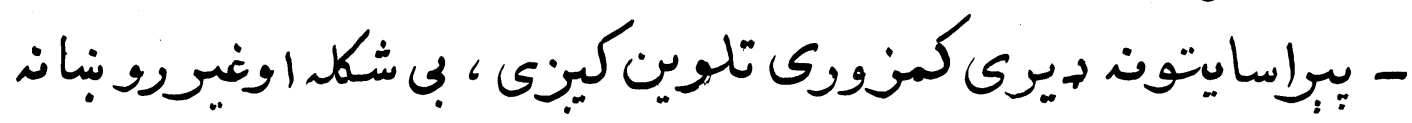

$$
\text { . }
$$

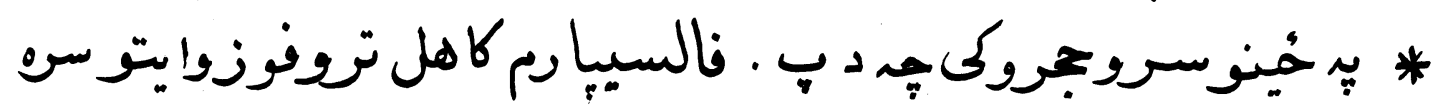

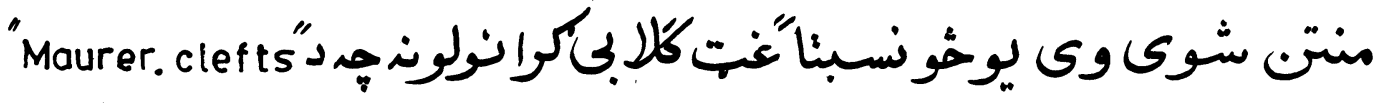

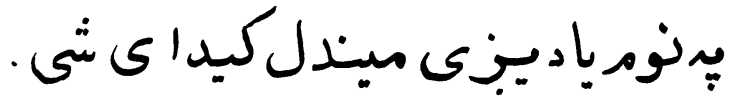

$$
\begin{aligned}
& \text { حكزارش وركول د نتيجِيو : }
\end{aligned}
$$

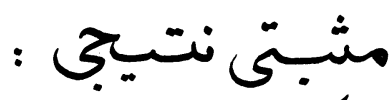

$$
\begin{aligned}
& \text { تذكروركريى : }
\end{aligned}
$$

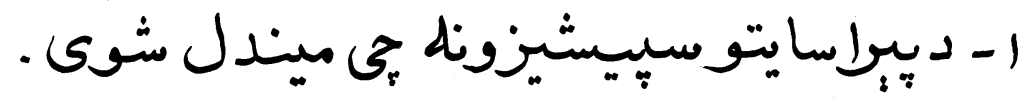

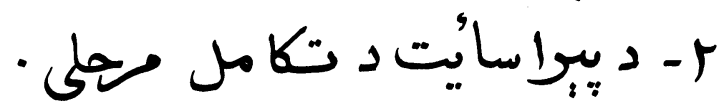

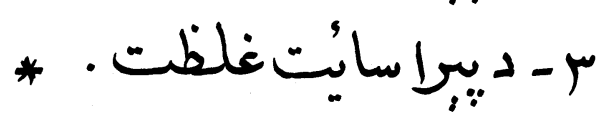

منال

د ملارياديباسايتو معاينىمنتبنى وى .

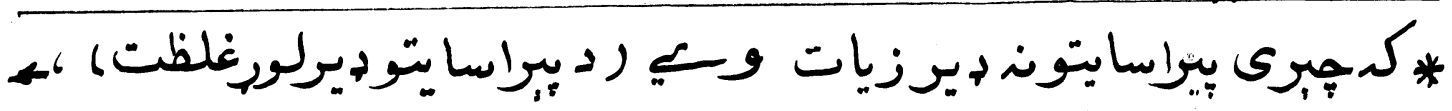




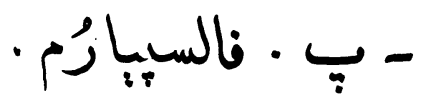

$$
\begin{aligned}
& \text { - بيرترفوزوايتون - بالي }
\end{aligned}
$$

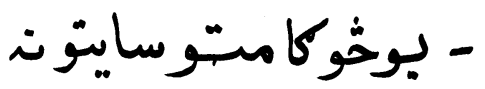

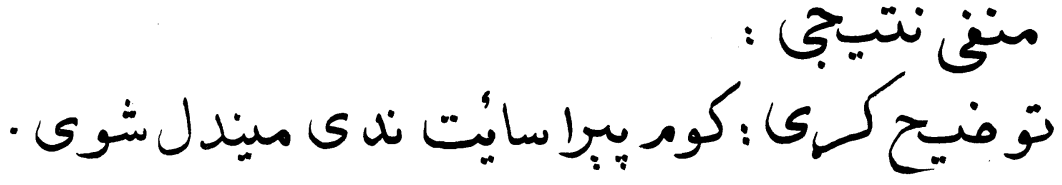

$$
\begin{aligned}
& \text { با الهميت يتكى : }
\end{aligned}
$$

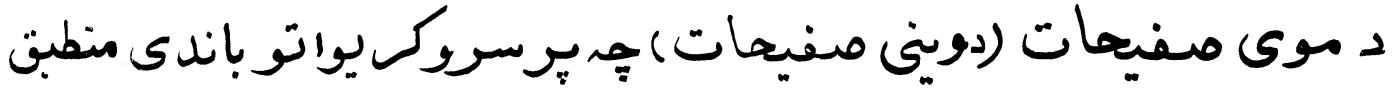

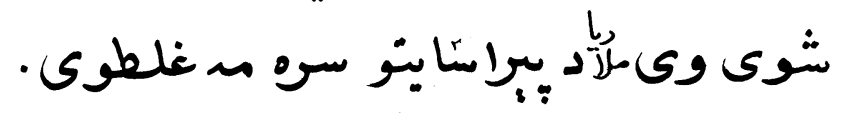

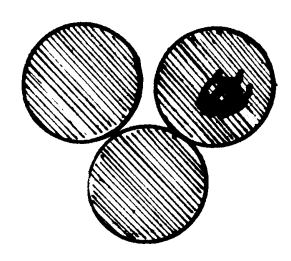

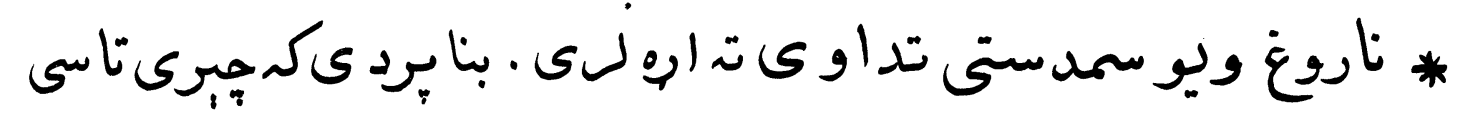

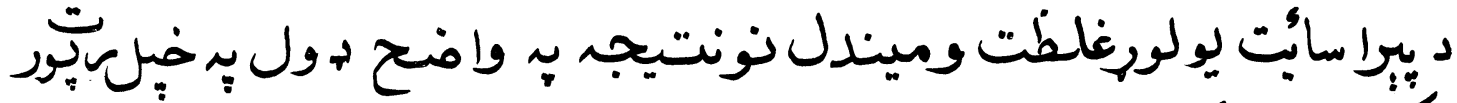

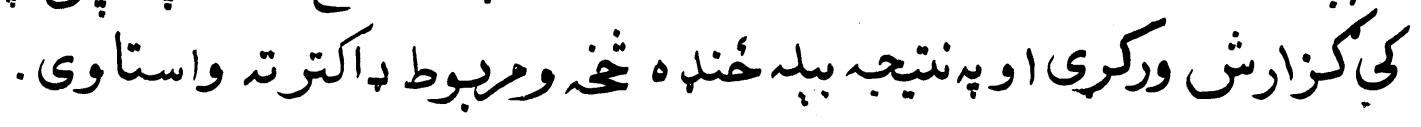




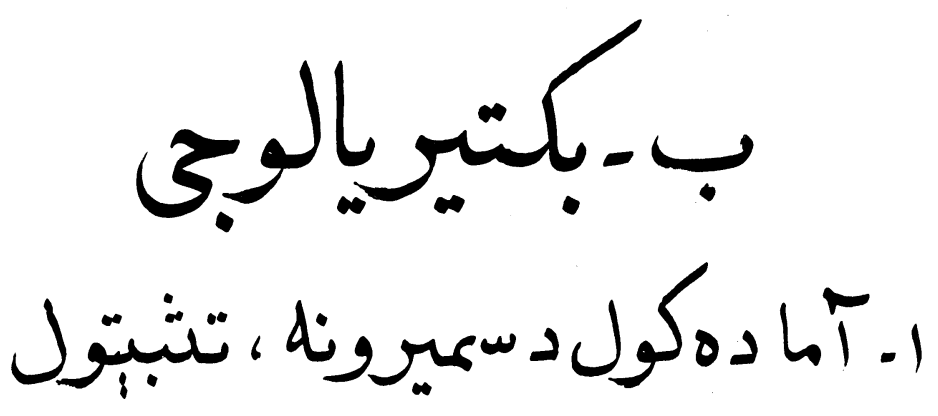

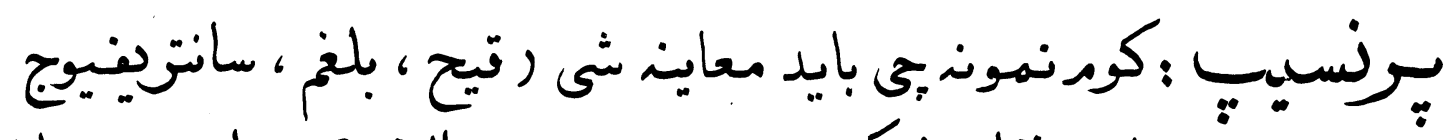

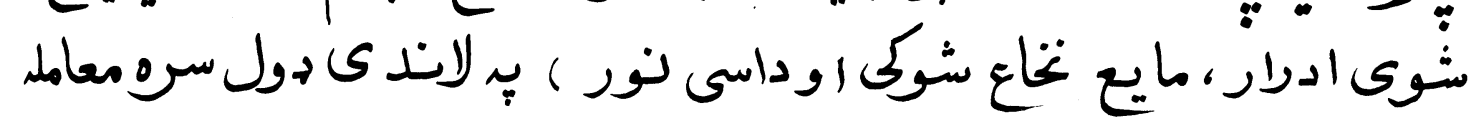

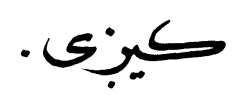

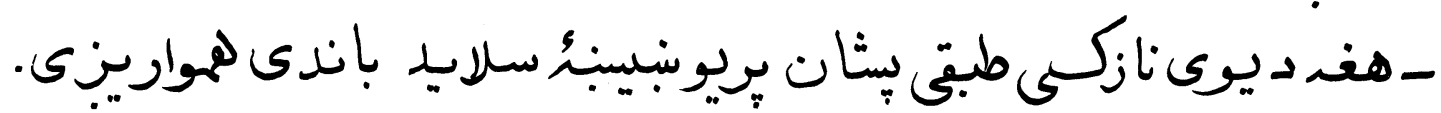

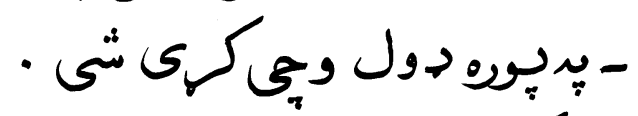

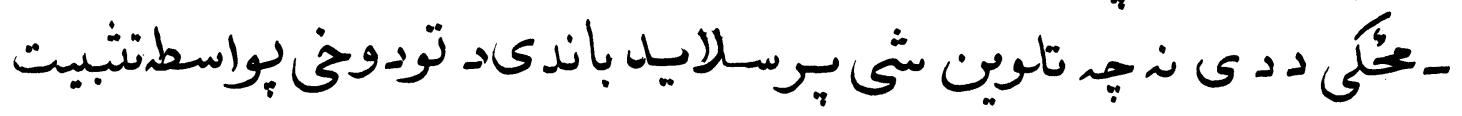
كئب

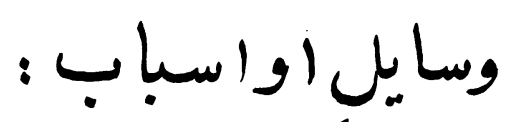

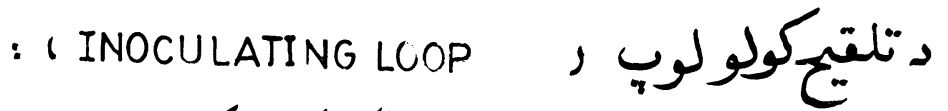

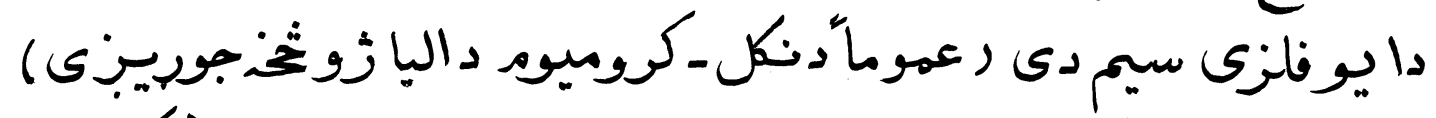

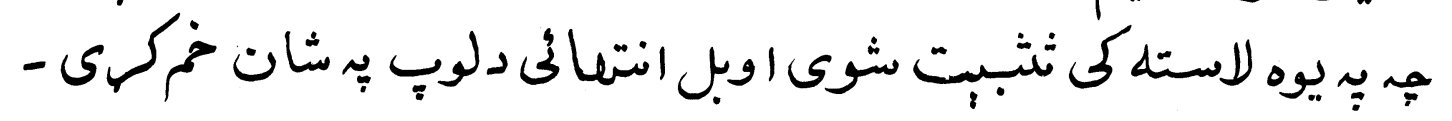

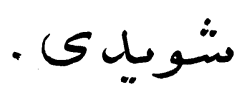

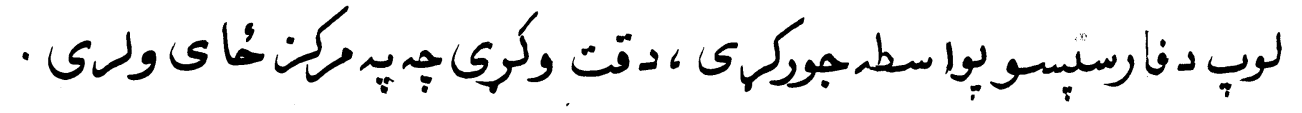




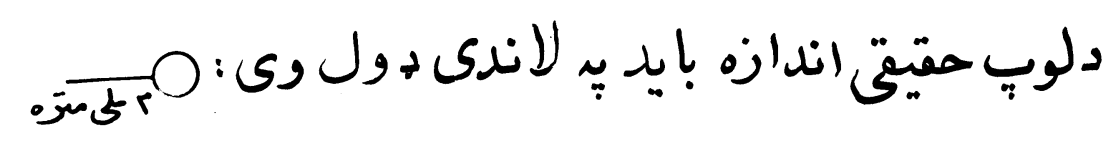

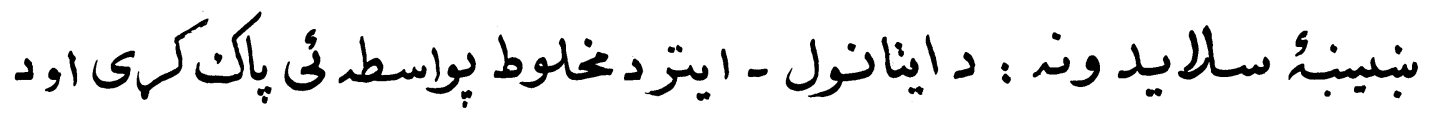

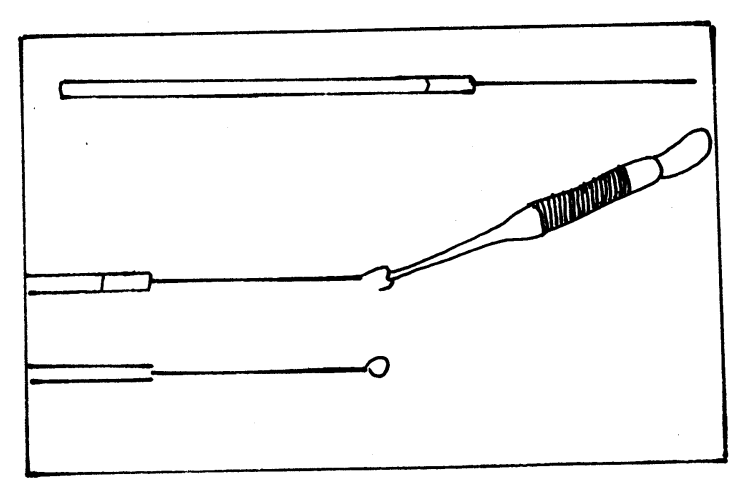

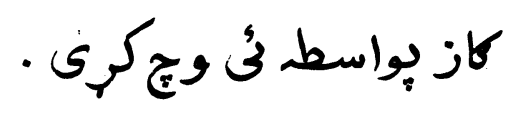$$
\text { بنس بنز : بون }
$$

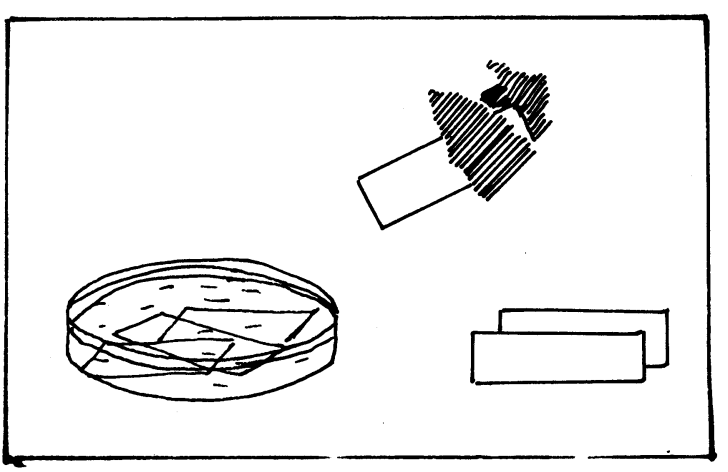

\section{د سميرآماده كول :}

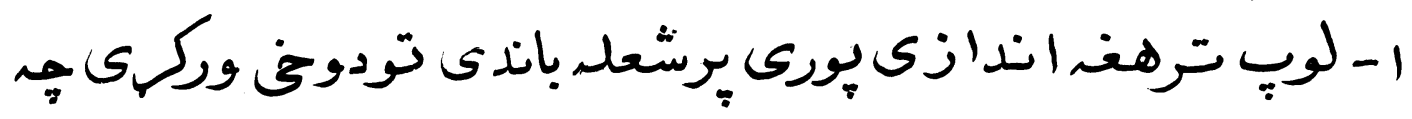

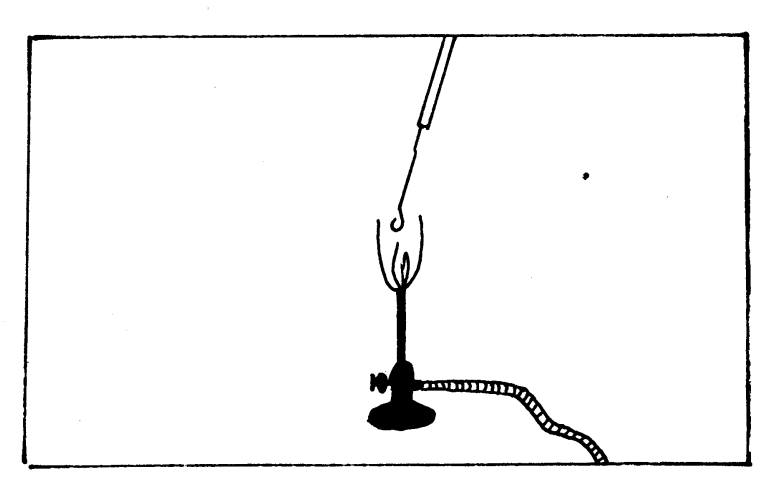

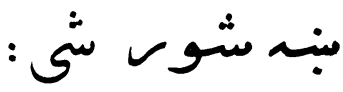

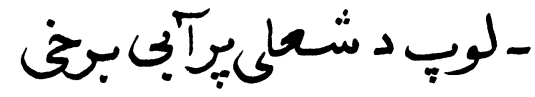

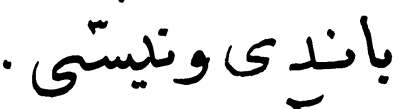

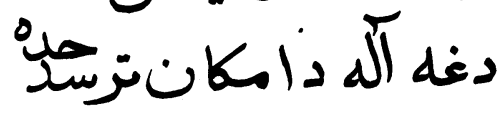

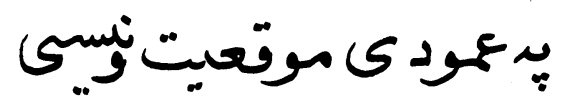

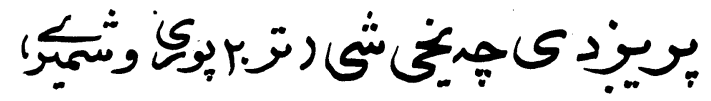

$|r|$ 


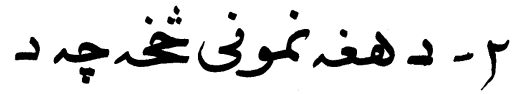

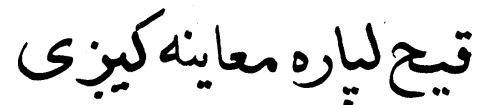
يواندازه واخلى يداسى تتيب سوه هِلوبي د مايع بوبسطح باندى كبنينبود بوسيطوكي

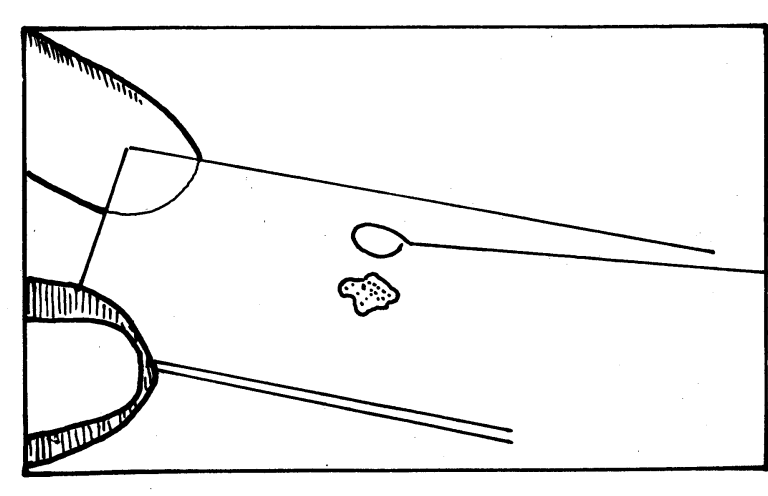

س - لوبي برسلايديكانذ كيبدى اوحفنيفاهِغ

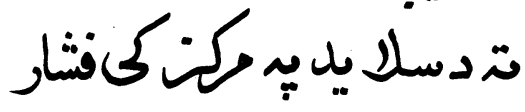

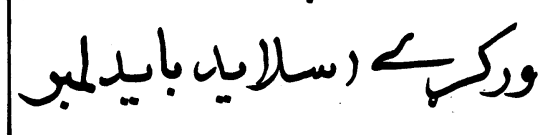

ولوى ).

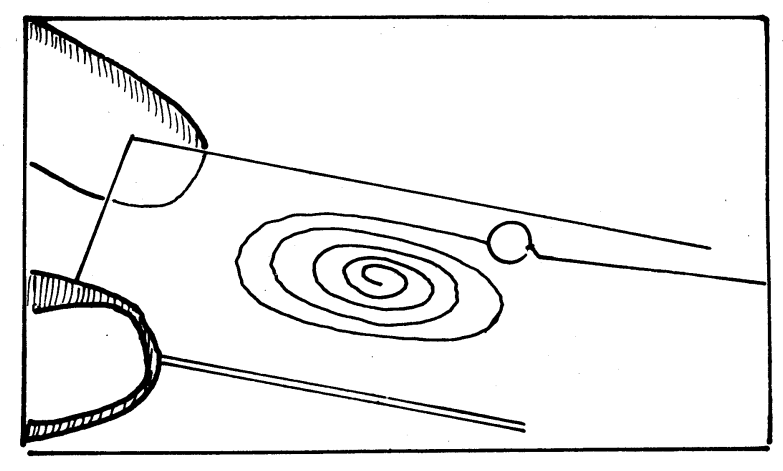

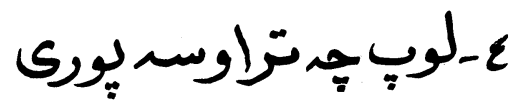

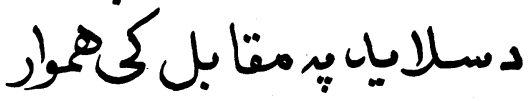
نيول شيويدى هغدتيو

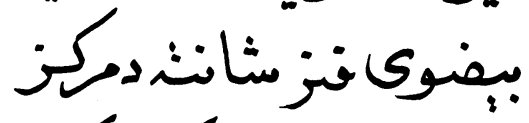

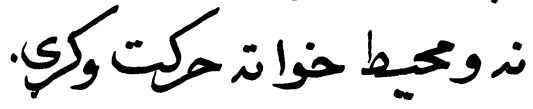

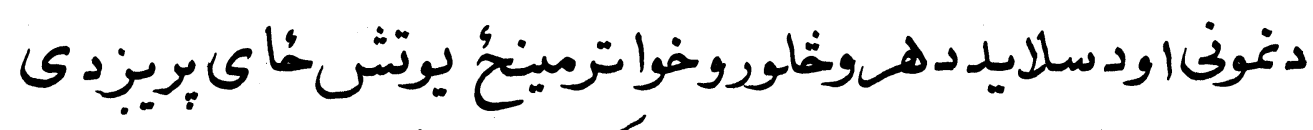

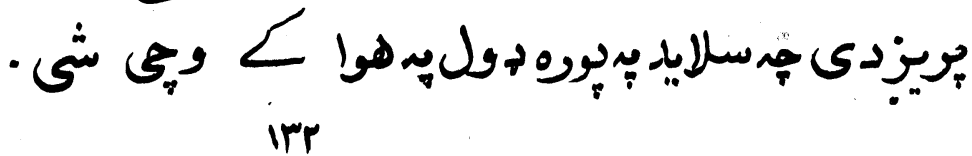




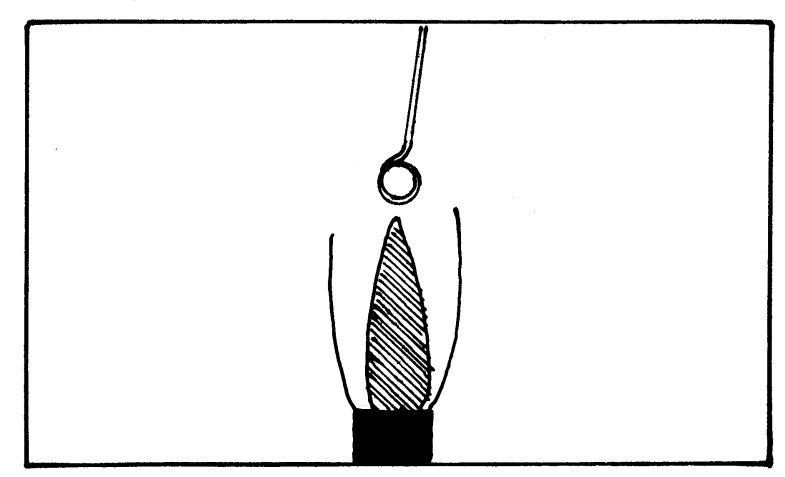

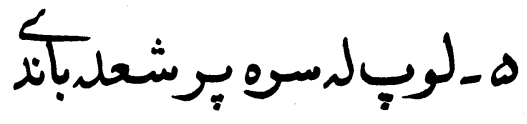

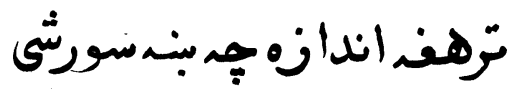
تودونى وركهى تزخوجي

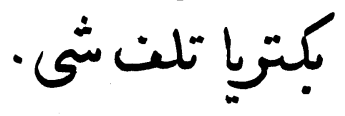

خينى وختونبن نبنيونبانى

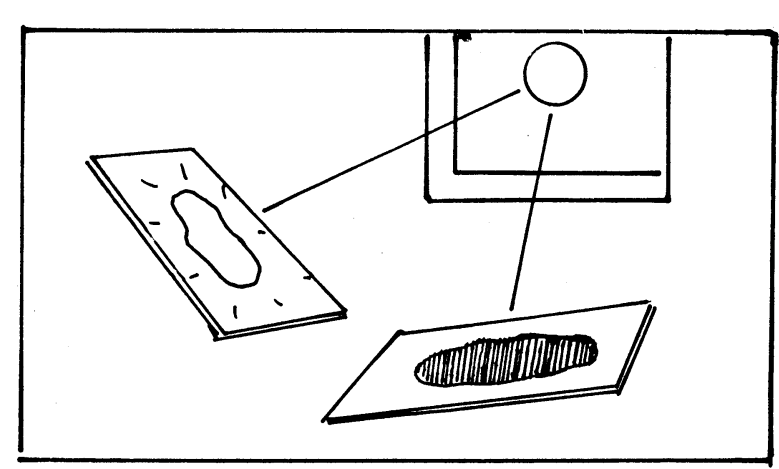

صميرون دباندينوينابعو

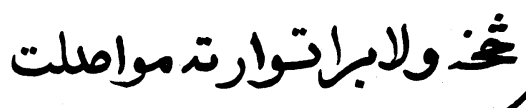
كوى .

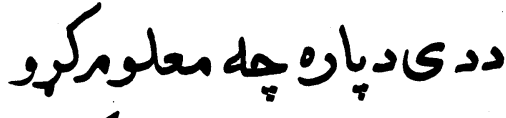

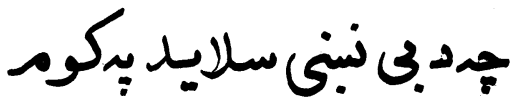

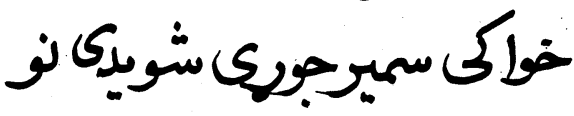

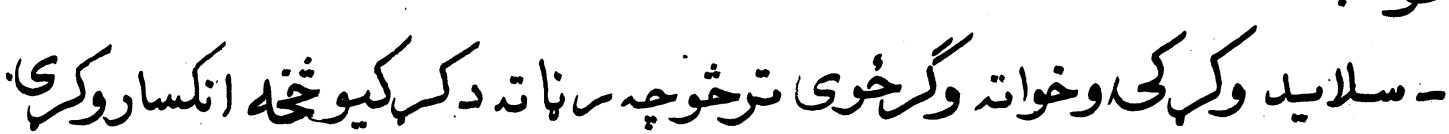

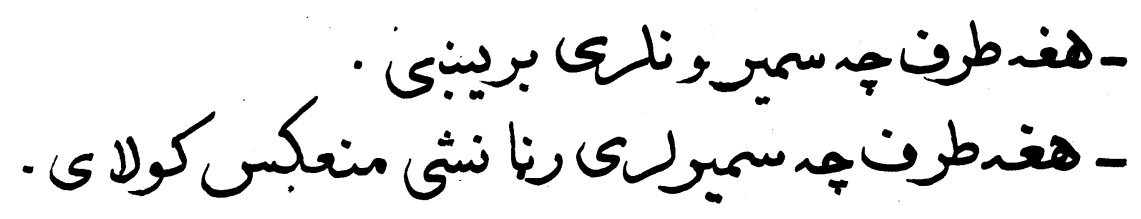




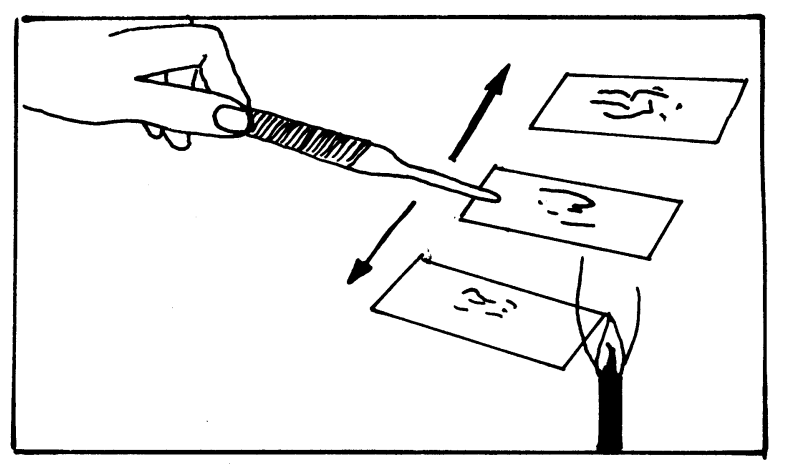

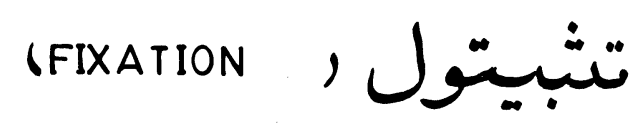

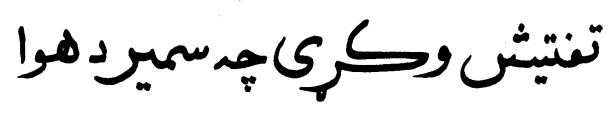

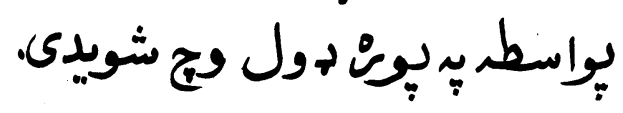

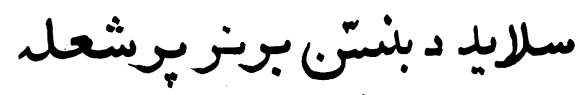

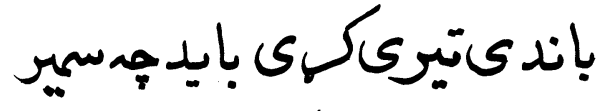

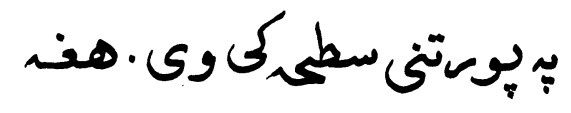

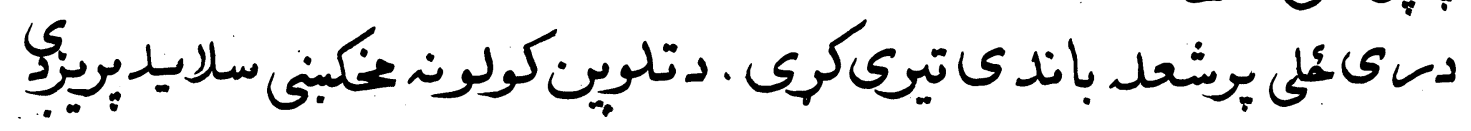

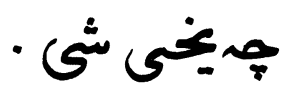




$$
\text { دوتوبكلبسيلا دزيل- نيلسن نلوين }
$$

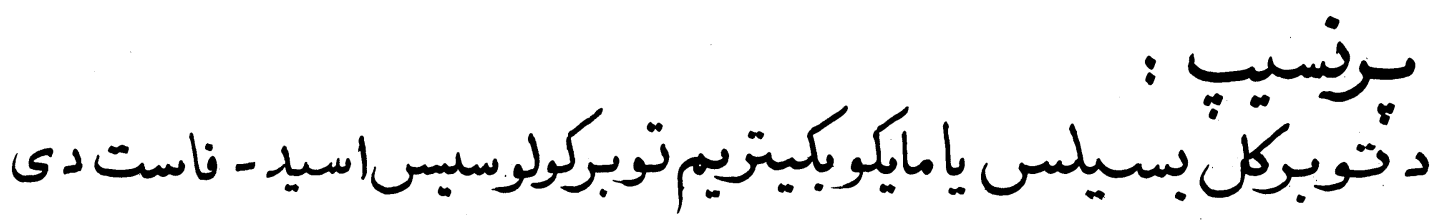

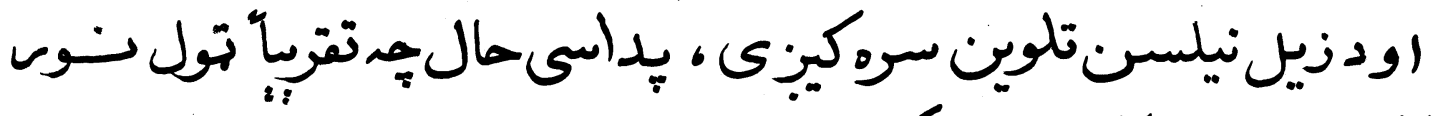

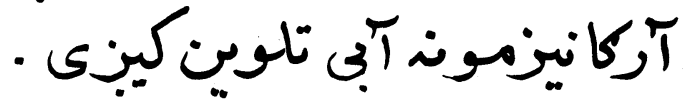

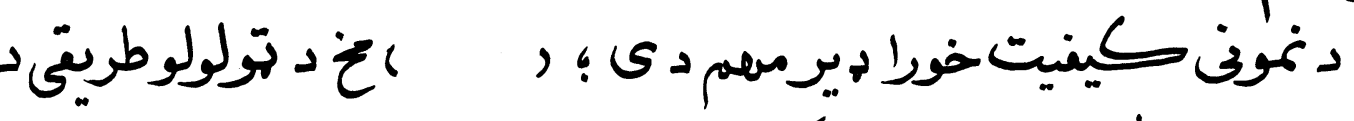

$$
\text { دبلغ تيولي : }
$$
مستقيى معا ينى ليار دى وكنّشئ.

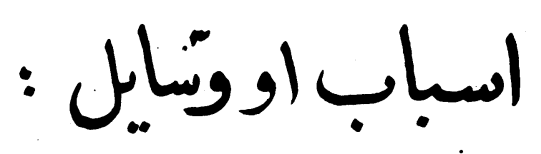

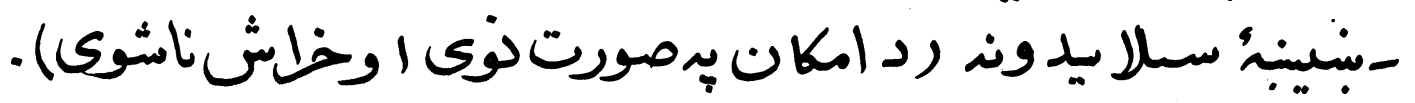

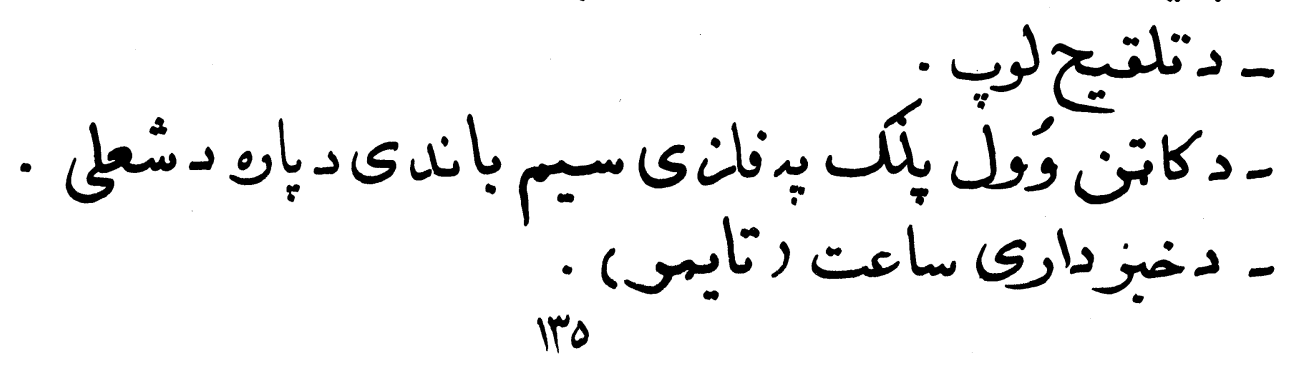




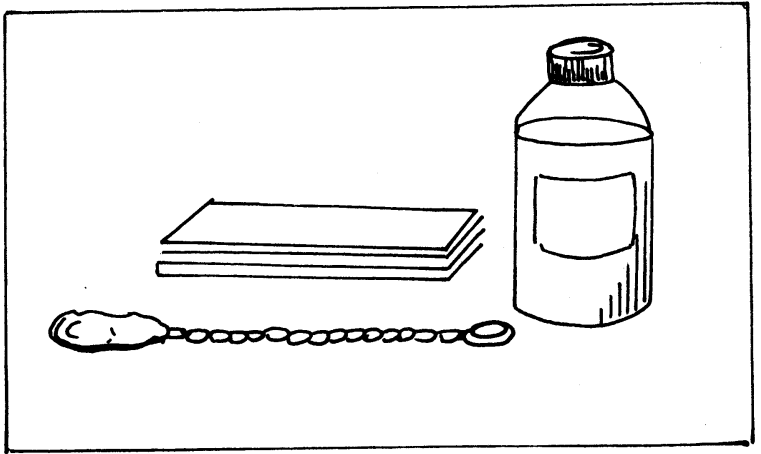

$$
\begin{aligned}
& \text { معارون (صينتّون ) : }
\end{aligned}
$$

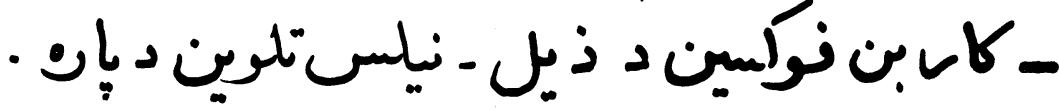

$$
\begin{aligned}
& \text { - آيسد - اينانول }
\end{aligned}
$$

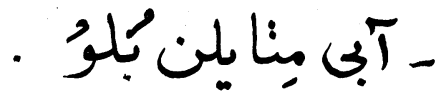

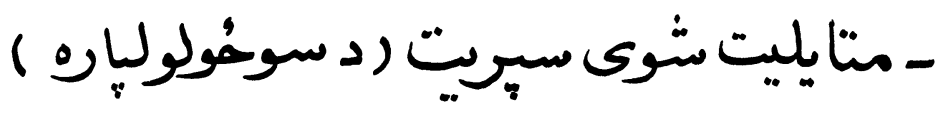

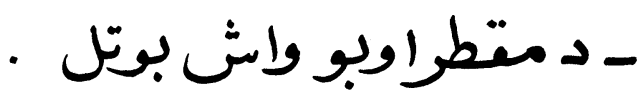

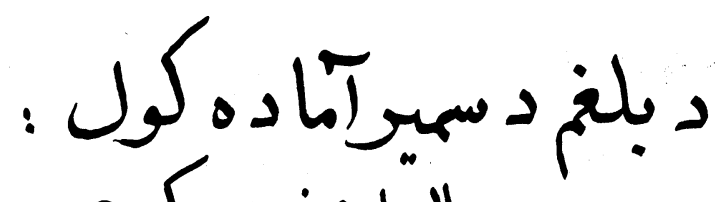

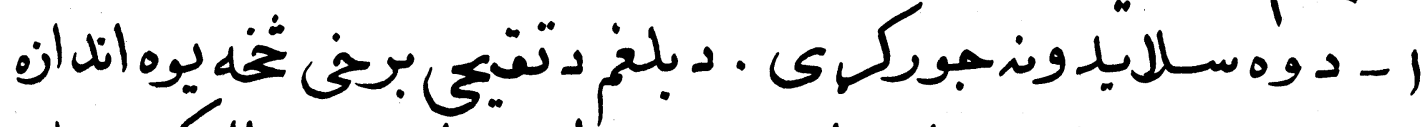

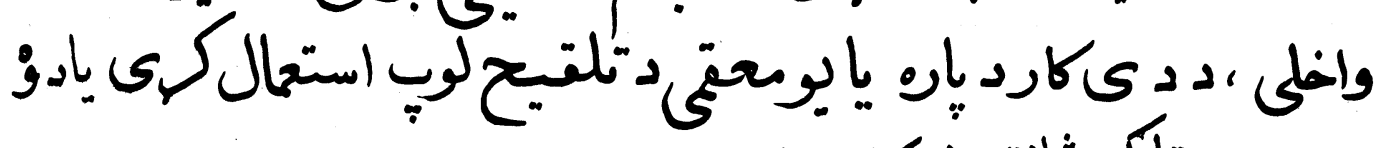

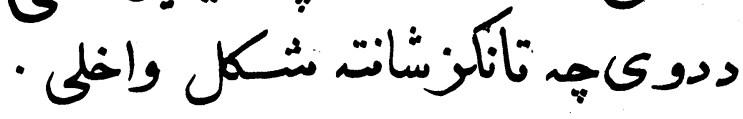

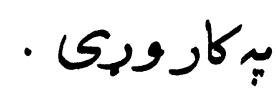




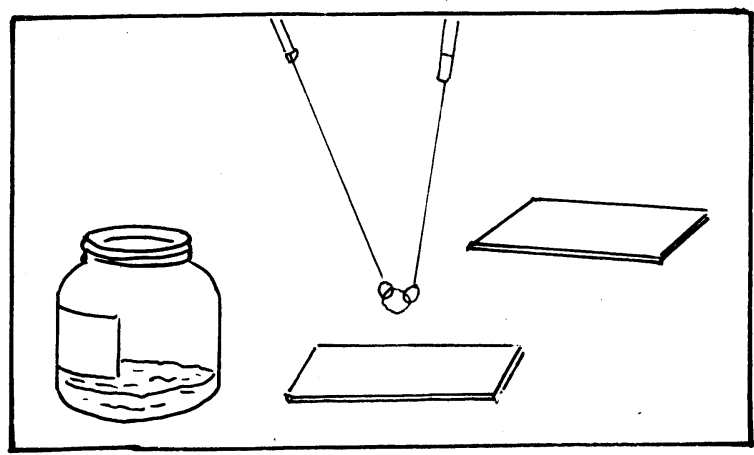

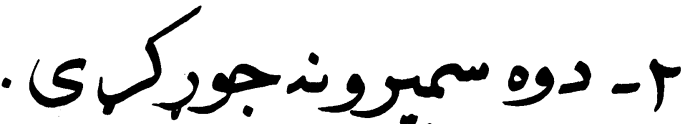

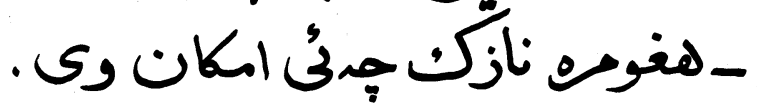

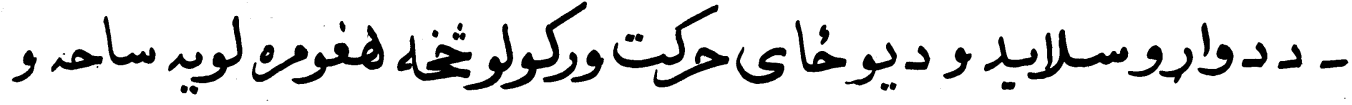

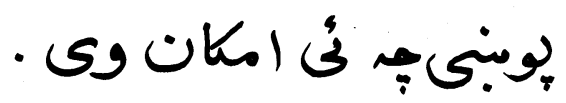

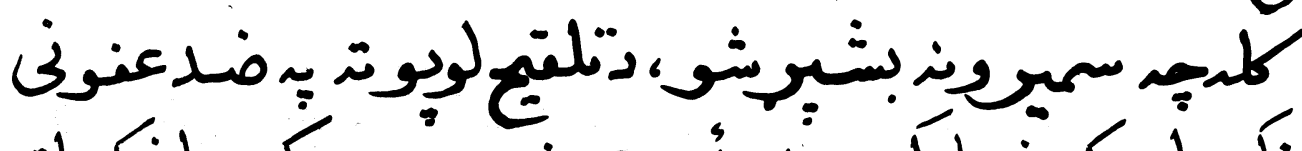

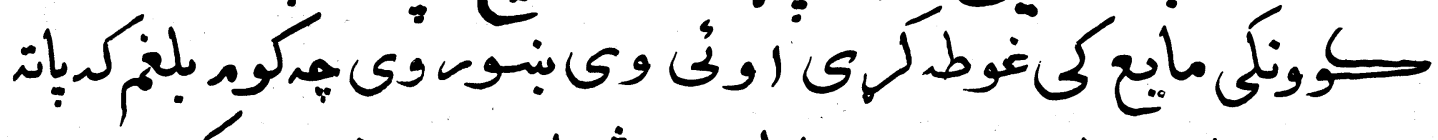

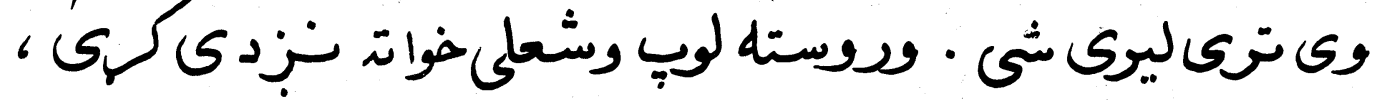

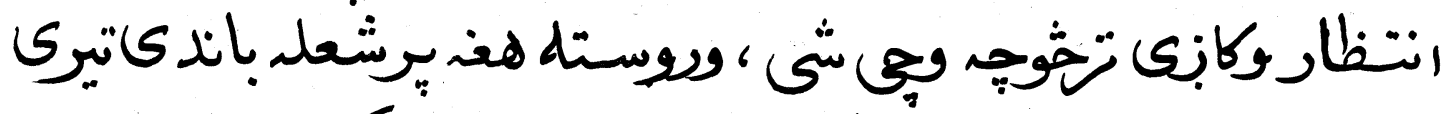

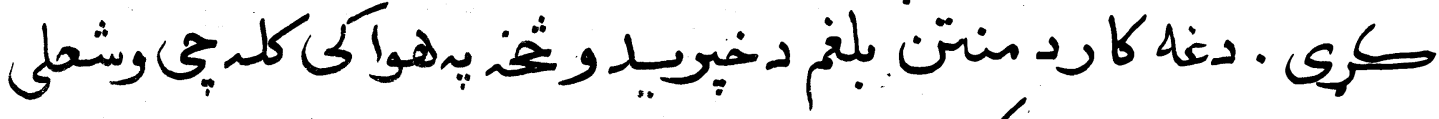

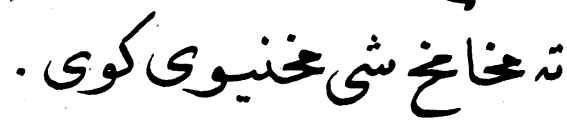




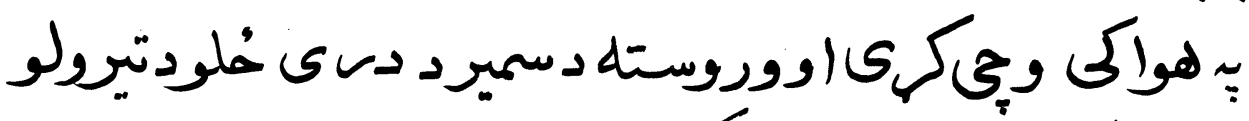

$$
\text { r-تثبيتول : }
$$

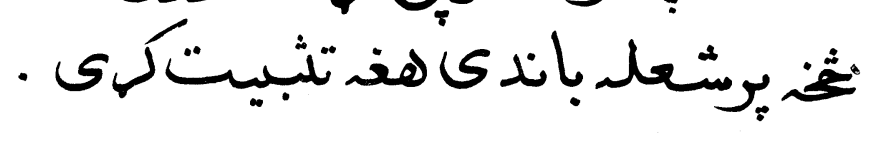

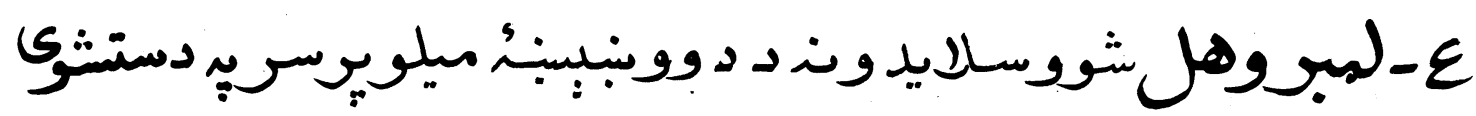

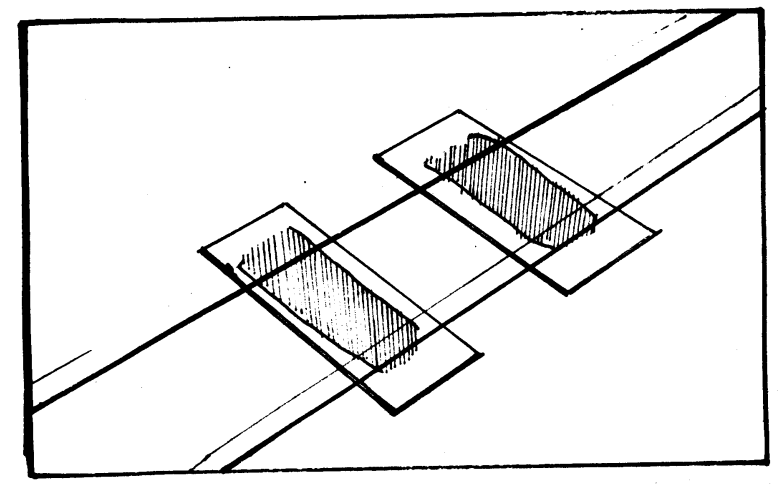

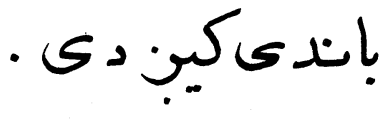
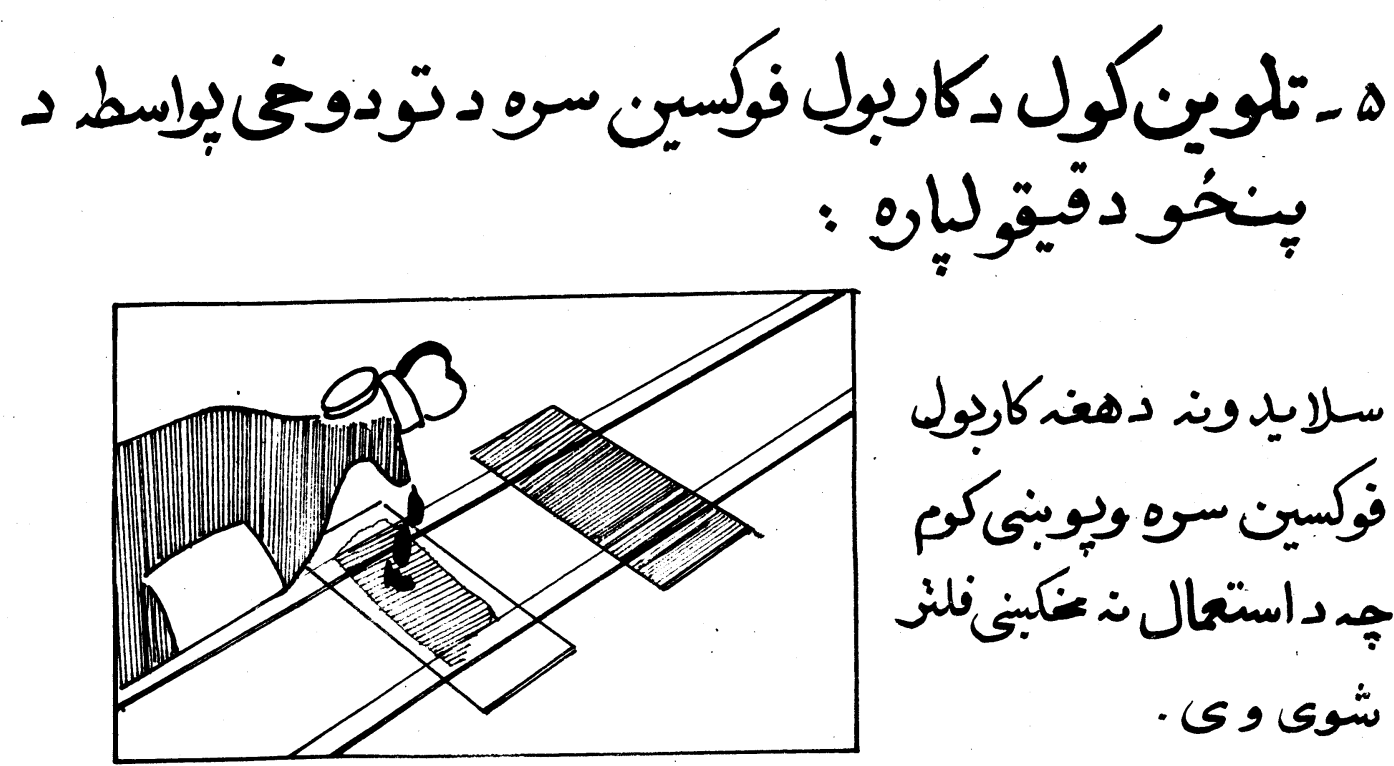

فلاريدون ذهعنكاريول فوكسين سوه ويوبنى دهنم جِ د استحال ن غَكنى فلنُ شَوى وى . دكاتث وول سُواب بِيمِتايليت IrA شوى سبريتكىنيتكرى. 


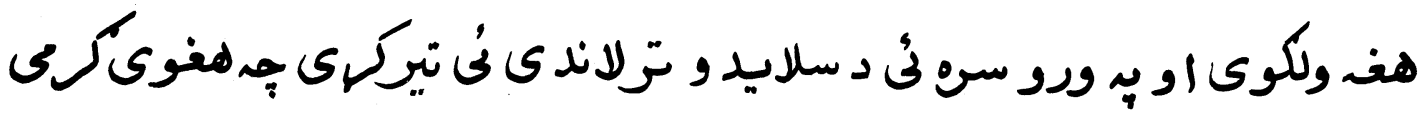
كرى .

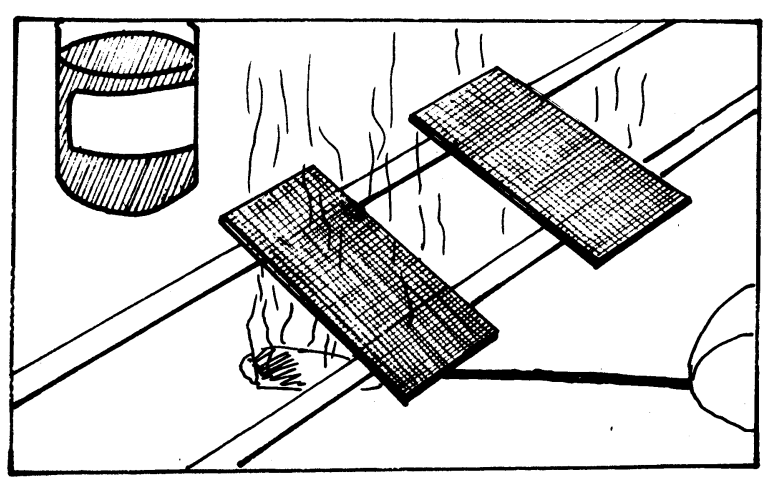

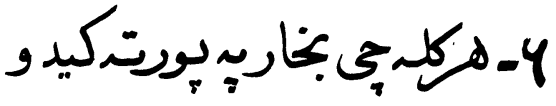

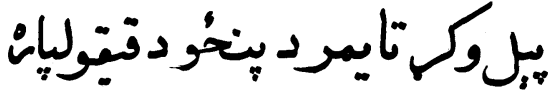

$$
\begin{aligned}
& \text { كيبزى }
\end{aligned}
$$

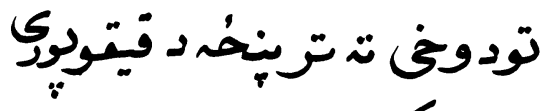

$$
\begin{aligned}
& \text { دوام وركى جـ بخاروليدل }
\end{aligned}
$$

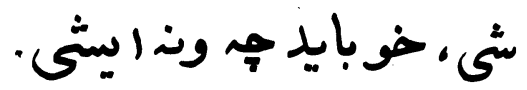

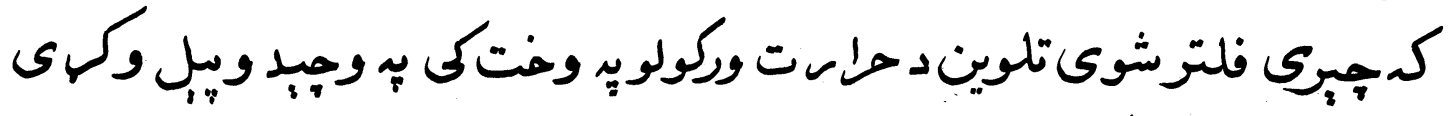

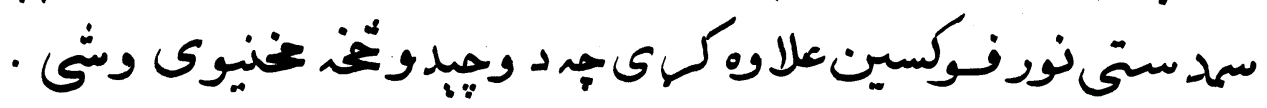

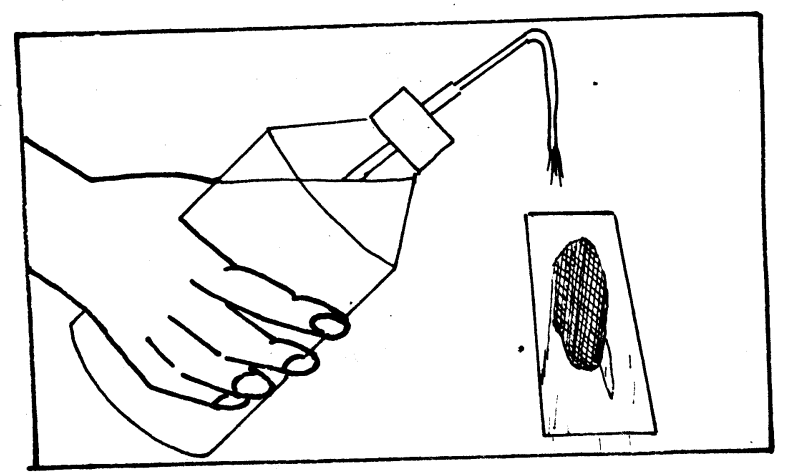

لـ - دمتطرى وبوبواسط

$$
\text { كُمينخَ. }
$$

سوركمى ، سلايدوني تي

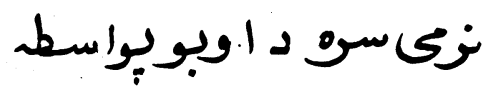

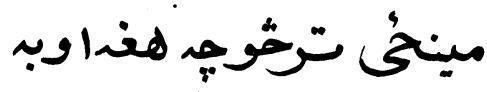

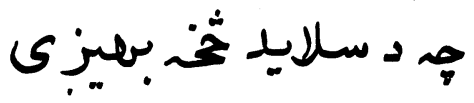

$$
\begin{aligned}
& \text { ببرنّ وى . }
\end{aligned}
$$




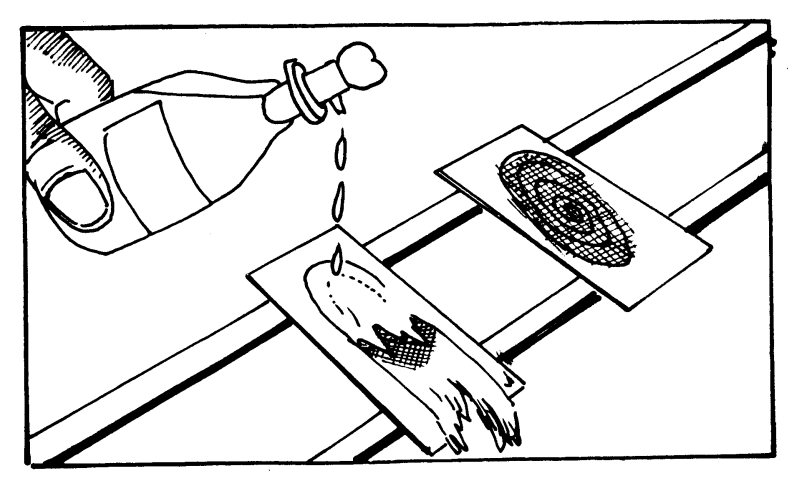

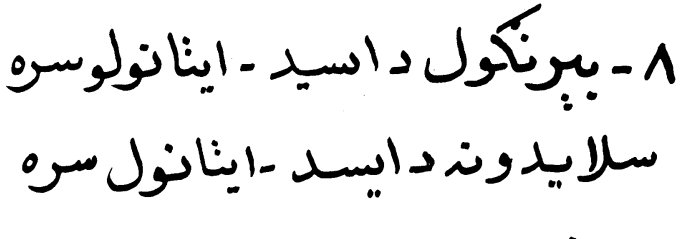

$$
\begin{aligned}
& \text { ويوبنى · } \\
& \text { درى دقيتى نى كبنيزي دى . } \\
& \text { سلايدوند نل دعادى اوبو } \\
& \text { يواسطر ومينخى او اوبنىنتش }
\end{aligned}
$$

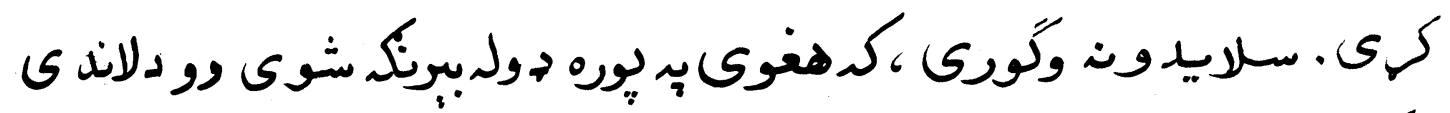

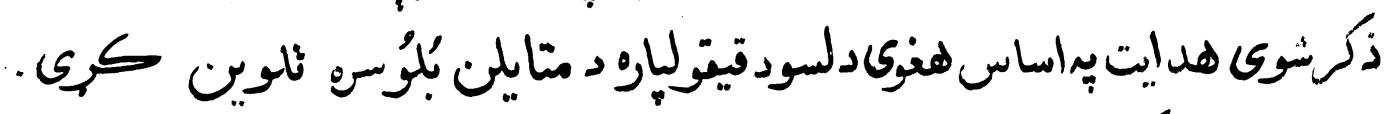

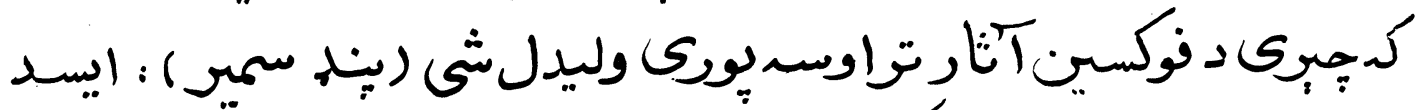

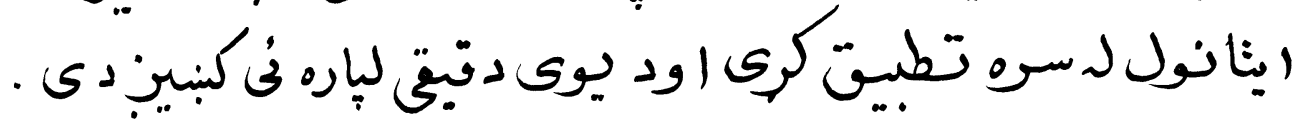

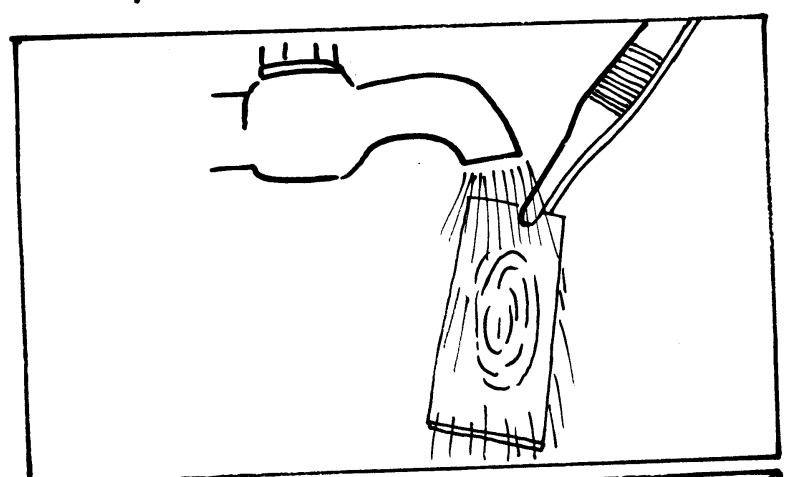

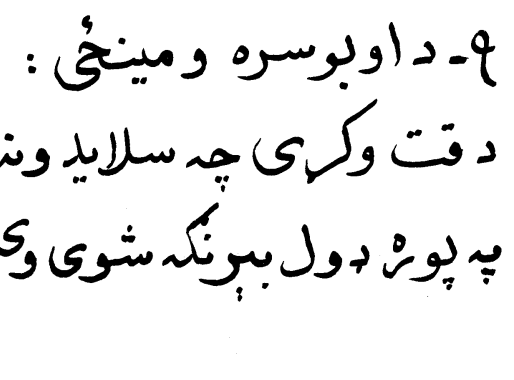

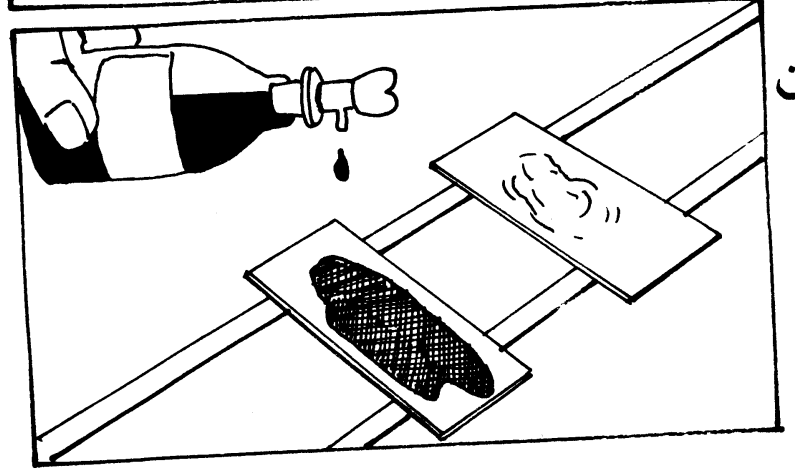

. إو - تلوين كول دمتايلن.

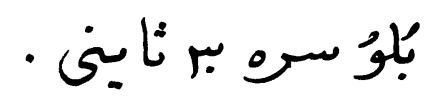

سلا يل وند ددى تلوين

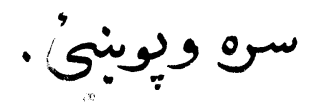




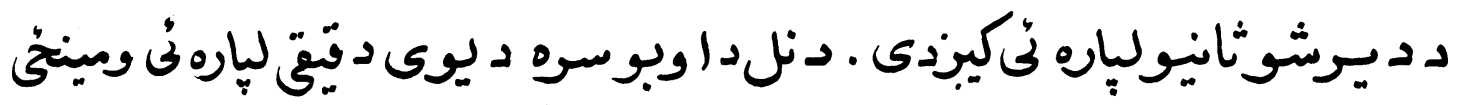

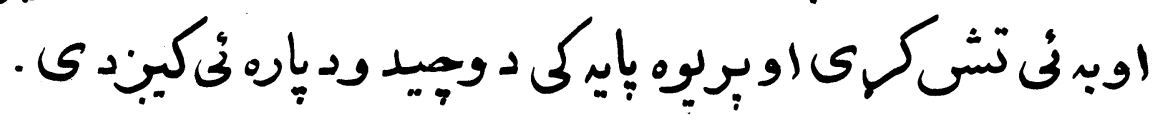

$$
\text { د مسلايد معاينكول : }
$$
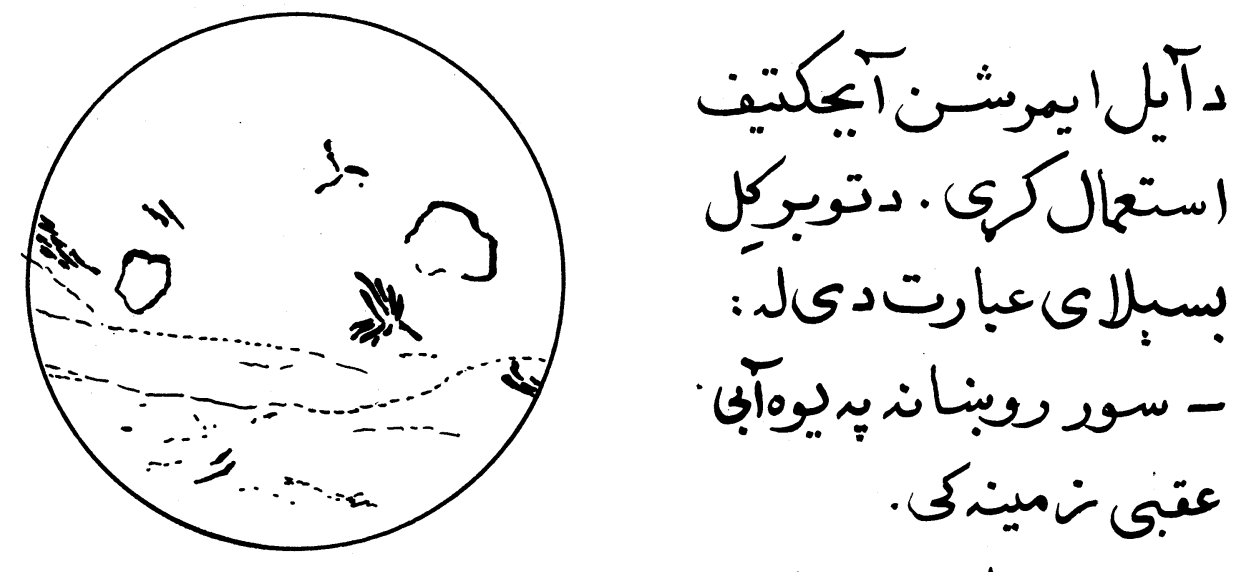

- مستقيم اخنيت مايل

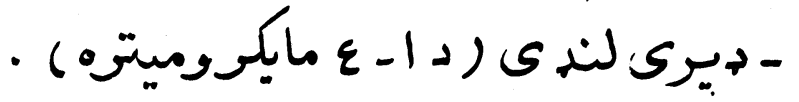

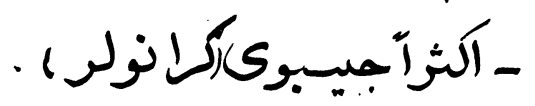

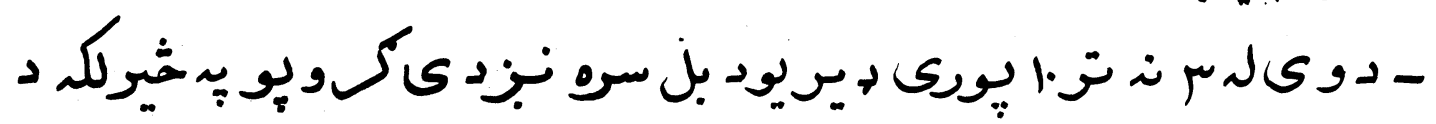

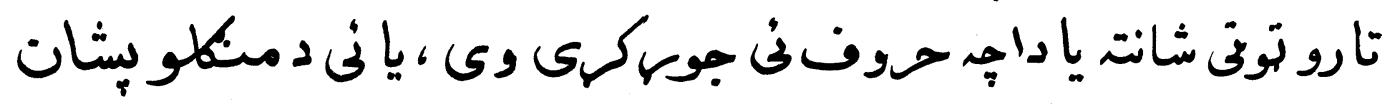

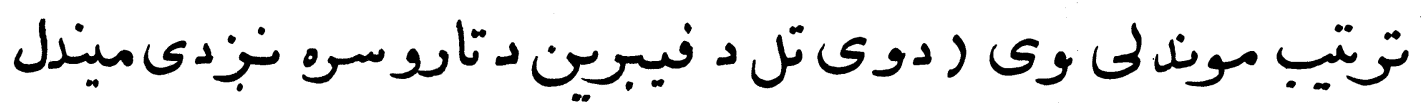

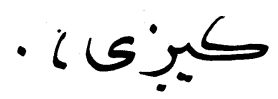




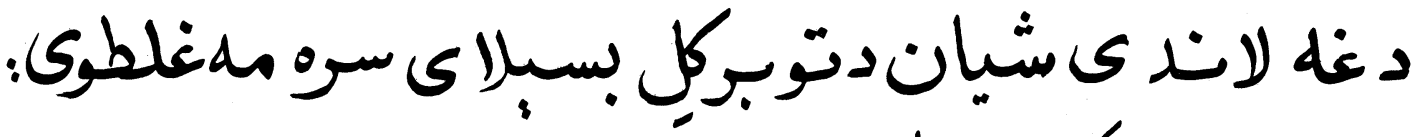

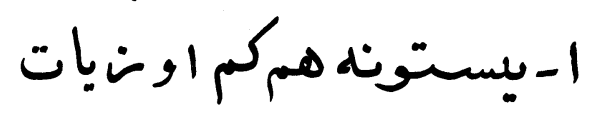

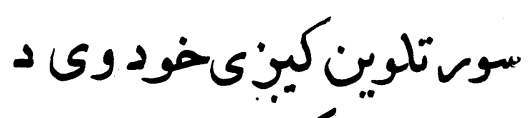
تودوخ وركولوسره دلويو

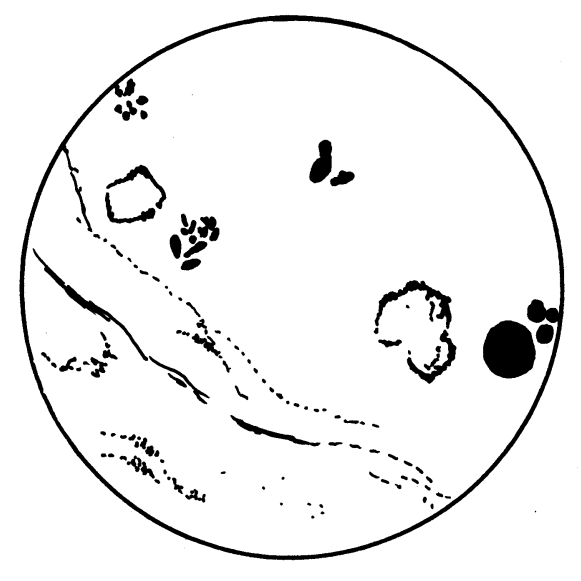

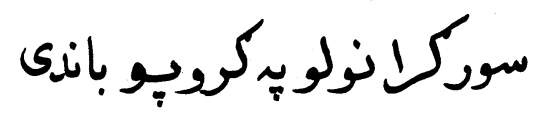

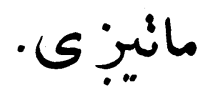

ب ا- د دتلوين درسوباتو داغونز (كلمجيم سلايد

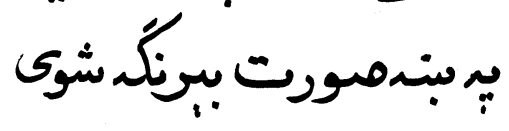

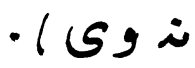

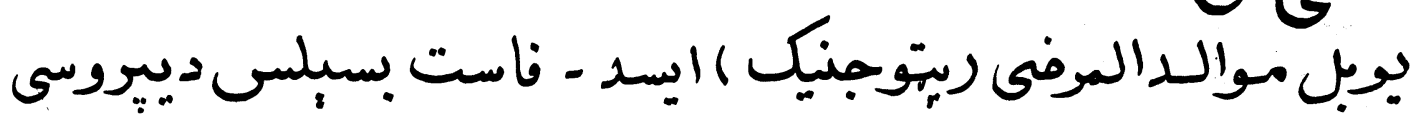

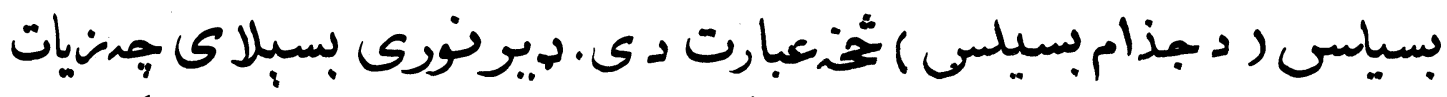

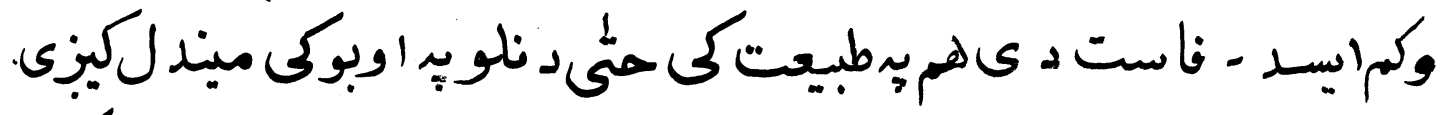

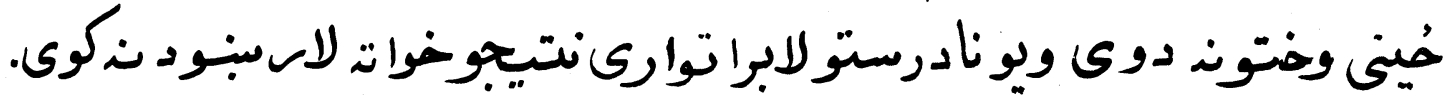




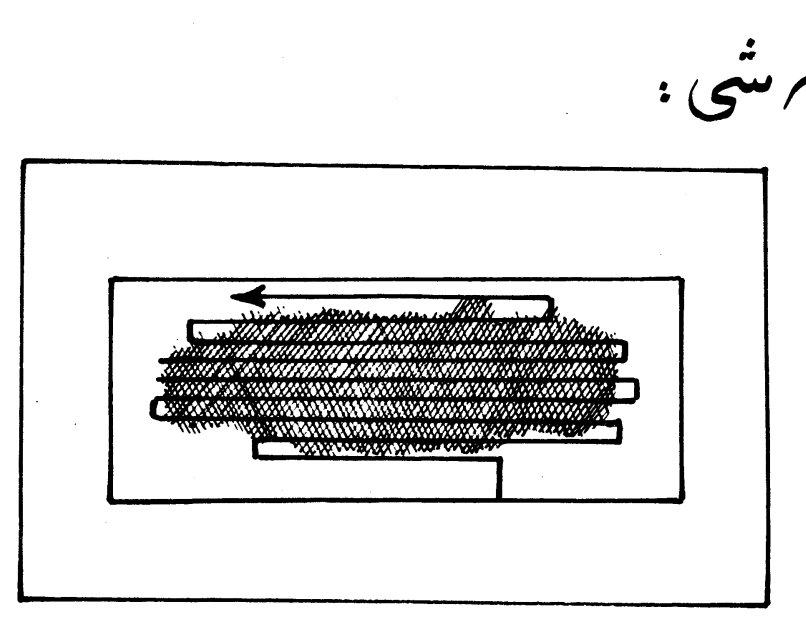

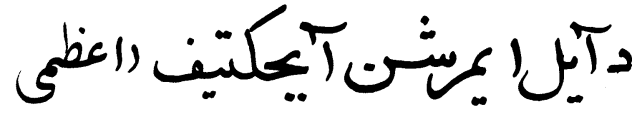

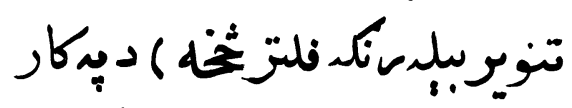
ويوسسب اولنى سلايد بمكمل ديكل

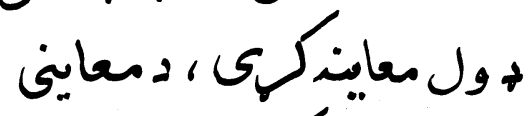

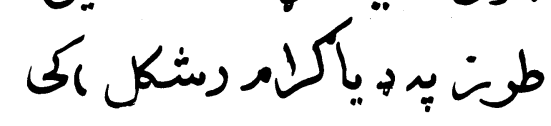
نبودل شوى . نيأ

\section{منتى سلايد}

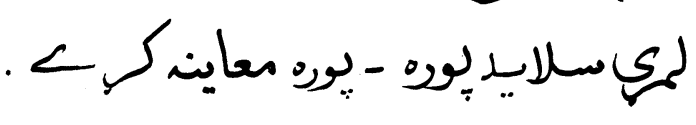

(.ادقيقى) ، وروسته ددويم سلايد

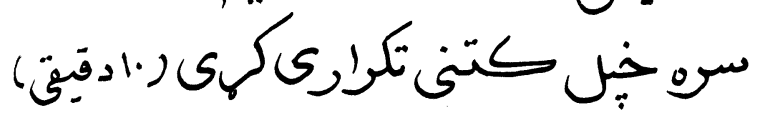

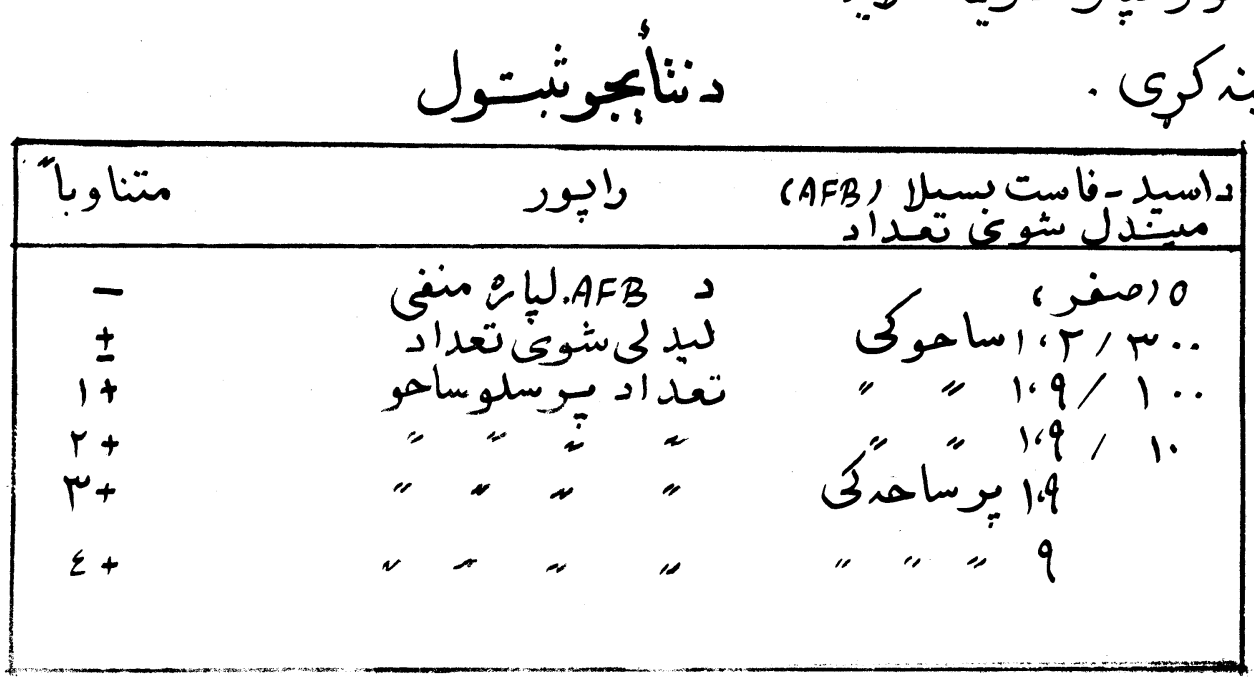

كلدجدس اليسد- فاست

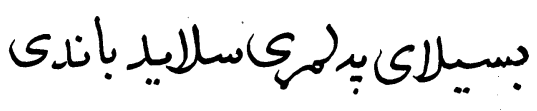

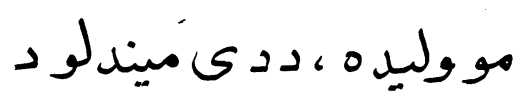
تانيسكولو لبإِ د ويه سلايد - ماين كئري 


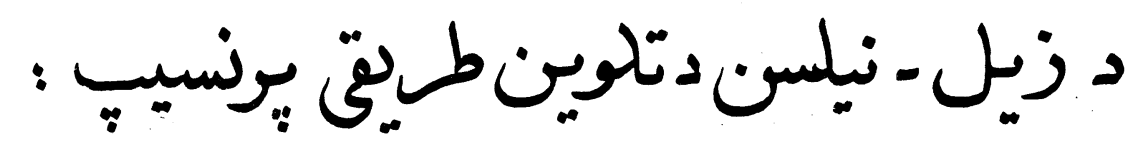

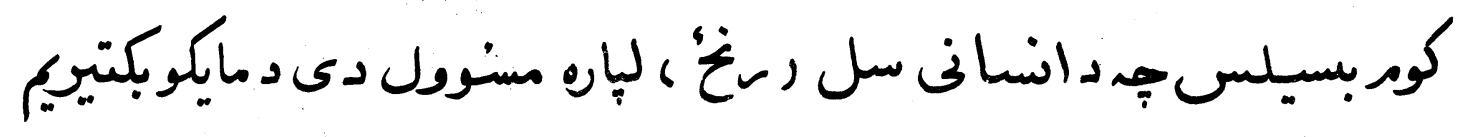

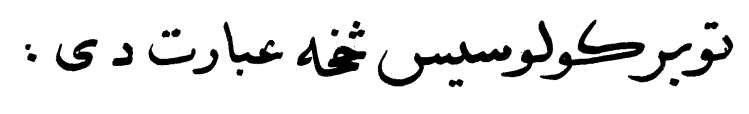

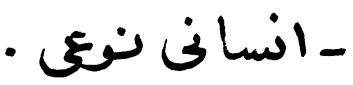

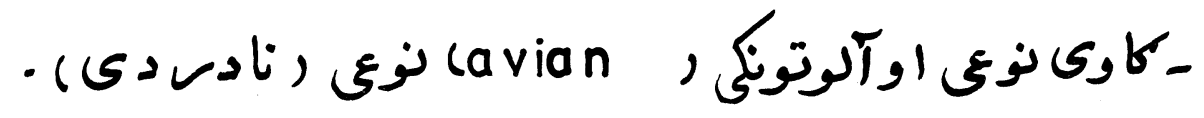

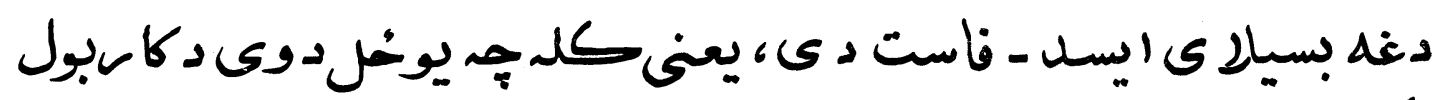

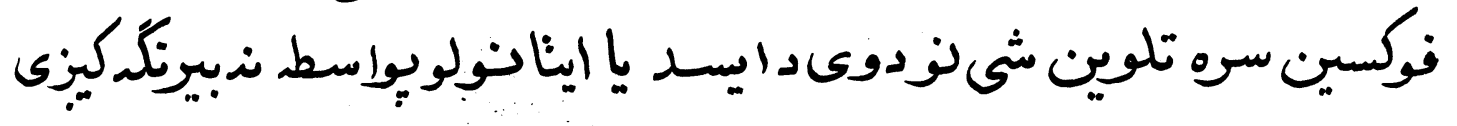

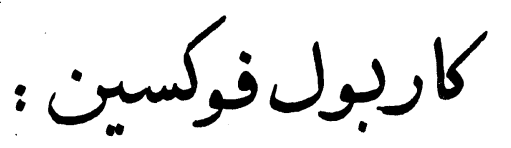

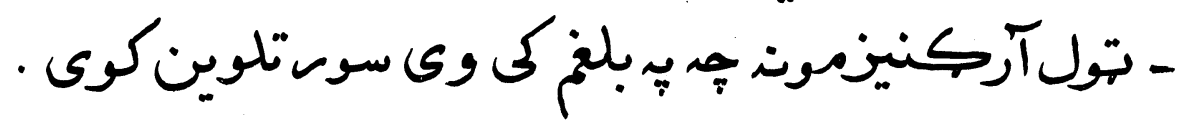
argojistitiod

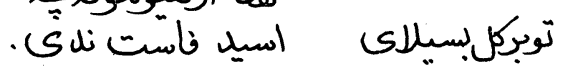

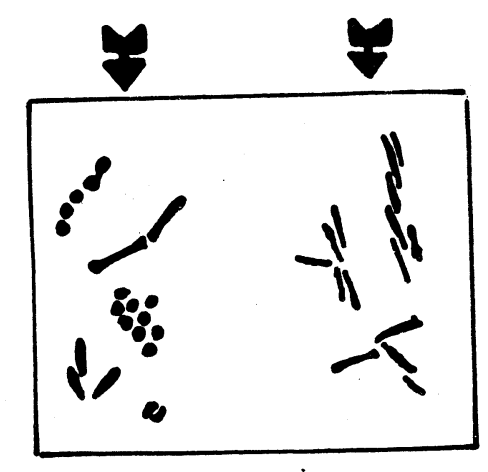

$1 \varepsilon \varepsilon$ 


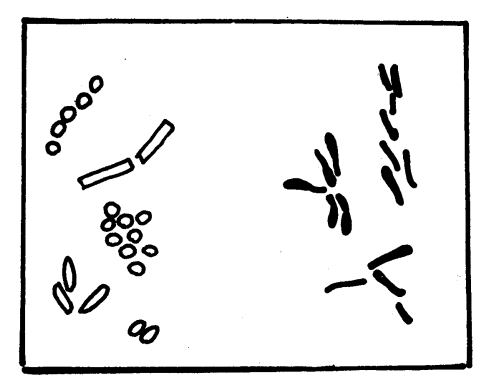

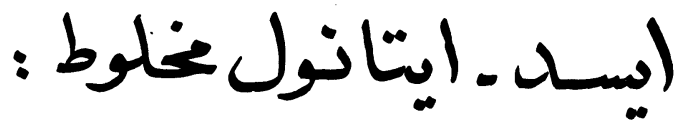

$$
\begin{aligned}
& \text { - تولآسكنيزمونا اويجلوى } \\
& \text { عناصريرت د ايسد - فاست } \\
& \text { بـينلاى (توبركلبسيلاى) }
\end{aligned}
$$

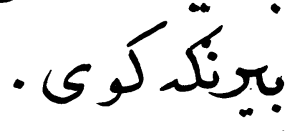

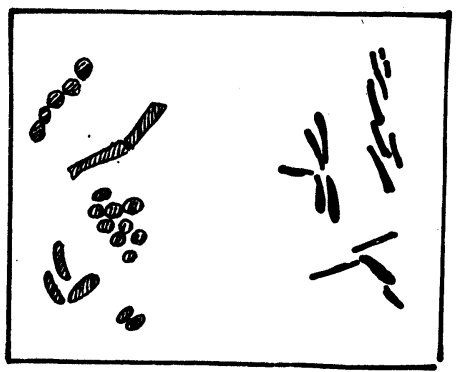

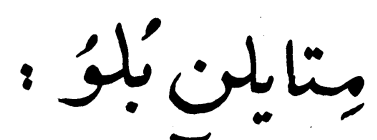

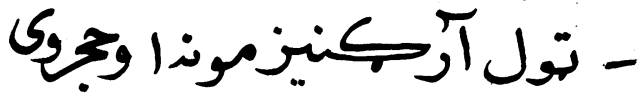

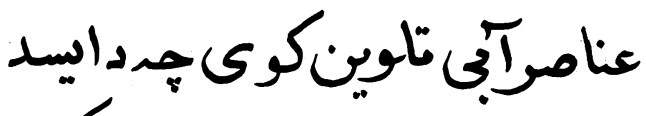

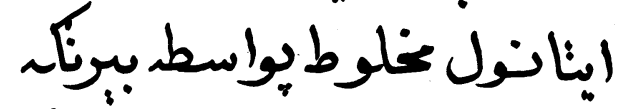

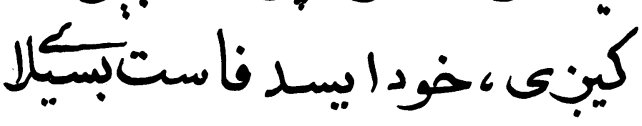
سوريات كيبزى.

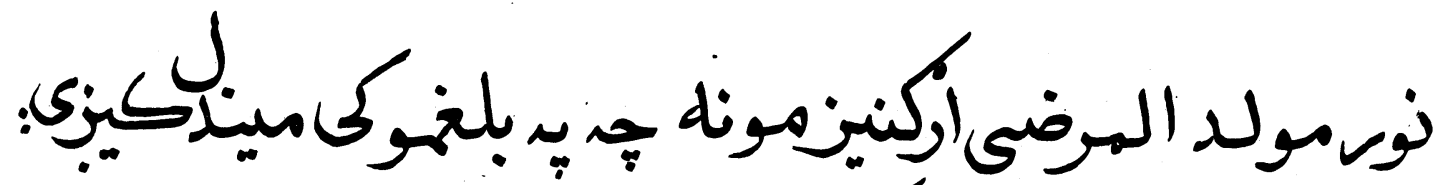

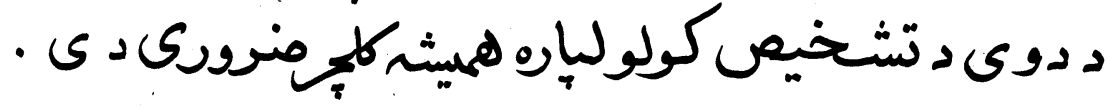

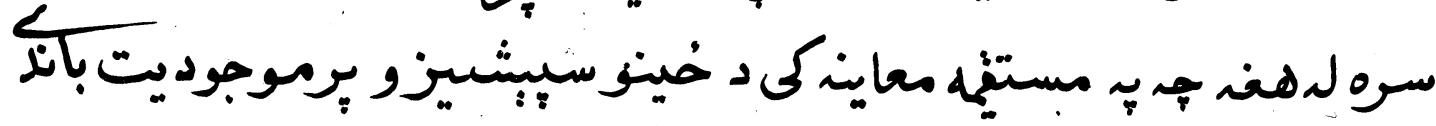

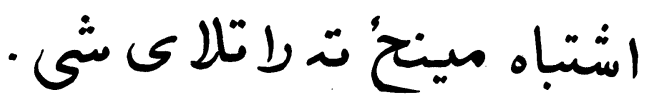


(Pneumococci ) (الن، نيموكوكساى )

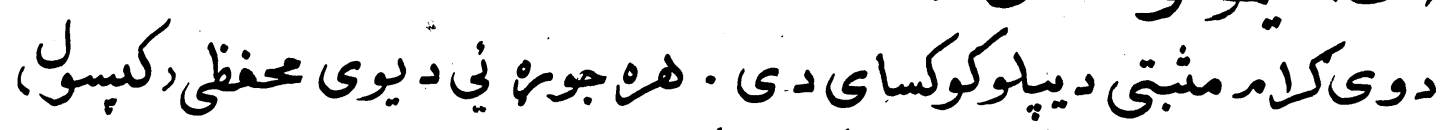

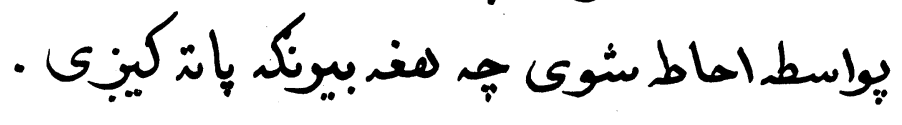

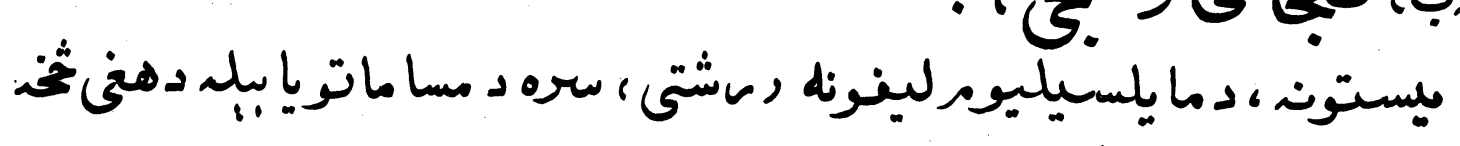

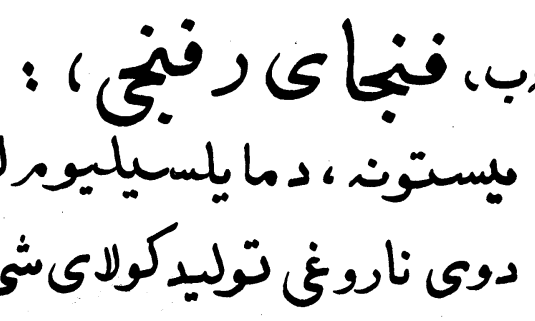
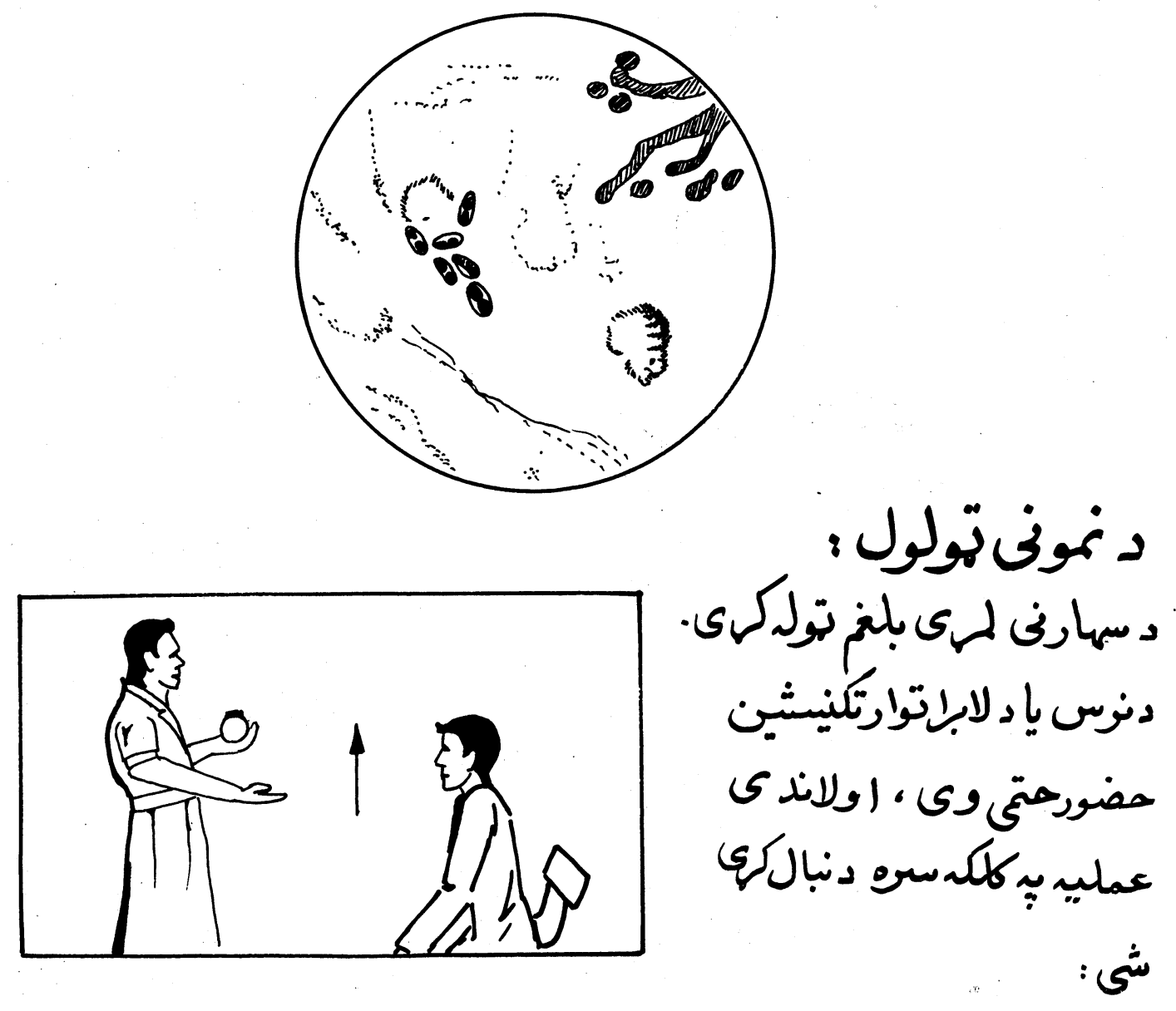


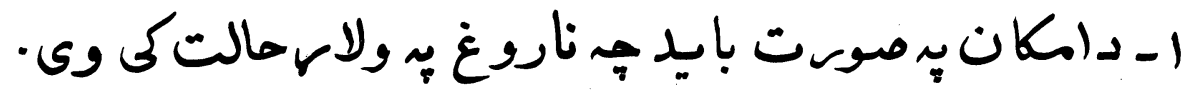

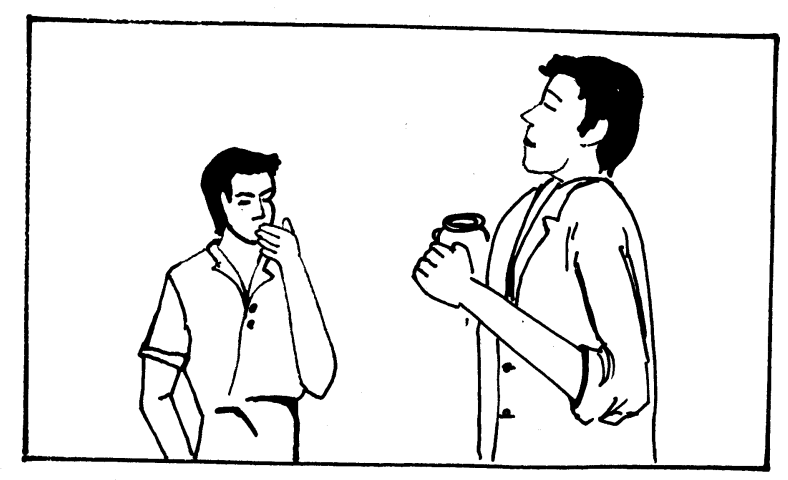

$$
\begin{aligned}
& \text { r - بايد جِ هذ يوه زوره } \\
& \text { تنفس وكهى توخوجي } \\
& \text { خَّ سنبى دك كرى }
\end{aligned}
$$

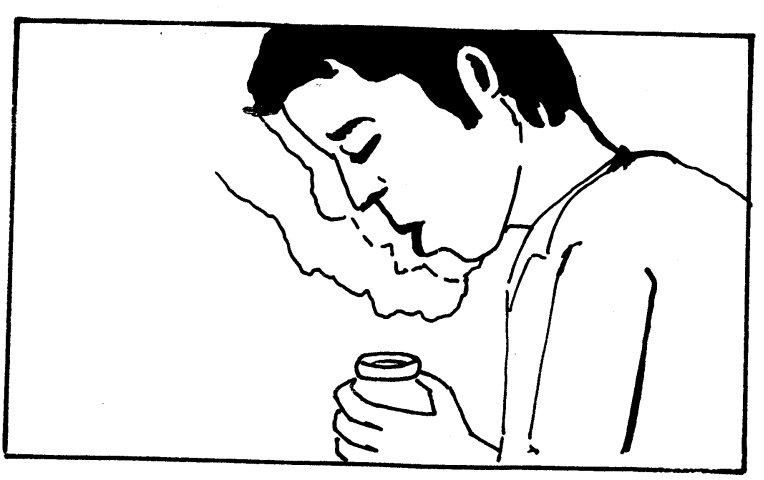

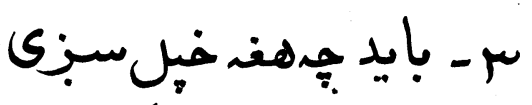

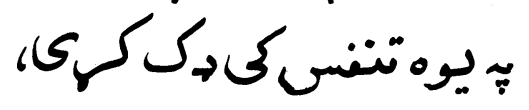
ا وهغومه خورتخى جينى

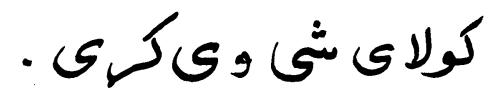

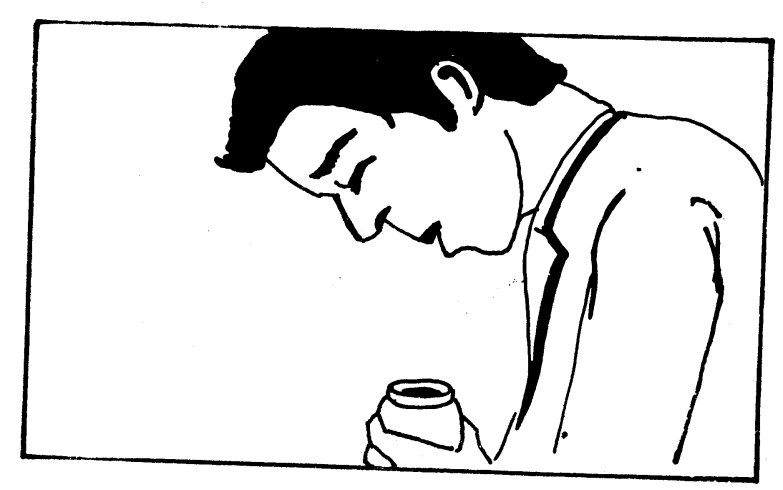

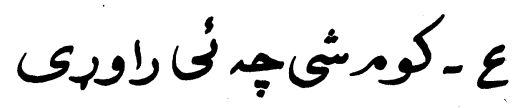

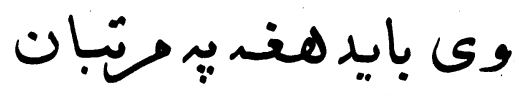

فُ توكي . 


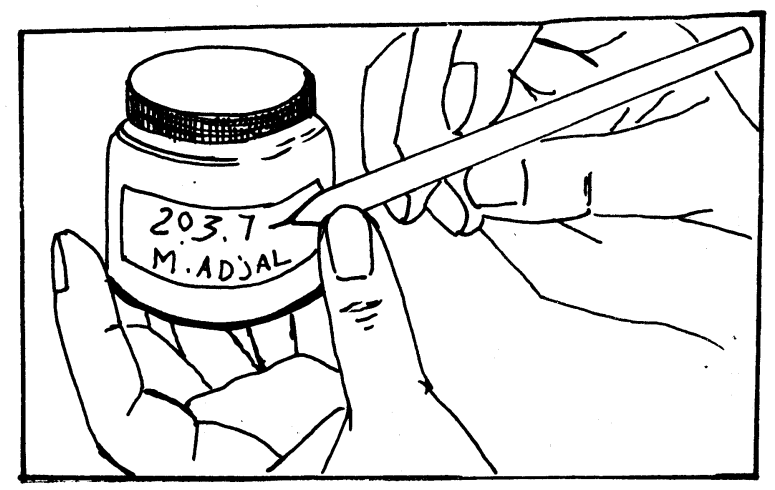

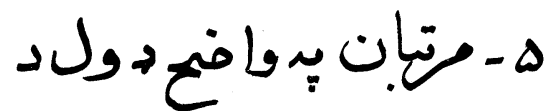

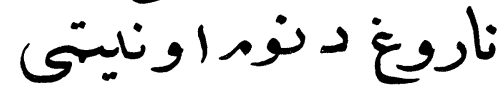

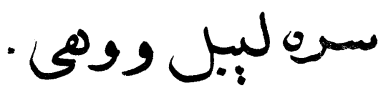

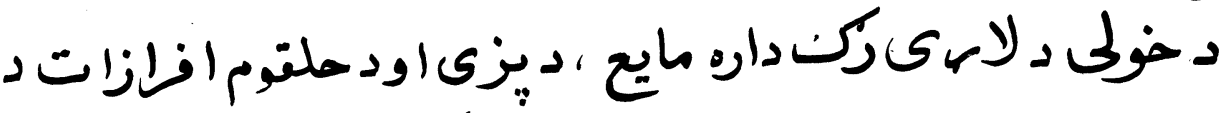

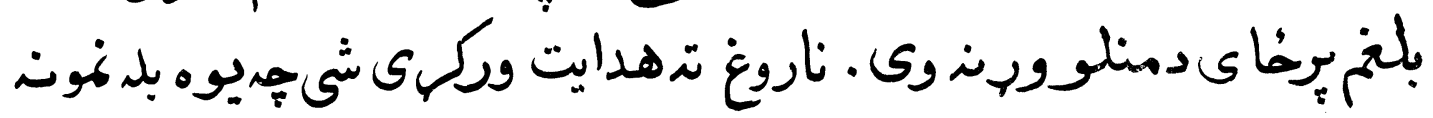

$$
\text { توليدكاندى. }
$$

\section{د ن تِولولو نه وروسته :}

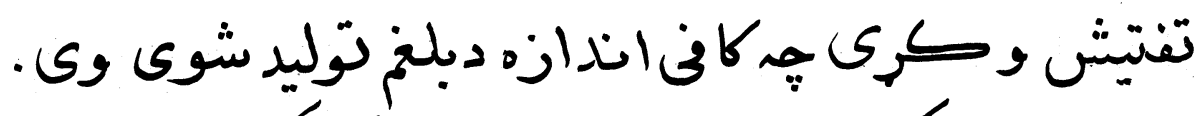

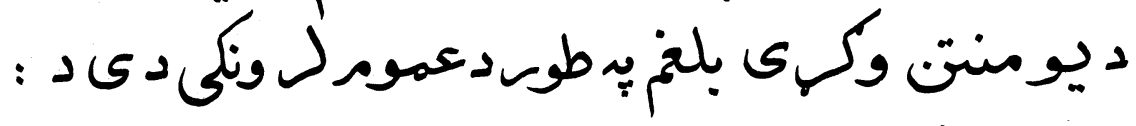

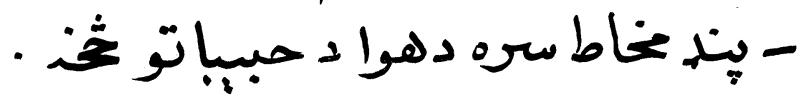

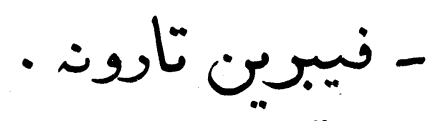

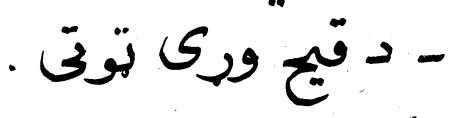
ـ كلدكلد وينى نصواريى بجن وكون. 


$$
\begin{aligned}
& \text { دريمه برخ } \\
& \text { عـ د اد راربول، آزّموينه } \\
& \text { اـ د ادراردنمونى تولول اومنظه ئي : }
\end{aligned}
$$

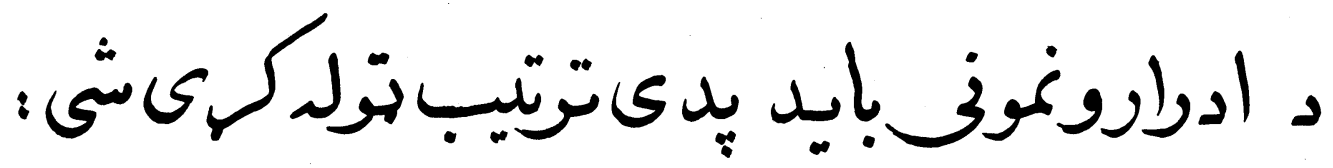

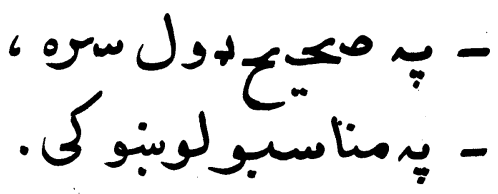

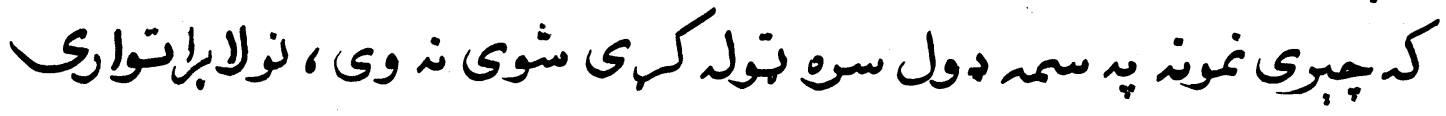

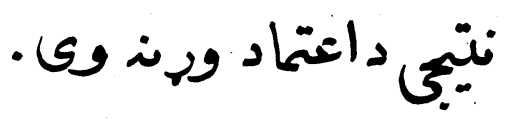

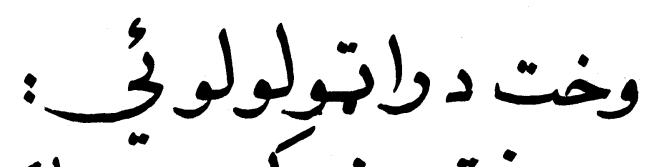

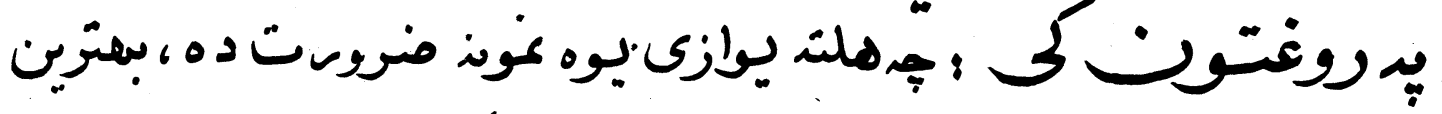

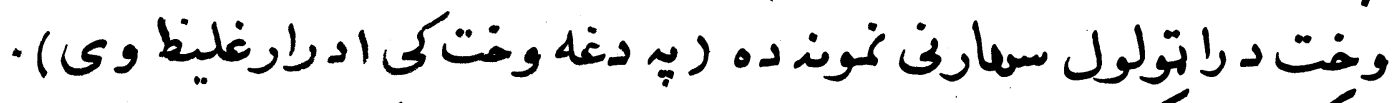

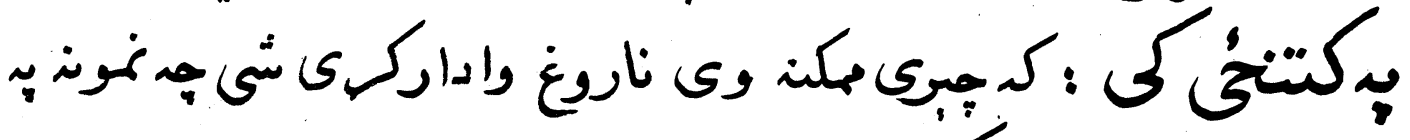

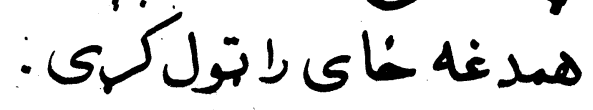




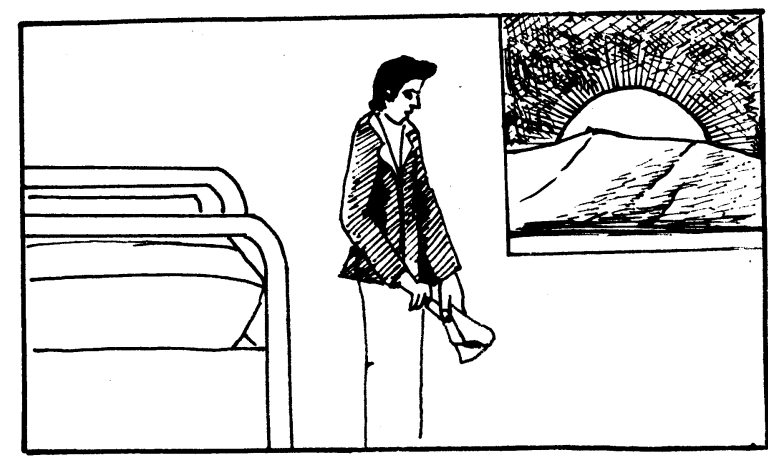

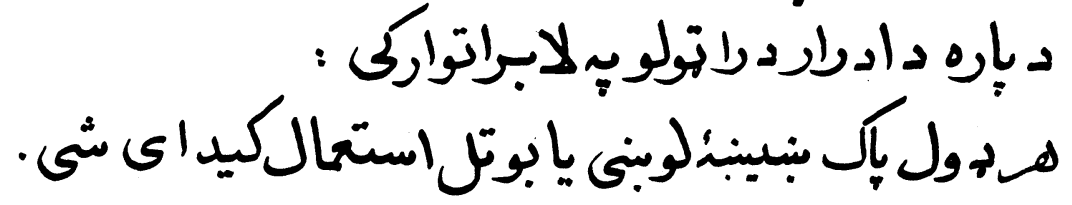

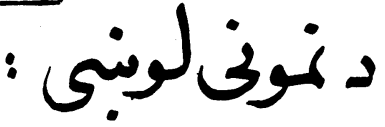

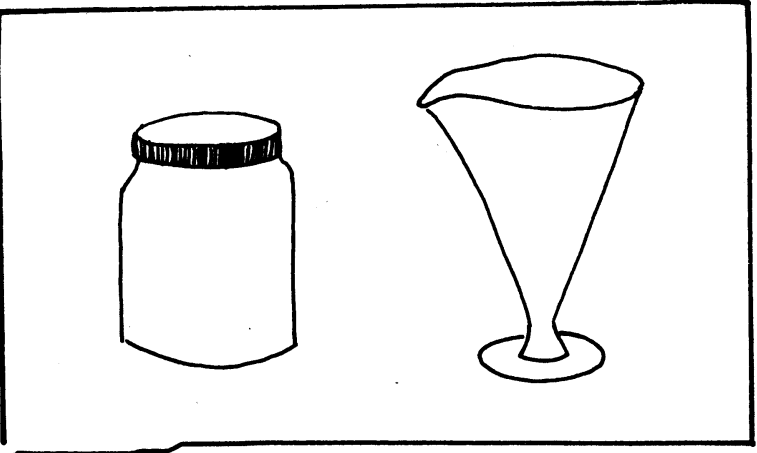

مقد ار د ادرارجى بايد تولى كيى شيى :

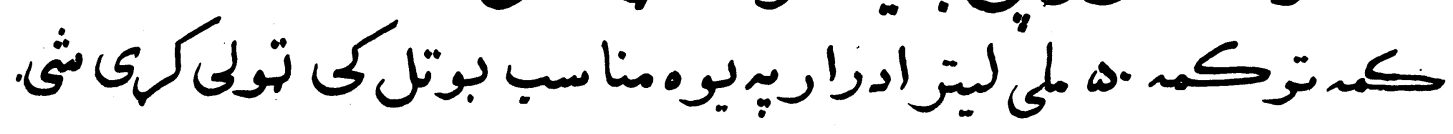




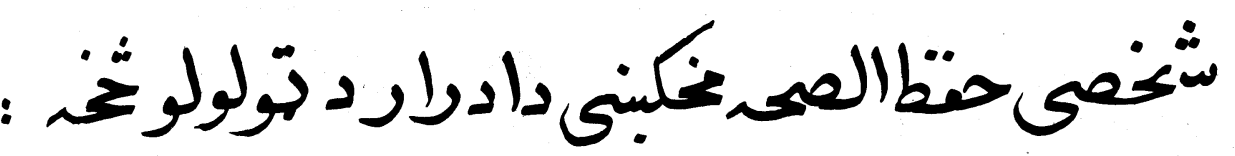

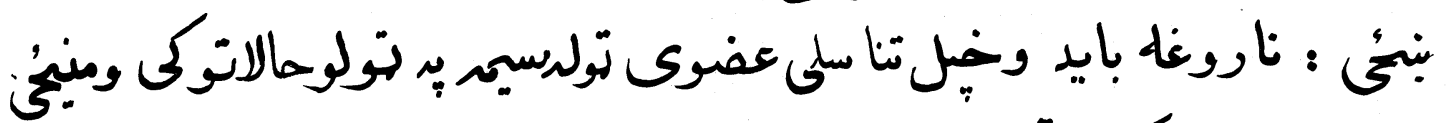

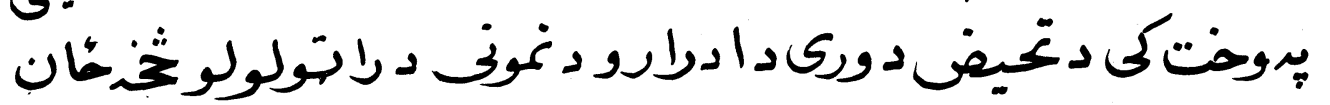

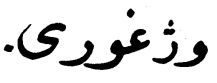

نارين : يوازى دبكتريالوبى مطايناتولياره بَريول ضرورى دى.

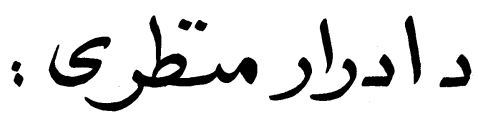

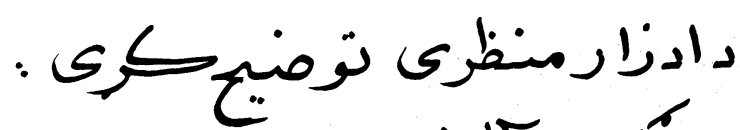

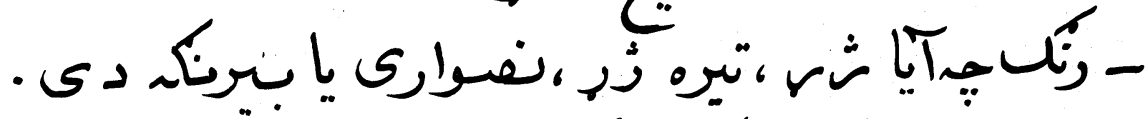

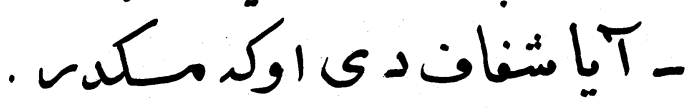

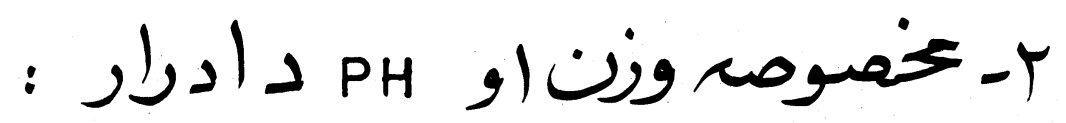

كضوص وزن ( SPECIFIC GRAVITY,SG )

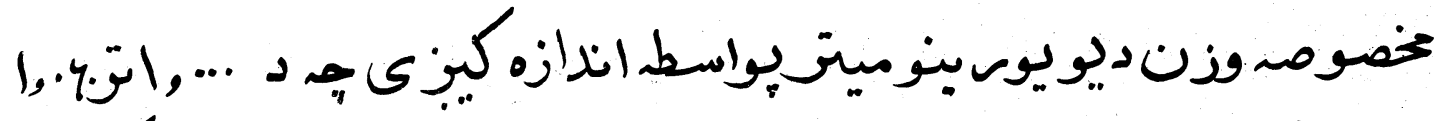

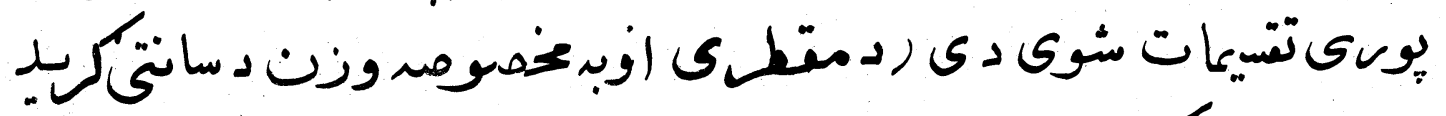

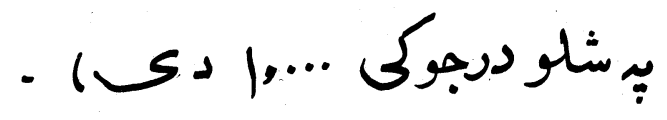

$|2|$ 
د د ى آزمايبنت ارزينت :

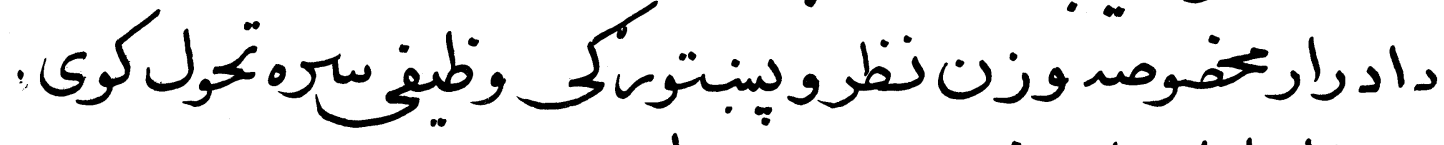

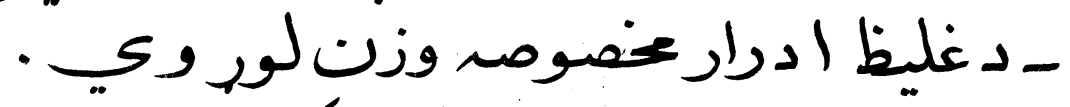

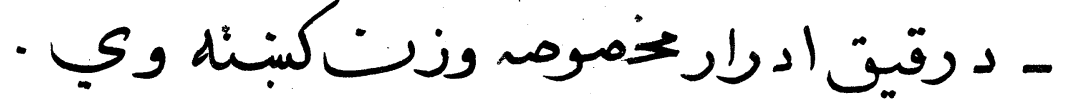

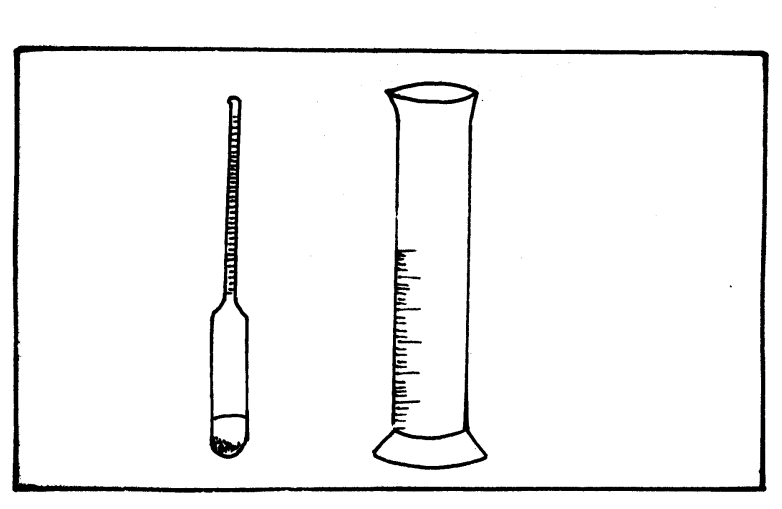

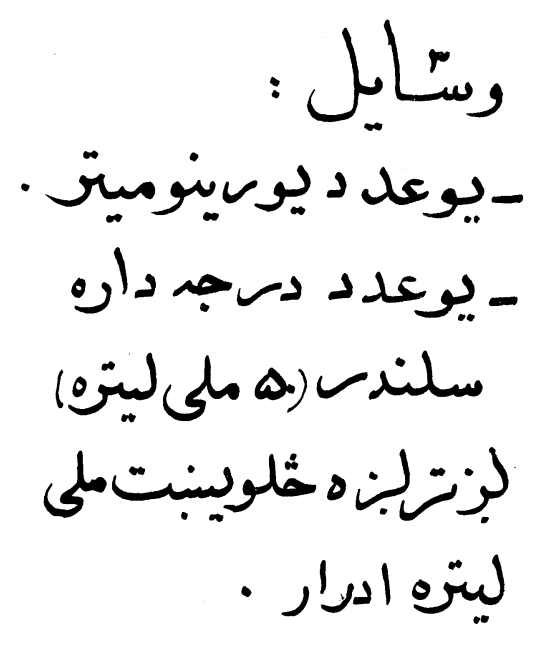

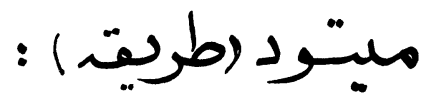

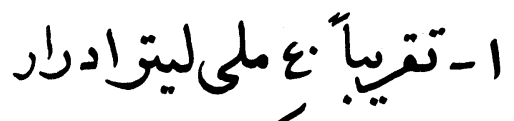

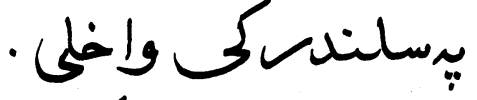

r-يورينوميتريبكارى

سوه بي ادراسوبك داخل

كرى اونىخوشيىكي

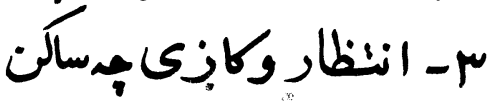

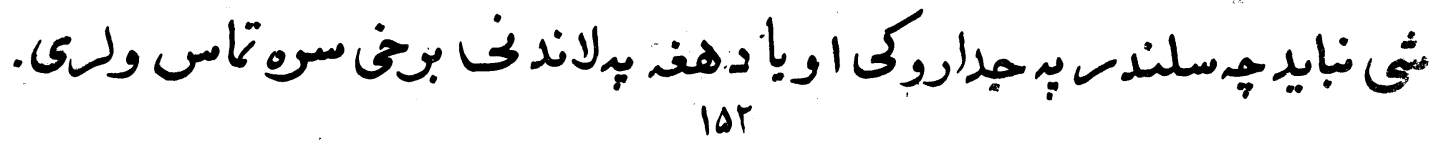




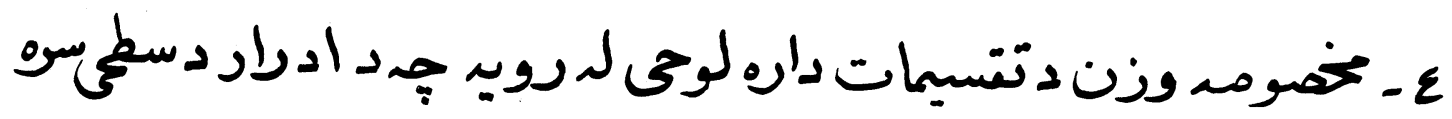

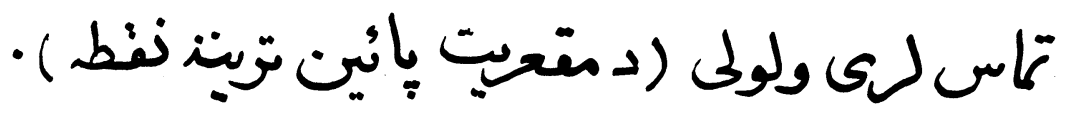
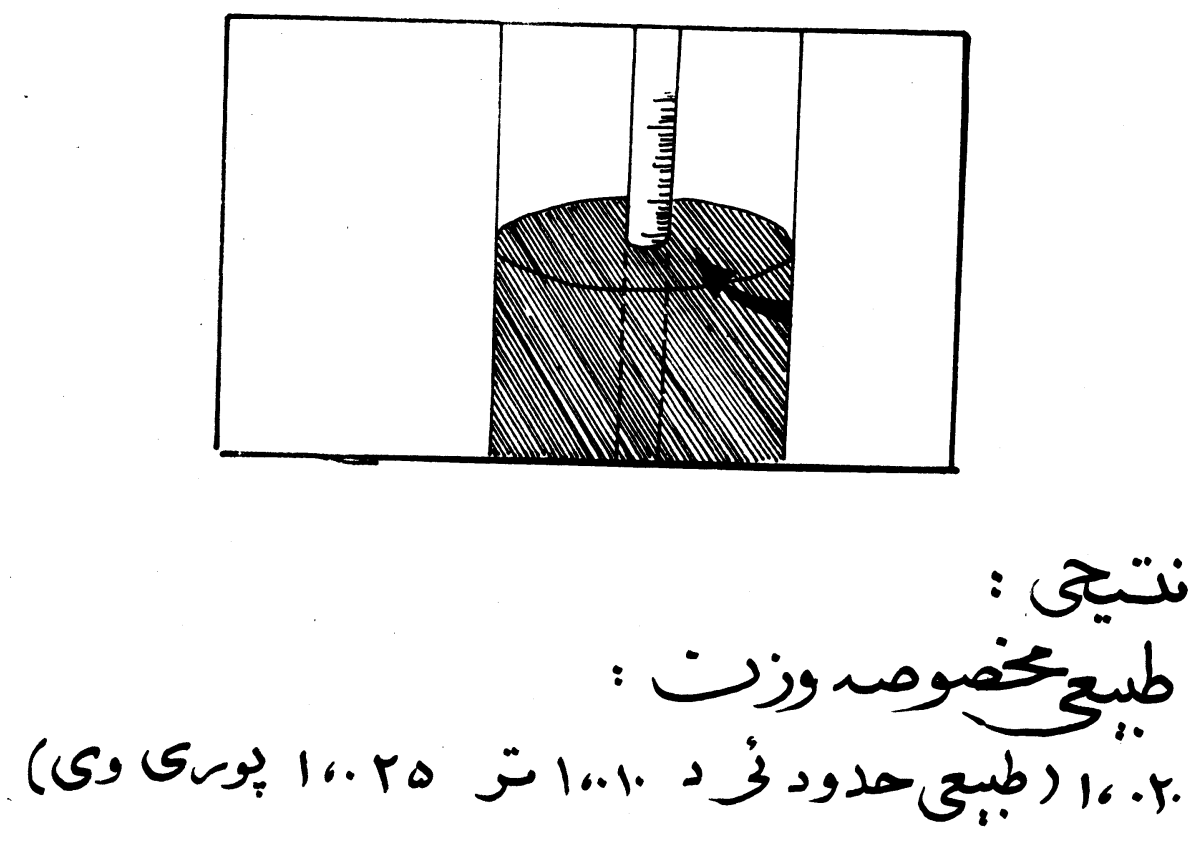

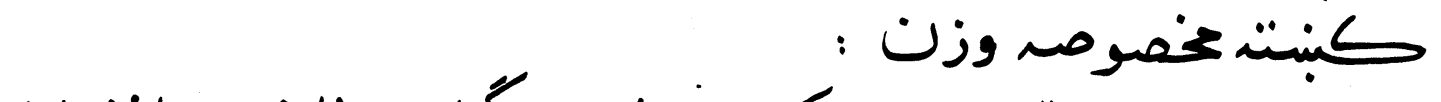

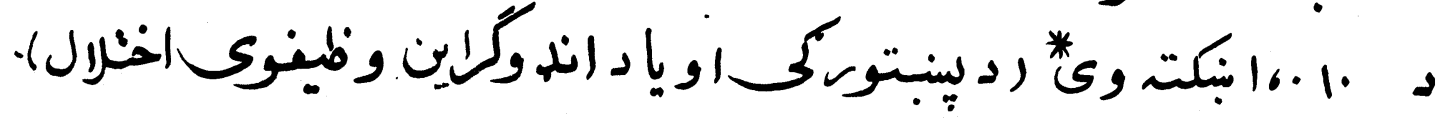

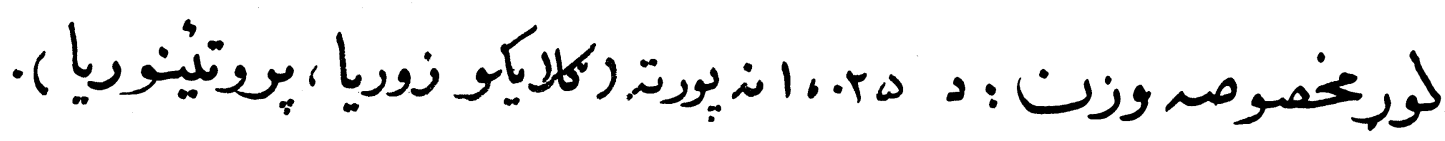

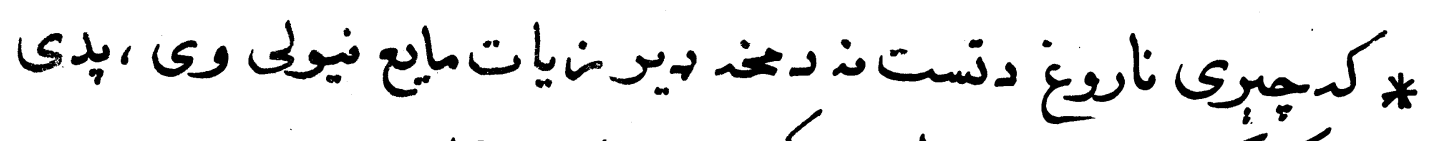

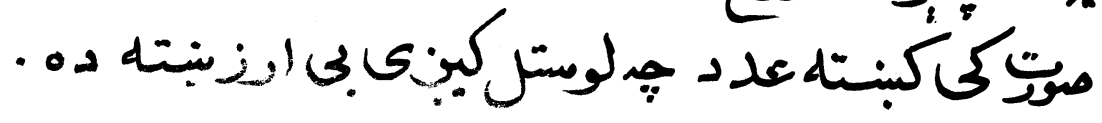




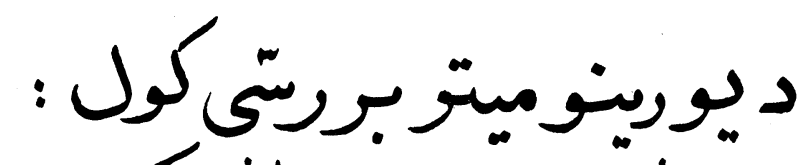

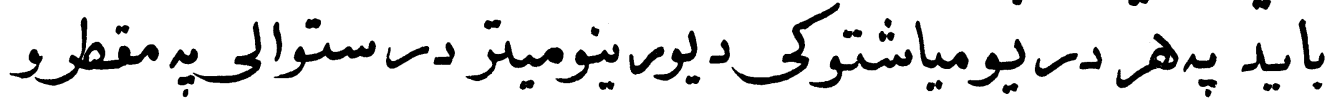

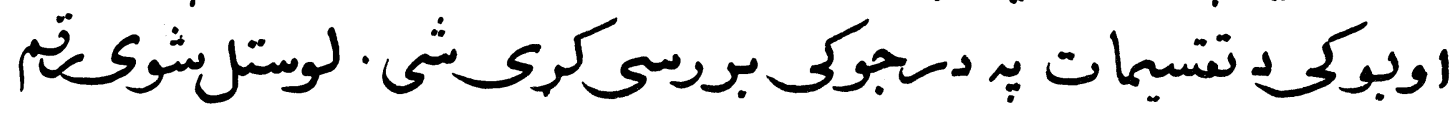

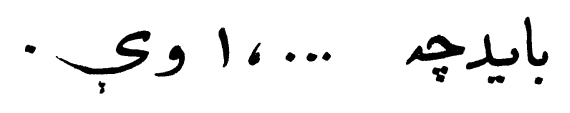

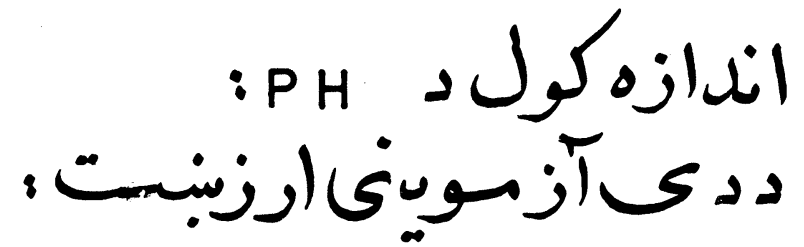

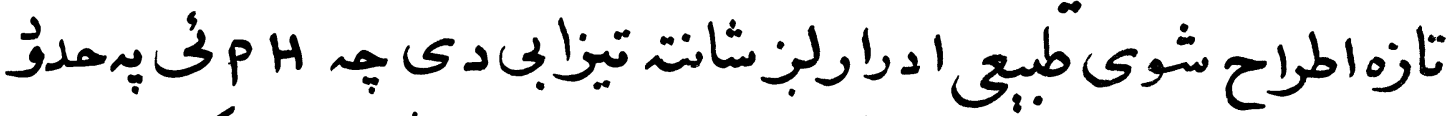

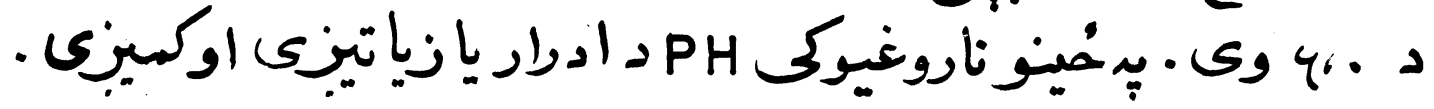

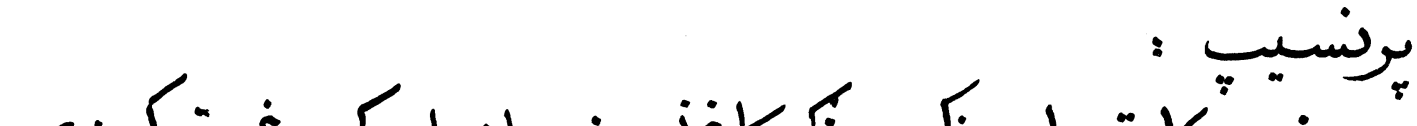

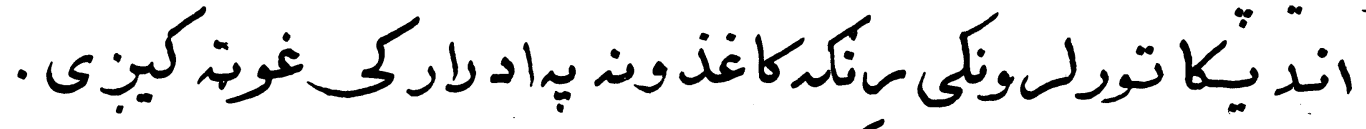

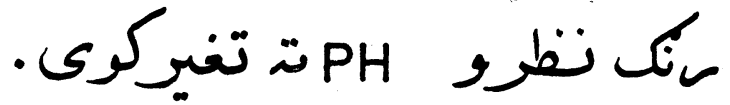

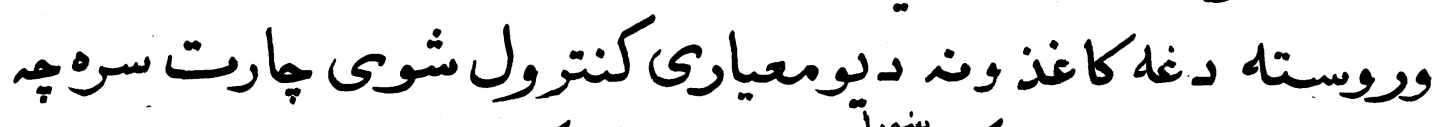

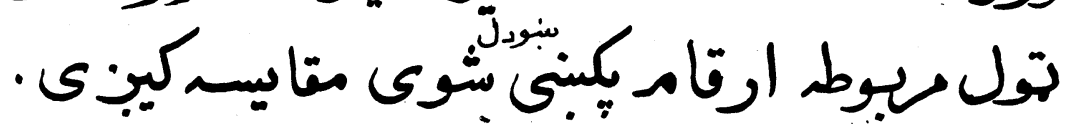

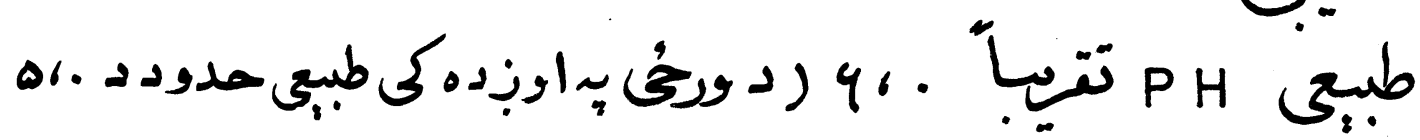

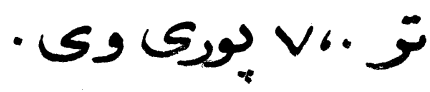


تيزابج

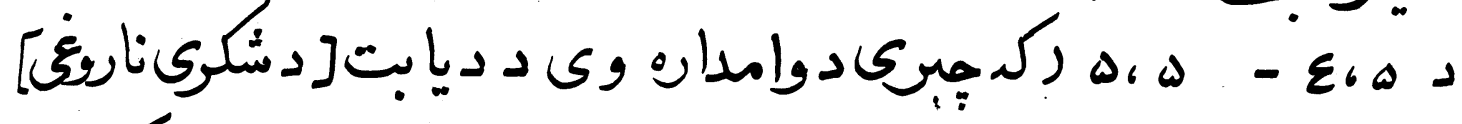

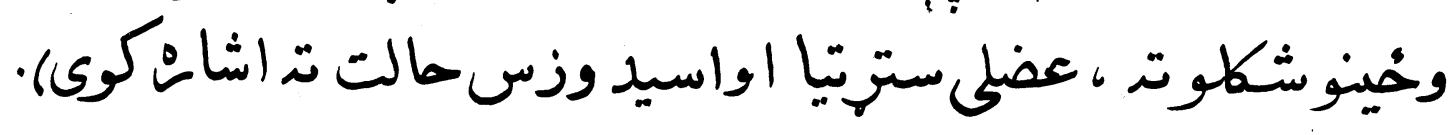

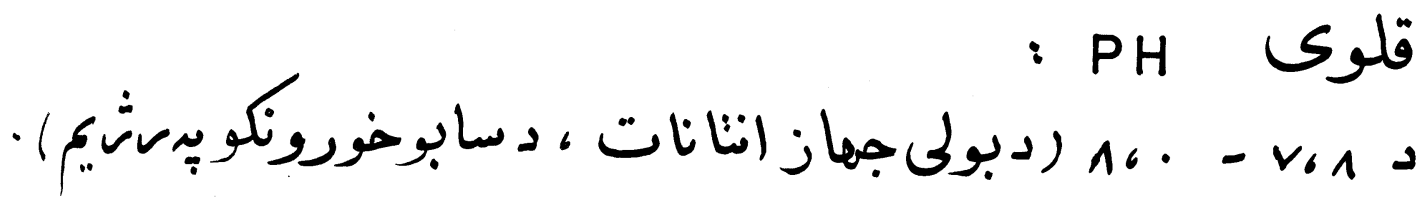

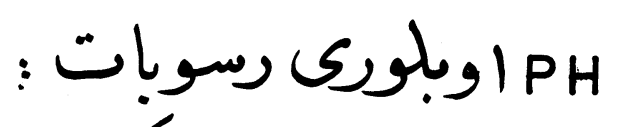

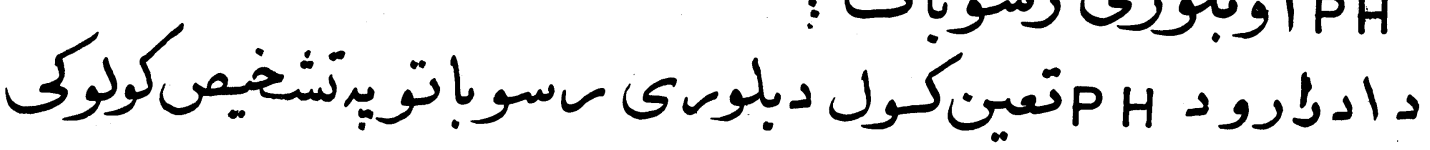
كتورى دى ك.

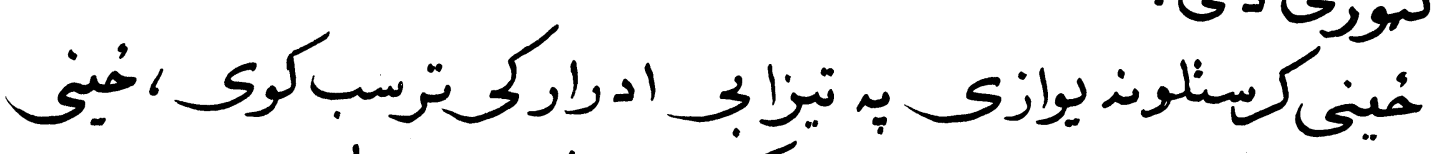
نوريوازيى يَ قلوى ادراركى . دمثال بِ دول :

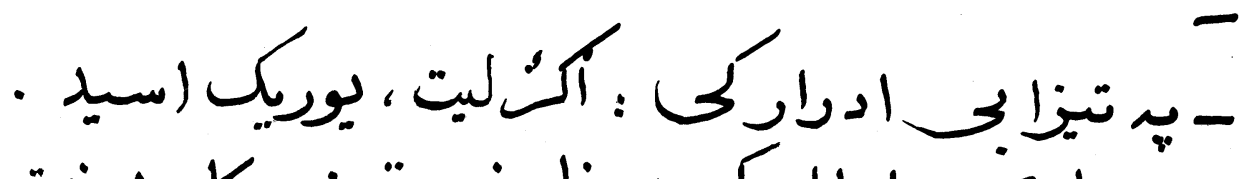

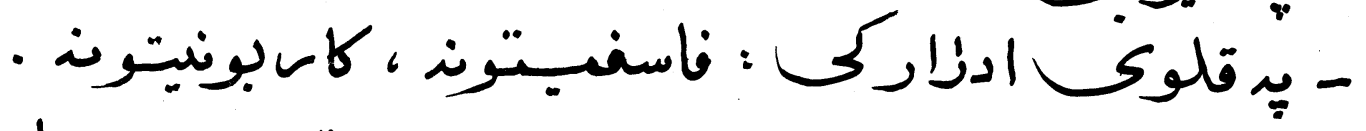

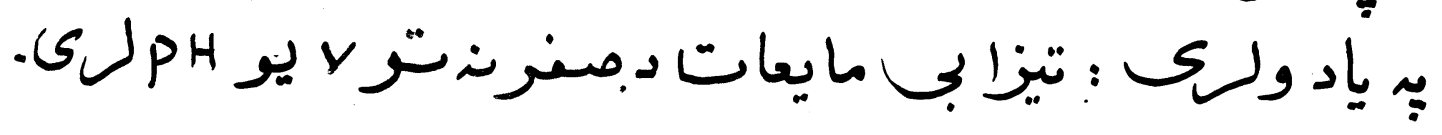
(صغوديوبيراسيد وى )

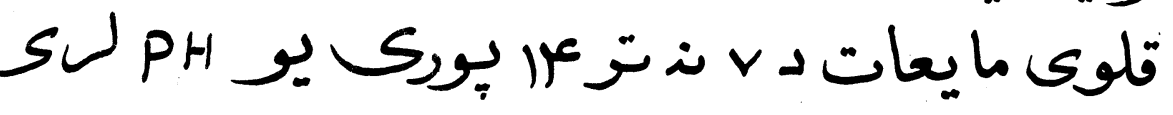

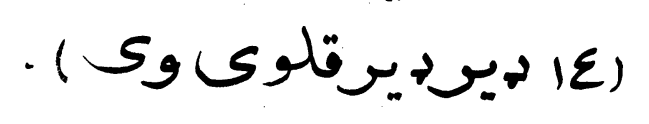




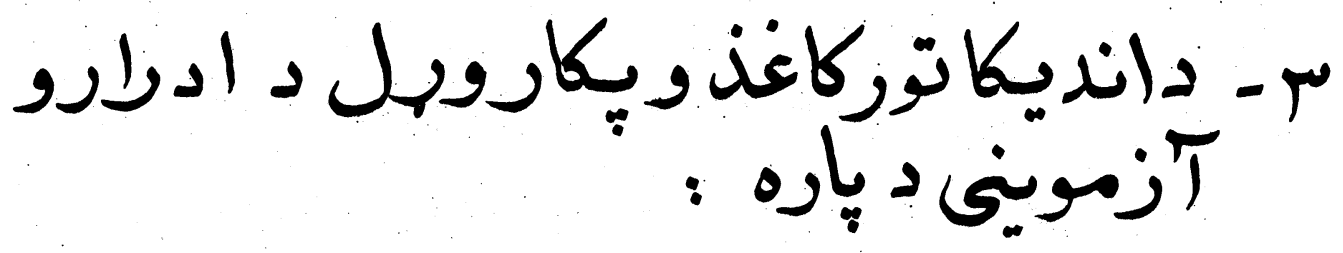

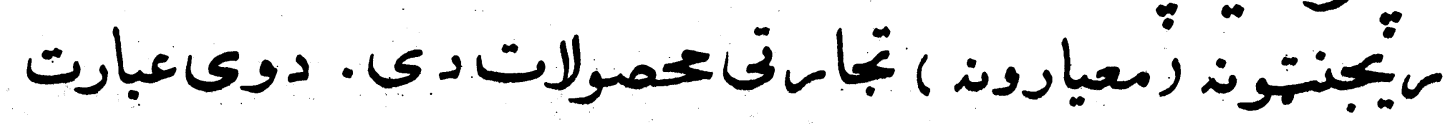
دى دئل

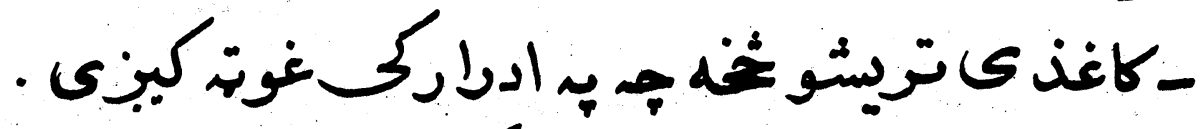

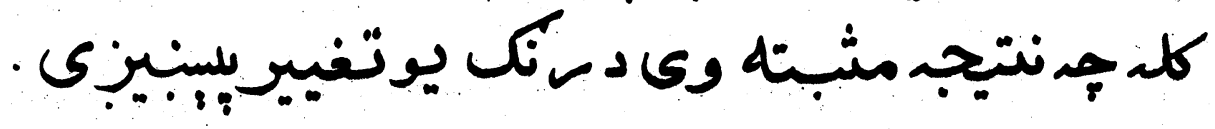

د بكار وليوليارن لانبنودنه اولانم احتياطونه :

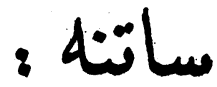

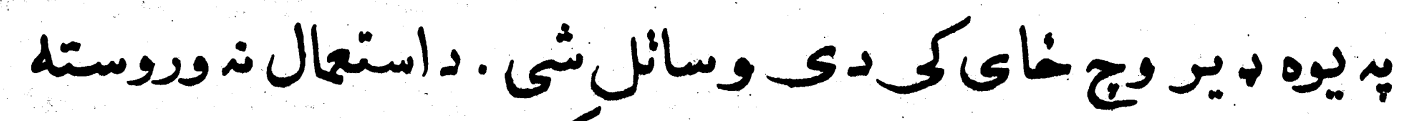

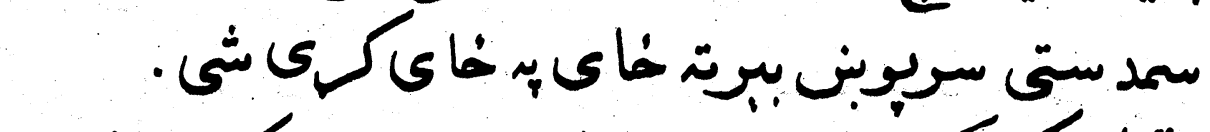

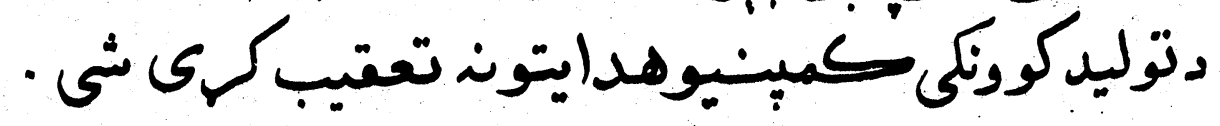

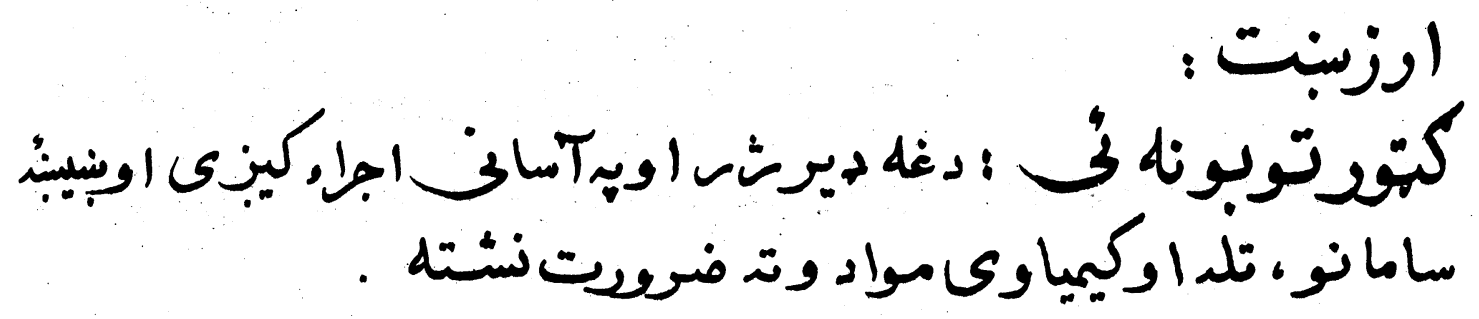




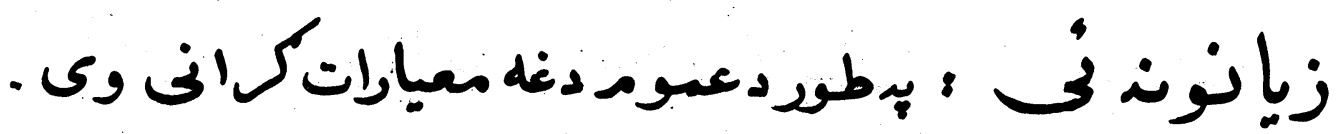

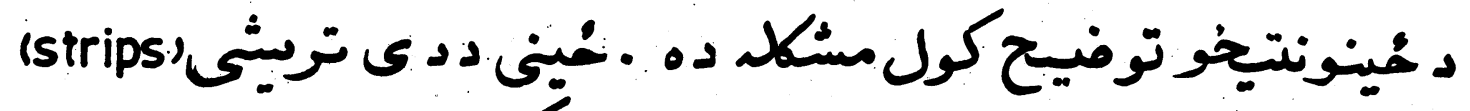

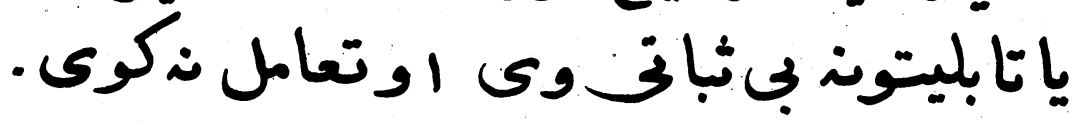

$$
\begin{aligned}
& \text { دكاغذى دانديكانتورو جـونين : }
\end{aligned}
$$

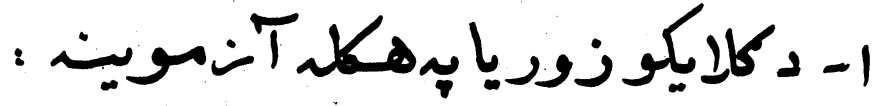

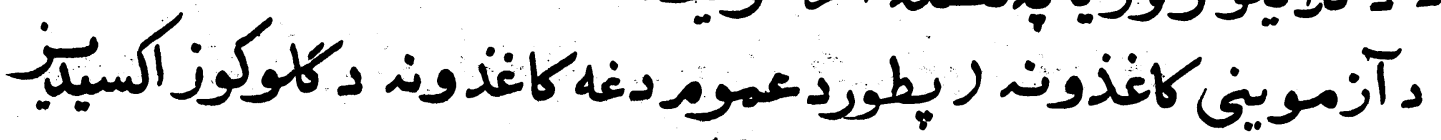

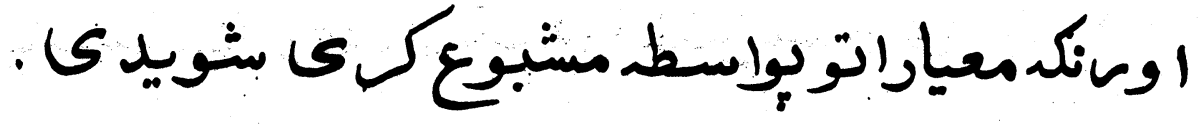

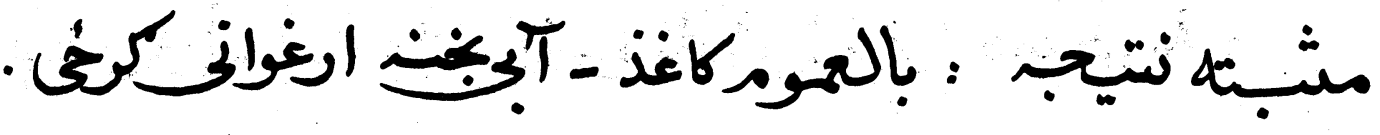

$$
\text { كبتورتوبتُ }
$$

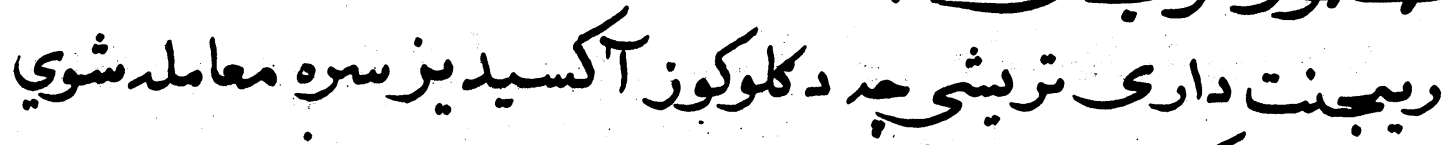

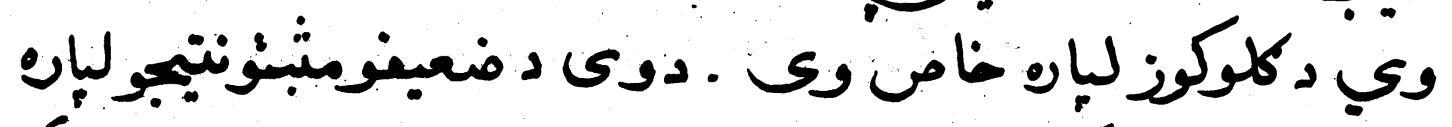

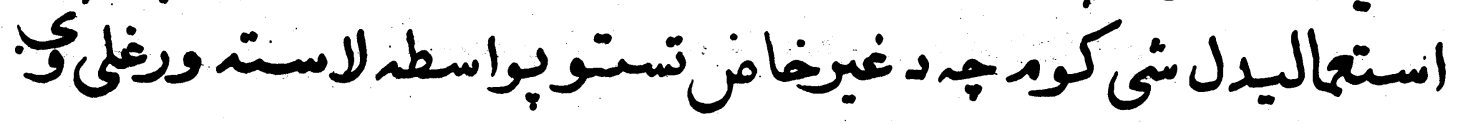

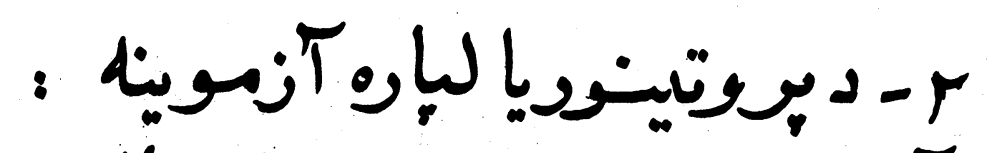

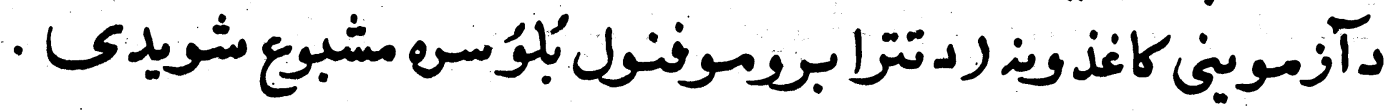




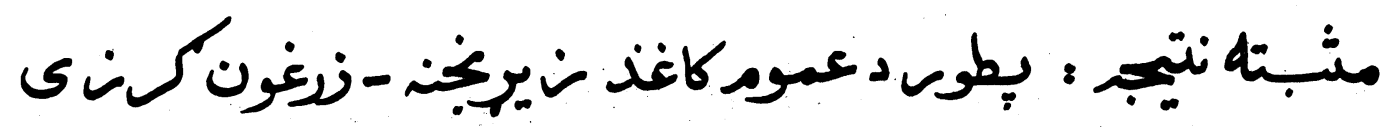

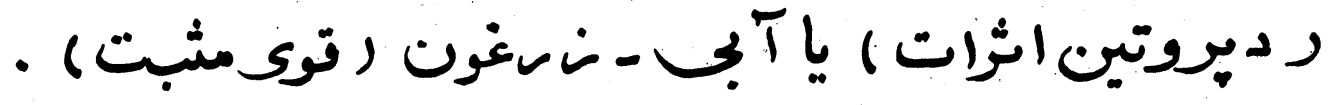

زيانق

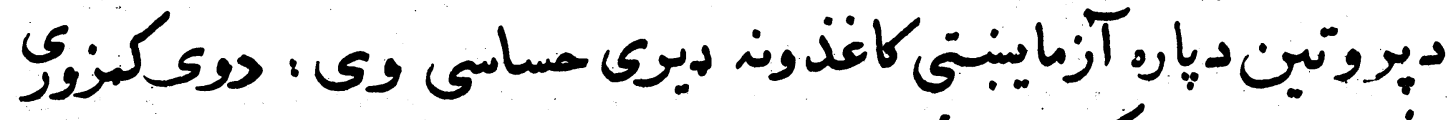

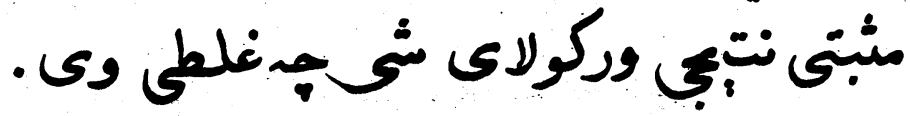

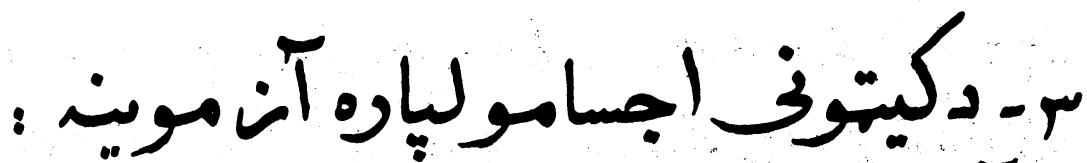

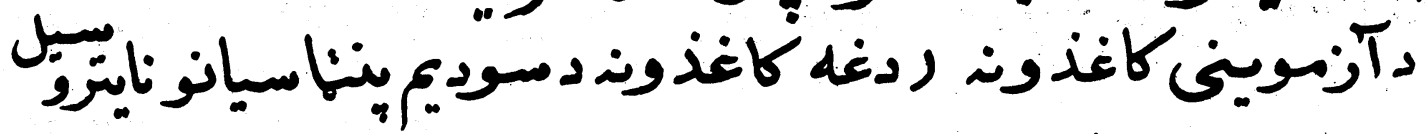

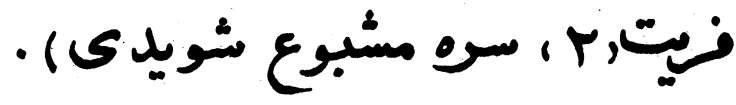

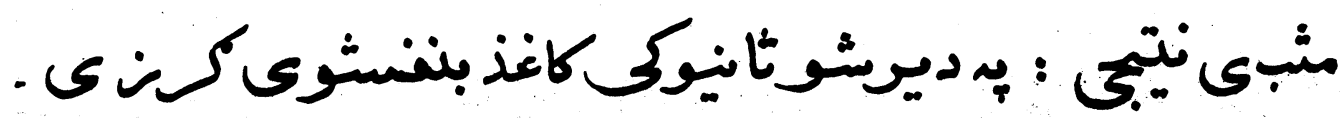

عـ د وينى لهارو آنموين :

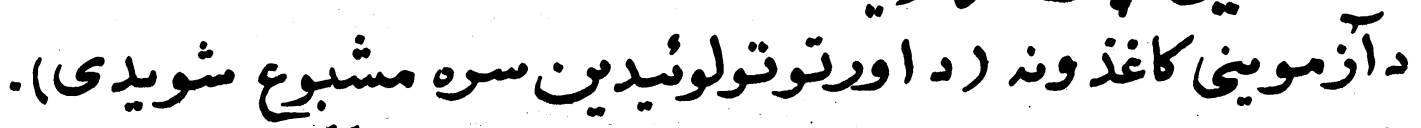

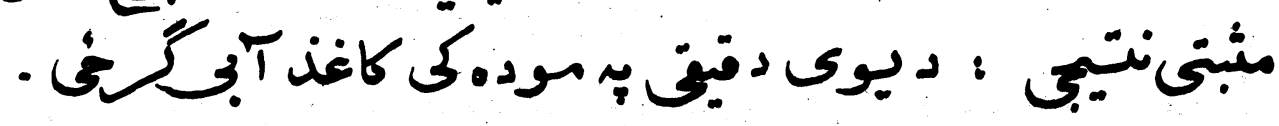

10.1 


\section{ع عـ ت ع عببات د ادرار}

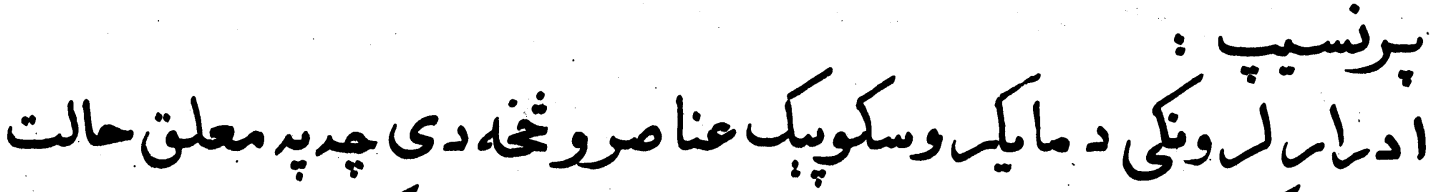

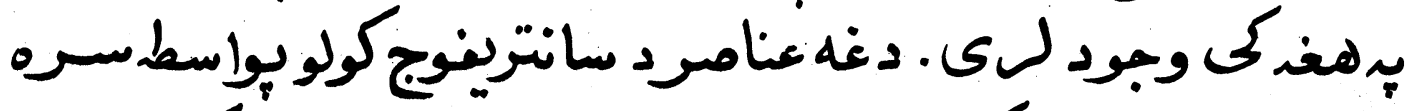

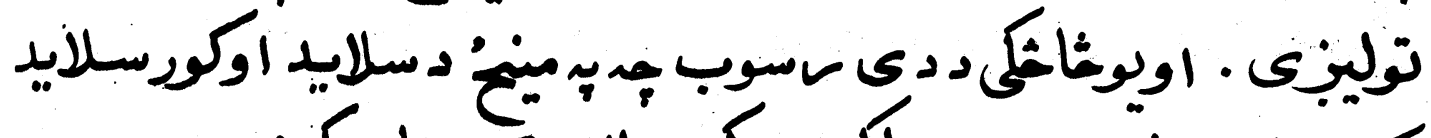

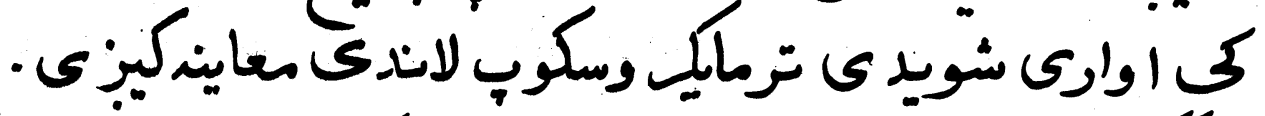

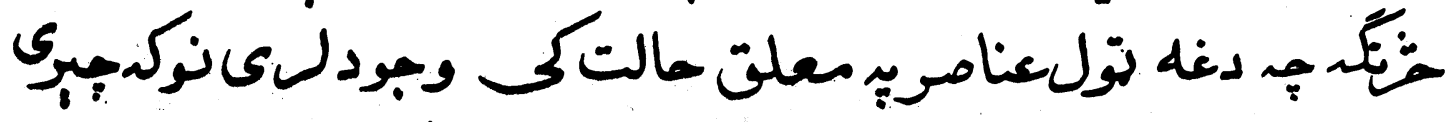

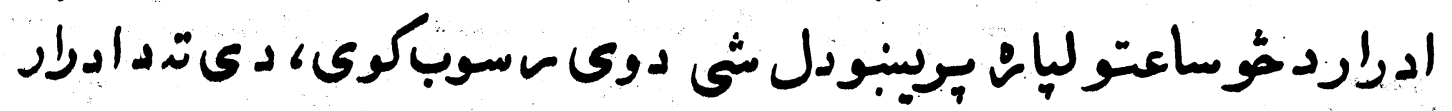

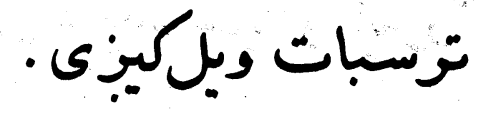

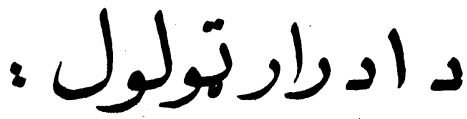

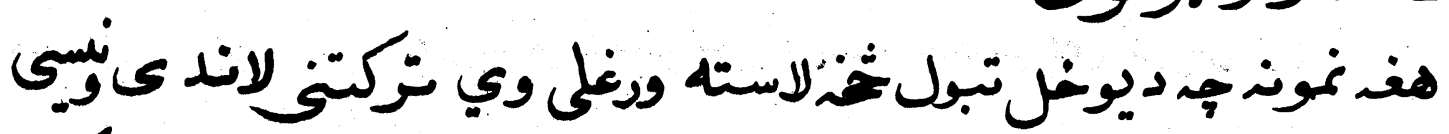

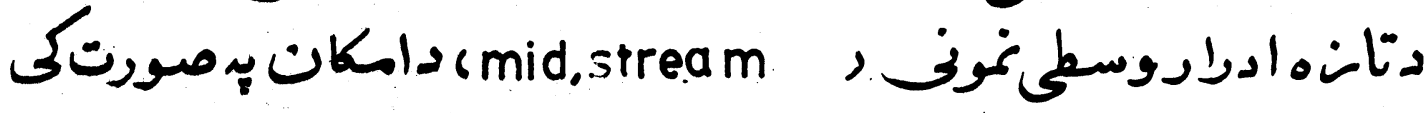

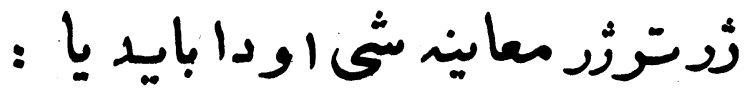

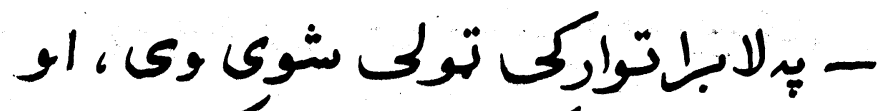

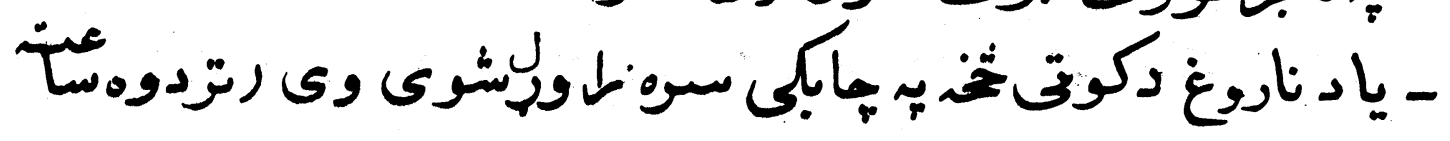

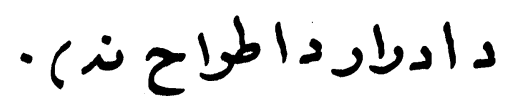

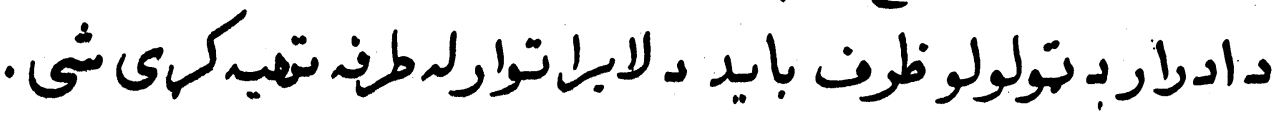

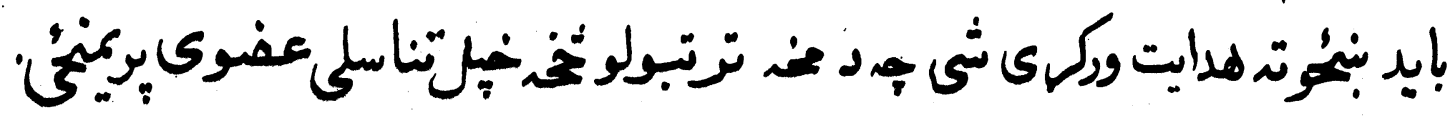




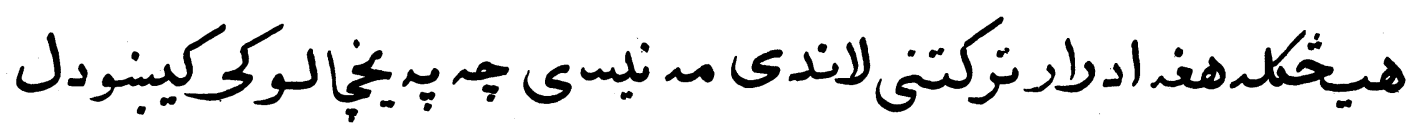

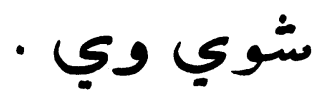

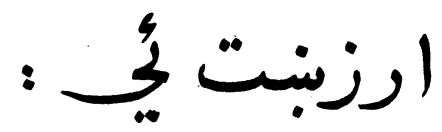

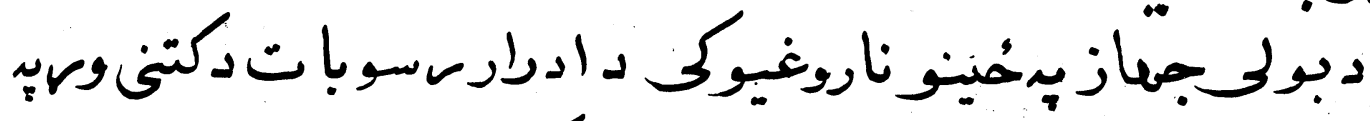
اندازه تغيير سوكى. لاندى عنامرميندل كيداى شيى

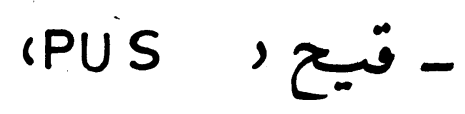

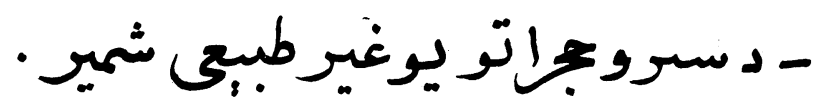

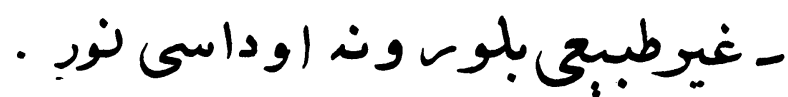

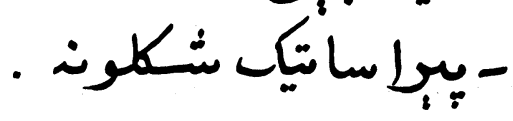

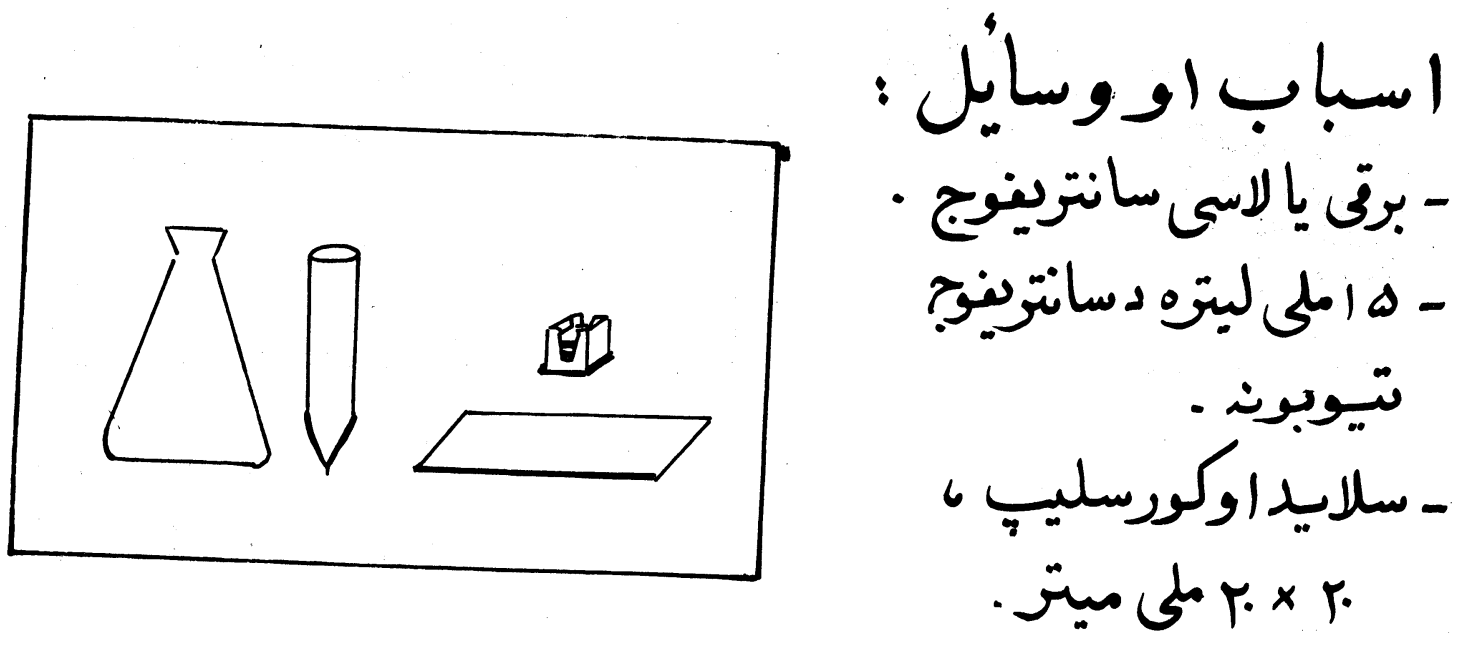

14. 

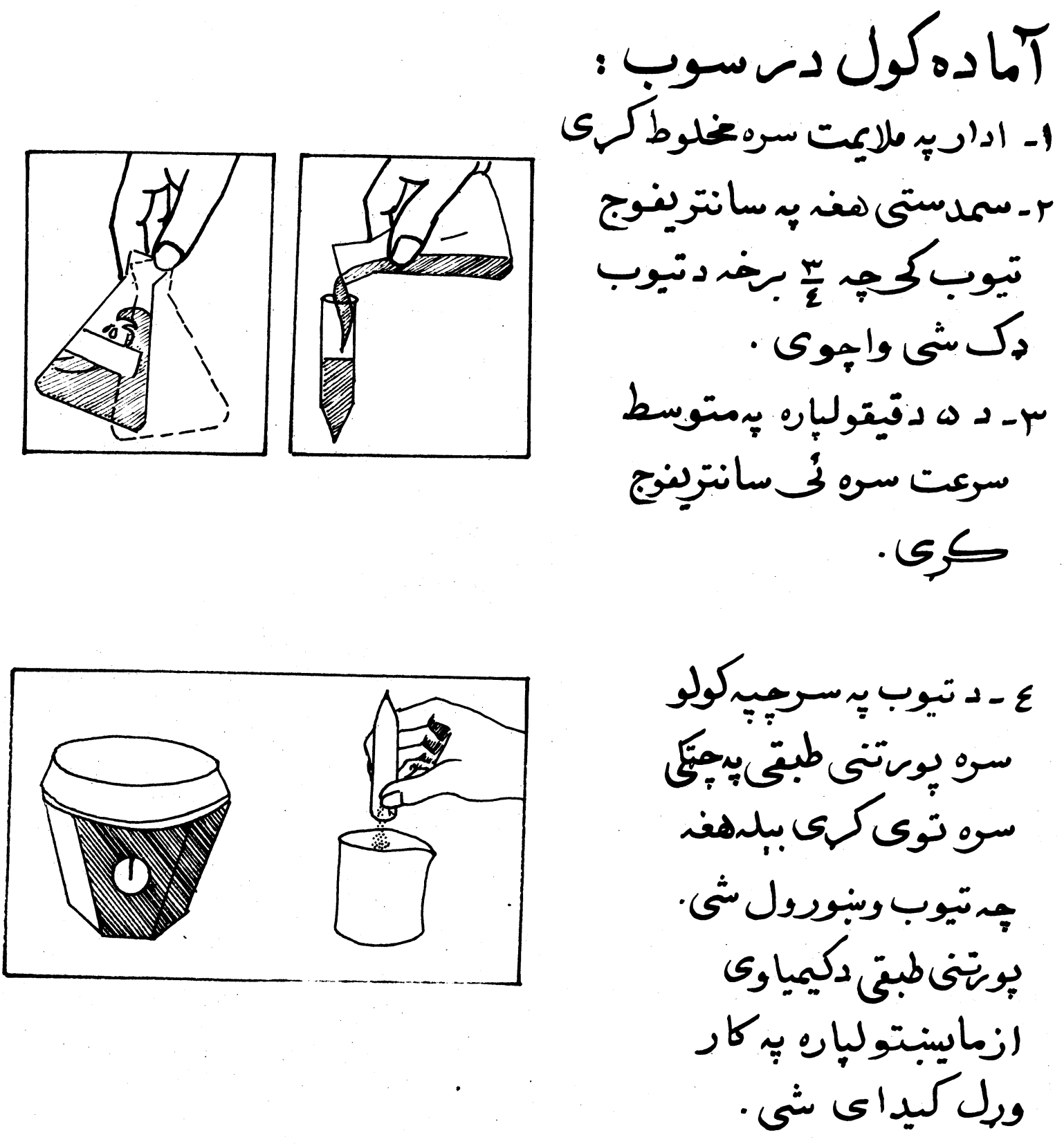


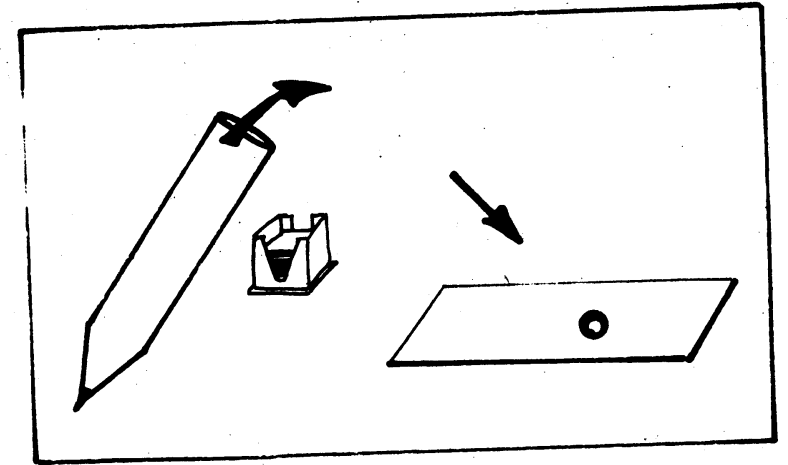

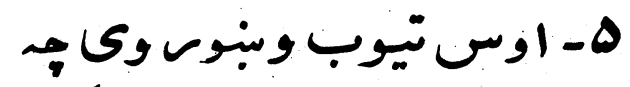

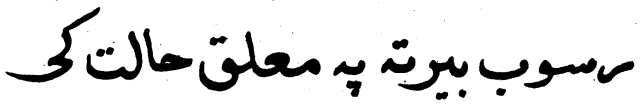

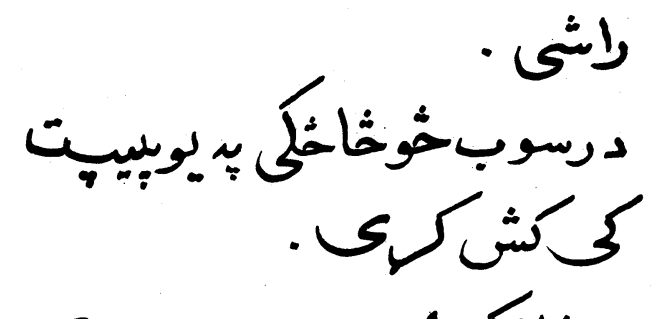

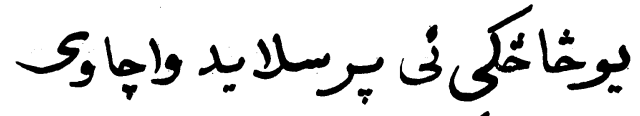

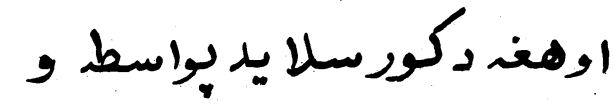

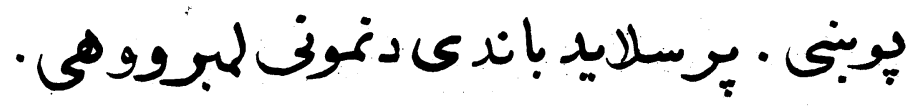

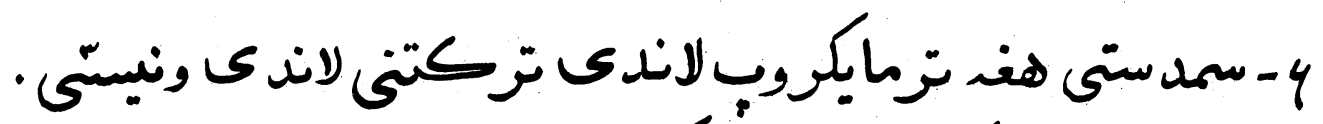
-

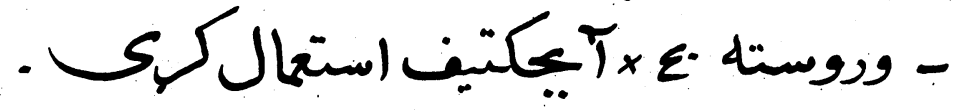

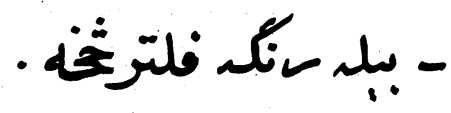

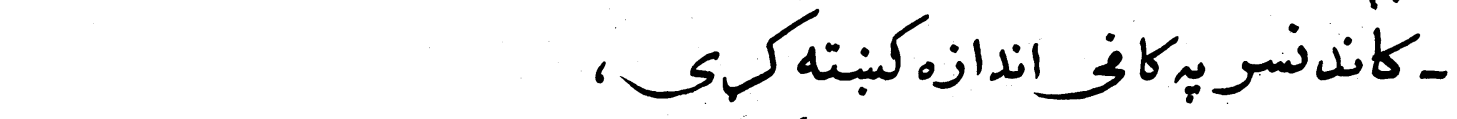

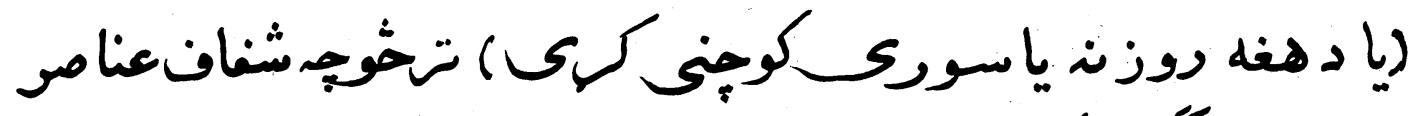

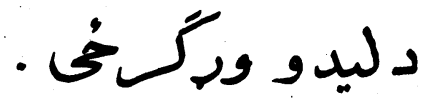


شايد دغه لاندى شئند ادراربه رسوباتوكك وميندلثى:

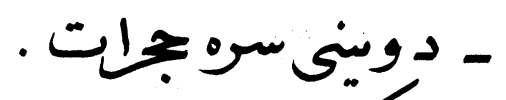
ـ لوكوسايتون.

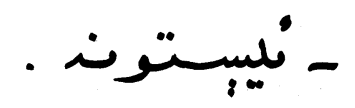
- ت تريكوموناس.

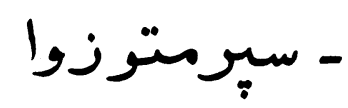
- د اليتبليالجزات ـ كاستون - دايتيان

- دبريإسايتوهكى اوشفبه رلاسوا)

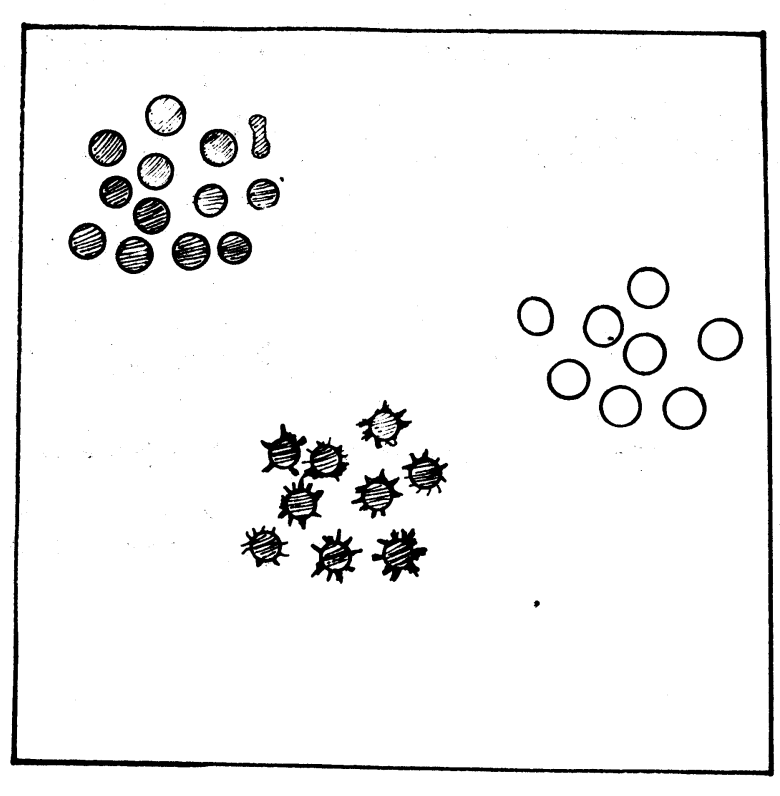

- بلورات - دبرايتفي

النال - دوينى سمو جدات . احتال لـى هي دوى يي دغل

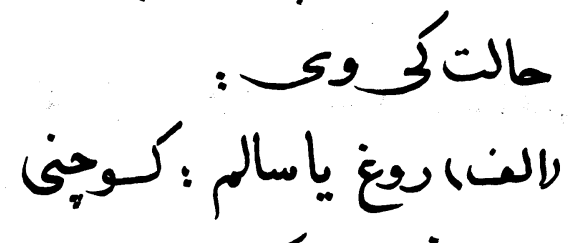

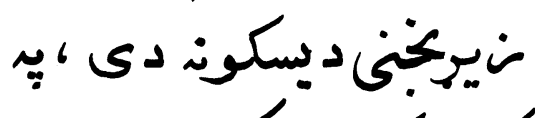

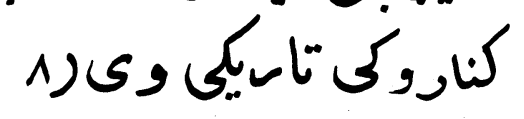
مايكسوميتر 


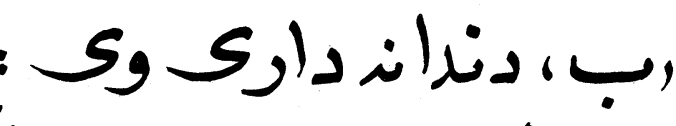

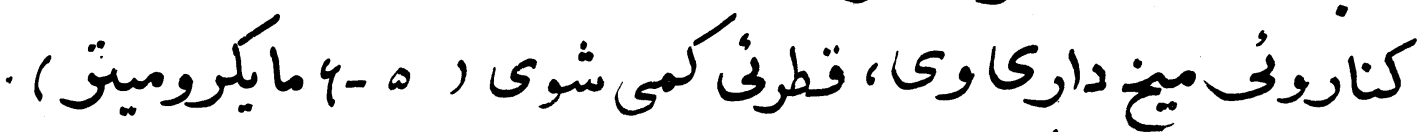

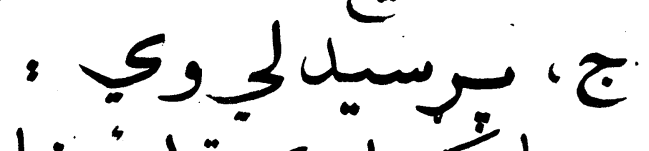

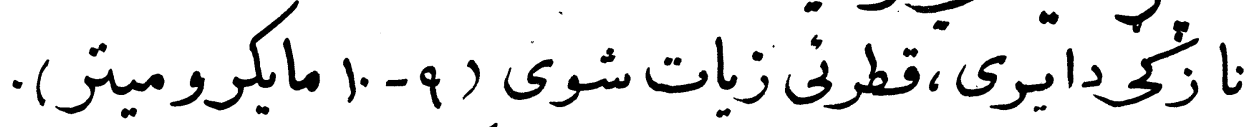

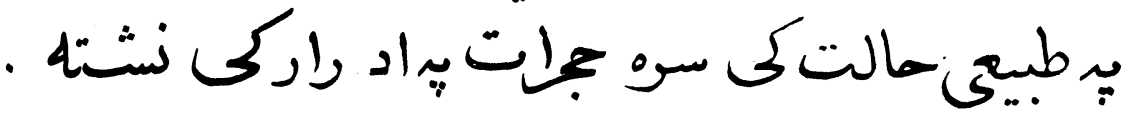

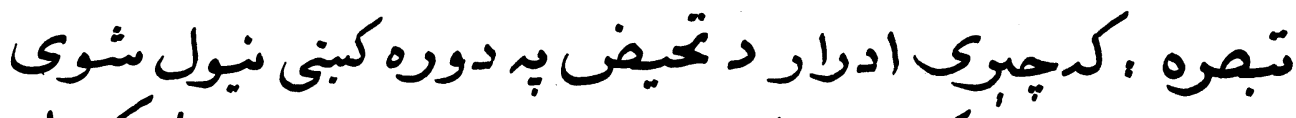

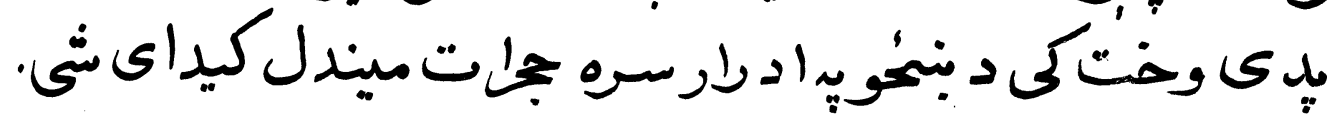

$$
1.4
$$

$$
\begin{aligned}
& \text { ب : لوكوسايتون ( سبن كريوات ) }
\end{aligned}
$$

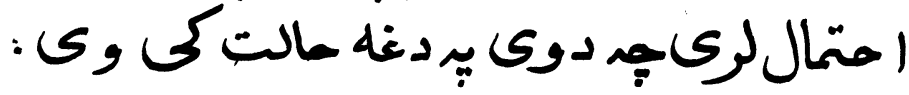

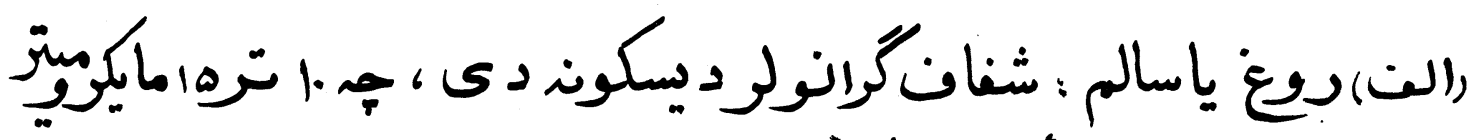

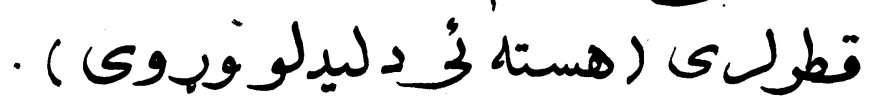

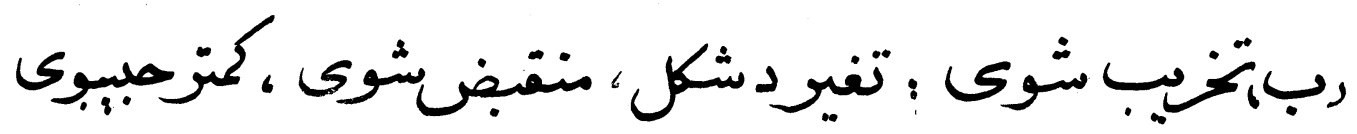

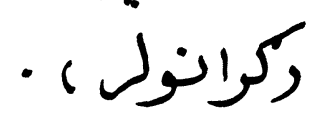

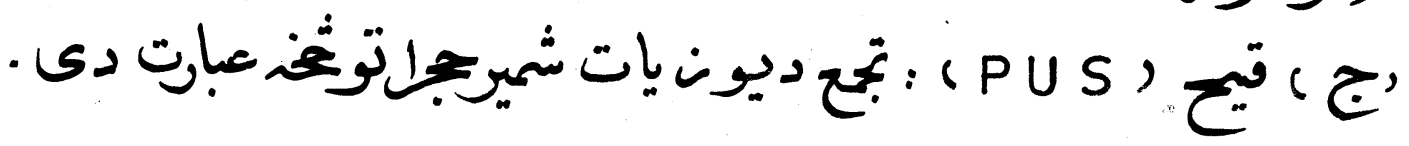




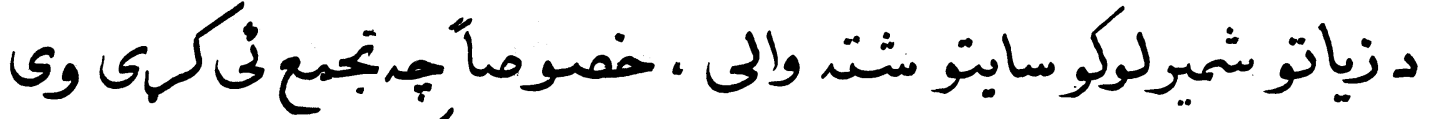

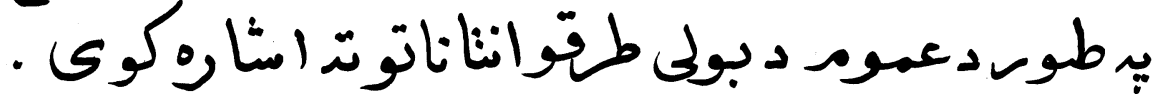

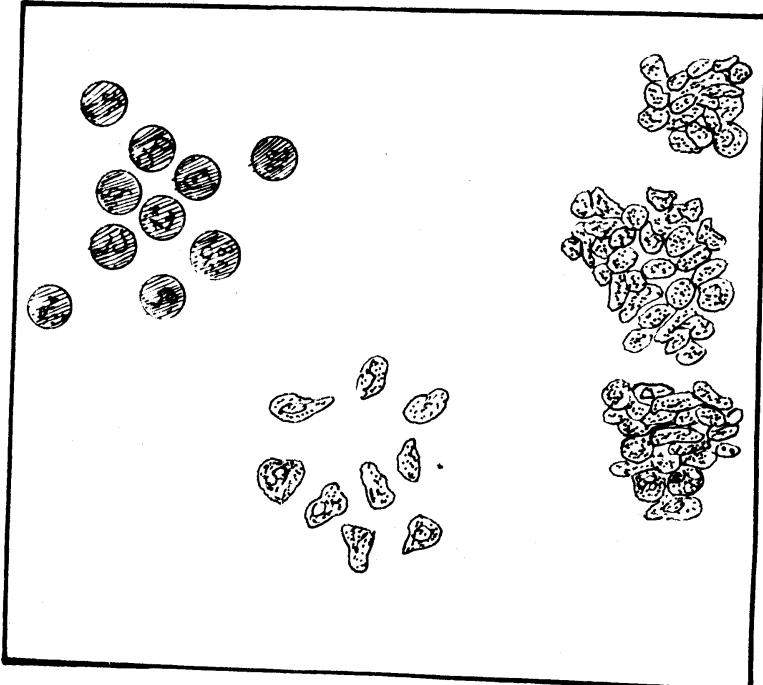

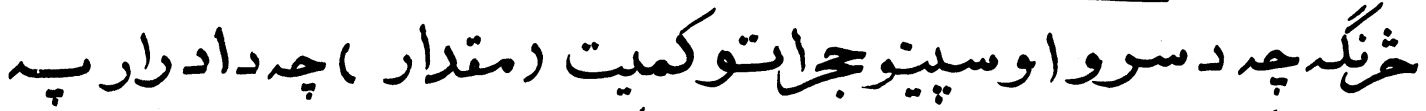

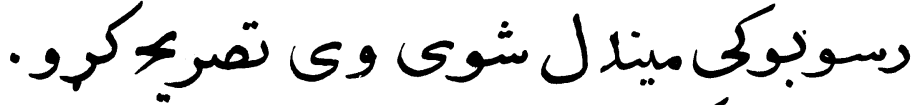

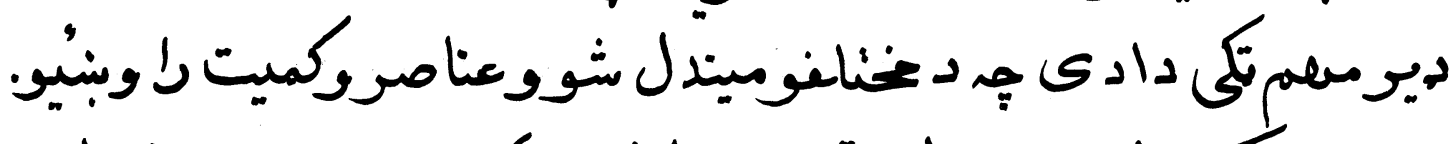

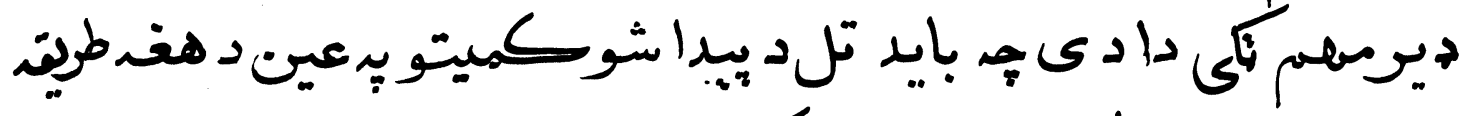

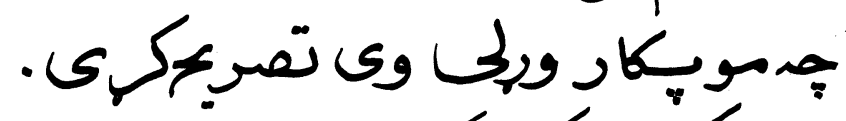

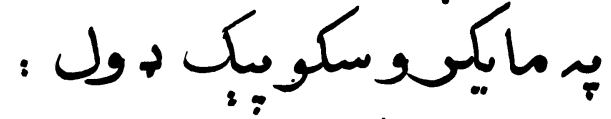

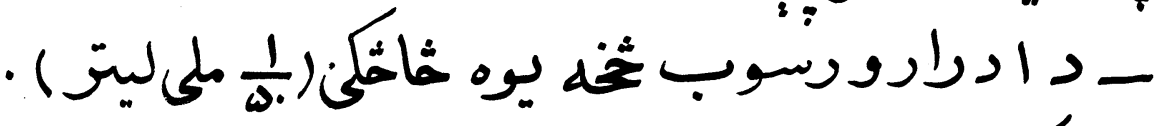

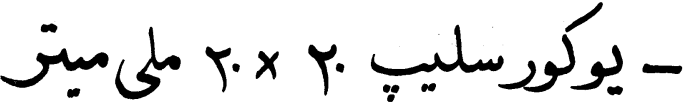

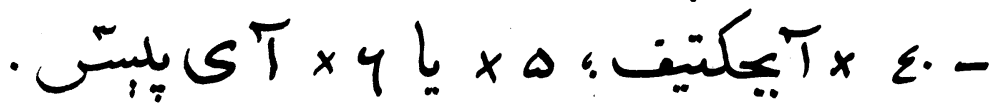
تركتئ لاندى ونيسّي : 
سوه جملت

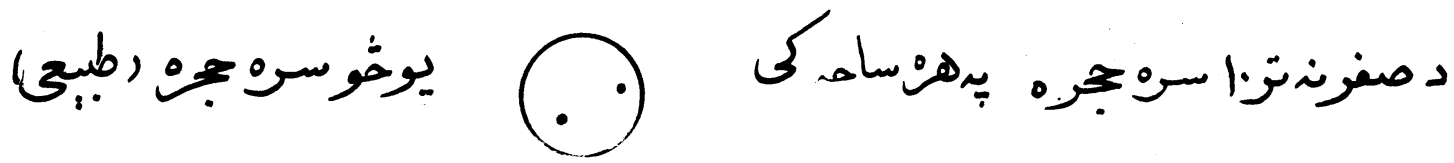

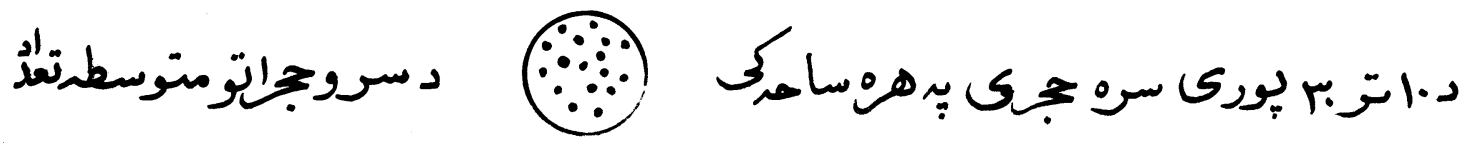

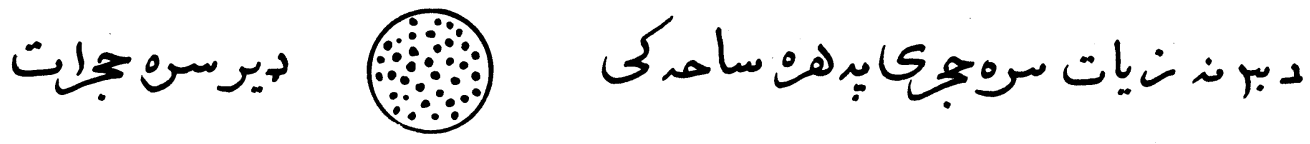

لوكوسايتون

يوخولوكوسايتون (طبعى)

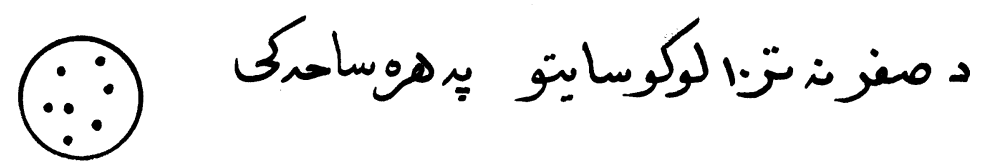

د. - - ب بورى لوكوما يتوبهن ساحكى

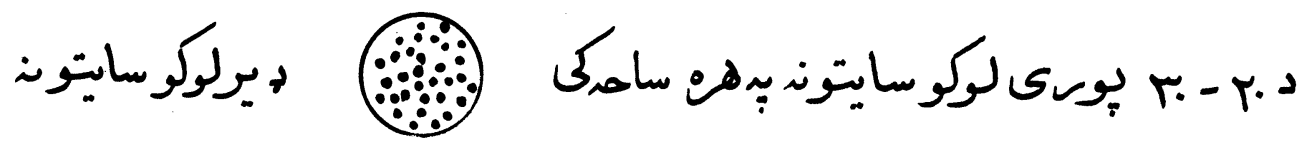

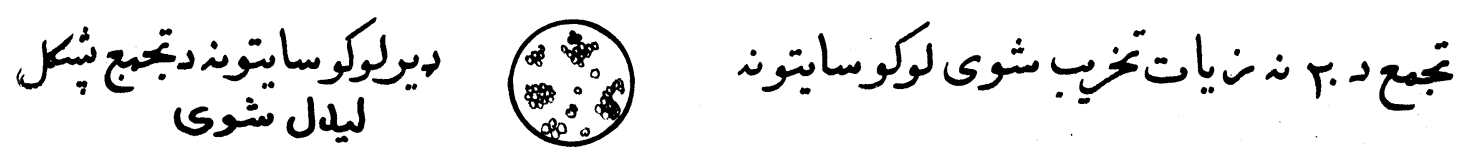

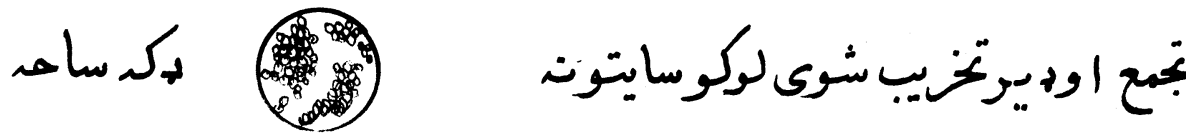

144 


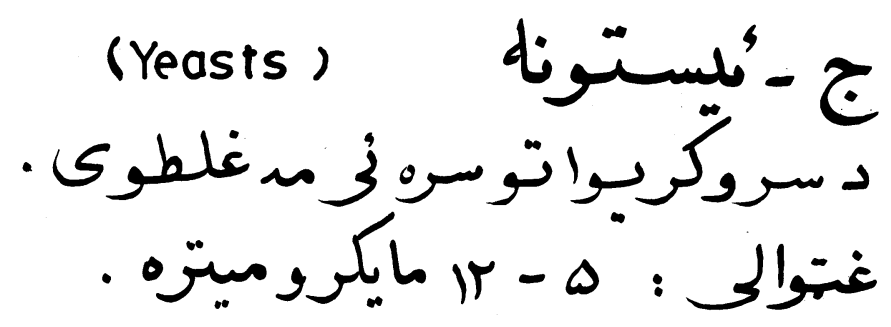

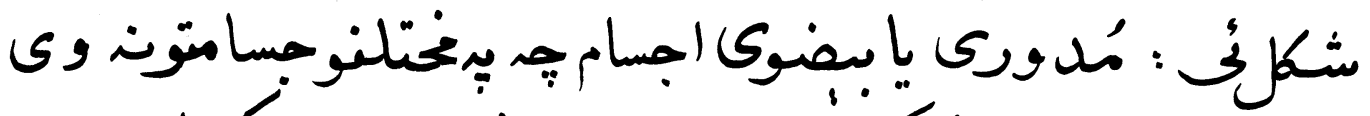

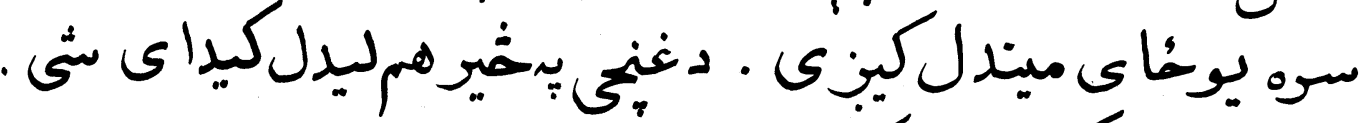

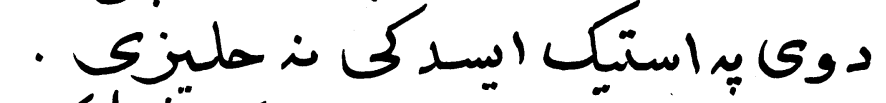

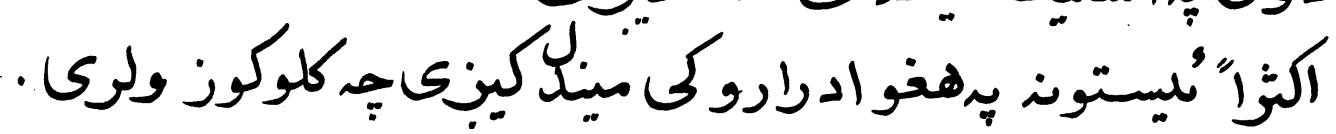

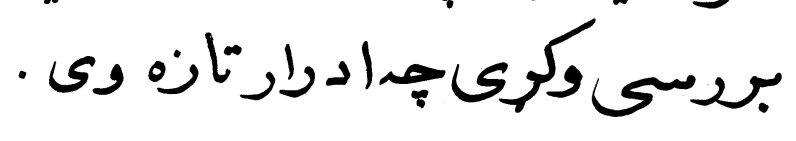

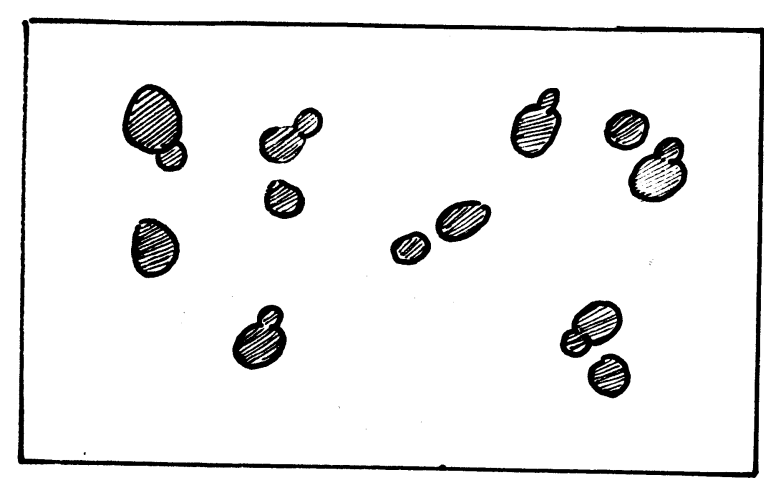

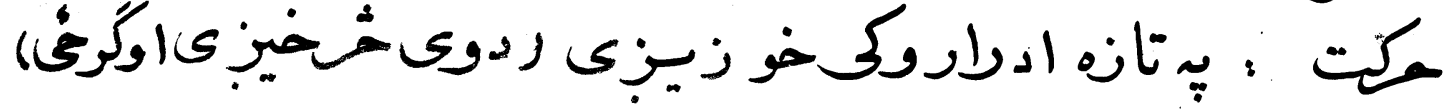

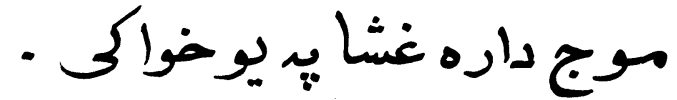

$$
\begin{aligned}
& \text { فلاجيلا :كماوبيش دليدلو ويدوى). }
\end{aligned}
$$




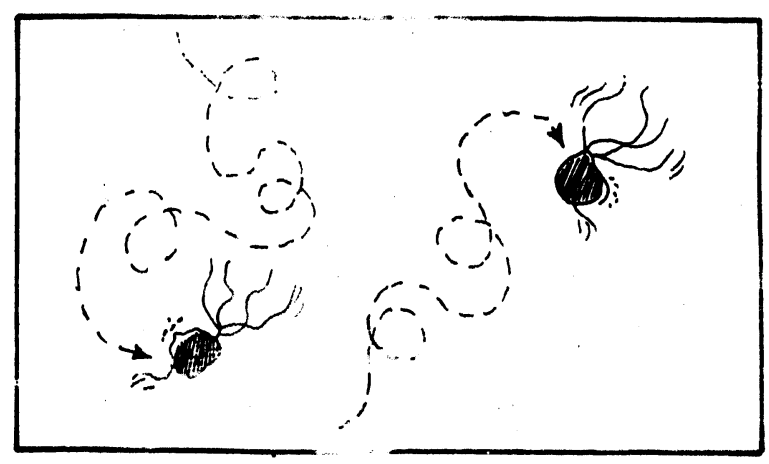

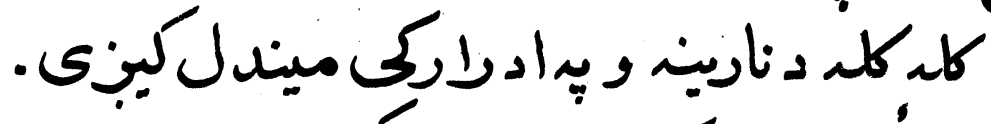

$$
\text { ع - ستبمتمتوزوا : }
$$

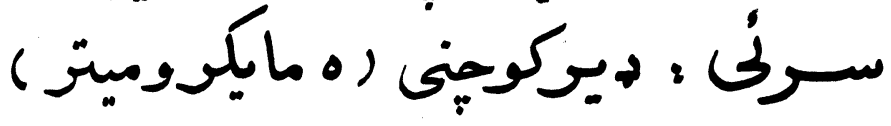

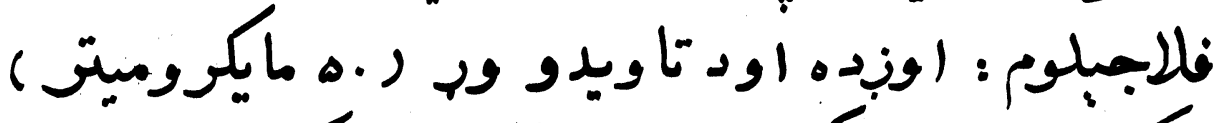

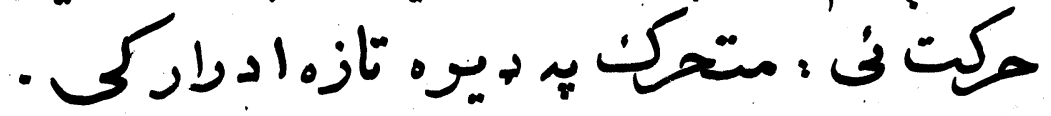

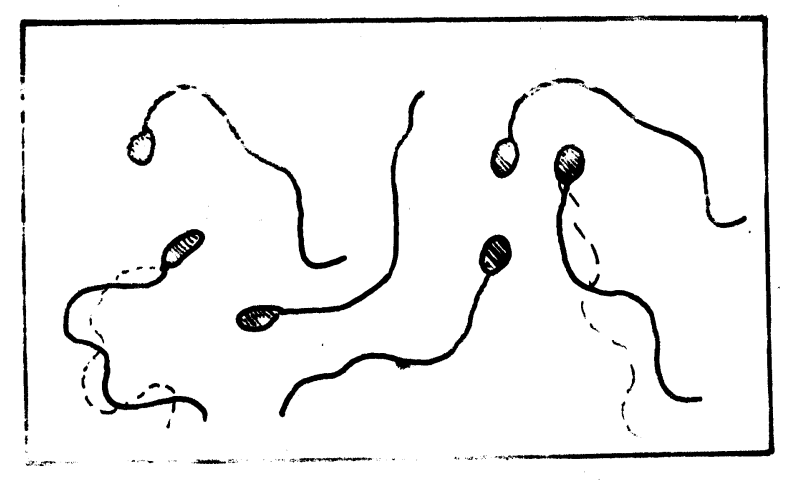




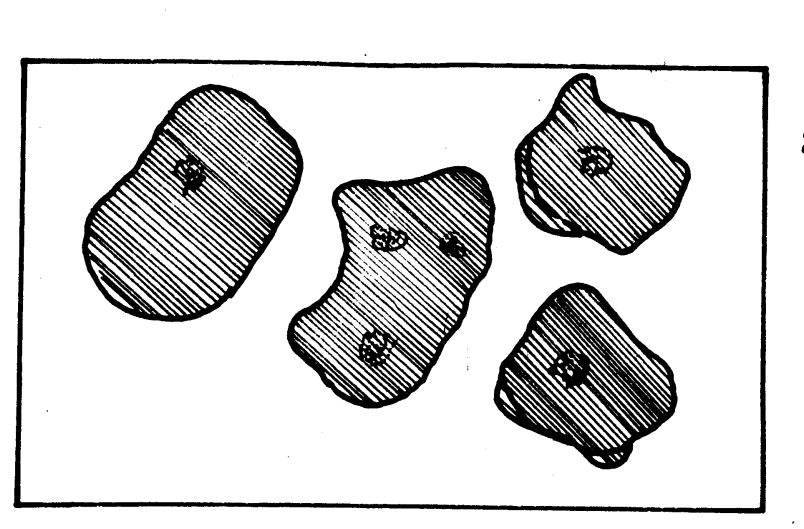

و- د إيتبيليالجرى :

ا - تنلسيـ إيتيليليالجري :

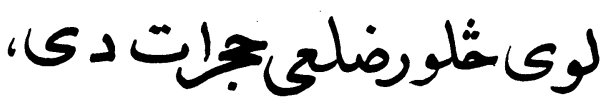

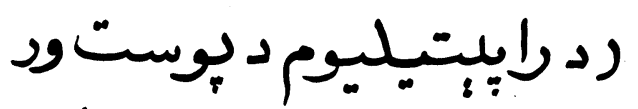

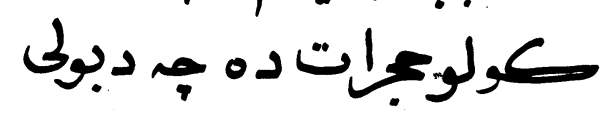

جماز (واعضاويخهنشئت

كوى )

دوى د ن ن

- مالب ياد

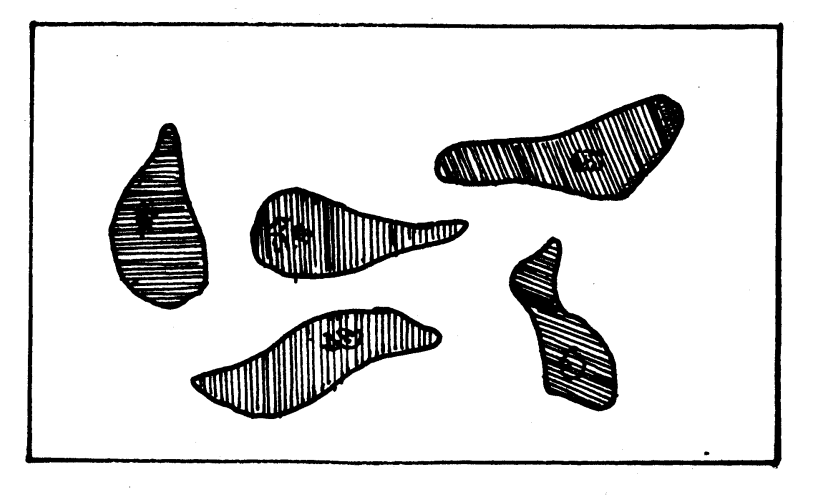

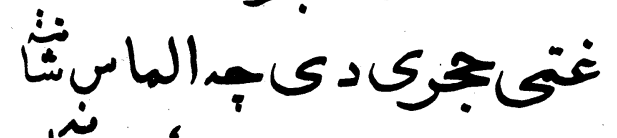

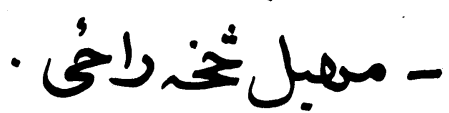

r- دمثانى جرات :

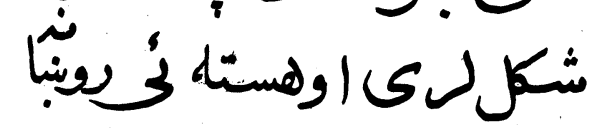

وى .

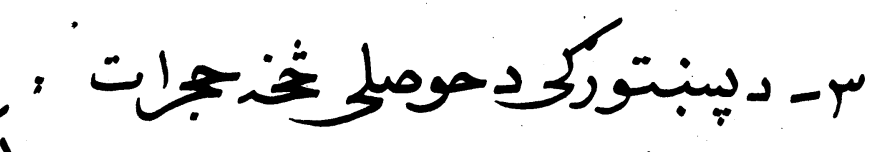

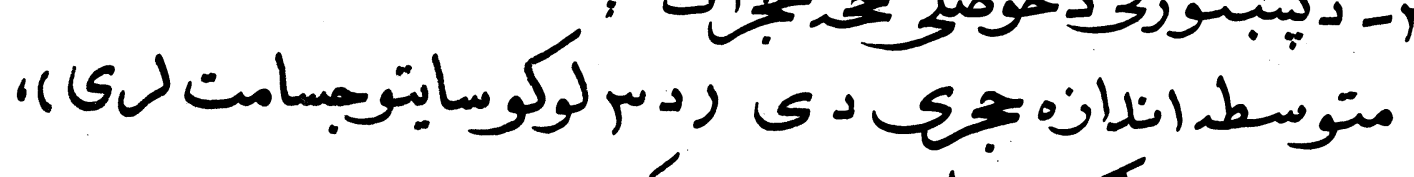

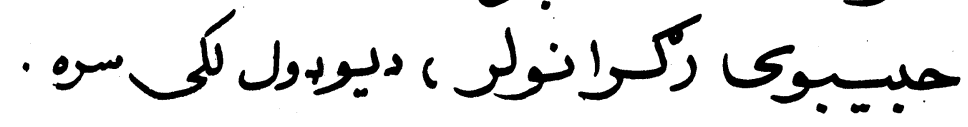

149 


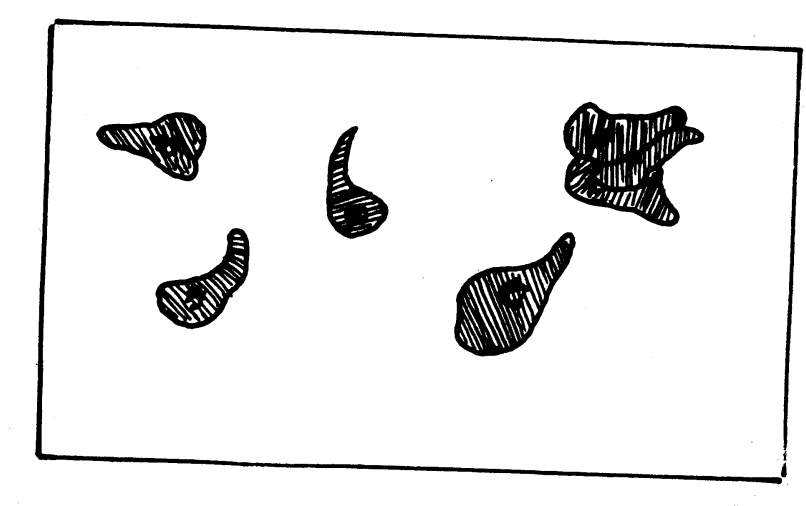

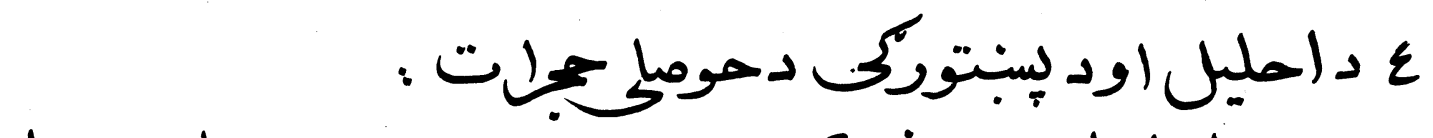

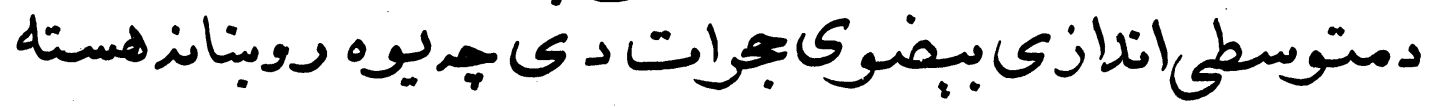

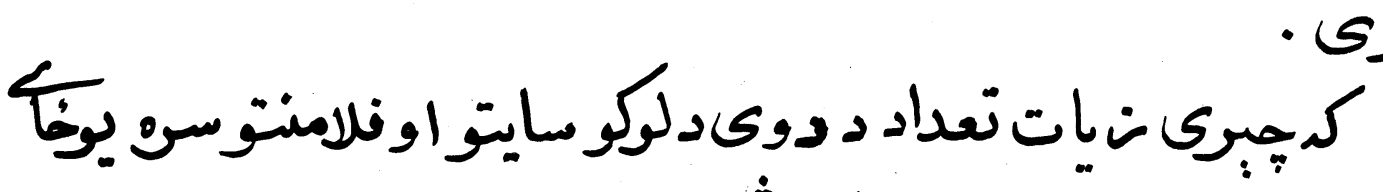

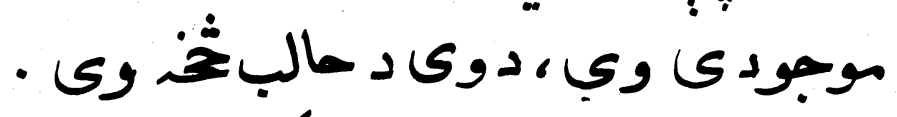

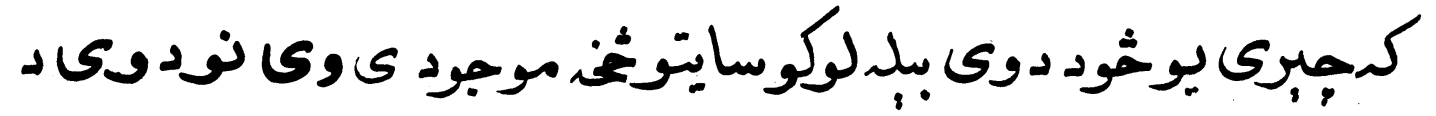

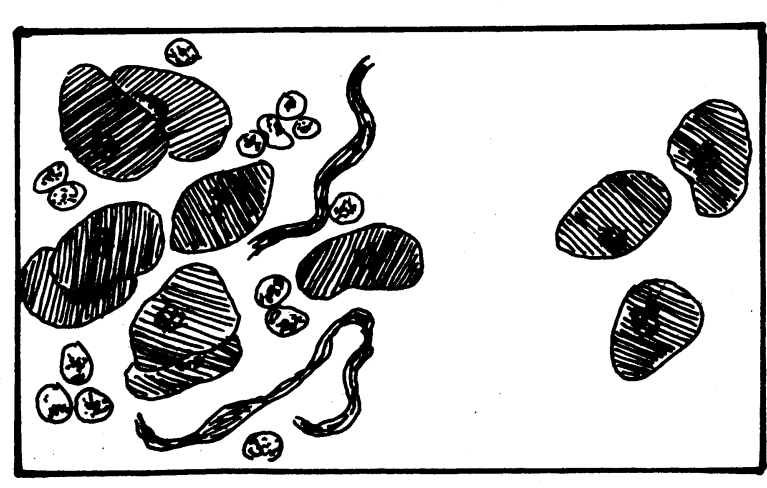

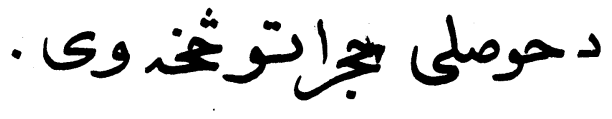




$$
\begin{aligned}
& \text { هـ دينتيتونكى يجات : }
\end{aligned}
$$

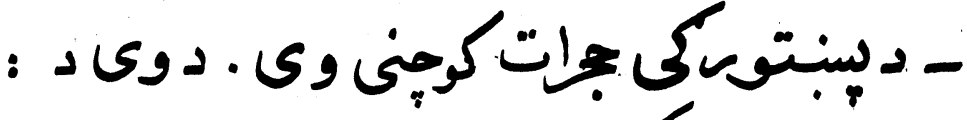

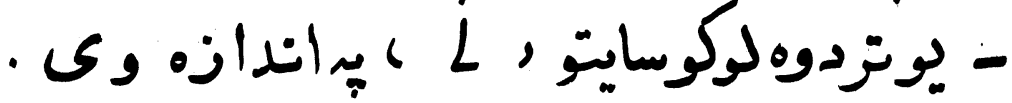

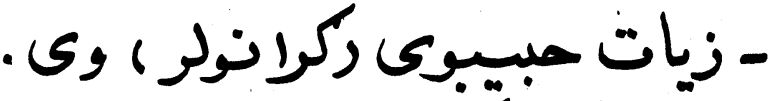

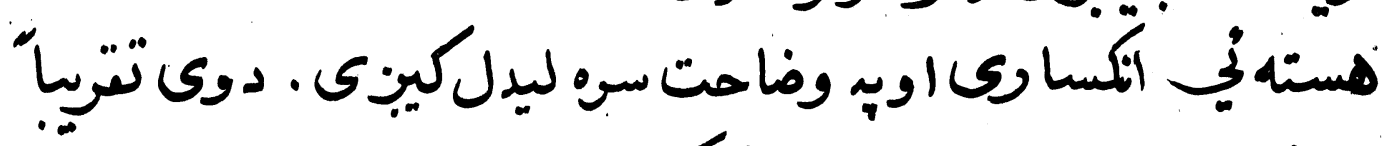

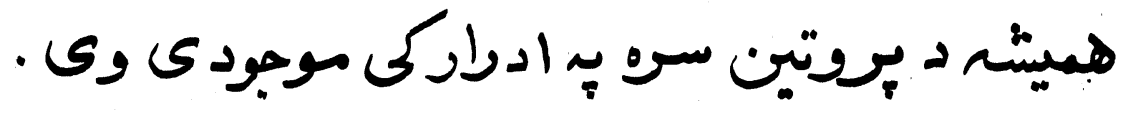

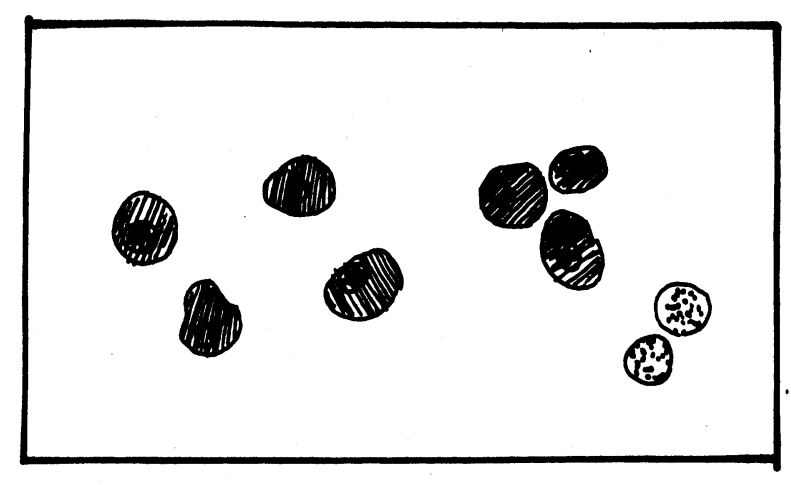

ز-كاستونه : و استوانات ) :

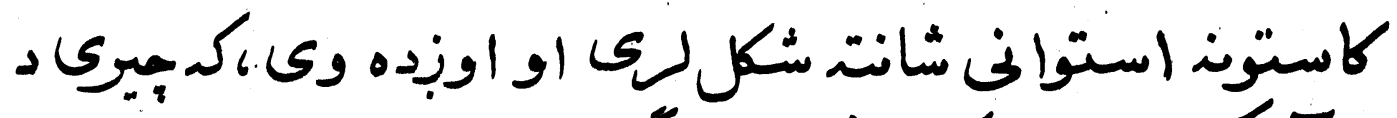

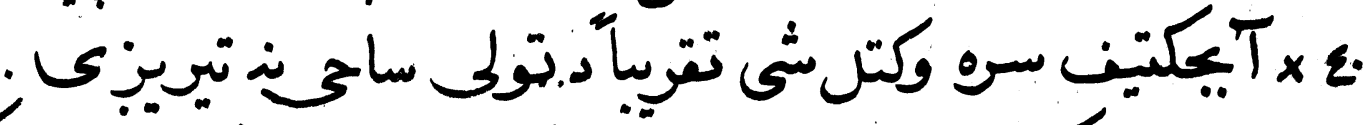

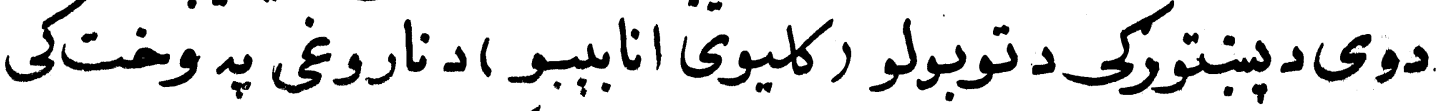

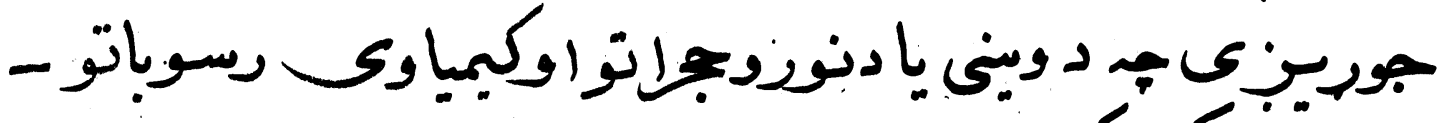

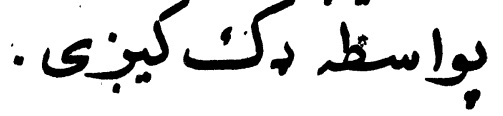




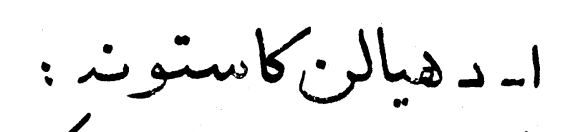

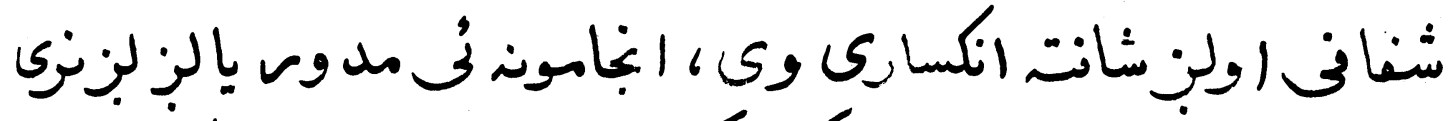

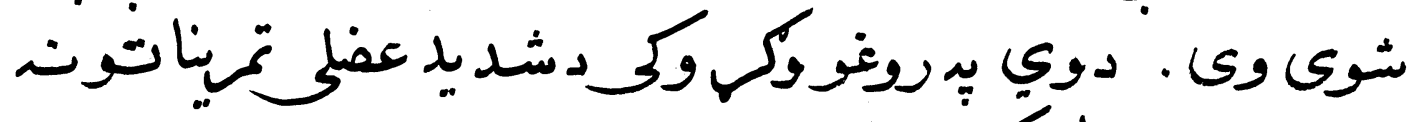

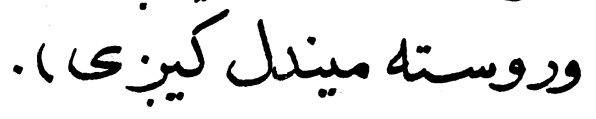

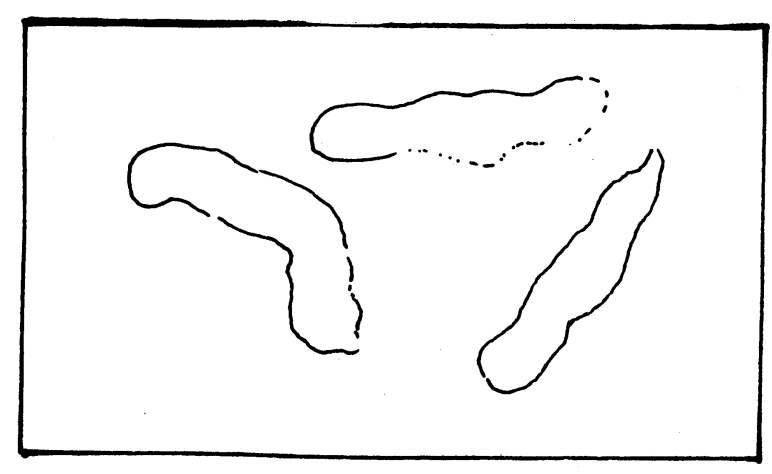

بك-كرانولركاستون (حمبيبوى (ستوانى):

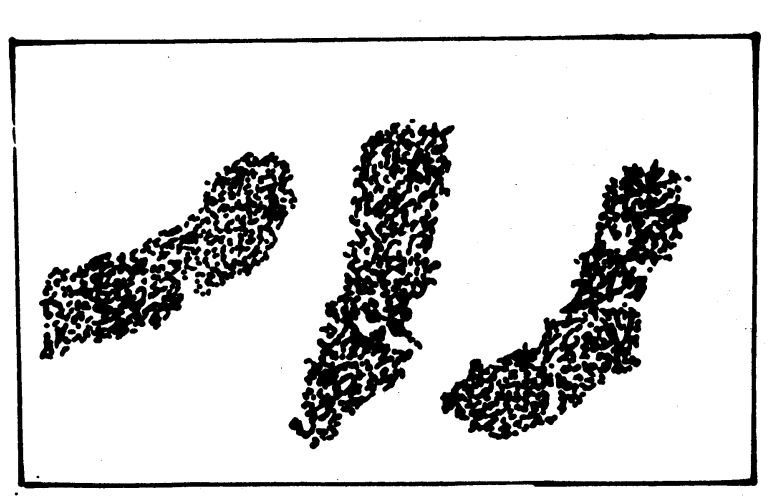

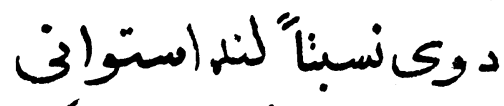

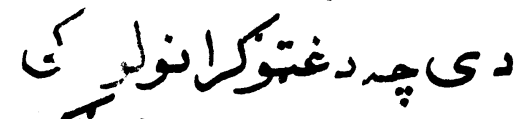

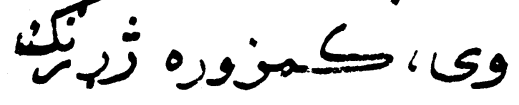

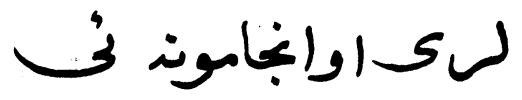

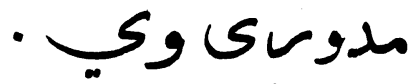
ردغه كلا نولوين (هبيج)

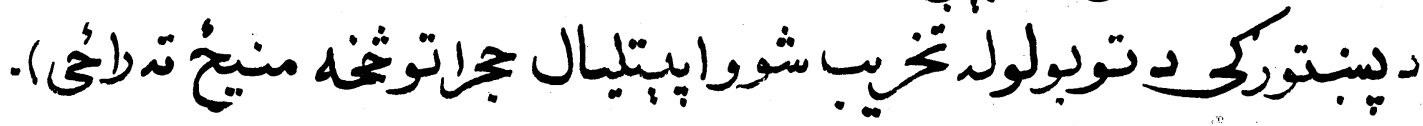




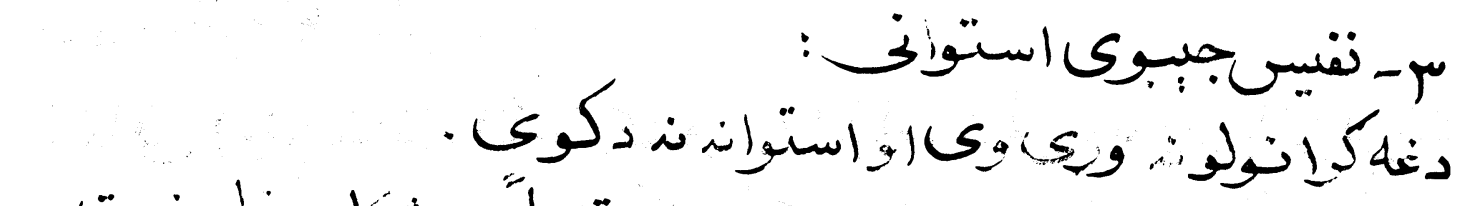

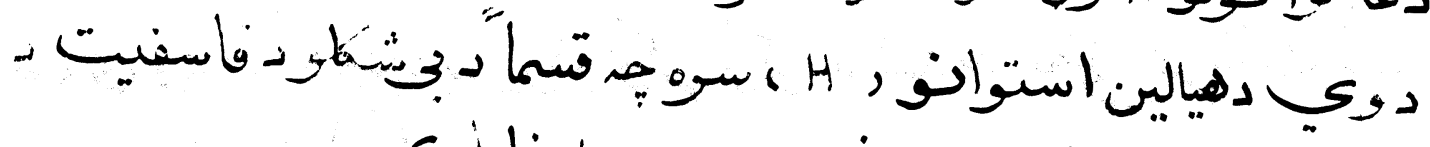

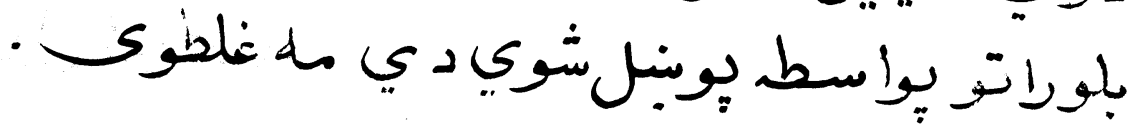

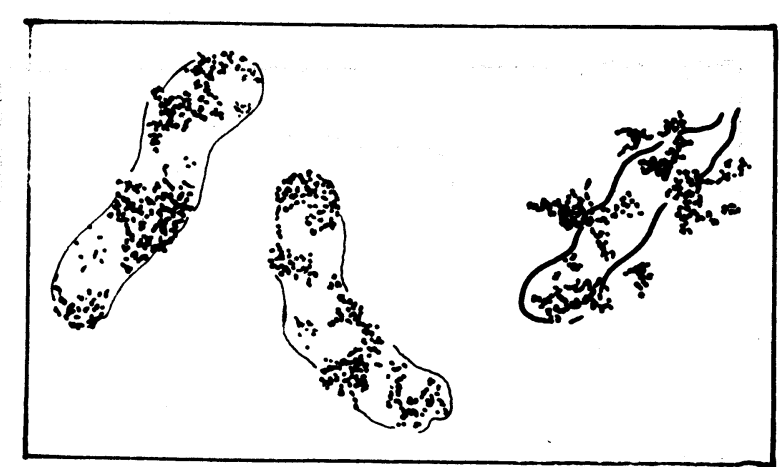

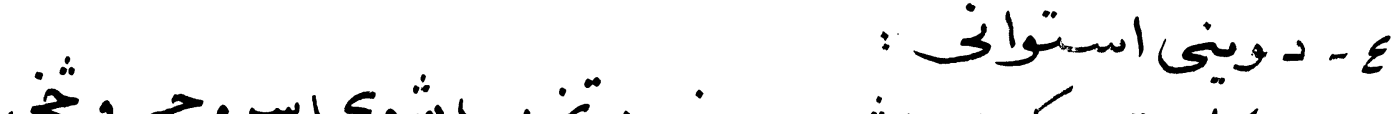

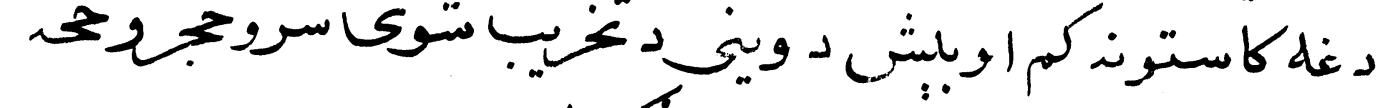

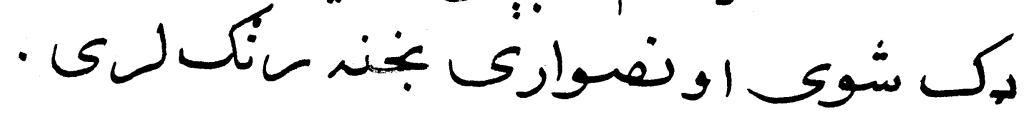

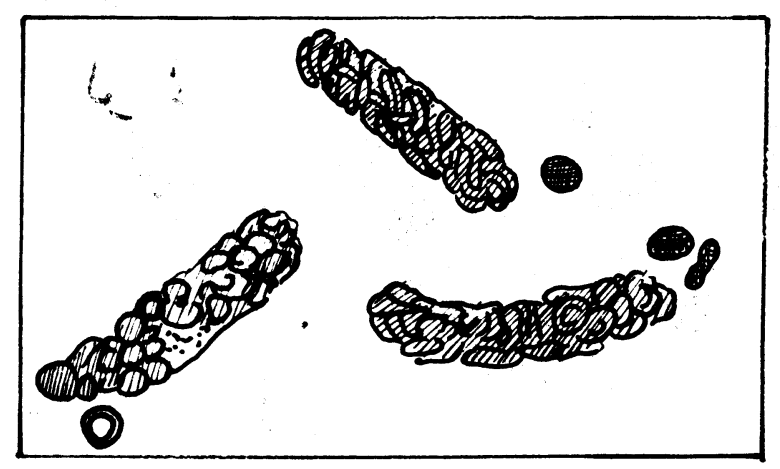




$$
\text { هـ د د تيه استقانه : }
$$

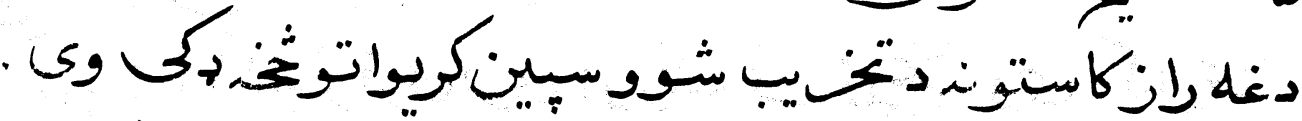

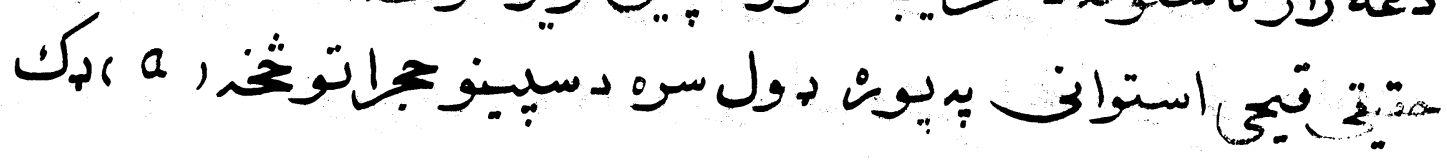

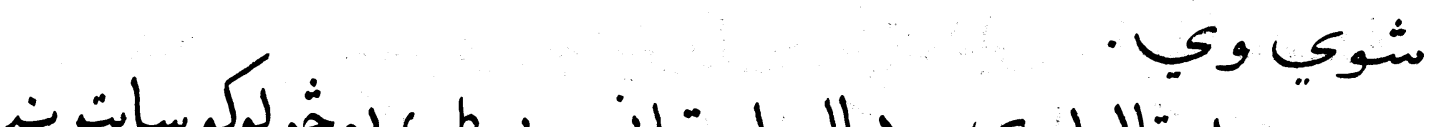

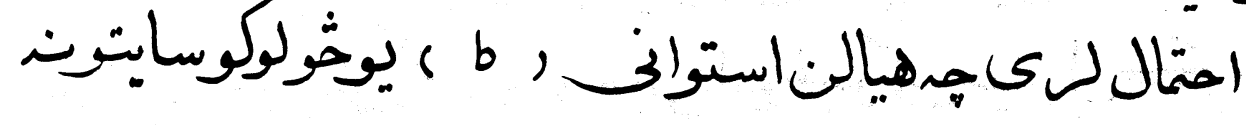

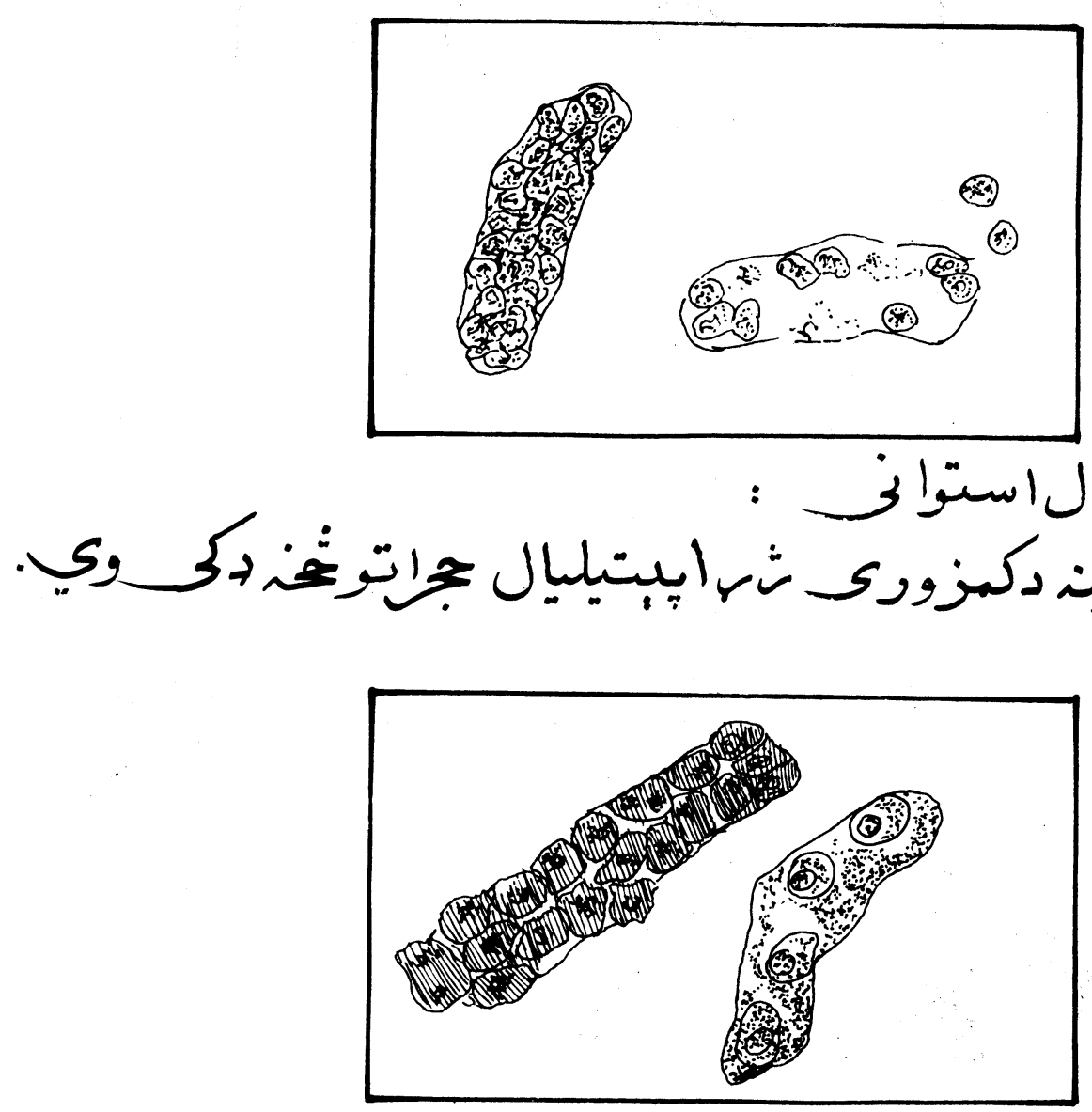




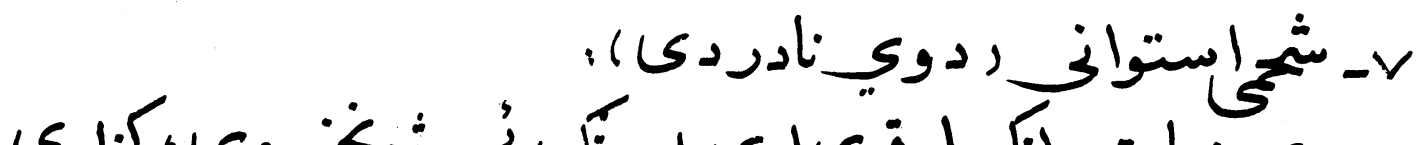

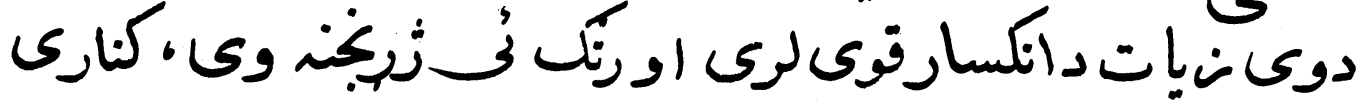

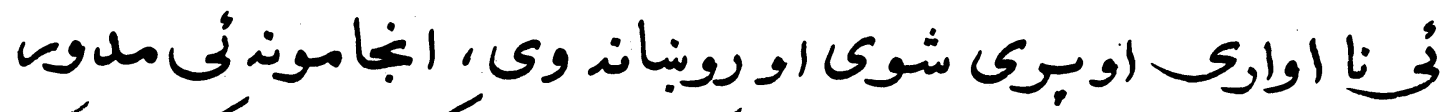

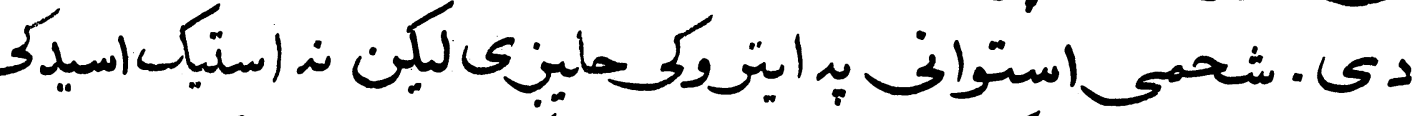

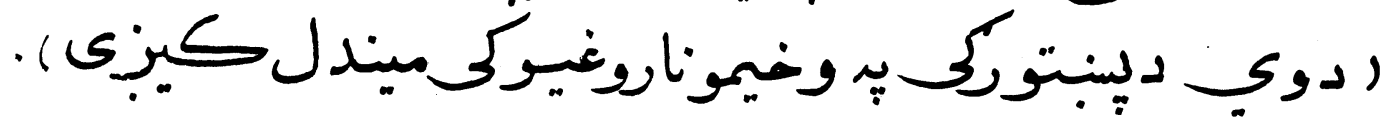

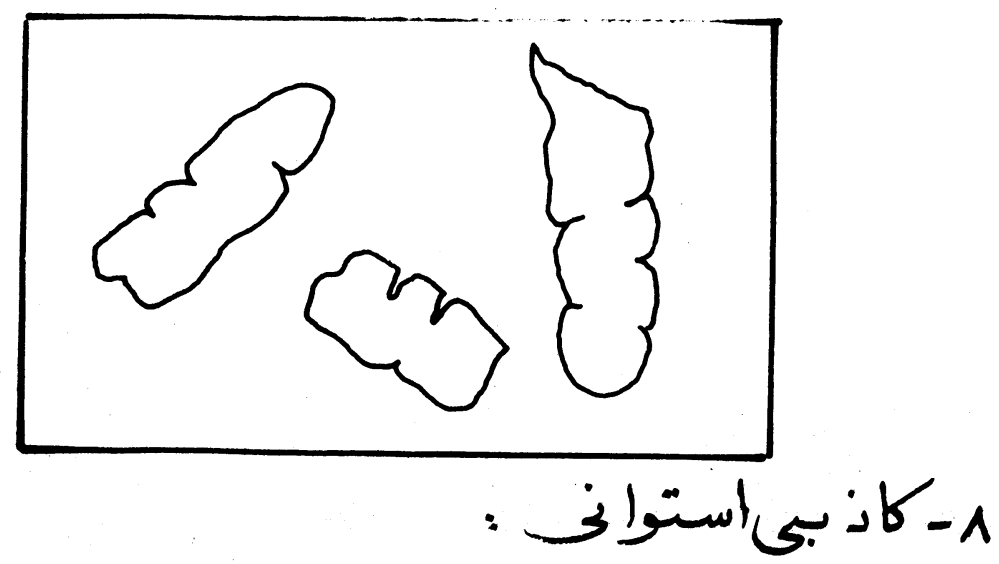

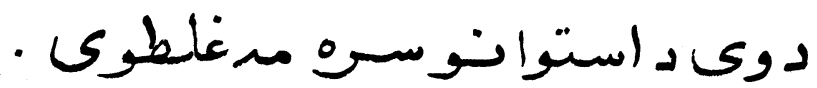

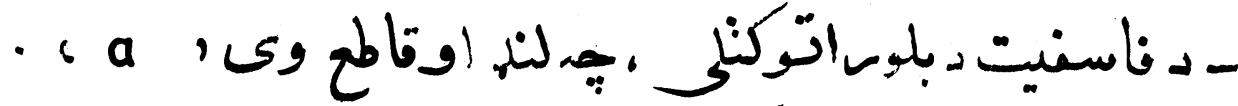

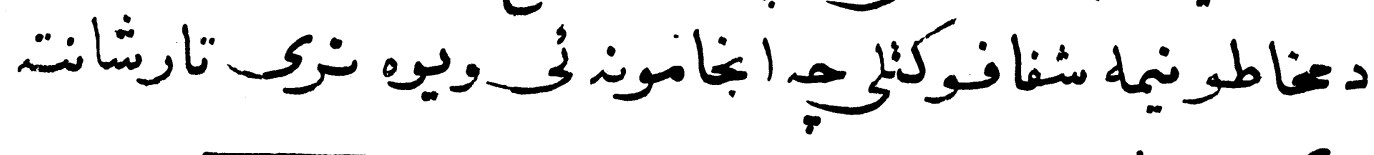

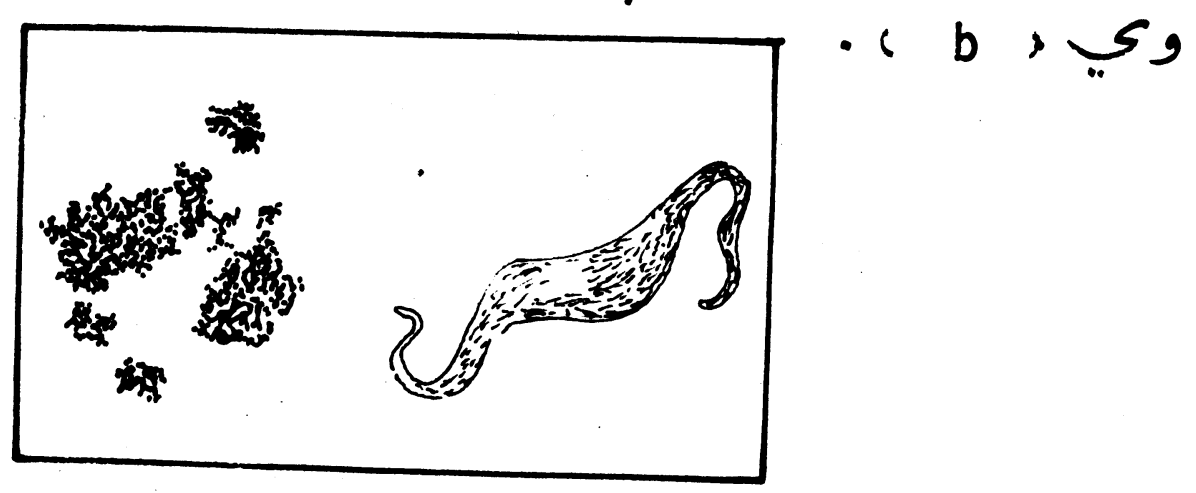




$$
\text { 9- متفنق خارج مواد : }
$$

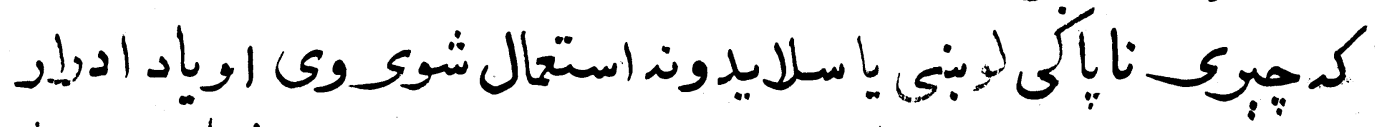

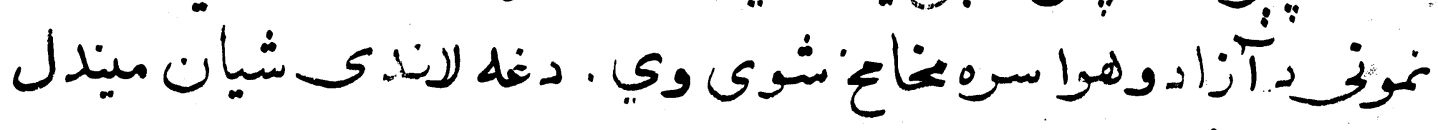

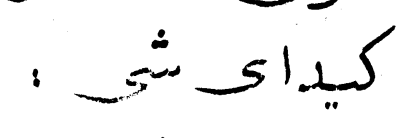

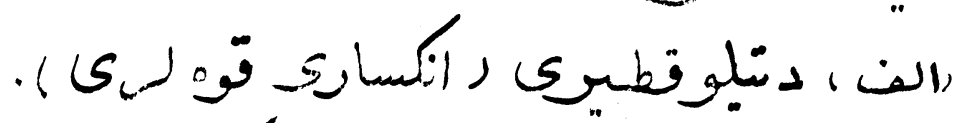

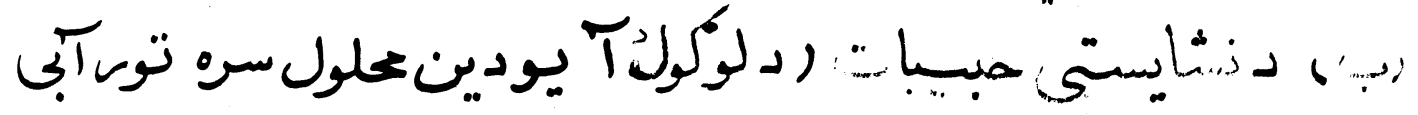

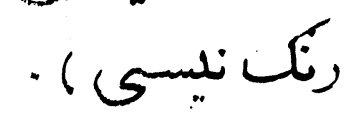

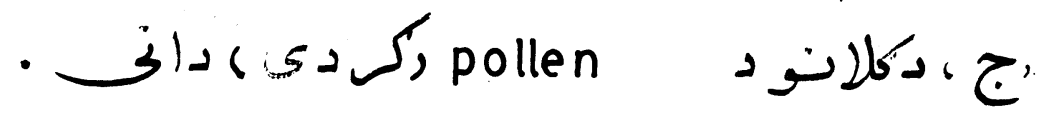

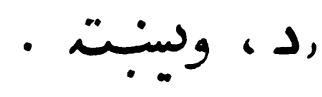

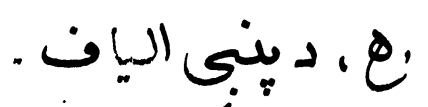

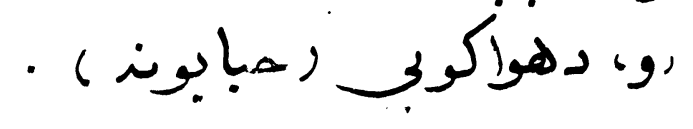

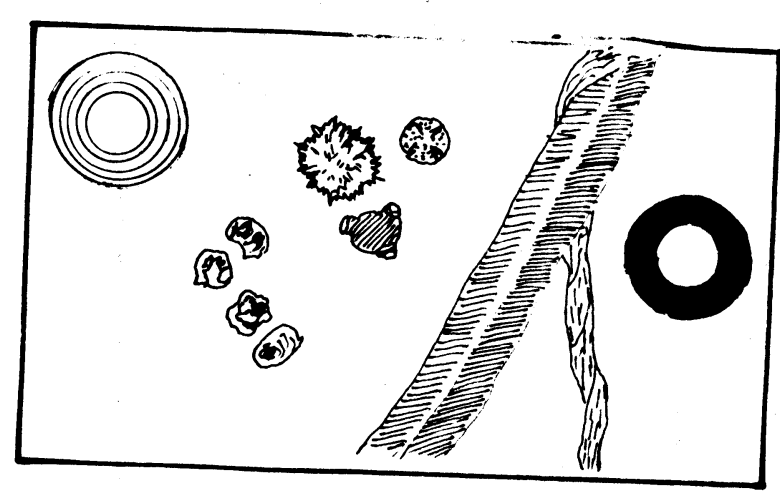




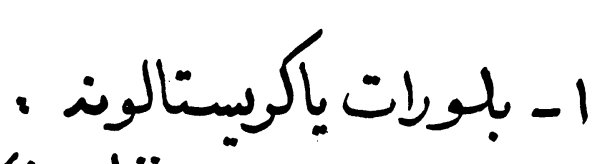

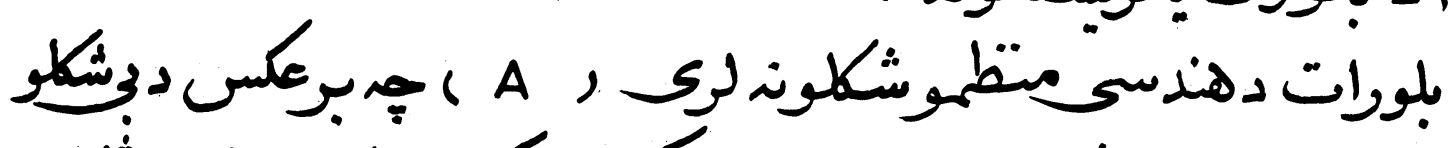

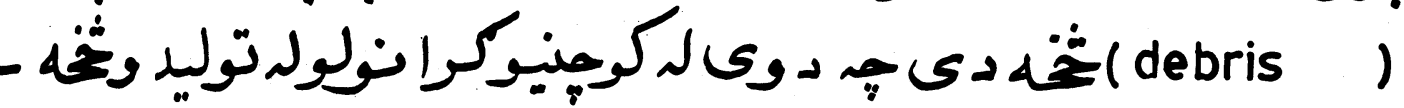

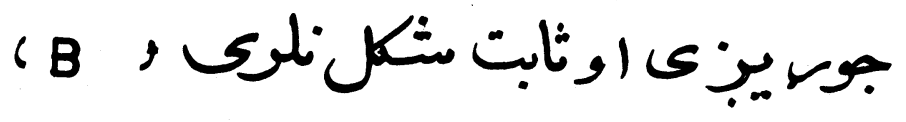
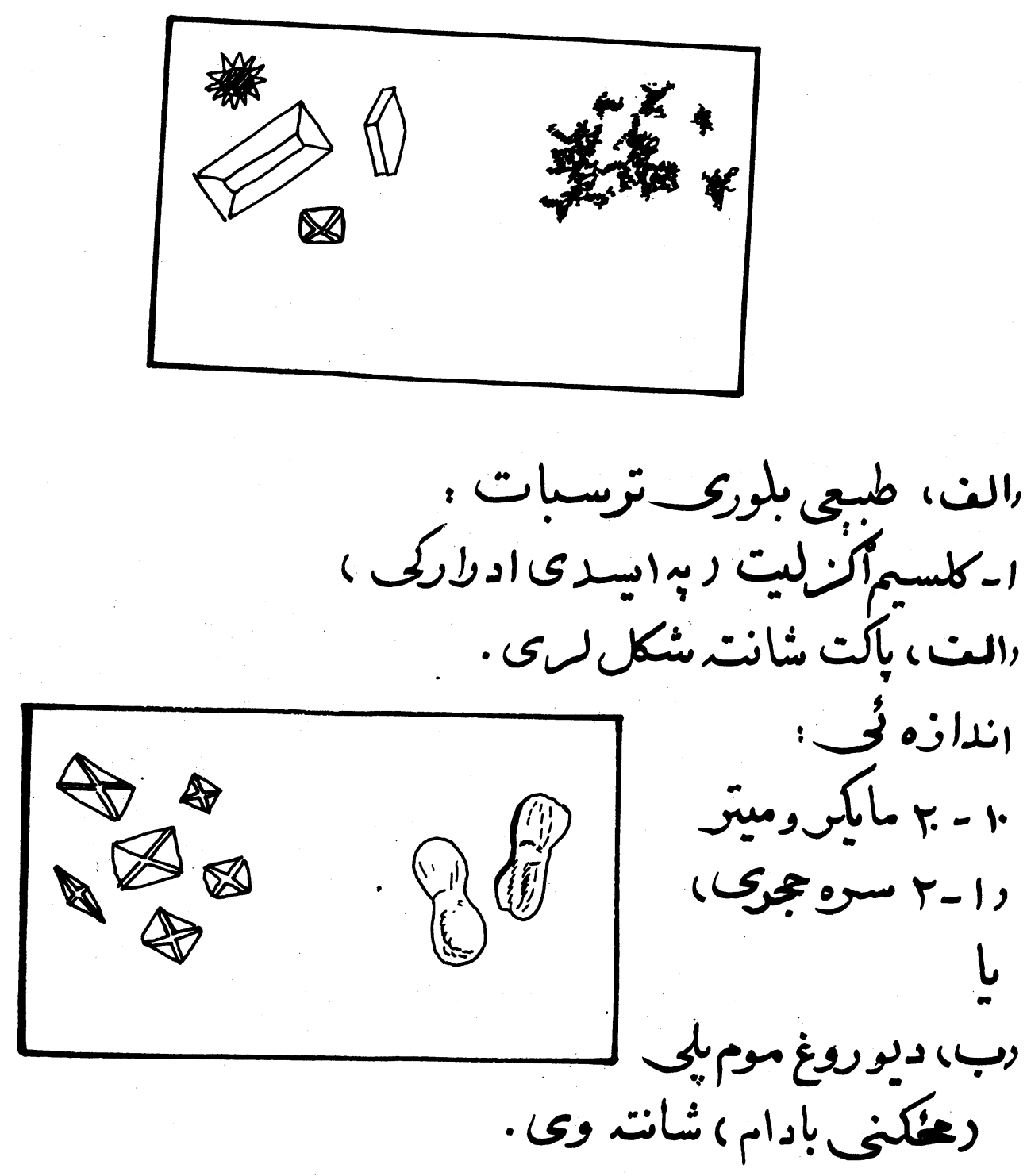

IVV 


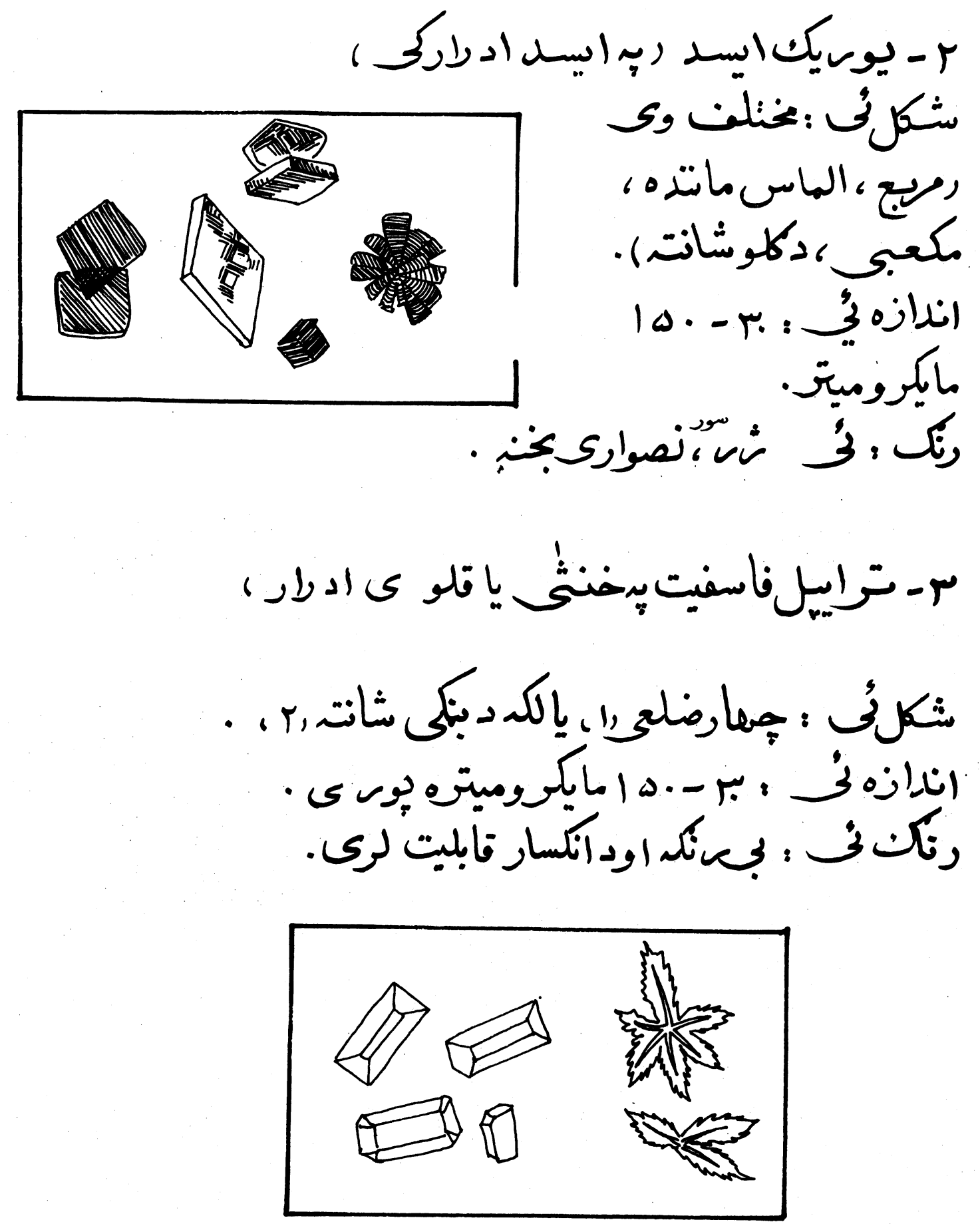

IVA 


$$
\text { ع-يوسيتون (تلوى ادراركى) }
$$

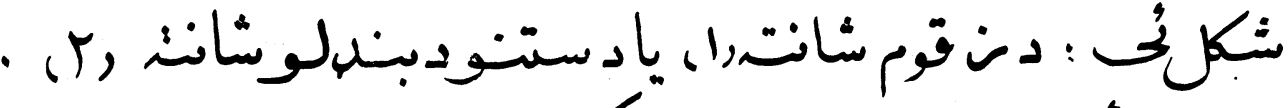

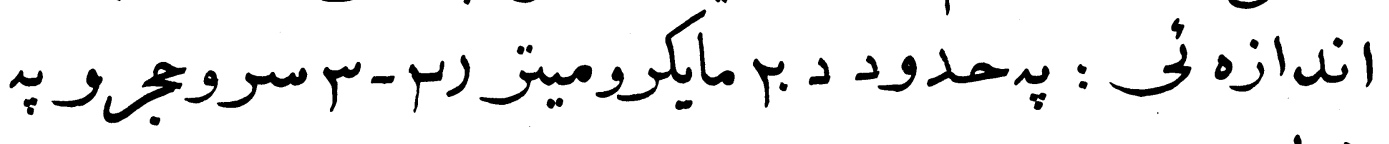

$$
\begin{aligned}
& \text { اندازه) }
\end{aligned}
$$

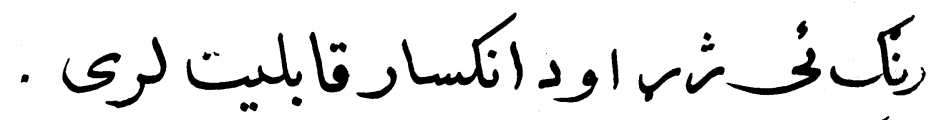

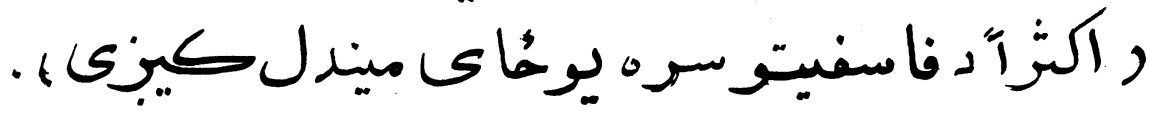

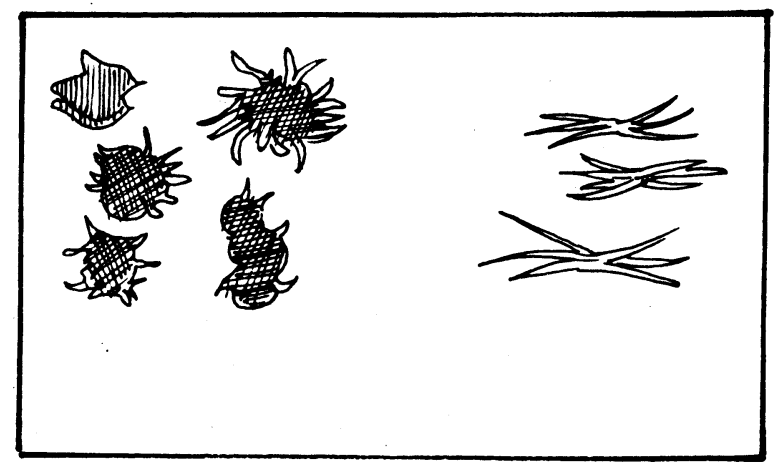

$$
\text { هـ كوم بلوراتجيك كمنعمومنيت لرى : }
$$

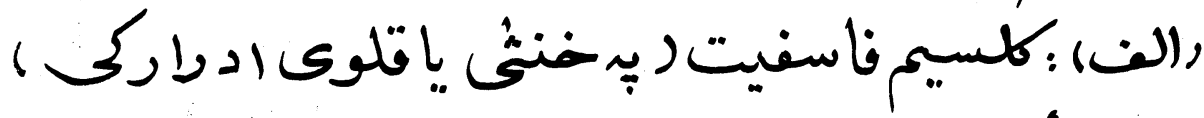
شكلنى ، ستاره ماتنده .

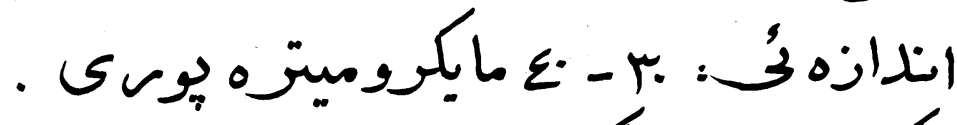

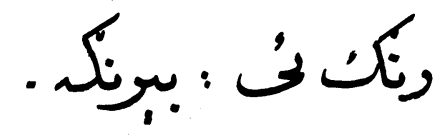


ب :كلسيم كابونيت (خنى يُ إنلوى ادراركى ).

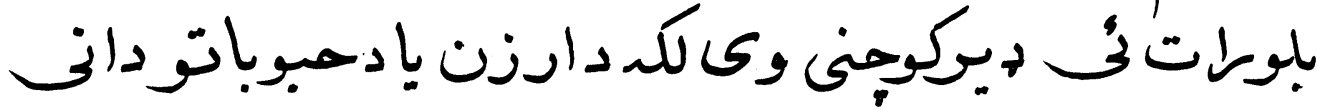

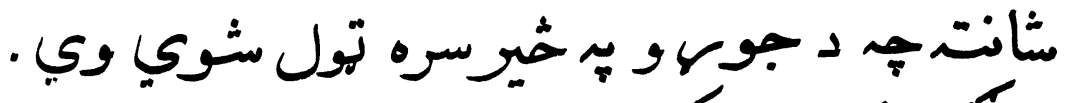

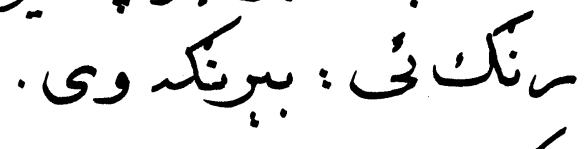

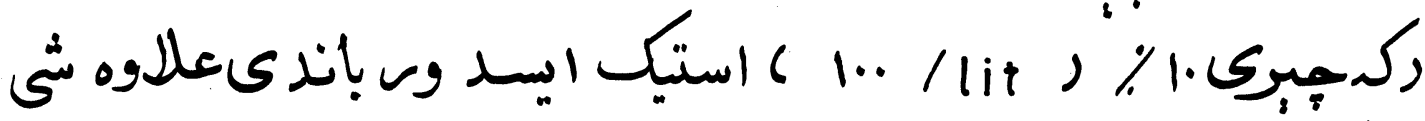
حكيبِى اودغازويوقانح توليده ورىا .

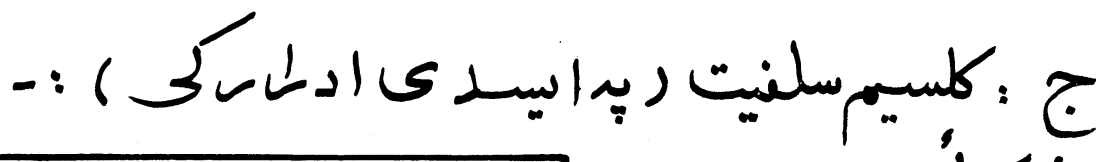

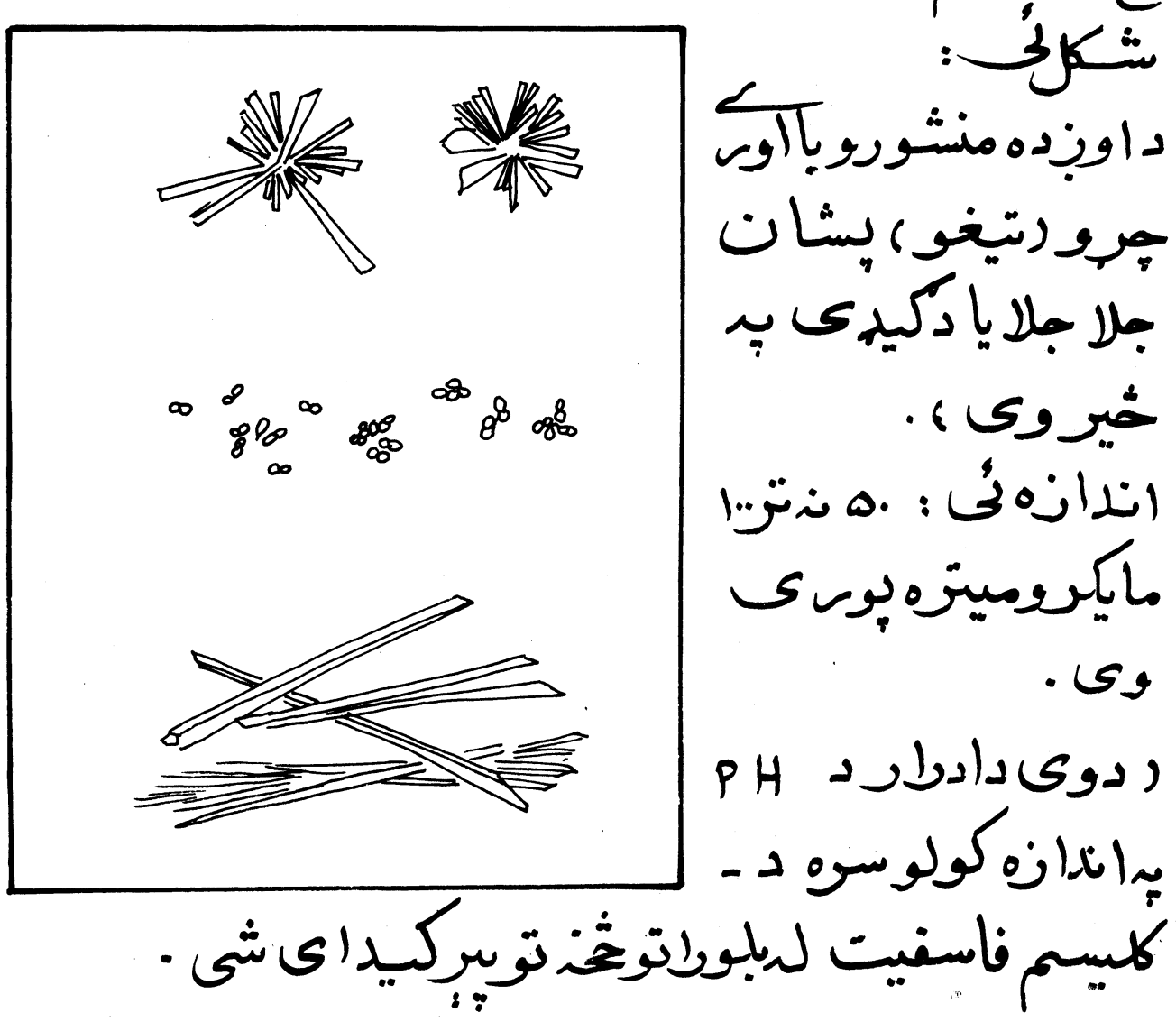




$$
\text { ب- دوينيجاتولوبحت }
$$

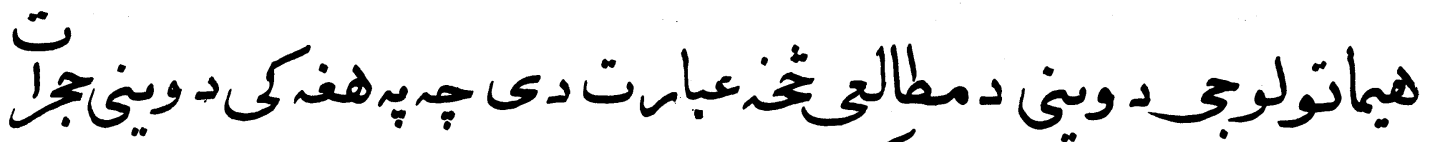

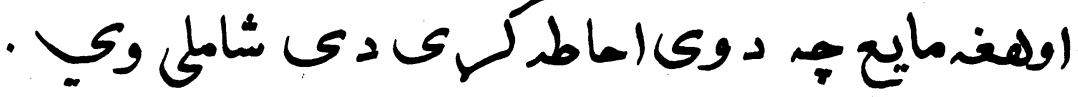
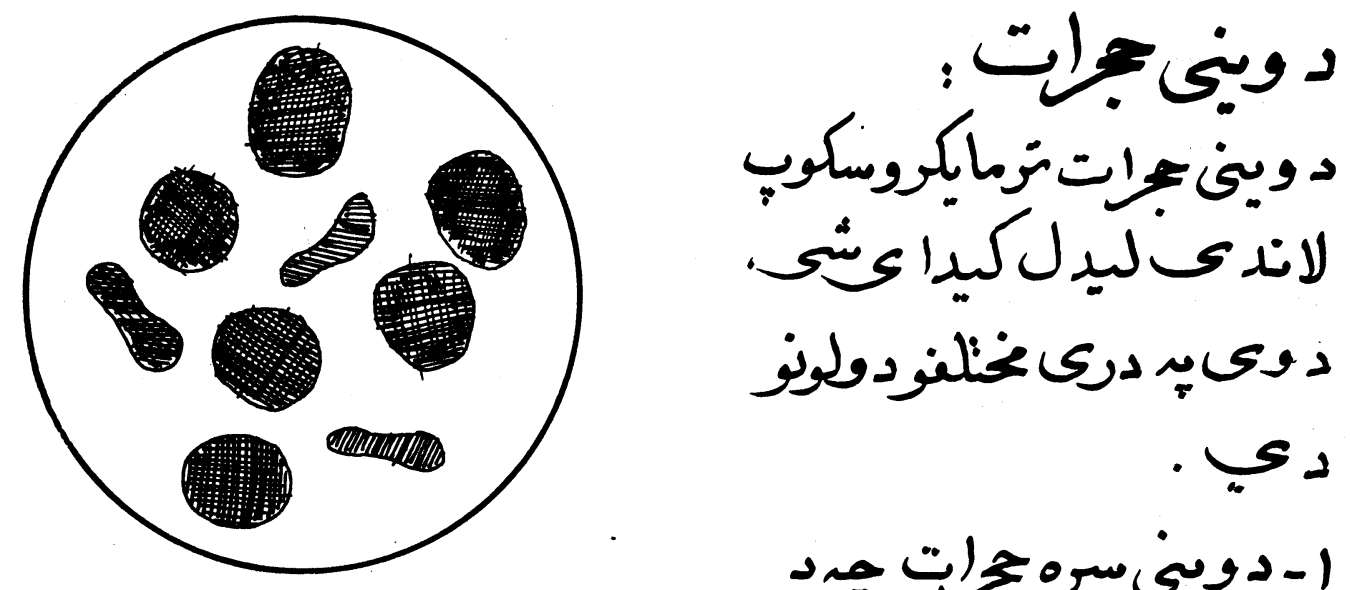

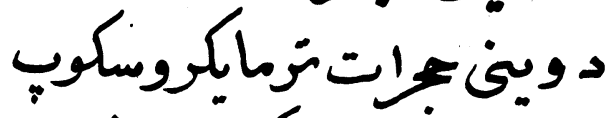

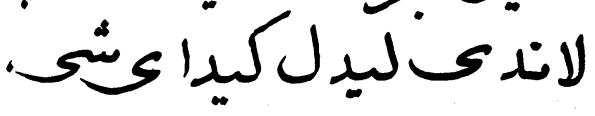
دويى درى ليخلنفودوليو دوب.

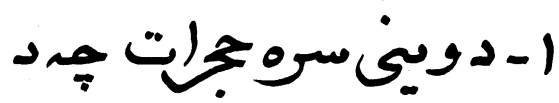
اريتّروسابتوي نامه هم يادي ينزي .

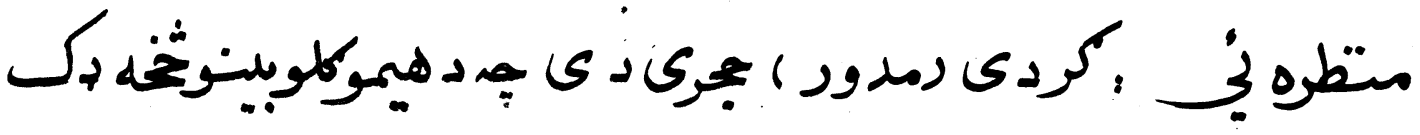
شويلى.

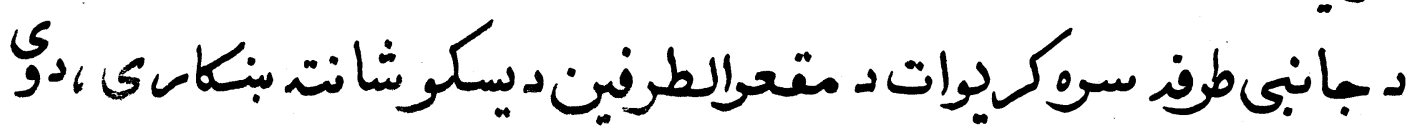

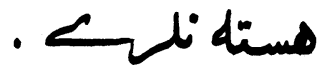




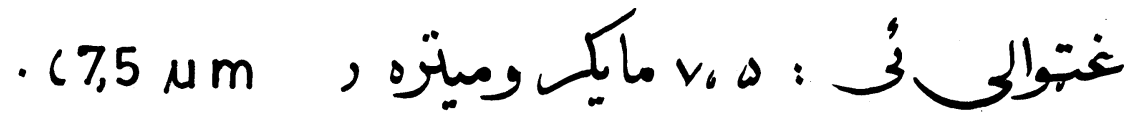

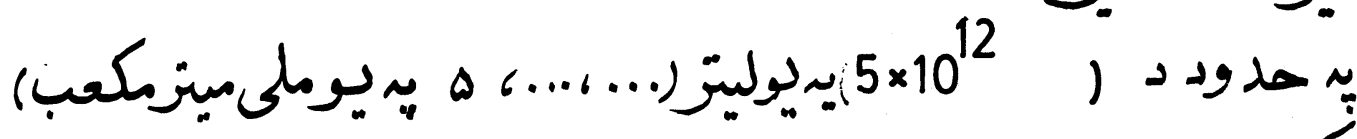

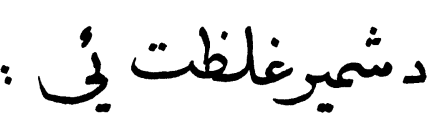

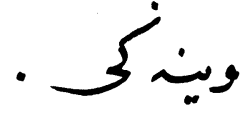

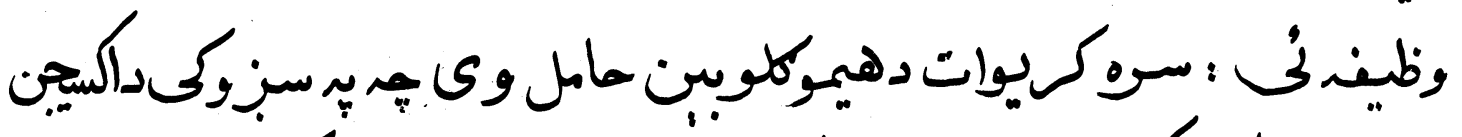

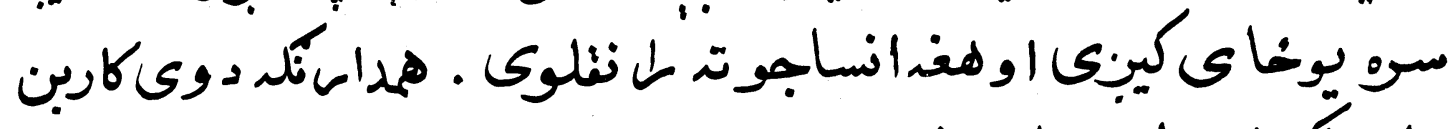

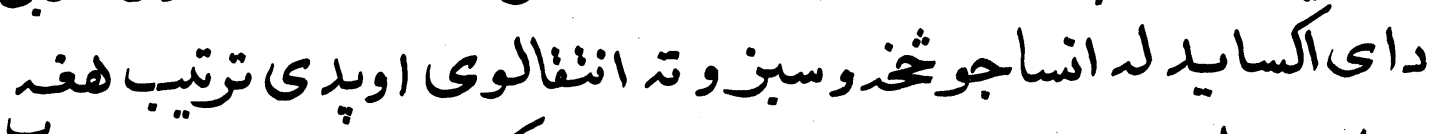

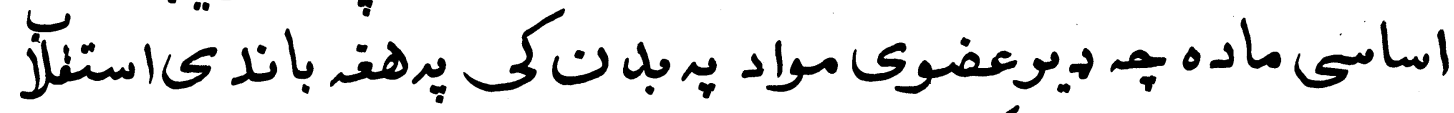

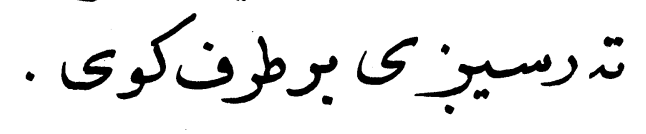

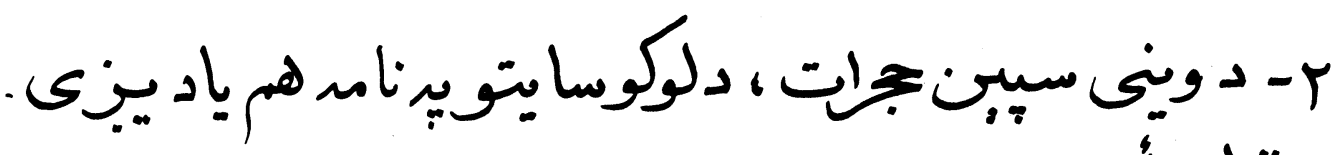

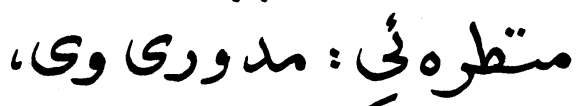

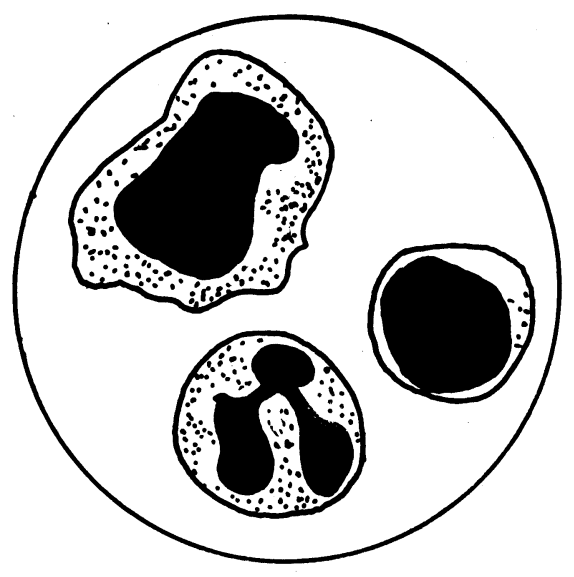

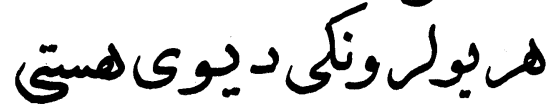

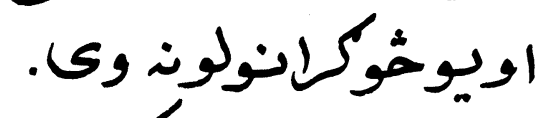

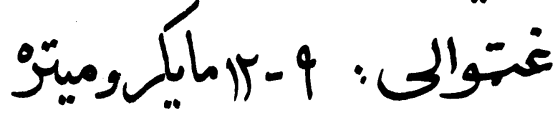
وي • ونمرئر د شيميرغلظت : بيدحدود

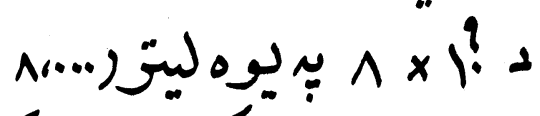

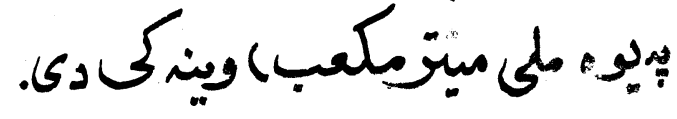
IAT 


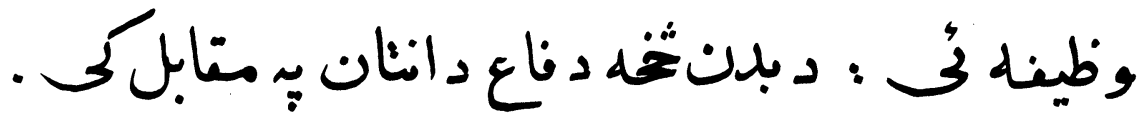

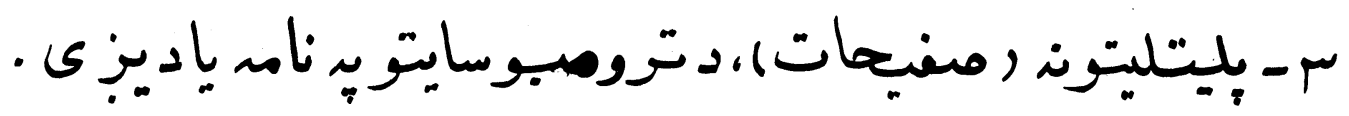

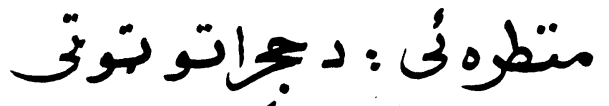

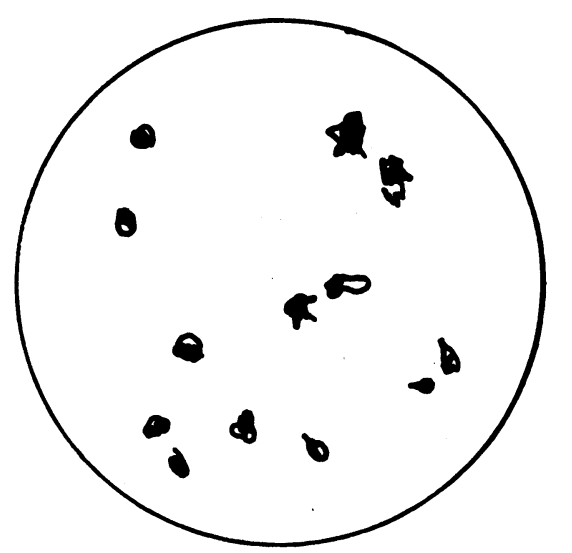

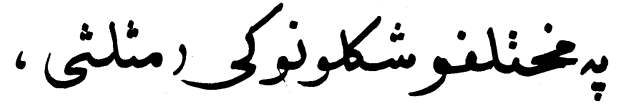

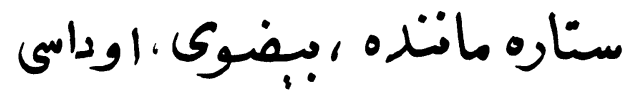

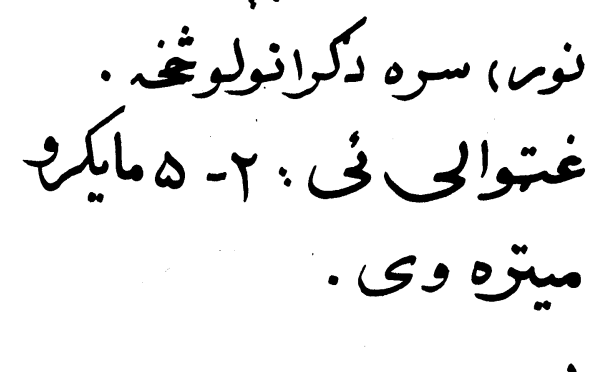
دشمهيغلظت : بحهدود

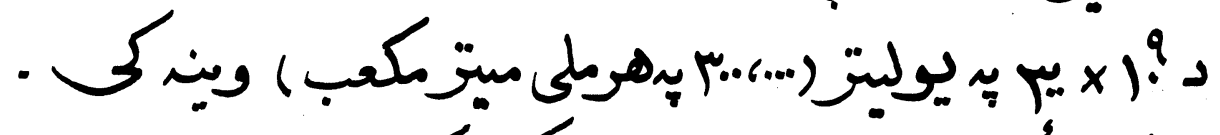

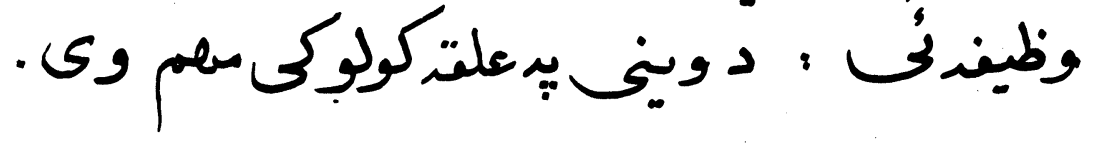

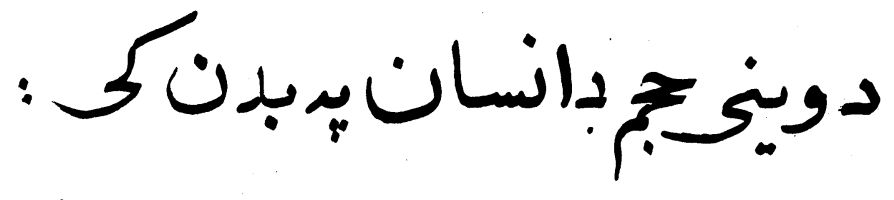

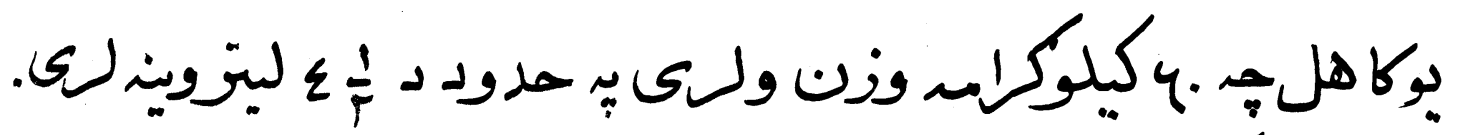

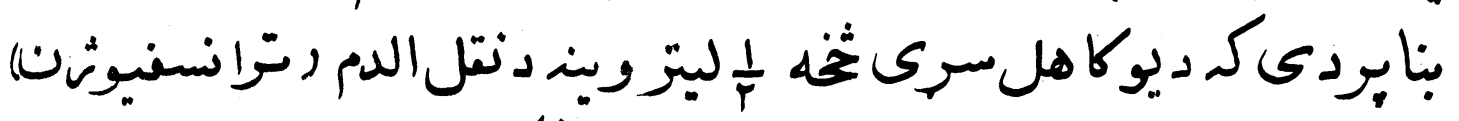

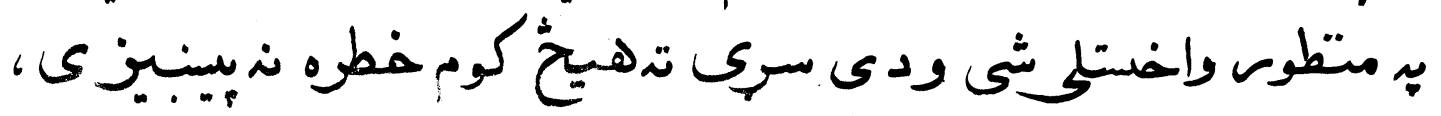




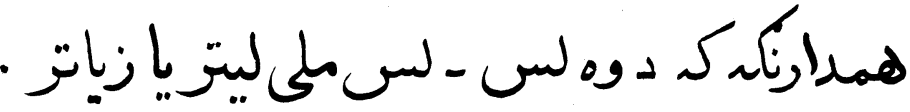

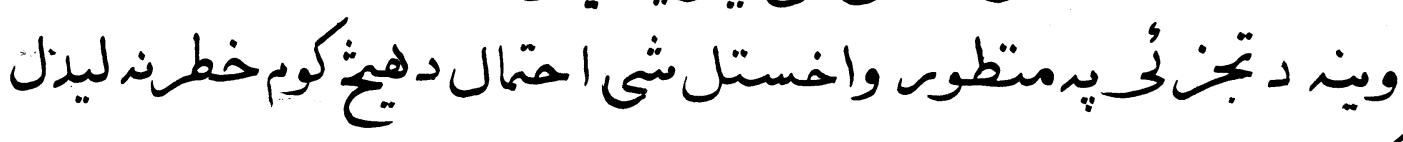

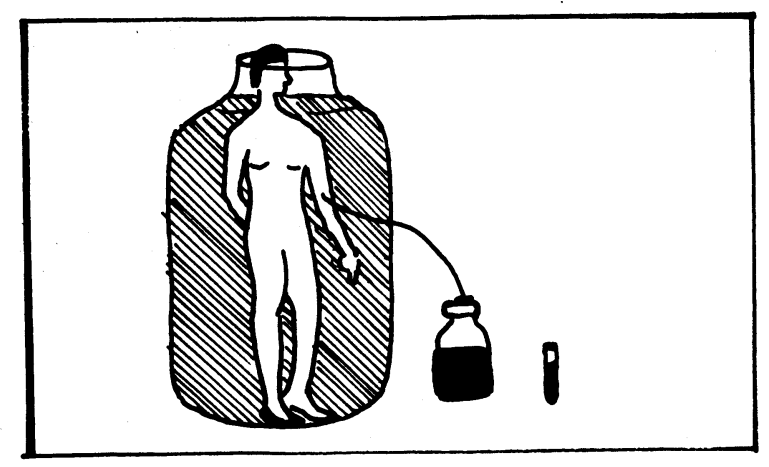

كيزى .

نوبايد تاسى دغنه

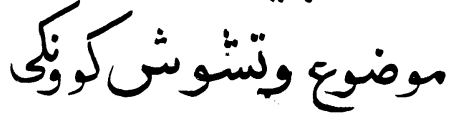
ناروغانوتتدهغوى ولني

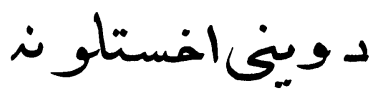

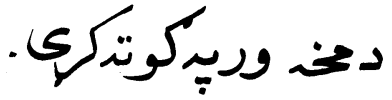

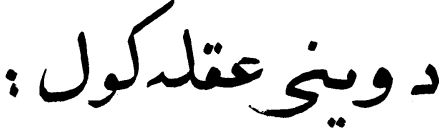

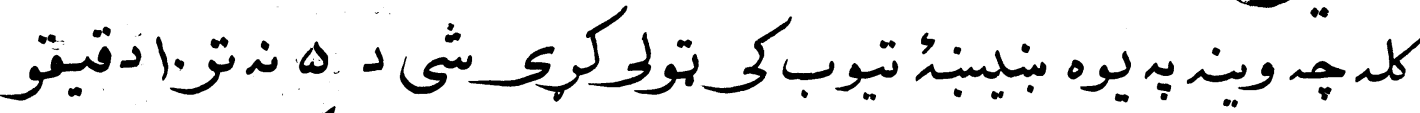

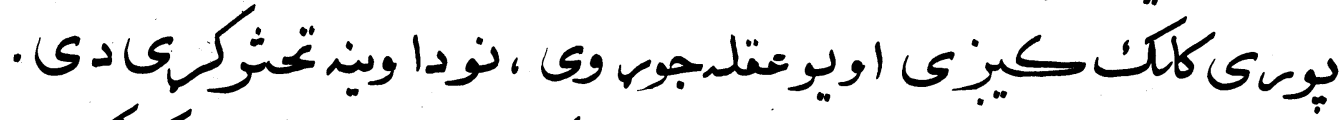

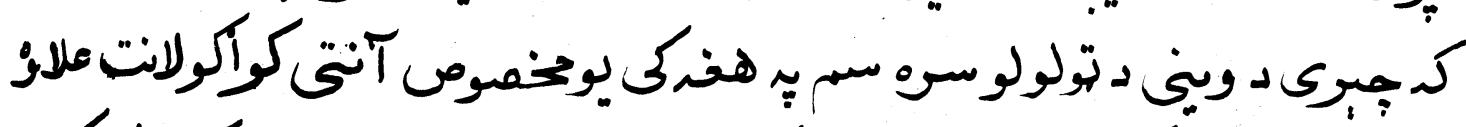

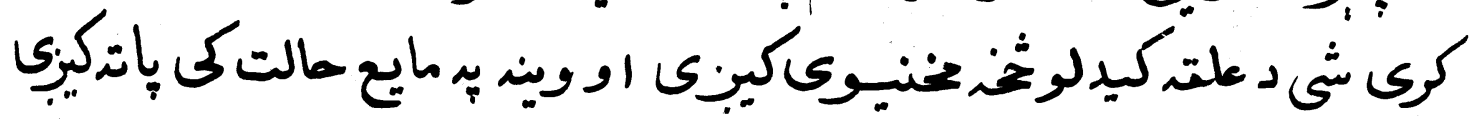

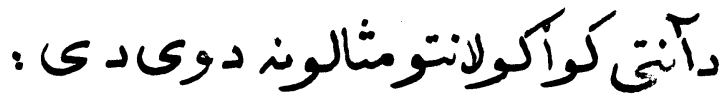

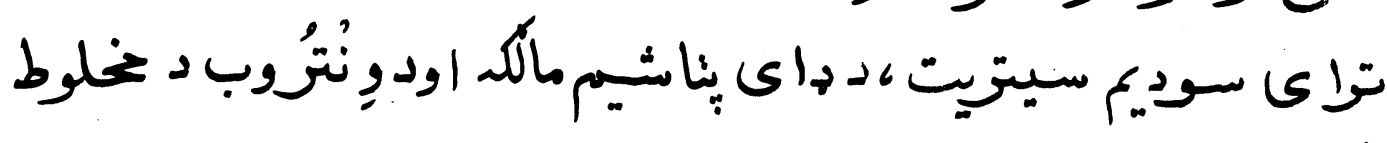




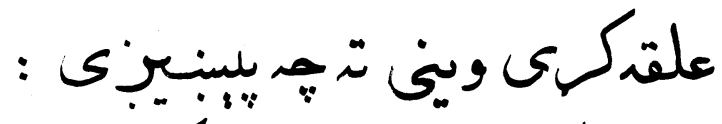

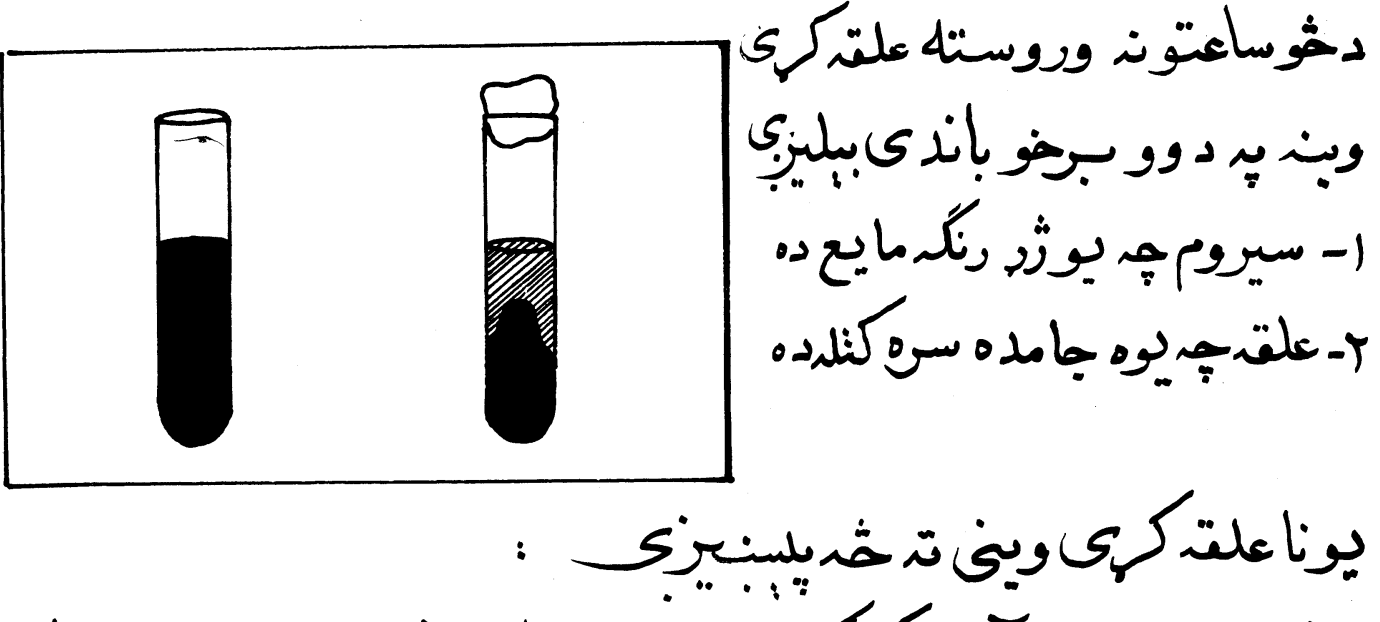

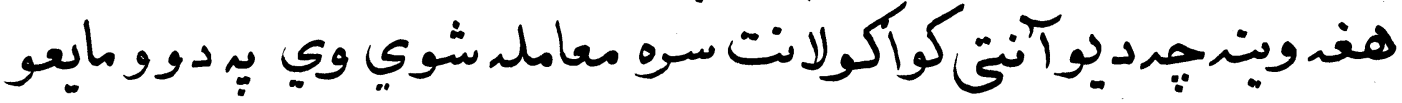

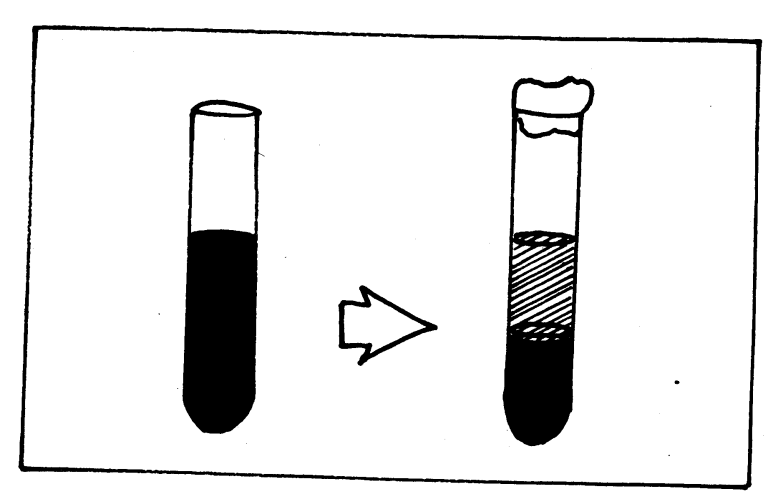

$$
\begin{aligned}
& \text { برخو باندكىبليبيى. }
\end{aligned}
$$

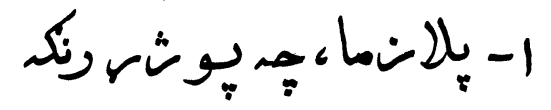

$$
\begin{aligned}
& \text { مايع ده. }
\end{aligned}
$$

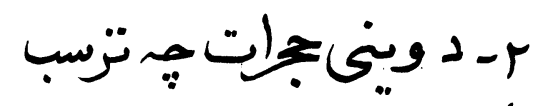

$$
\begin{aligned}
& \text { كوي وي : }
\end{aligned}
$$

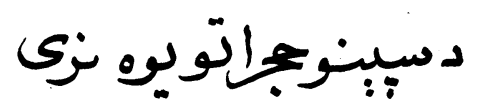

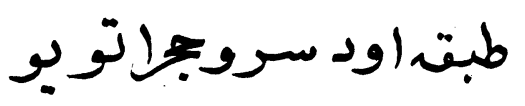

$$
\begin{aligned}
& \text { سموب • منات }
\end{aligned}
$$




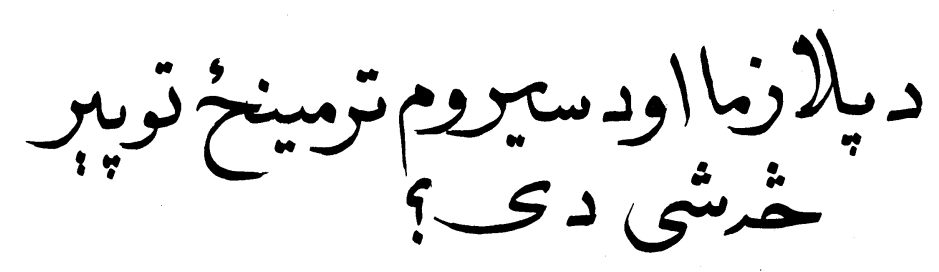

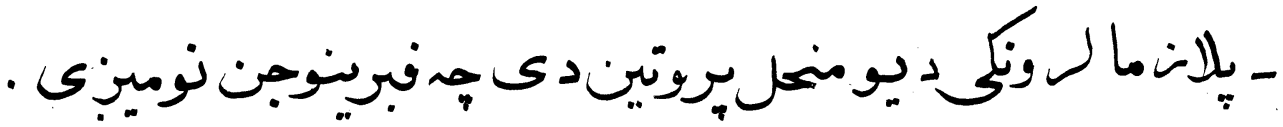

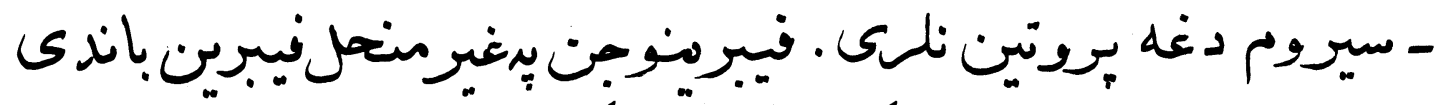

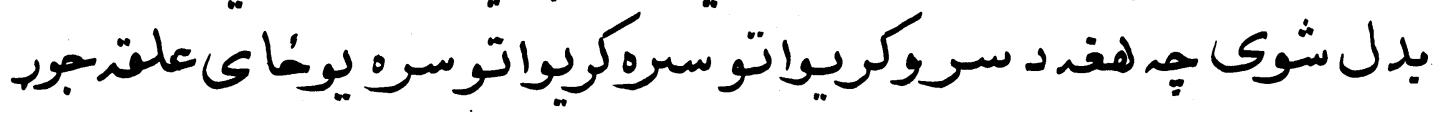

$$
\text { د وريد ثخده وينت تولول }
$$

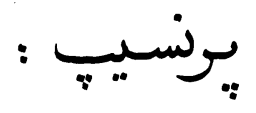

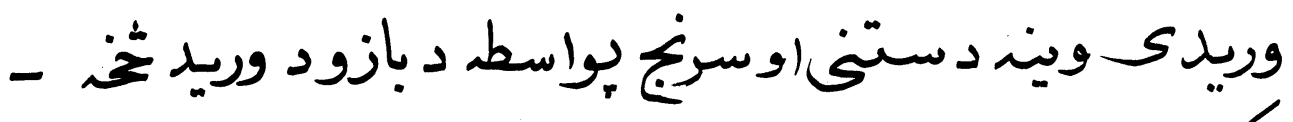

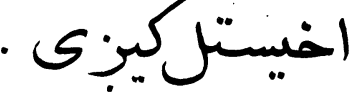

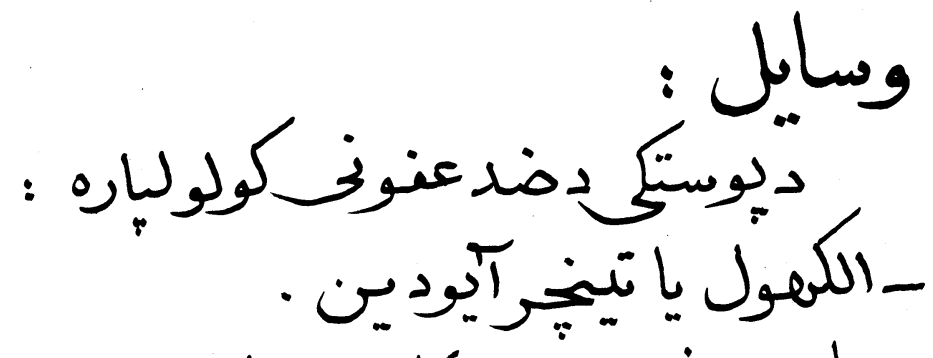

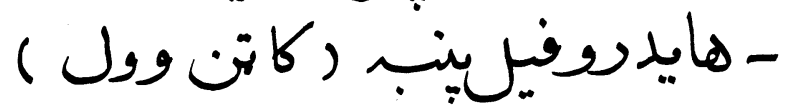




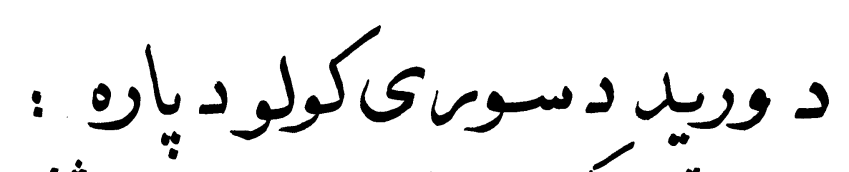

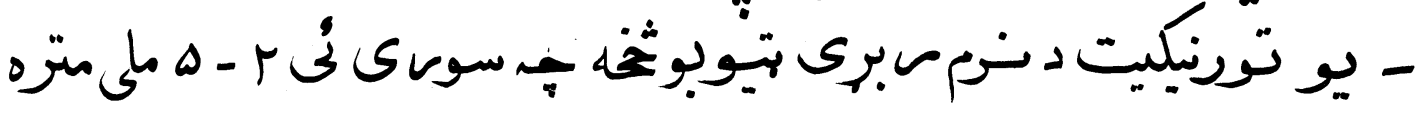

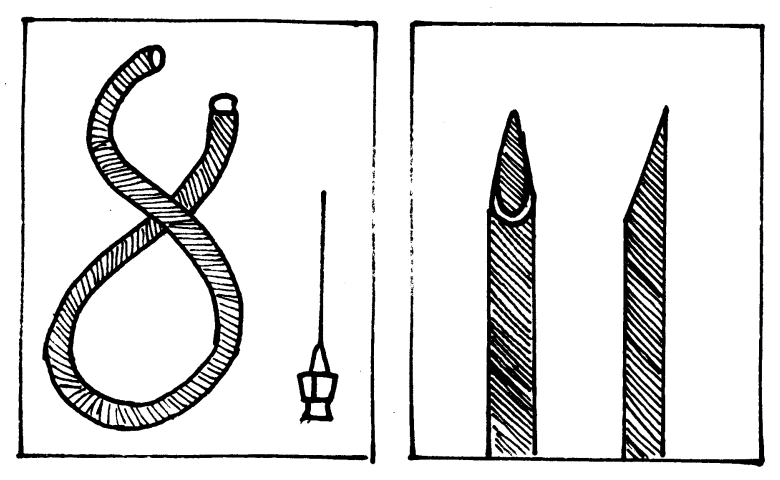

.

: -

اوبد والكـ : : - •ع ملمته

: تطر

9.

( 1 (19) 190

$(=11)=15$

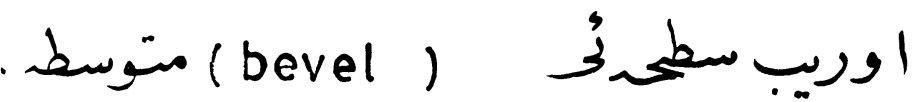
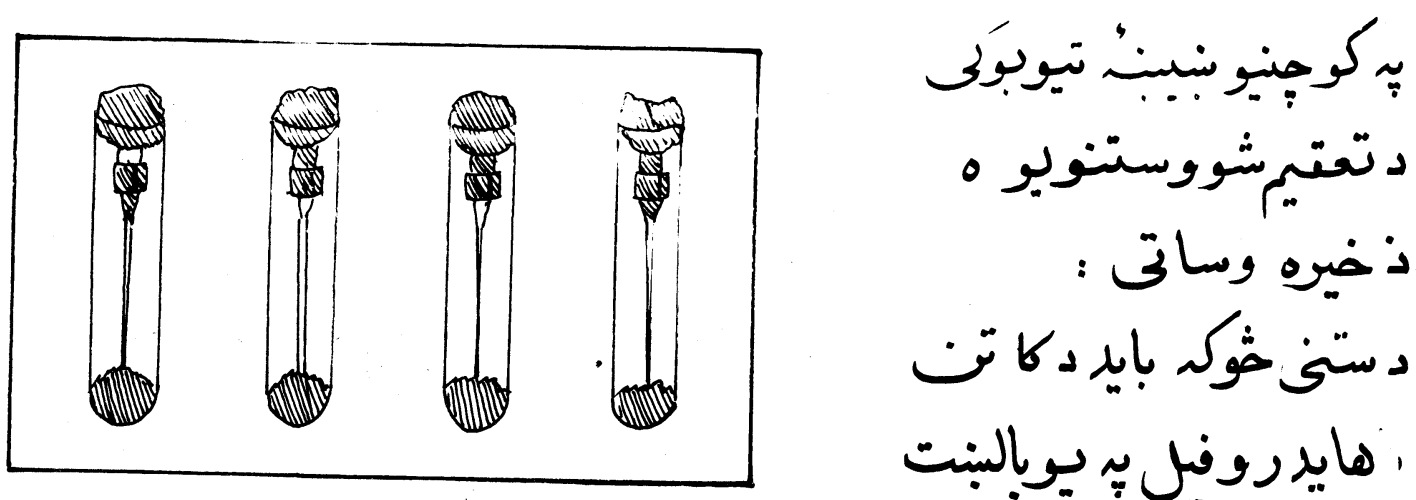

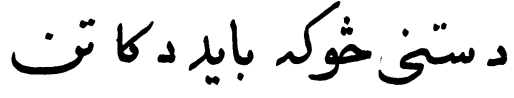

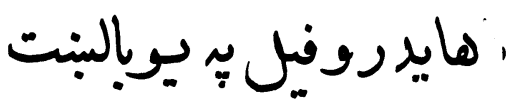

باندى دمول سُوى وى،

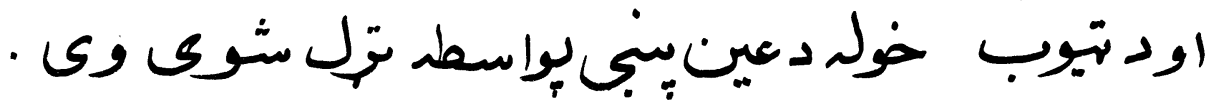




\section{د وينحـد نَولولولياره :}

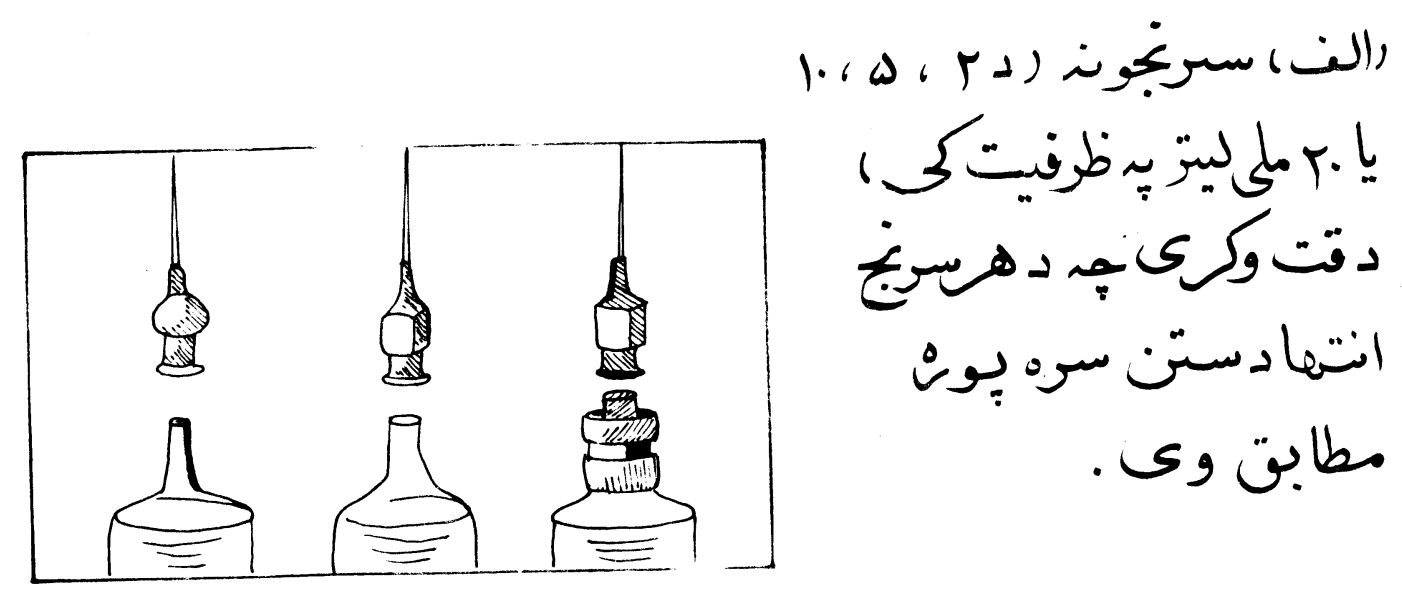

P. = Pravaz Recurd syringe

$L$. = Luer syringe

$L L$. Luer Lok syrnge

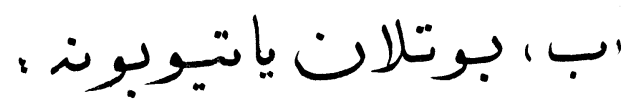

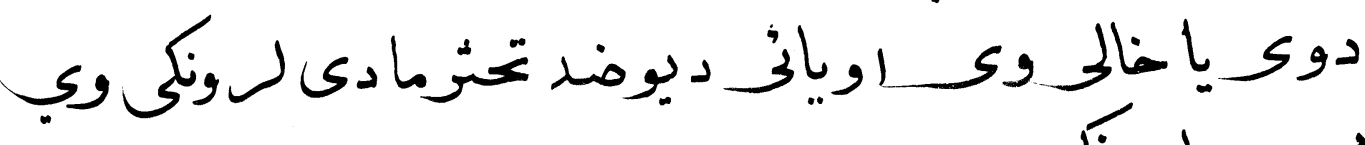

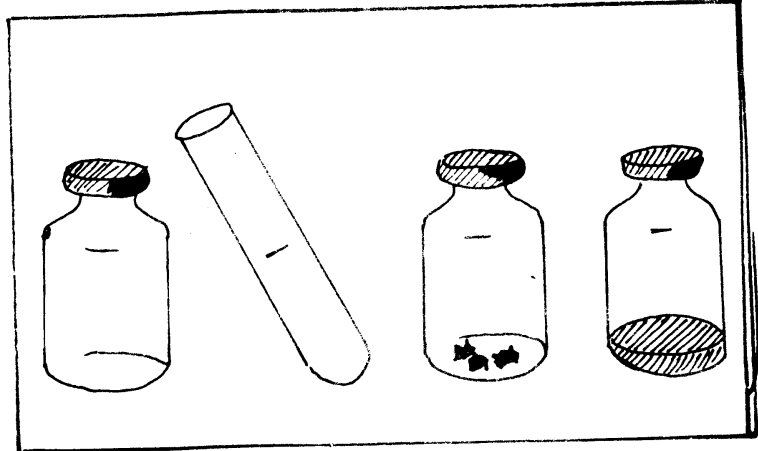

اوهوومورلرونكل ديسيوه وكي

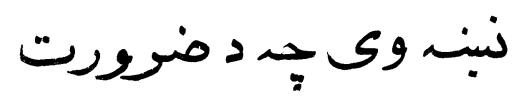

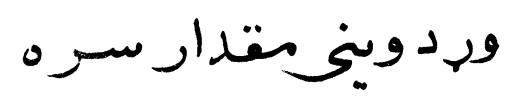

مطابت وكي 


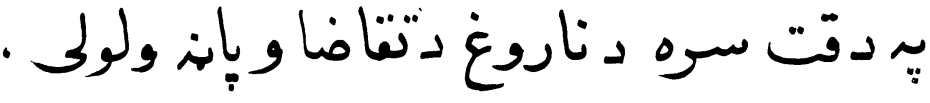

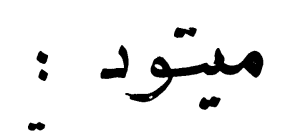

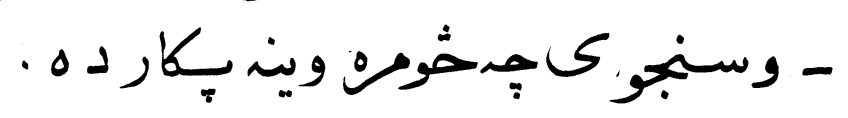

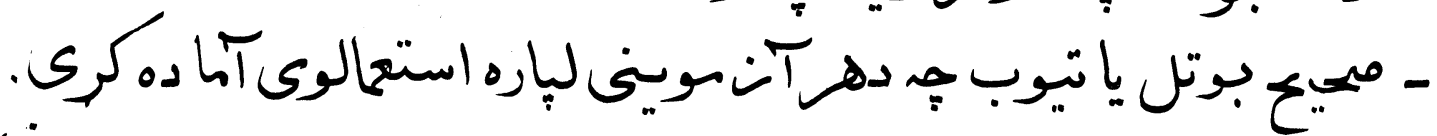

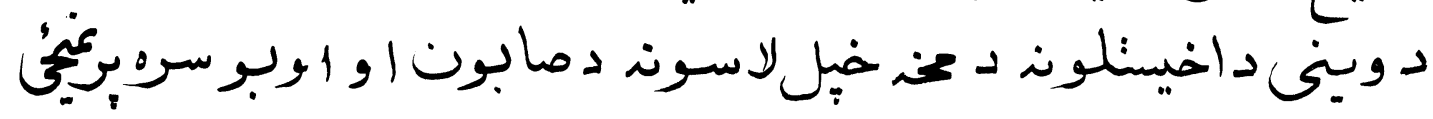

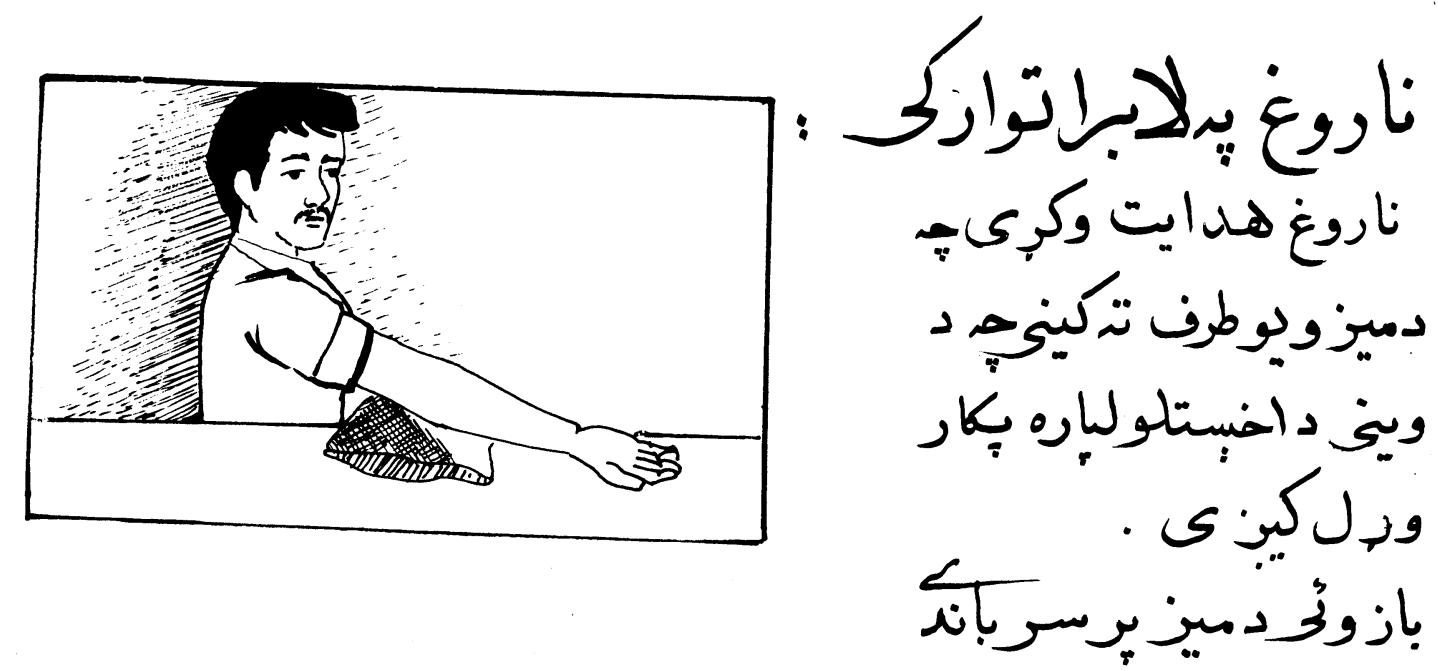

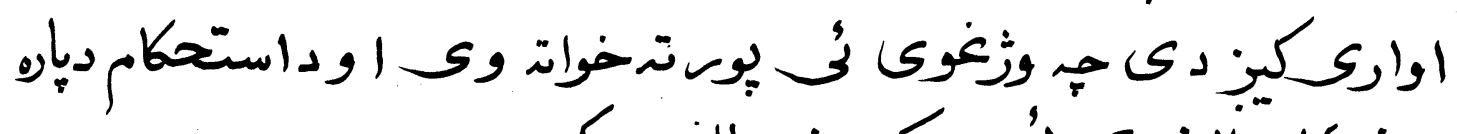

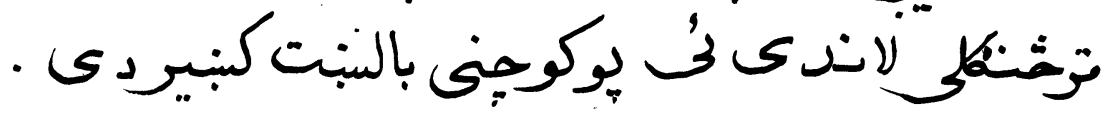

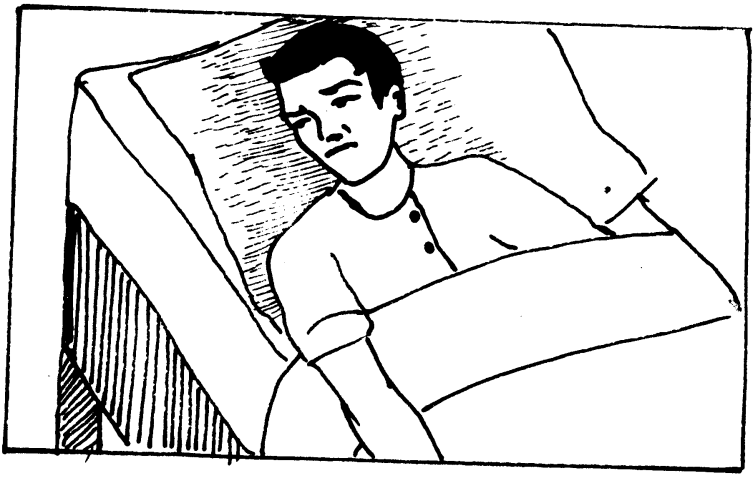

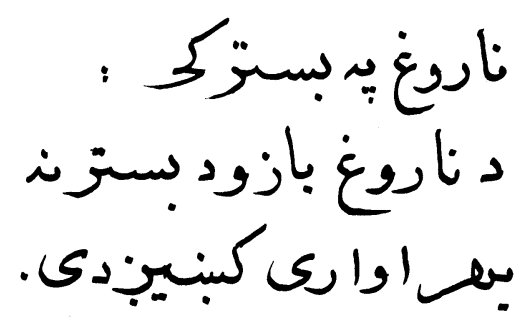

119 


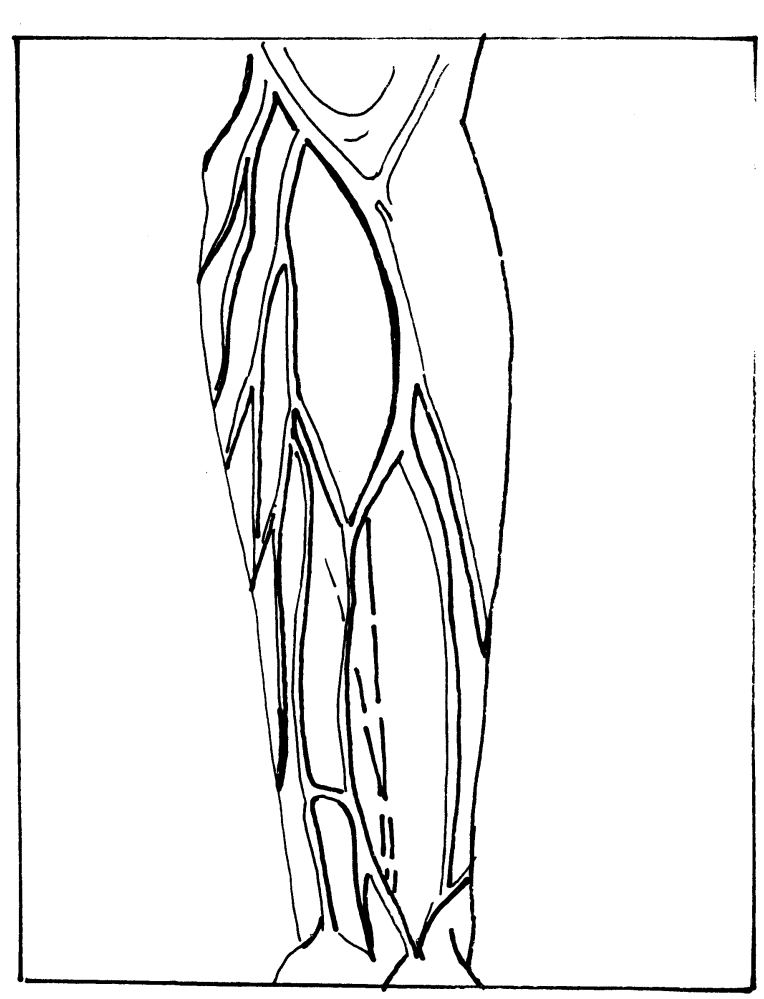

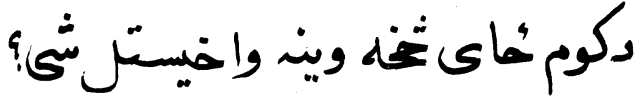

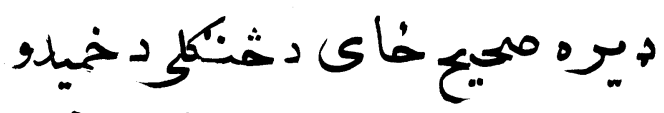

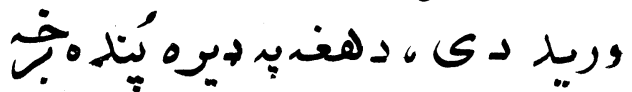

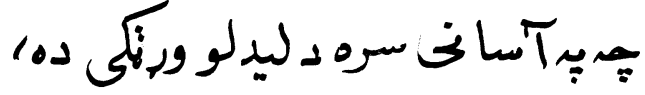

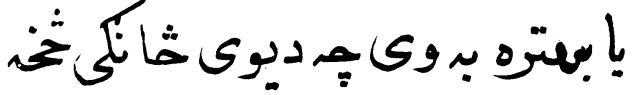

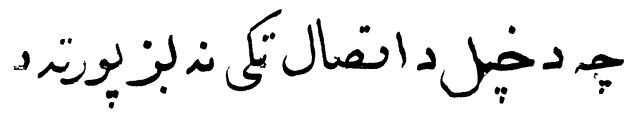

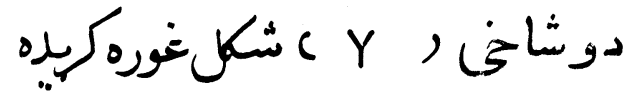
• (1) د منروص ت سره سمد r -

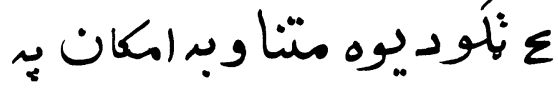

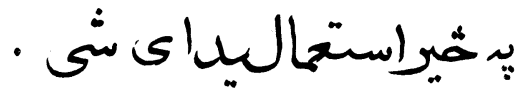

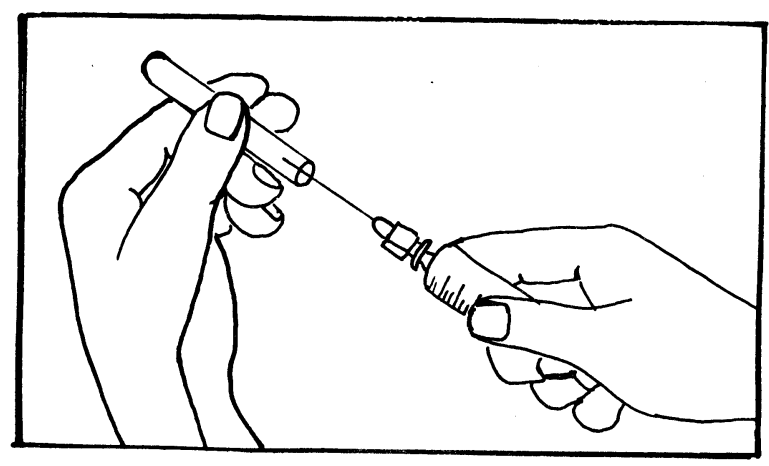

د سريخ :

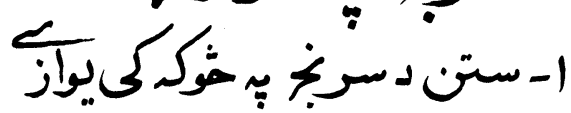

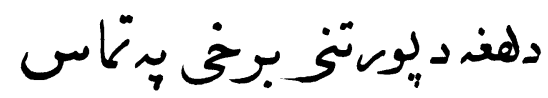

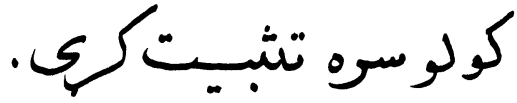

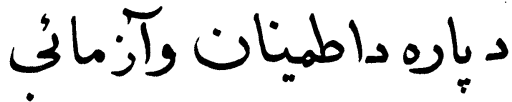

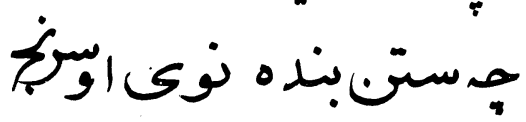
• لهوا واتخلى 


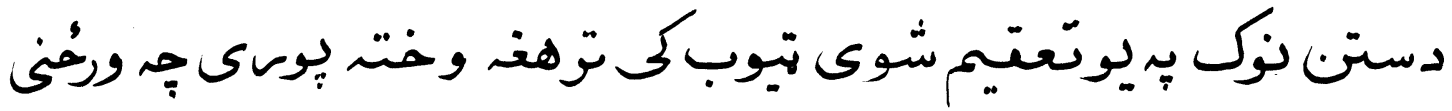

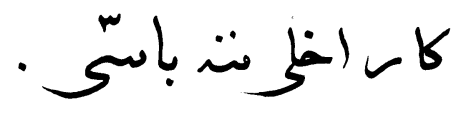
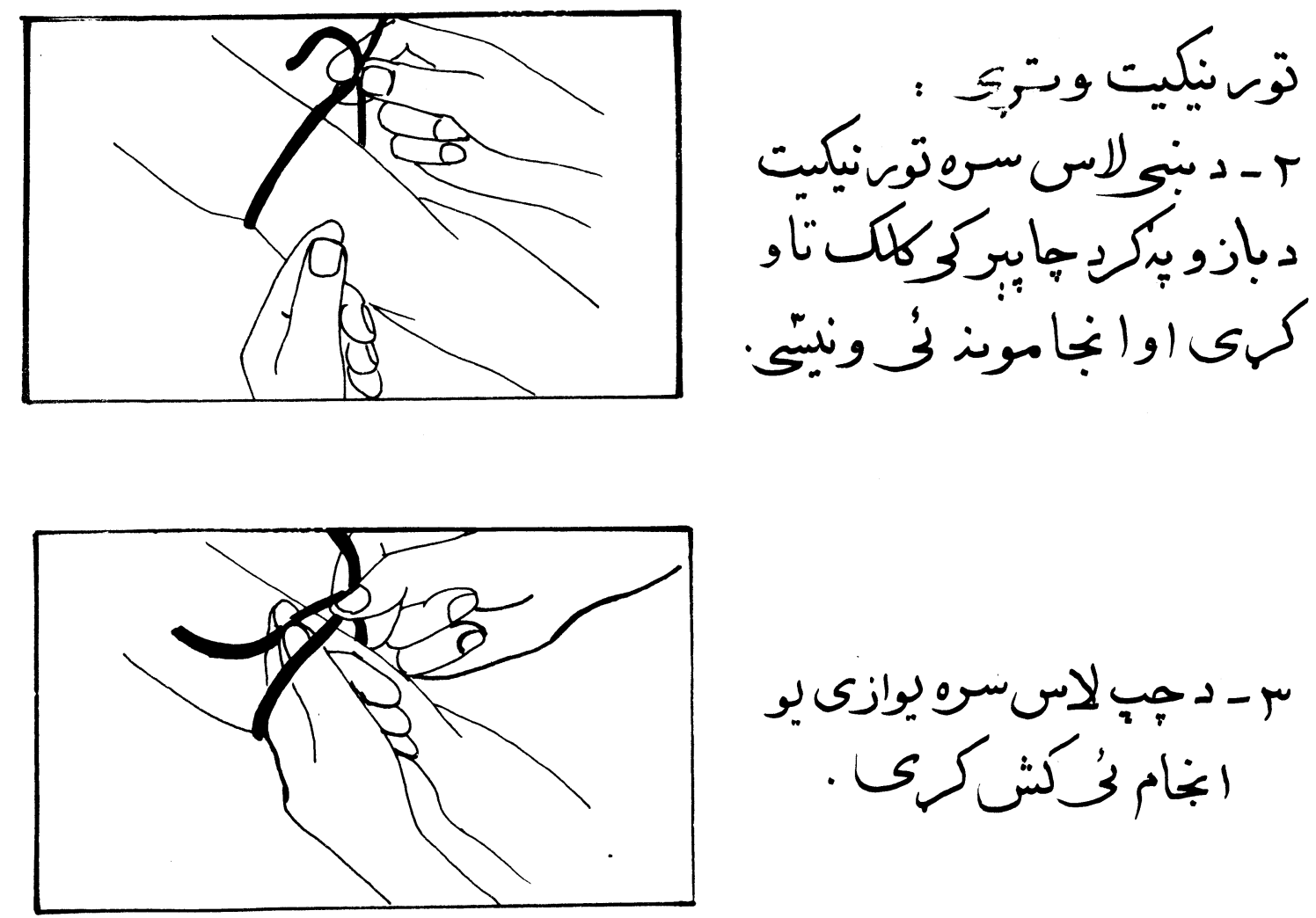

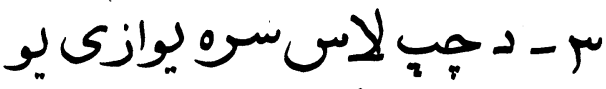

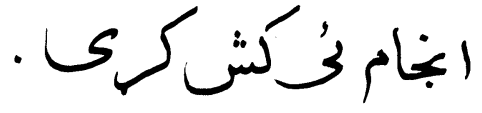

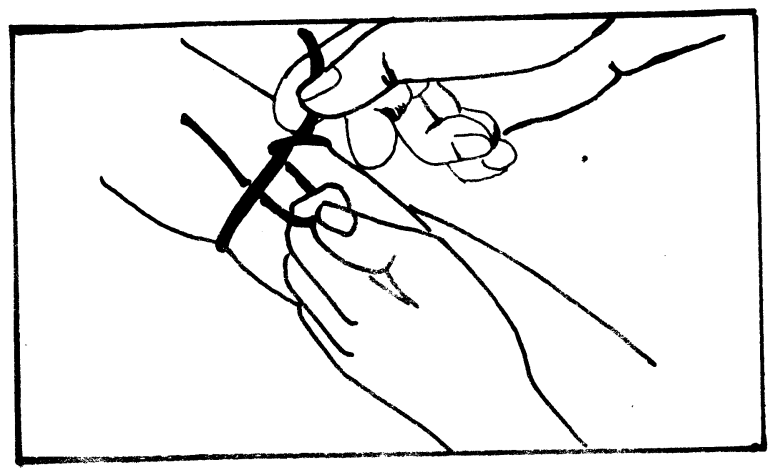

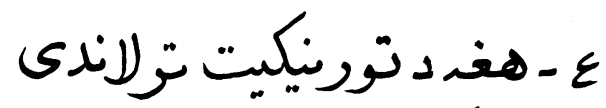

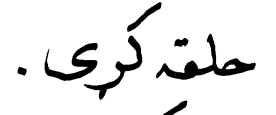

تونيكيت صرت هنوي كون

$$
\begin{aligned}
& \text { كاكَ وتربل شيى جِ د وبنى } \\
& \text { جاين لبخة وروشتي }
\end{aligned}
$$




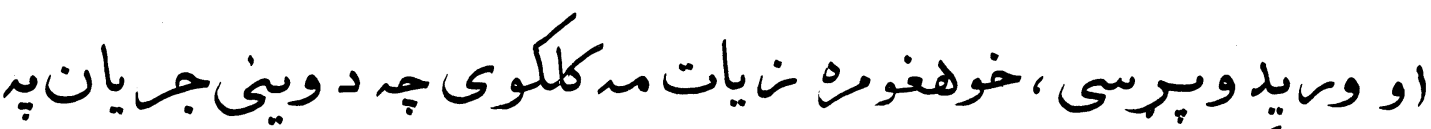

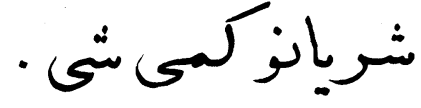

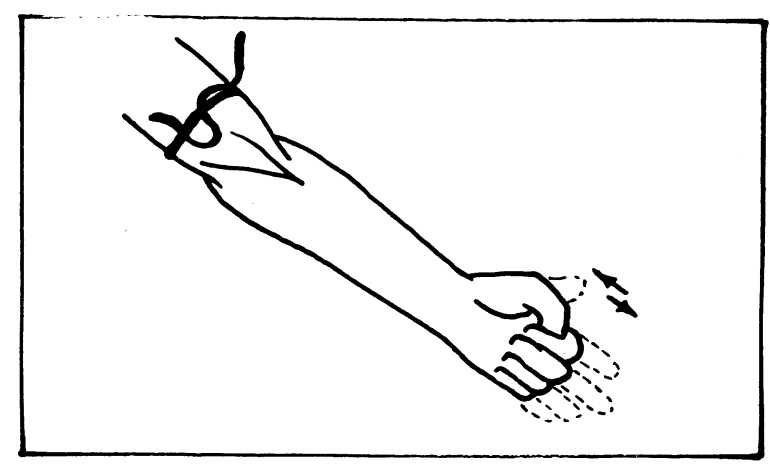

هـ دد دى دياره جـ وريلـون

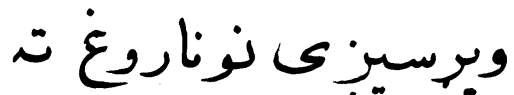

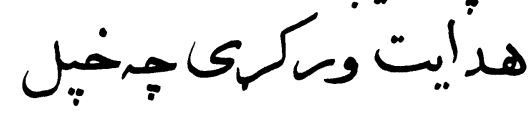

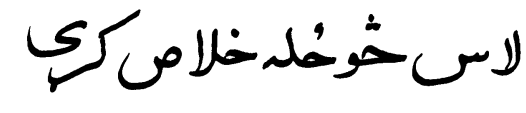

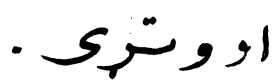

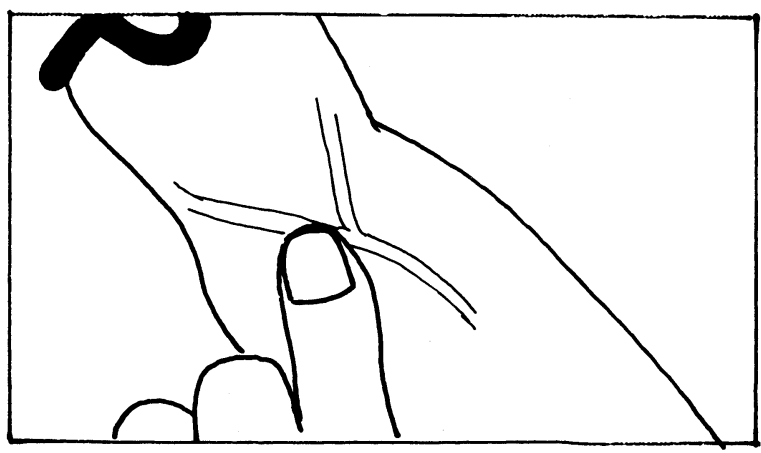

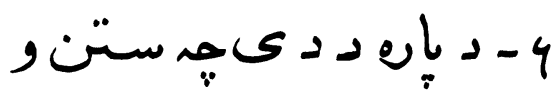
كومى خُاي تَ داخل كِّي

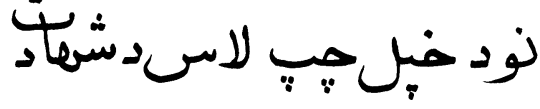

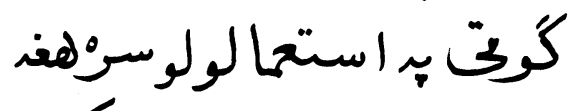

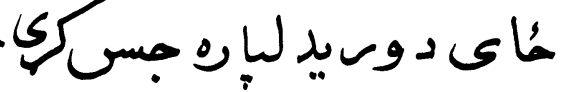

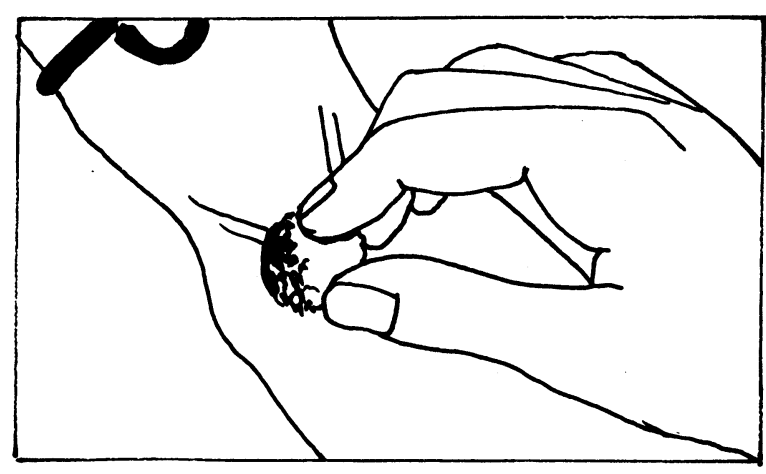

ل- د بوستك هف سيمه 2

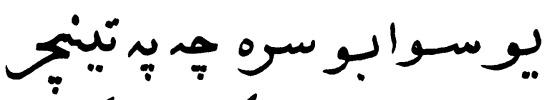

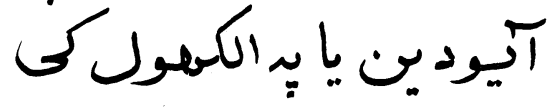
غوتَ شوى وى ضى ضدعنونى 


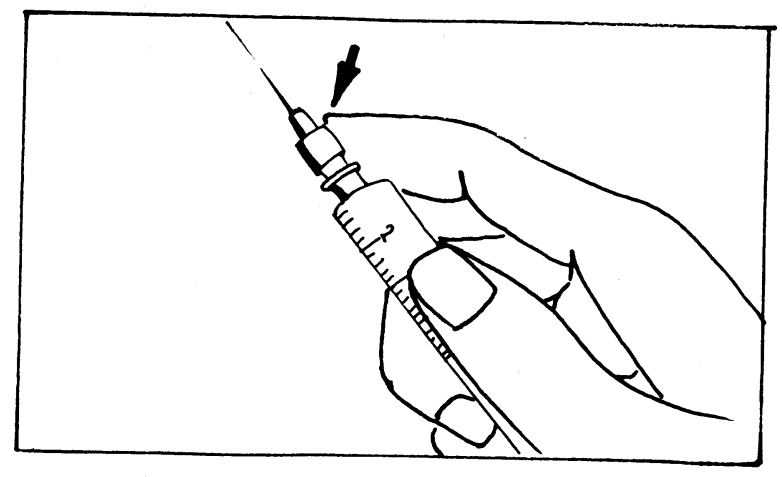

$$
\begin{aligned}
& \text { 1- سرج بِ بنبى لاسك وافلى } \\
& \text { اوخبلدشيهادت بكوت }
\end{aligned}
$$

دستن يورتخبرتخ بمتمابل

كح ونبيى · برتخير

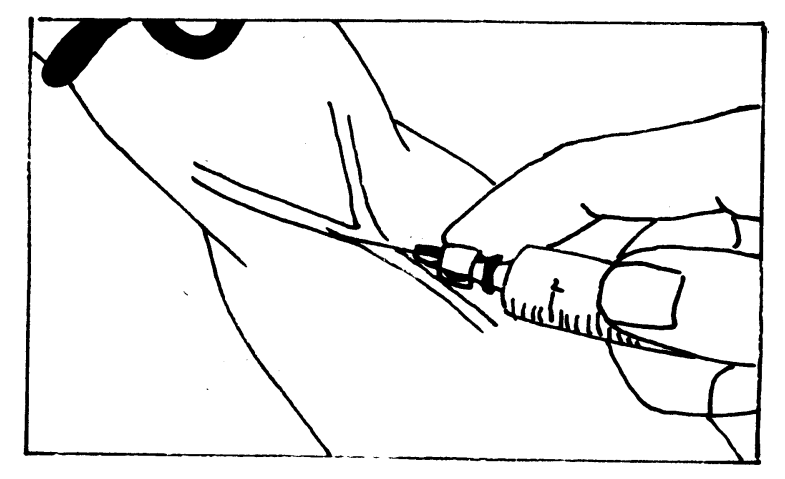

و- ستن ن داسىموتعيت

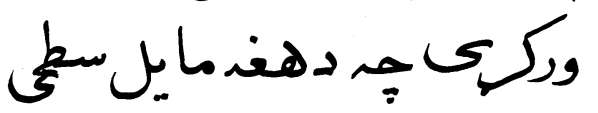

$$
\text { קوست وى . }
$$

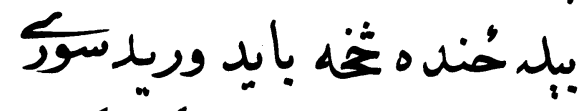

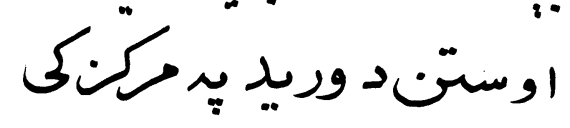
داخلكرى.
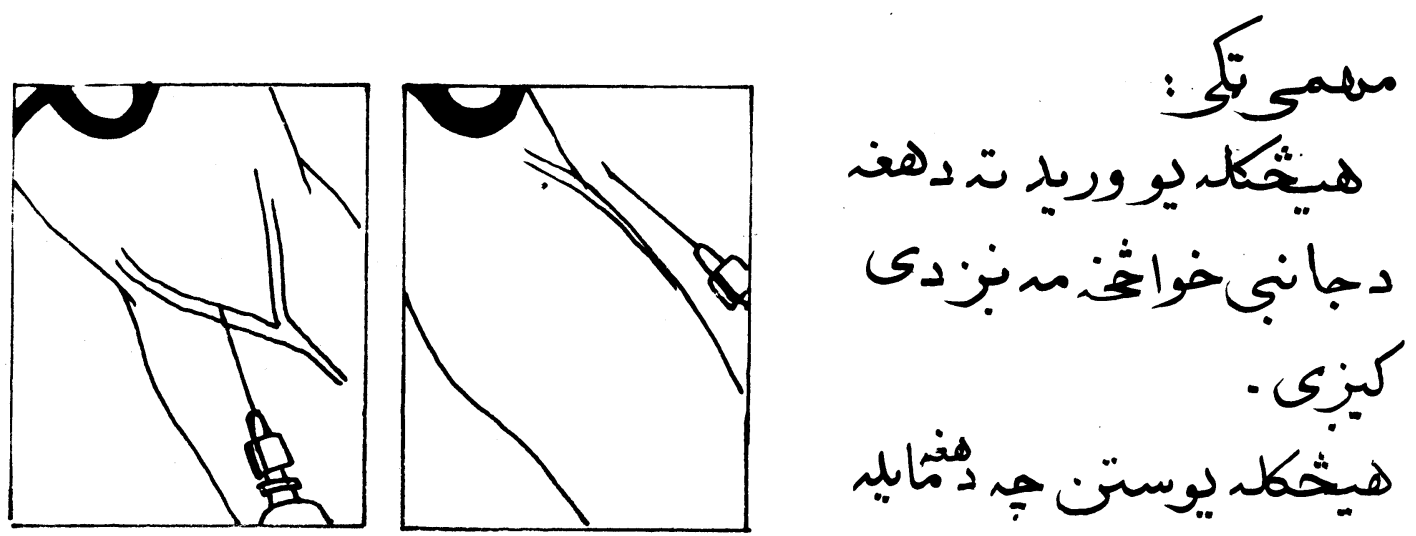

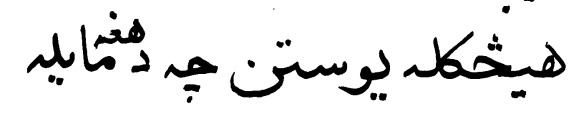

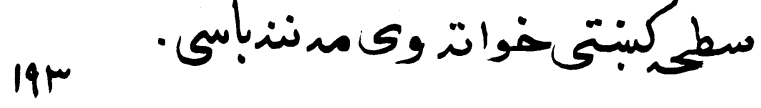



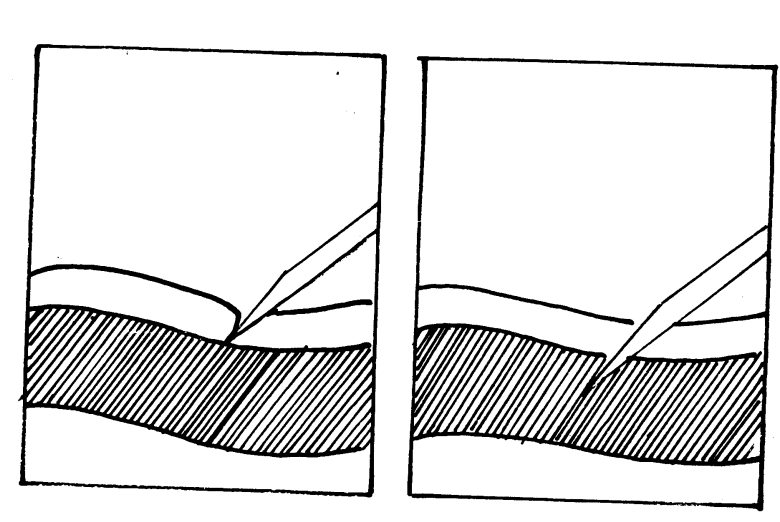

تاسح دنتوتلحسىكوى :

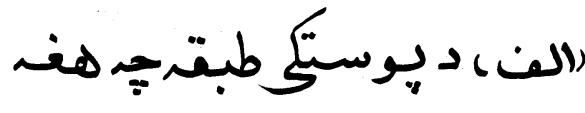
تئكسنت لرى .

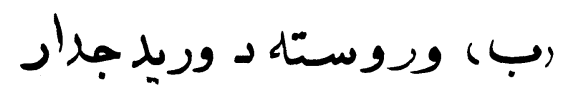

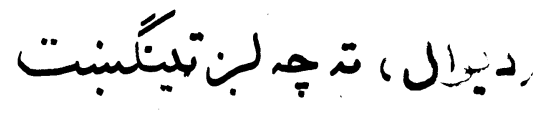

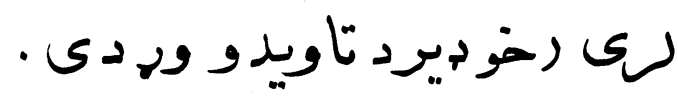

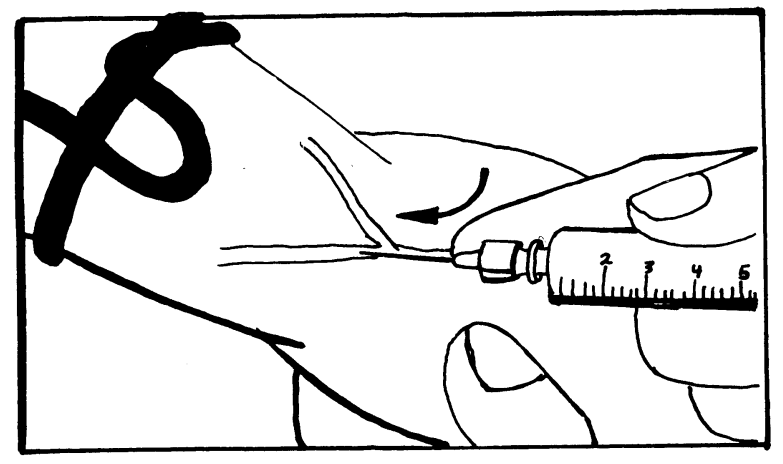

• - مستن د وصيد د خططي

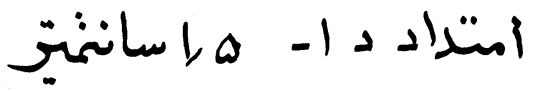

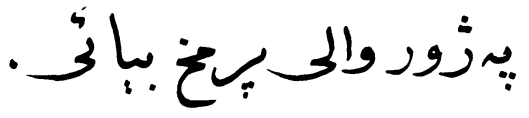

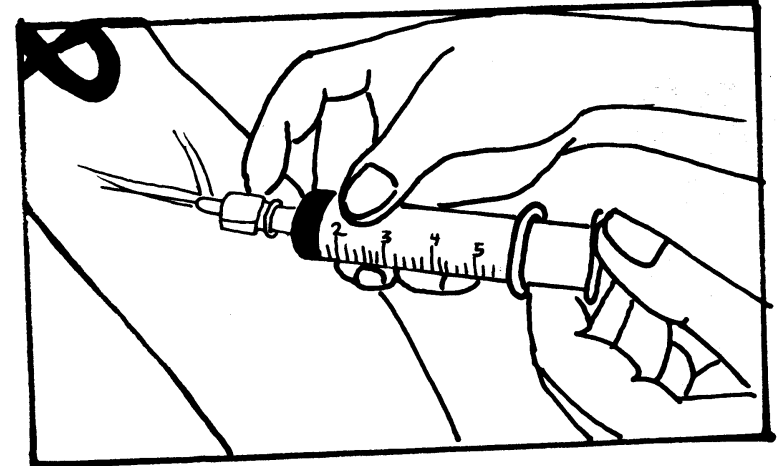

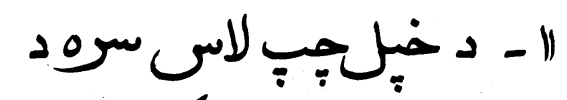

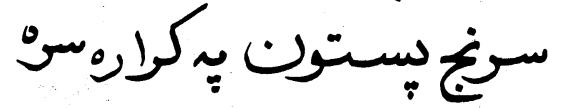
وشاتخ كنثكي .

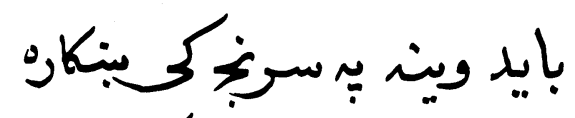

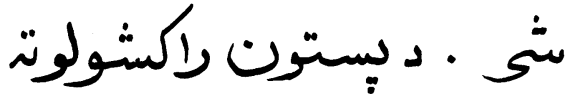

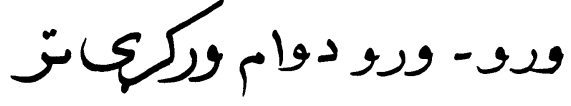

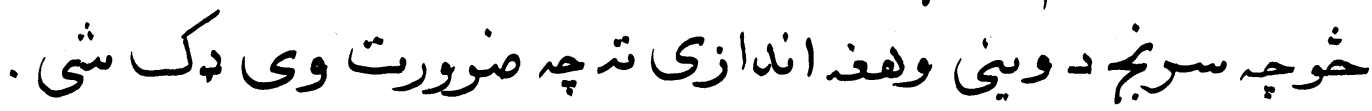




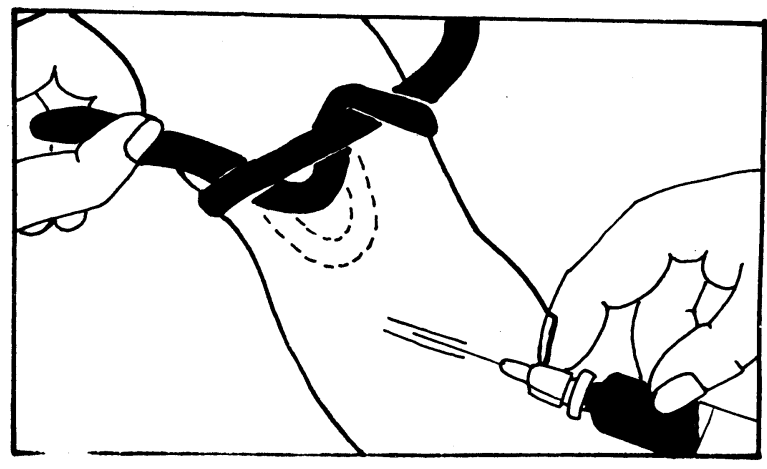

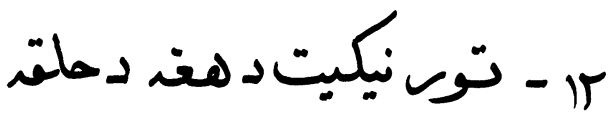

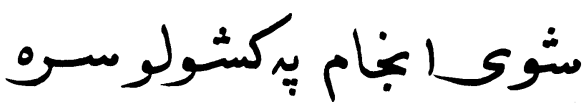
ليركي .

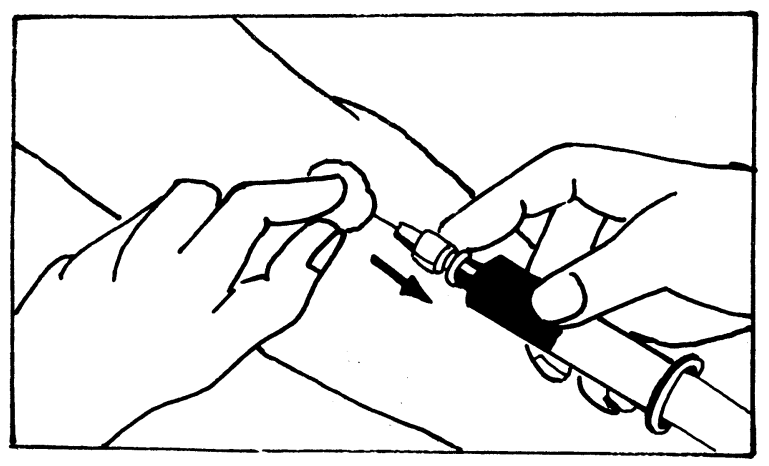

$$
\begin{aligned}
& \text { سر - يو وج سُولاب دستتح } \\
& \text { كبنيت ستوى نمثل باندى هـ اوستي } \\
& \text { حكت سو، ترلاندى د دسواب } \\
& \text { لا وكابزى . }
\end{aligned}
$$
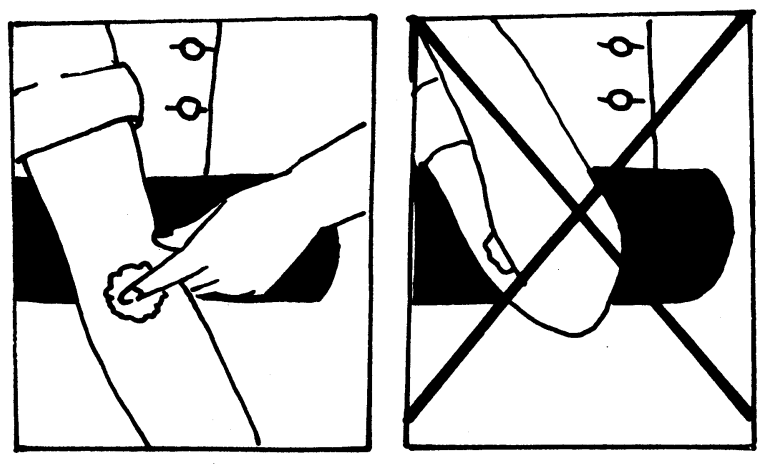

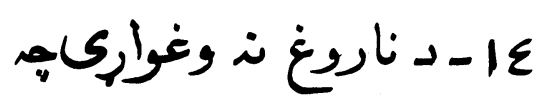

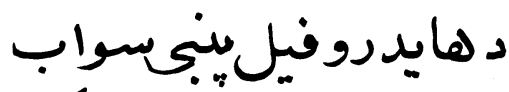

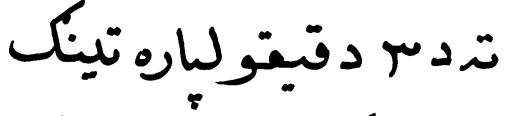

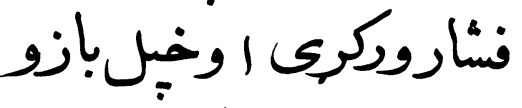

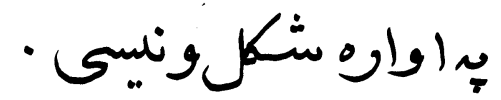

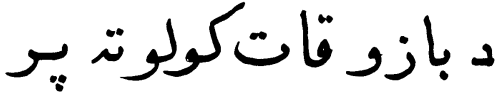

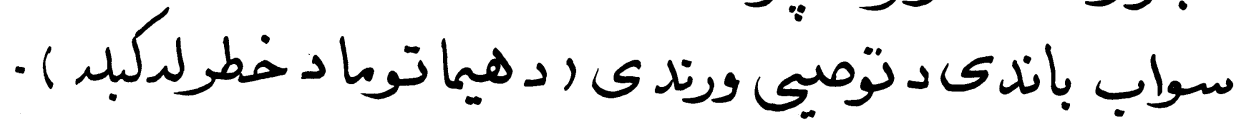




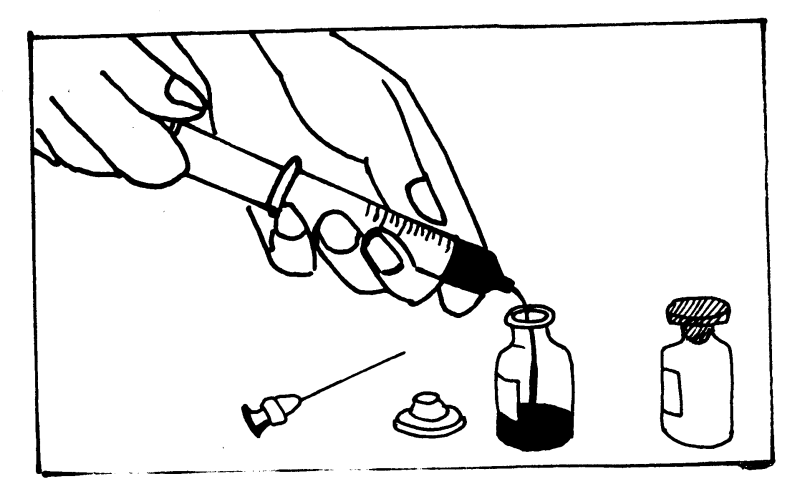

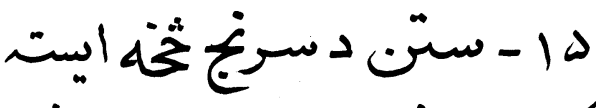

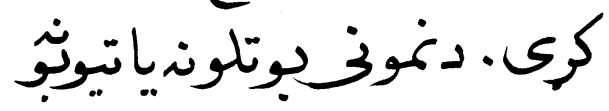
ترنبنى شوى علاعى سره د ويني

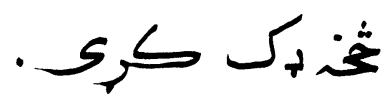

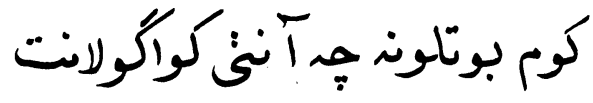
لرىهنوى خُوحُلدجيَ(وراسته كرى . رئ.

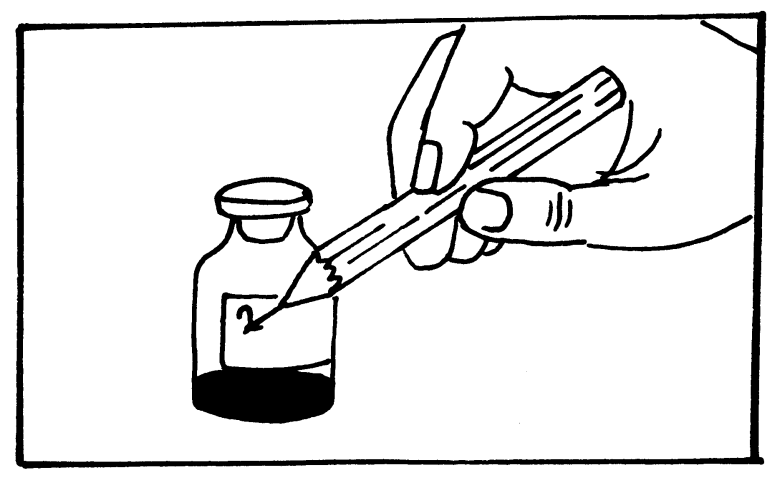

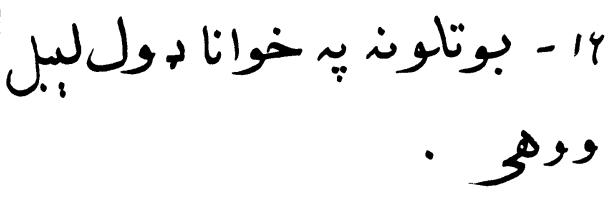

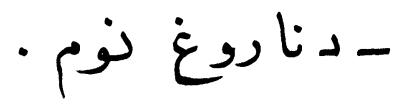

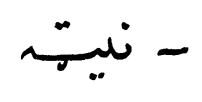

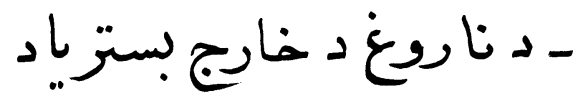

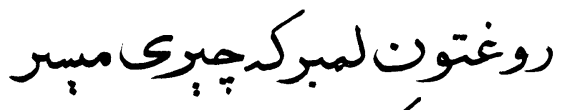
وى ويكى -

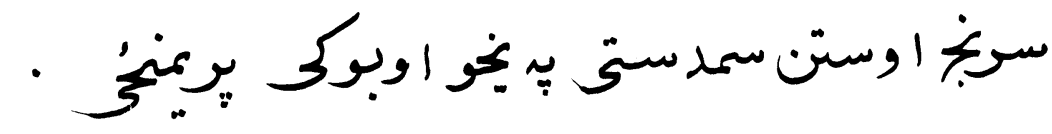




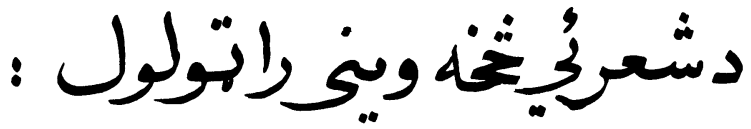

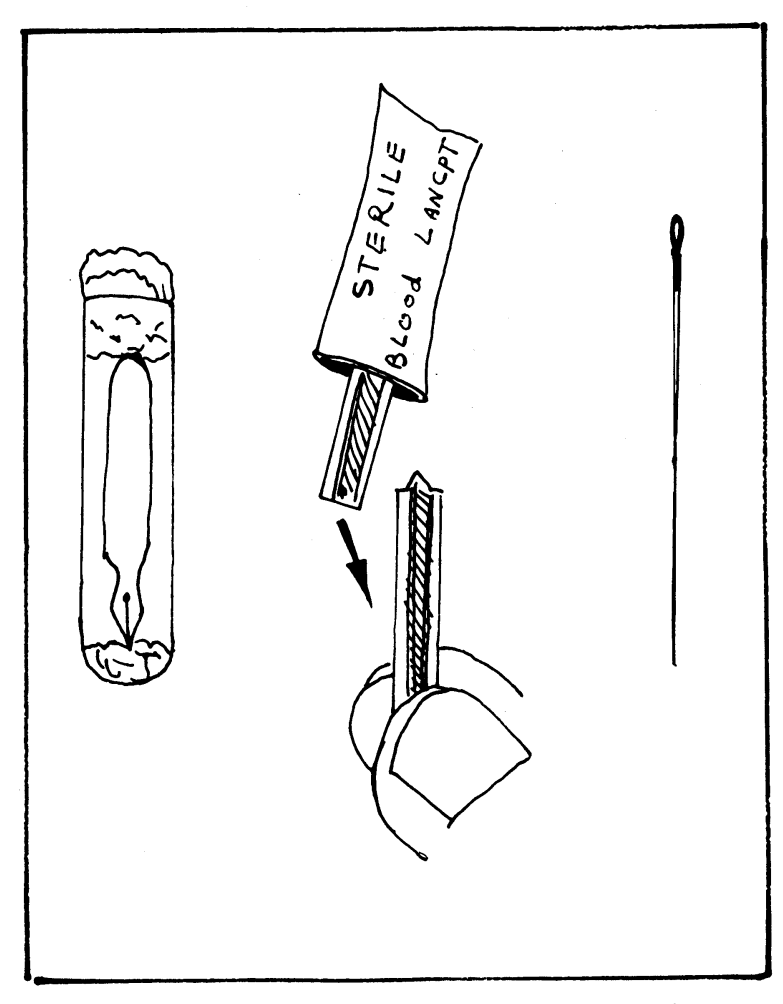

دخينولابزاتوا رى معايناتوليار

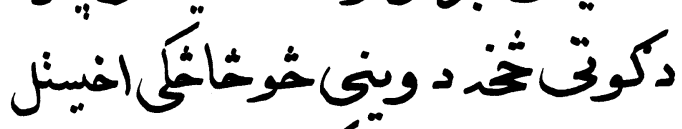

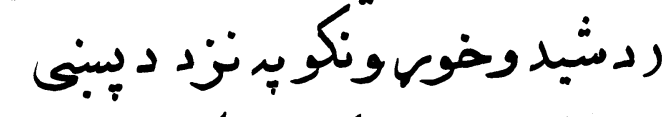
دلوككونىخ كنايت كوى مثالون :

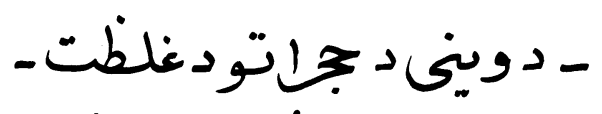
تعداد ("COUNT"

- داريتروسايت دفركثنونجيج. - داندازكول دهيمكلوبين. - د ديباسيتولتول.

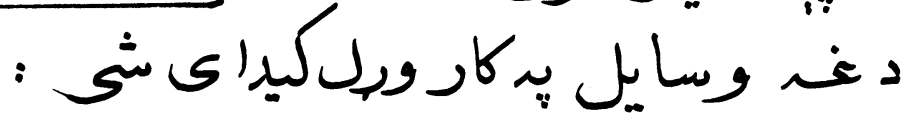

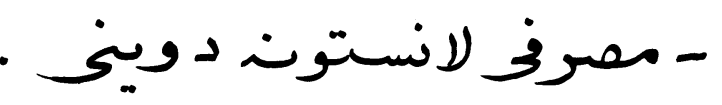
ـ تعتيم شوفىلانستون .

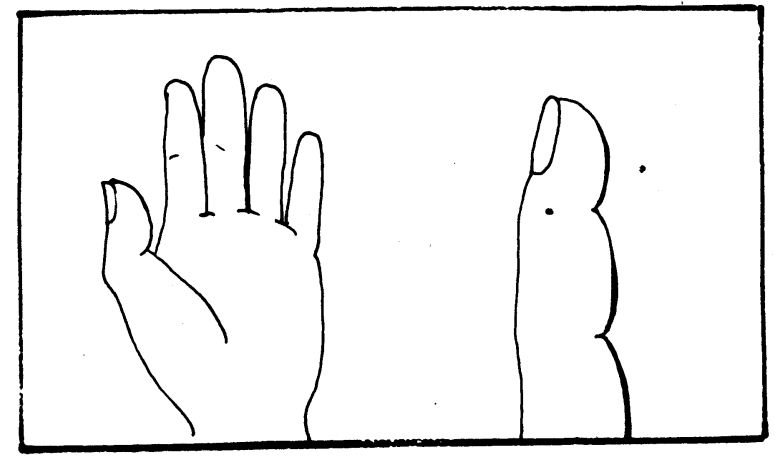

$19 v$

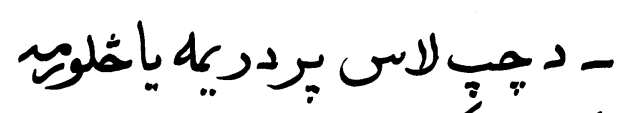
كوتّنَّ. 
ـ دكوتى يوه خنده (لكد ثئكده بجى بنودل شوى ) نسبت دكوتى وسر

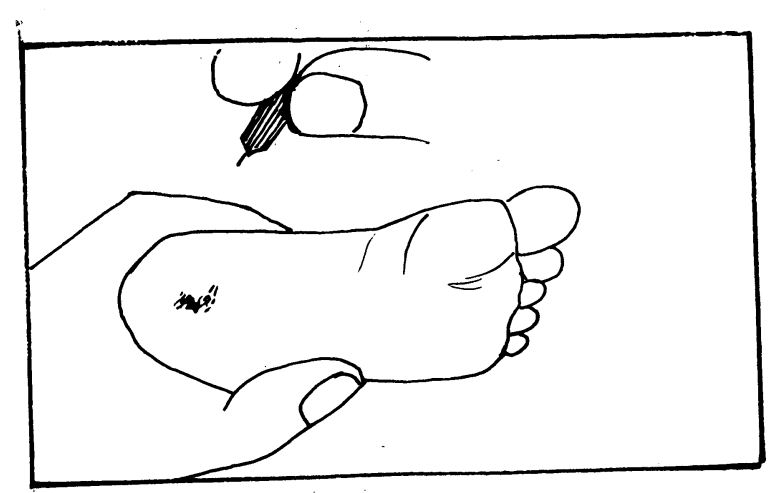

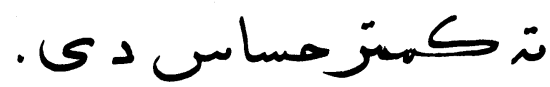

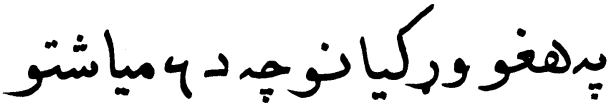

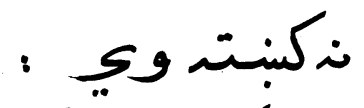

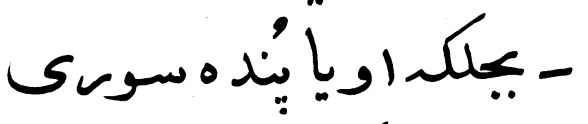

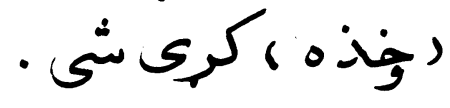
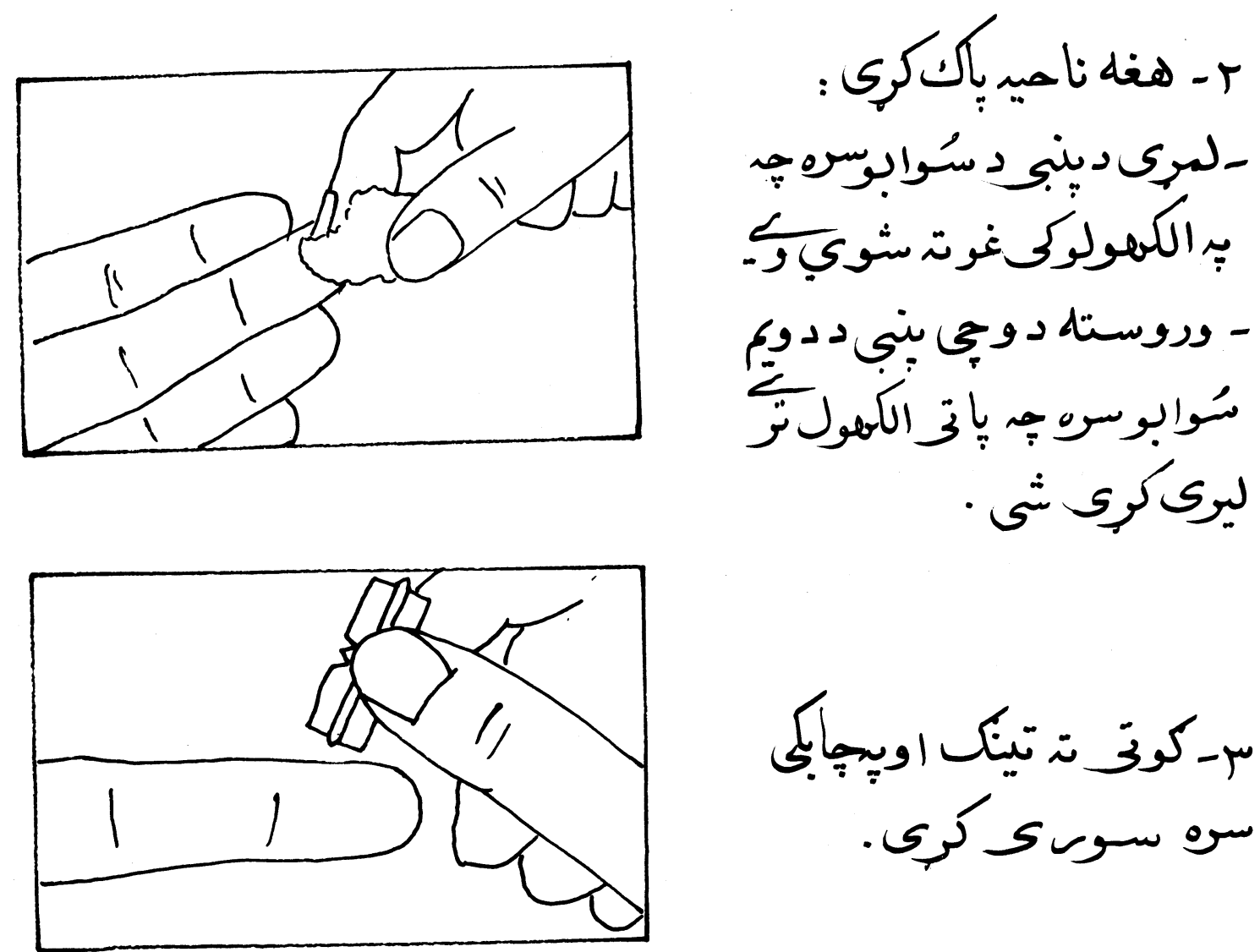

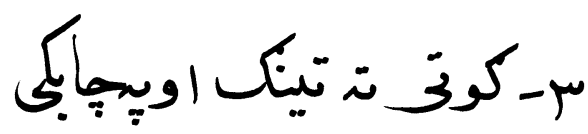
سو سوسك كري. 


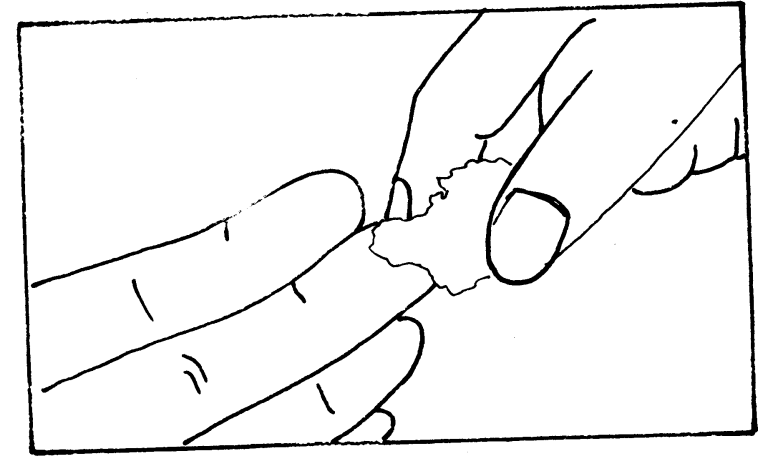

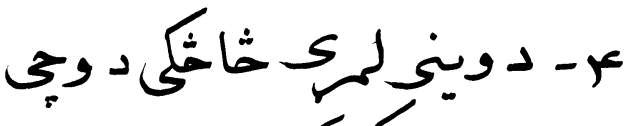

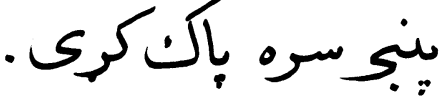

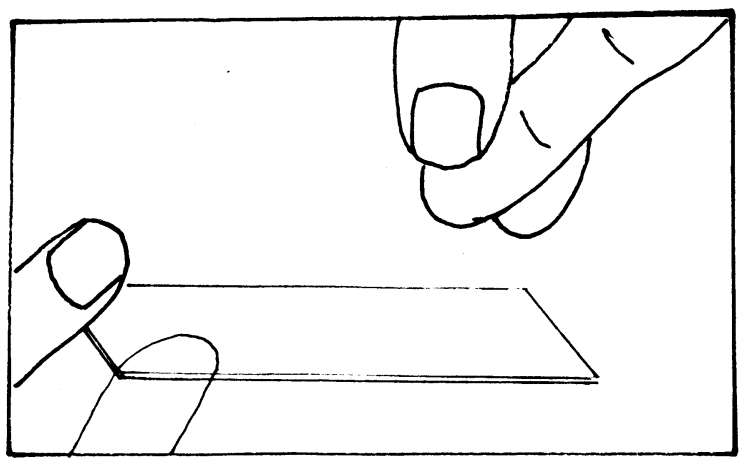

هـ - دخبل بنى لاس سره :

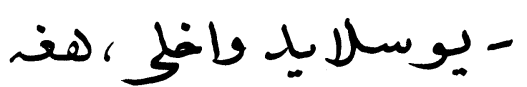

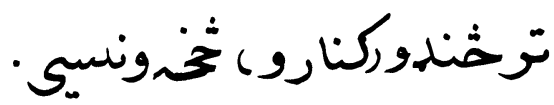

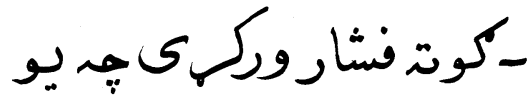

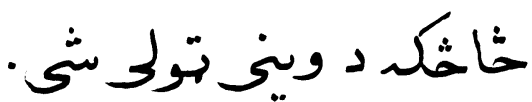

\section{دلوكوساتود تِعداد غنلطت}

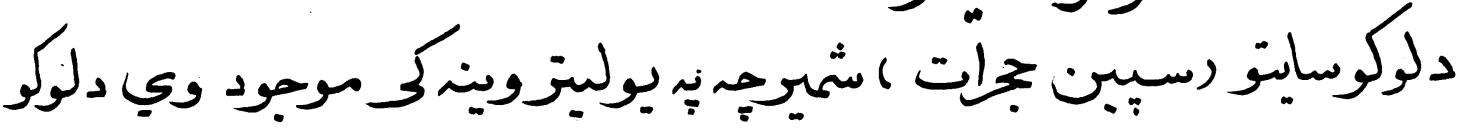

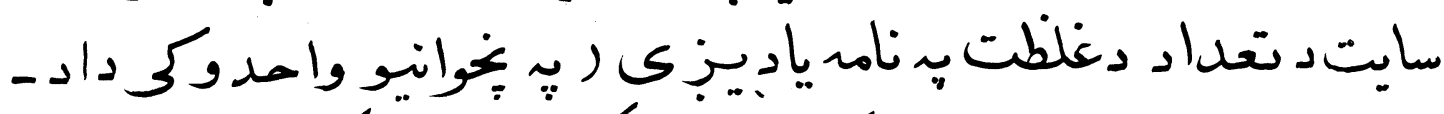

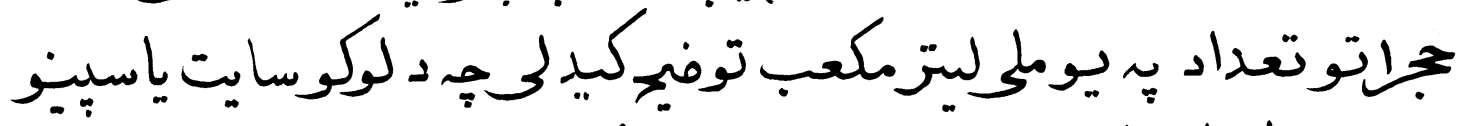

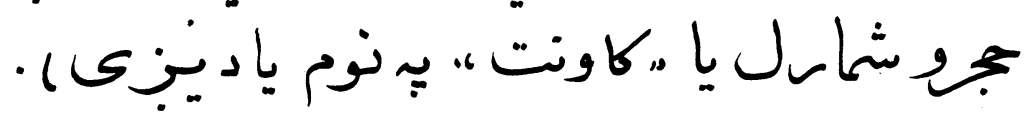

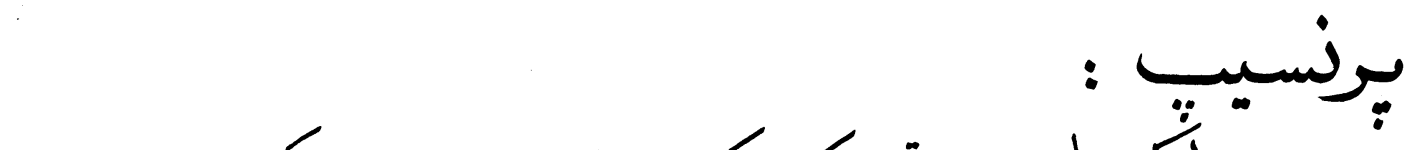

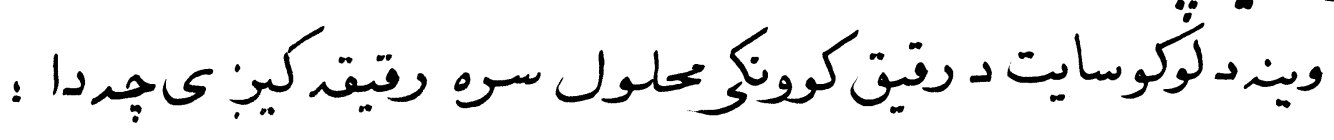




$$
\begin{aligned}
& \text { - سره بحات هيماليسى رتخيب ،كوى . }
\end{aligned}
$$

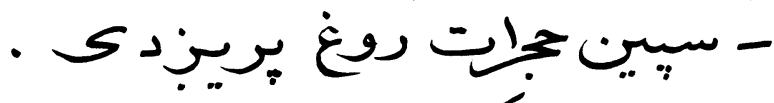

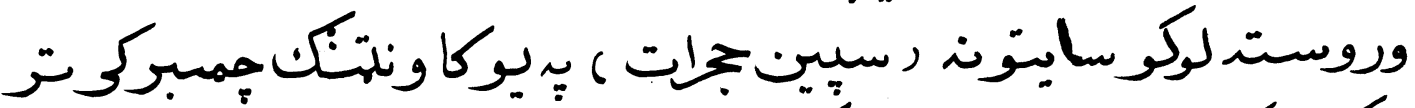

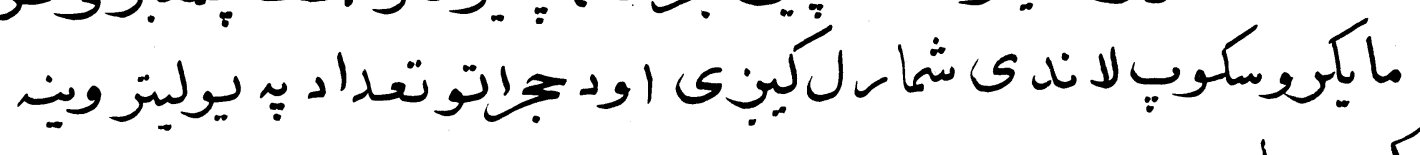

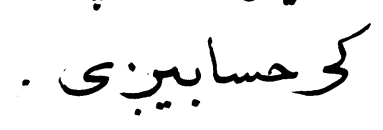

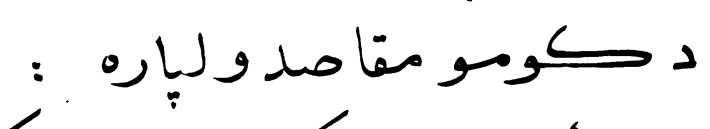

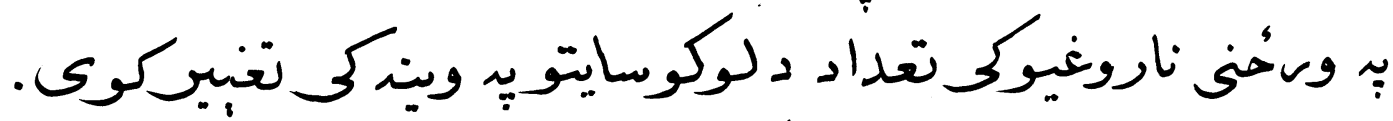

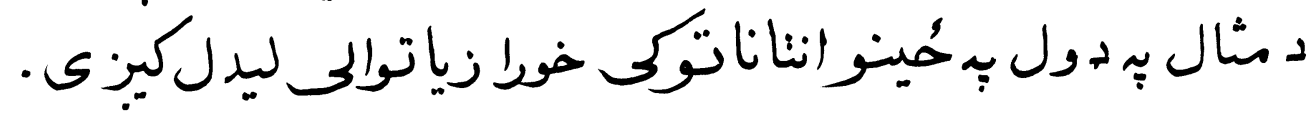

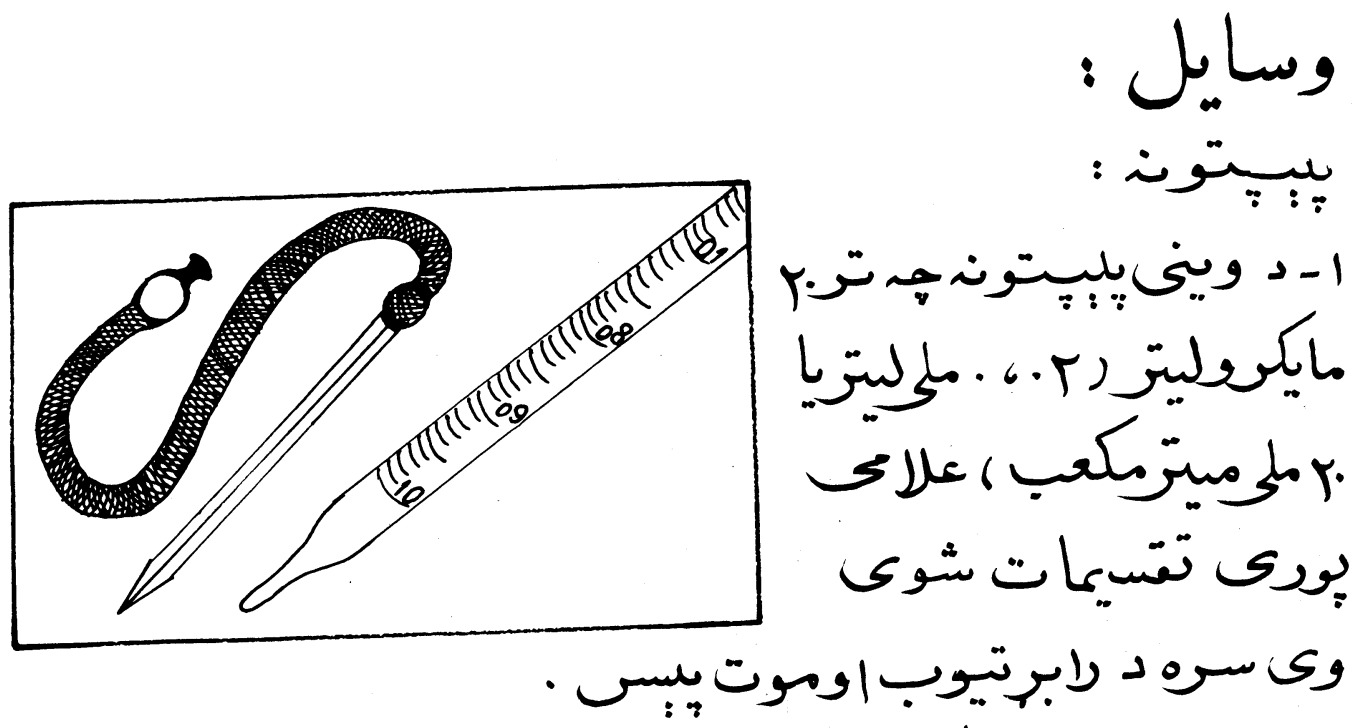

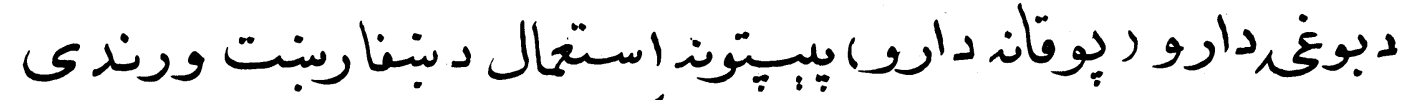

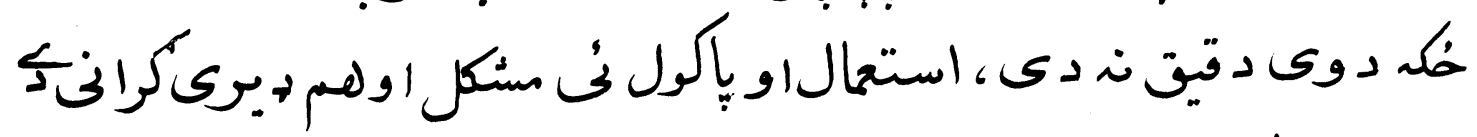

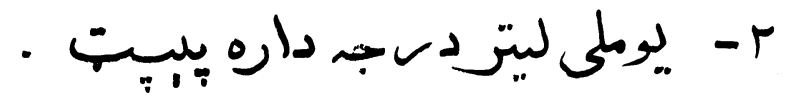




$$
\frac{3}{-1}
$$




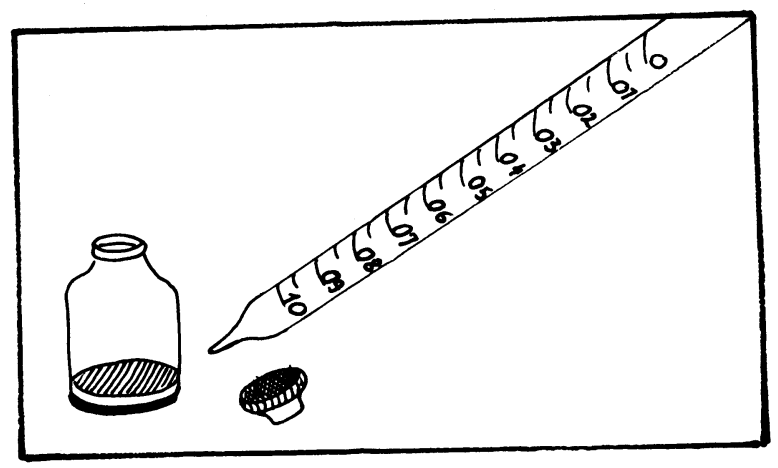

متّود :

ا- ديوملريتردهر دار

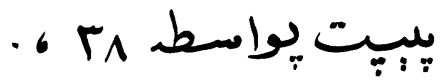

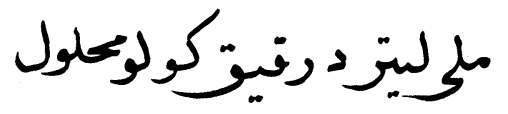

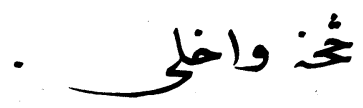

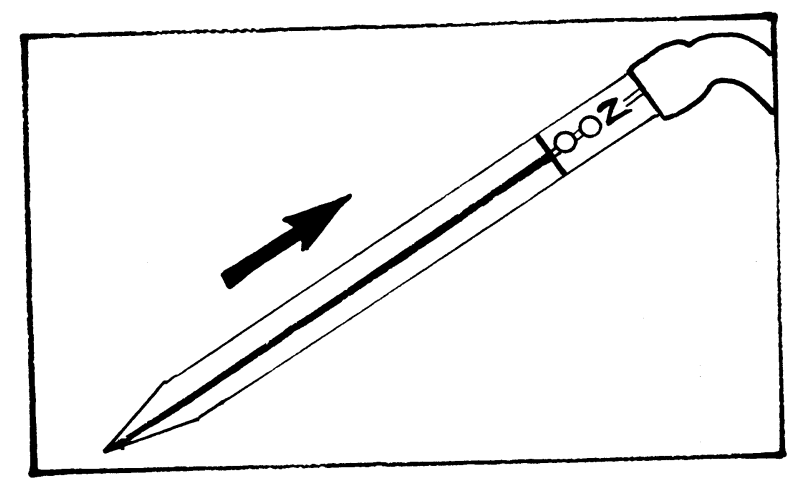

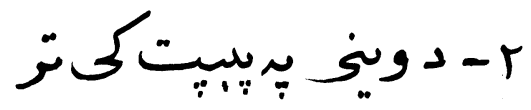
r. 6. علامى يوصى ده وريل

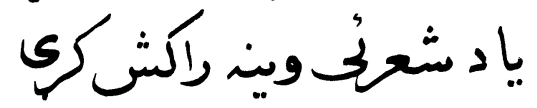

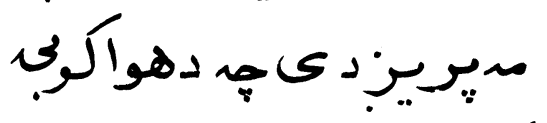
كيكى داخل شعى .

دوريدى وينى يُصورت

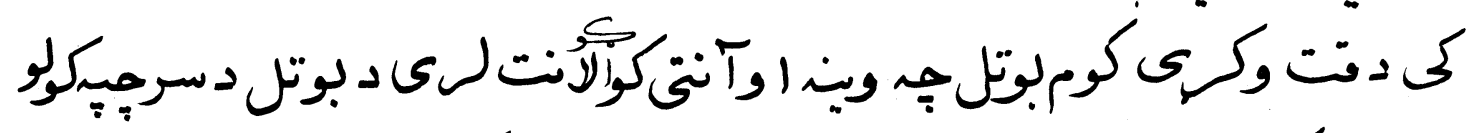

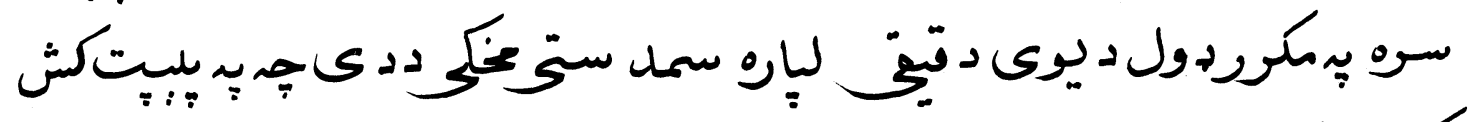

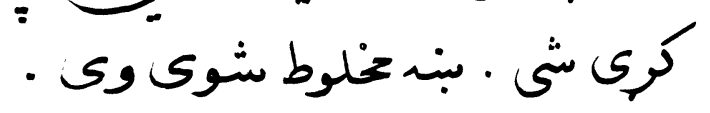

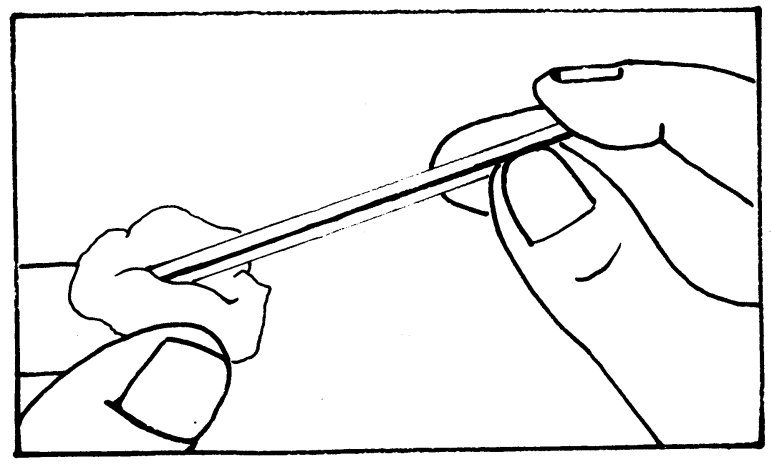

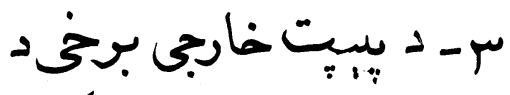

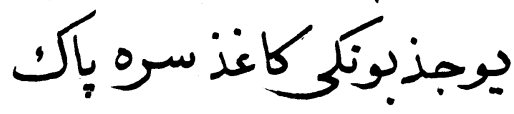
كرى .

$r \cdot r$ 


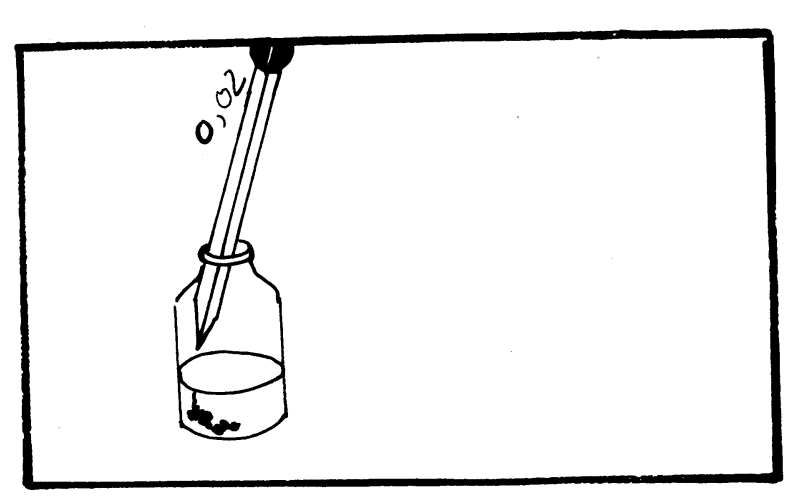

$$
\begin{aligned}
& \text { ع- ويند رنيقكورنكيعلول }
\end{aligned}
$$

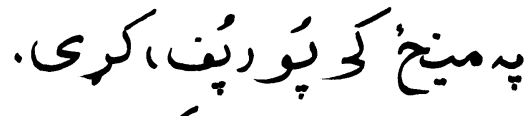

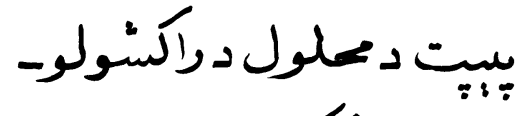

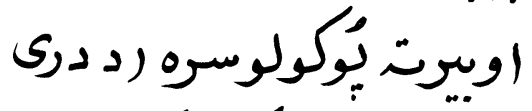

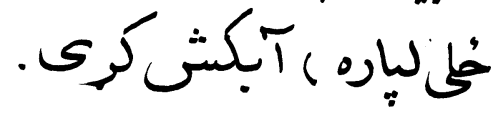

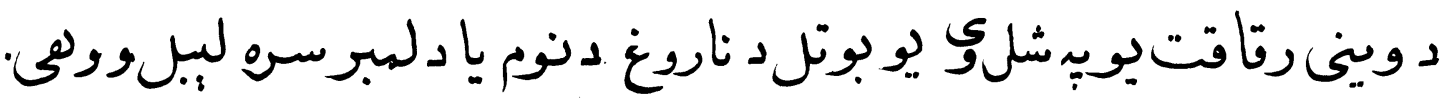

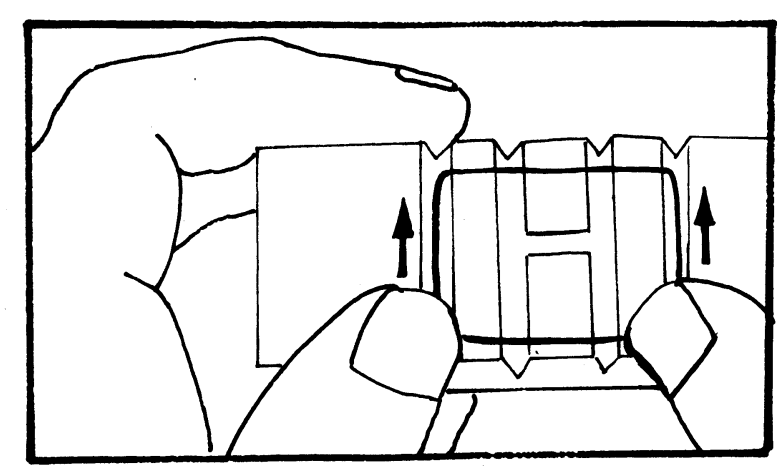

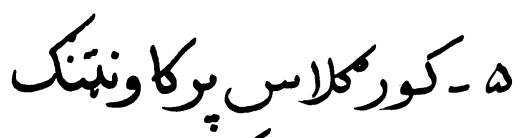

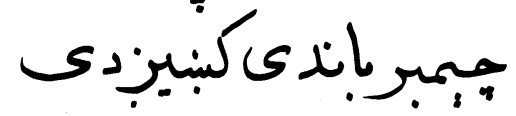

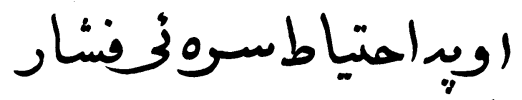

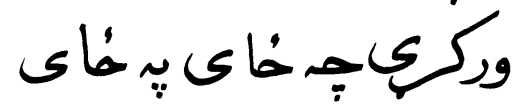

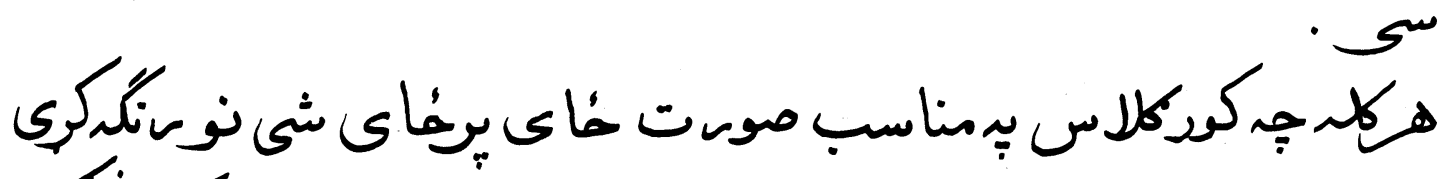

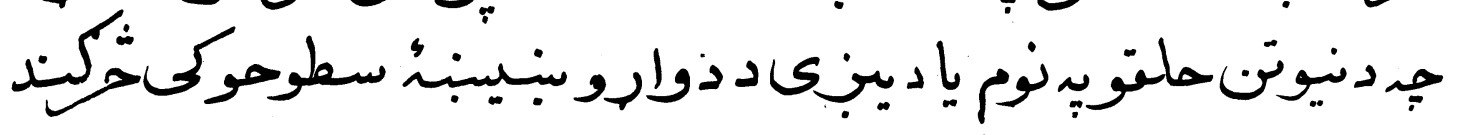

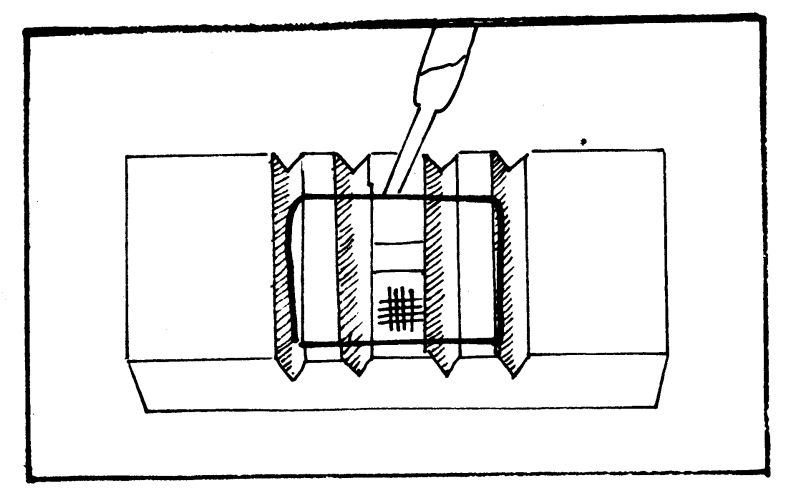
-

4- رقتو سشوى وين سنـ

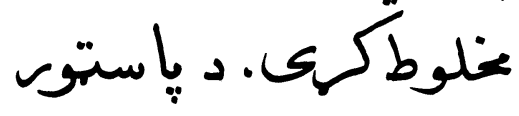

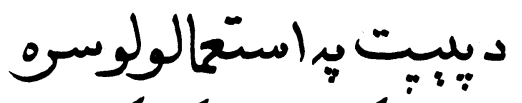

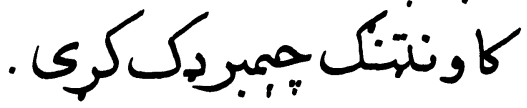
p.r 
خواحتياط وكهى هِد خطكثى شوى سيمى ن نيات جك نتى . :

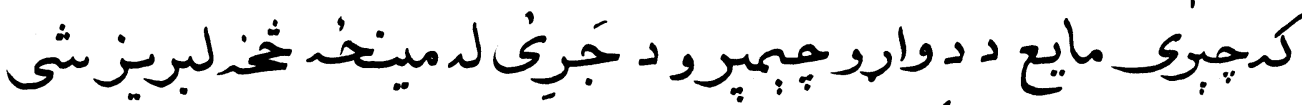

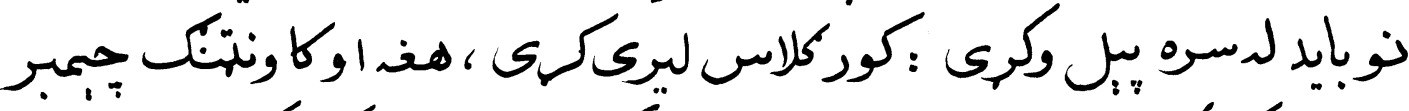

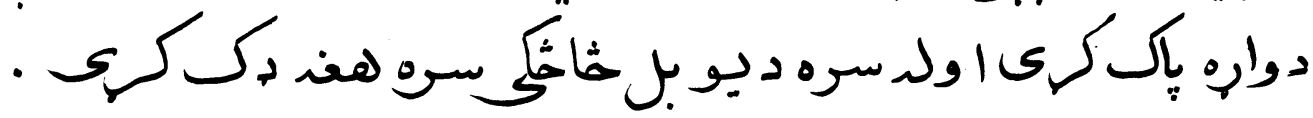

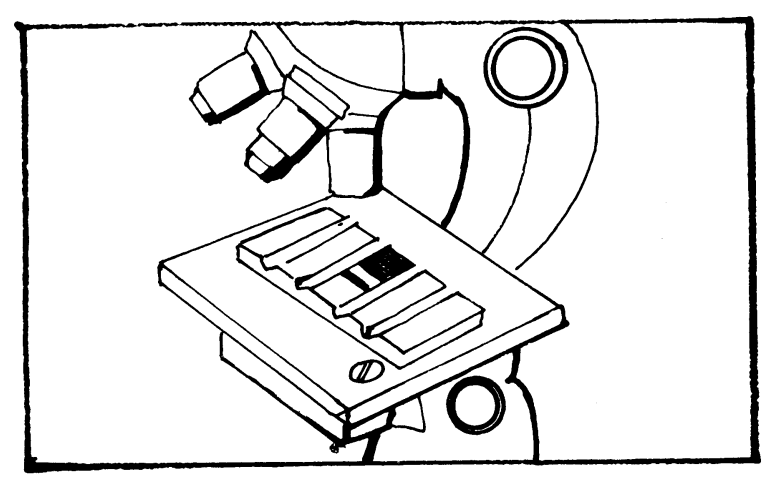

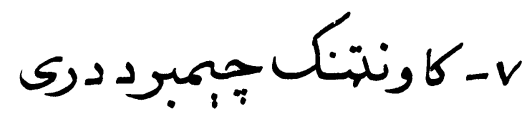

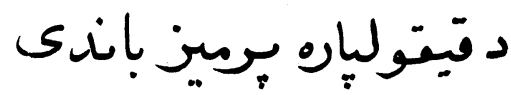

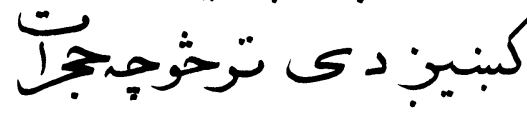

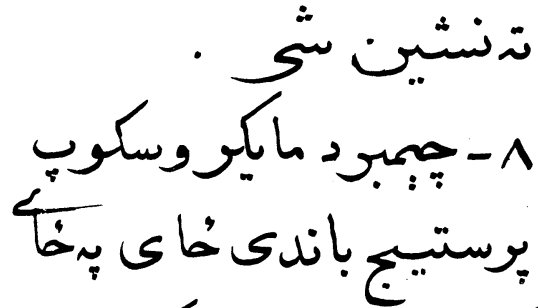

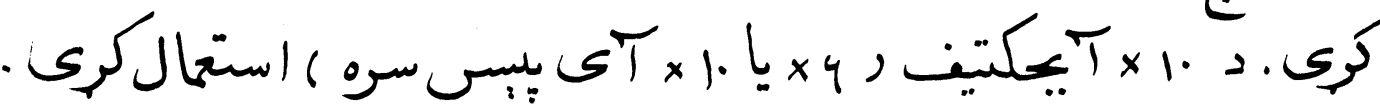

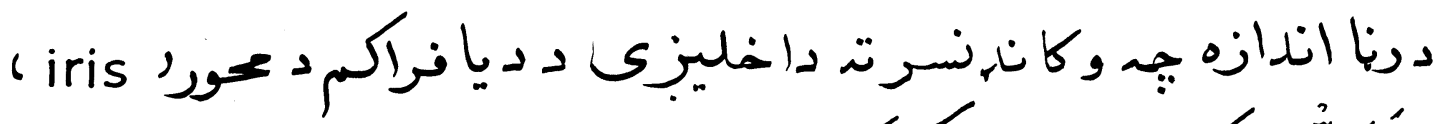

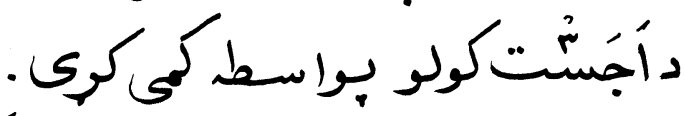

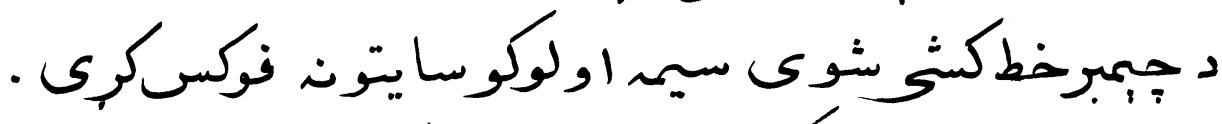

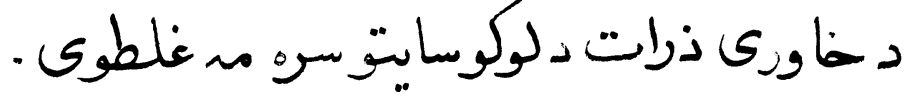




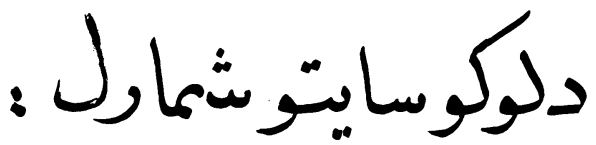

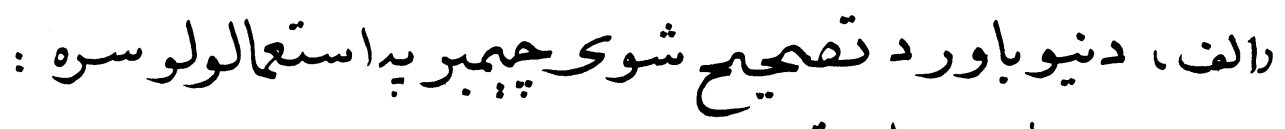

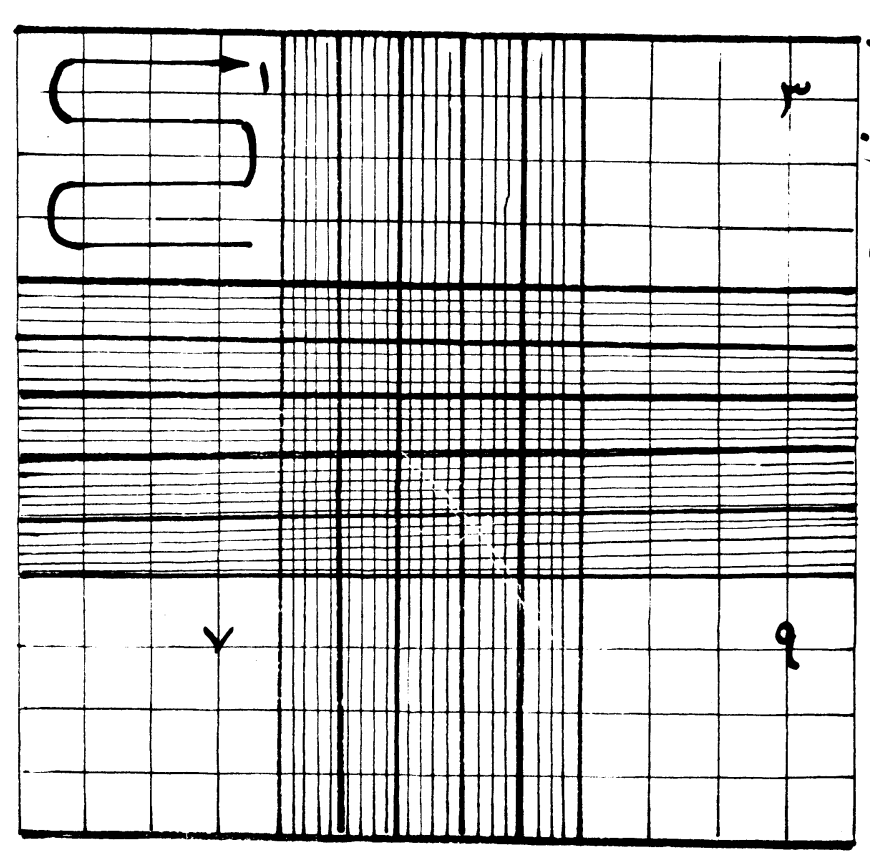

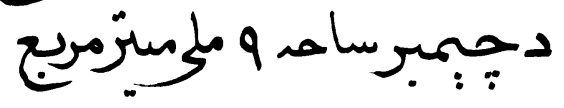

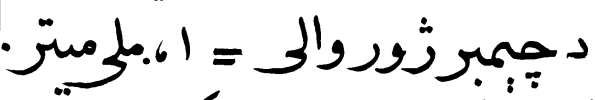

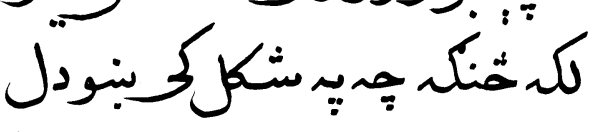

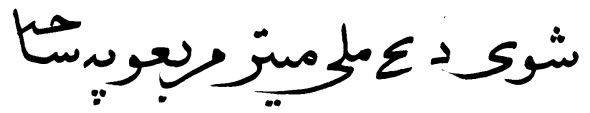
كم دغنه طلور حبو

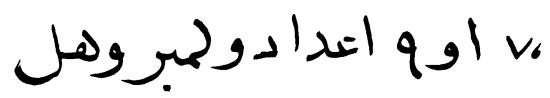

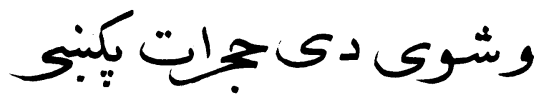

$$
\text { - وشنمرى }
$$

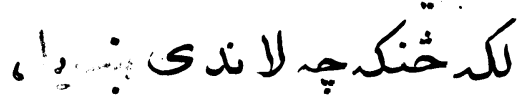

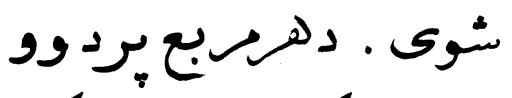

\begin{tabular}{|l|l|l|l|l|}
\hline 0 & 0 & 0 & 0 \\
\hline 0 & 0 & 0 & 0 \\
\hline 0
\end{tabular}

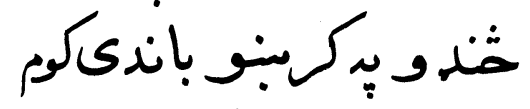

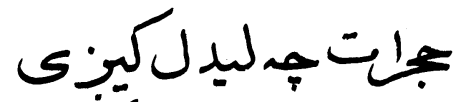
دوى لعم يُشماركَّ داخل .5

دغله ربج دمَلوس شيمارل

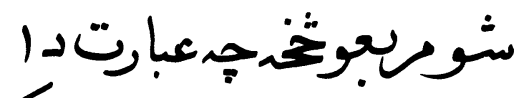
: 


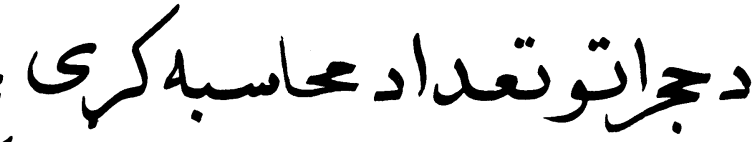

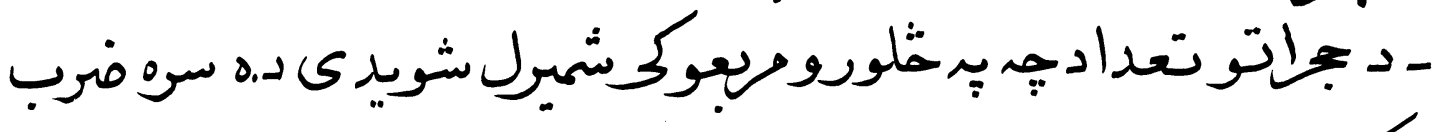

$$
\text { كري تصغ }
$$

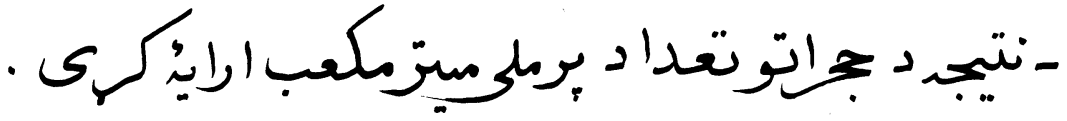

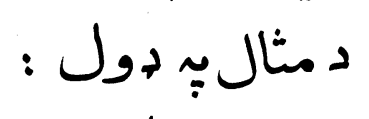

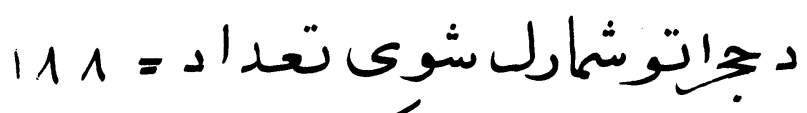

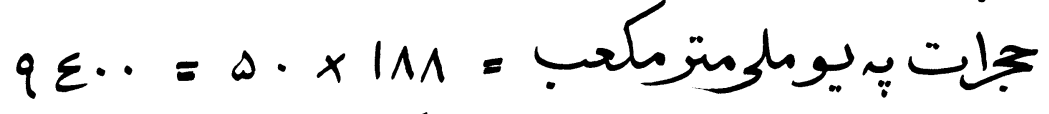

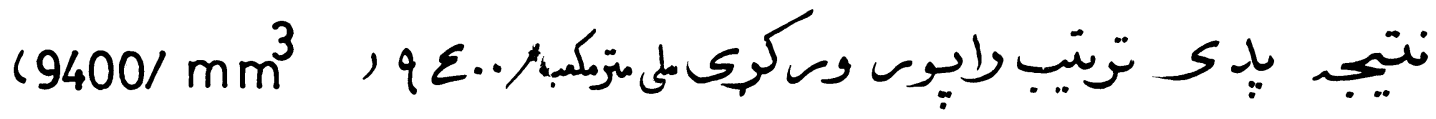

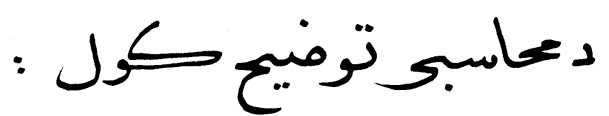

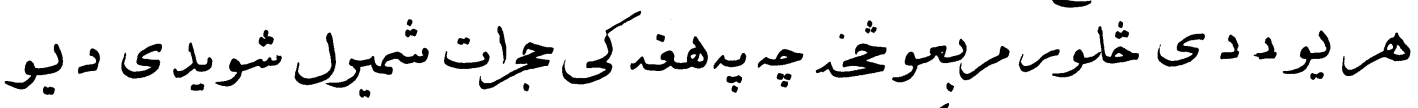

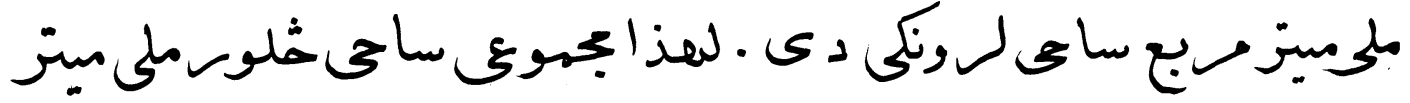

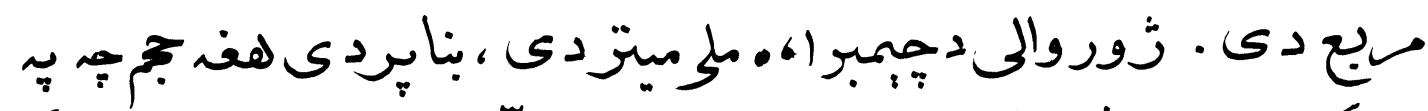

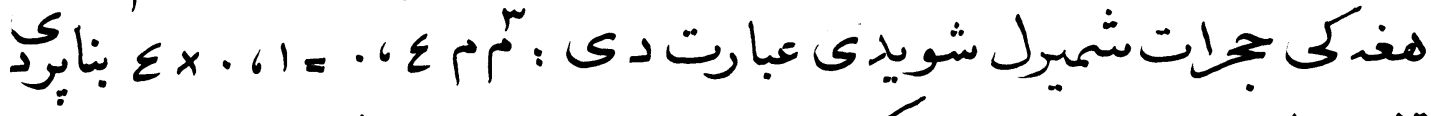

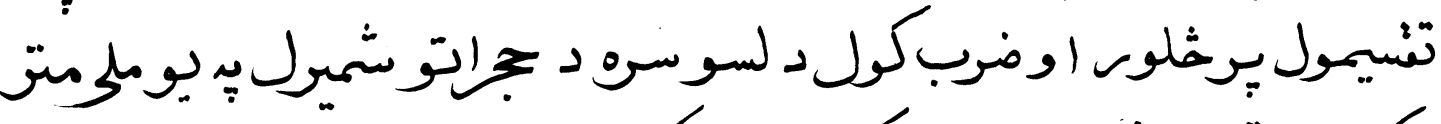

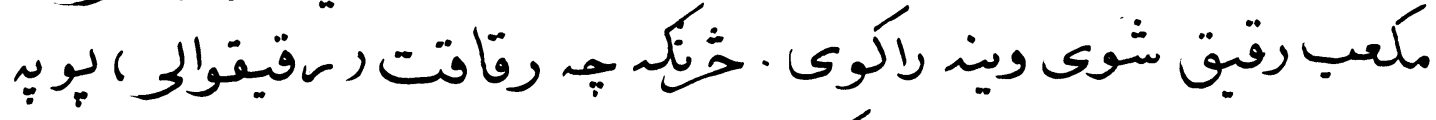

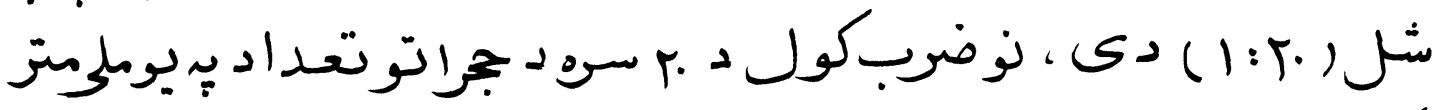

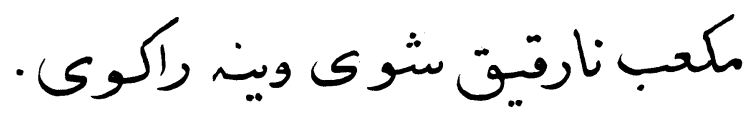




$$
\text { دالٍ بلاندى +ول اختصاركِيى : }
$$

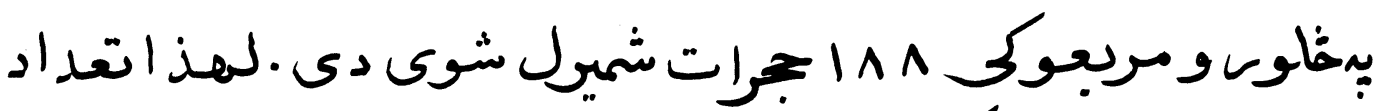

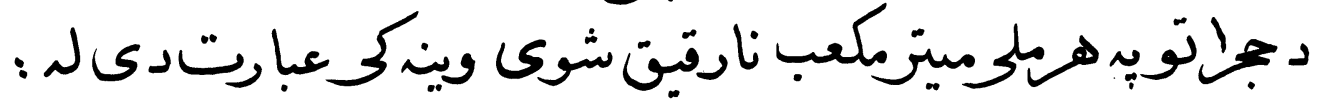

$$
\frac{111 \times 1 \cdot \times r \cdot}{\varepsilon}=111 \times 0 \cdot=9 \varepsilon \cdot \cdot
$$

$$
\begin{aligned}
& \text { : بوانح واحدون: }
\end{aligned}
$$

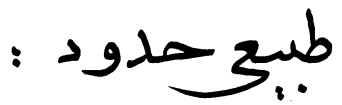

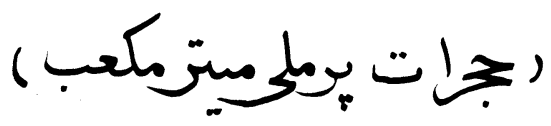

$$
\begin{aligned}
& 1 \ldots .-\varepsilon \cdots \\
& \text { نارينَاونبنحُ } \\
& 1 \cdots-\varepsilon \cdots \\
& \text { دلسوكالوكوحنينان } \\
& 11 \cdots-\varepsilon \cdots \\
& \text { د درى كالوكوجينيان }
\end{aligned}
$$

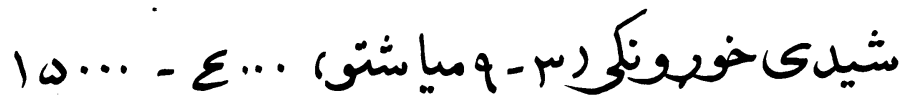

$$
\begin{aligned}
& \text { نوى يبداشوى ماشومات } \\
& \text { لور ارقام : }
\end{aligned}
$$

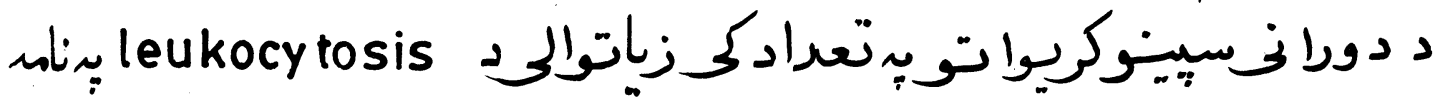

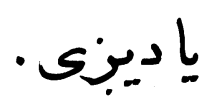




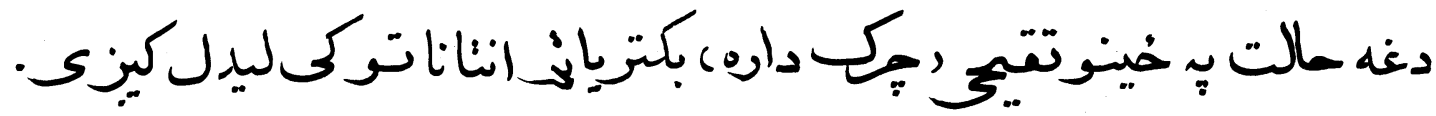

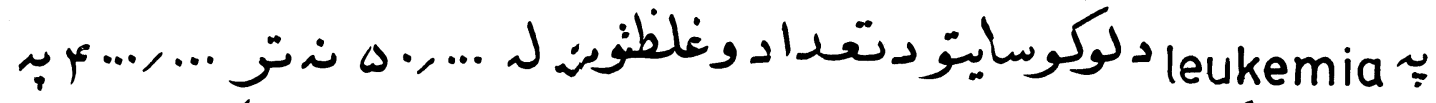

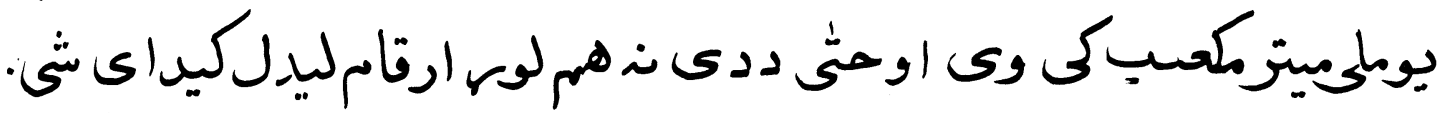

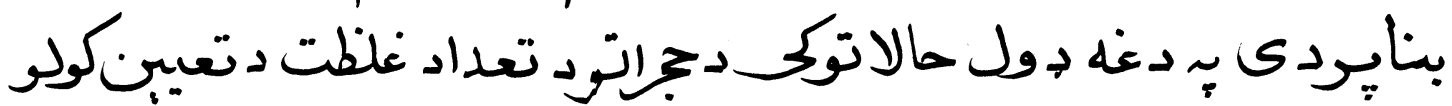

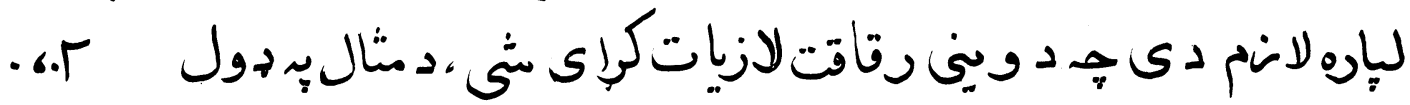

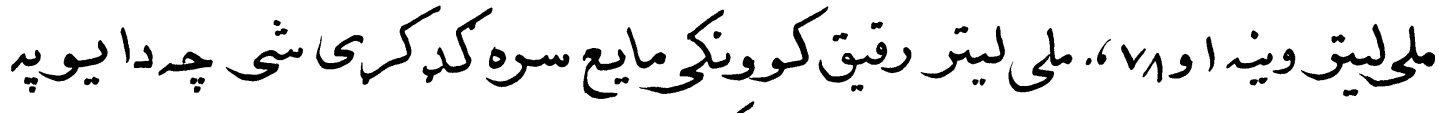

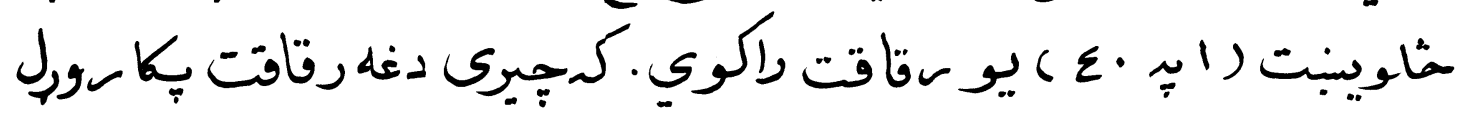

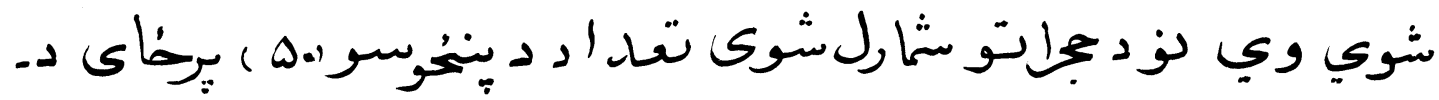

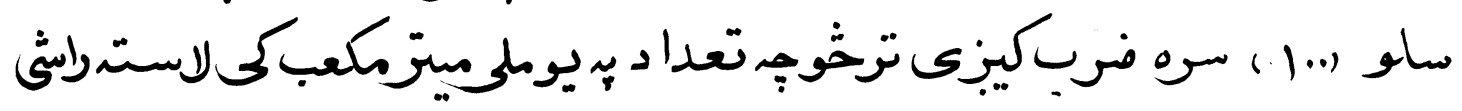

\section{كن: إنهاه}

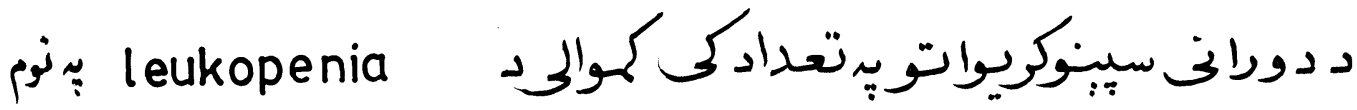

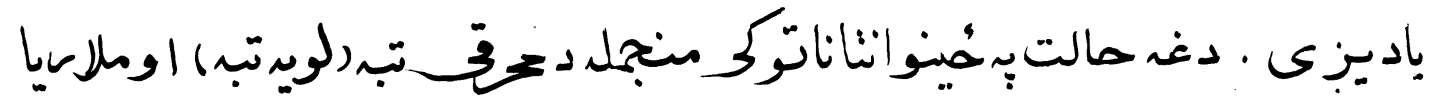

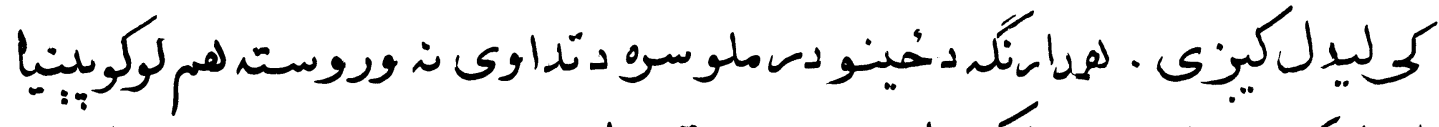

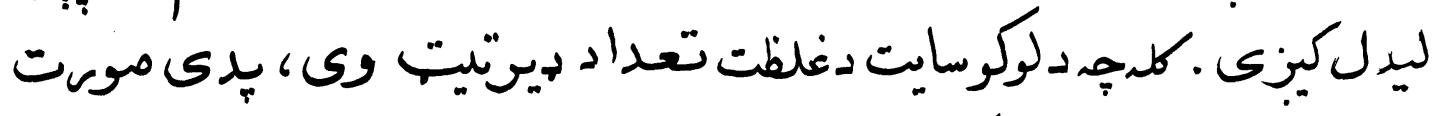

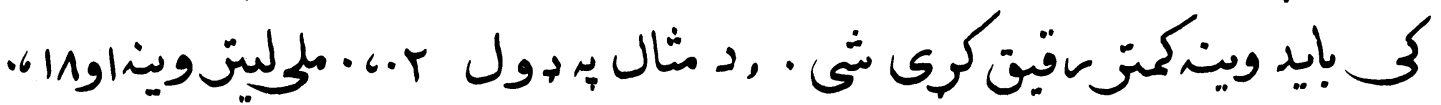

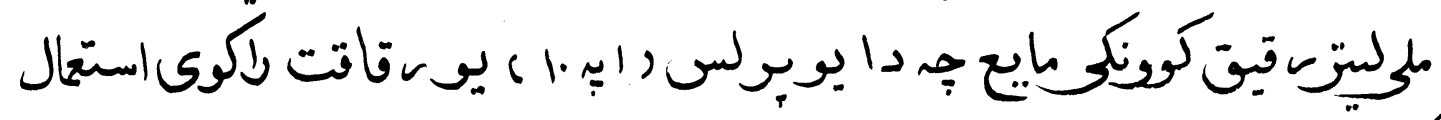

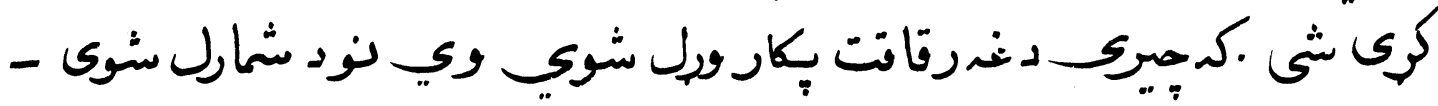

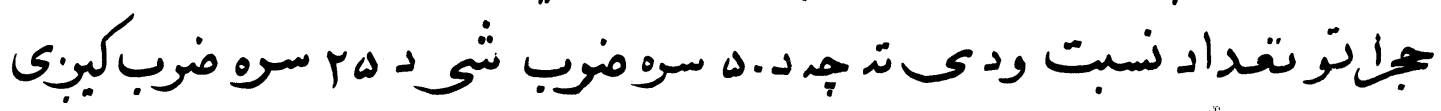




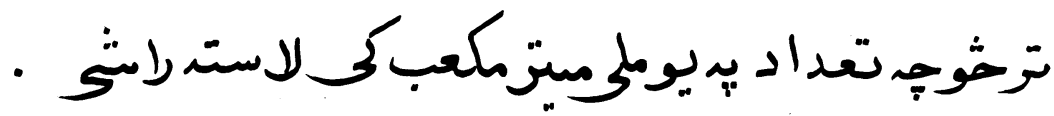

اندازه كول دهيموكلوبند : Sahli بِطيق

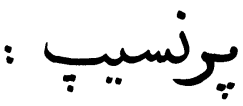

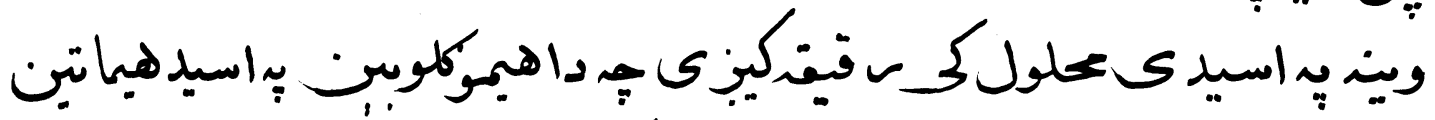

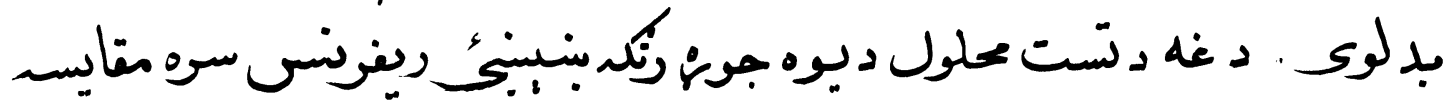

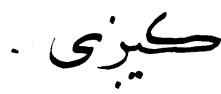

وسايل :

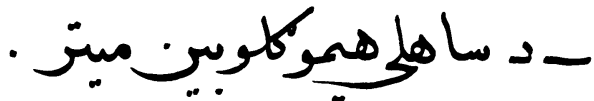

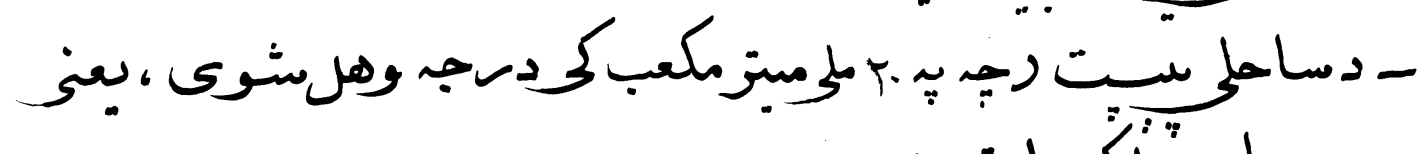

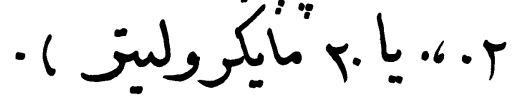

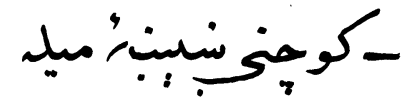

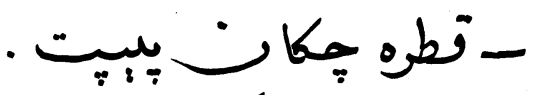

- حزبكوبنك كاغذ

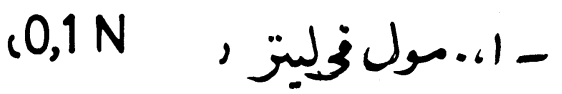

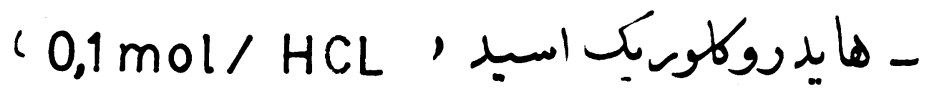

$r . q$ 


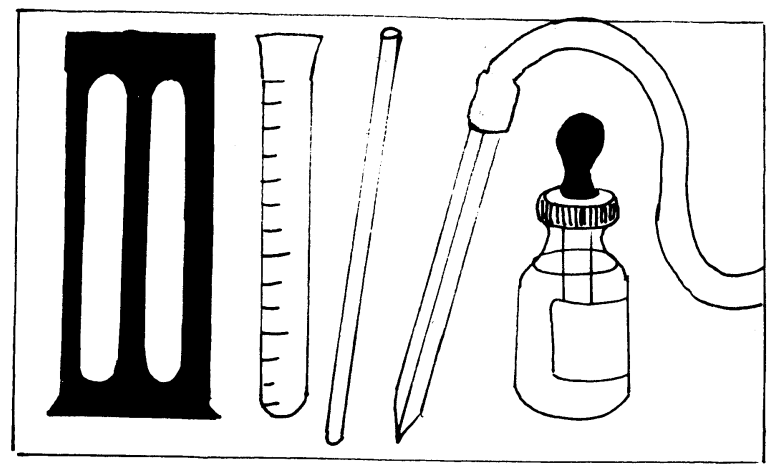

يو نادرسته طريقه :

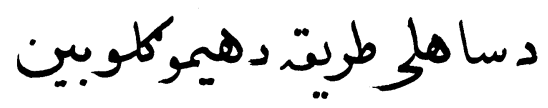

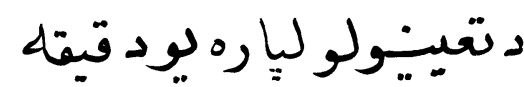

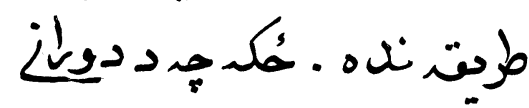

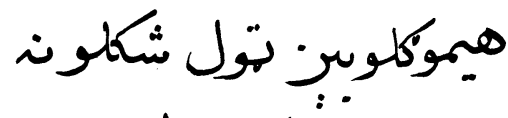

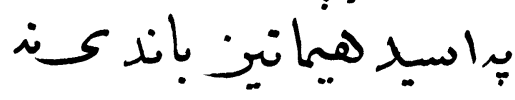

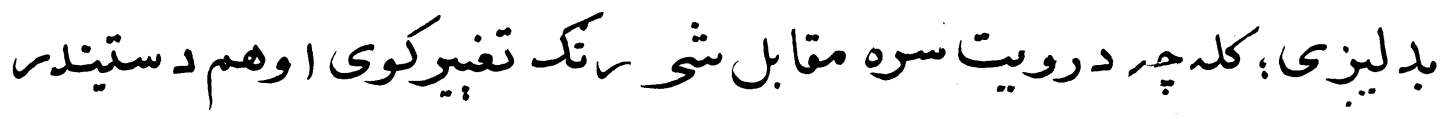

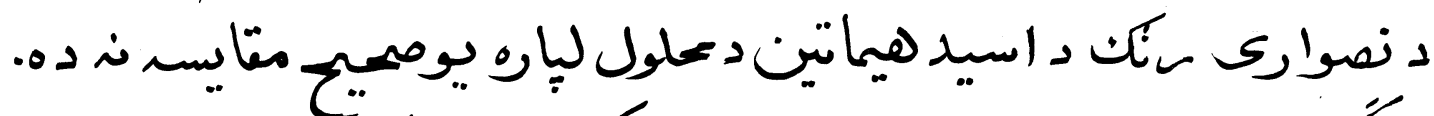

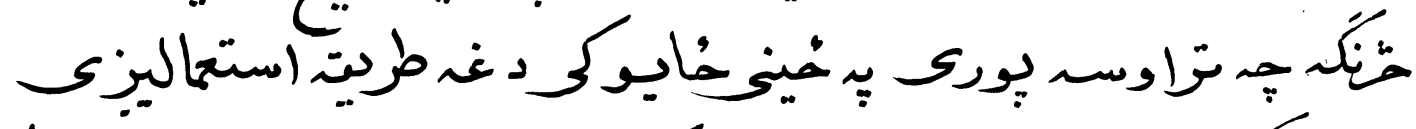

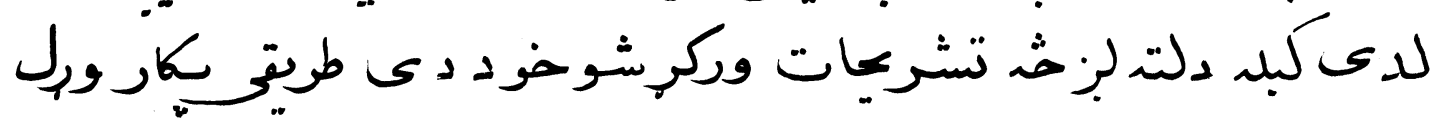

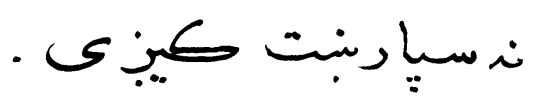

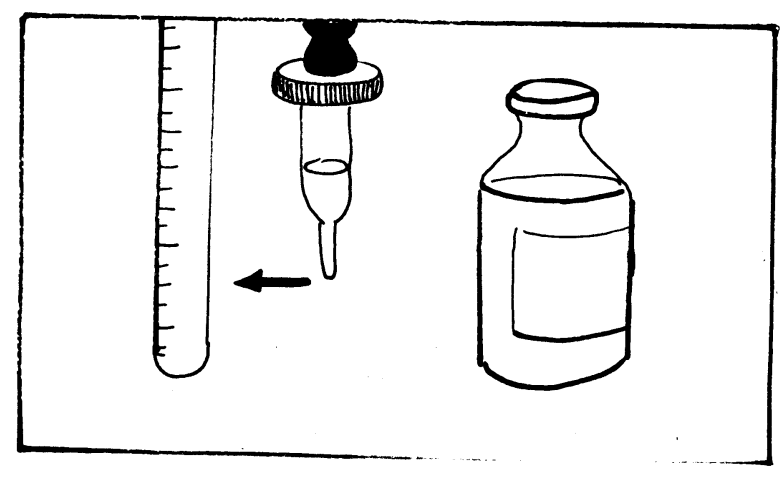

$$
\begin{aligned}
& \text { ميتود : } \\
& 1 \text { ـ تتسيمات شوكى }
\end{aligned}
$$

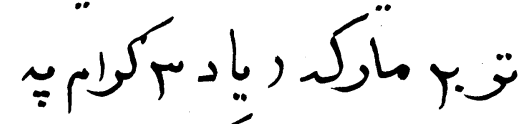

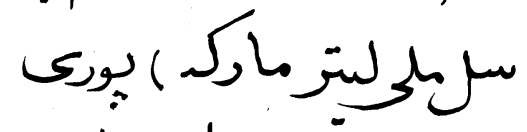

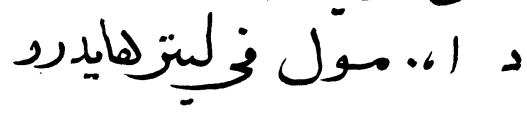

$$
\begin{aligned}
& \text { كوريكا سبيد , HCL } \\
& \text { سمه هُك كرى }
\end{aligned}
$$




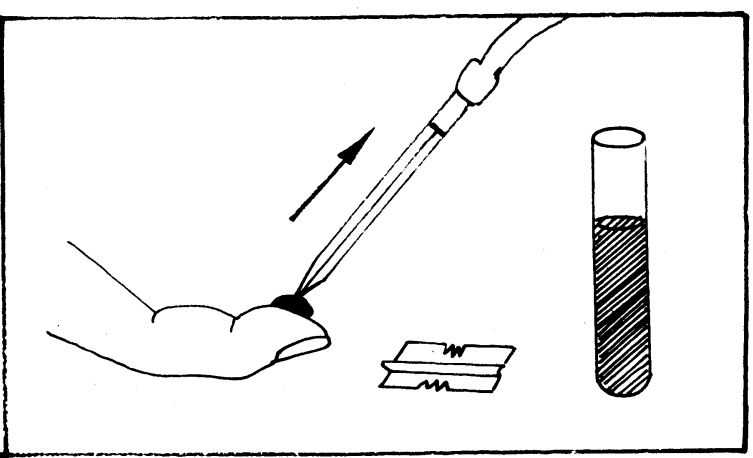

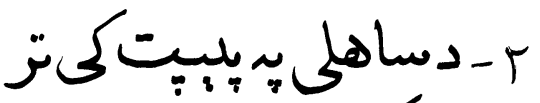

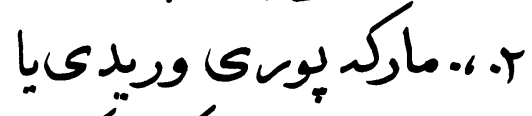

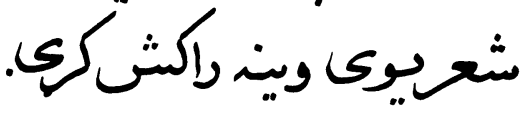

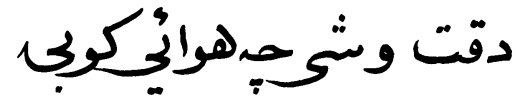

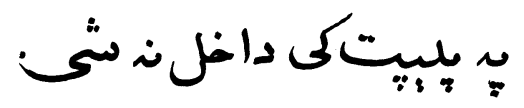
دوريلى ويخحمس دوتت

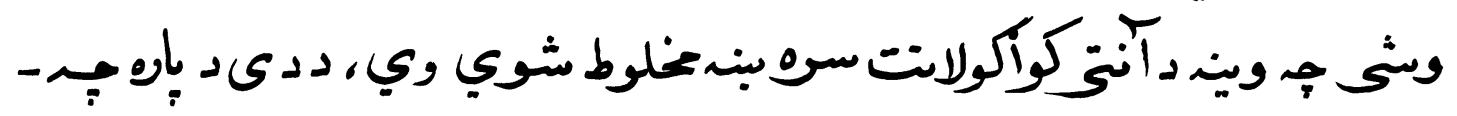

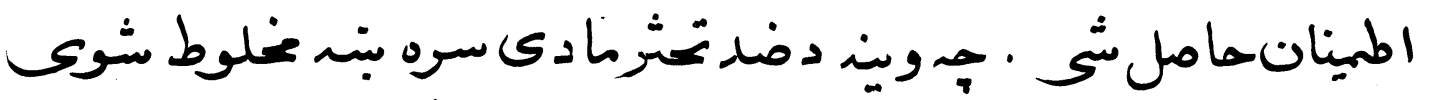

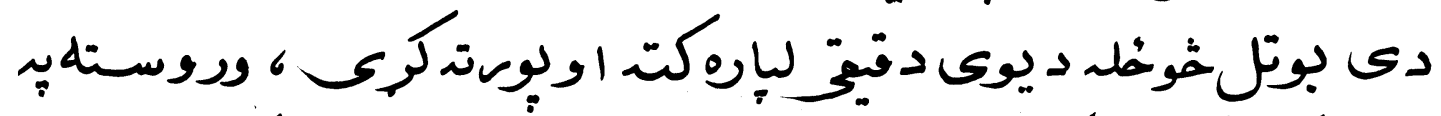

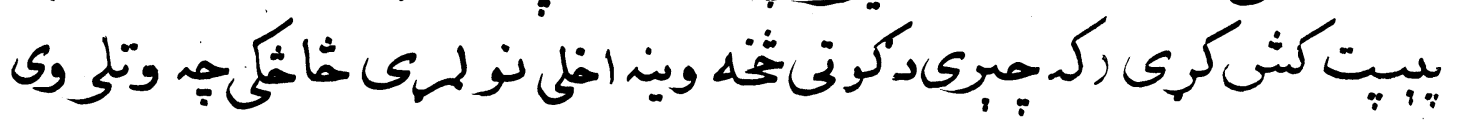

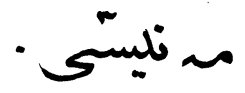

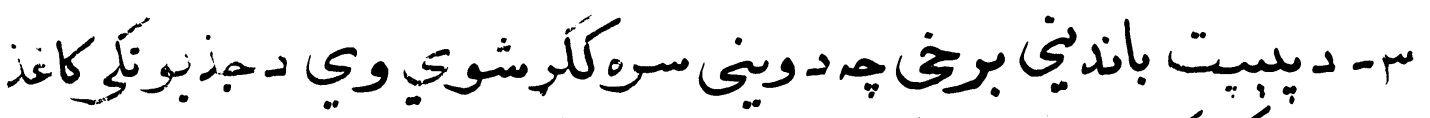

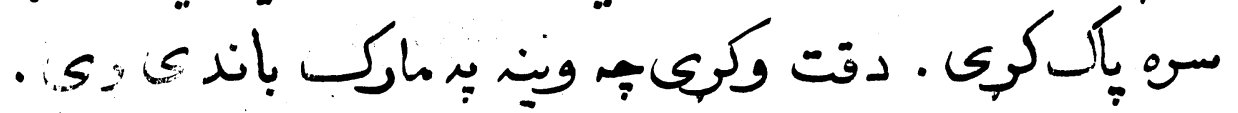

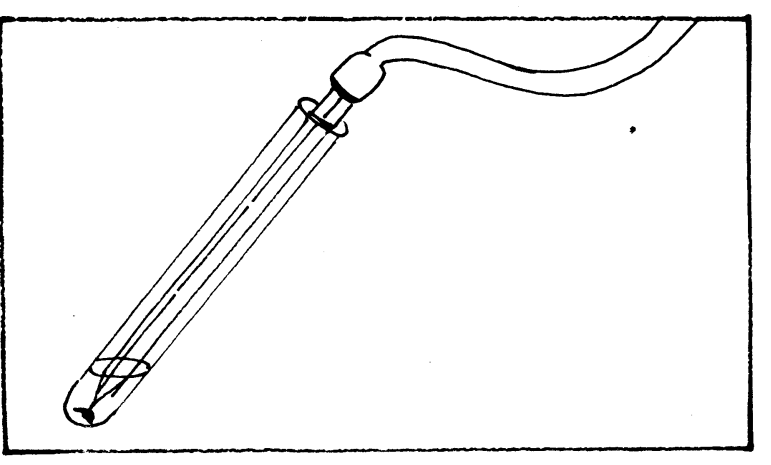

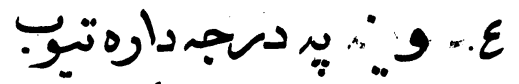

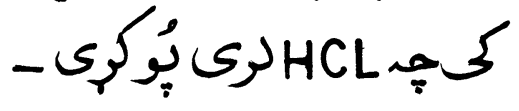

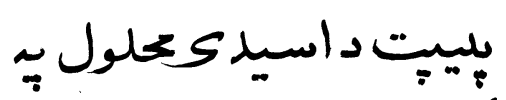

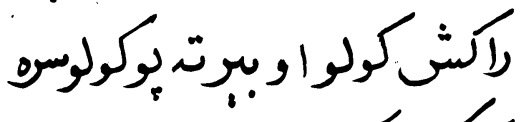

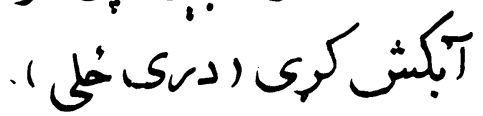




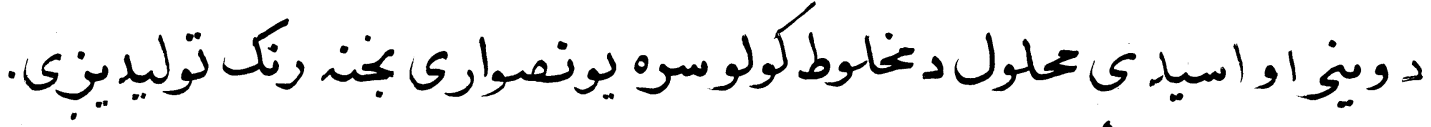

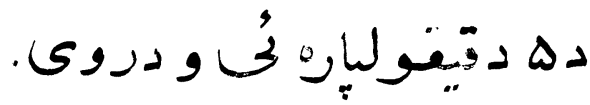

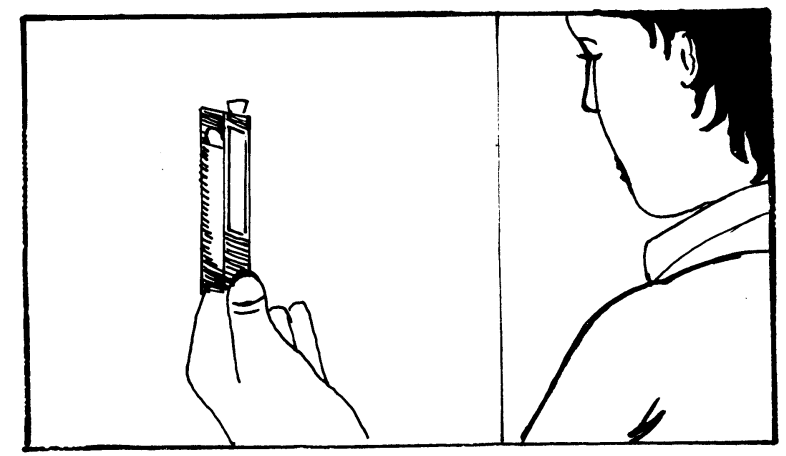

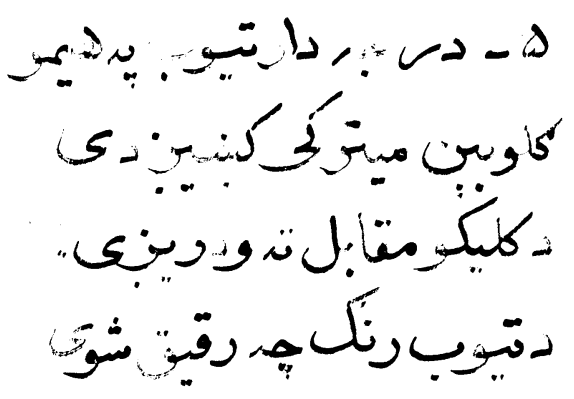

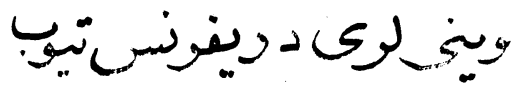

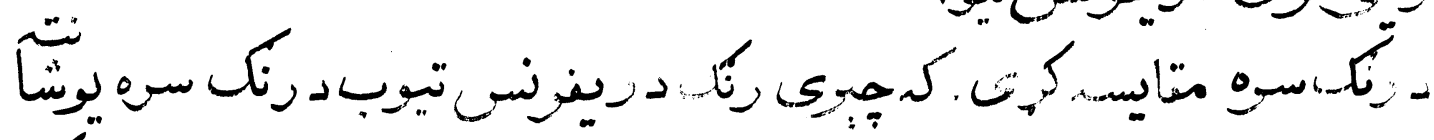

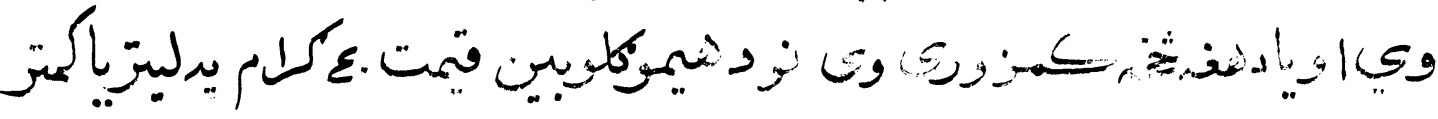

- (sy rixd)

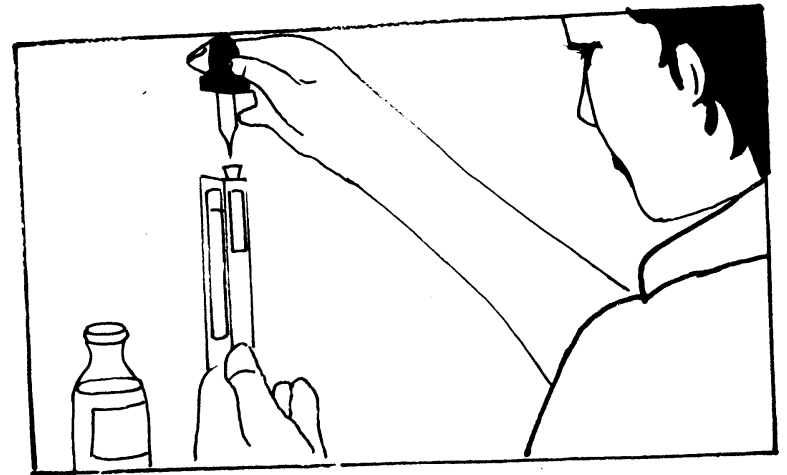

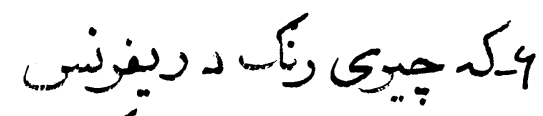

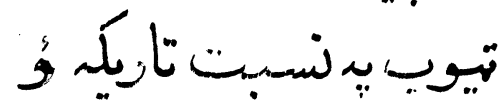

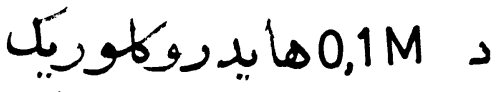

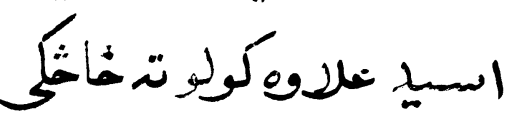

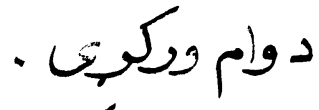
دهرة:

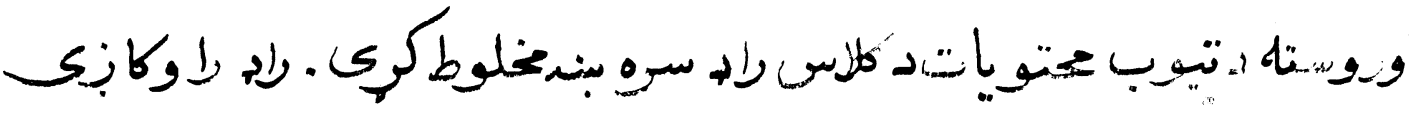




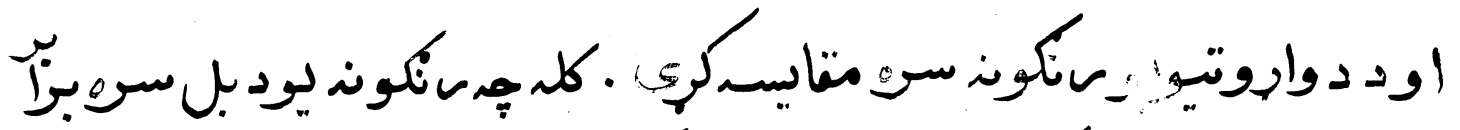

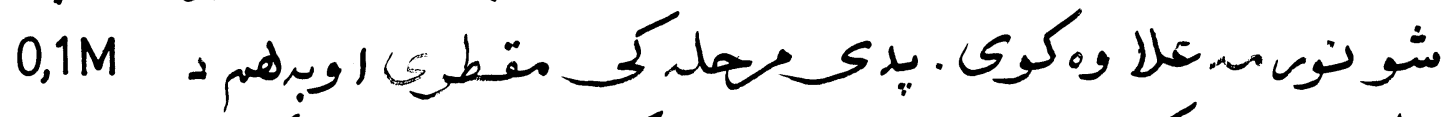

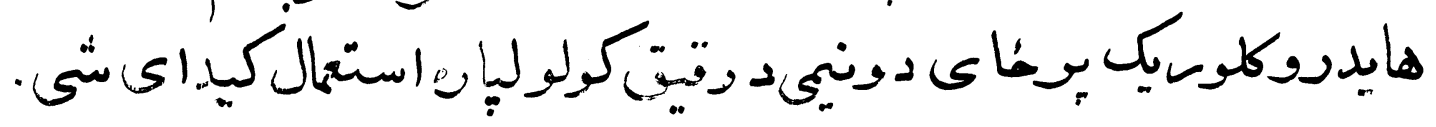

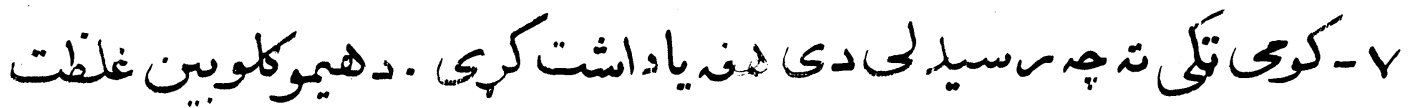

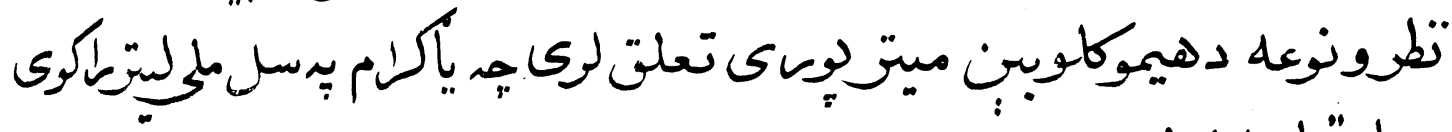

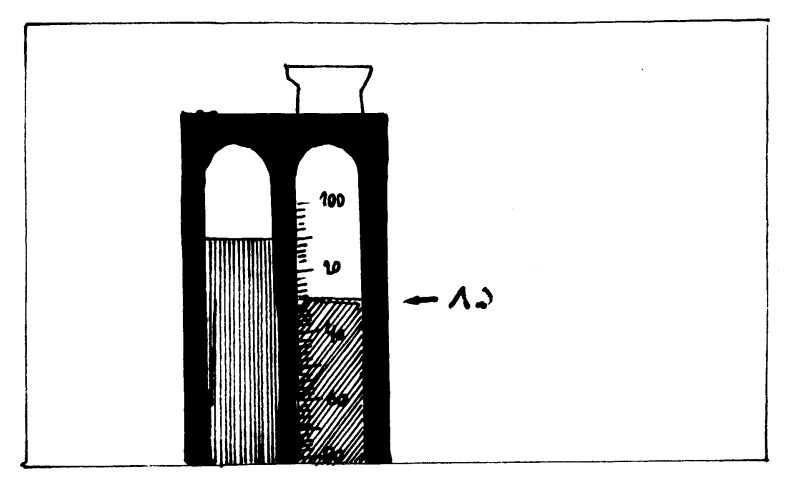

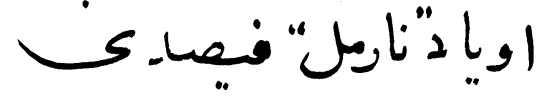

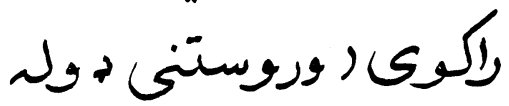

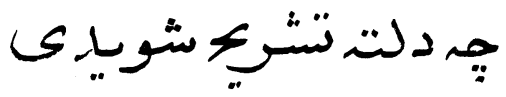
دسفامينت وينذى) .

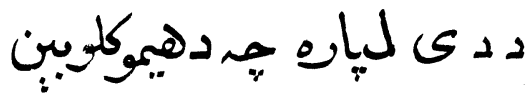
وك/100

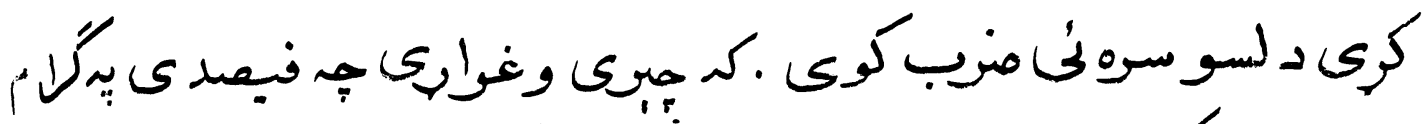

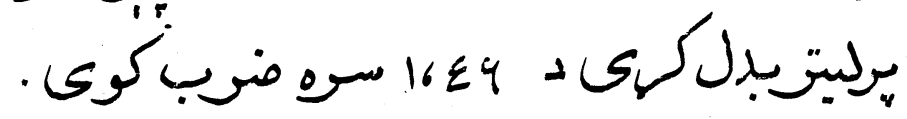

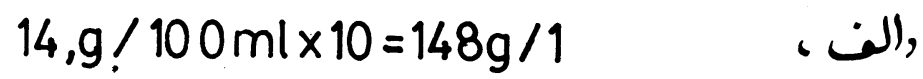

$$
\begin{aligned}
& 85 \% \times 1,46=124 \mathrm{~g} / 1 \\
& \text { ، ب (ب) }
\end{aligned}
$$

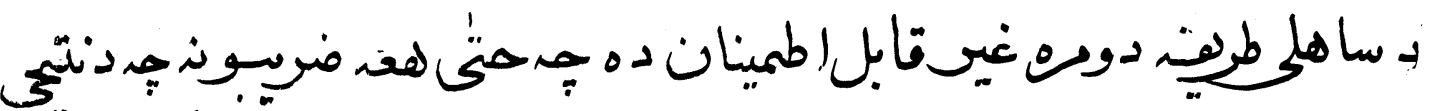

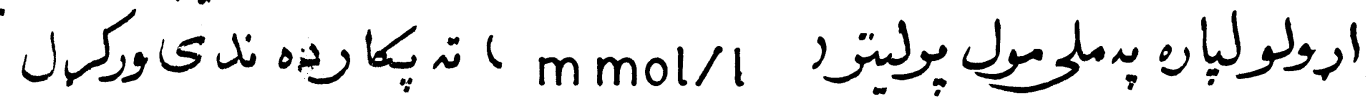




\section{دوينحـازكت فلمونوآمادهكول}

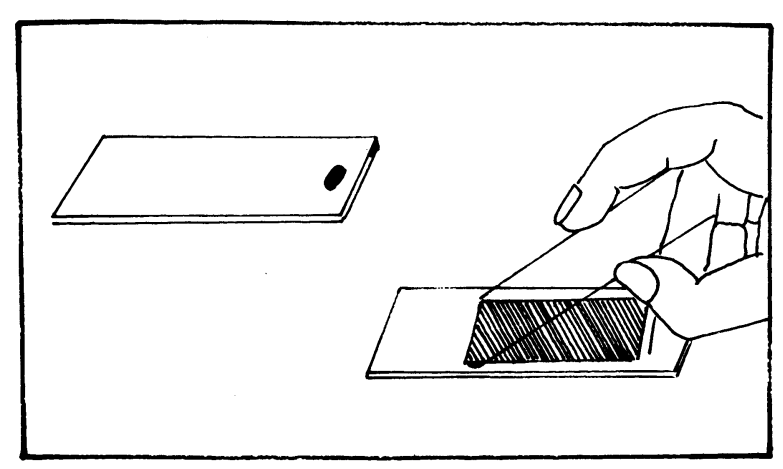

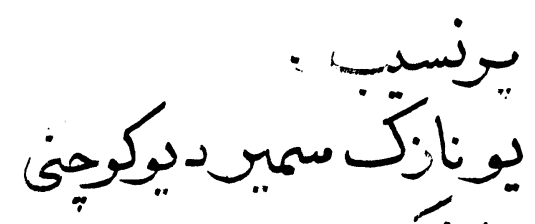

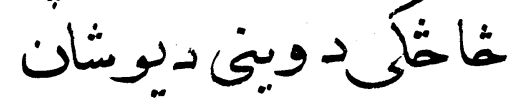
اوا ص ولوتخ بـيوسيلايد

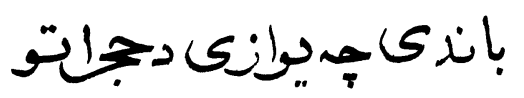
يو طبترجوبوكيى تهيركيداى شىى .

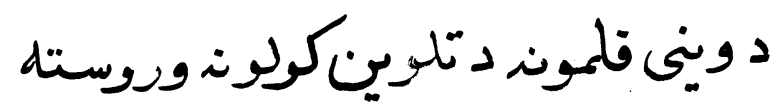

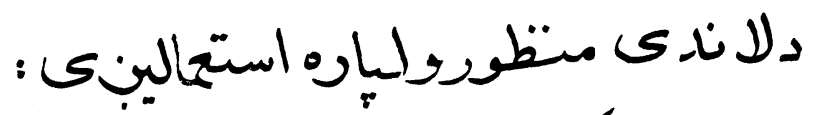

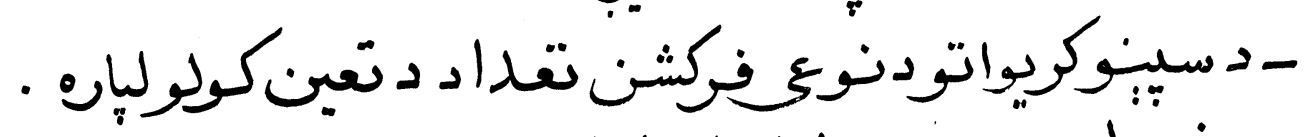

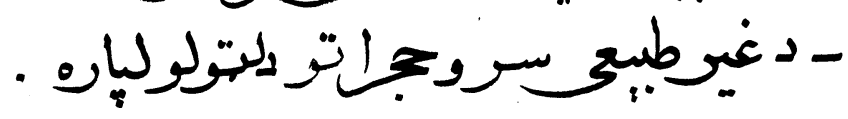

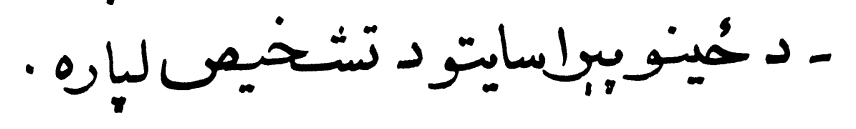

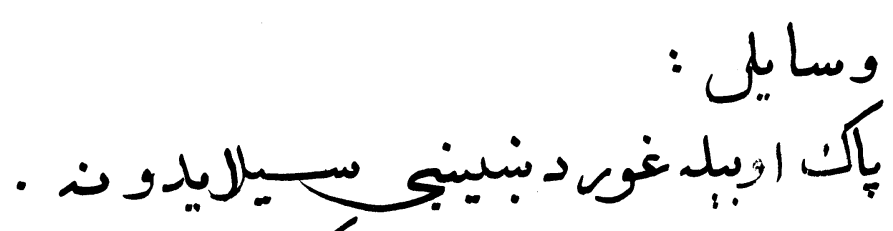

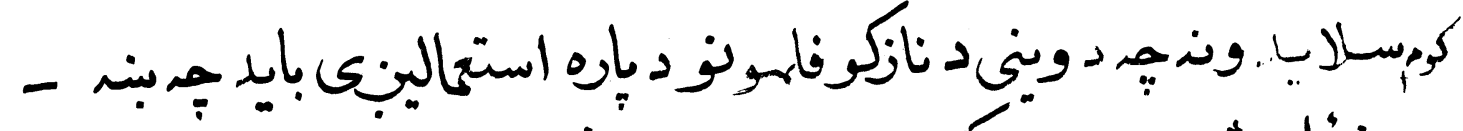

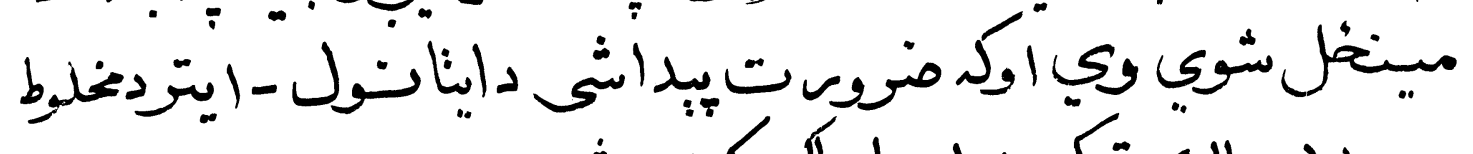

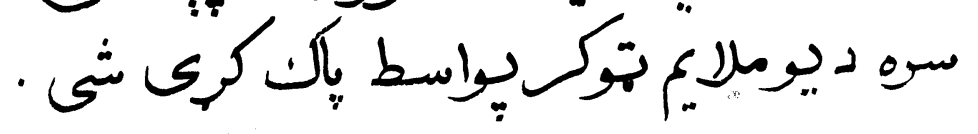




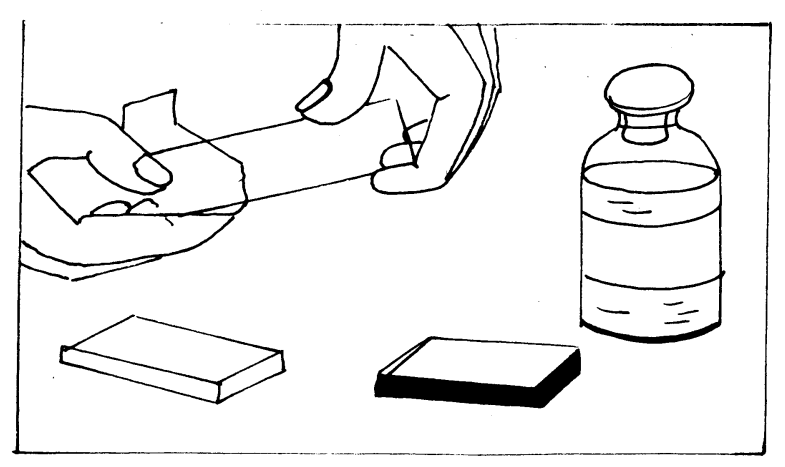

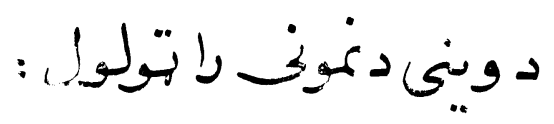

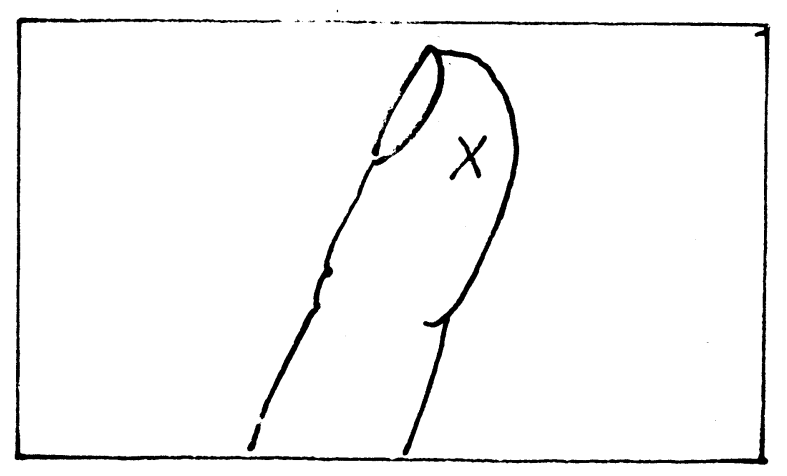

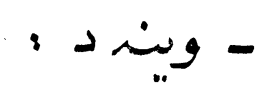

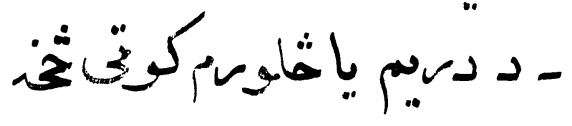
- بوريوسير بـ باندى وإخلى.

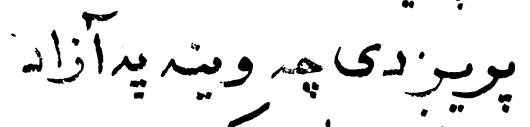

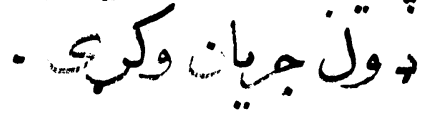
لدي د بجاتود نعدادو

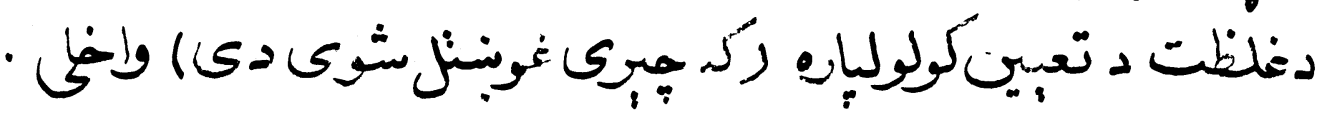

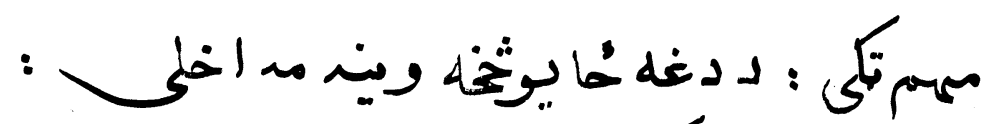

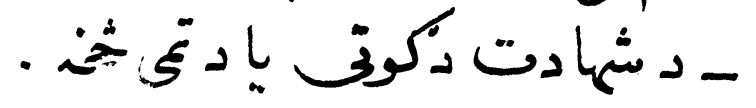

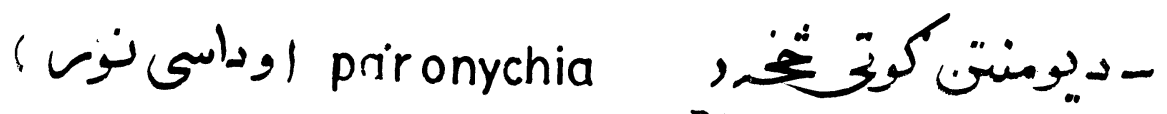

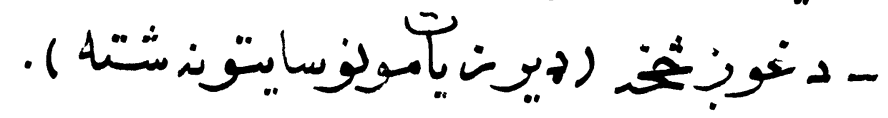



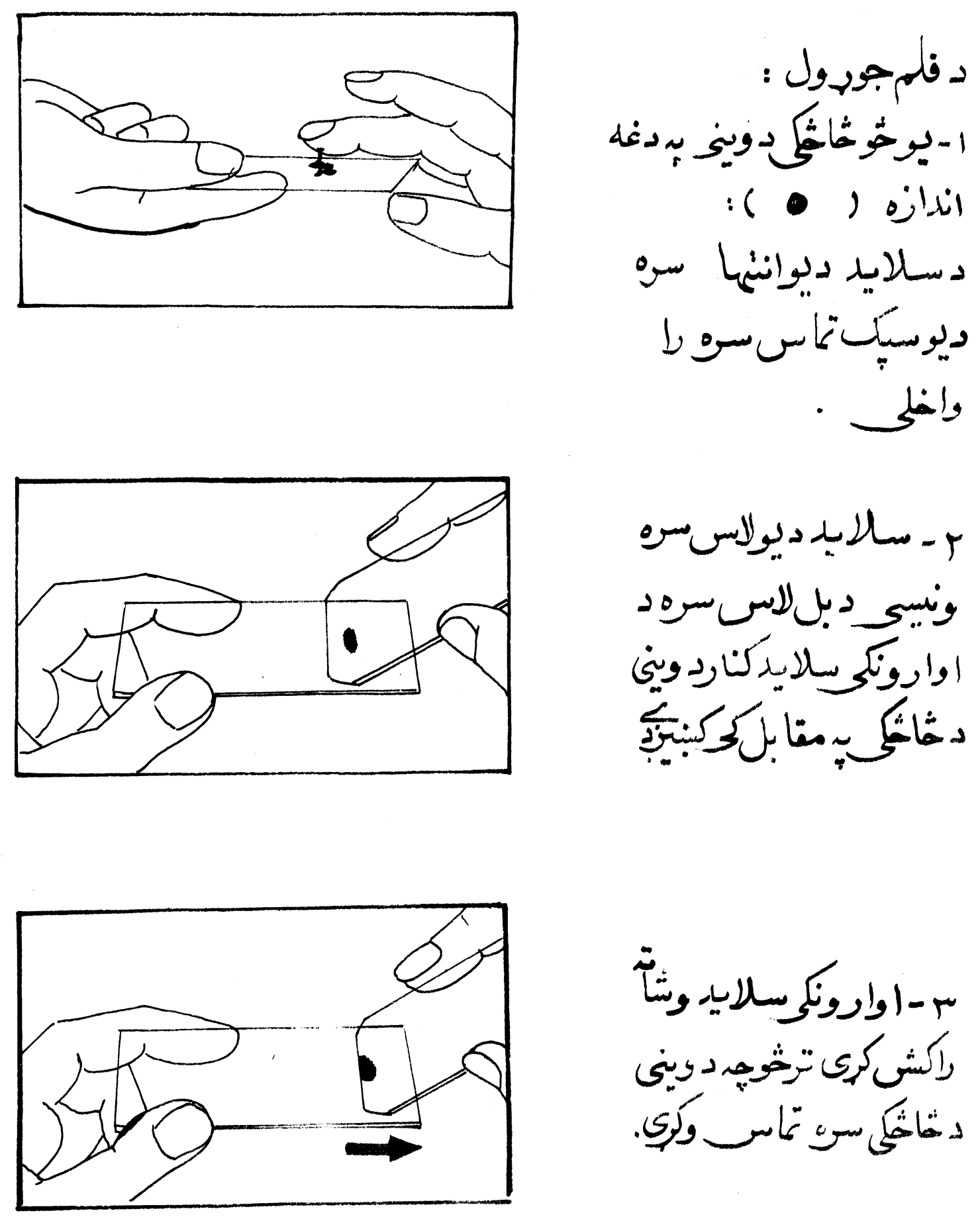

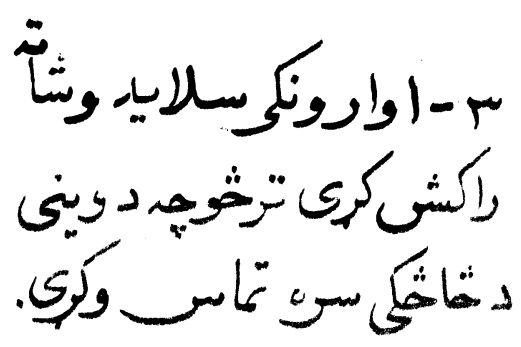




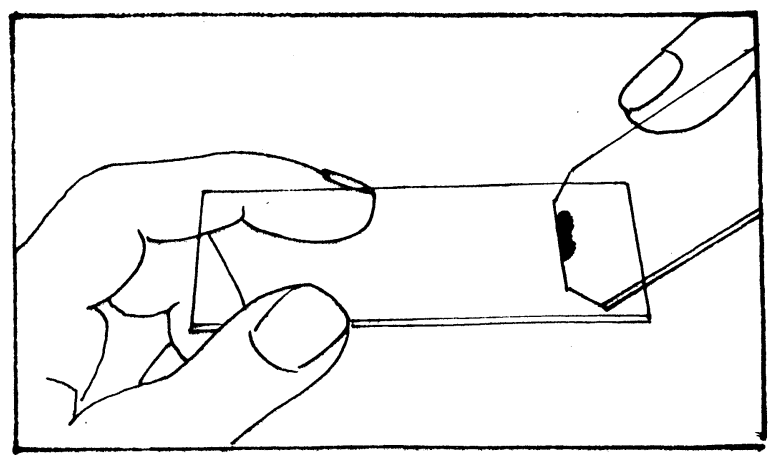

ع- ب-بِيزد

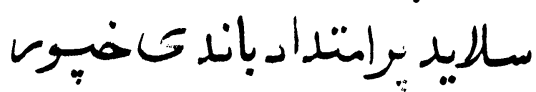

ن

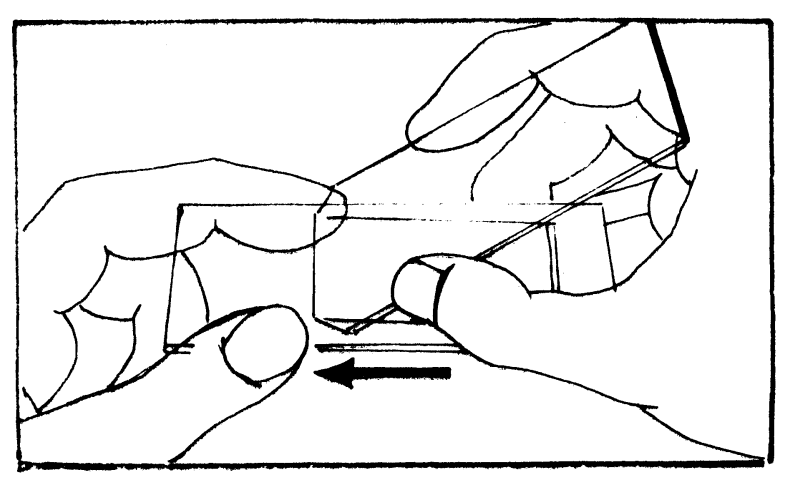

هـ اوارونكى - د سلايلـ و

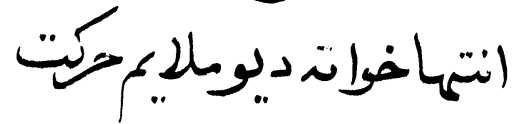

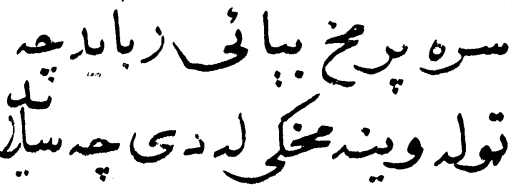

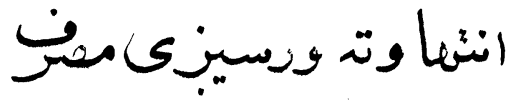

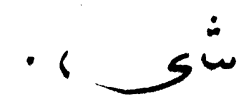

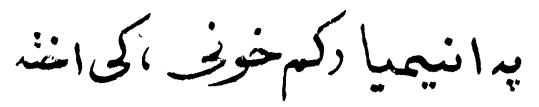

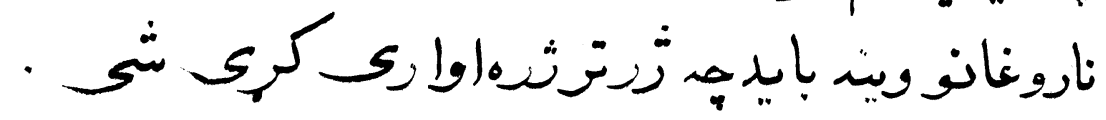
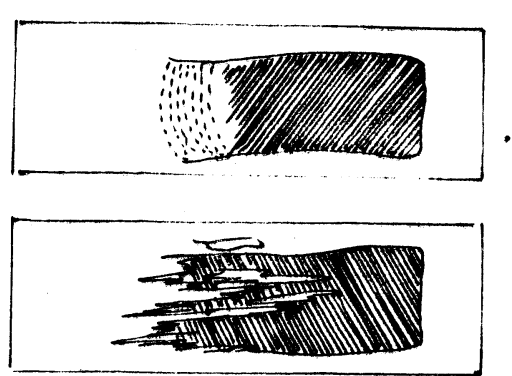

4 - دقت وكري) بحتناعت

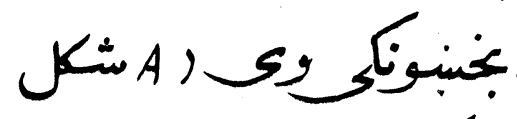

ن وكوصى ) :

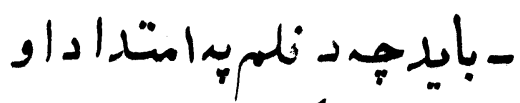

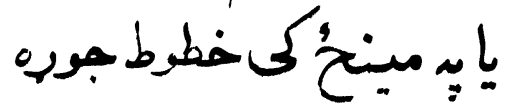
شوىندو ويكاودهنكل

riv 


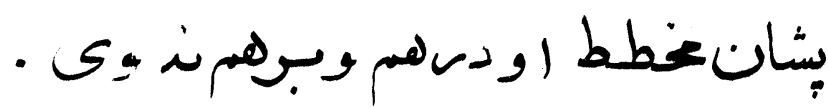

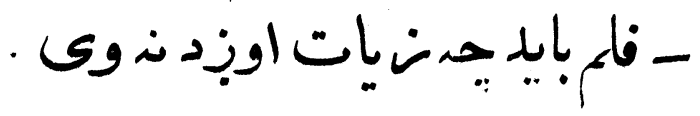

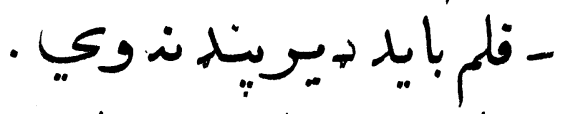

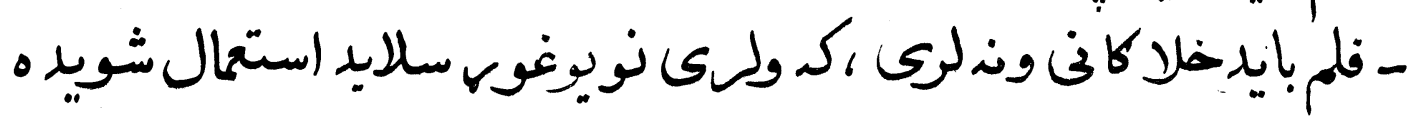

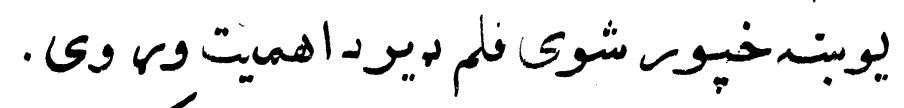

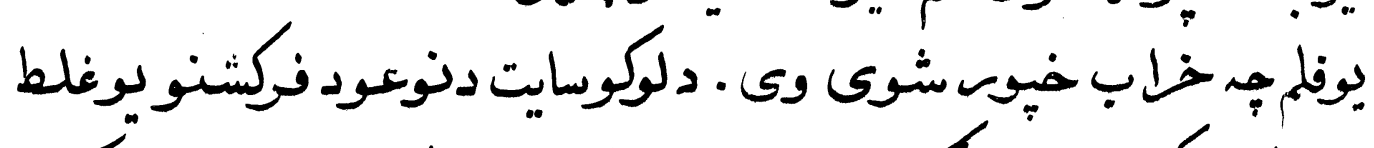

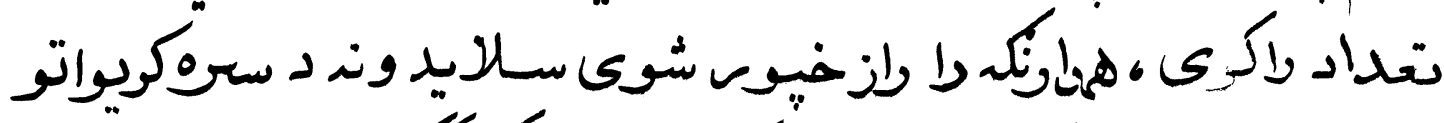

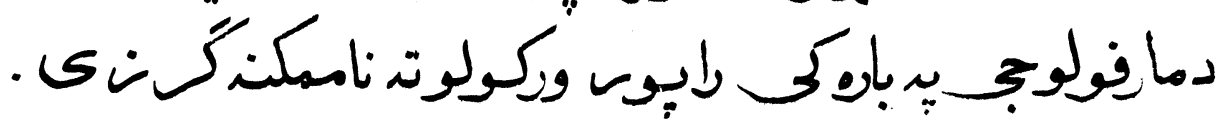
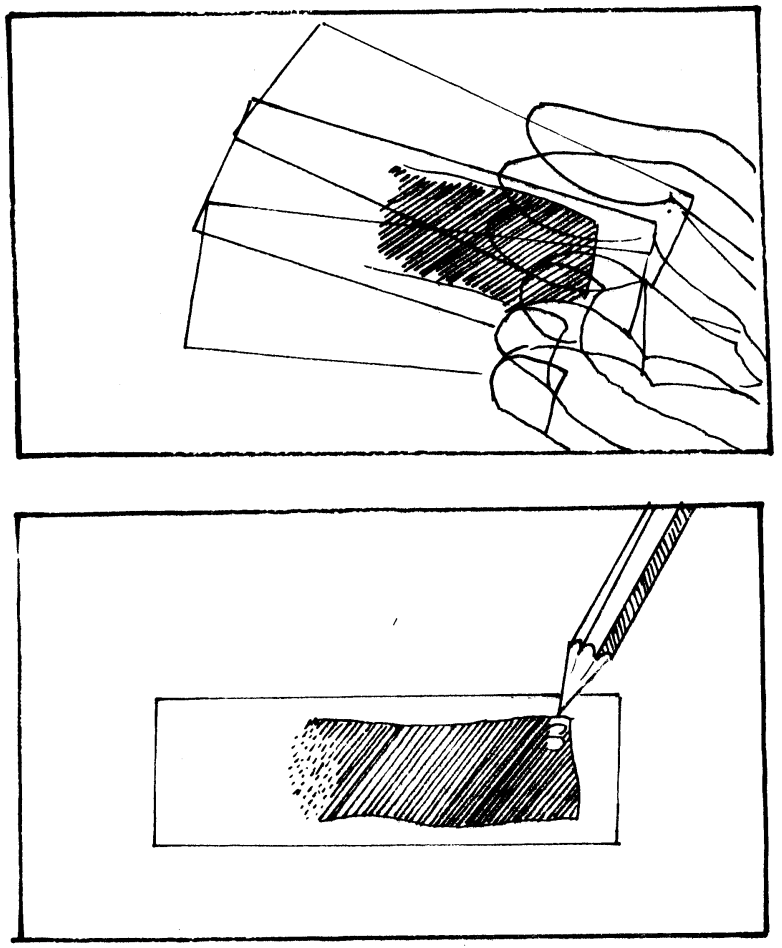

YA وساتلشح بومناسب وجيج دهغندييرضوريكى وي توني

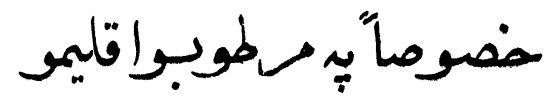
وجنشوى فلم دناروغ دنمي

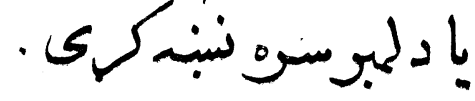

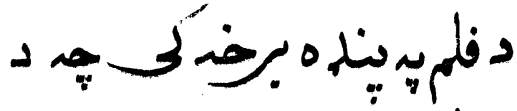

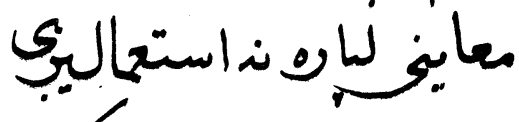

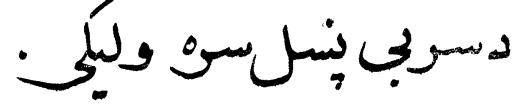




\section{دوينى نازكونممتلويت:}

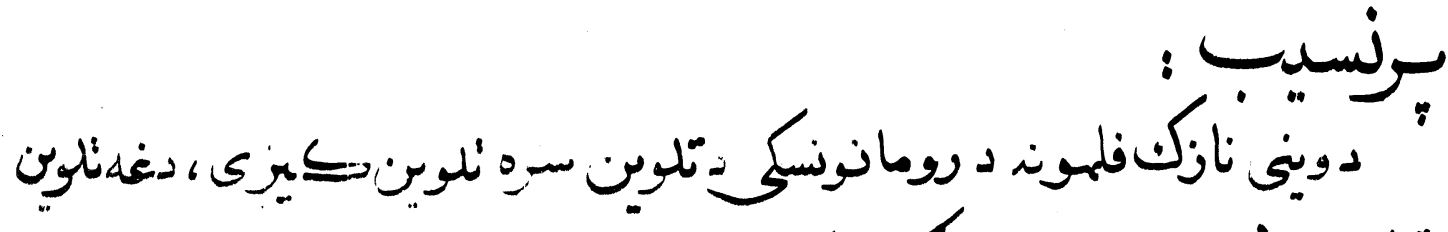

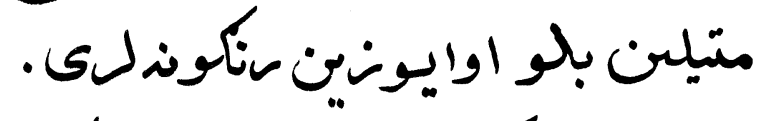

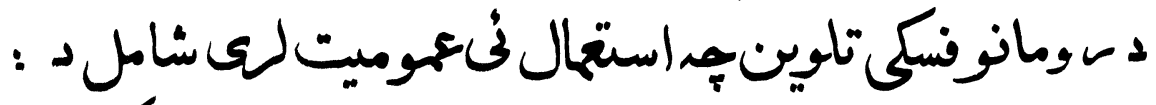

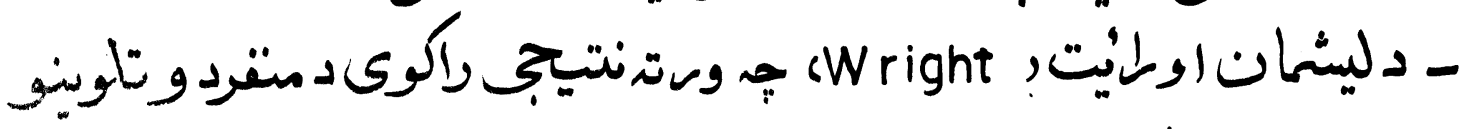

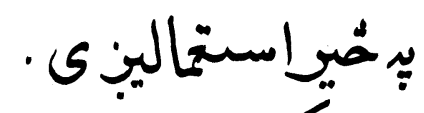

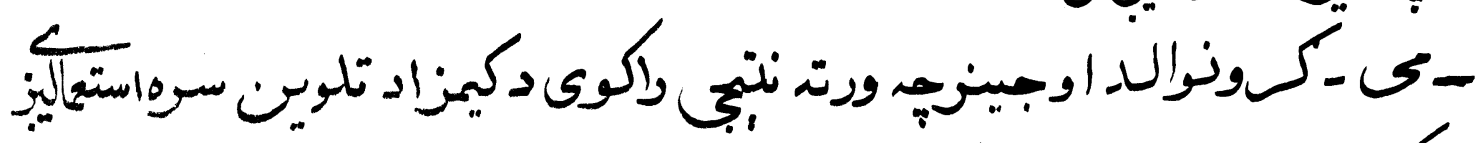

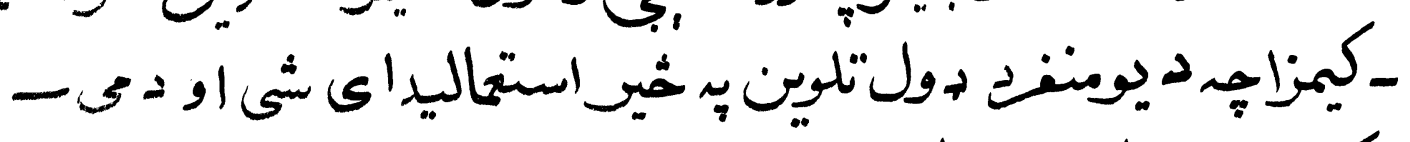

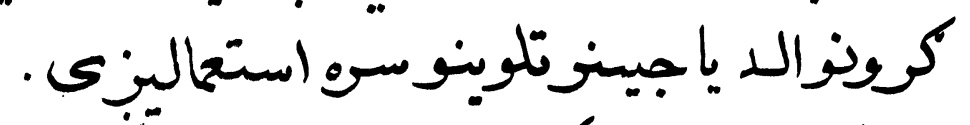

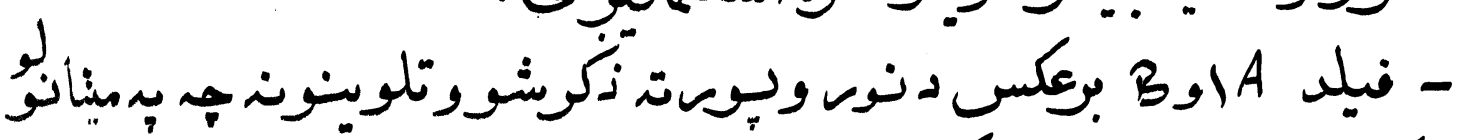

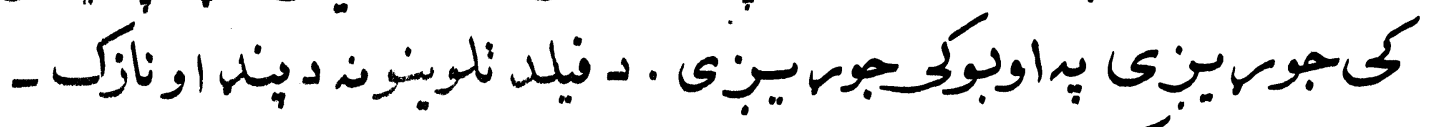

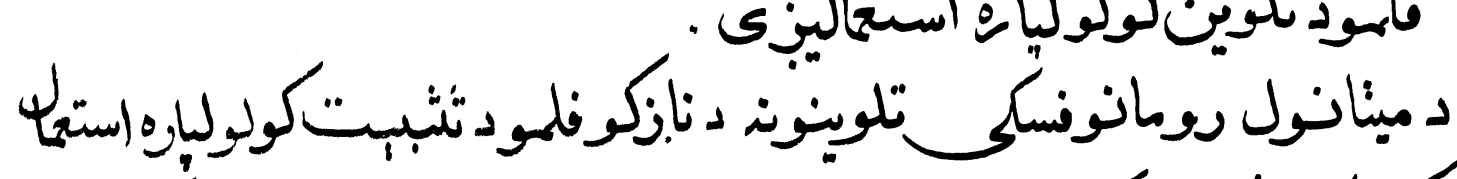

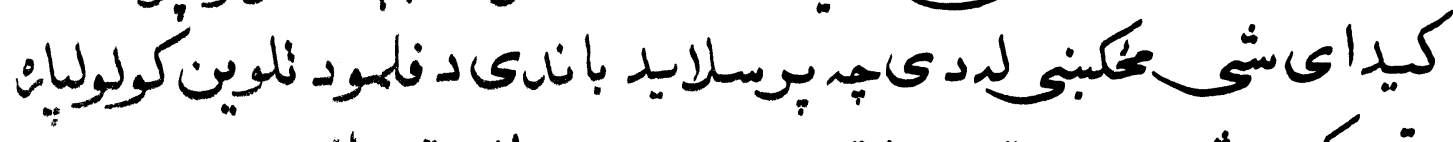

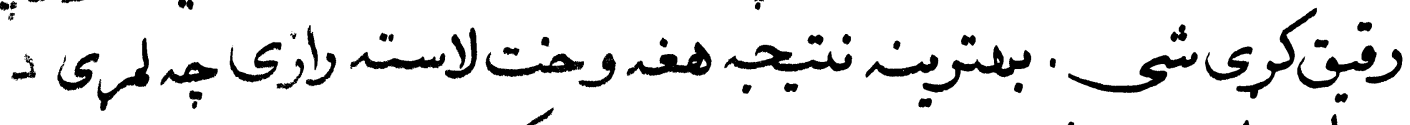

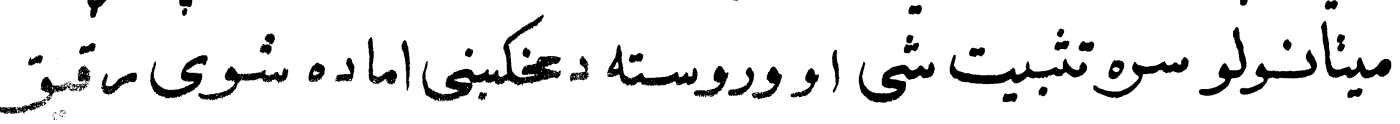

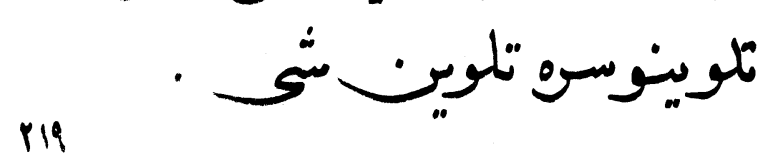




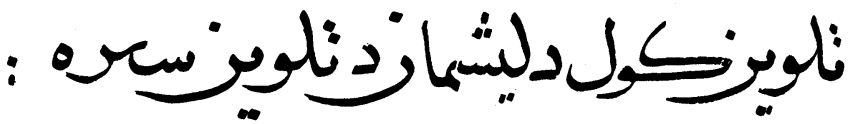

وسيال :

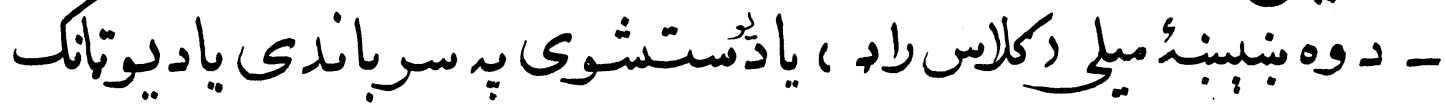

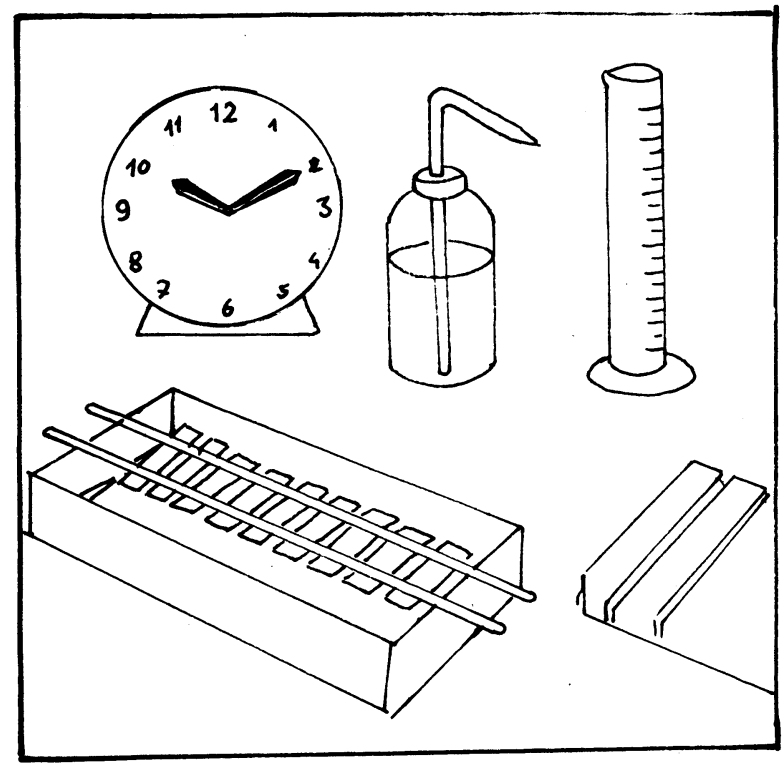

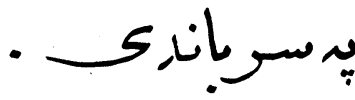

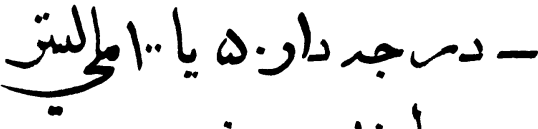

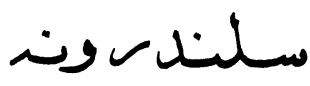

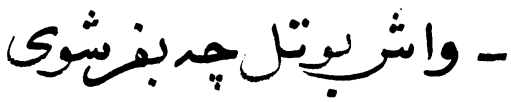

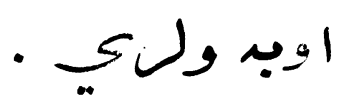

ـ وقفوى تايمس ساعت.

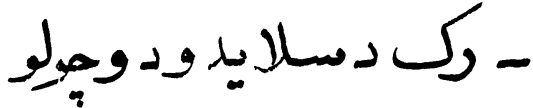

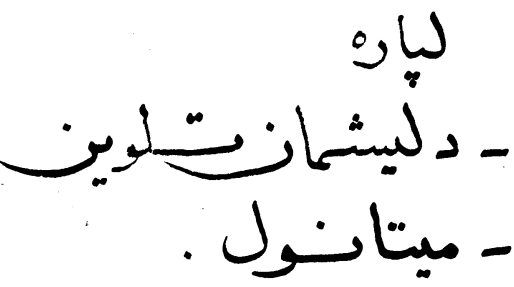
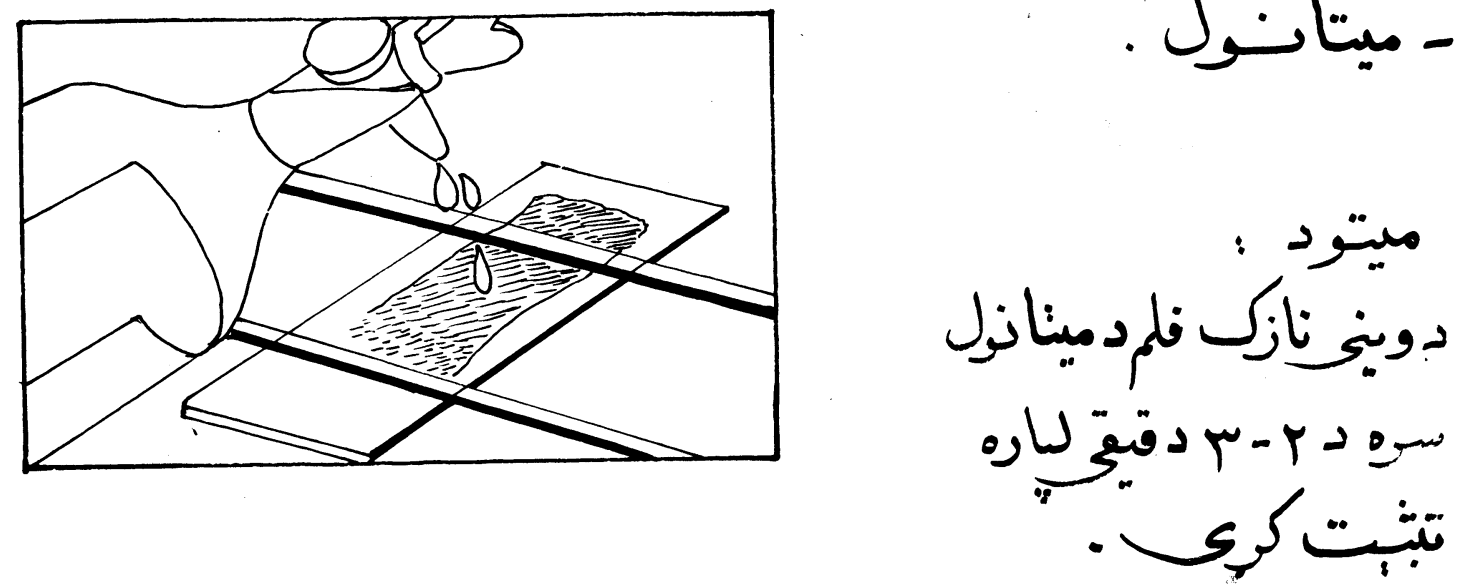


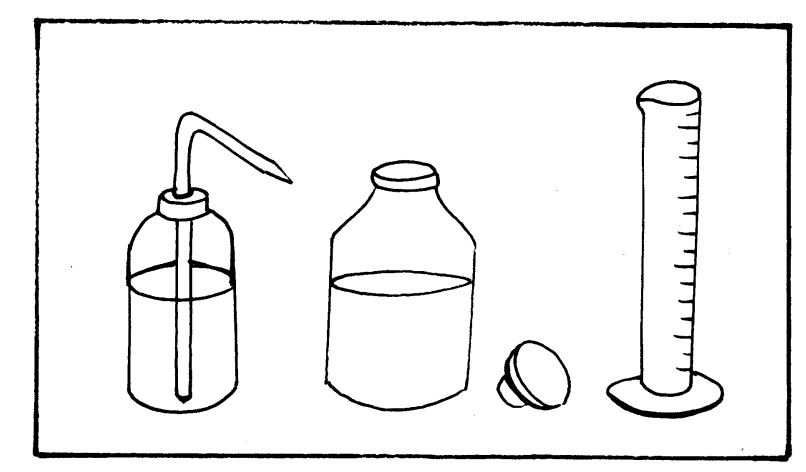

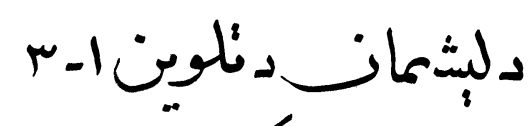

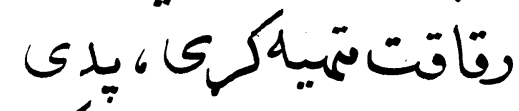

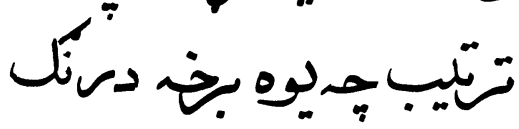
اودو وبخوبنيشئي

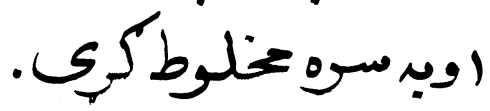

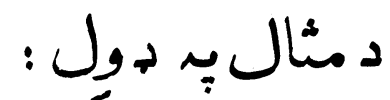

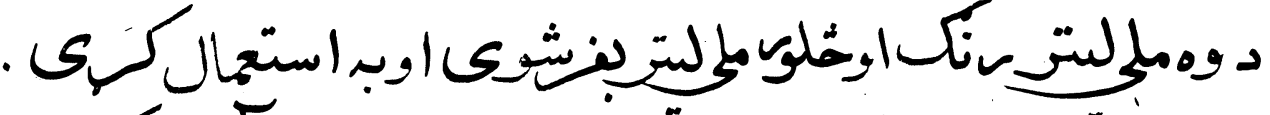

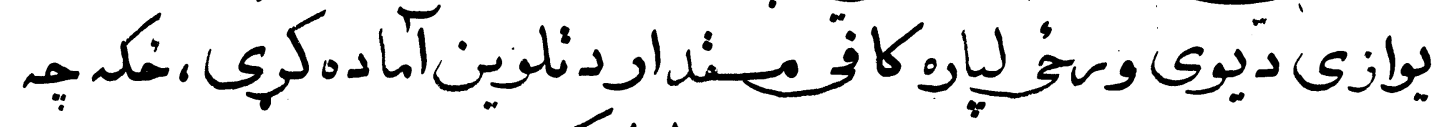

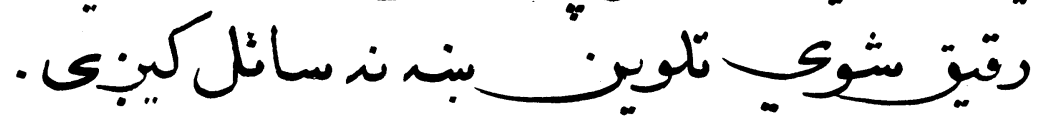

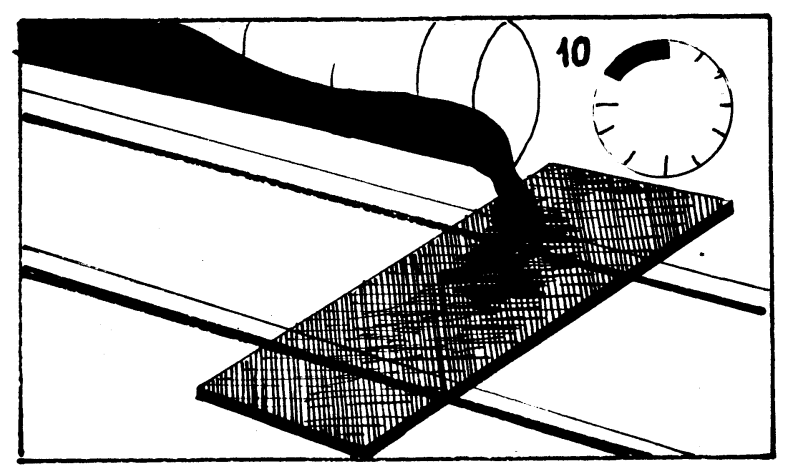

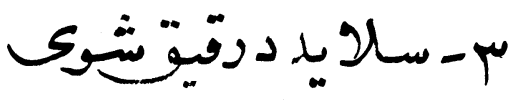

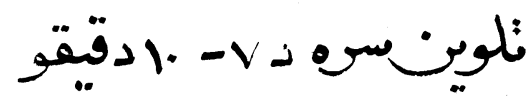

$$
\begin{aligned}
& \text {. }
\end{aligned}
$$

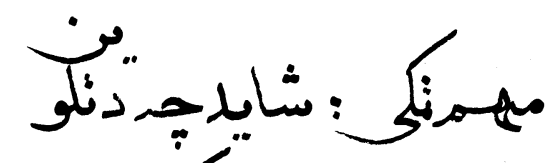

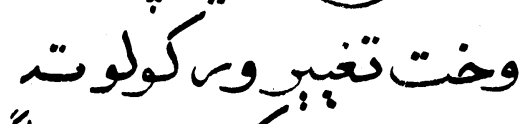

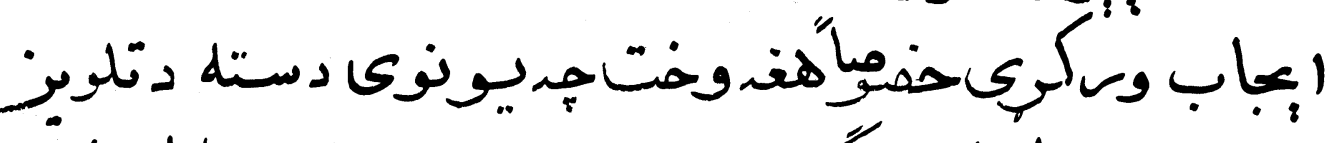

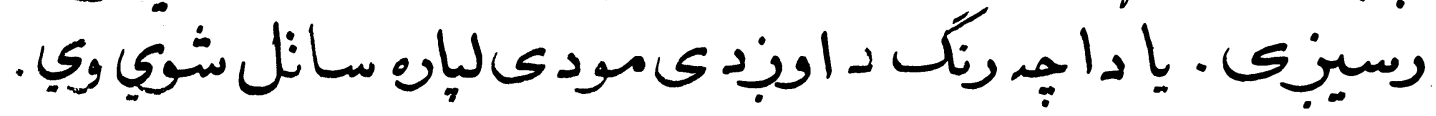




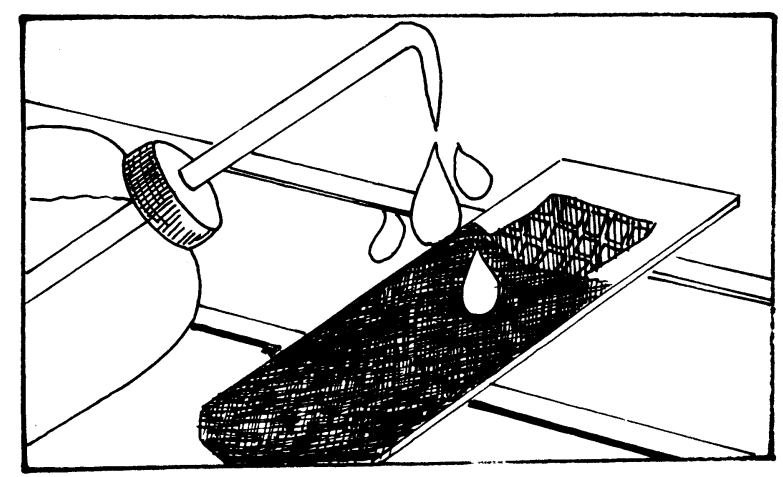

ع- صنكت د بن شيثوىاولب

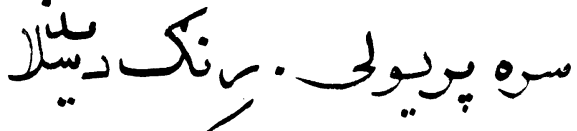
ثخرمستويوى حمكل دنغله

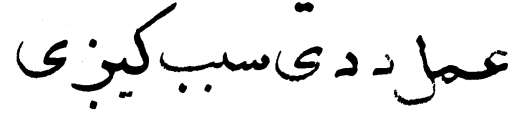

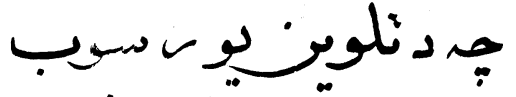

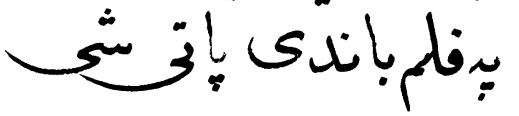

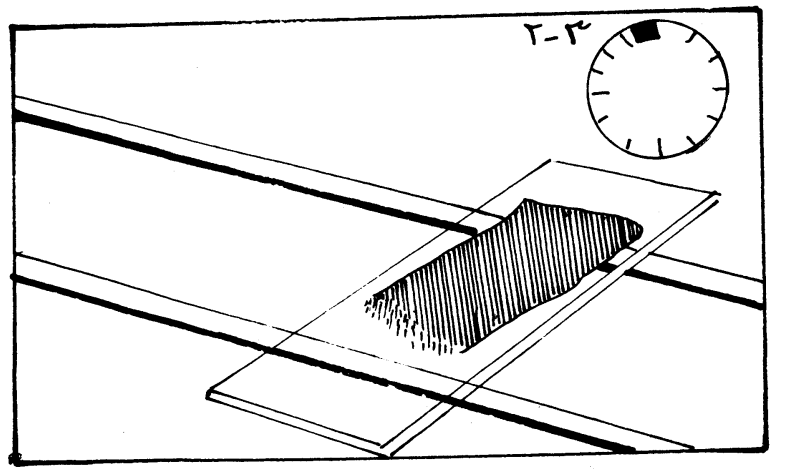

ه - د ب- س دقتقوليار

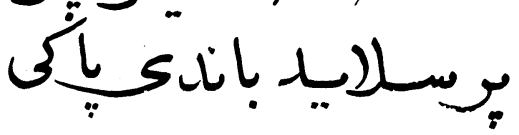

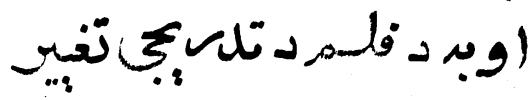

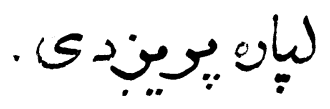

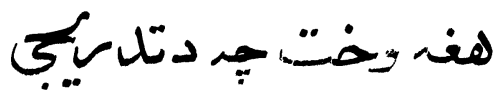

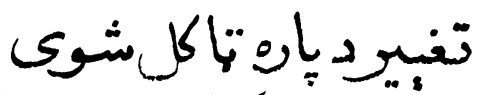

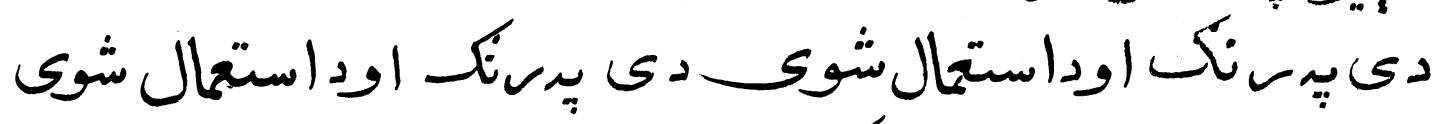

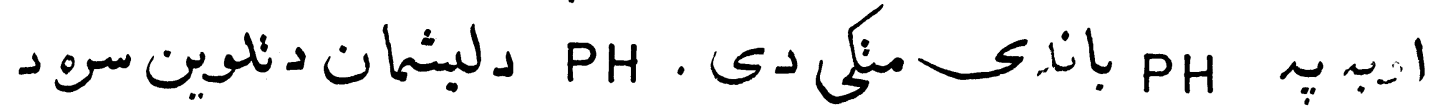

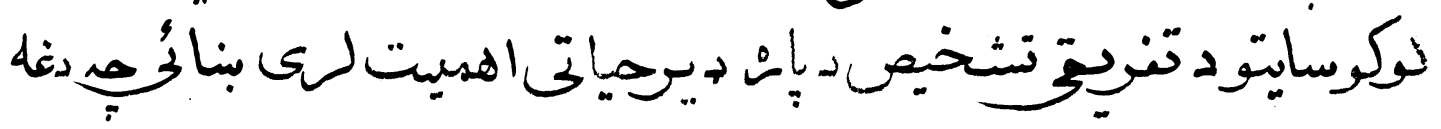

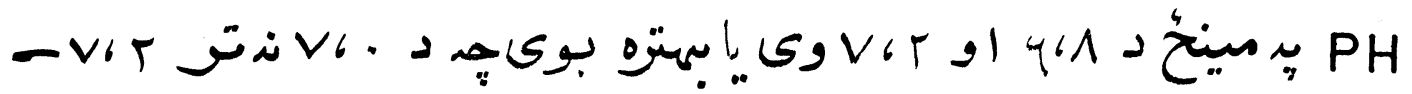

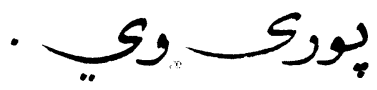




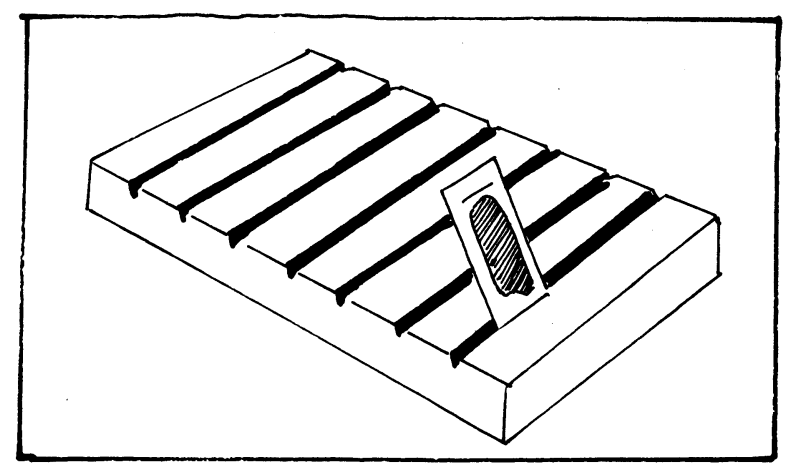

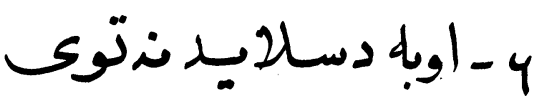

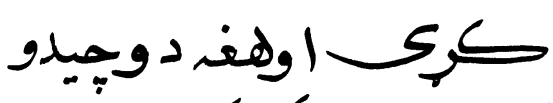

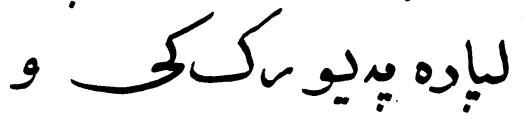

$$
\begin{aligned}
& \text { : Sar }
\end{aligned}
$$

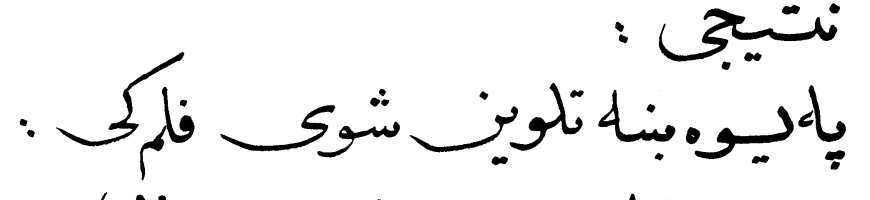

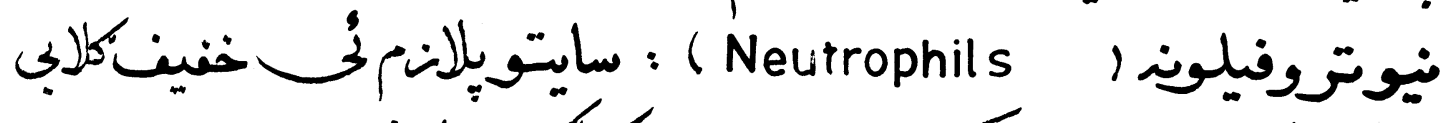

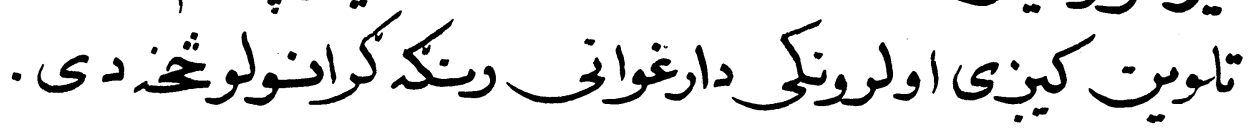

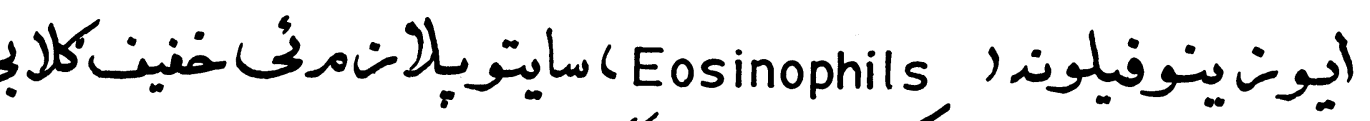

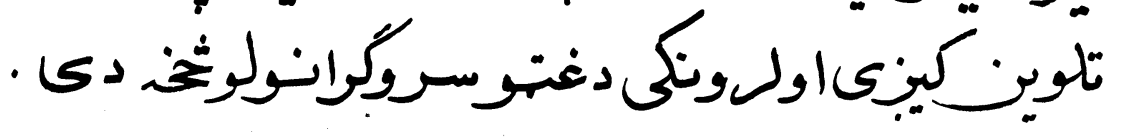

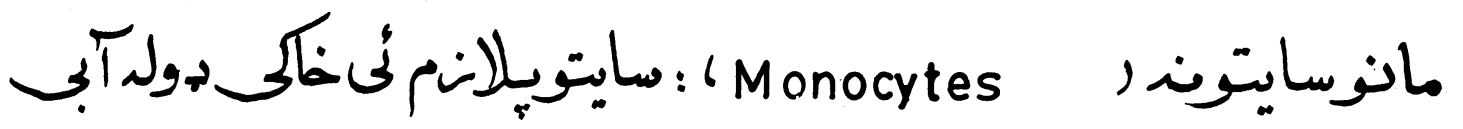

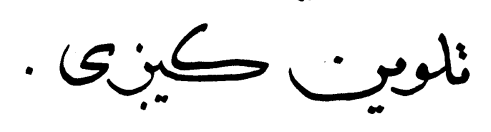

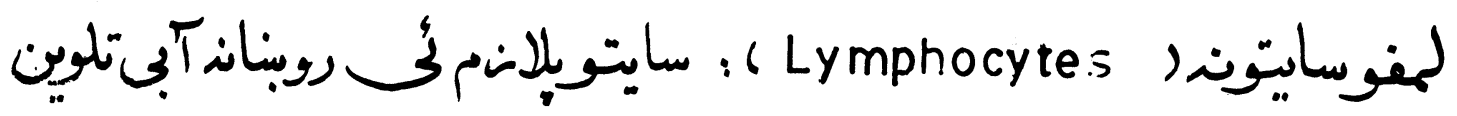

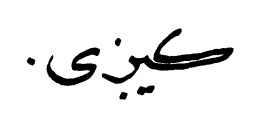




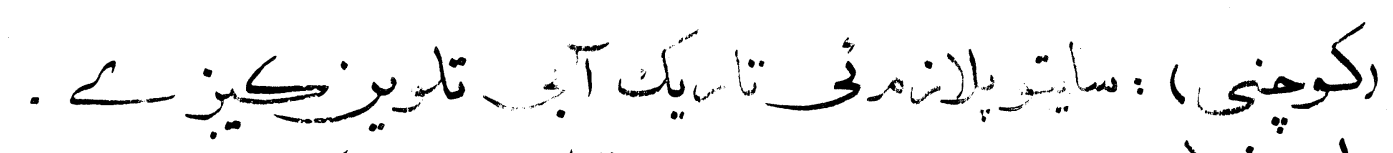

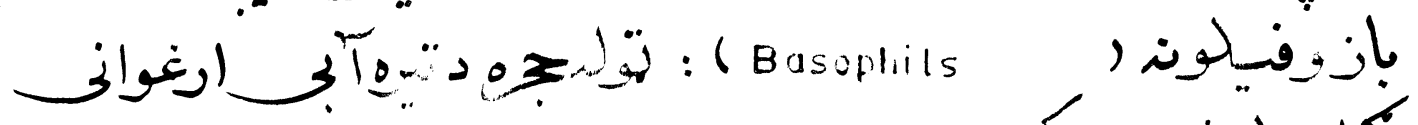

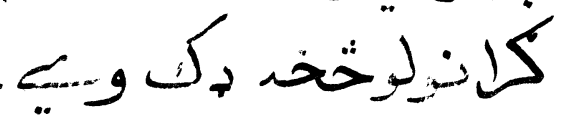

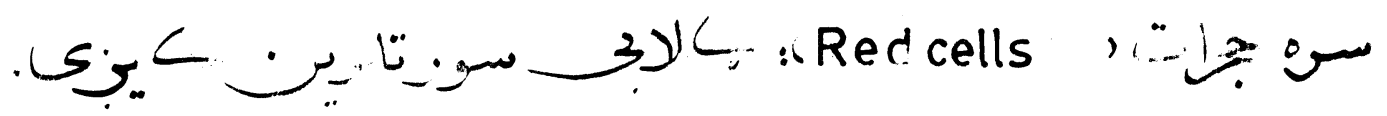

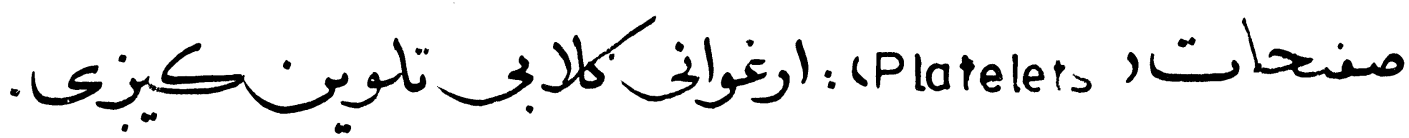

دركو سايت د زكتين: دانواعوتحداد

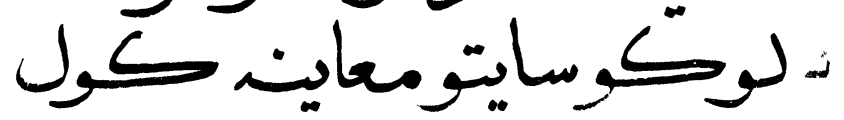

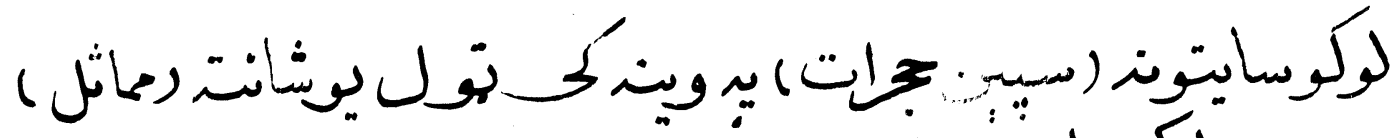

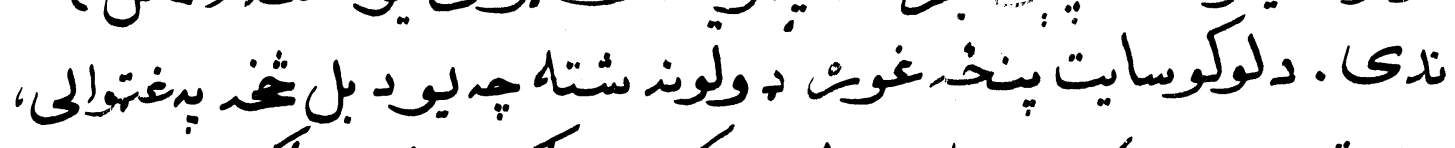

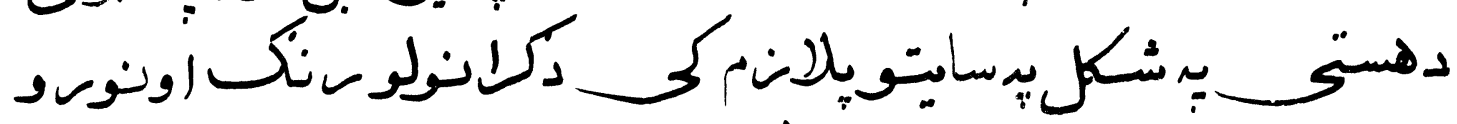

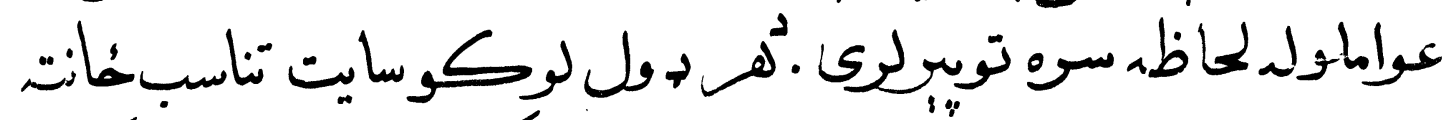

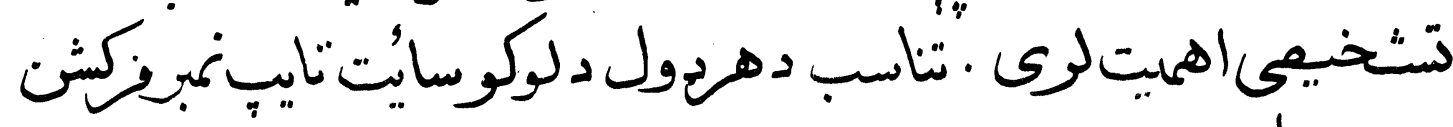

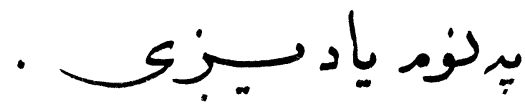

$r r \varepsilon$ 


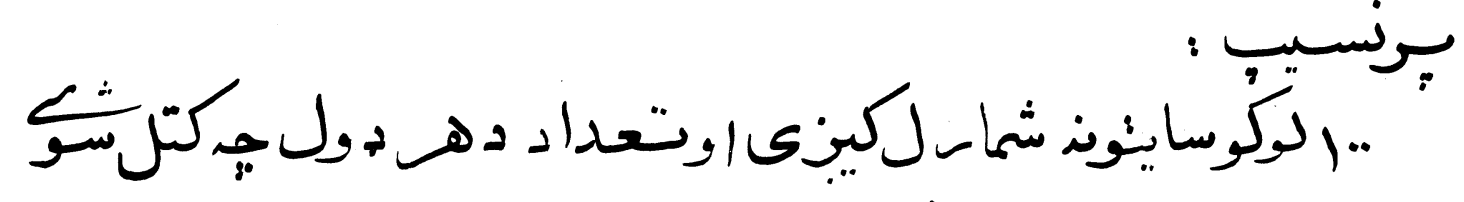

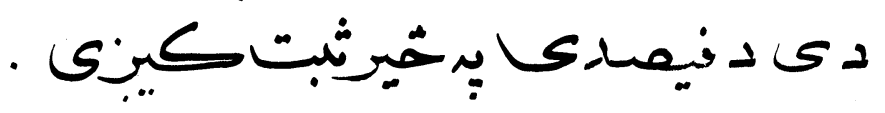

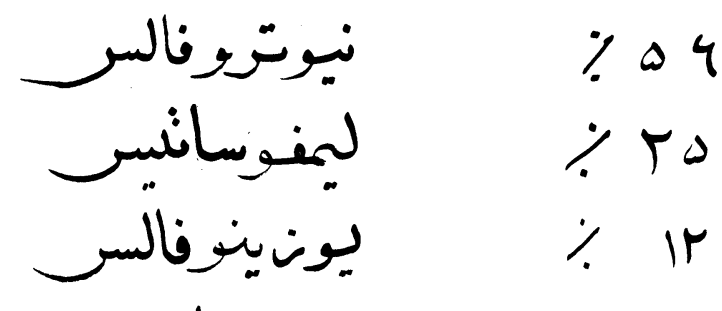

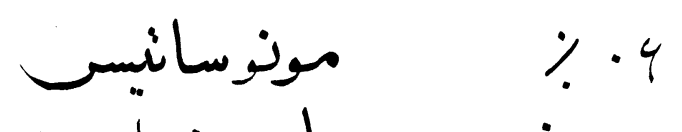

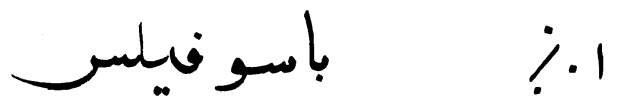

دنولوبجوى فيصدى بايد جر ..ا وى .

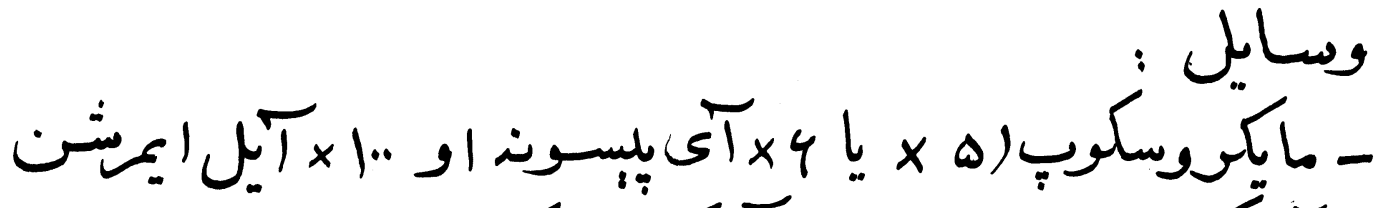

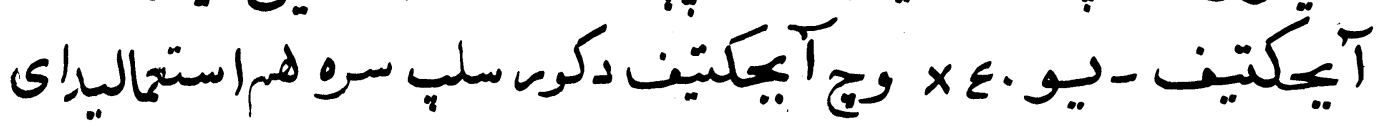

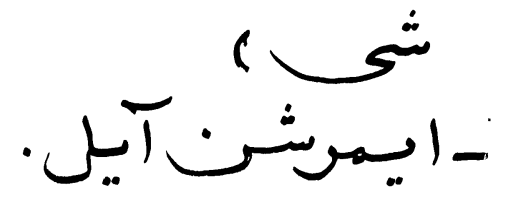

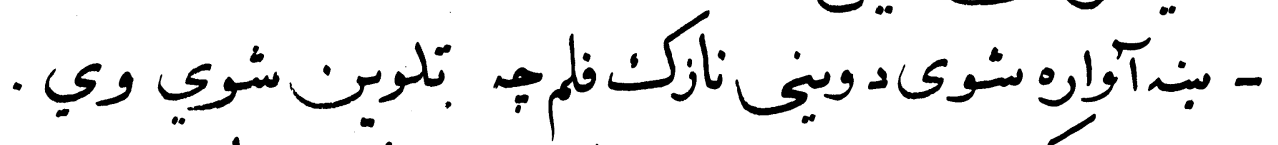

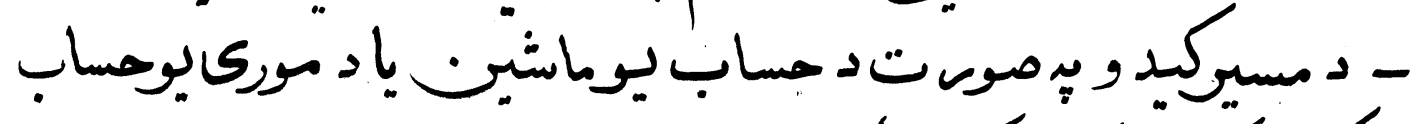

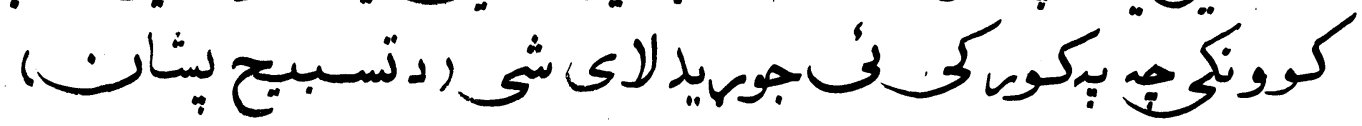




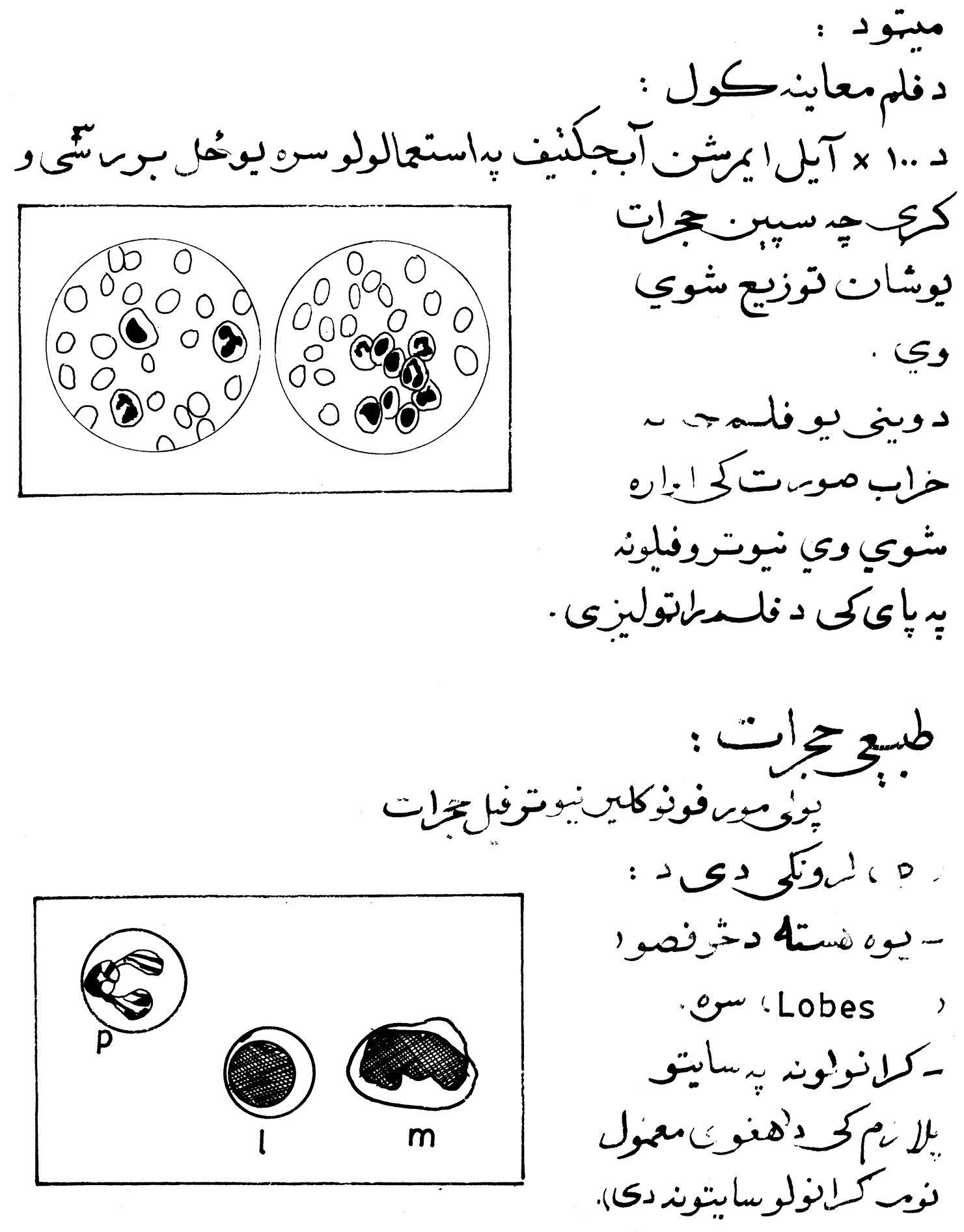

pry 


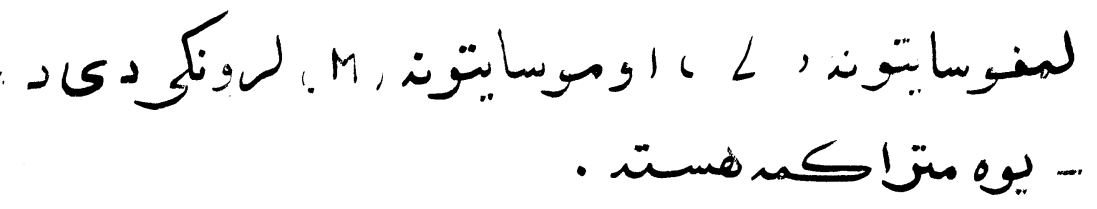

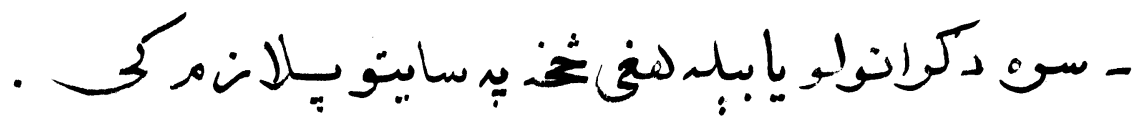

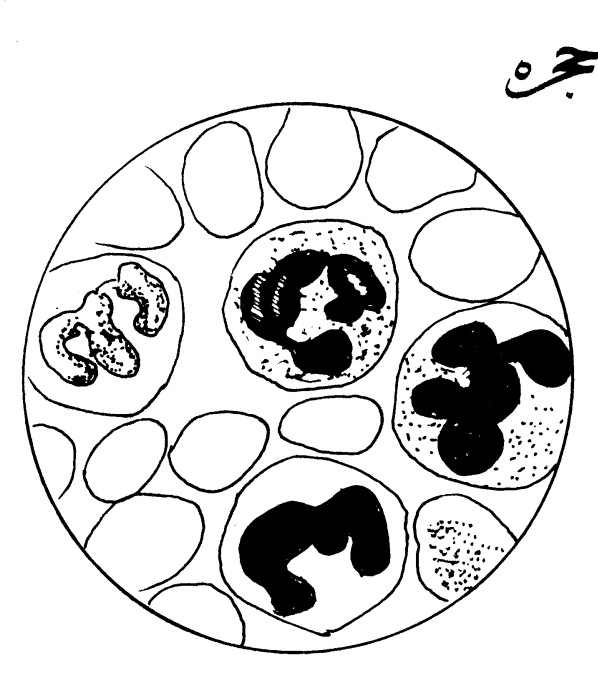

الن - بالممونوينوكينيوتروفيلج.

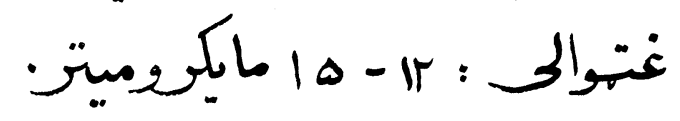

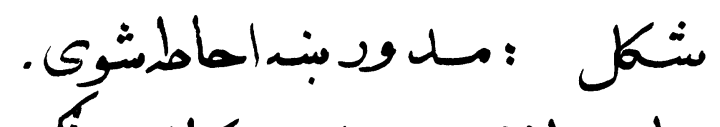

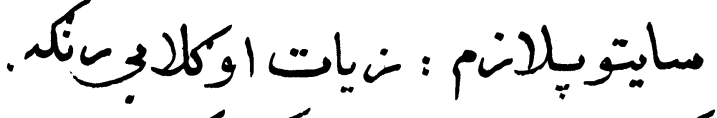

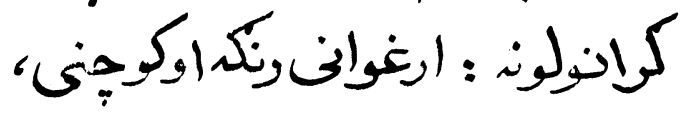

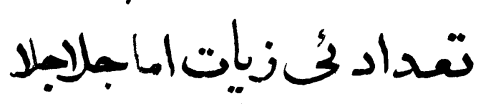

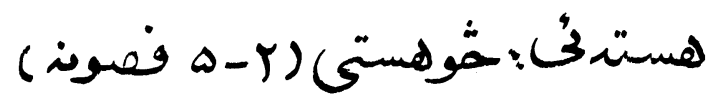

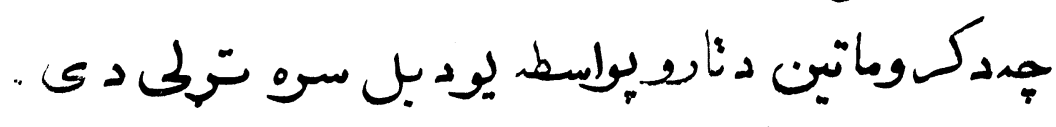

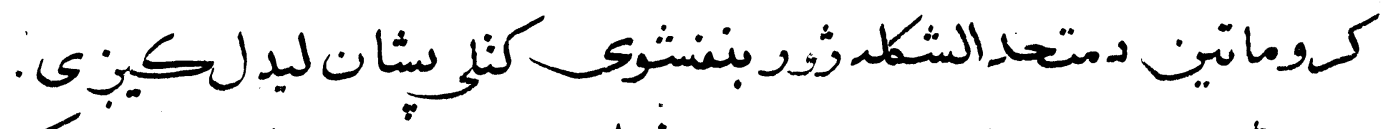

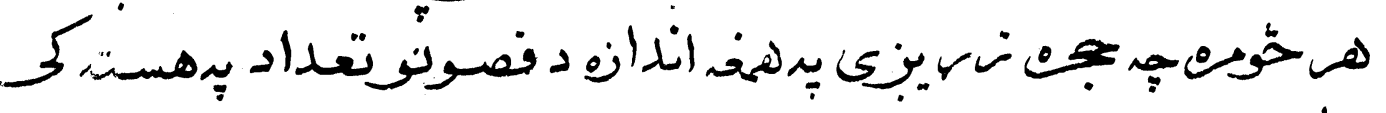

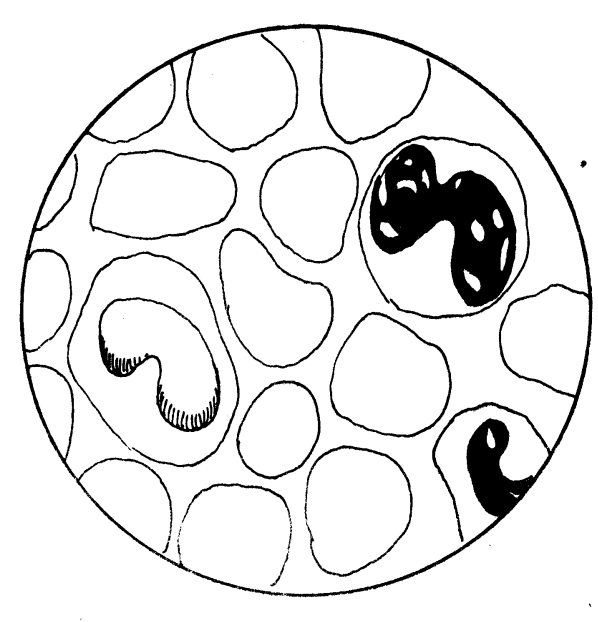

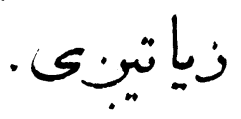

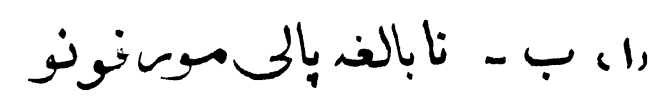

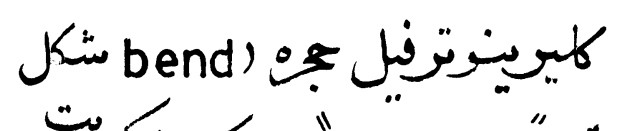

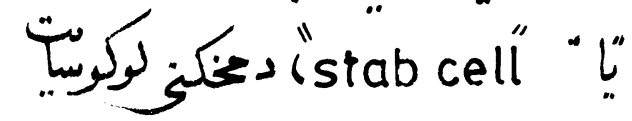

rrv 


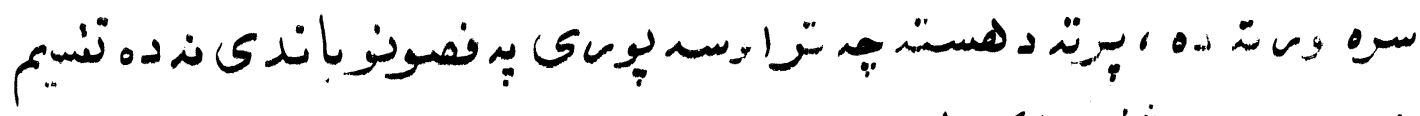

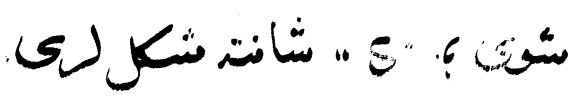

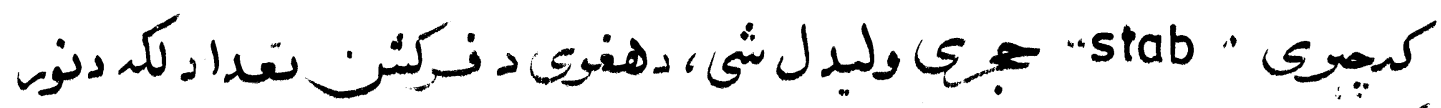

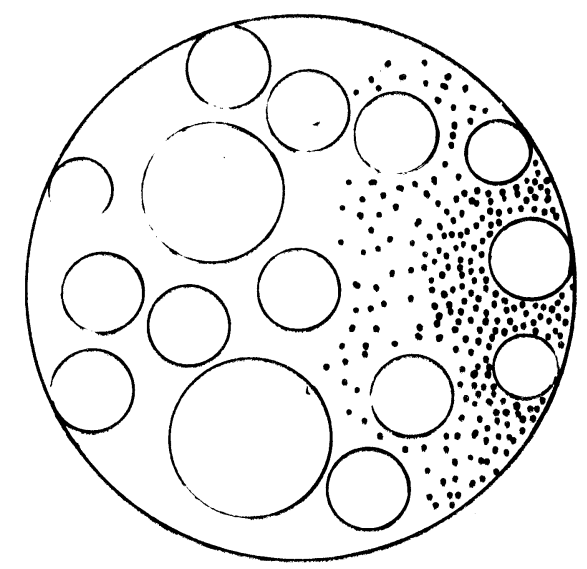

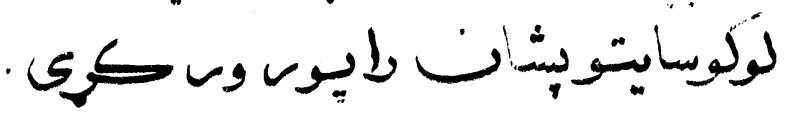

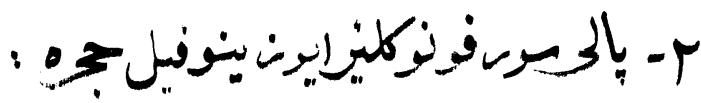

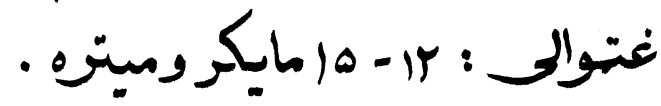

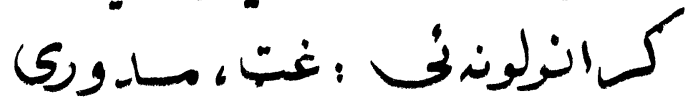

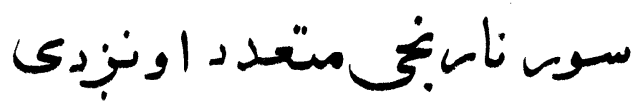

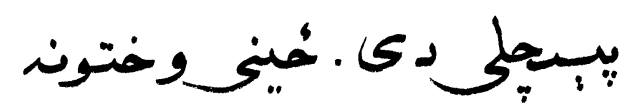

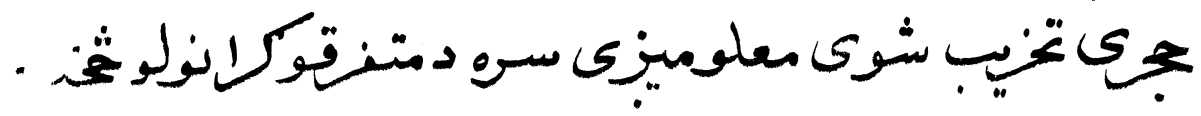

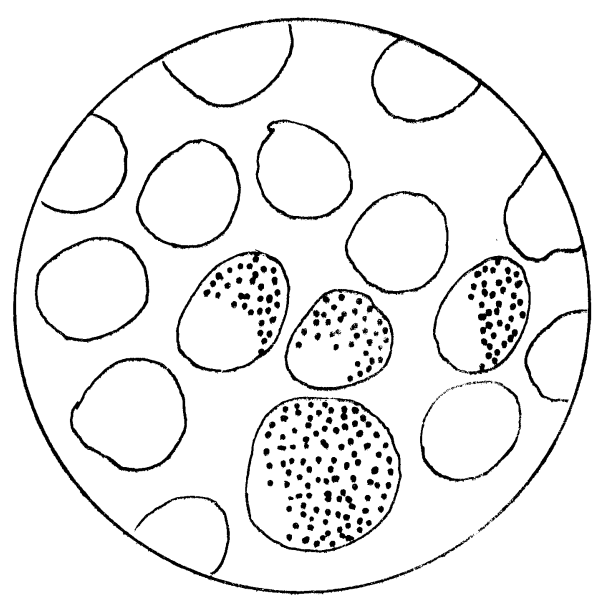

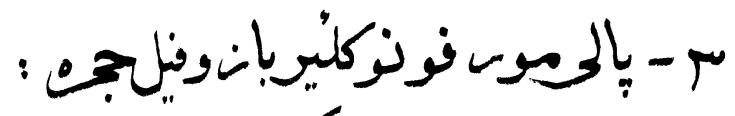

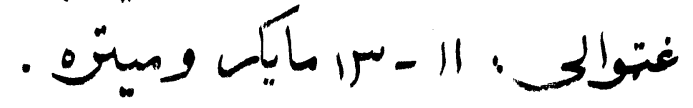

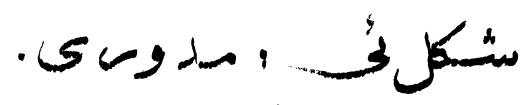

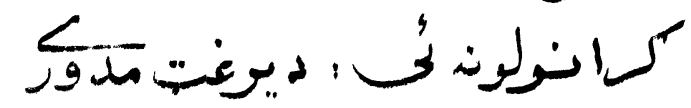

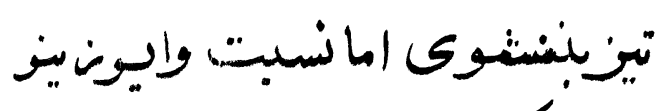

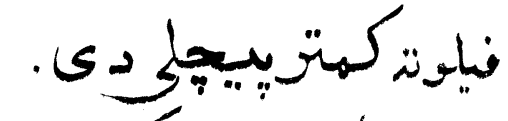

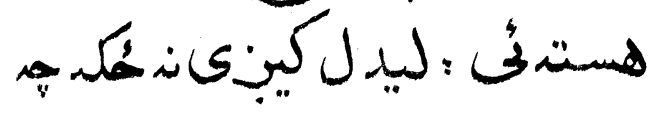




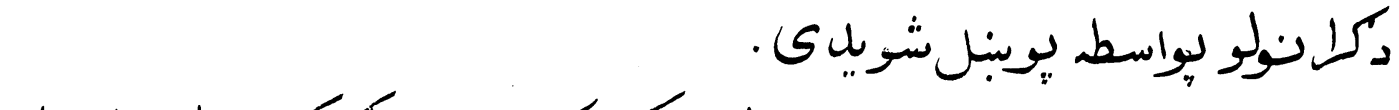

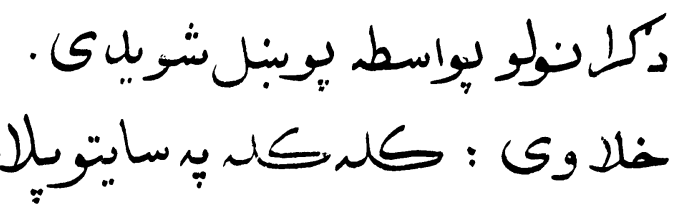

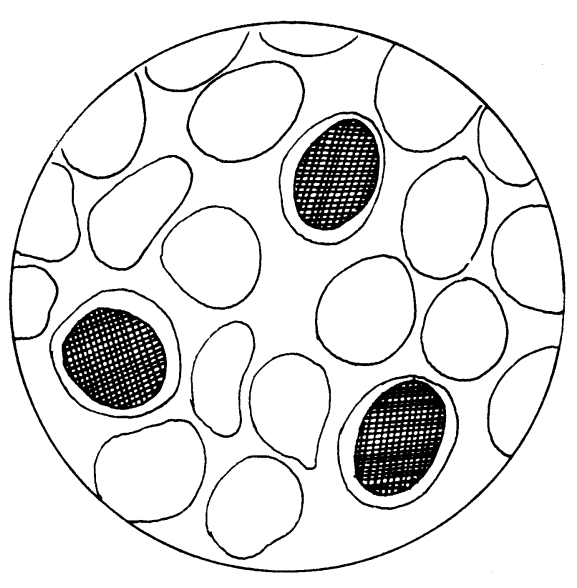
كينى : كلاء

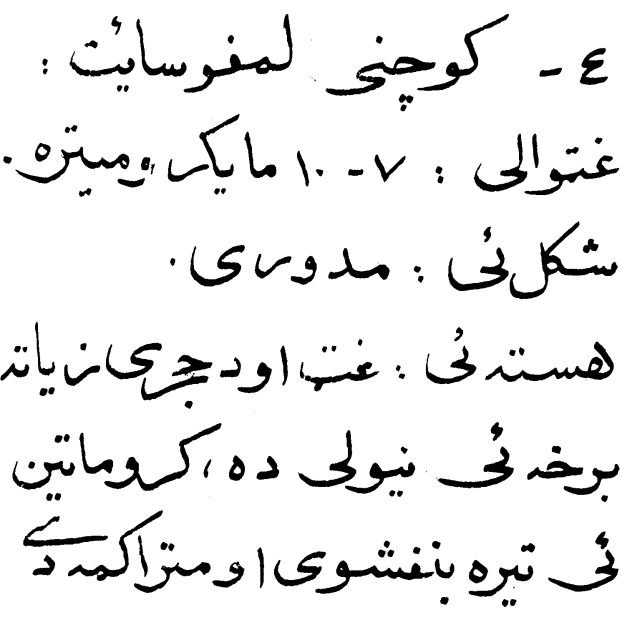

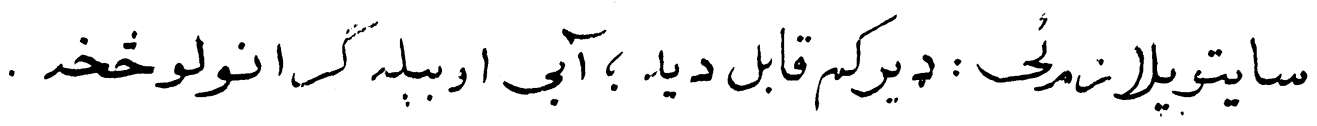
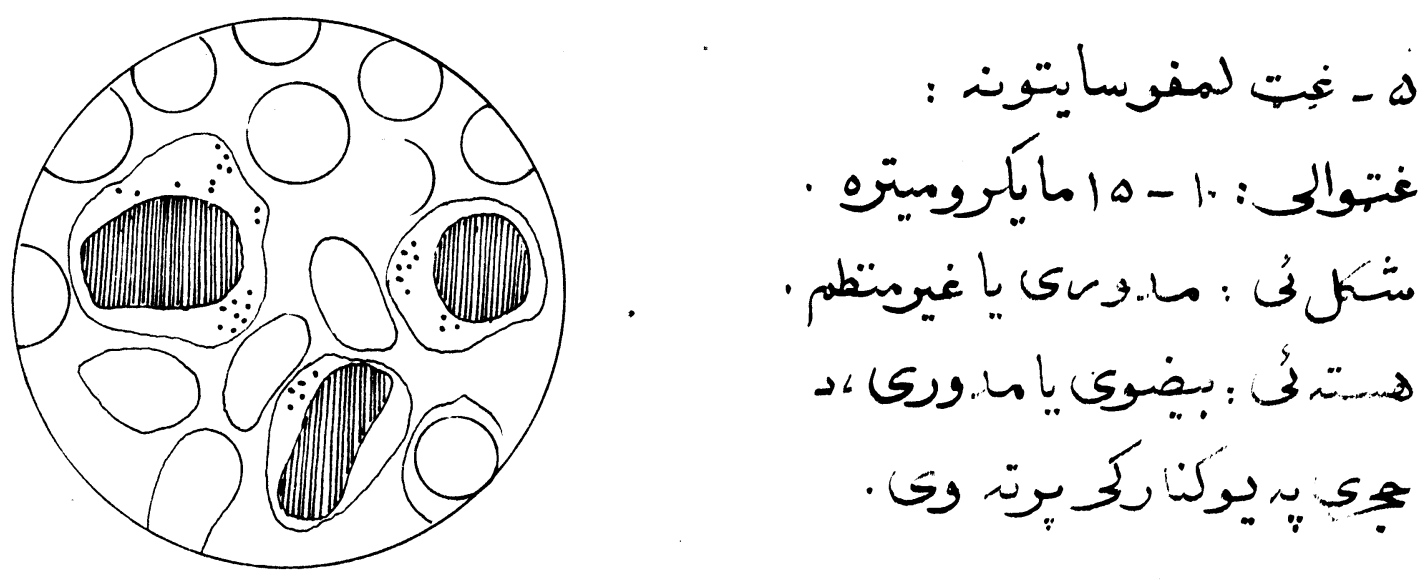


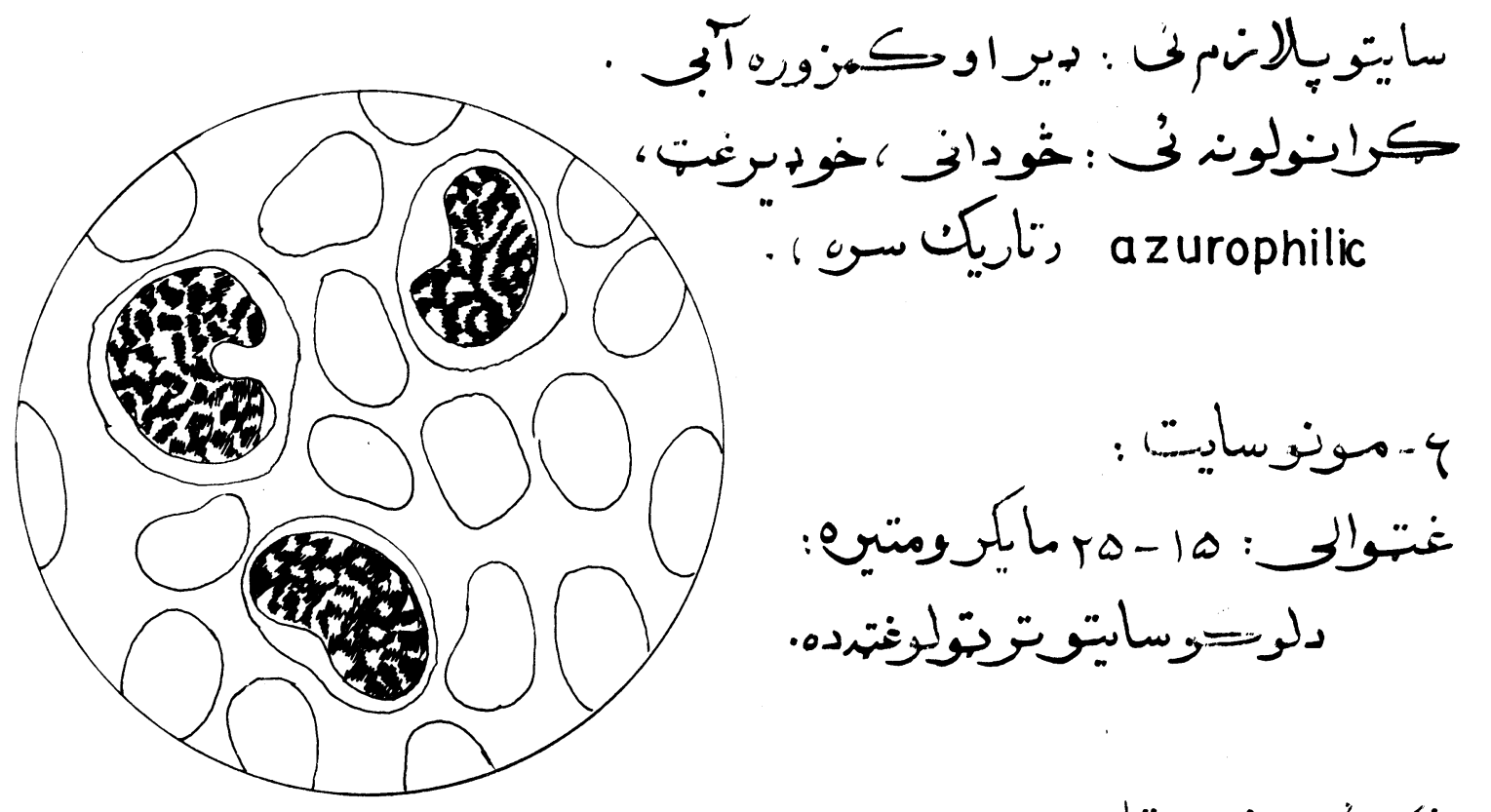

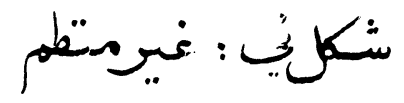

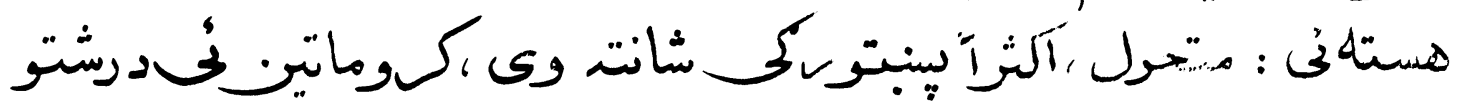

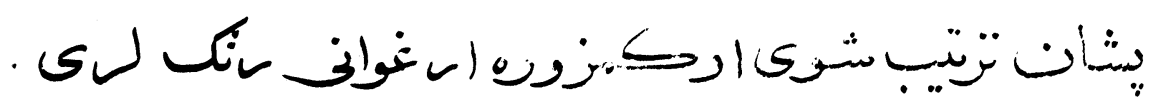

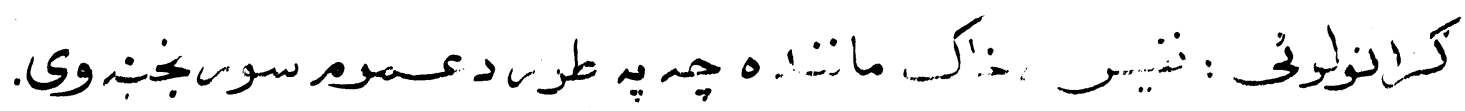

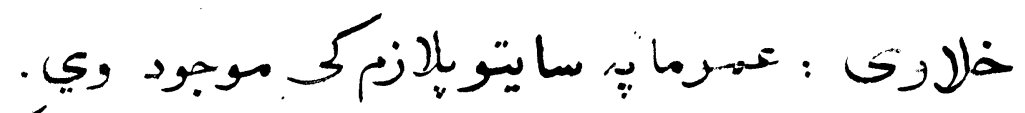

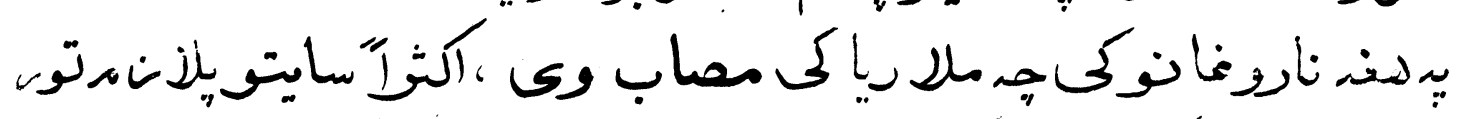

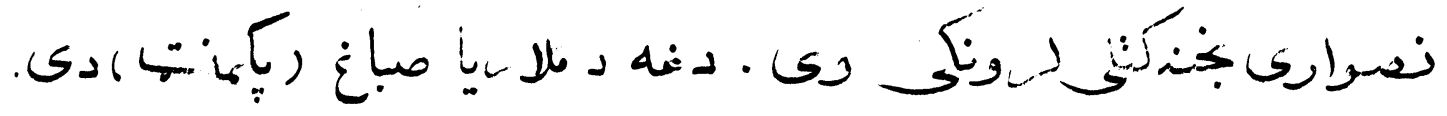




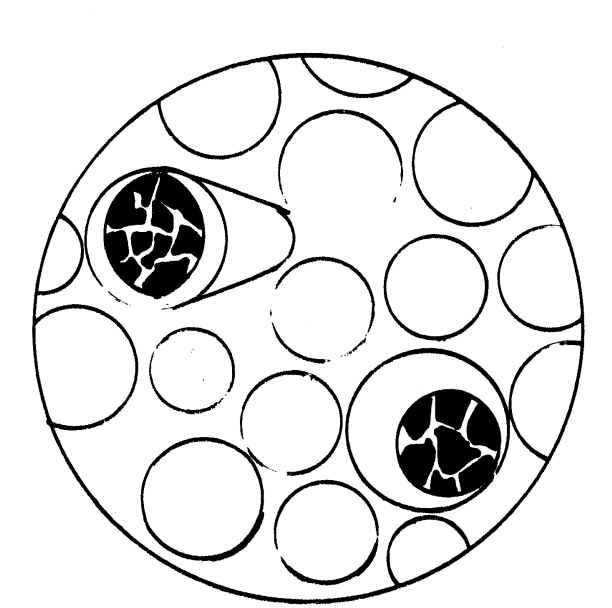

نادسياغبلمبحجةجات:

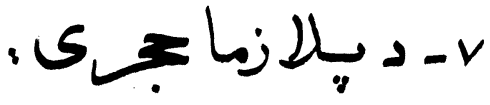

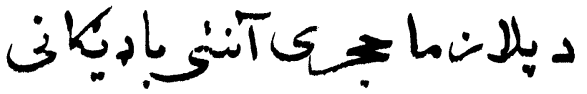

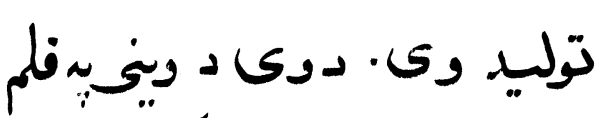

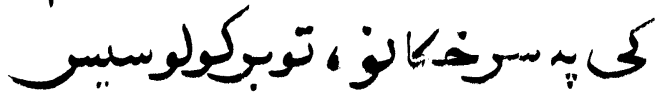

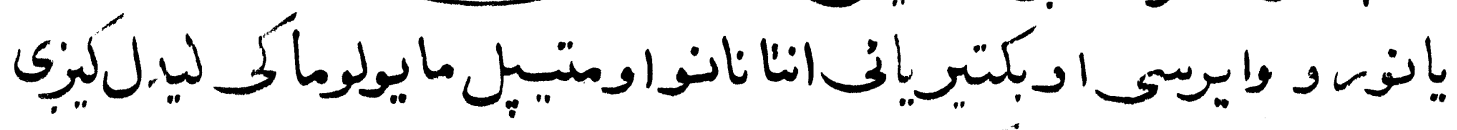

غترالهى :

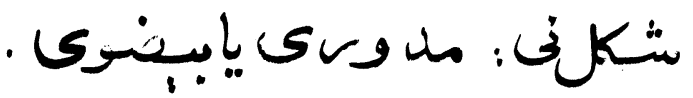

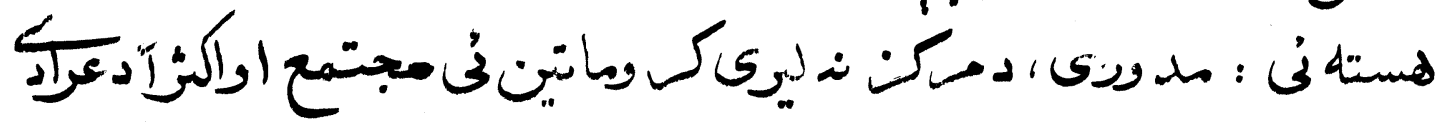

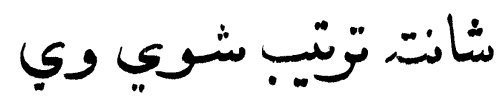

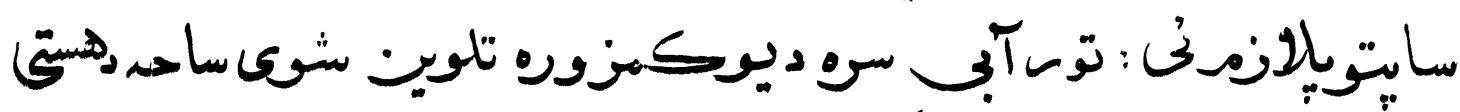

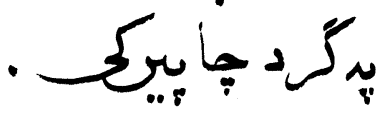

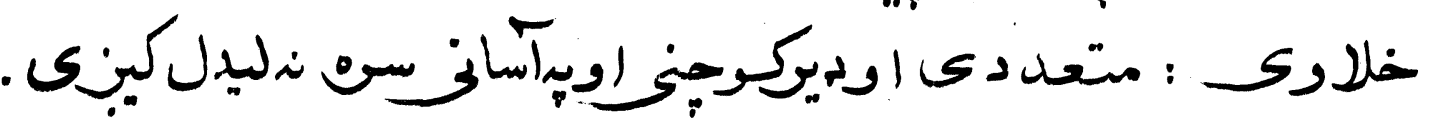

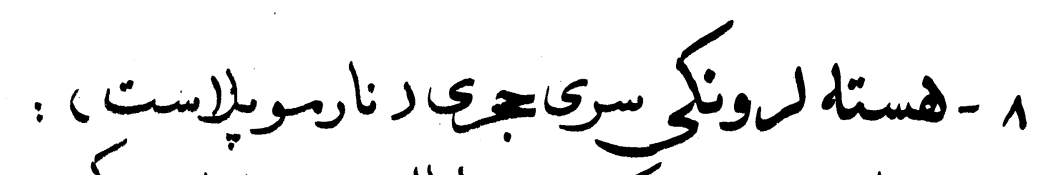

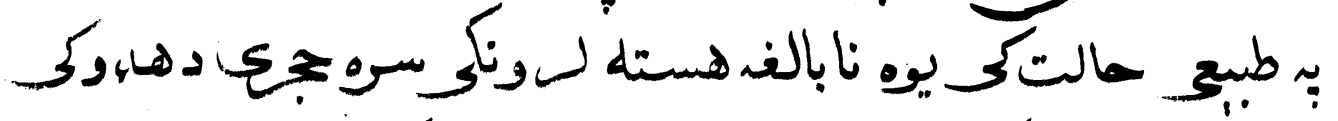

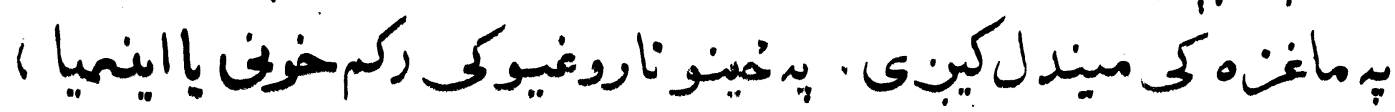

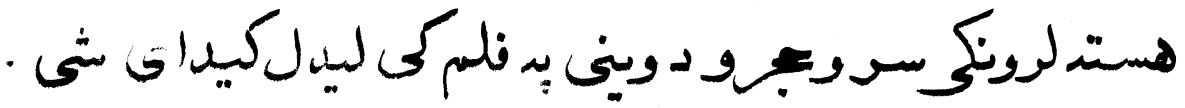

rri 


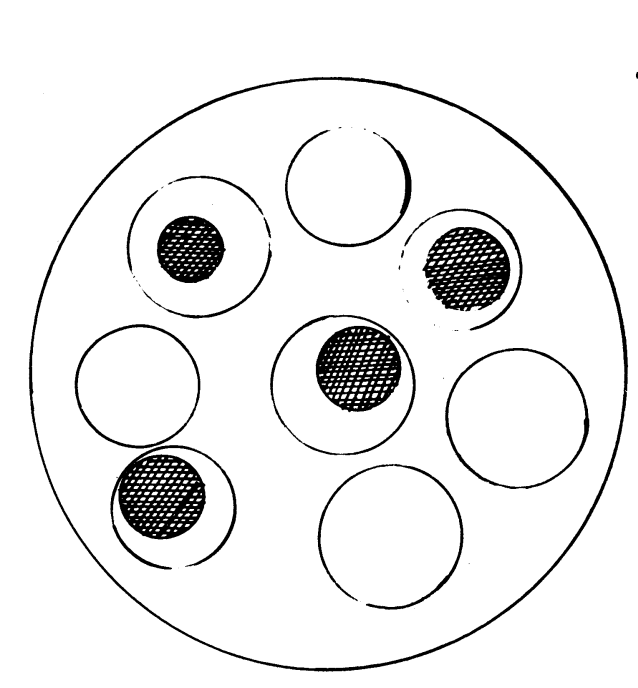

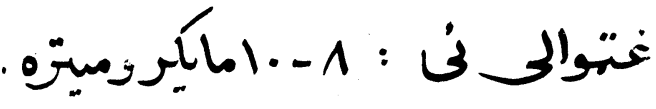

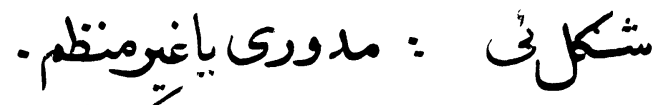

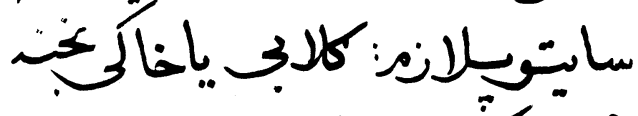

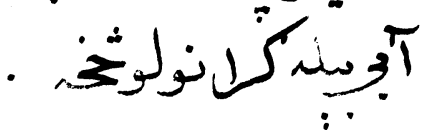

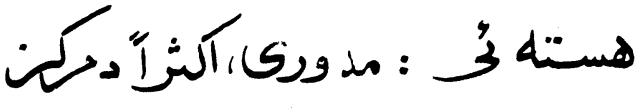

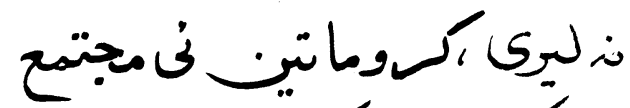

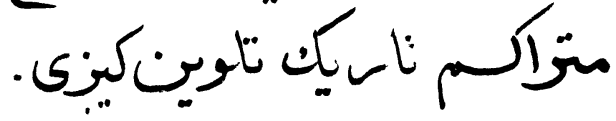

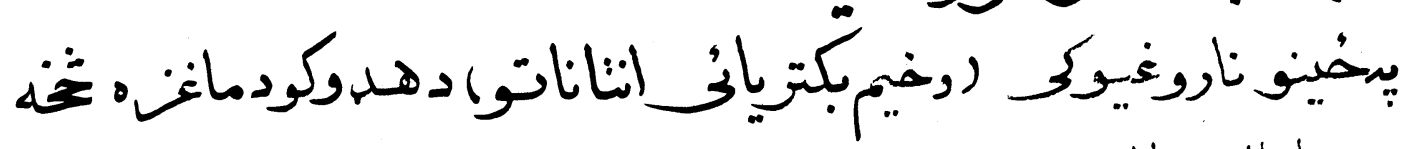
q نابالغنكاينولوسايت .

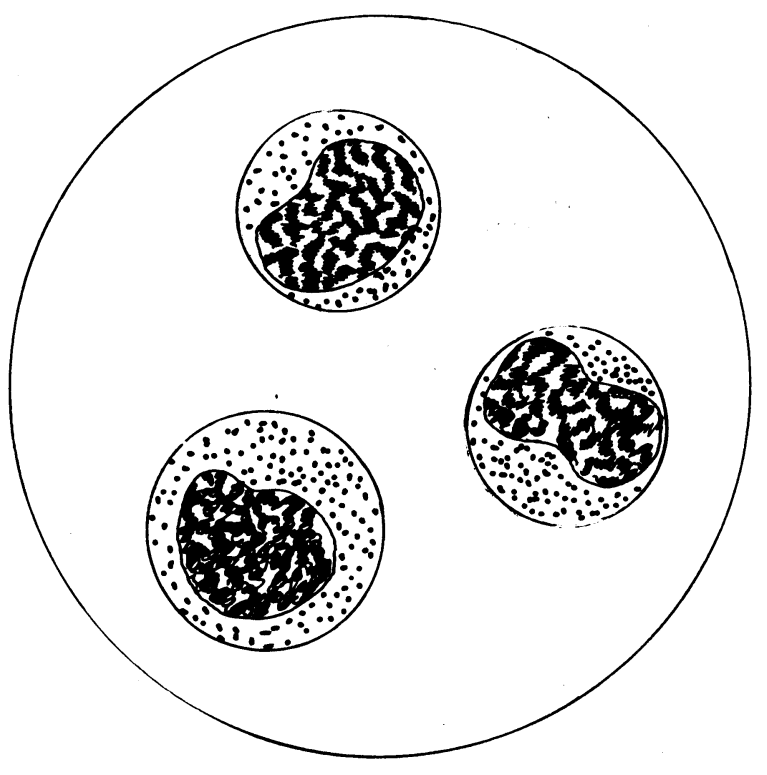

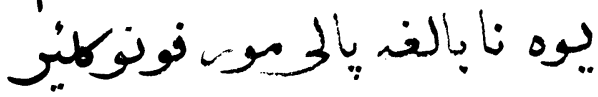
حسي إنولوسايت وينى دونان

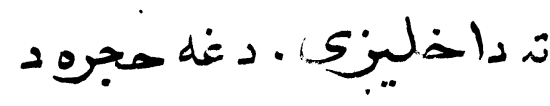

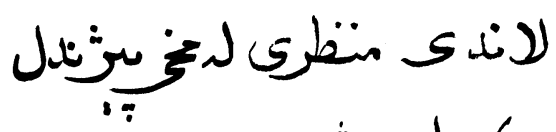
كيداى شتح

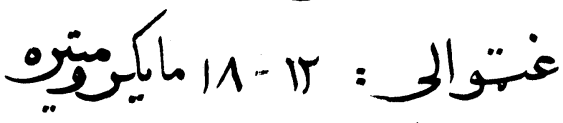

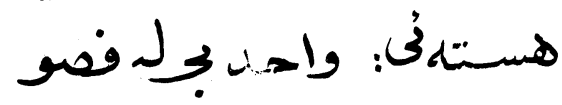

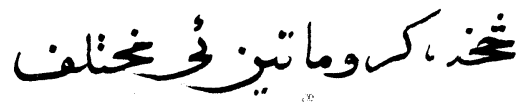




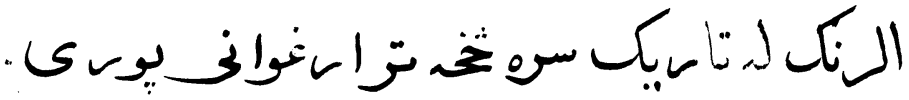

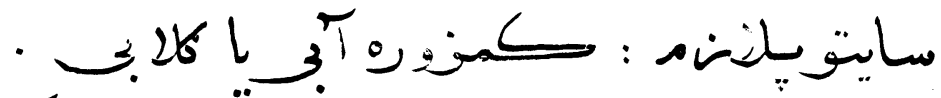

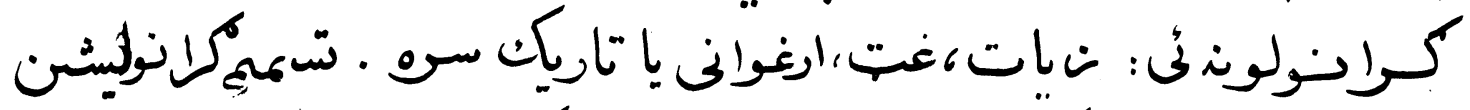

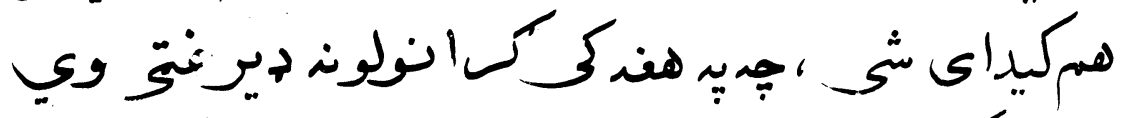

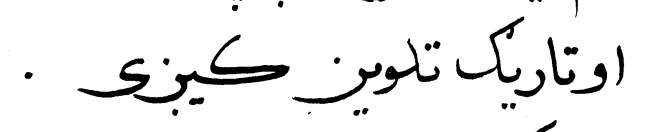

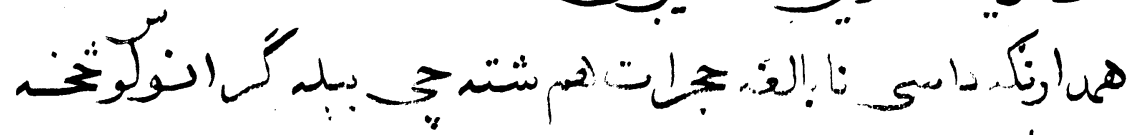

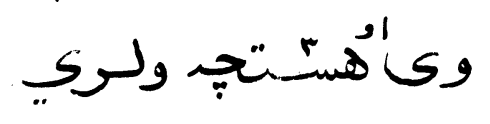

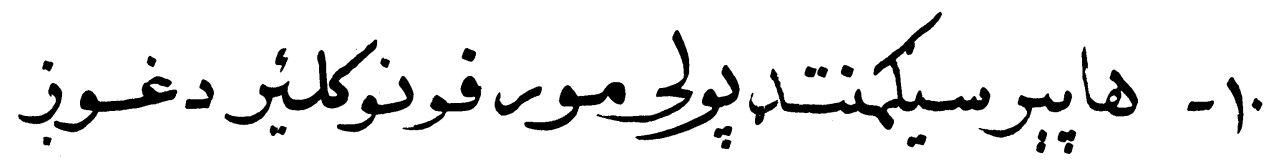
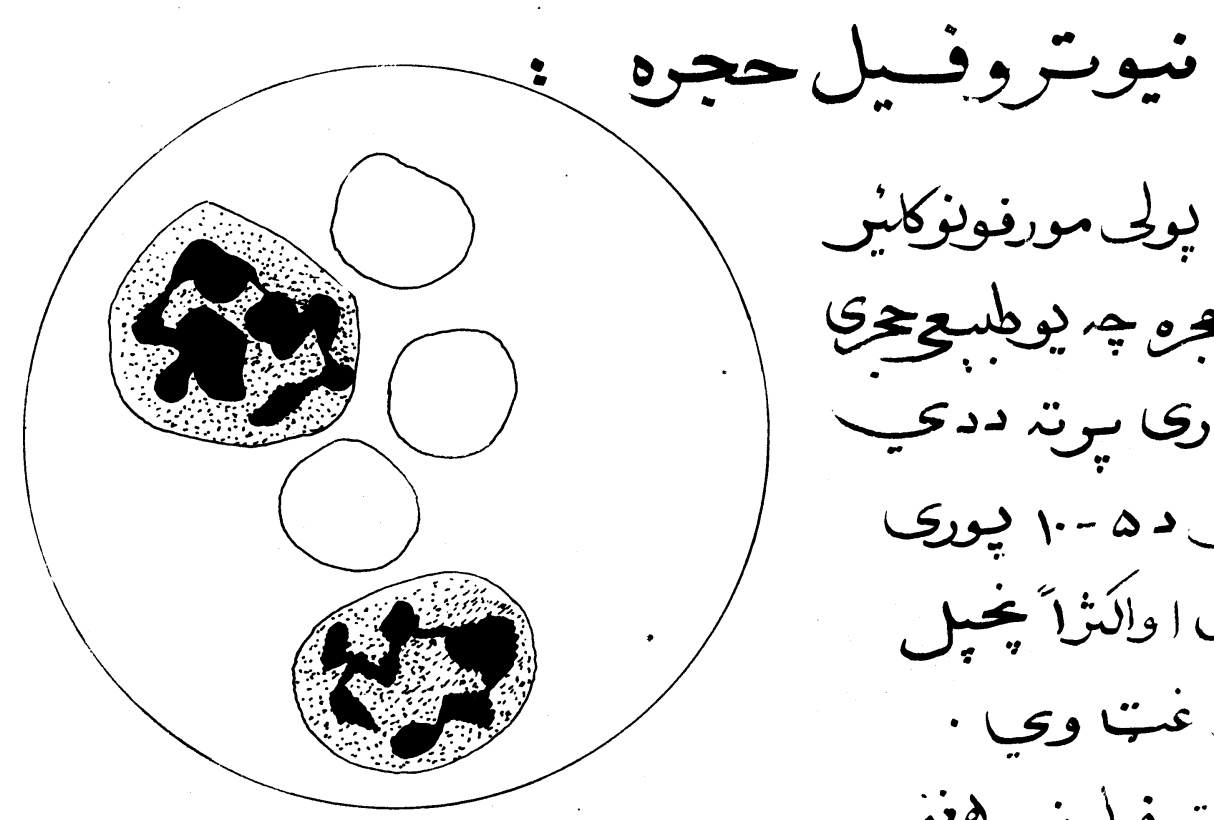

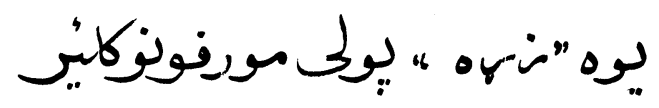

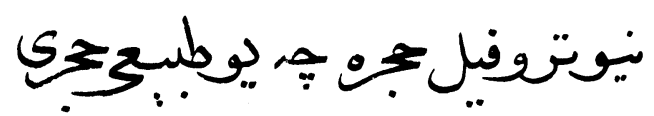

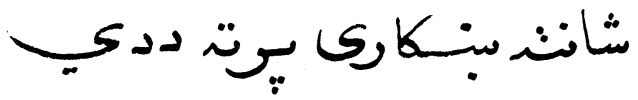

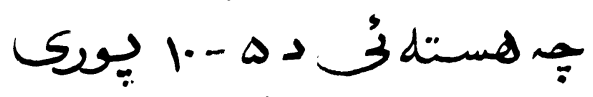

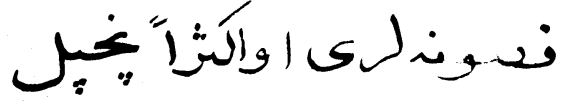

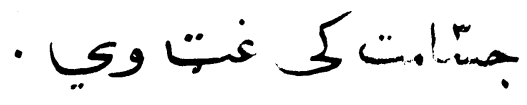

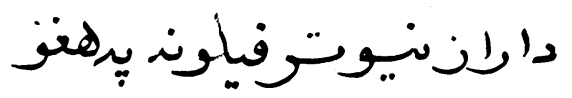

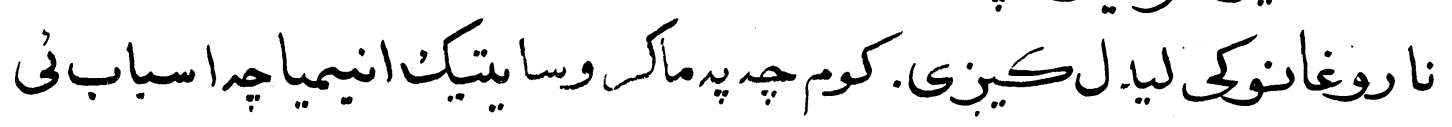


دفاليكساسيديا واينامين 12 12،تدات وىى.

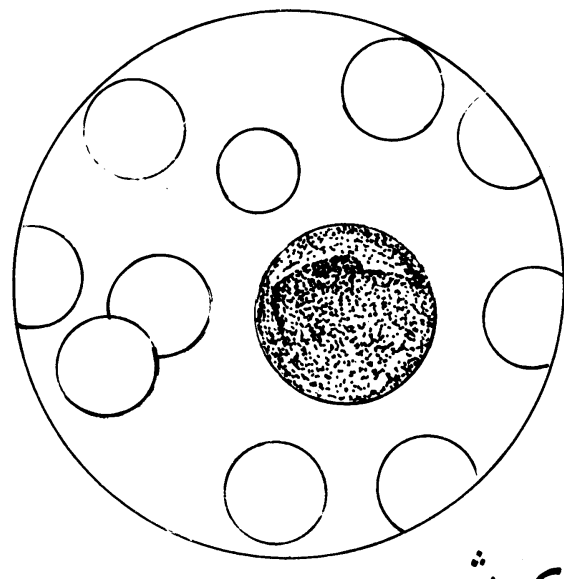

11 - غنووصفيفوسيايت :

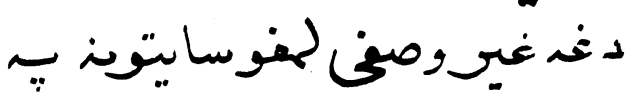

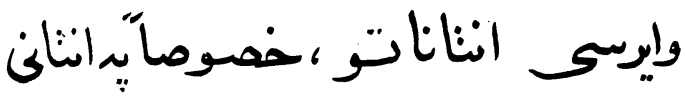

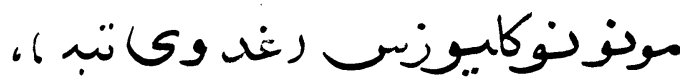
توره تخخ: اوسرخيكانوكى ليدل

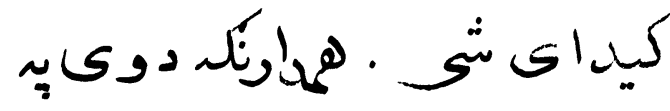

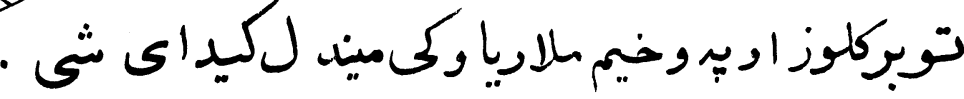

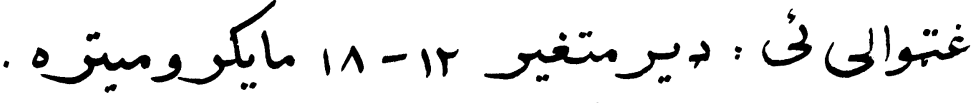

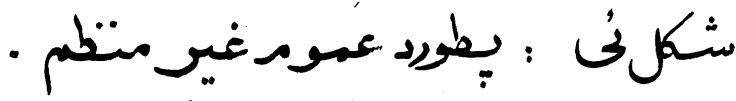

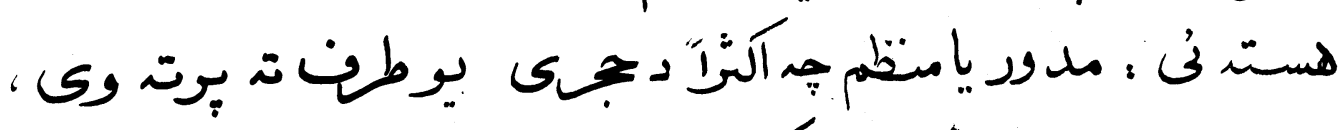

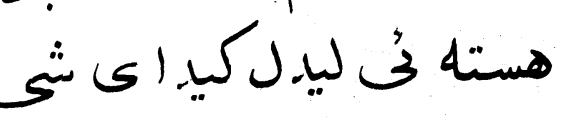

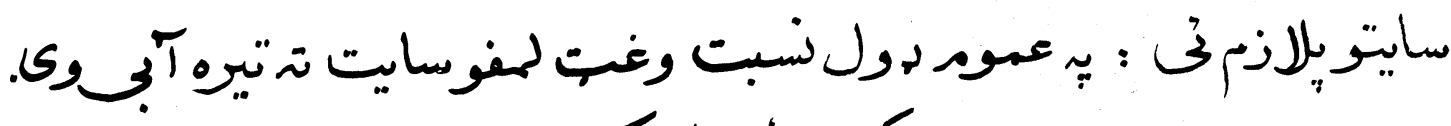

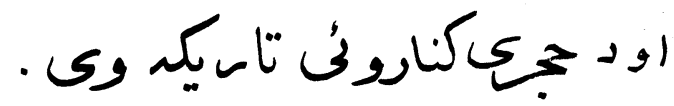

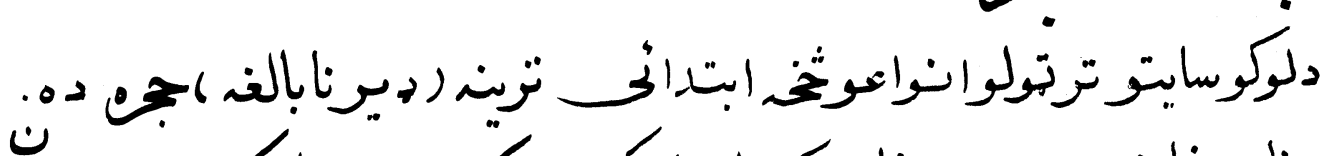

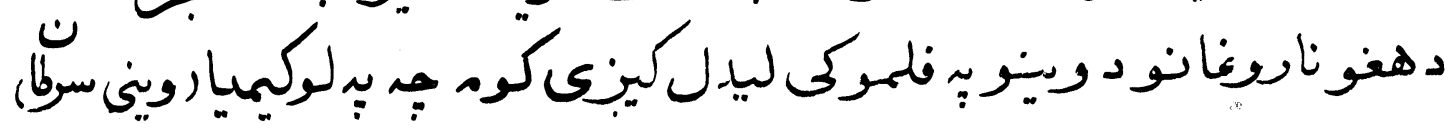




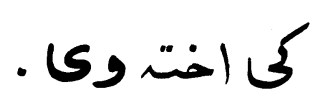

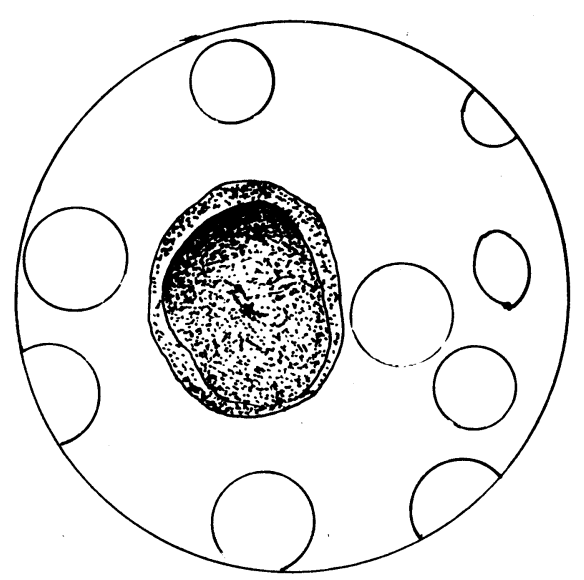

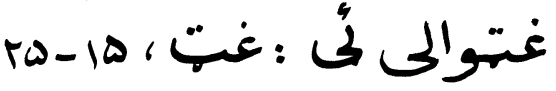

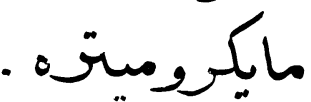

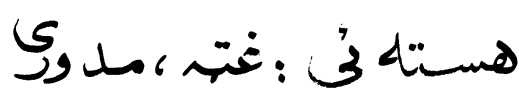
كمزورهارغواتن، تل

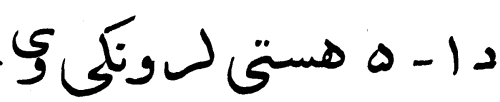

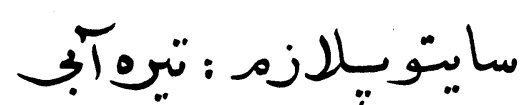

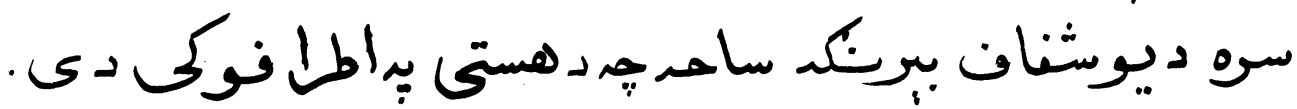

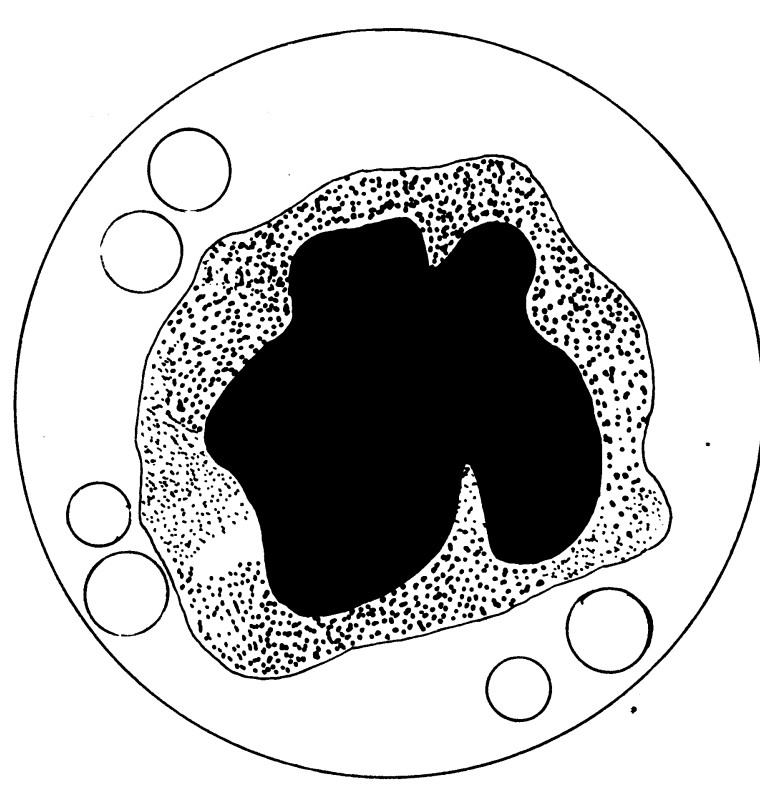

مر - ميكاكاريوسايت ، دمنيحاتوربيتيتليتس،

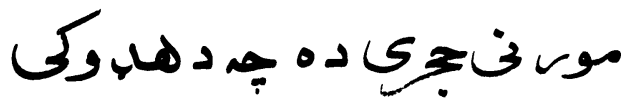

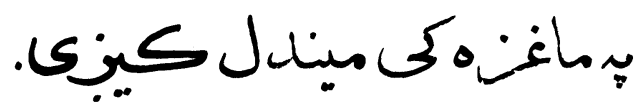

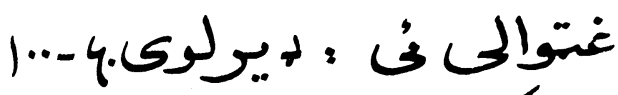

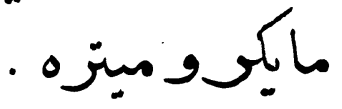

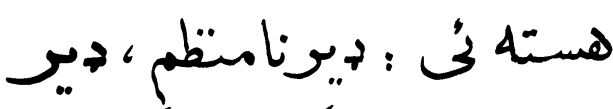

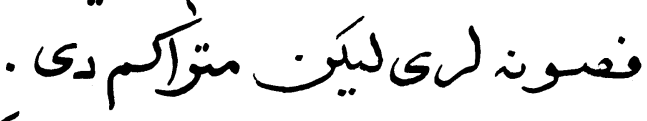

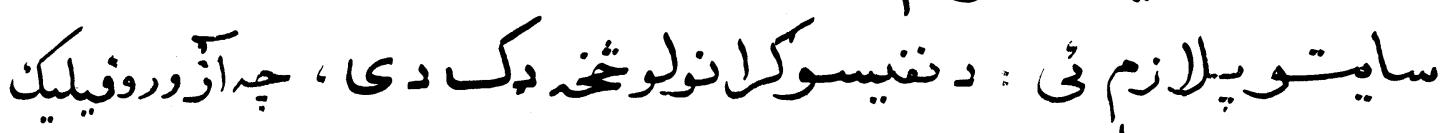
وى اوصفيحاتوستون دن

rrs 


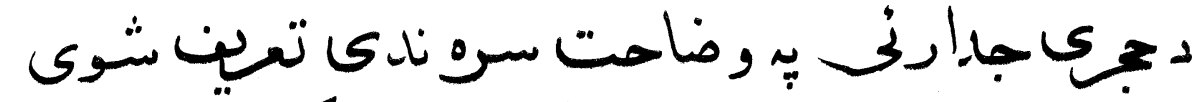

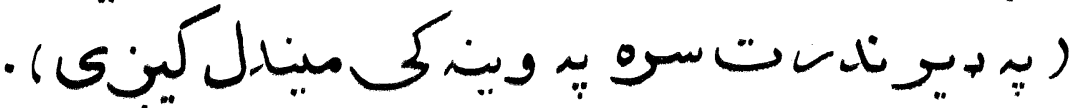

ij.

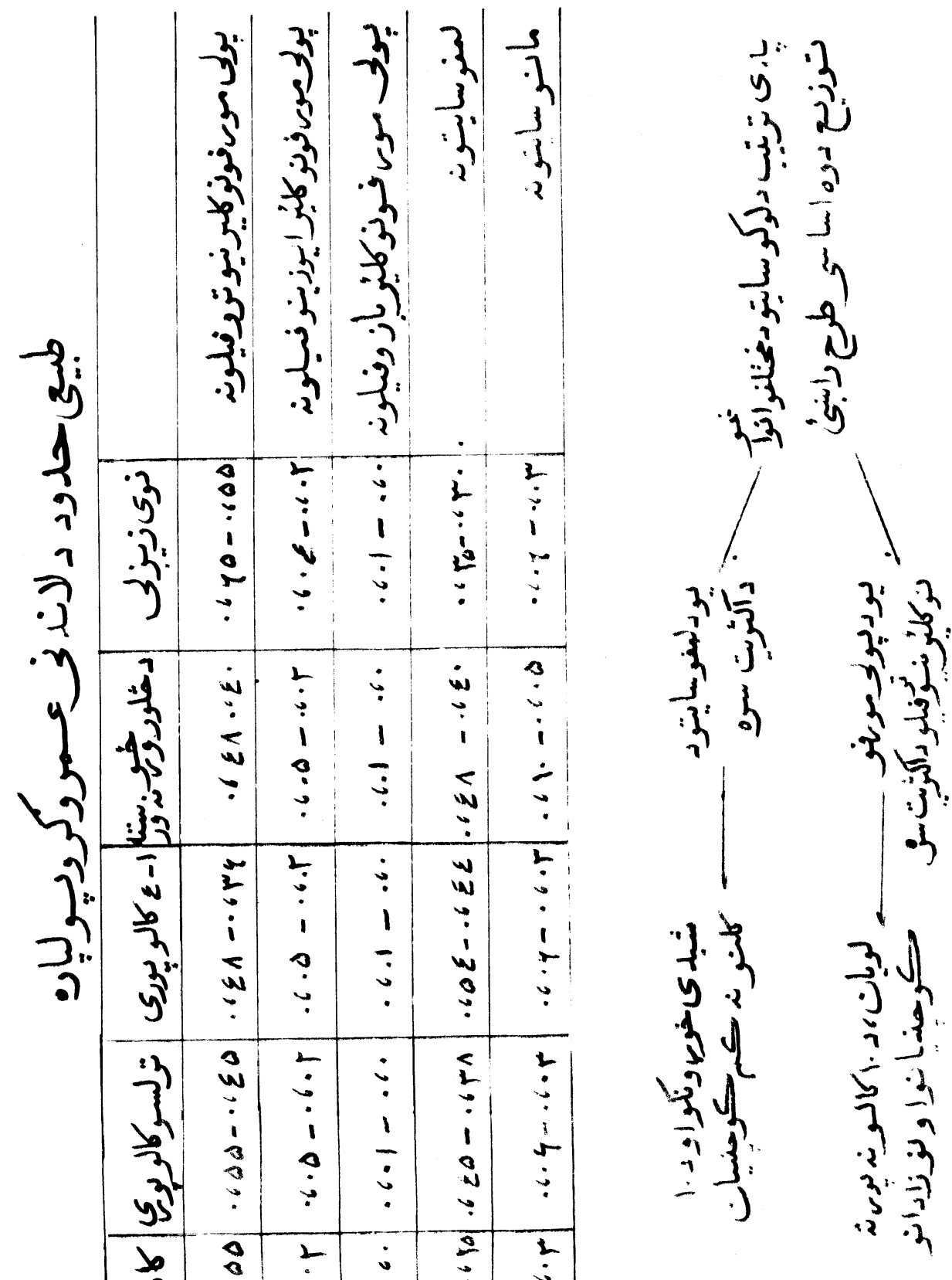

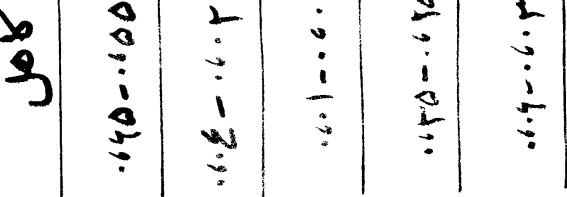

rry 


\section{غيوطبححالات :}

رالن) نيوترفيليا ، دنيتزفيلويونبتى زياتوالى (د ه4 ، ، نيورت )

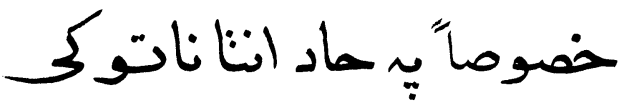

رب، ايوزينوفيليا : دايوزينو فيلويونسبت زياتوالحـ دهـهـ، نـ

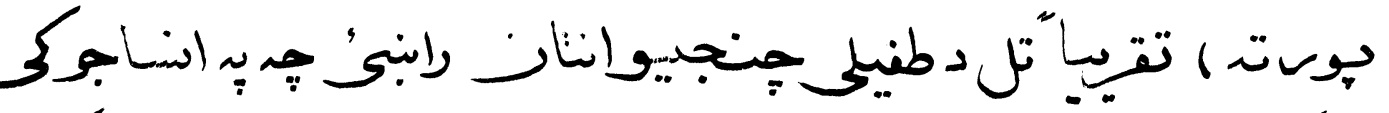

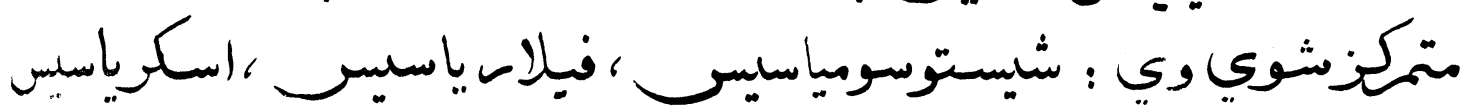

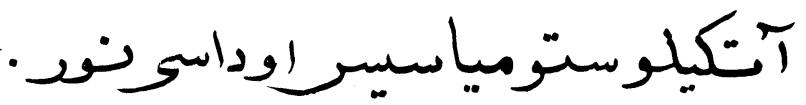

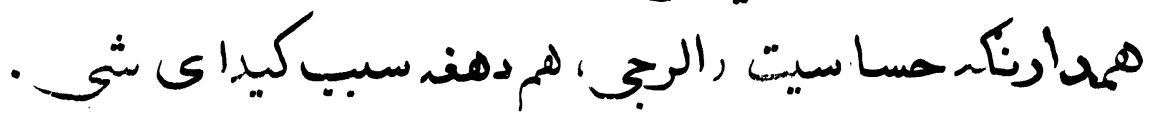

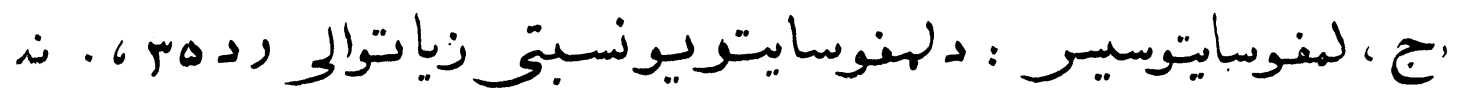

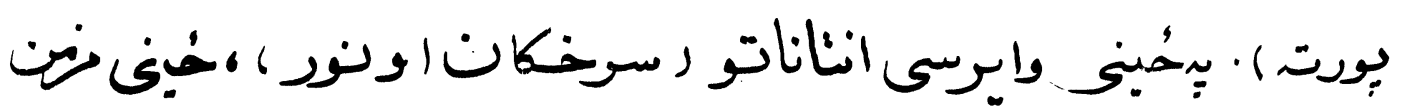

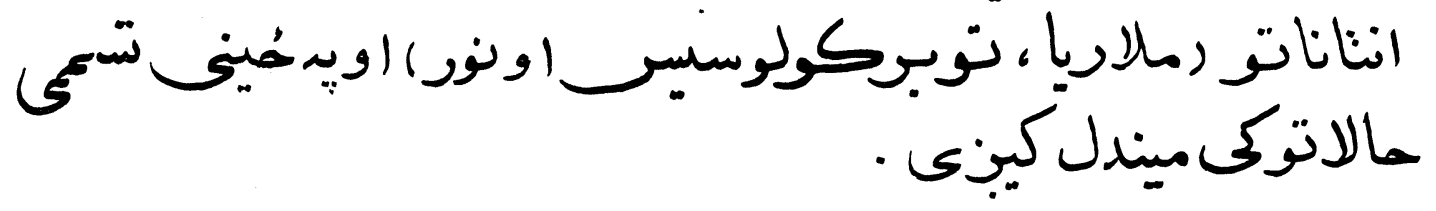

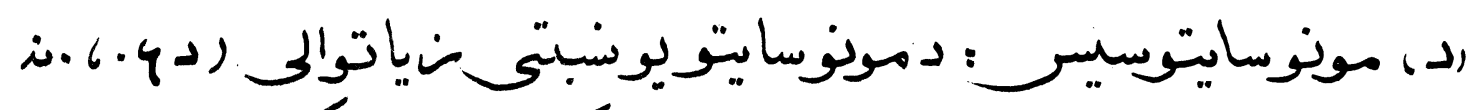

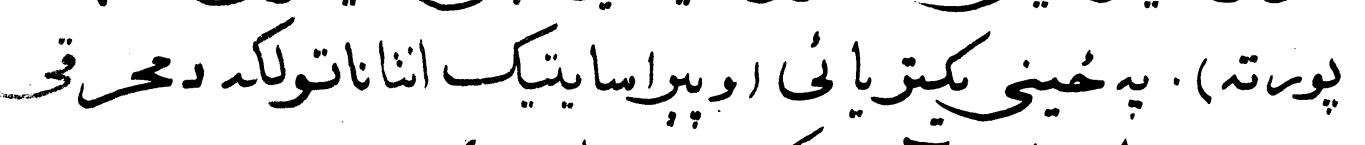

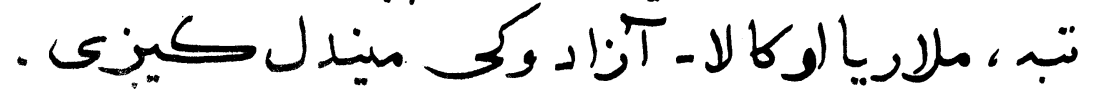




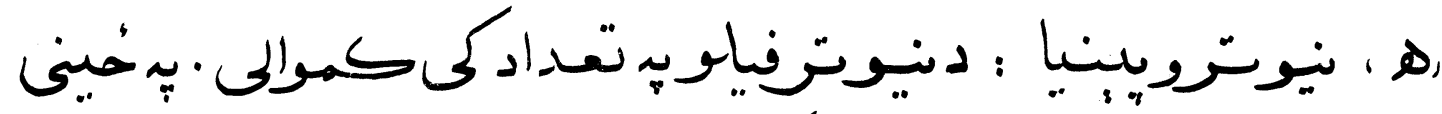

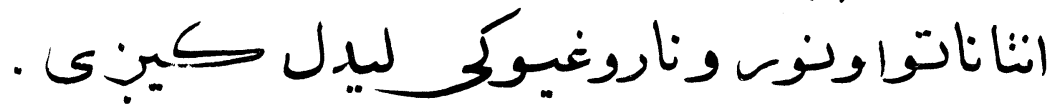

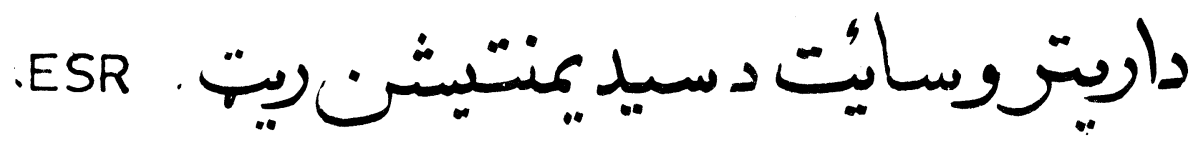
( د مسروكريواتِوديّرب سرعت)

هونسيت:

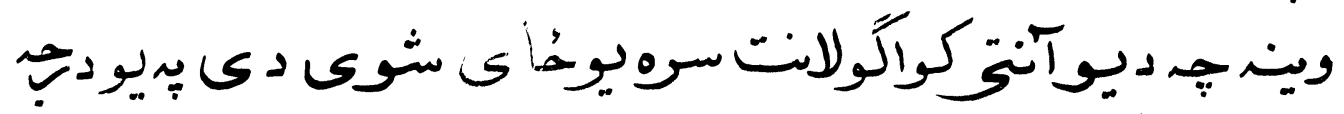

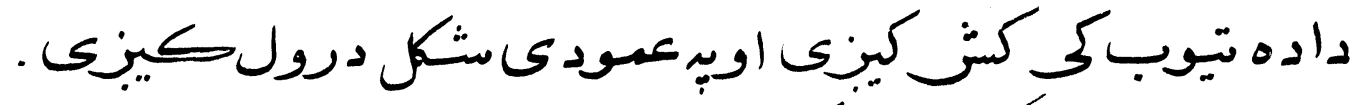

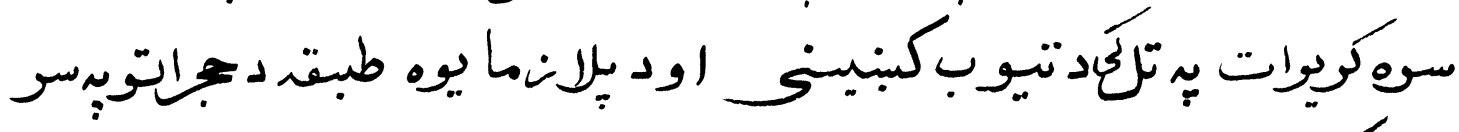

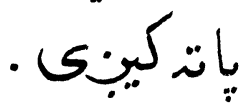

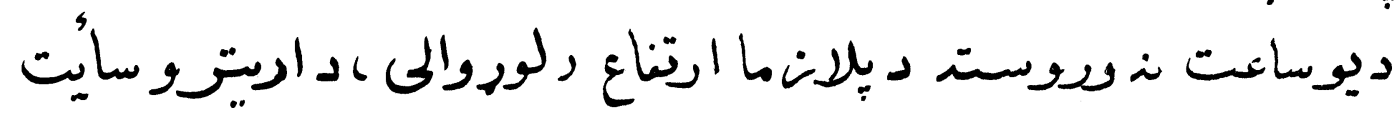

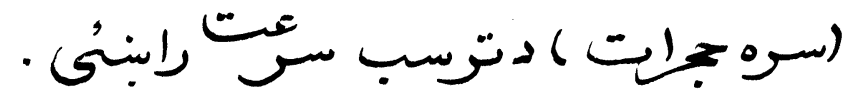

وسايل :

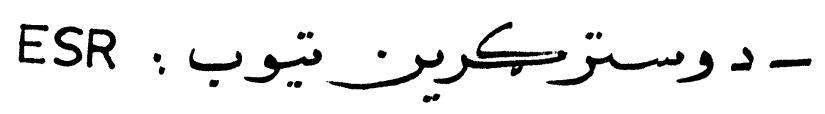

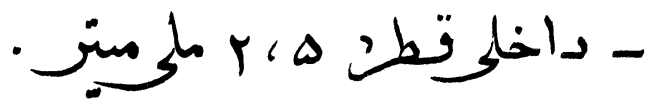

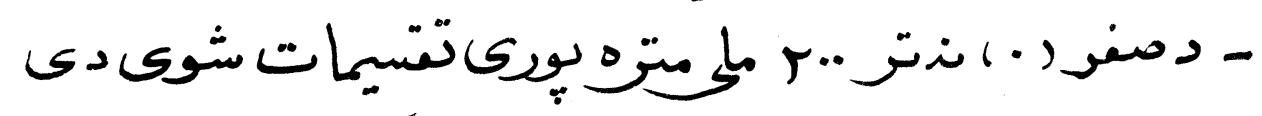

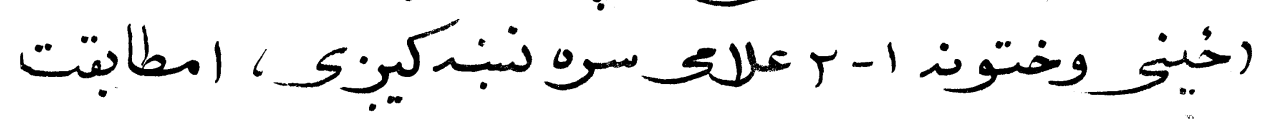




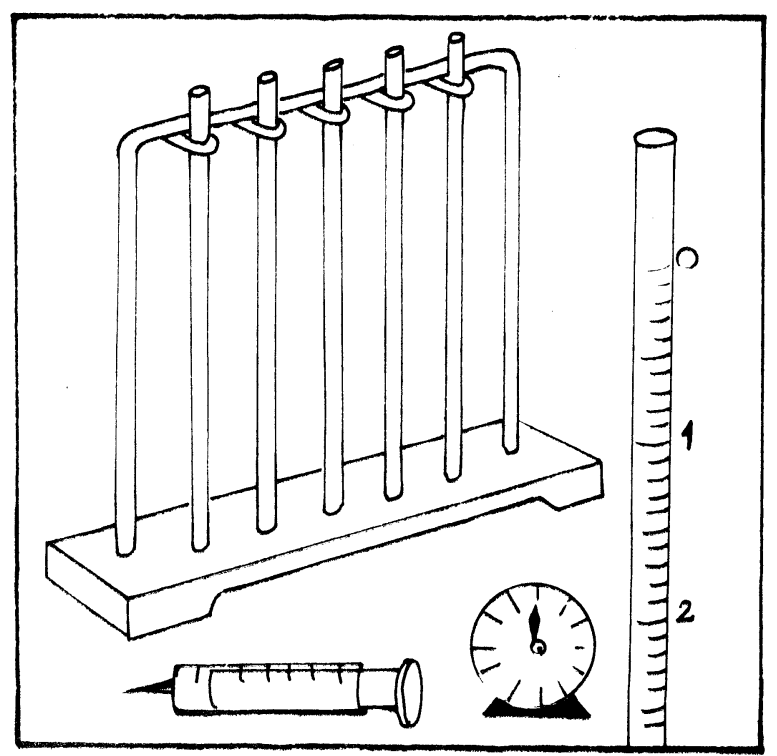

كوى اود ·اسوت اوץ

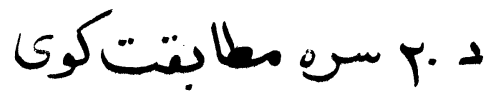
اوداستحزور 6.

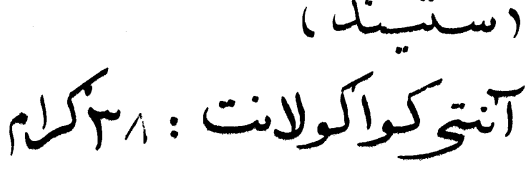

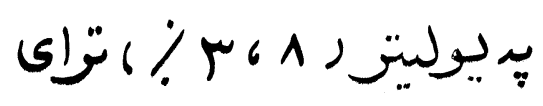

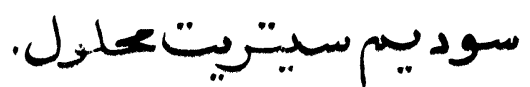

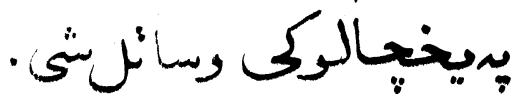
- ينغ ملإليته سرئ. - تايمر -

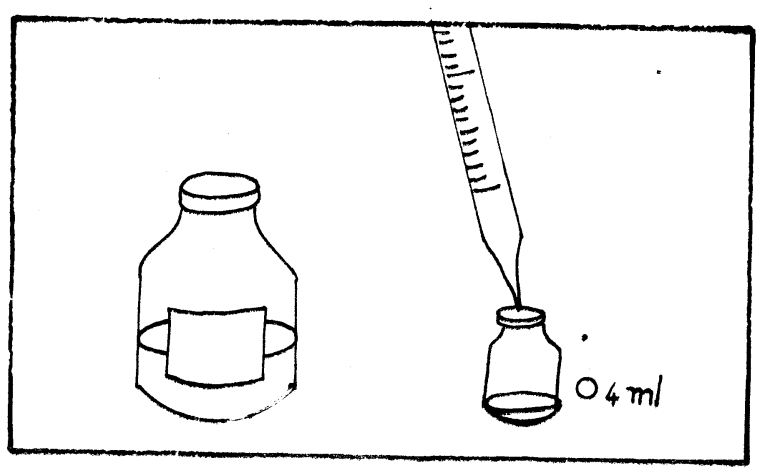

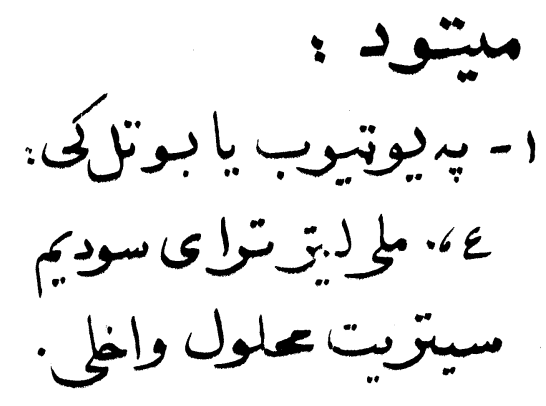




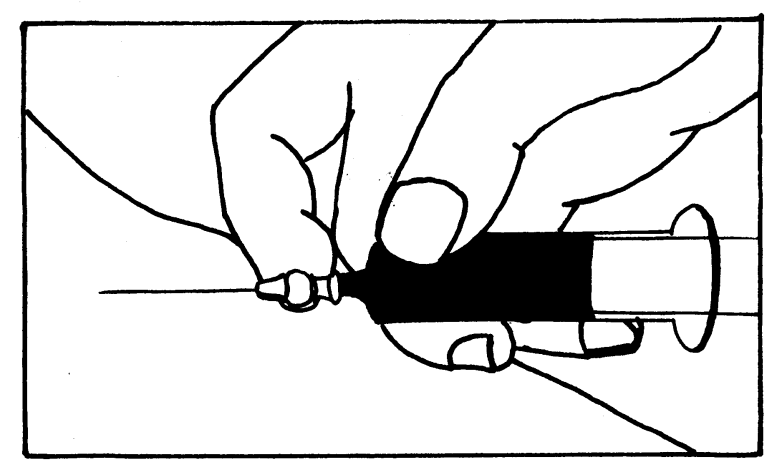

:

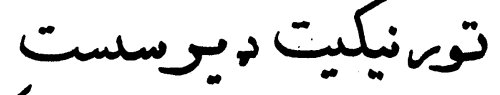

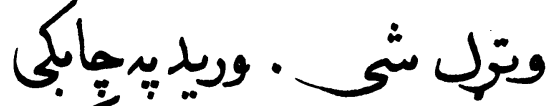

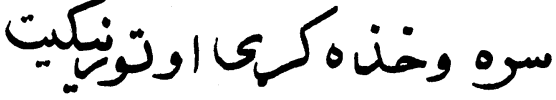
- خومئك $: 5$

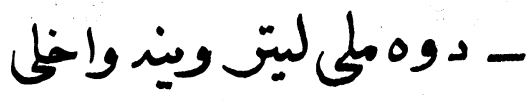

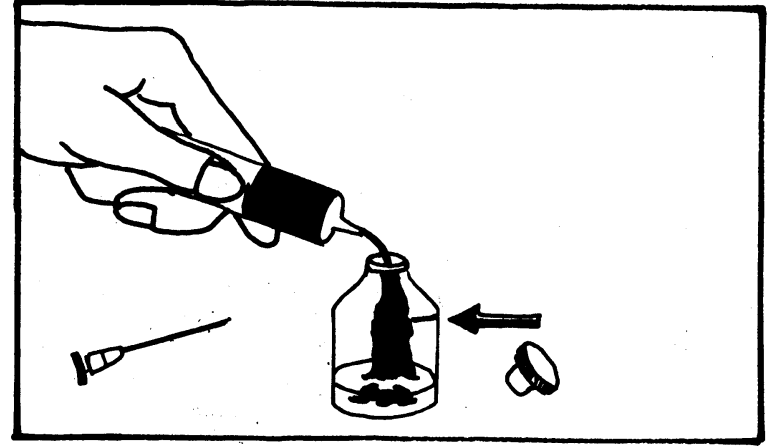

س - ستن دسونَّ ن وكانك

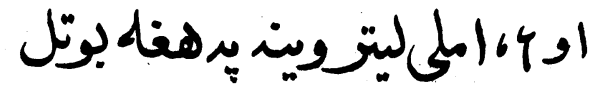
كى

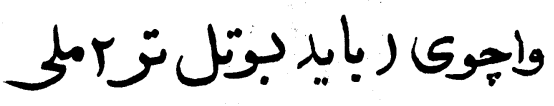
لستر $\cdot(s)$

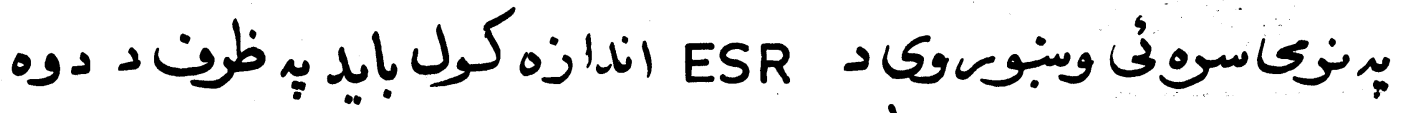

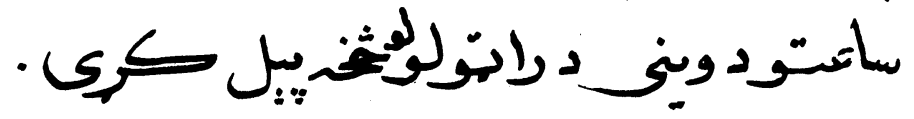

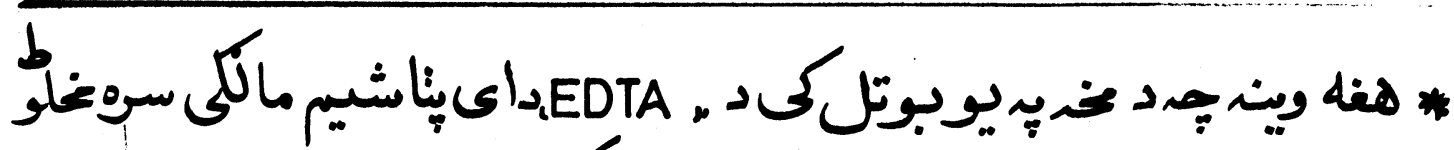

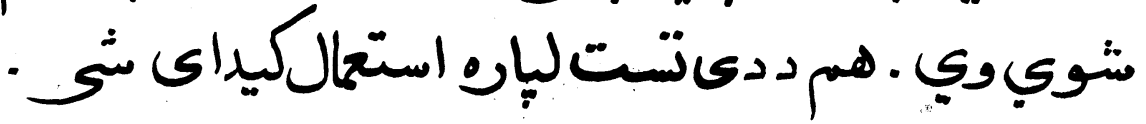
re. 


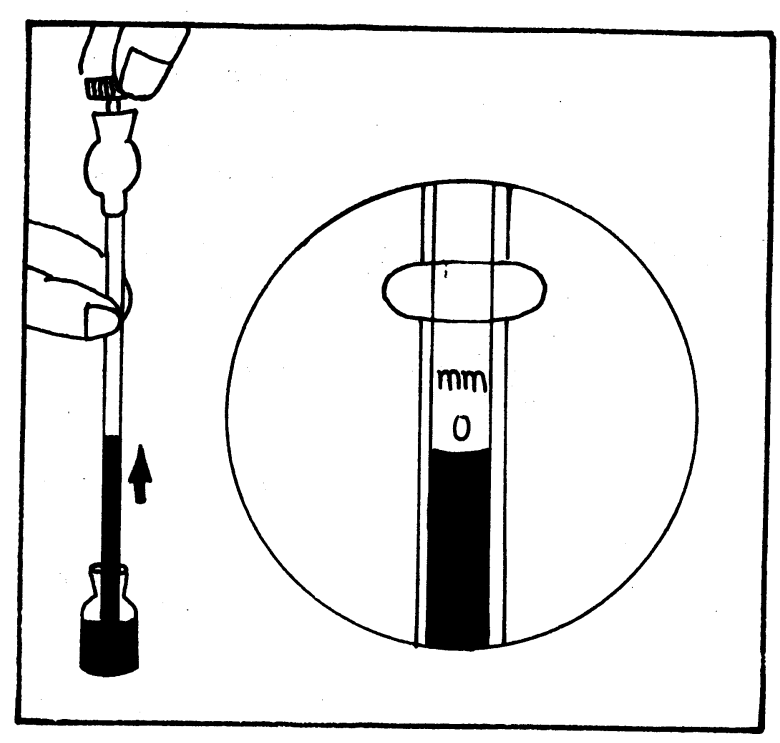

$$
\begin{aligned}
& \text { ع-سيتريت للونكى ويند د } \\
& \text { وستركسين يَتيوي } \\
& \text { رادامكان بِصوست ديوتيو }
\end{aligned}
$$

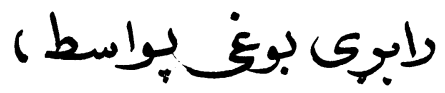

ه-تيوب دوستككين

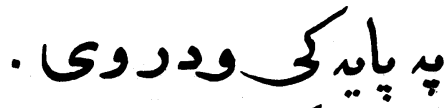
دقت وكيى بريتيوب

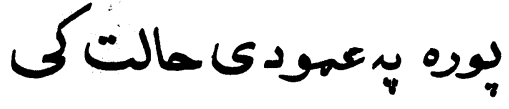

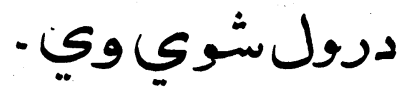
بند دقت وكيحاجيه تيوبكى هوانىكوبين وى . اوهم دنت وكري

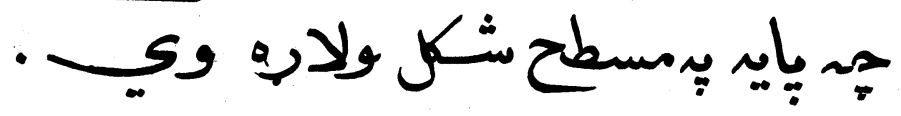




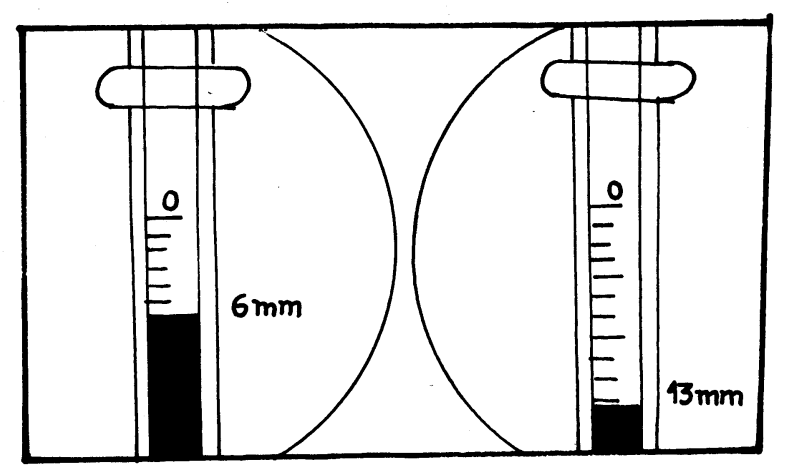

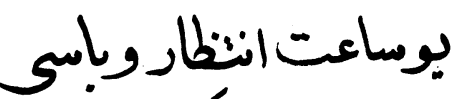

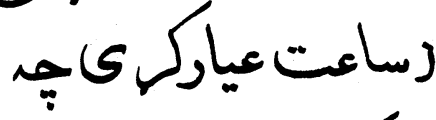
زيكت ووهح )، وروسته

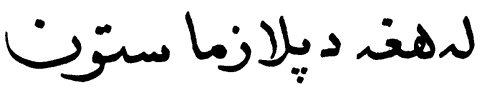

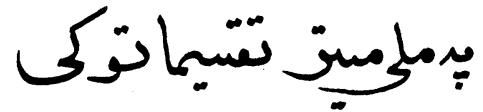
جمد صنز , . كا رديتوب

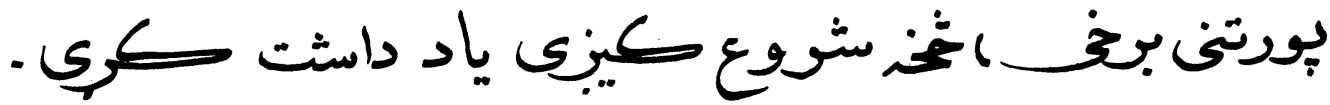

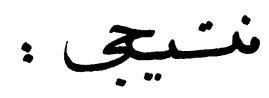

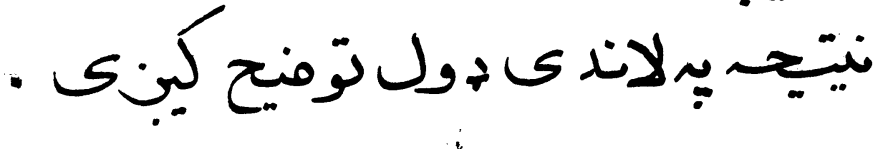
ESR -...- $\mathrm{mm} / \mathrm{h}$

$110 \mathrm{~mm} / \mathrm{h}$ طبيح حدودنى : $314 \mathrm{~mm} / \mathrm{h}$ : ناريتن :نبتى :

: ESR

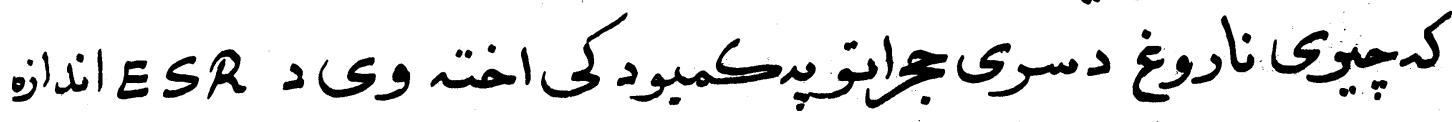
.

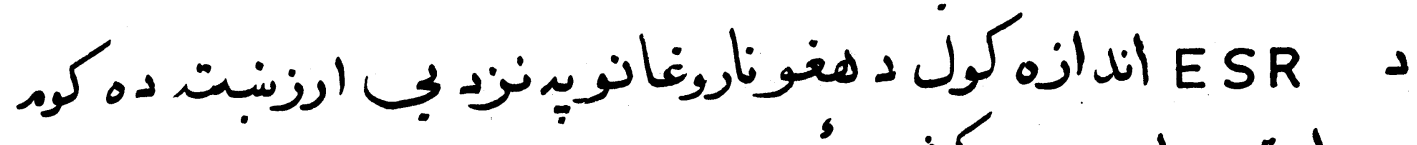

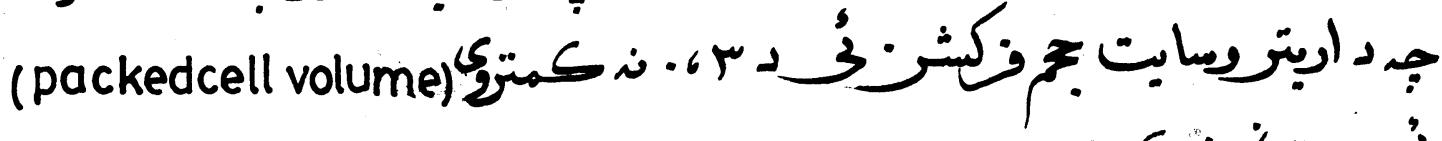

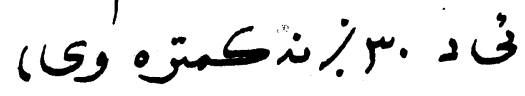


Dehydration 91 ESR

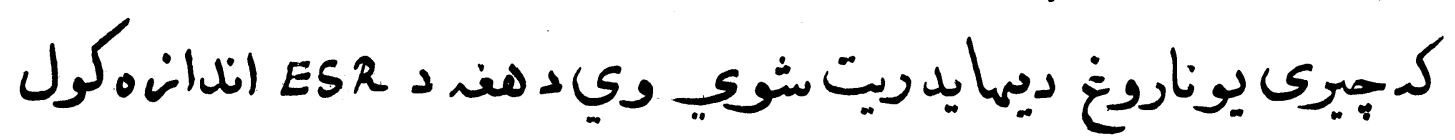

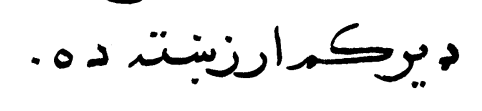

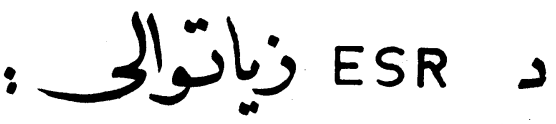

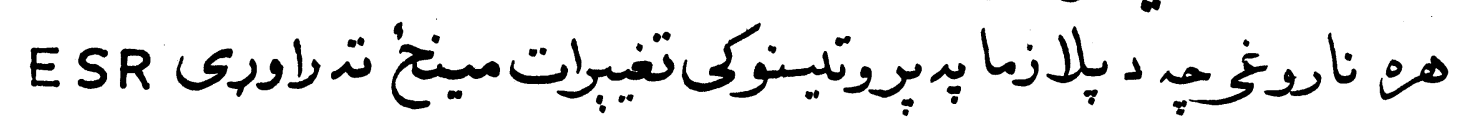

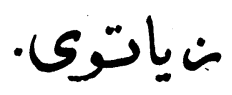

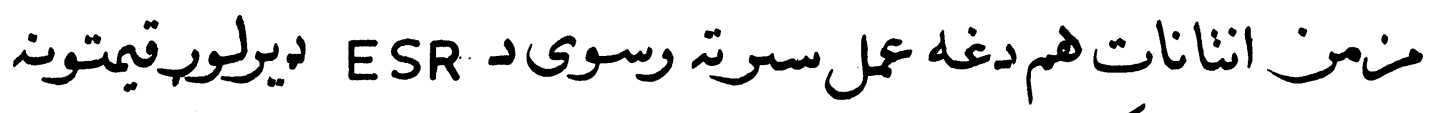

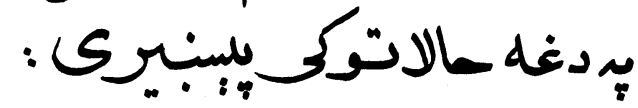

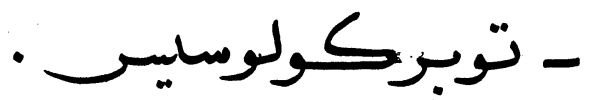

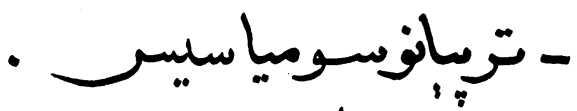
- خبنبُوناروغيتو.

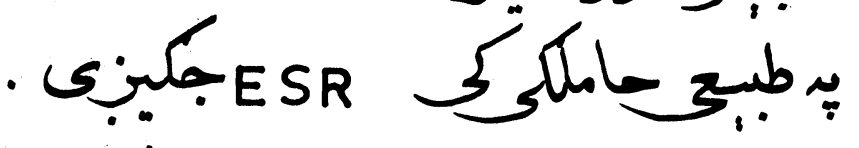

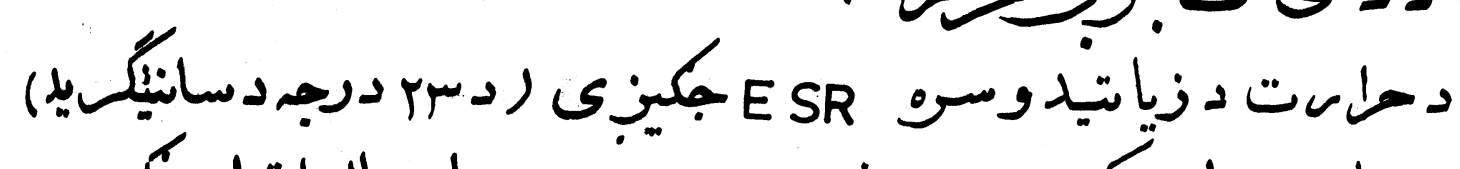

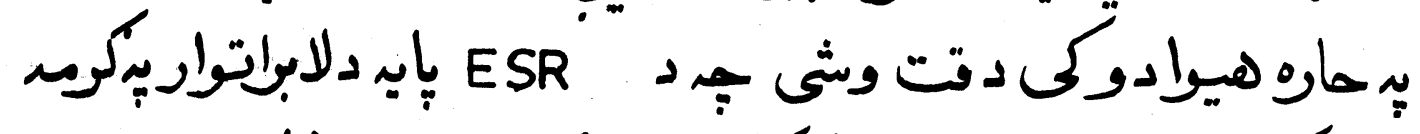

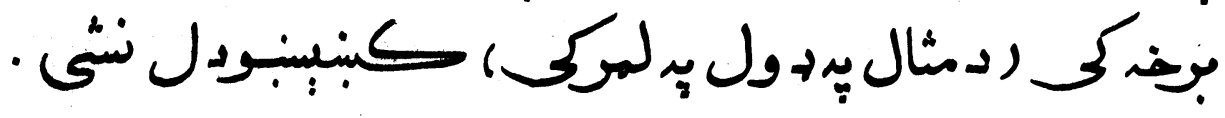




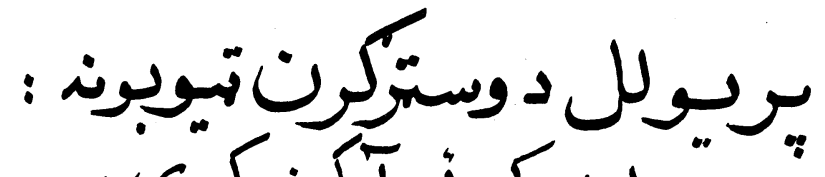

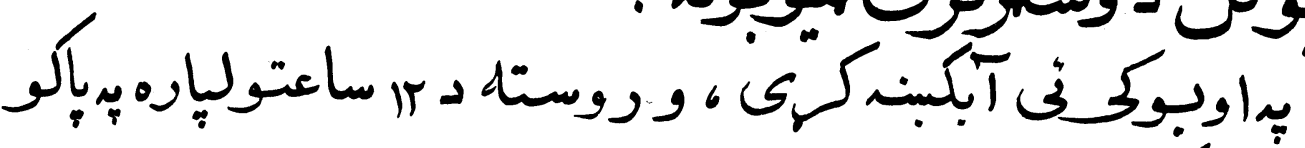

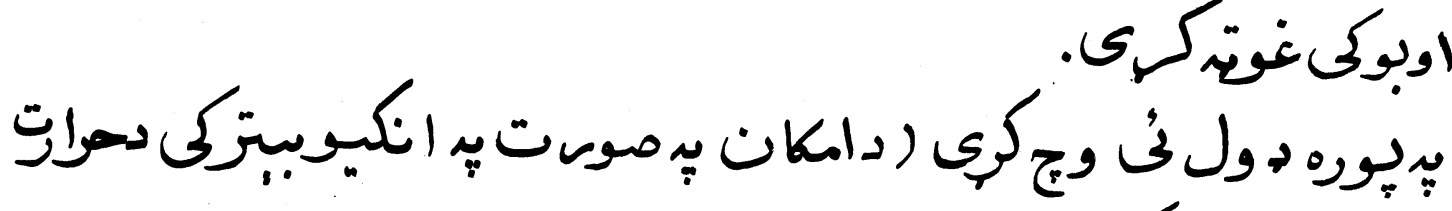

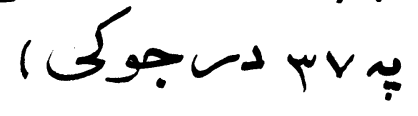

دكالحمينيخلويودرون ، اسيل ون اواينانول مساستحالوى.

دوينحـدجـان موده : د Duke طيتي

Bleeding Time Duke Method

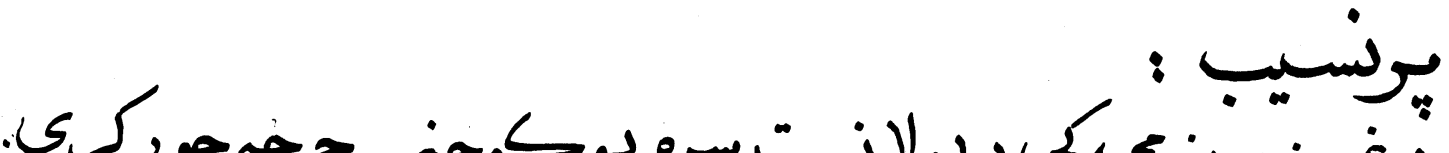

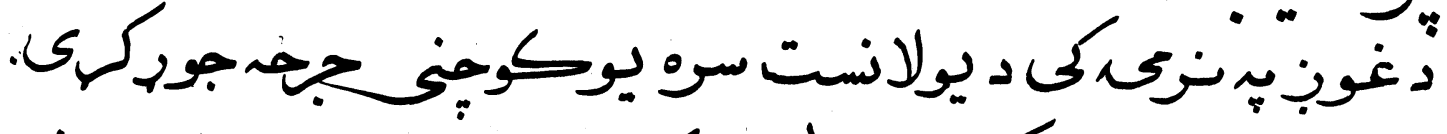

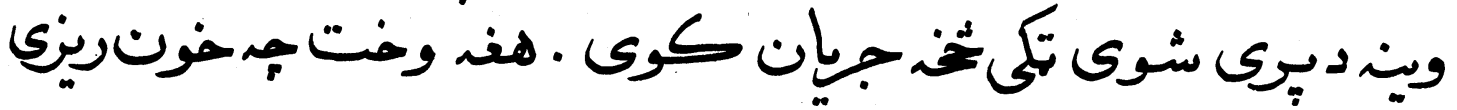

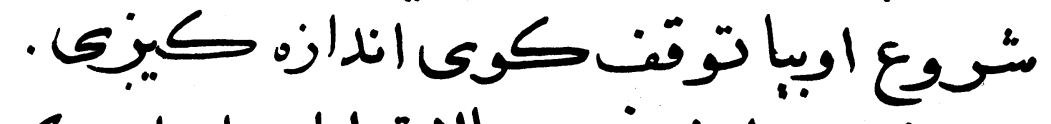

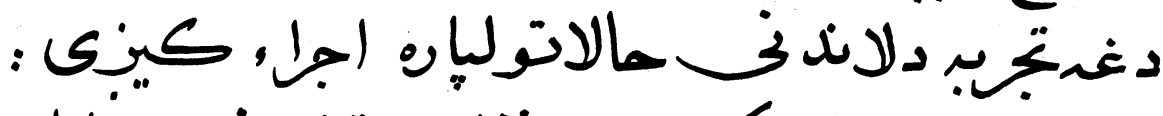

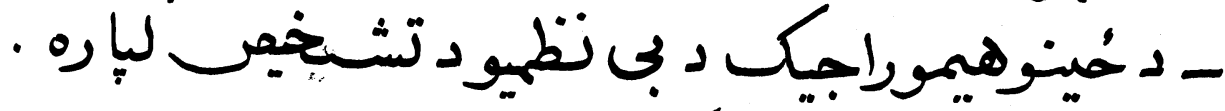

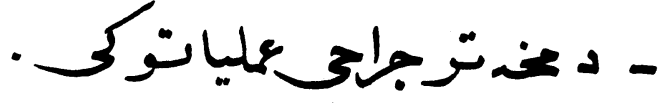

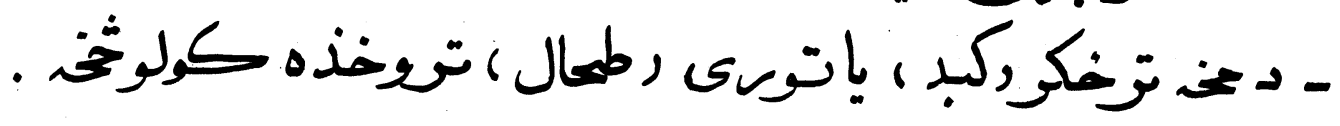



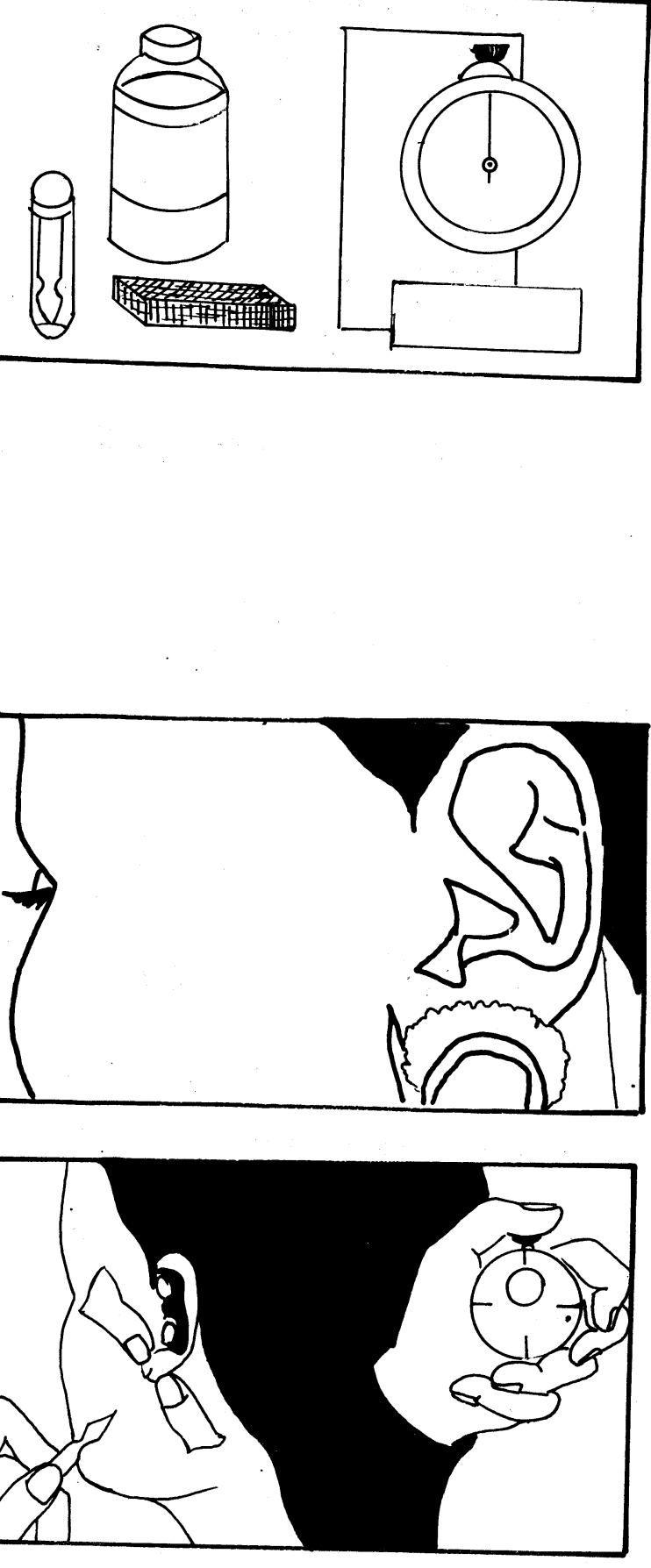

res
- يوه معقد دوينىلانست.

$$
\text { - الكهول }
$$

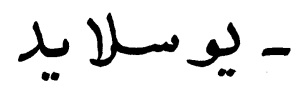

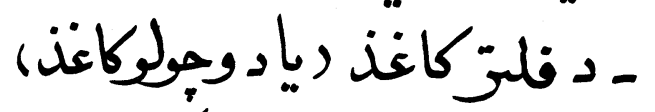

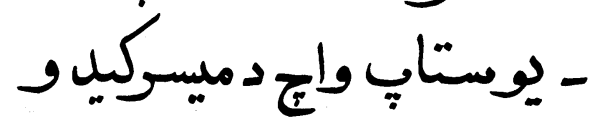

ي موروث

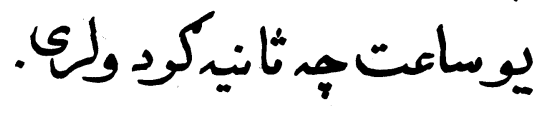

$$
\text { :مشتود }
$$

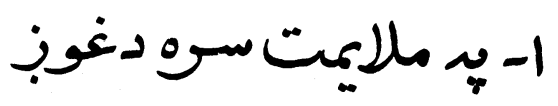

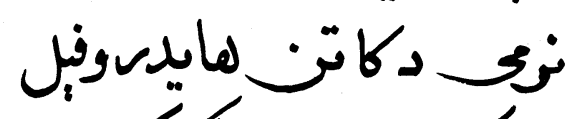

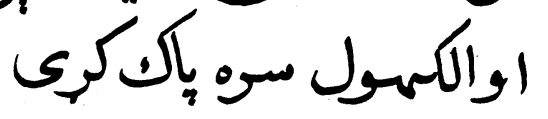

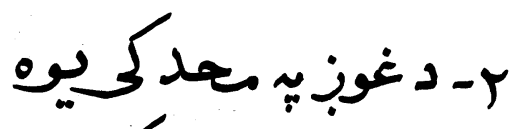

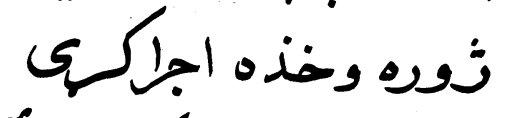

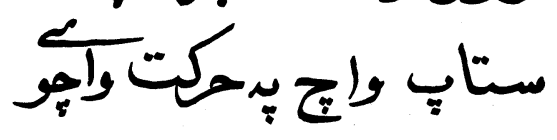

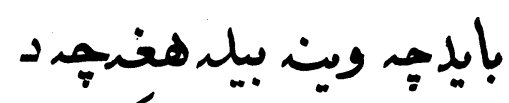

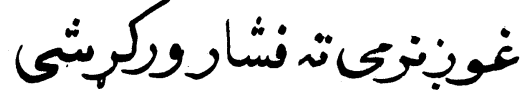




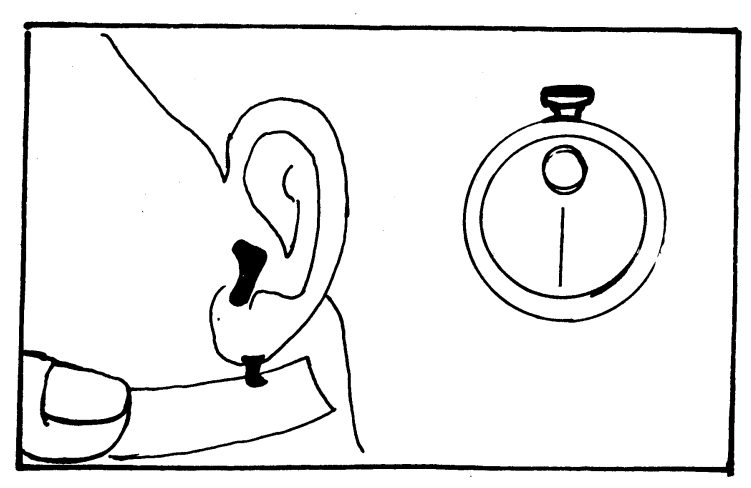

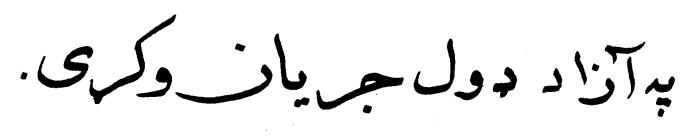

" - وروستهل د بץ نأنيو :

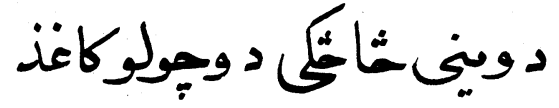

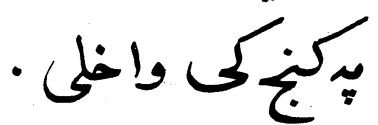

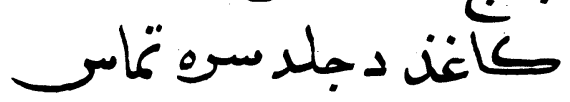
ون
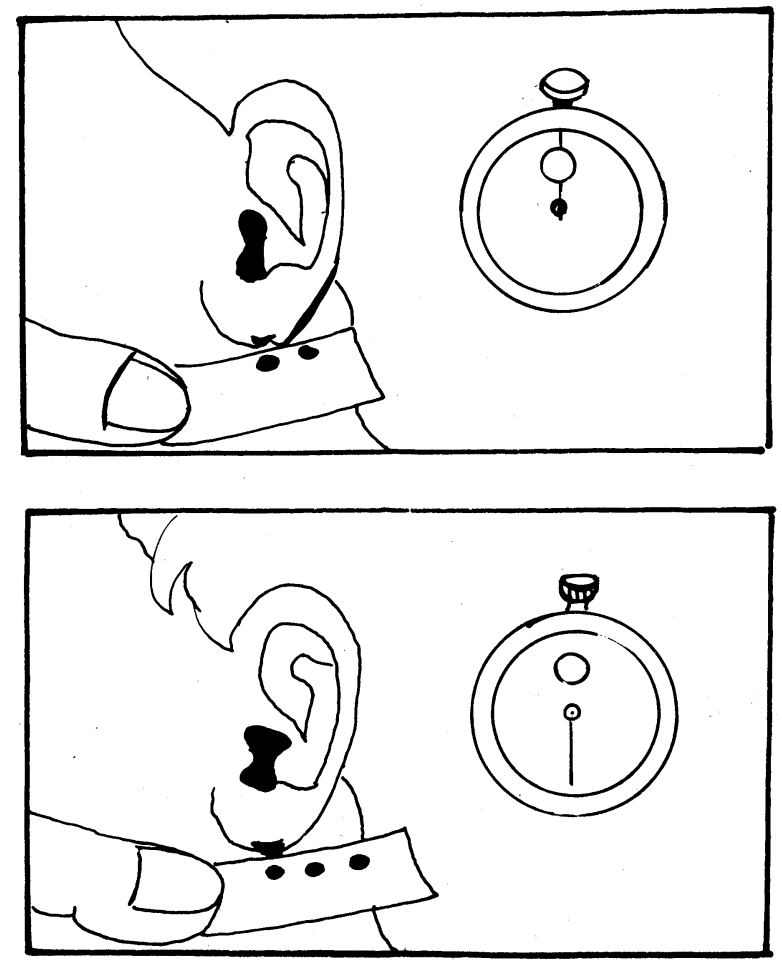

ع- بيا برثانيى انتظاروكأز

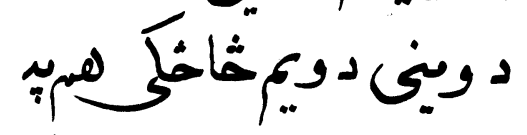
عين ترتيب سته واخلى، لزيليى دكاغذد تريشى مِاونده كَكى.

هـ برهددى تيتي دويني تولويلوت دهوي برثانيب

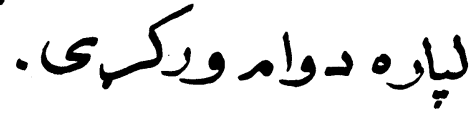

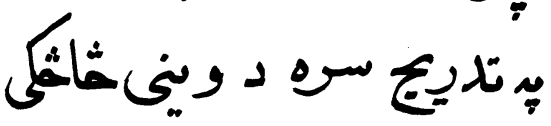

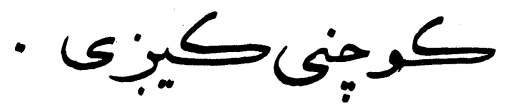




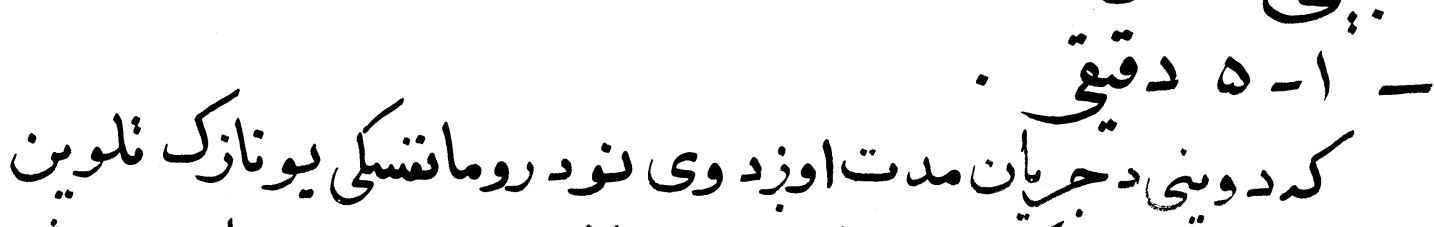

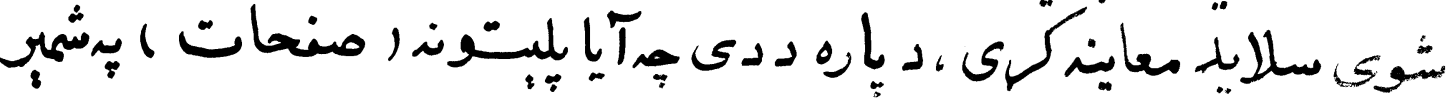

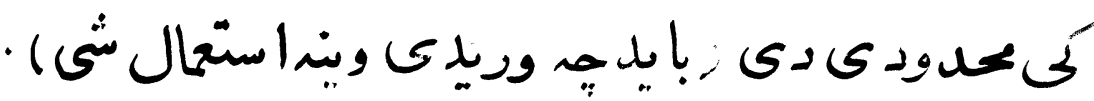

$$
\text { دوينى ينه فلم آما ده ككول }
$$

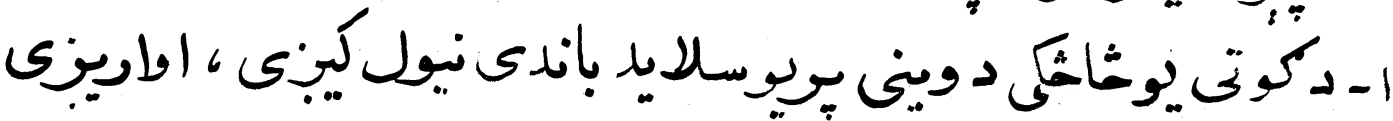

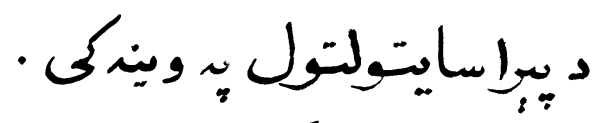

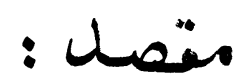

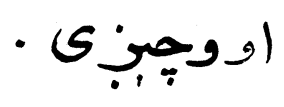

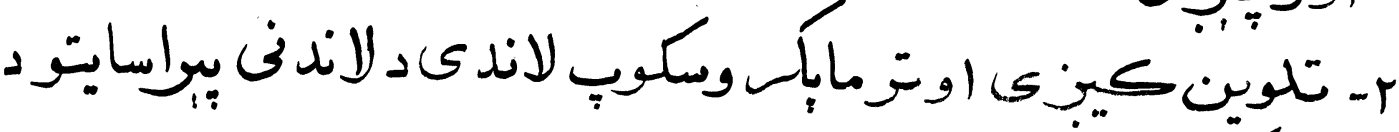

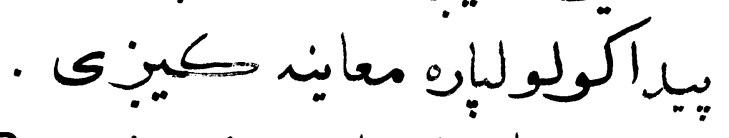

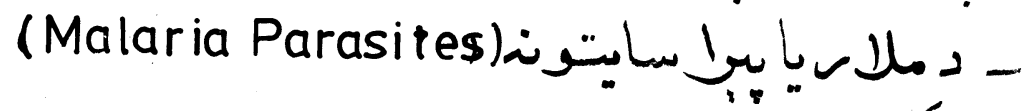

'Micotilaiae

$$
\text { ـ ماكَوونلاريا }
$$

‘Trepanosues,

(Borreliae

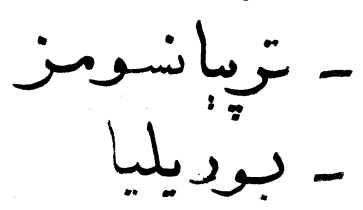




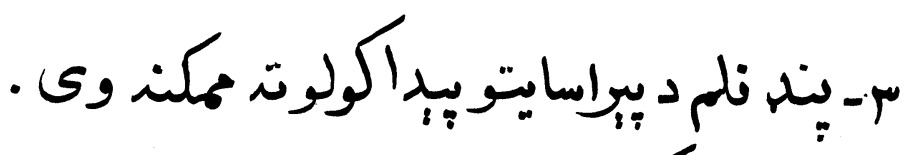

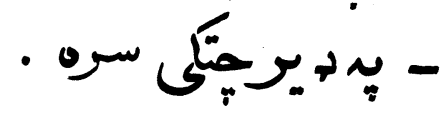

ـ ولوجي دهنوى تعداد يحلدود هم وىى.

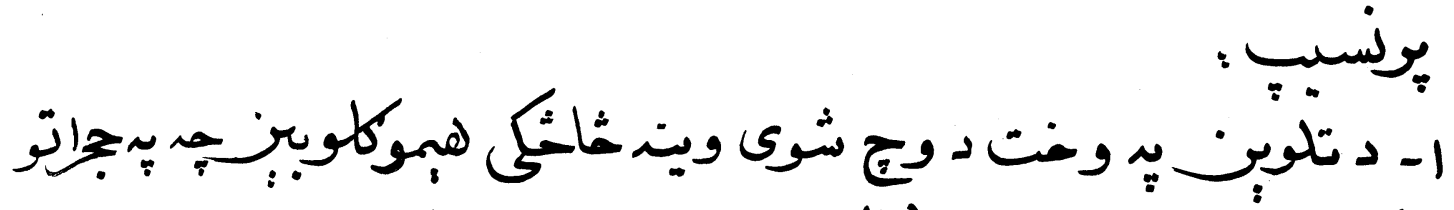

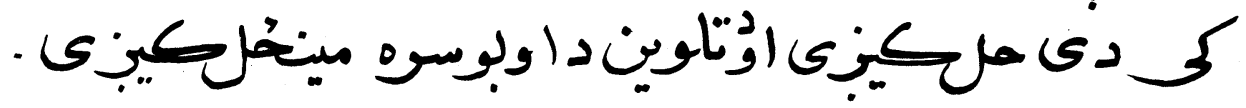
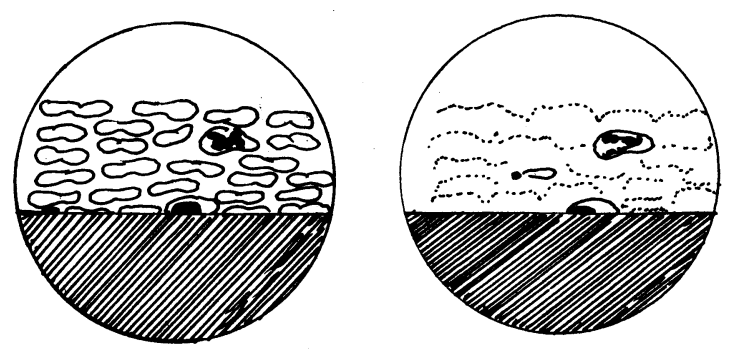

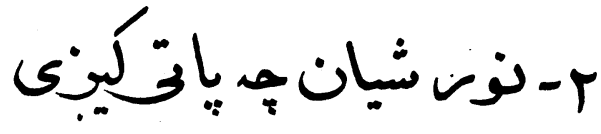

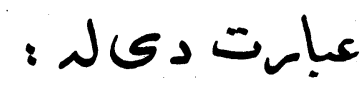

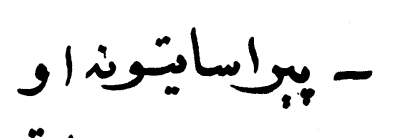

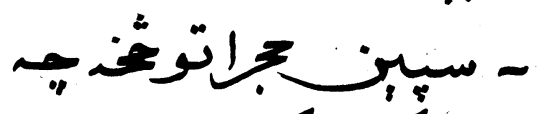

تومايكريكوبِ لاندى

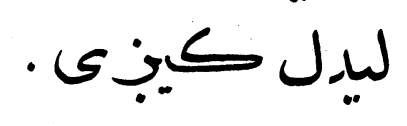
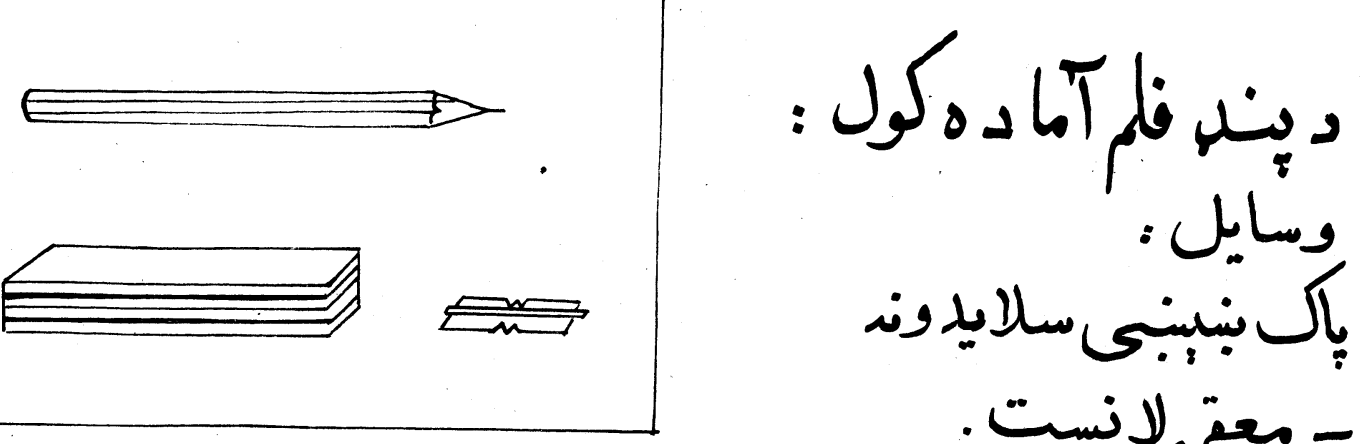

$$
\text { - مينانمل متنست }
$$

$r \varepsilon q$ 


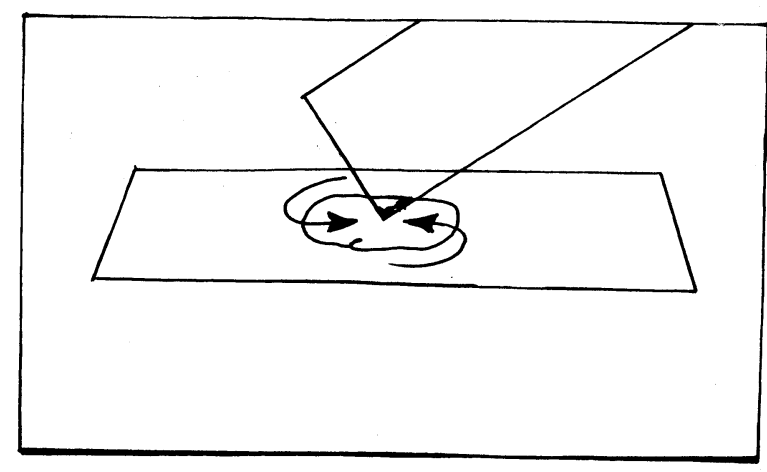

$$
\begin{aligned}
& \text { ـ هايدونيل بنب } \\
& \text {-موينـل -هايل }
\end{aligned}
$$

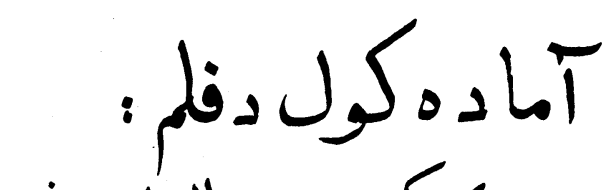

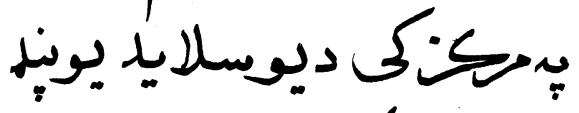

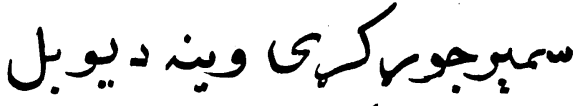

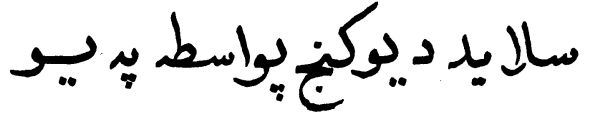

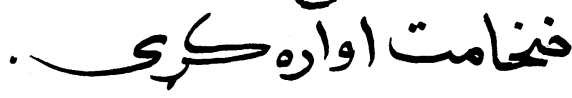

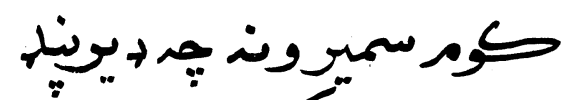

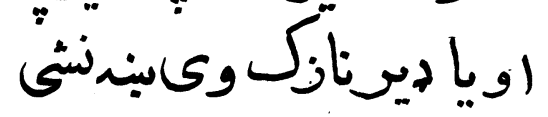

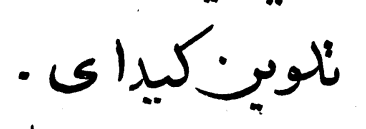

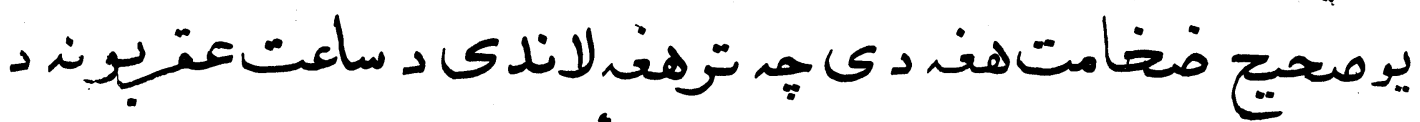

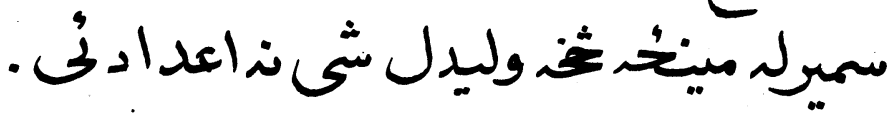

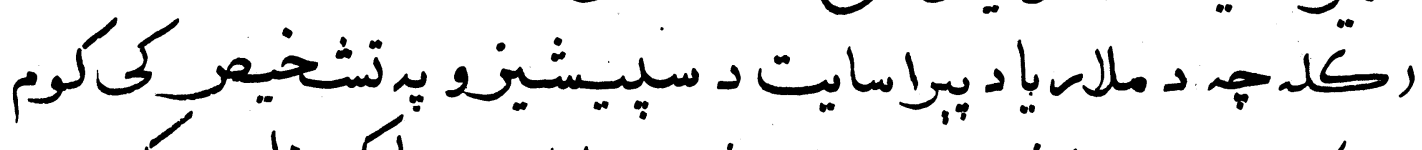

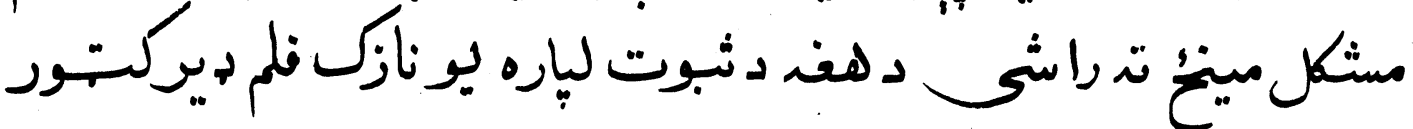

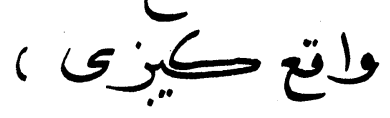

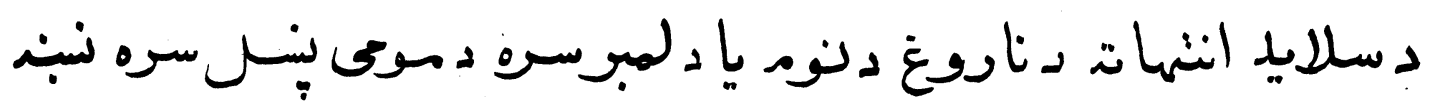
. 


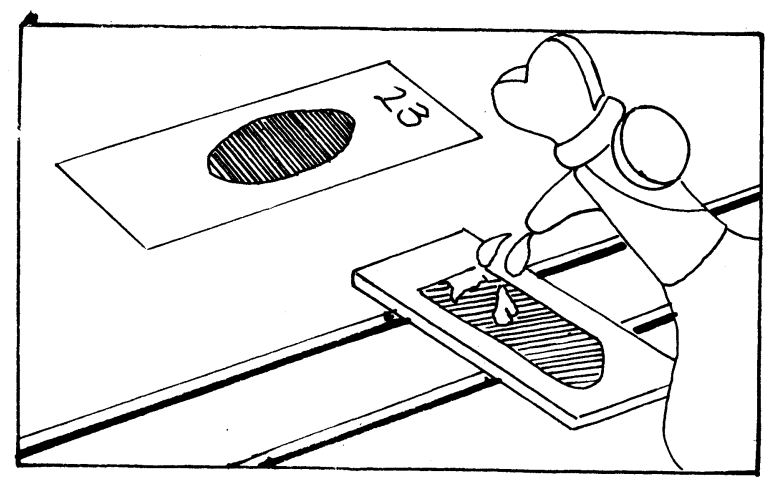

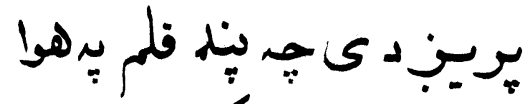

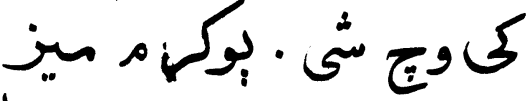

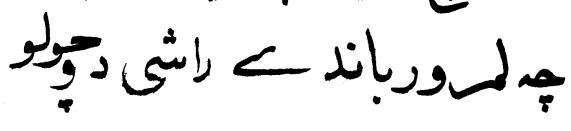

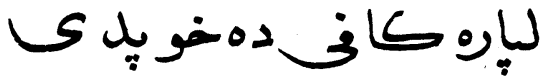

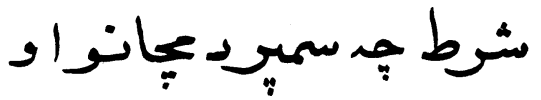

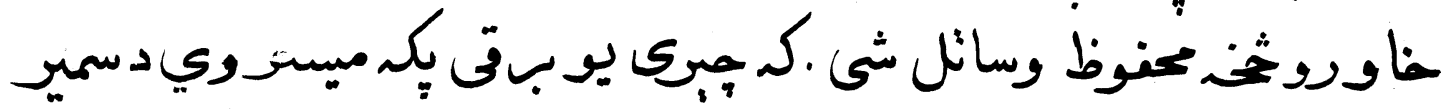

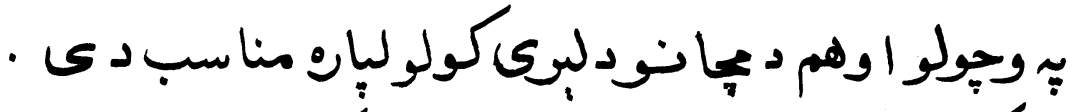

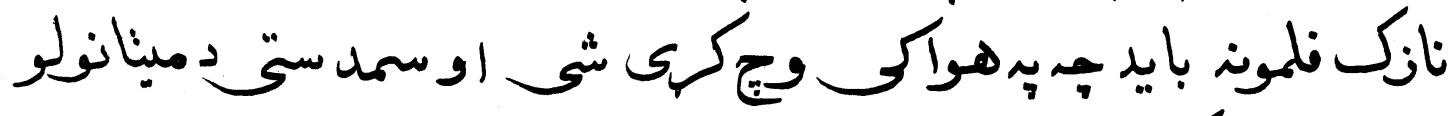

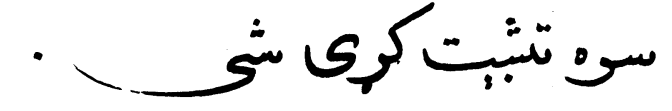

